\title{
aproximações sobre a obra de Salvador Candia
}

Eduardo Rocha Ferroni

orientadora Profa. Dra. Regina Maria Prosperi Meyer

dissertação de mestrado

Faculdade de Arquitetura e Urbanismo da Universidade de São Paulo

São Paulo, 2008 


\section{aproximações sobre a obra de Salvador Candia}

\section{Eduardo Rocha Ferroni}

orientadora Profa. Dra. Regina Maria Prosperi Meyer

\section{Dissertação de mestrado}

Faculdade de Arquitetura e Urbanismo da Universidade de São Paulo

Área de concentração Projeto, Espaço e Cultura

São Paulo, 2008 
AUTORIZO A REPRODUÇÃO E DIVULGAÇÃO TOTAL OU PARCIAL DESTE

TRABALHO, POR QUALQUER MEIO CONVENCIONAL OU ELETRÔNICO, PARA FINS

DE ESTUDO E PESQUISA, DESDE QUE CITADA A FONTE.

E-MAIL: eduardo@cooperantes.com.br

Ferroni, Eduardo Rocha

F396a Aproximações sobre a obra de Salvador Candia / Eduardo Rocha Ferroni. -- São Paulo, 2008.

308 p. : il.

Dissertação (Mestrado - Área de Concentração: Projeto Espaço e Cultura) - FAUUSP.

Orientadora: Regina Maria Prosperi Meyer

1.Arquitetura moderna - São Paulo(SP) 2.Projeto de Arquitetura 3.Candia, Salvador, 1924-1991 I.Título

CDU 72.036(816.11) 
este trabalho contou com a colaboração de professores, colegas e amigos

agradeço a

Regina Meyer, pela orientação e pelo incentivo

Maria Helena Flynn e Joana Mello pelas conversas e pela bibliografia

Helena Ayoub e Max Risselada, pela bibliografia

Abílio Guerra e Luis Antonio Jorge pela qualificação

Cássia Buitoni, pela grande ajuda com a diagramação

Shundi Iwamizu e Minoru Naruto pelas conversas

Pablo Hereñú novamente pelo companheirismo

Bruno Nicolielo, pela forte ajuda com os desenhos

Paula Ferroni pelas revisões e Anne Dieterich pelas revisões e pela tradução do resumo

Raimundo e Tereza Schnorrenberg, e Yasuhiro Aida pela organização e pela confiança em relação ao Arquivo Salvador Candia

Roberto Amá (in memoriam) e Giancarlo Gasperini pelas colaborações com o Arquivo Salvador Candia, e pelos depoimentos

Lélio Reiner, Fernando Arantes e Vitor Lotufo pelos depoimentos

Norma Cianflone Cassares, pela orientação em relação aos cuidados com o acervo

às bibliotecárias Edna, Estelita e Maria José

agradeço ao apoio dado pela Escola da Cidade, particularmente a Ciro Pirondi e Anália Amorim aos alunos bolsistas da Escola da Cidade: Gabriel Esteves Ribeiro, Luis Fernando Pedroza, e particularmente a Carolina Milani de Oliveira e Giovanna Lavorato Genistretti 



\section{resumo}

Este trabalho traça um panorama da obra de Salvador Candia, arquiteto brasileiro que atuou predominantemente para o mercado da construção na cidade de São Paulo entre as décadas de 1950 e 1980. Para a realização desta pesquisa, o material remanescente do escritório do arquiteto foi reunido, organizado e pré-catalogado em fichas de obras e projetos, sendo que o seu arquivo se encontra em fase de processamento sob a guarda da Escola da Cidade, em São Paulo. Com base neste arquivo, no levantamento de informações bibliográficas complementares e em depoimentos de arquitetos que com ele trabalharam e conviveram, procurou-se situar a sua obra frente a um quadro mais amplo da arquitetura moderna em São Paulo. O primeiro capítulo comenta o período de formação do arquiteto, e os vínculos e parcerias de trabalho que ele estabeleceu desde os primeiros anos de sua atividade profissional. O segundo capítulo aborda a emergência de novos programas na metrópole paulistana, principalmente a partir das décadas de 40 e 50, e a forma como os arquitetos procuraram equacioná-los naquele momento, determinando também em grande parte a atuação posterior de Salvador Candia. O terceiro capítulo levanta algumas das questões que consideramos mais relevantes em sua obra. O quarto capítulo apresenta três projetos, que se referem às questões levantadas no capítulo anterior. Ao final do trabalho, são anexadas as fichas dos projetos e obras levantados durante a pesquisa e um conjunto de textos de autoria do arquiteto. 



\section{abstract}

The present work gives an overview of the oeuvre of Salvador Candia, Brazilian architect who practised primarily for the construction market of the city of São Paulo from the 1950's to the 1980's. In order to carry out the investigation, the material left behind from the architect's office was collected, organized and pre-catalogued in fact sheets about built and un-built projects; the archives are kept at the architectural school Escola da Cidade in São Paulo. Being based on these records, on complementary biographical information, and on statements given by architects and people who worked with and lived alongside Candia, the present work tries to position his oeuvre within a broader context of modern architecture in São Paulo. The first chapter regards the period of the architect's training and education, as well as the ties and work partnerships, which he formed since the early days of his professional career. The second chapter deals with the emerging of new functional programmes in the São Paulo metropolis, mainly from the 1940's and 1950's onward, and the way in which architects tried to solve them at the time, these occurrences being a determining factor for the henceforth practice of Salvador Candia. The third chapter presents a selection of issues that are considered particularly relevant in his work. The fourth chapter gives a description of three selected projects referring to the issues raised in the previous chapter. Finally, annexed to the current work are the fact sheets of the projects, which have been surveyed during the research and a number of texts by the architect. 



\section{sumário}

introdução

I formação e parcerias de trabalho

antecedentes

grupo de resistência

contatos com o exterior

- Museu de Arte Moderna e as Bienais

colaborações

parceiros de trabalho: afirmação de um repertório

Il emergência de novos programas

novos problemas

habitação vertical

galerias comerciais

edifícios-conjunto

experimentando soluções

III questões recorrentes

o sentido urbano do edifício

razão construtiva e expressão plástica

planta funcional

integrar as artes

arquiteto/professor

IV leitura de três projetos

Edifício Metropolitano

Edifício Joelma

188

Conjunto em Perdizes

considerações finais 

introdução 


\section{introdução}

Este trabalho surgiu da intenção de se reunirem algumas obras do arquiteto Salvador Candia construídas em São Paulo, que apesar de notoriamente reconhecidas entre os arquitetos no meio profissional e acadêmico, ainda não haviam sido estudadas em conjunto sob um aspecto que nos parecia relevante: a relação que estes edifícios estabelecem com o meio urbano onde estão situados, e o modo como seus projetos respondem às condicionantes urbanísticas em sua implantação. ${ }^{1}$

Durante o processo de levantamento do material referente aos projetos, tivemos acesso ao acervo remanescente do escritório Salvador Candia Arquitetos Associados S/C Ltda, que no momento se encontrava disperso em dois endereços: uma parte dos projetos permanecia guardada em sua antiga residência em poder de seus herdeiros, e outra parte havia sido selecionada pelo seu ex-colaborador Roberto Amá em meados de 1990 com o intuito de realizar uma pesquisa que infelizmente não pôde empreender, tendo falecido prematuramente em junho de 2006.

No período decorrente entre o início de 2005 e o fim de 2006, pudemos reunir os dois acervos sob a guarda da Associação de ensino de Arquitetura e Urbanismo de São Paulo - Escola da Cidade. Diante da possibilidade de se organizar e tornar acessível ao público esse vasto acervo de projetos, fotografias de obras e documentos diversos de grande interesse, procuramos adaptar o escopo da pesquisa originalmente estabelecido, de forma a abranger a obra em caráter mais amplo, no intuito de constituir uma mostra organizada do arquivo para consulta, e subsidiar a curadoria do material a ser posteriormente restaurado, digitalizado e disponibilizado ao público.

Sob essa perspectiva mais ampla, procuramos traçar aproximações sucessivas sobre

1 Os projetos que seriam estudados originalmente sob esta ótica seriam: Edifício João Ramalho ("Superquadra em Perdizes" -1953-54), Edifícios para o Conjunto Ana Rosa (1951-57), e Edifício Metrópole (1959-60). 
a obra do arquiteto, de modo a compor um panorama de sua atuação frente ao quadro da arquitetura moderna em São Paulo.

Numa primeira aproximação (Capítulo I), procuramos compreender o processo de formação do arquiteto, e as diversas parcerias de trabalho que ele desenvolveu durante a sua atuação profissional. A idéia de formação é aqui entendida em caráter mais abrangente, e refere-se não só ao período em que Salvador Candia freqüentou o curso de Engenharia do Instituto Mackenzie, mas também aos vínculos profissionais que ele viria a estabelecer posteriormente. Para tanto foram levantados documentos pessoais, depoimentos de amigos e colegas, e pesquisas bibliográficas complementares.

A segunda aproximação (Capítulo II) refere-se ao contexto em que Salvador Candia inicia sua atividade profissional, no fim da década de 1940 em São Paulo. Neste capítulo abordamos a emergência de determinados programas arquitetônicos e urbanísticos que, embora já estivessem presentes no desenvolvimento da metrópole paulistana há algumas décadas, passariam a se impor em uma escala até então inusitada, exigindo novas respostas dos arquitetos atuantes naquele momento. As experiências empreendidas por Candia neste sentido trariam repercussões significativas para o desenvolvimento posterior de sua arquitetura.

O Capítulo III aproxima-se de questões recorrentes em sua obra, a partir de um ponto de vista mais abrangente. Com base na pesquisa sobre o material do Arquivo Salvador Candia, os projetos foram abordados sob os aspectos de sua relação com o entorno urbano, de sua lógica construtiva e de sua organização funcional. Este capítulo aborda também a relação experimentada em certos projetos entre a arquitetura e as artes plásticas, e finalmente a sua atuação como professor.

O quarto capítulo apresenta mais detalhadamente três projetos considerados representativos das questões levantadas no capítulo anterior.

Ao final deste volume são anexadas as fichas de projetos levantados e alguns textos de autoria do arquiteto. 

formação e parcerias de trabalho 

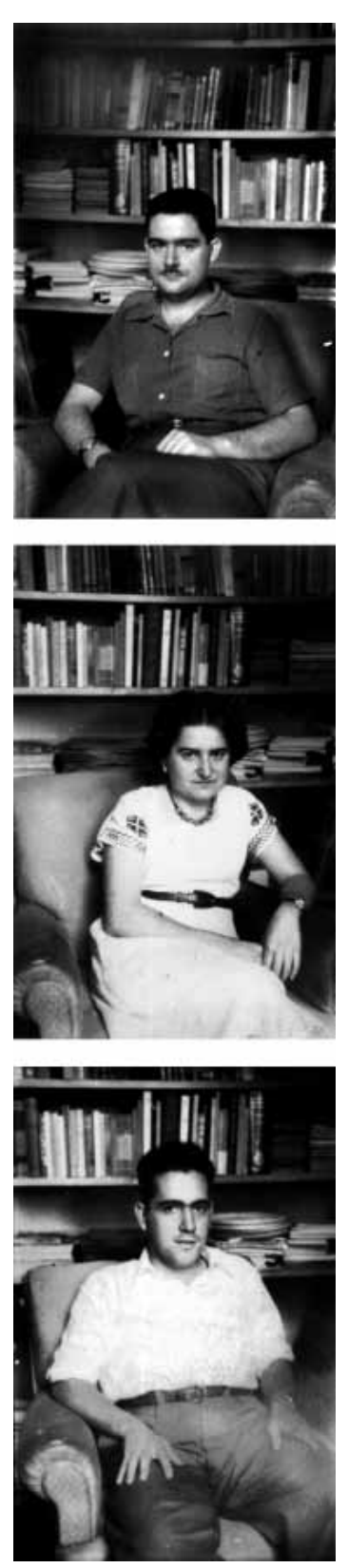

\section{antecedentes}

Salvador Roque Augusto Candia, filho primogênito de imigrantes italianos oriundos da vila de Aieta, na Calábria, nasceu em 6 de agosto de 1924 em Campo Grande (MS), mudando-se com a família para a capital paulista em 1933. Após a morte dos pais, continuou morando com os irmãos Rubens e Madalena em São Paulo até o fim de sua vida em 1991. A ascendência italiana da família exerceu uma significativa influência na formação do arquiteto, tendo cultivado um contato intenso com a cultura daquele país, e se aproximado de colegas que compartilhavam das mesmas raízes, dentre os quais se encontravam Rino Levi (1901-1965), Miguel Forte (1915-2002), Plínio Croce (19211984), e Giancarlo Gasperini (1926). ${ }^{1}$ Este último, com quem Candia passou a conviver a partir dos anos 1950, comenta:

Era uma família extraordinária, muito especial. Mas muito fechada, de uma certa forma. Eu freqüentava a casa deles na região da Augusta, eles moravam num sobradinho. A rua era meio inclinada, você passava uma cancelazinha e tinha que descer dois degraus, e chegava nesse hall. E a casa era sempre muito fechada, assim. Tinha uma salinha de estar, e a mãe dele vivia lá. Quando comecei a freqüentar o pai dele estava ainda vivo (...) Os pais eram italianos. O Salvador também, era praticamente italiano. Ele tinha muito orgulho disso. ${ }^{2}$

1 Diversos autores comentam a importância da imigração italiana na constituição da cultura arquitetônica paulistana. Podemos destacar a pesquisa realizada pelo Professor Renato Anelli, do Grupo de Pesquisa Arqbras do Departamento de formação do seu círculo de convívio profissional.

2 GASPERINI, Giancarlo. Depoimento prestado ao autor em 5-12-2007.
Arquitetura e Urbanismo da EESC-USP. Consideramos que a ascendência italiana do arquiteto foi um fator determinante na 
A casa a que Gasperini se refere era o sobrado da rua Caio Prado, no 365 , projeto de Ramos de Azevedo (1851 - 1928) que havia sido escolhido por influência de Salvador após a mudança da família, tendo sido posteriormente vendido para a ampliação do hotel Ca'doro. A identificação com o país de origem dos pais teria fomentado a busca por uma formação de caráter mais abrangente e cosmopolita, através da procura por livros e periódicos estrangeiros, e da realização de diversas viagens de estudos por meio das quais pôde presenciar o processo de reconstrução das cidades européias no segundo pós-guerra, e a profícua atuação dos arquitetos europeus radicados naquele momento nos Estados Unidos; num período particularmente oportuno para a disseminação da arquitetura moderna internacional. ${ }^{3}$ Segundo Miguel Forte, colega veterano do curso de arquitetura com quem viria posteriormente a lecionar no Mackenzie, Candia era reconhecido por seu cosmopolitismo:

(...) o Salvador, então, como eu te falei, ele era muito polêmico. E ele era um grande apaixonado da Itália. Quando ele falava da Itália, ele ficava emocionado. "Miguel, você tem que ir para a Itália, naquele lugar", e coisa, ele dava dicas, explicava. "Você tem que ir com Laura aqui, de barco", ele programava tudo. "Tem que comer naquele restaurante, aquela osteria”, entende? Ele dava todas as informações. E a paixão dele pela Itália era tão grande (...), que ele duas vezes por ano ia para a Europa, para poder ir à Itália. Ele ia também a outros lugares, outros países, ele conhecia a Espanha (...) Ele falava "Precisa ir à Espanha, pra ver isso, pra ver aquilo..." E falava sempre com aquele ar de uma pessoa muito empolgada (...) Ele comprava muitos livros de arquitetura e livros de arte. Então tinha na casa dele uma biblioteca impressionante de importante. Ele tinha uma cultura muito grande, entende? ${ }^{4}$

$3 \mathrm{O}$ termo empregado refere-se à escala inédita na qual foram aplicados conceitos desenvolvidos nas décadas anteriores pelos arquitetos modernos, tanto na reconstrução de cidades européias como Rotterdam e Berlin, quanto no período de prosperidade vivido pela economia Norte Americana a partir do segundo pós guerra.

4 Depoimento prestado a Mariana Kunni, 2000. 


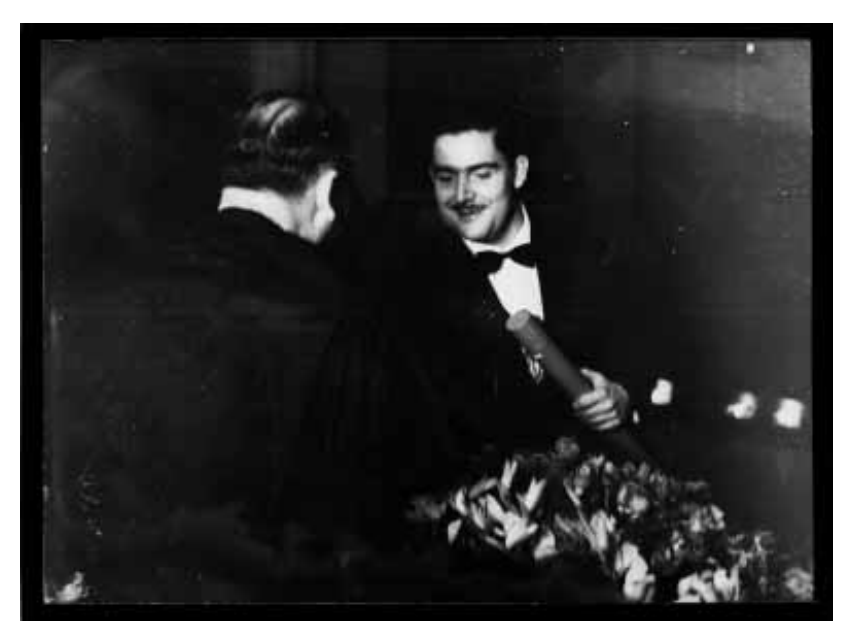

Colação de Grau no Mackenzie , 1948 foto arquivo $S$. Candia
Candia iniciou seus estudos no antigo curso de Arquitetura da Escola de Engenharia do Instituto Mackenzie, tendo posteriormente se matriculado na recém fundada Faculdade de Arquitetura daquela instituição (1947), para concluir sua formação em 1948.

O ensino da arquitetura no Mackenzie havia sido oficialmente inaugurado em 1917 em associação com o curso de engenharia. Sua criação deveu-se à iniciativa pessoal de Christiano Stockler das Neves (1889-1982) que, tendo se formado em 1911 pela Graduate School of Fine Arts da Universidade de Pensilvânia (EUA), pretendia aplicar os métodos de ensino que ali vivenciara, baseados em uma adaptação do programa da Escola de Belas Artes de Paris às circunstâncias culturais e tecnológicas norte-americanas do início do século XX. Exercendo um papel extremamente centralizador, dirigiu a orientação didática do curso durante 40 anos mantendo a sua doutrina "clássica" em resistência à adesão progressiva das artes modernas no meio cultural paulistano, até o momento da sua aposentadoria compulsória em 1957, quando não pôde mais sustentar a mesma posição diante da pressão dos alunos.

Christiano era filho do célebre engenheiro Samuel das Neves (1863-1937), junto ao qual dirigiu o escritório de projetos responsável pela construção de um significativo acervo de obras representativas da burguesia paulistana nas primeiras décadas do século XX, dentre os quais se destacam os Palacetes Prates (edifícios utilizados pela Prefeitura e Automóvel Club, situados no parque Anhangabaú, realizados por Samuel das Neves em 1912-14), o "arranha-céu" Sampaio Moreira (implantado em 1924 na rua Libero Badaró, em terreno especialmente escolhido para situar-se a meia distância ao fundo dos palacetes projetados por Samuel), e a Estação Ferroviária da Sorocabana (atual Estação Júlio Prestes, 1926). Polemista obstinado, o arquiteto exerceu um papel importante em defesa da regulamentação da classe profissional, tendo participado ativamente do debate público sobre as questões da profissão através de jornais e periódicos especializados, onde defendia com veemência a tradição da arquitetura acadêmica das Belas 
Artes em contraposição às manifestações pioneiras da arquitetura moderna, que chegou por vezes a definir como "comunismo arquitetônico" ou arquitetura "internacionalista judia”. Introduziu em São Paulo a corrente arquitetônica definida como "Luís XVI Modernizado", que bem representava uma associação ideal entre a tradição francesa e o progresso norte-americano. Pode-se considerar que estes atributos responderam prontamente às aspirações da burguesia paulistana até um certo momento, conforme veremos adiante.

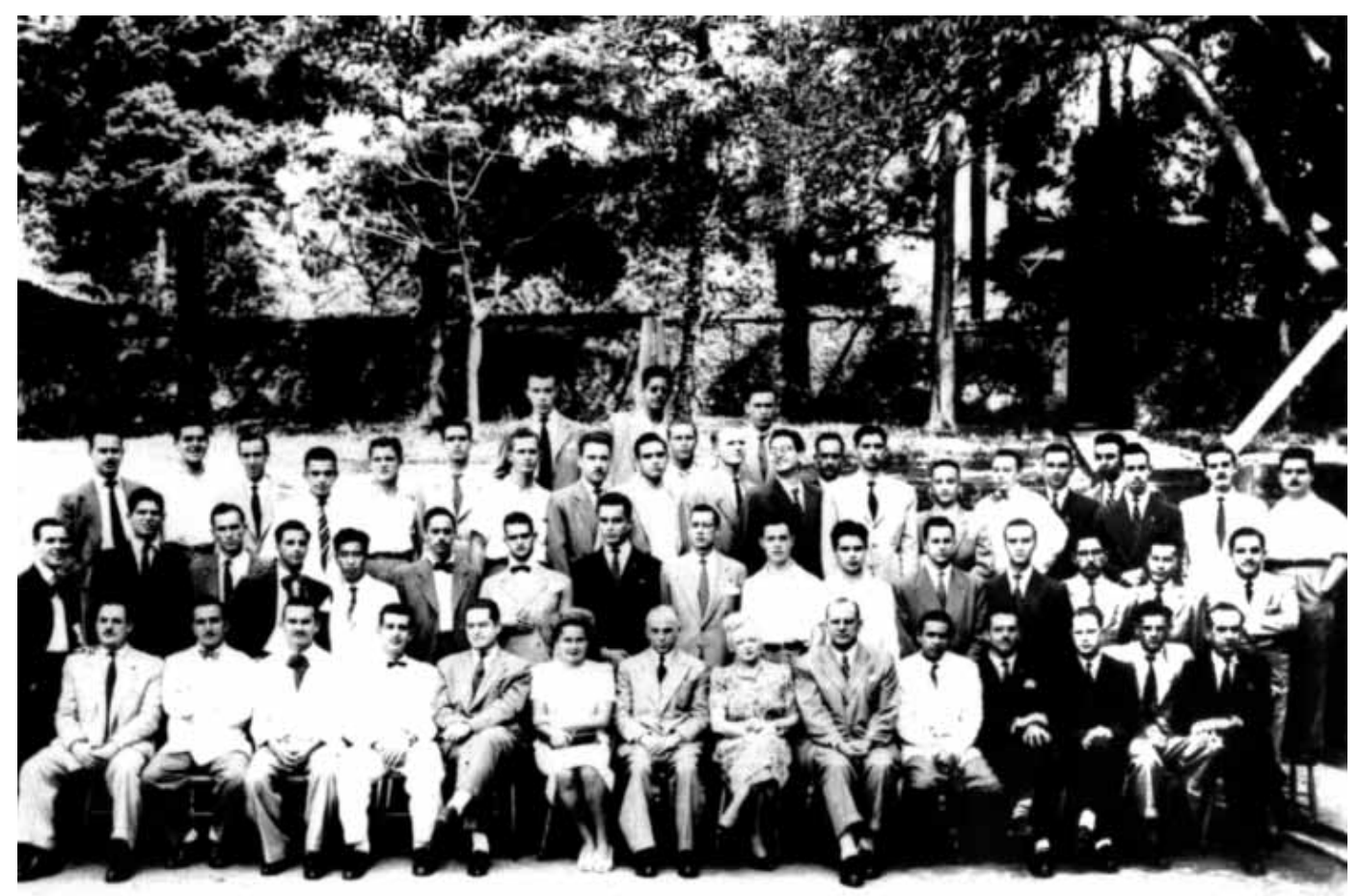

5 NEVES, Christiano Stockler das. "Comunismo architectonico: Vaticínios de Keyserling para o Brasil” In: Architectura e Construcções n.13, vol I, 1930. p. 04-06.

6 LEMOS, Carlos Alberto Cerqueira. Viagem pela Carne/ Carlos A. C. Lemos. São Paulo: Editora da Universidade de São Paulo, 2005. p. 137
Christiano Stockler das Neves ao centro com o corpo docente e discente da Faculdade de Arquitetura Mackenzie em 1947.

Salvador Candia é o primeiro da direita para a esquerda.

São Paulo, 31/12/1947, Acervo do Centro Histórico do Mackenzie.

fonte: PEREIRA, Gustavo. Christiano Stocker das Neves formaça do curso de Arquitetura do Mackenzie College. Um estudo sobre a disseminação dos

métodos da "École de Beaux-Arts de Paris" e das "Fine métodos da "Ecole de Beaux-Arts de Paris" e das "Fine Arts Schools" norte-amichas. 2005, Dissertaça de Mestrado - Faculdade de Arquitetura e Urbanismo 


\section{grupo de resistência}

(...) existia um grupo - Jacob Ruchti, Galiano Ciampaglia, Igor Sresnewsky e outros poucos - que, escondido do Christiano, estudava por conta própria os movimentos da arquitetura dessa época. Então nós ficávamos empolgados com Frank Lloyd Wright, Le Corbusier, Mies van der Rohe, Gropius, Richard Neutra e, quase que escondidos dos nossos professores de projeto, ficávamos manuseando revistas e livros com as publicações desses arquitetos. E contávamos um para o outro: "Você viu? Olha, eu comprei um novo livro, você viu a residência do Frank Lloyd Wright publicada?", "Você viu aquela obra do Mies van der Rohe?" E assim por diante. Então isso era como se nós estivéssemos nos informando por conta própria, éramos professores uns dos outros. ${ }^{7}$

Durante as quatro décadas em que dirigiu o curso de arquitetura, Stockler das Neves assumira a posição de patron d'atelier com a colaboração dos demais professores a ele submetidos, muitos dos quais haviam sido seus próprios alunos. O curso baseava-se na assimilação dos elementos clássicos através dos poucos manuais disponíveis, alguns dos quais haviam sido compilados pelo próprio diretor nos primeiros anos de ensino. $\mathrm{O}$ aprendizado de projeto se dava através da resolução dos programas estipulados pelos professores a partir de duas ordens distintas de grandeza: Pequenas Composições e Grandes Composições, a exemplo dos B Class Problems e A Class Problems adotados pelas escolas de Belas Artes norte americanas. Os temas propostos para a realização destes projetos também estavam fortemente vinculados aos seus cursos de origem.

7 FORTE, Miguel. Diário de um jovem arquiteto: minha viagem aos Estados Unidos em 1947/ Miguel Forte. São Paulo: Editora Mackenzie, 2001. p.15 
Propunha-se muitas vezes a concepção de fragmentos isolados de edifícios hipotéticos: Ala Lateral, Pórtico, Grande Vestíbulo, Pavilhão Central. A idéia de Composição assume neste caso o significado de montagem de elementos pré-determinados sob regras compositivas rígidas, num sistema fechado de elaboração de projetos.

A prática do desenho era também ensinada como elemento central do processo de aprendizado, seja através da observação dos elementos clássicos a serem assimilados, ou pela elaboração apurada das pranchas de apresentação dos projetos segundo uma metodologia rigorosa. As disciplinas referentes à tecnologia da construção eram ainda no final da década de 40 , segundo relatos de ex-alunos, tratadas de forma anacrônica, sob a influência das tradições acadêmicas. ${ }^{8}$ Exemplo disso são as aulas de estereometria para o dimensionamento e corte das construções em pedra, que tinham uma importância significativa no repertório alegórico da arquitetura eclética, apesar de serem cada vez menos empregadas de forma efetiva como parte constituinte da construção. Os estudantes manifestavam o seu descontentamento com o conteúdo didático do curso, principalmente no que diz respeito à falta de maiores informações técnicas e ao dogmatismo acadêmico de Stockler das Neves:

(...) O que havia na época da minha formação profissional, nos anos 40, era pouco ou, melhor, não havia nada. Quer dizer, havia o Mackenzie, que não era nada, onde entrei, mas que todo mundo dizia que era uma grande escola. Era escola acadêmica de belas artes, e no primeiro ou no segundo ano eu já estava totalmente desiludido. Entendi que a escola não ia me dar nada e que existia uma coisa parecida, com um curso de arquitetura, na Escola Politécnica, que tinha uma formação mais tecnológica. Nós, do Mackenzie, das belas artes, espiávamos com certa inveja os da Poli, achávamos que eles eram mais sérios porque estudavam matemática, física, etc., que a gente estudava também, mas não com a forma e com a dimensão que eram necessárias. (...) 8 A presença do professor Roberto Zuccolo a partir de 1953 na disciplina de Sistemas Estruturais viria a contribuir
posteriormente para a mudança deste quadro.
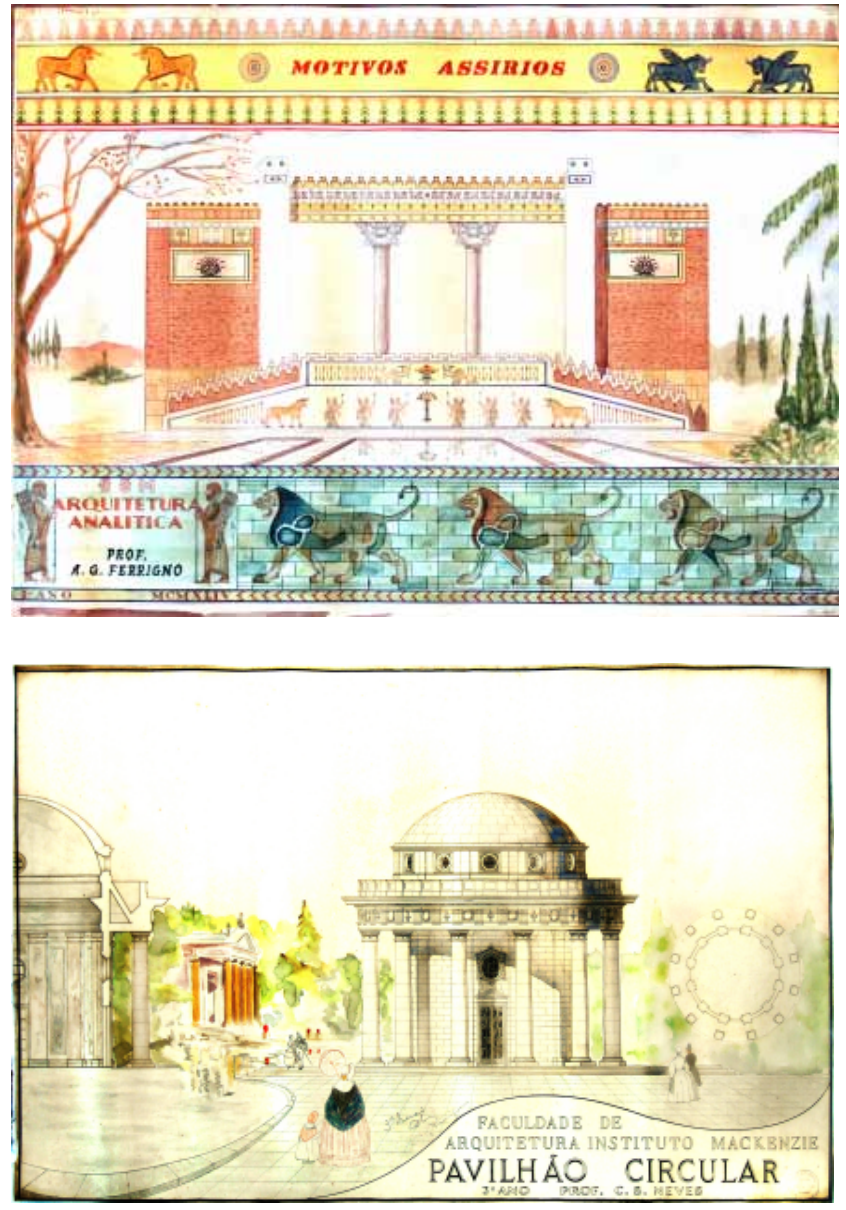

Projetos do aluno Salvador Candia (arquivo S. Candia) à esquerda acima: Exercício de Arquitetura Analítica do I ano, 1944.

à esquerda abaixo: Exercício de Composição do III ano, 1946

à direita acima:

Exercício de Arquitetura Analítica do II ano, 1945 


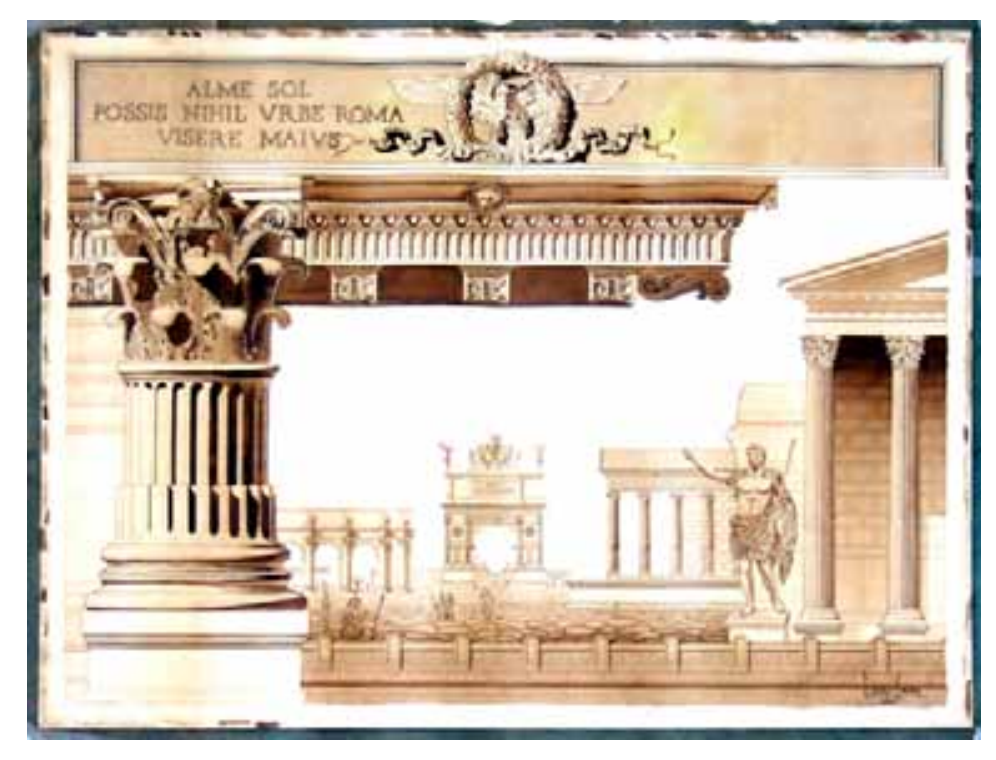

Comecei a perceber que, não tendo escola, deveria promover minha formação me aproximando dos colegas e trabalhando com eles. De fato, comecei a freqüentar e a trabalhar nos escritórios do Artigas, do Rino, do Bratke, e a ler o mais possível. Depois, quando voltei à escola, já como professor, descobri (e hoje não sei exatamente como é que anda, desconfio que não anda muito bem) que vocês não estão lendo como a gente, que naquela época lia como que por desespero, por paixão. A gente dormia com Le Corbusier, com Mies, com Frank Lloyd Wright. Ainda tenho os Le Corbusier virados, anotados etc. e tal. Depois, discutíamos entre nós, com o Artigas, com o Rino, havia brigas incríveis, brigas no melhor sentido.

Aí, começou a minha formação e comecei a ver também que precisava - além de ler - viajar, ver obras. Eu sempre tive uma formação artística. Ajudei o Museu de Arte Moderna, do qual fui sócio-fundador. Sempre achei que arquitetura era arte. Mas tive uma formação técnica-física, matemática, a parte estática toda. E descobri que não adiantava só ler ou só conhecer arquitetos, ou só aprender a desenhar e imitar o traço do Le Corbusier, do Artigas (eu sempre gostei muito do desenho dele). Achei que precisava começar a entender de obra. Isso foi uma coisa que o Mies me ensinou: que eu tinha que aprender a construir, que a arquitetura era construção, não era belas artes, pelo menos não era só belas artes. ${ }^{9}$

A postura totalitária do velho diretor, que procurava inibir o contato dos seus alunos com idéias que considerasse inapropriadas (tendo chegado a cancelar a assinatura de revistas estrangeiras consideradas demasiadamente progressistas), acabava por instigar os alunos à procura de novas informações como uma forma de resistência. Este aprendizado "clandestino" caracterizou sucessivas gerações de mackenzistas entre as décadas

9 ARQUITETURA e Desenvolvimento Nacional. Depoimentos de arquitetos paulistas. IAB-SP, São Paulo: Editora Pini LTDA, 1979. Depoimento de Salvador Candia. 
de 30 e $50,{ }^{10}$ e acabou por configurar um grupo diversificado de colegas que cultivavam o interesse solidário pelas artes modernas internacionais. Buscavam novas informações através de periódicos estrangeiros, contato com os arquitetos modernos atuantes em São Paulo, e - quando possível - viagens de estudo ao exterior. Dentre os colegas que estiveram mais presentes no período de formação de Salvador Candia, encontram-se Miguel Forte (turma de 1939), Igor Sresnewsky (1939), Jacob Ruchti (1940), Plínio Croce (1946), Gastão Rachou (1948), Roberto Aflalo (1950), Carlos Millan (1951), Luiz Roberto Carvalho Franco (1951) e Sidney da Fonseca (1951). Carlos Lemos (1950), então recém ingressado na faculdade, comenta a disputa do professor com o grupo de insurgentes:

Logo percebi que (Stockler das Neves) estava querendo nos cooptar; éramos dezesseis recém-chegados, para que não fôssemos influenciados pelos veteranos, menos numerosos, não chegavam possivelmente a dez alunos, dentre os quais estavam Plínio Croce, Salvador Candia, Carlos Bahiana, Gastão Rachou, todos visceralmente "desobedientes" às ordens classicizantes. Como a nova escola era parca de áreas disponíveis ao ensino, todos os alunos, novos e velhos ainda ligados à escola de engenharia, tinham suas pranchetas num mesmo salão, transformado em ateliê coletivo. Logo, logo todos se irmanaram num só bloco coeso, defensor da modernidade, afrontando o diretor, ou "dono" do curso, que, no entanto, não tinha poder nem autoridade suficiente para impedir que se projetasse dentro da contemporaneidade arquitetônica. Modernidade que não sabíamos bem como fosse, no entanto. Vivíamos, assim, numa situação esdrúxula: nossa prática nada tinha a ver com a teoria apregoada. Era uma escola ao contrário, não possuía biblioteca

10 O arquiteto Oswaldo Bratke, formado no Mackenzie em 1930, recorda que a ortodoxia do professor provocava antagonismo por parte dos alunos. Bratke foi neste momento se referenciar na obra do francês Paul Cret (1876-1945), antagonismo por parte dos alunos. Bratke foi neste momento se referenciar na obra do francês Paul Cret (1876-1945),
professor da Pensilvânia também reverenciado por Christiano. (ver SEGAWA, Hugo. Oswaldo Arthur Bratke. São Paulo: ProEditores, 1997, p.14)

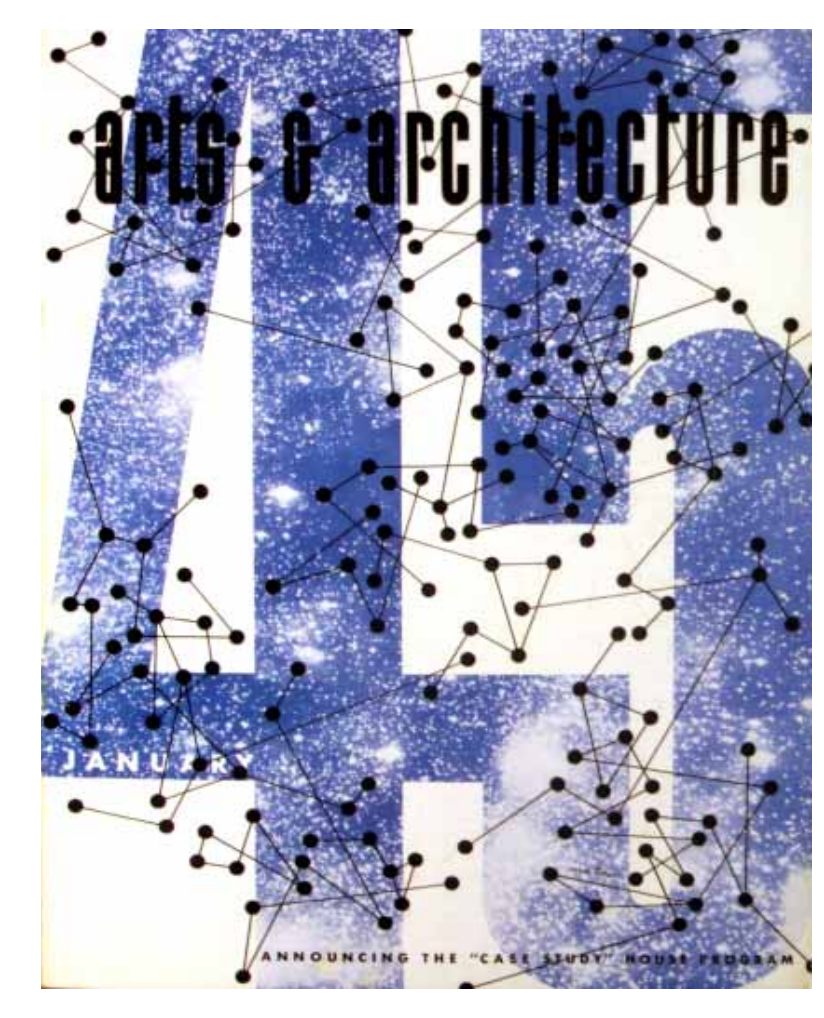

esquerda:

Arts \& Architecture. Janeiro, 1945

anúncio do programa das "Case study

houses"

fonte: SMITH, Elisabeth A. T. The Complete

Case Study Houses Program 1945-1966.

Köln: Taschen, 2002. p. 14

direita:

PILOTIS. São Paulo, n. 4, fevereiro 1950

capa de Aldo Bonadei (1906-1974) 


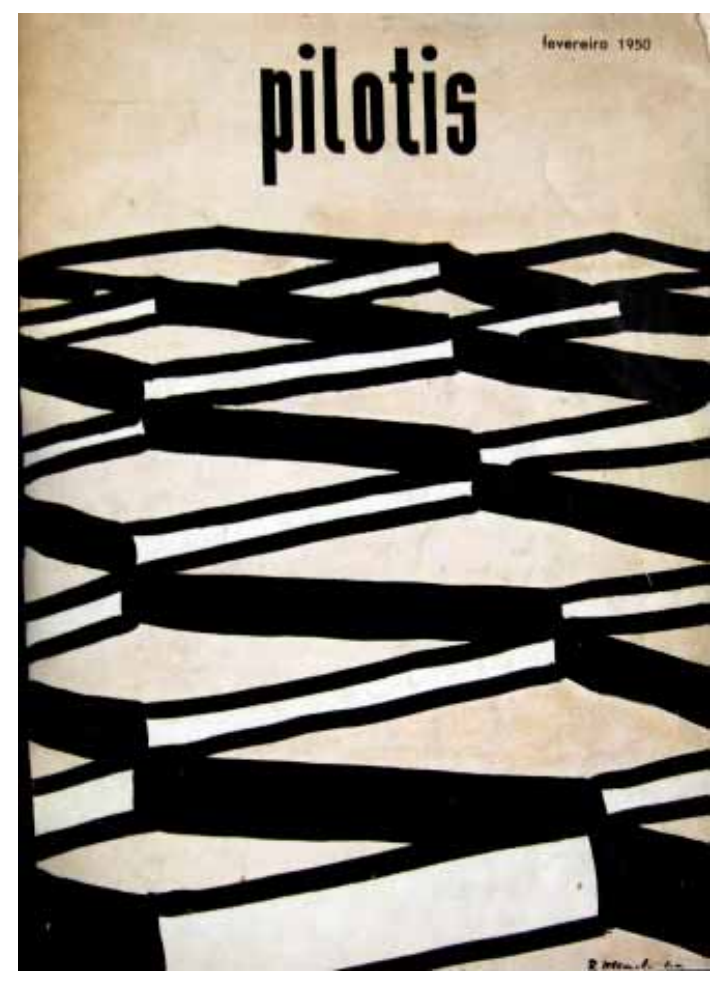

especializada e ali as revistas americanas de arquitetura moderna eram escondidas e folheadas somente quando Christiano se ausentava. Foram memoráveis as discussões desse professor com Plínio Croce, cujo projeto-tese do sexto ano (cinco de engenharia mais um ligado à especialização arquitetônica), era de um arranha-céu para escritórios. Às vezes, quase chegavam às vias de fato; no meio da gritaria, ambos baixinhos, pareciam dois galos garnisés trocando esporadas. Creio que a permanente rouquidão de Plínio começou a partir daqueles dias. ${ }^{11}$

No final da década de 40, passam a surgir manifestações organizadas dos estudantes contra a ortodoxia do curso. É nesse momento que surge a revista Pilotis, editada pelo formando Candia junto aos colegas Carlos Millan, Jorge Wilheim, Paola Tagliacozzo, Roberto Carvalho Franco e Sidney da Fonseca.

Tendo sido editada semestralmente por apenas três anos, a Pilotis ultrapassou rapidamente o âmbito universitário do Mackenzie, estabelecendo contatos de representação no Rio de Janeiro, Belo Horizonte, Recife, Lima (Peru) e Chicago (EUA), estando sediada no sobrado da rua Caio Prado, 365. Mantendo ainda um caráter fortemente combativo contra a orientação didática da faculdade, passa a promover e divulgar as artes modernas em ensaios feitos pelos próprios editores, por ensaístas convidados ou através da transcrição de autores estrangeiros sobre arquitetura, artes plásticas, música, e cinema. A linguagem gráfica adotada faz menção à revista norte americana Arts \& Architecture do editor John Entenza (1903-1984), responsável pelo célebre programa de construção das Case Study Houses (1945-66) na Califórnia. Aquela revista tivera ampla repercussão entre os arquitetos paulistanos, tendo inclusive publicado a casa de Oswaldo Bratke na rua Avanhandava em 1948. ${ }^{12}$

11 LEMOS, Carlos Alberto Cerqueira. Viagem pela Carne/ Carlos A. C. Lemos. São Paulo: Editora da Universidade de São Paulo, 2005. p. 137.

12 SEGAWA, Hugo. Oswaldo Arthur Bratke. São Paulo: ProEditores, 1997. p. 22. 
Para tratar dos diversos campos artísticos abordados pela Pilotis, o grupo contou com a participação de figuras proeminentes no cenário artístico paulistano, como os italianos Roberto Sambonet (1924-1995) e Pietro M. Bardi (1900-1999), diretor do recém fundado Museu de Arte de São Paulo; além do jovem violinista e maestro Roberto Schnorrenberg (1929-1983), que cultivaria uma grande amizade com Salvador Candia. A razão fundamental que conferia entretanto um sentido à diversidade de assuntos abordados pela revista era o embate às forças do conservadorismo, que para os estudantes estava personificado na figura de Stockler das Neves. Cumpre lembrar que o diretor exercia também um papel de certo peso no panorama político paulistano, tendo sido prefeito da cidade por um curto período em 1947, indicado pelo então governador Adhemar de Barros. ${ }^{13}$ Suas posições correspondiam, de fato, ao pensamento de uma parcela significativa da sociedade paulistana naquele momento. ${ }^{14}$

Em resposta a um abaixo assinado expedido pelos alunos em $1949^{15}$ contra o conteúdo didático do curso, o professor comenta:

Pelos termos do abaixo assinado dos alunos desta Faculdade, dirigido a este Conselho, em data de 6 de Outubro, do corrente, verificam-se os propósitos em que se acham certos alunos para a implantação do falso modernismo arquitetônico neste estabelecimento. É uma continuação do movimento de infiltração de elementos 13 Segundo Gustavo Pereira (2005), o mandato de apenas cinco meses de Stockler das Neves não logrou sustentar-se porque
fora obrigado a aumentar as tarifas do transporte público para viabilizar a criação da CMTC - Cia. Municipal de Transportes Coletivos.

14 O arquiteto Fábio Penteado, formado no Mackenzie em 1953, comenta em entrevista concedida a A. Melendez e F. Serapião em 2004: "O diretor, Christiano Stockler das Neves, proibia que fossem citados os nomes de Le Corbusier e Oscar Niemeyer. Para ele, o que os dois faziam era arquitetura comunista. Mais tarde, depreendi que, na verdade, o professor Cristiano não manifestava sua idéia, mas representava o grupo dominante da cultura paulista." In: "Como paisagem urbana, São Paulo é de uma tristeza absoluta” entrevista de Fábio Penteado concedida a A. Melendez e F. Serapião Projeto Design edição 290 abril 2004 in:<http://www.arcoweb.com.br/entrevista/entrevista55.asp> acessado em 13/01/2008.

15 A resposta emitida por Stockler das Neves encontra-se em BREIA (2005), p. 257. Não dispomos do conteúdo do abaixoassinado. 
estranhos, interessados em desrespeitar o nosso ensino, iniciado, no ano passado, após os conceitos que emitimos em nossa aula inaugural, conceitos estes contrários às duas descabidas pretensões.

Além de irreverente e impertinente, aquele documento dos alunos não exprime a verdade dos fatos.

Assim é que no item 1 afirma que nada foi feito no sentido aos caprichos individuais ou de grupos. Por isto é que se diz: Ars longa, vita brevis.

Discutido e combatido como é, não está o falso credo, anti-tradicional, em curso de consagração, em parte alguma, para ser imposto numa instituição de ensino ou na sociedade, máxime havendo divergências profundas entre os próprios apologistas, sinal evidente de que jamais atingirão seus propósitos.

O que existe por aí na construção de edifícios modernistas não convence ninguém das vantagens preconizadas e propaladas por seus adeptos. Pelo contrário, revelam flagrante incoerência que obrigam à iluminação artificial durante o dia, ou então as grandes vidraças, cujo excesso de luminosidade prejudica o sistema nervoso e os internos, conforme afirmou Carvel.

Que aspecto teriam das nossas cidades se todos os edifícios, de um lado da rua, apresentassem os inestéticos brise-soleil e do outro, grandes fachadas envidraçadas, tudo no mesmo molde futuresco?

Os maciços e os vazios, na arquitetura, representam o mesmo papel que o claroescuro, na pintura. Teríamos estruturas envidraçadas e nada mais, coisa ao alcance dos profissionais da engenharia e da indústria da construção. Para isto não é preciso qualquer conhecimento da arte. Estão deste modo, contribuindo os arquitetos modernistas para a exclusão da arquitetura, como fator de cultura e civilização das justas aspirações da classe no campo profissional.

Quem ousaria, num Conservatório de Música obrigar os professores ao ensino exclusivo da música da moda? Ousaria o aluno impor a orientação do ensino da 
música aos dirigentes do Conservatório?

Por ventura é a música moderna superior ou igual à dos grandes mestres do passado: Haydn, Beethoven, Bach, Mozart, Schumann, Chopin e outros?

Admitiria a direção do Conservatório que os alunos saíssem sem conhecer esses grandes gênios? Poderiam os modernistas prescindir dos ensinamentos que os antigos mestres nos legaram?

Está a humanidade presente em condições de igualar ou superar, nas artes em geral, aos gigantes do passado?

É o audaz Corbusier um emulo de Ictunus, Miguel Ângelo ou Garnier? Picasso, Portinari, De Chirico, etc., podem se ombrear com Rafael, Ticiano, Velazquez, Rubens, Rembrandt e outros?

De Chirico foi mais sincero, rompendo com o falso modernismo de seus companheiros de negócio.

É a igreja de Pampulha comparável à Notre Dame, Rheims, Colônia, Milão, Batalha? É o Ministério da Educação (Le Corbusier) superior ao da Fazenda que lhe fica contíguo (obra de brasileiros)?

É o prédio da C.B.I., no Anhangabaú, superior ao Banco do Estado, como concepção arquitetônica?

Tendo em vista o tipo de "salões corridos" e fachadas envidraçadas dos prédios modernistas, é ou não tal prática, uma mercantilização da arquitetura?

Há valor artístico nessas composições simplistas que justifiquem honorários profissionais idênticos às que requerem maiores estudos, tempo e despesas?

Não é a concepção arquitetônica que mais avulta no computo dos honorários profissionais dos arquitetos? E por que? ${ }^{16}$

16 Ata da $25^{\circ}$ Reunião do C.T.A., de 18 de Novembro de 1949, transcrita por Maria Teresa de Stockler e Breia. In: BREIA, Maria Teresa de Stockler e. A transição do ensino da arquitetura Beaux-Arts para o ensino da arquitetura moderna na Faculdade de Arquitetura Mackenzie - 1947-1965. 2005, Tese de Douturado - FAU USP, São Paulo. p. 257. 
No entender de Christiano, o despojamento estilístico da arquitetura moderna implicaria em uma perda gradual dos conhecimentos específicos dos arquitetos e das prerrogativas da classe no campo profissional. A renúncia à ornamentação estilística do ecletismo poderia significar o empobrecimento das técnicas construtivas e o progressivo barateamento das construções. As suas preocupações se mostraram até certo sentido pertinentes, tendo a sua própria atuação profissional sido marcada por essas mudanças. De fato, o início da sua colaboração em 1912 com Samuel das Neves após o seu retorno dos EUA, fora marcado pela adoção de uma nova postura do escritório, que passou a partir daquele momento a se apropriar de um controle mais intenso das diversas etapas da construção dos edifícios que projetava, tentando imprimir maior coesão entre partido, detalhamento e rigor construtivo. Exemplo disso são as concepções e detalhamento de estilo e ornamentação das fachadas, que eram freqüentemente atribuídas a empresas especializadas nesse trabalho, e que passaram a ser produzidas dentro do próprio escritório, preservando a coerência com o partido adotado. Há entretanto uma segunda fase na obra de Stockler das Neves, caracterizada a partir da década de 40 pela incorporação gradual de um estilo de ornamentação mais simplificado, aproximando-se do Art Déco ou do Clássico Modernizado. Esta mudança permitia a manutenção das regras compositivas tradicionais, respondendo entretanto à demanda por uma simplificação progressiva das técnicas de execução e acabamento, conforme as exigências do mercado da construção. Atendia-se também desta forma aos anseios crescentes de parte da sociedade industrial paulistana pela superação dos atributos culturais da aristocracia cafeeira, principalmente após a revolução de 1930. Segundo Pereira (2005. p. 252):

A sociedade paulista deixava de se identificar com os estilos acadêmicos utilizados até então, e que de certa maneira ficaram marcados como linguagem da aristocracia cafeeira. O Estado Novo, que se apresentava como um novo momento político- 
social, exigia uma nova forma de expressão no campo da arquitetura, que fizesse o contraponto necessário com os estilos acadêmicos, vistos como passadistas. O Art-Déco se inseria nesse contexto como uma opção mais moderada, despojada da ornamentação carregada do academicismo, mas evitando a liberdade formal e o funcionalismo do Movimento Moderno.

Ainda que tenha feito concessões às mudanças impostas pelo mercado de trabalho em sua atuação profissional, Christiano persistiu o quanto pôde na manutenção da doutrina acadêmica proferida no Mackenzie. A argumentação sentensiosa exposta na ata do Conselho Técnico Administrativo, redigida em resposta ao abaixo assinado dos alunos, teve uma réplica não menos provocativa publicada no editorial da Pilotis $n^{\circ}$ 4 de Fevereiro de 1950, com o título de "As quatro Bestas". Recorrendo de forma não menos dogmática ao aspecto moralizante que entendiam estar contido nas propostas de renovação das artes modernas, os editores da Pilotis procuram rebater um a um os exemplos levantados pelo diretor com base em novos modelos:

Toda pessoa de suficiente discernimento, que tenho tido o bom senso de se preocupar com os problemas da época em que vivemos, ter-se-á mais de uma vez perguntado qual a causa da enfermidade que aparentemente contamina a humanidade.

Mas se o mundo atual sofre de uma doença, ela nada mais e do que uma das fases de decadência pelos quais periodicamente passa a humanidade. Essa decadência tem suas razões de ser e é dela que está nascendo uma nova fase: uma fase que o jovem tem obrigação moral de analisar, a fim de se orientar e poder trabalhar na construção da sociedade que hora se está constituindo.

Porém, nossa geração encontra inúmeras dificuldades para se orientar, pois nada a ajuda; ao contrário, quase tudo dificulta, desde a má vontade dos mestres até a desconfiança e superficialidade do leigo e o comercialismo do editor. Como em toda 
fase de decadência, como em todo período pré-clássico e revolucionário, assistimos presentemente à derradeira cavalgada de quatro bestas a serviço das velharias sem sentido, do mau gosto e dos preconceitos morais e formais, resíduos estéreis de uma fase da sociedade que vem desde a revolução francesa ate nossos dias; quatro velhas e decadentes bestas que periodicamente realizam esta última e feroz cavalgada: a Má

Fé, a Presunção, a Ignorância e a Desonestidade. O barulho de suas patas ainda nos aborrece, clamando pela arquitetura que nunca existiu, a dos "Grand Prix de Rome", pela única pintura à qual os ignorantes estão habituados, aquela que se assemelha à natureza por eles vista sem fantasia, sem coração e sem cérebro; clamam pela música que não cansa e pelo cinema em que histórias piegas satisfazem sua imaginação atrofiada. Comandam aquela massa de preguiçosos e medíocres que nunca tiveram a paciência de aprender, por exemplo, que equilíbrio não significa simetria, que pintura não é literatura, que a perspectiva teve uma existência de apenas quinhentos anos, mas que nem por isso Giotto e Picasso deixam de ser mestres como Rafael ou Rembrandt. Comandam os medrosos sem iniciativa o sem vontade suficiente para aprender que a tonalidade em música, teve menos de quatrocentos anos de vida, mas que nem por isso Palestrina ou Schoenberg são menos importantes que Mozart ou Brahms.

Mas finalmente essas quatro bestas vão sendo abandonadas por suas hostes. $\mathrm{O}$ apoio dos verdadeiros mestres e a boa vontade dos honestos vai dissipando a poeira estéril dos preconceitos, que asfixia os pequenos e os fracos, aqueles que não tiveram uma oportunidade para se fortalecer. As falsidades e os preconceitos vão sendo abandonadas.

Mas, para que a nossa vida e arte deixem de ser experimentais e provisórias, para que alcancemos a nobre posição máxima atingida periodicamente pelo homem, precisamos de trabalho e de tempo. E a nós, jovens de todas as partes, cabe trabalhar para que esse tempo seja encurtado. A nós cabe o dever moral de procurar os verdadeiros mestres, partindo de um "nada sei" modesto e humilde, procurando 
educarmo-nos, mantendo o espírito jovem e esclarecido e não preconcebido e velho; tomando conhecimento de nossa verdadeira posição e responsabilidade na sociedade atual, pois hoje em dia somente aquelas quatro bestas podem acreditar na honestidade dum individualismo extremado e egoísta, numa vida dia-a-dia.

Somente assim dissipar-se-á a poeira das patas inúteis e as quatro bestas morrerão sua morte natural; e somente então o homem voltará a ser simples e verdadeiro, poderá encarar serenamente os outros homens e terá novamente confiança em suas mãos. ${ }^{17}$

A radicalidade empregada no editorial da Pilotis é representativa das aspirações deste grupo de jovens arquitetos, que procuraram embasar os seus posicionamentos através da busca de informação em figuras consagradas da arquitetura moderna internacional, como é o caso da publicação do artigo "Integrar o Homem", extraído do último capítulo de "Time, Space and Architecture" de Sigfried Giedion (1888-1968), do artigo escrito sobre a obra de Marcel Breuer por Salvador Candia, e da residência publicada de Richard Neutra (Pilotis $n^{\circ} 4$ ), cujo material inédito fora enviado pelo próprio arquiteto a pedido de seus editores:

Que Neutra nasceu em Viena e exerce suas atividades na Califórnia, tendo realizado tais e tais obras é história por demais conhecida para ser contada. O que se deve relatar é o seguinte: pelo exemplar de "pilotis" que lhe enviamos, Neutra prontamente respondeu com uma gentilíssima carta acompanhada de vinte fotografias de Julius Schulman mostrando duas de suas últimas residências - uma das quais inédita - pondo-as à disposição da revista. "Pilotis" sente-se na obrigação de registrar aqui esse fato, para dizer da comoção causada pela significância de seu gesto. ${ }^{18}$

17 PILOTIS. São Paulo, n. 4, fevereiro 1950

18 PILOTIS. São Paulo, n. 4, fevereiro 1950

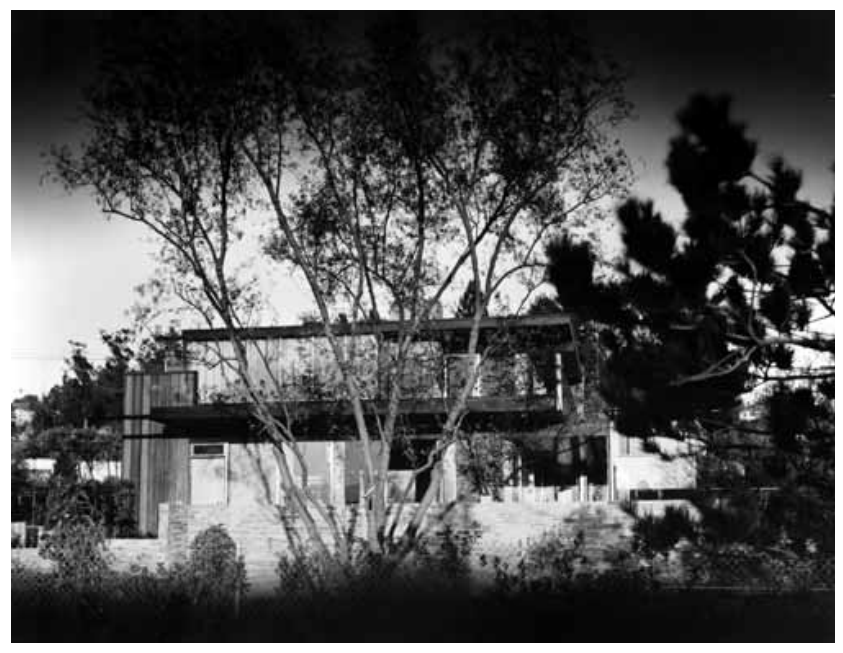




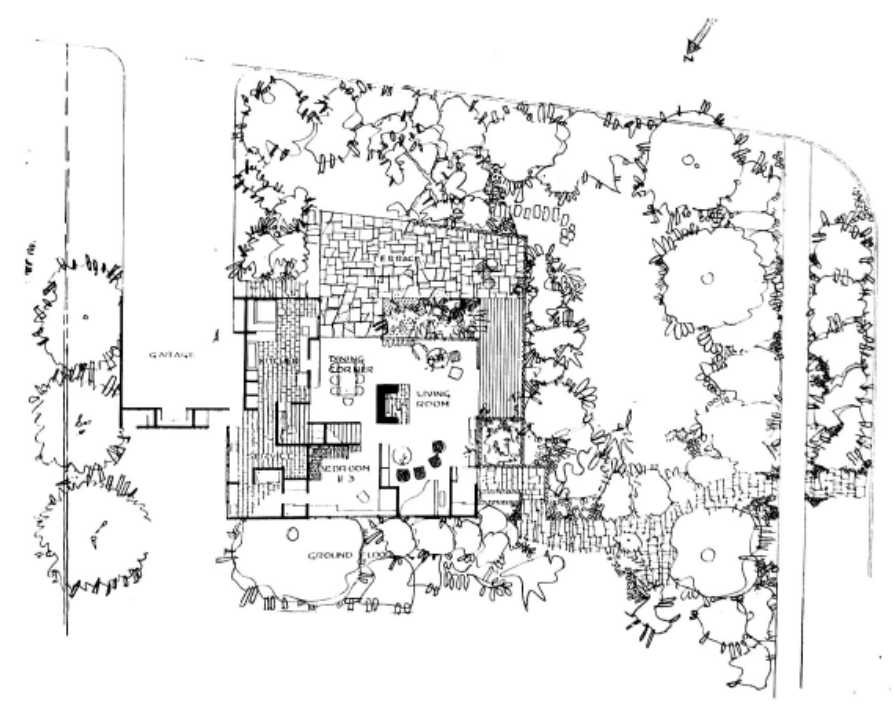

acima: Casa Treweek Richard Neutra fonte: PILOTIS. São Paulo, n. 4, fevereiro 1950

à esquerda: Casa Treweek ensaio fotográfico de Julius Schulman fonte: arquivo S. Candia, circa 1950
No número anterior enviado a Neutra, constava uma resenha de Jorge Wilheim sobre a edição brasileira de seu livro Arquitetura Social em países de clima quente. ${ }^{19}$ Esta publicação teria um impacto extremamente inspirador para o grupo, principalmente no que diz respeito ao emprego de novas técnicas e materiais de construção, e às idéias difundidas pelo arquiteto sobre arquitetura escolar.

Em seu artigo intitulado "Marcel Breuer: da Bauhaus à casa no jardim”, Candia apresenta a trajetória do arquiteto húngaro, atendo-se mais detalhadamente na análise das casas realizadas nos Estados Unidos, onde destaca alguns elementos freqüentes em sua obra como o contraste no emprego de materiais naturais e industrializados, e as experiências de arranjo do programa doméstico das casas bi-nucleadas. Estes atributos identificados por Candia na obra de Breuer estiveram presentes posteriormente na concepção de alguns de seus próprios projetos.

Encontra-se também publicado na revista Pilotis um conjunto de obras de arquitetos brasileiros, alguns dos quais estabeleceram um importante diálogo com a obra posterior dos jovens editores, como Oswaldo Bratke, Rino Levi, e Vilanova Artigas. O Studio de Arte Palma, dos italianos Lina Bo, Pietro Bardi e Giancarlo Palanti, que teve a sua loja "Insubra" publicada pela revista, atesta o interesse do grupo editorial pela arquitetura de interiores, numa inquietação que se materializou posteriormente em 1952 com a fundação da loja Branco \& Preto por iniciativa de Miguel Forte, Jacob Ruchti, Plínio Croce, Roberto Aflalo, Carlos Millan e Chen Y Hua. Conforme comenta Candia:

Naquela época, ninguém fazia arquitetura de interiores em São Paulo, numa linha moderna. Existiam apenas decoradores antiquados e uma ou outra incursão da

19 NEUTRA, Richard. Arquitetura social em paises de clima quente / Architecture of social concern in regions of mild climate. São Paulo, Gerth Todtmann, 1948 
arquiteta Lina Bo Bardi através do Studio d’Arte Palma. Ela era fixada em cadeiras e as primeiras que projetou foram colocadas no auditório do Museu de Arte de São Paulo. A Lina dedicou-se, também, à arquitetura de interiores e projetou duas lojas que nós publicamos na revista "Pilotis", para mostrar aos colegas esse tipo de trabalho. ${ }^{20}$

A Pilotis estabeleceu contato com diversos grupos que naquele momento se organizavam pela consolidação das artes modernas em São Paulo, como o Instituto dos Arquitetos do Brasil, que apoiava a publicação, e o Museu de Arte de São Paulo, na figura de seu então diretor Pietro Maria Bardi. Foi através do contato de Jorge Wilheim, que trabalhava na montagem da primeira exposição de Alexander Calder em São Paulo pelo MASP em outubro de 1948, que o grupo obteve do artista o desenho para a capa do seu terceiro número:

Ele estava com uma exposição aqui no Brasil, eu trabalhava no MASP naquela ocasião, quando o MASP inaugurou na rua 7 de Abril, ajudei na montagem da exposição junto com ele, uma exposição que foi desenhada pela Lina Bo Bardi e aí com a ousadia do jovem estudante pedi ao Calder para desenhar a capa e ele o fez (...) e só lançou Pilotis, as letras avulsas em cima da capa e depois assinou. O que valia era a assinatura. ${ }^{21}$

20 Depoimento de Salvador Candia prestado a Marlene Acayaba. In: ACAYABA, Marlene Milan. Branco \& Preto: uma história de design brasileiro nos anos 50. 1991, Tese de Doutoramento - Faculdade de Arquitetura, Universidade de São Paulo, São Paulo. p. 6-3.

21 Depoimento de Jorge Wilheim prestado a Sérgio Matera. In: MATERA, Sérgio. Carlos Millan, um estudo sobre a produção em arquitetura. 2005, Dissertação de mestrado - Faculdade de Arquitetura, Universidade de São Paulo, São Paulo. 


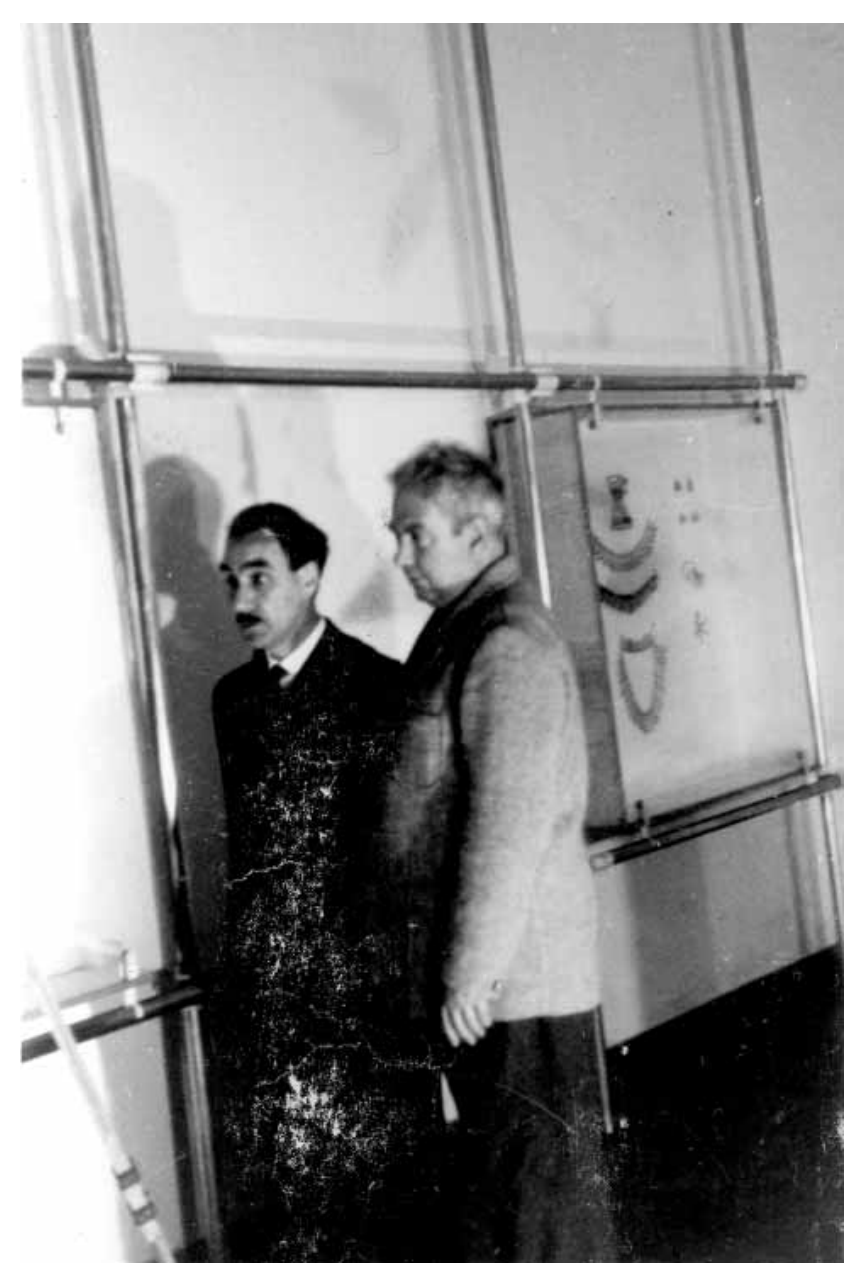

acima:

Pietro M. Bardi e Alexander Calder na abertura da exposição do escultor no Museu de Arte de São Paulo, 1948. fonte: arquivo S. Candia

à esquerda: Revista Pilotis III, 1949 capa de Alexander Calder

\section{contatos com o exterior}

Num ambiente provinciano, recorrer aos autores estrangeiros, responsáveis por uma produção muito admirada, era uma forma evidente de avalizar os trabalhos locais - além de responder à demanda primordial que havia naquele momento, anterior à construção de Brasília, sobre qual era a função do arquiteto na sociedade.22

A atuação dos colegas Miguel Forte e Jacob Ruchti, ex-alunos do Mackenzie formados respectivamente em 1939 e 1940, constituiu uma importante referência para as gerações posteriores:

Opositor radical da orientação estética de Christiano, Jacob manteve com ele polêmicas violentas. Também no ambiente estudantil paulista exerceu um papel fundamental para a introdução das discussões sobre arquitetura moderna (...) Em colaboração com o colega de classe Igor Sresnewsky, Jacob publicou na "Revista de Engenharia Mackenzie" com o título de "Arquitetura Funcional", um resumo do artigo "New Building Art in Califórnia", de Richard Neutra, escrito em 1935. Esse foi um dos primeiros textos divulgados em São Paulo que veiculou as idéias de um arquiteto estrangeiro com orientação moderna. ${ }^{23}$

Figura importante na formação de Salvador Candia, Jacob era filho do arquiteto suíço Frederico Ruchti, que tendo se formado na Technische Universität de Berlin

22 ACAYABA, Marlene Milan. Branco \& Preto: uma história de design brasileiro nos anos 50. 1991, Tese de Doutoramento - Faculdade de Arquitetura, Universidade de São Paulo, São Paulo. p. 5-25.

23 IDEM. p. 5-4. 
viera ao Brasil em 1919 trabalhar para a família Klabin ${ }^{24}$. Frederico tornou-se amigo de Gregori Warchavchik (1896-1976), arquiteto russo recém imigrado que casara-se com Mina Klabin em 1927. Jacob trabalhou então com Warchavchik, através do qual conheceu o arquiteto Vilanova Artigas, tendo sido também apresentado a diversos artistas como Bonadei, Volpi e Di Cavalcanti ${ }^{25}$. Filho de mãe russa, Ruchti aprendeu diversas línguas e teve acesso a uma rica formação cultural através dos seus pais. Atuou intensamente junto ao meio artístico paulistano a partir de meados da década de 30, tendo participado posteriormente da criação da Escola de Design do Instituto de Arte Contemporânea do MASP em 1951 como professor de Composição. Teve também uma atuação importante na organização das Bienais de Arte promovidas pelo MAM-SP a partir do mesmo ano.

Em 1947 Ruchti e Forte empreenderam uma longa viagem de estudos aos Estados Unidos, onde travaram contato pessoal com diversos expoentes da arquitetura e das artes modernas atuantes naquele país. Visitaram obras de Richard Neutra (Palm Spring), Marcel Breuer e Walter Gropius (Boston), e a extraordinária oficina de esculturas de Alexander Calder (Roxbury), cujo trabalho fora entusiasticamente divulgado por Rino Levi e Henrique Mindlin no Brasil. Encontraram o então diretor do museu de arte moderna de Nova York Phillip Johnson (1906-2005), que haviam conhecido ocasionalmente em sua visita ao Brasil na casa de Mina e Gregori Warchavchik.

Porém a experiência que mais profundamente marcou a dupla de jovens arquitetos neste tour pela América foi o encontro com Frank Lloyd Wright (1867-1959) em sua comunidade de aprendizes de Taliesin East (Wisconsin), onde ficaram hospedados e puderam vivenciar as formas de trabalho e de ensino empregadas pelo velho mestre.

\footnotetext{
24 MACHADO, Lélio Reiner. Depoimento prestado ao autor em 16-01-2008. (Reiner Machado foi sócio de Jacob Ruchti entre 1966-1974)

25 ACAYABA, Marlene Milan. Branco \& Preto: uma história de design brasileiro nos anos 50. 1991, Tese de Doutoramento
} - Faculdade de Arquitetura, Universidade de São Paulo, São Paulo. p. 5-5

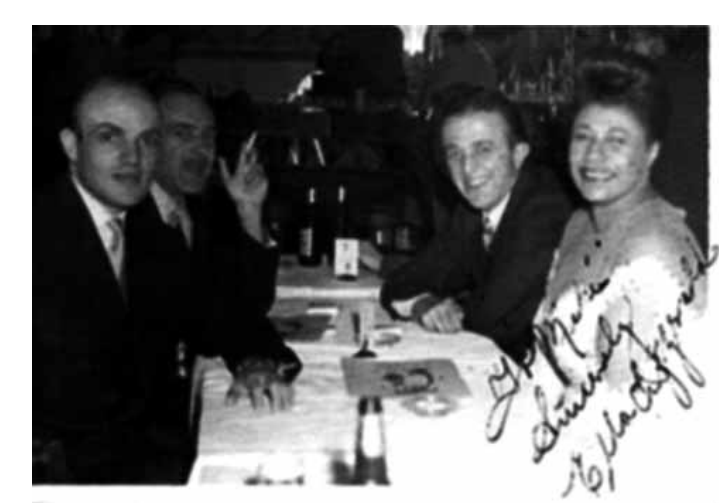

acima:

Miguel Forte, Jacob Ruchti, Ella Fitzgerald, e Renato Fileppo, 1947. Os arquitetos conheceram a cantora no Club Downbeat, em Nova York p. 121

fonte: Junqueira, Monica. DOCOMOMO, Porta Retratos: Miguel Forte, In:<http://www.docomomo.org.br/portar etratos\%20M\%20Forte.htm > Consulta em 13/12/2007 
Finda a viagem, a força das idéias de Wright permaneceria presente em incursões posteriores de Jacob Ruchti e, de forma mais notória, em Miguel Forte.

Naquele mesmo ano Salvador Candia, ainda estudante, realizou uma viagem de estudos aos Estados Unidos e à Europa, onde pôde vislumbrar o iminente processo de reconstrução do II pós-guerra. Com base em alguns registros de que dispomos sobre esta viagem, ${ }^{26}$ pode-se inferir que Candia acompanhou a comitiva de arquitetos organizada pelo IAB naquela ocasião. No retorno, o instituto promoveu uma exposição das fotografias da viagem na galeria Prestes Maia, em São Paulo. Candia trabalhava naquele momento como estagiário no escritório de Rino Levi, que integrou a organização do roteiro:

Em 1947, com colegas do IAB-SP, Levi organizou uma viagem para a Europa. Ao longo de mais de dois meses visitaram Roma, Florença, Veneza, Milão, seguindo para a Suíça, França, Bélgica, Holanda, Inglaterra, Portugal e retornando ao Brasil por Nova Iorque. Sendo sua primeira viagem à Itália desde o período de escola, Levi reencontrou alguns de seus antigos colegas, presenciando a reconstrução italiana e européia. ${ }^{27}$

Alguns registros fotográficos atestam o contato do jovem estudante com obras fundamentais do movimento moderno, além da visita a cidades referenciais da historiografia urbanística e arquitetônica, como Veneza e Paris. Em uma das fotos identifica-se, entre uma profusão de projetos, pranchetas e modelos, o atelier de Le Corbusier (1887-

26 Foram localizadas algumas fotografias que participaram da exposição da viagem organizada pelo IAB, além de algumas anotações em livros adquiridos na viagem. Segundo o anúncio da mostra em diversos jornais da época (ver páginas seguintes), os arquitetos teriam também estendido sua viagem ao Peru. Não sabemos se Candia acompanhou toda a excursão, mas provavelmente o seu contato com Eduardo Meira Alva, correspondente peruano da "Pilotis", se deva a esta viagem.

27 ANELLI, Renato; GUERRA, Abílio. Rino Levi: Arquitetura e Cidade. Fotos: Nelson Kon. São Paulo: Romano Guerra, 2001. p 32. 

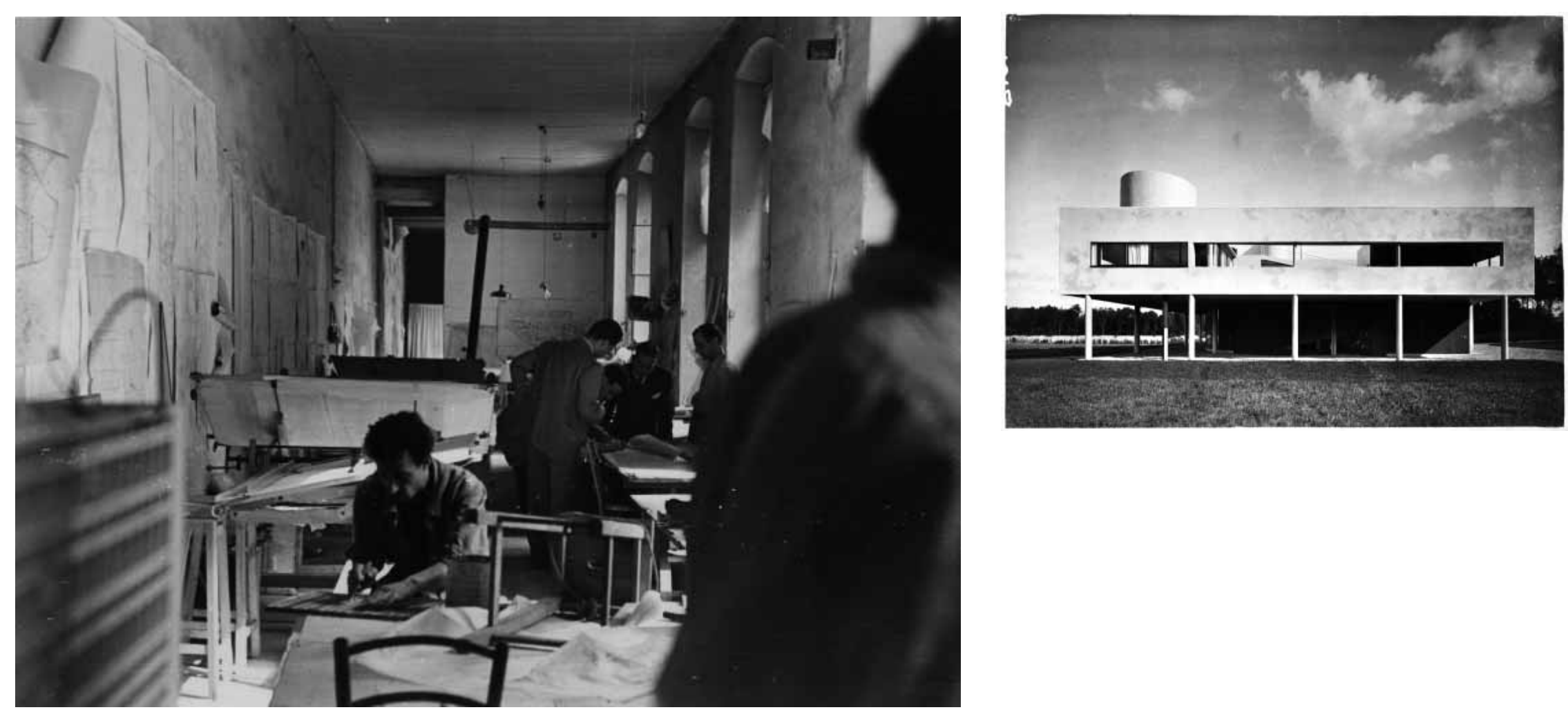

esquerda:

Atelier de Le Corbusier, rue de Sèvres, Paris.

fonte: arquivo S. Candia

centro:

Ville Savoye, Poissy. Le Corbusier, 1929-31

fonte: arquivo S. Candia

direita:

Anúncio no Jornal Gazeta, São Paulo.

fonte: arquivo S. Candia 


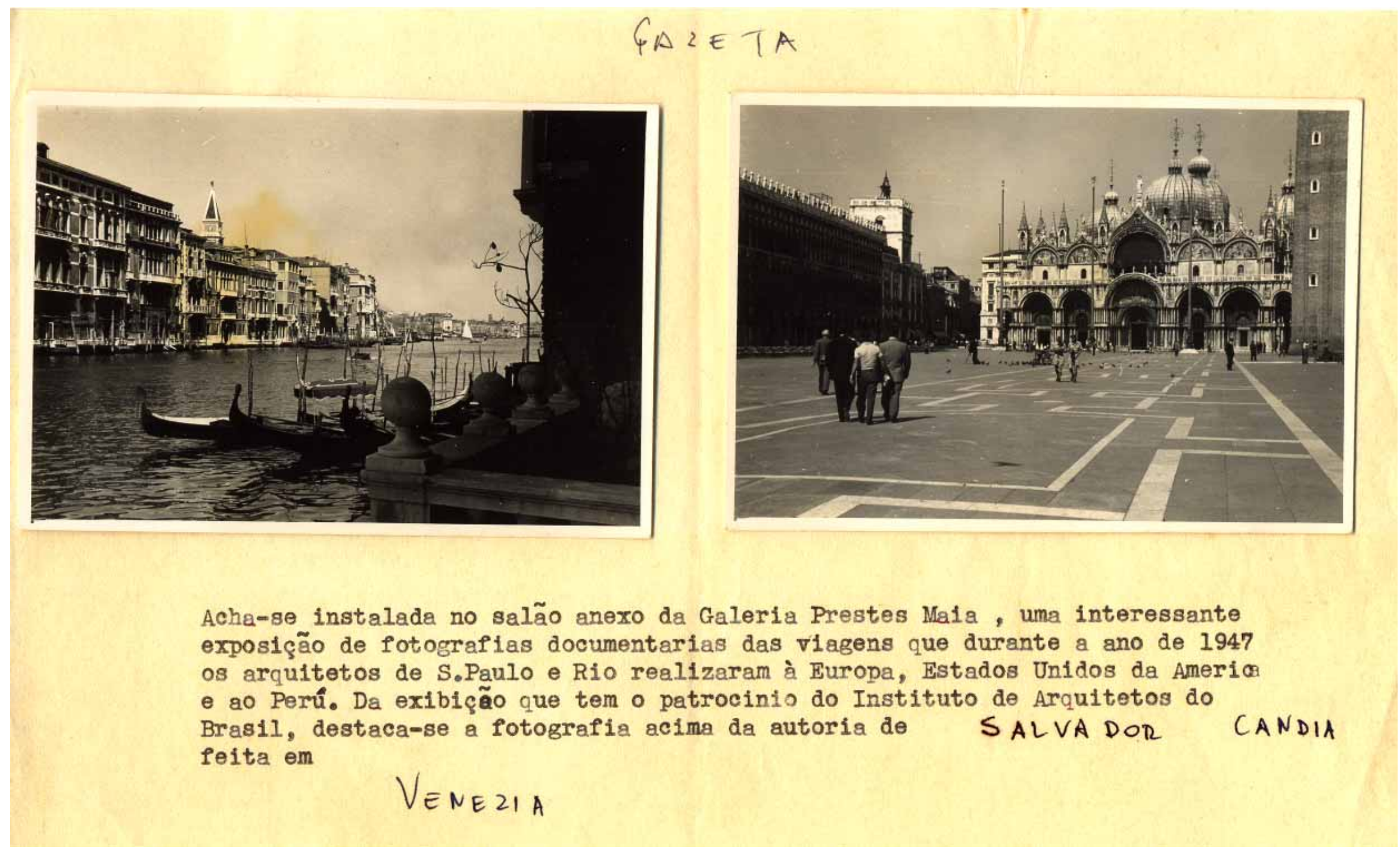


1965) na rue de Sèvres, Paris. Sobre este arquiteto Candia escreveria posteriormente, em reportagem publicada por ocasião do centenário de seu nascimento:

Pela sua arrebatada personalidade, pelo espírito barroco e o amor ao discurso, características de nossa formação - de todas as estrelas do movimento de arquitetura moderna, para os brasileiros Le Corbusier foi a mais cintilante.

(...) A capela de Ronchamp é uma quase escultura abstrata. LC trabalhou cinco anos a partir do projeto que esteve na primeira Bienal de São Paulo, mudando, refazendo, retocando. Pronta, todo o lirismo corbusiano, esplende sobre a colina. Encimada por poderosa voluta que lhe serve de cobertura, estão as largas enseadas de muros côncavos, torres semi-cilíndricas, todas em muros brancos, rugosos, com sulcos e aberturas que criam sombras. Dentro, o volume como negativo das superfícies descritas, onde se insinuam luzes através de pequenos vidros de cor: Egeu e Bizâncio.

Memória, criação e amor. A nave de Deus chegara. ${ }^{28}$

Reconhecendo a importância do diálogo estabelecido entre Corbusier e os arquitetos brasileiros, particularmente no Rio de Janeiro através da construção do edifício do Ministério da Educação e Saúde Pública em 1936, Candia reverencia neste artigo a força lírica empregada na experimentação formal de Ronchamp (1950-53), embora a sua obra fosse se pautar mais propriamente pelas idéias "racionalistas" defendidas pelo arquiteto suíço, aqui representadas por dois edifícios urbanos que Candia iria visitar ainda em 1947: o Pavilhão Suíço da cidade universitária de Paris (1930-32) e o edifício em Porte Molitor, Paris (1933), que seria também posteriormente lembrado por Candia naquela mesma reportagem quarenta anos depois: "O prédio com sua residência no alto, na Porte Molitor, tantas vezes reproduzido no Brasil.” É interessante notar que estes dois

28 CANDIA, Salvador. Roteiro de um arquiteto. Folha de São Paulo, São Paulo, 19 Set. 1987.
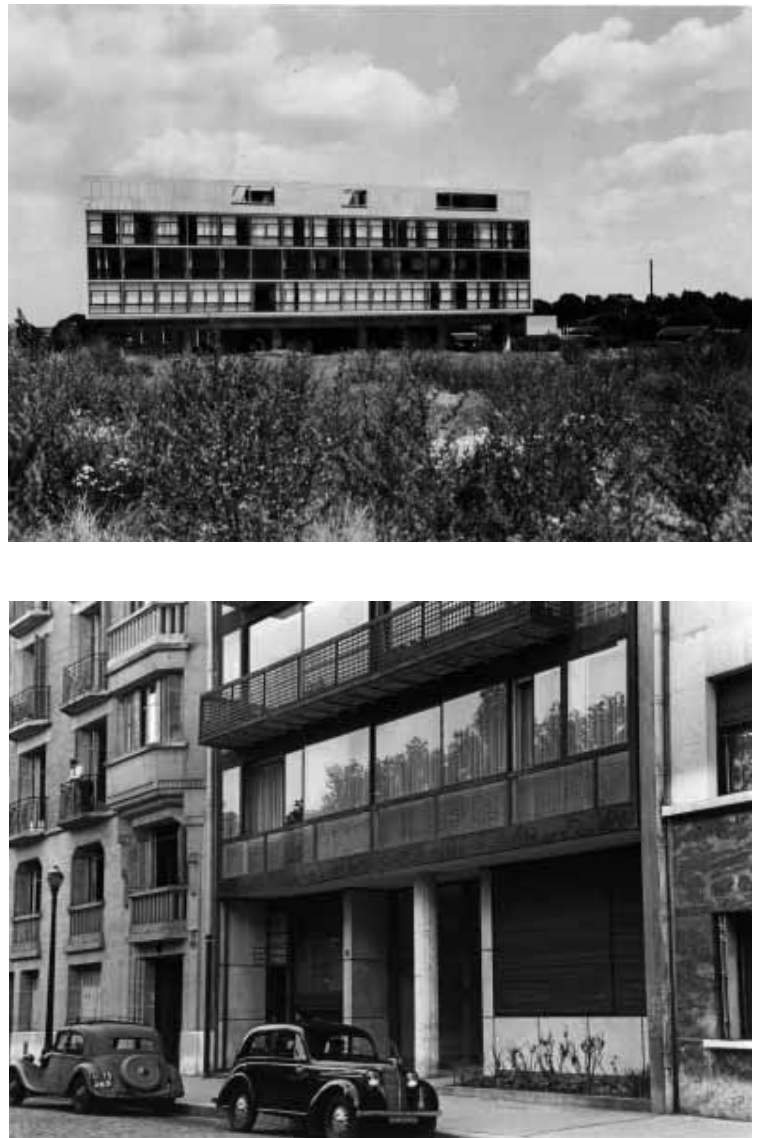

acima (esta e a próxima página):

Pavilhão Suísso na Cidade Universitária de Paris.

Le Corbusier, 1930-32.

fonte: arquivo $S$. Candia.

abaixo (esta e a próxima página)

Edifício Porte Molitor, Paris.

Le Corbusier, 1933.

fonte: arquivo $S$. Candia. 

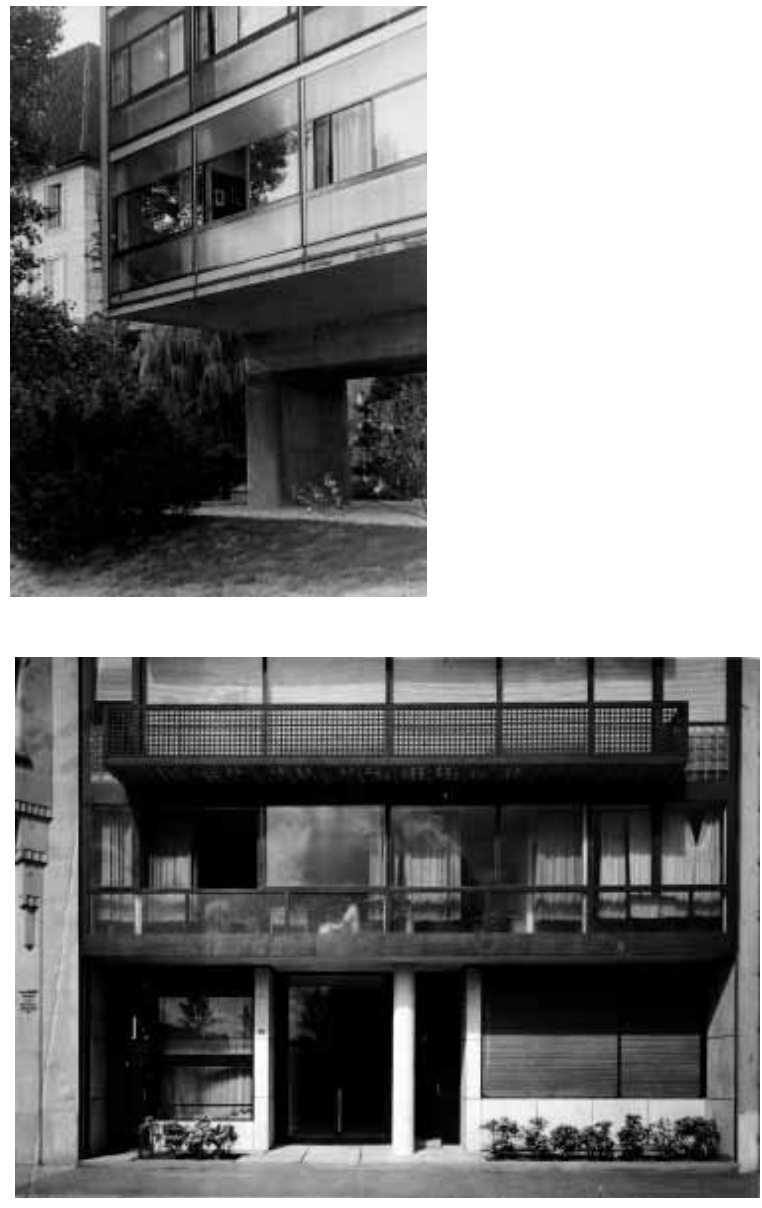

edifícios, quase contemporâneos, representam duas formas distintas de se construir a cidade: o pavilhão dos estudantes na Cidade Universitária prefigura a idéia de liberar o rés-do-chão para devolvê-lo ao domínio público, conforme se veria representado em tantos projetos urbanos de Corbusier. O Porte Molitor assume uma postura diversa, colando-se aos edifícios vizinhos e deles tirando proveito plástico: estando solidário à estrutura urbana existente, suas qualidades se reforçam por contraste. Através do recuo de seu pavimento térreo para abrigar o acesso, da construção do terraço-jardim na cobertura, da criação de grandes aberturas em níveis variados de opacidade e transparência com o uso de novos materiais, o edifício se destaca fortemente de seu entorno, embora respeitando a estrutura urbana existente. Em relação a este procedimento, cabe lembrar a relevância no Brasil da obra do arquiteto alemão Franz Heep (1902-1978), atuante em São Paulo desde meados da década de 40, de quem Candia posteriormente guardaria uma profunda admiração e amizade. Tendo trabalhado com Adolf Meyer nas grandes obras de urbanização empreendidas em Frankfurt nos anos 20, e colaborado com Corbusier na execução de algumas de suas obras no final dos anos 30, Heep soube interpretar em seus projetos brasileiros alguns dos conceitos apreendidos principalmente em sua colaboração com o mestre suíço, tendo empregado de forma pioneira em São Paulo o uso dos quebra-sóis móveis em toda a extensão de uma fachada numa obra de grande escala - a exemplo do já citado MESP - na sede do jornal "O Estado de São Paulo", realizado para o escritório de Jacques Pilon em 1946. ${ }^{29}$ A obra de Heep oferece notáveis exemplos de edifícios modernos magistralmente inseridos na trama urbana existente, tendo contribuído de maneira decisiva para a formação do repertório formal presente na obra de Salvador Candia.

Mas foi no entanto no retorno dessa viagem de estudos de 1947, em sua passagem posterior por Nova York, que o arquiteto teria estabelecido seus contatos mais

29 BARBOSA, Marcelo Consiglio. A obra de Adolf Franz Heep no Brasil. 2002, Dissertação de Mestrado - Faculdade de Arquitetura, Universidade de São Paulo, São Paulo. p. 35. 
significativos:

Em sua viagem a Nova York, Salvador Candia descobriu Bernardo Rudovsky, arquiteto austríaco que tinha morado em São Paulo antes da guerra, mas tinha ido embora, pois não via futuro no Brasil. Em seu período paulista, construiu as casas Arnstein e Frontini publicadas entre os quarenta projetos modernos que representaram a arquitetura brasileira, no livro Brazil Builds, elaborado pelo Museu de Arte Moderna de Nova York em 1942. Fora viver nos Estados Unidos, graças ao móvel que desenvolveu para a loja Casa \& Jardim (...) Através desse contato, Candia conheceu a revista Interior's dirigida por Rudovsky e alguns arquitetos americanos (...) Também em Nova York, através de Henrique Mindlin, Candia conheceu Phillip Johnson que, tal qual um arauto de Mies van der Rohe, organizava uma grande exposição do mestre alemão. Era a primeira vez, fora da Alemanha, que a obra de Mies era exibida, com a intenção de apresentá-lo como um dos mestres da arquitetura moderna. Candia não chegou a ver essa mostra, mas como sócio do museu recebeu o catálogo. Identificado com a obra de Mies, tornou-se um miesiano. As possibilidades da Indústria, a simplicidade geométrica e a clareza na ordenação o atraíram. Anos depois, construiu edifícios a partir dessa influência. ${ }^{30}$

O contato com Bernard Rudofsky (1905-1988) certamente abriu os horizontes do jovem estudante quanto às possibilidades de atuação profissional; desde as incursões do arquiteto austríaco sobre o universo do design através da produção de mobiliário, logotipos, calçados e acessórios femininos (Bernardo Sandals, 1946-64), até sua participação em diversas publicações sobre arquitetura, artes e decoração (a revista Interior's, assim como a Arts \& Architecture de John Entenza fomentaram a criação da Pilotis no

30 ACAYABA, Marlene Milan. Branco \& Preto: uma história de design brasileiro nos anos 50. 1991, Tese de Doutoramento - Faculdade de Arquitetura, Universidade de São Paulo, São Paulo. p. 5-9 


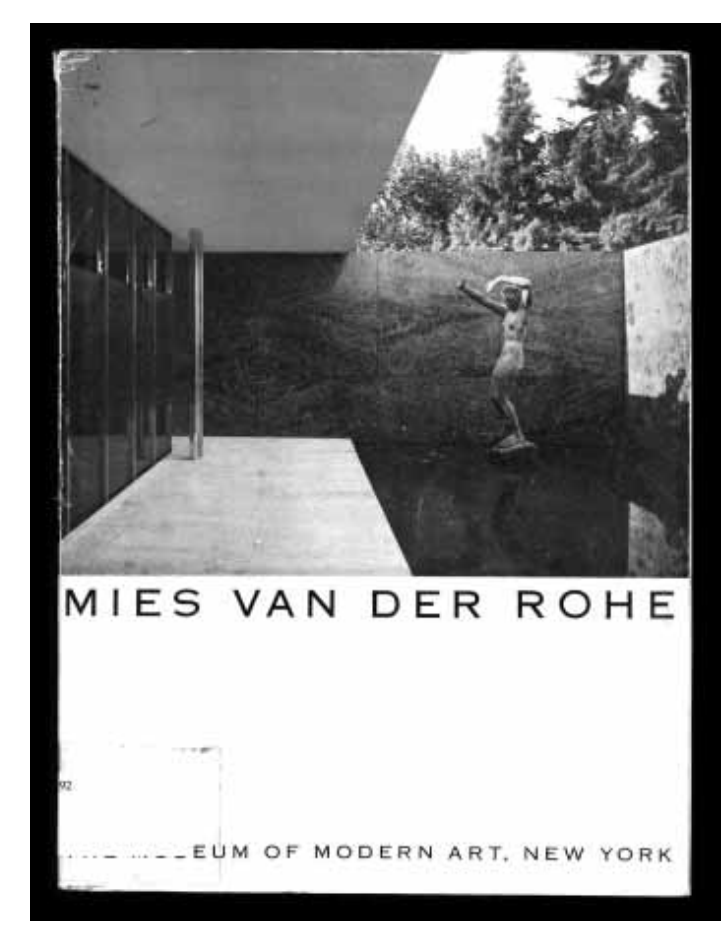

JOHNSON, Philip C. Mies van der Rohe. Nova York: The Museum of Modern Art, 1947. ano seguinte). A pesquisa empreendida por Rudofsky sobre o universo doméstico, do desenho dos móveis até a construção de uma série de casas onde experimenta a organização do programa em torno de pátios referenciados em estudos sobre a arquitetura vernacular mediterrânea, também teria rebatimento nas casas projetadas por Candia, conforme veremos.

Sua aproximação com a obra de Ludwig Mies van der Rohe (1886-1969), através do catálogo da exposição do MOMA de 1947, ${ }^{31}$ teve um impacto significativo para o desenvolvimento posterior de seu trabalho. Auto definindo-se como miesiano, o arquiteto procuraria interpretar, através de seus projetos, determinados aspectos da linguagem plástica e construtiva desenvolvida pelo mestre alemão principalmente em sua fase norte-americana, compreendendo-os dentro das circunstâncias do clima e da indústria da construção locais. Conforme demonstraremos adiante, esta referência inicial soma-se à participação de diversas outras contribuições em sua trajetória profissional.

Em 1956, Candia obteve através de uma bolsa Fullbright do governo norte-americano um estágio no Departamento de Arquitetura do M.I.T. (Massachusetts Institute of Technology) em Cambridge, EUA. ${ }^{32}$

Registros fotográficos de viagens de estudos posteriormente empreendidas por Candia em diversos momentos de sua carreira testemunham uma preocupação constante em conhecer e vivenciar os exemplos aos quais por vezes se referia em sua atividade como professor e como arquiteto.

\footnotetext{
31 ver imagem anexa
}

32 Este estágio no M.I.T. é erroneamente mencionado como sendo no "Haiti", na apresentação do arquiteto publicada por ocasião de um conjunto de depoimentos prestados por diversas gerações ao IAB em 1979. In: ARQUITETURA e Desenvolvimento Nacional. Depoimentos de arquitetos paulistas. IAB-SP, São Paulo: Editora Pini LTDA, 1979. Depoimento de Salvador Candia. 


\section{- Museu de Arte Modema e as Bienais}

E a Bienal tem cumprido assim os seus desígnios, como as outras bienais. Como instrumento de penetração imperialista, vem oferecer à burguesia brasileira amedrontada o cosmopolitismo como arma de combate ao povo, ao mesmo tempo que faz um grande negócio, colocando em nosso mercado a sua produção, aniquilando a nossa cultura, escravizando o nosso povo. ${ }^{33}$

No artigo intitulado "A Bienal é contra os artistas brasileiros" publicado em Fundamentos, Revista de Cultura Moderna (São Paulo, n. 23, ano 4, dez. 1951), Vilanova Artigas expõe os antagonismos que marcaram a recepção, entre os artistas paulistanos, das primeiras Bienais internacionais promovidas pelo Museu de Arte Moderna de São Paulo a partir de 1951. O debate em torno do comprometimento político e social dos artistas brasileiros havia se acirrado a partir do fim da década de 40, com a inauguração de duas exposições dos artistas abstracionistas estrangeiros Alexander Calder (em exposição que antecedeu sua vinda a São Paulo em outubro de 1948) e Max Bill, no Rio de Janeiro e São Paulo, respectivamente.

O realismo nas artes plásticas, defendido como meio de comunicação social e atuação política pelas revistas Fundamentos (São Paulo), Horizonte (Porto Alegre) e Joaquim (Curitiba), estava associado à idéia de se fomentar a constituição de uma arte genuinamente brasileira e popular, como forma de resistência à crescente influência cultural norte-americana no contexto da Guerra Fria iminente. Segundo Amaral (2003):

O realismo é visto, nesse pós-guerra, como um novo humanismo visível na arte, em 33 ARTIGAS, João Batista Vilanova. Caminhos da arquitetura/ Vilanova Artigas (organização José Tavares Correia de Lira, Rosa Artigas). São Paulo: Cosac Naify, 2004. à direita acima:

BIENAL DO MUSEU DE ARTE MODERNA DE SÃO PAULO. Catálogo Geral (segunda edição).

São Paulo: EDIAM - Edições Americanas de Arte e Arquitetura, 1951

à direita abaixo:

II BIENAL DO MUSEU DE ARTE MODERNA DE SÃO PAULO. Catálogo Geral.

São Paulo: EDIAM - Edições Americanas de Arte Arquitetura, 1953 

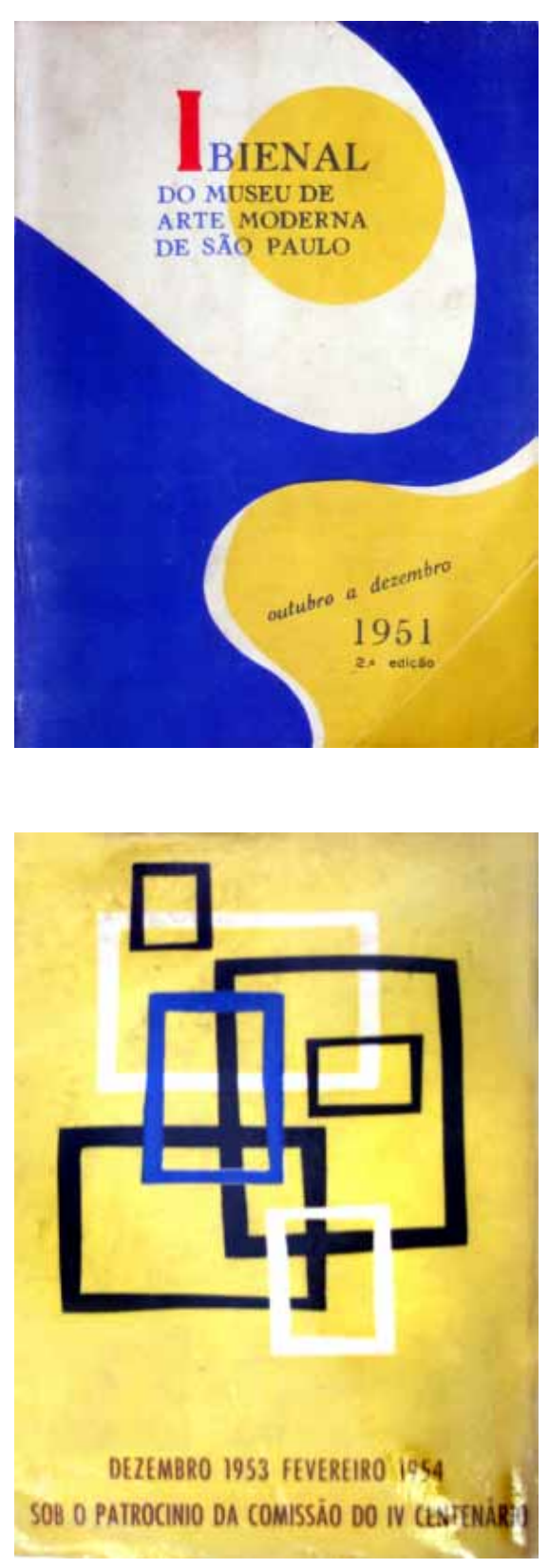

contraposição à conflagração sangrenta de que saía o mundo, e em cujo desfecho a tecnologia mortífera acenara com um engenho traumatizante, como a bomba atômica. ${ }^{34}$

De fato, o Museu de Arte Moderna esteve, desde a sua fundação, diretamente vinculado ao aporte cultural norte-americano. Assim como a sua versão carioca, o museu teve o acervo constituído a partir de uma doação em 1946 de Nelson Rockefeller, então presidente do MOMA de Nova York, que emprestou também seu estatuto para a constituição jurídica dos novos museus. ${ }^{35} \mathrm{~A}$ iniciativa de trazer tal empreendimento a São Paulo deveu-se fundamentalmente à atuação de Francisco Matarazzo Sobrinho, dono da metalúrgica Metalma, que representava naquele momento as aspirações da próspera burguesia industrial paulistana, de se aproximar daquela esfera de influência.

O arquiteto Julio Katinsky (1932), que foi aluno de Plínio Crocce na FAU USP em meados da década de 50, comenta a atuação do professor, e do grupo de colegas que compartilhavam das mesmas idéias - ao qual Candia pertencia - e os antagonismos que passariam a se criar a partir daquele momento entre os arquitetos (Acayaba, 1994. p. 1):

Essa, pois, me parece era sempre sua intenção: transmitir concretamente aos alunos seu entusiasmo pelo trabalho, sua confiança genuína em que pelo trabalho sempre se conseguiria chegar a soluções satisfatórias. Plínio fazia e refazia uma solução até concluir finalmente pelo que lhe parecia ser o melhor partido. "Arquitetura é detalhe",

34 AMARAL, Aracy, Arte para quê? : A preocupação social na arte brasileira, 1930-1970: subsídeos para uma história social da arte no Brasil. São Paulo: Estúdio Nobel, 2003. p. 239.

35 BIANCHI, Ronaldo. MAM, Uma história sem fim. 2006, Dissertação de Mestrado - Pontifícia Universidade Católica, São Paulo. 
vivia repetindo. Muitos anos depois, eu surpreendi Salvador Candia dizendo: "Deus está no detalhe". O outro traço comum era a firme convicção (acredito que a todos os integrantes do grupo) de que o futuro da humanidade era o presente dos Estados Unidos da América. Penso que o entusiasmo comum por Frank Lloyd Wright advinha não só daquela mesma visão protoluterana do trabalho (tão impregnada na cultura saxônica), como da pregação democrática que o arquiteto americano exprimia em seus escritos.

Ouso dizer que conservei o respeito e a amizade pelo Plínio, mesmo quando me afastei dessas posturas que lhe eram tão caras. Talvez, da minha turma era eu o que mais conversava com ele e lembro-me bem de sua reação, como se tivesse recebido um inesperado golpe, quando eu lhe disse abruptamente: "Arquitetura não é detalhe". E penso que posso dizer o mesmo de Plínio Croce em relação a mim. Nossas relações ao longo de mais de trinta anos foram marcadas por um convívio afetuosamente respeitoso. É que então eu começava a me identificar com um outro movimento da arquitetura em São Paulo, mais bafejado pelas ideologias que se forjavam na Escola Politécnica e que viam na atividade dos engenheiros e arquitetos uma contribuição para a construção da cidadania (...) Esse compromisso entre profissão e cidadania que parecia aos nossos olhos de estudantes uma contribuição do novo pensamento de esquerda (...)

Mas esses dois grupos, devido à instalação da guerra fria, cada vez mais se olhavam com mais desconfiança (os "americanos" seriam "pró imperialismo", os "nacionais" seriam "pró cripto bolchevismo"), até desembocar em mútuo diálogo de surdos quanto às idéias e em acirrada competição quanto às relações cotidianas. E assim perdeu-se grande parte da consciência de que suas utopias eram partes complementares de uma mesma generosa visão da cultura e da sociedade.

Somente depois de 1970 os abismos foram sendo timidamente transpostos. 
A fundação do museu em 1948 contou todavia com a participação maciça de artistas e intelectuais, entusiasmados em dotar a instituição de um caráter educativo e popular, no intuito de promover o acesso às artes contemporâneas através de cursos, palestras e exposições. A mesma revista Fundamentos viria a comentar essa iniciativa em seu editorial (Amaral, 2003. p. 238): "Essa realização elogiável coloca nossa capital na posição pouco comum mesmo entre as grandes cidades, de possuir uma organização autônoma, inteiramente dedicada à manifestações modernas nos diversos campos da arte". O Museu deveria, deste modo, "incentivar o gosto artístico no campo da plástica, da música, da literatura e da arte em geral."

Salvador Candia integrou o grupo de arquitetos envolvidos na sua fundação, junto com Eduardo Kneese de Melo (então presidente do IAB), Rino Levi, Gregori Warchavchik, Luiz Saia, Galiano Ciampaglia, Miguel Forte, Jacob Ruchti, Gastão Rachou, Carlos Cascaldi e Vilanova Artigas, este último responsável pelo projeto de reforma para as novas instalações do museu no edifício dos Diários Associados na rua 7 de Abril em 1949.

O projeto de se empreenderem as grandes mostras internacionais a exemplo da Bienal de Veneza, já estava presente desde o momento de fundação do Museu, e para muitos representava uma forma de legitimação cultural e de integração efetiva com o universo das artes, para além das barreiras do provincianismo. Em entrevista prestada a Marlene Acayaba (1986) Candia comenta o seu entusiasmo com as Bienais e com o MAM, a partir de sua primeira visita à sede provisória da instituição em 1948:

Candia mencionou Ciccilo Matarazzo: um homem pouco culto mas muito generoso. E o impacto da visita à Metalurgica Matarazzo, onde viu pela primeira vez trinta quadros de Kandinsky. Da mesma forma referiu-se à II Bienal de São Paulo, quando, além da famosa Guernica, estavam expostos setenta quadros de Picasso. Neste ano havia pinturas de Klee, uma pequena retrospectiva do movimento cubista, mais os 
Marino Marini, os Calder e os Henry Moore. O meio artístico fervilhava e não media esforços para receber os estrangeiros que compareceram. Na III Bienal estiveram presentes, entre outros, Walter Gropius, Alvar Aalto, Herbert Read. ${ }^{36}$ Durante as Bienais, o trabalho nos escritórios era suspenso. Pela manha, os "iniciados" assistiam a filmes franceses e italianos projetados no cine Marrocos, à tarde ciceroneavam os convidados e à noite frequentavam religiosamente a Bienal. ${ }^{37}$

Como membro do Conselho Administrativo do MAM, Candia participou ativamente da organização das Exposições Internacionais de Arquitetura, tendo integrado o júri de Premiação do Concurso Internacional de Estudantes de Arquitetura e o Júri de Seleção, na II Bienal (1953-54), e o Júri de Premiação do concurso de estudantes de arquitetura da III Bienal (1955).

A exposição de 1953-54 foi particularmente marcante entre as primeiras Bienais. Caracterizada como a "Bienal do IV centenário", ela antecipou a inauguração do vasto programa de obras públicas e eventos comemorativos de 1954, tendo sido considerada pelo crítico Mário Pedrosa como “a maior exposição de arte moderna que se fez no mundo durante a década" ${ }^{38}$. Além do impacto provocado pela presença das obras de Picasso, Mondrian, Klee, Braque, e os escultores Alexander Calder e Marino Marini, a exposição contou com uma mostra especial de Henry Moore organizada por Herbert Read, premiada em sua categoria. Aproveitando a presença do escultor em São Paulo, organizou-se em Janeiro daquele ano uma excursão pela baixada santista. O grupo de ciceroni era formado, entre outros, por Candia, Croce, e o pernambucano Delson Lima,

\footnotetext{
36 Há nesse trecho uma provável confusão do transcrevente, em relação à data de participação destas três personalidades, que na verdade estiveram presentes da II Bienal (1953-54). Nota do autor.

37 ACAYABA, Marlene Milan. Dois arquitetos, duas experiências. Revista Projeto, São Paulo, n. 85, 1986.

38 SARAIVA, Roberta (org.). Vários autores. Calder no Brasil: crônica de uma amizade. São Paulo: Cosac Naify/ Pinacoteca do Estado, 2006. p. 159
}

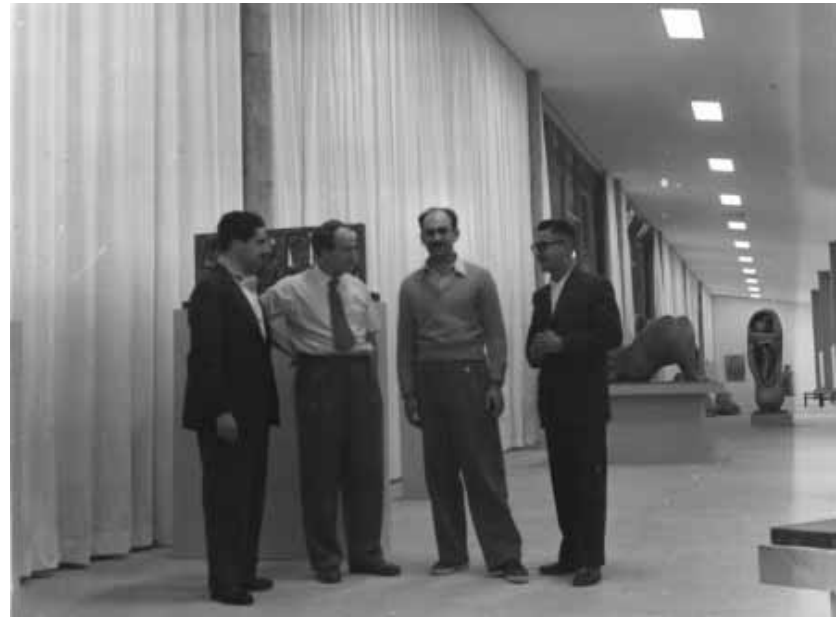

acima:

Salvador Candia, Henry Moore e Jacob Ruchti. II Bienal parque Ibirapuera, 1953. Foto enviada a Salvador Candia por Delson Lima em Janeiro de 1954. fonte: arquivo S. Candia

à direita acima:

Henry Moore, Salvador Candia e possivelmente Roberto Aflalo. Visita ao Guarujá, 1953. Foto enviada a Salvador Candia por Delson Lima em Janeiro de 1954. fonte: arquivo S. Candia

à direita abaixo:

Henry Moore. Visita ao Guarujá, 1953. Foto enviada a Salvador Candia por Delson Lima em Janeiro de 1954. fonte: arquivo S. Candia. 

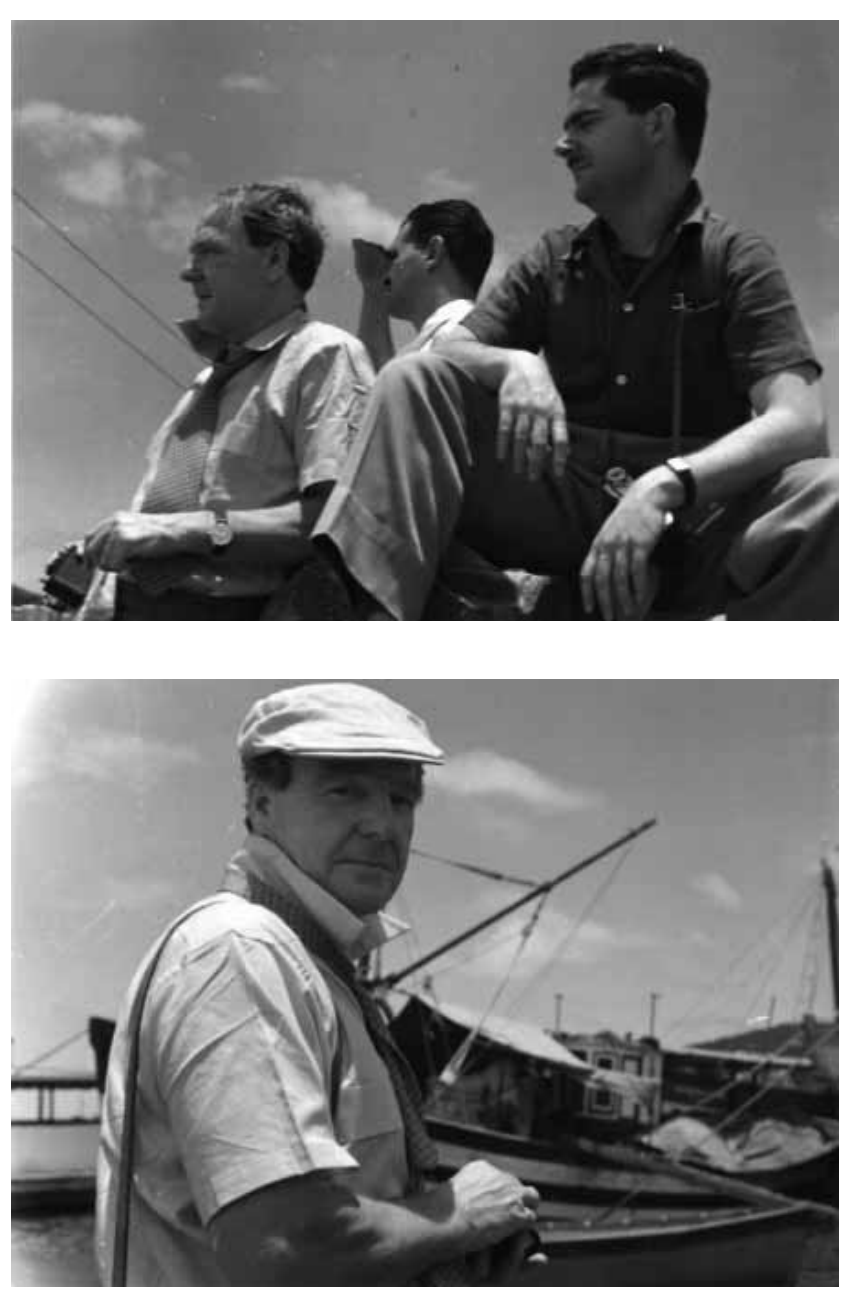

correspondente da revista Pilotis no Recife.

Na seção de arquitetura, a obra de Walter Gropius (1883-1969) foi exposta em destaque, tendo sido agraciada com o prêmio "São Paulo", criado pela Fundação Andréa e Virgínia Matarazzo. A encargo desta fundação, Gropius teve sua obra publicada em uma monografia escrita por Siegfried Giedion naquele mesmo ano.

A Salvador Candia coube, como integrante da direção do MAM, redigir o texto de apresentação da exposição de 1954:

As idéias que renovam a arquitetura de nossos dias, se revestem de tal vigor que transformam a nossa época em uma das datas maiores da história dessa arte.

Com efeito, a integração de homem, arte e ciência; a força do poder inventivo, o tipo de relações que a arquitetura mantém com as outras artes expressam um estado de espírito, um novo humanismo, dir-se-ia, em uma escala não conhecida desde o Renascimento.

No século XIX, a música e a pintura tinham sido capazes de renovar-se e de expressar condignamente o espírito de sua época - a arquitetura viveu a sua hora mais pretenciosa e vulgar - e escapa do total desprezo da crítica e da história, por força de um grupo de engenheiros que souberam puramente criar uma poética nova que transcende a técnica para ser arquitetura: Eifel, Paxton e Roebling. Criava-se a arquitetura contemporânea.

A Segunda Bienal não poderia esquecer esse movimento - e monta a Exposição Internacional de Arquitetura que apresenta as idéias novas, com trabalhos procedentes de países de cinco continentes - e sente-se satisfeita em exibi-la junto à pintura e escultura, como manifestações do mesmo espírito de cultura do mundo moderno.

É significativo que, dentro da exposição, a atração maior seja a obra de uma das mais nobres figuras da arte contemporânea: Walter Gropius. Sua obra e exemplo, de artista, de professor e de homem, sintetizam a renovação plástica, a integração artística e 
o espírito de liberdade incondicional que anima o homem de hoje. Sua vida é um testemunho de fé nesse homem. S. Paulo orgulha-se de receber Walter Gropius. ${ }^{39}$

A apresentação de Candia revela, além de sua afinidade com o discurso do próprio Gropius, a influência do pensamento de Giedion naquele momento entre os arquitetos da sua geração, a exemplo da breve tradução publicada pelos estudantes na Pilotis em 1949.

A presença do crítico suíço na primeira Bienal em 1951 como presidente do júri teve um peso estratégico na legitimação do evento em âmbito internacional (que resultou por exemplo na publicação do número especial sobre o Brasil da revista L'Architecture d'aujourd'hui em 1952). Em 1956, Giedion escreve o prefácio do livro Arquitetura Moderna no Brasil, de Henrique Mindlin. Amigo pessoal de Corbusier, Gropius, Moholy-Nagy, e co-fundador dos CIAM (Congressos Internacionais de Arquitetura Moderna, 1928-56), do qual era Secretário Geral, Giedion militava em defesa do movimento moderno internacional, e contribuiu para o direcionamento crítico das primeiras Exposições Internacionais de Arquitetura (EIA) realizadas no Brasil. Cumpre notar que os júris internacionais foram compostos em grande parte por representantes internacionais dos CIAM: J. Sakakura, Kenzo Tange, Marcel Breuer, Ernesto N. Rogers.

Na ocasião da sua visita em 1951 Giedion sugeriu, junto aos demais membros do Júri, que a EIA realizasse um concurso internacional de projetos realizados pelas escolas de arquitetura. Aceita a sugestão, apresentou-se na ocasião da II Bienal o concurso de estudantes para a realização de "um tema único, de acordo com as condições regionais de cada país: Centro Cívico para um grupo residencial de 10.000 habitantes.”40 O tema

39 II BIENAL do Museu de Arte Moderna de São Paulo. Catálogo Geral. São Paulo: Edições Americanas de Arte e Arquitetura/ Museu de Arte Moderna de São Paulo, 1953. p. 315.

40 IDEM. p.341 
proposto para o concurso demonstra ainda o alinhamento de seus organizadores com as questões levantadas pelo VIII Congresso, como "O Coração da cidade" e a questão da "monumentalidade" no âmbito da arquitetura moderna.

Em 1957 (IV Bienal), Candia recebe, juntamente com Plínio Croce e Roberto Aflalo, o primeiro prêmio da categoria "Habitações Coletivas" pelo edifício João Ramalho (projetado entre 1953-54), que concorria, entre outras obras, com o Conjunto Nacional, de David Libeskind (1956), e o edifício Três Marias, de Abelardo de Souza (1955), dois marcos significativos da arquitetura paulistana. $\mathrm{O}$ júri responsável pela premiação era composto por Marcel Breuer, Kenzo Tange, Phillip Johnson, Jacob Ruchti, Mário Torres, Sílvio Vasconcelos e Francisco Beck. O edifício premiado fôra concebido para integrar o projeto de ocupação integral de uma quadra habitacional no bairro das Perdizes, em respeito às diretrizes da Carta de Atenas (IV CIAM, 1933). Sua premiação sinalizou o compromisso dos arquitetos ligados à Bienal, em promover a superação do urbanismo conservador e normativo das cidades brasileiras, e incentivar a implementação das idéias modernas junto aos investidores do mercado imobiliário habitacional, como era o caso do Banco Hipotecário Lar Brasileiro, responsável por aquele empreendimento. Vale lembrar que neste mesmo evento, o projeto vencedor do concurso de Brasília de Lúcio Costa fora homenageado com uma sala especial "Hors-Concours". 


\section{colaborações}

Os primeiros anos de experiência profissional de Salvador Candia são determinantes para o desenvolvimento posterior de sua obra. Entre o final dos anos 40 e o início dos 50, o arquiteto cultivou relações de trabalho com grupos distintos de afinidade profissional, que certamente enriqueceram o seu repertório projetual, além de ter estabelecido uma vasta rede de diálogo em setores distintos das artes e da arquitetura paulistanas.

Ainda estudante Candia freqüentou o Clube dos Artistas e as reuniões do recémfundado departamento paulista do IAB (1943), no edifício Esther:

Nesses anos, já existia o Instituto de Arquitetos de São Paulo (estou falando de 1945, 1946) e comecei a me interessar pelo IAB. Eles eram uns 50 e se encontravam no Instituto de Arquitetos, no porão de um dos prédios que talvez ainda seja um dos mais lindos do Brasil, o edifício Esther. Eu ia lá e encontrava o Artigas, o Rino Levi, o Bratke, o Kneese, uma porção de pessoas que eu, como estudante, achava que não eram bem arquitetos. Eles não tinham aquele fervor, aquele sagrado fervor, que nos meus 20 anos eu achava que deviam ter.

Além de ter freqüentado os escritórios de Vilanova Artigas e Oswaldo Bratke, Candia colaborou também no final da década de 1940 com Rino Levi, tendo absorvido então uma série de posturas que viria a adotar em sua obra posterior: a precisa inserção dos edifícios no meio urbano, a clareza na resolução funcional das plantas, o cuidado com as questões de conforto ambiental, e a atenção especial com os detalhes e

41 Depoimento de Salvador Candia in ARQUITETURA e Desenvolvimento Nacional. Depoimentos de arquitetos paulistas. IAB-SP, São Paulo: Editora Pini LTDA, 1979 


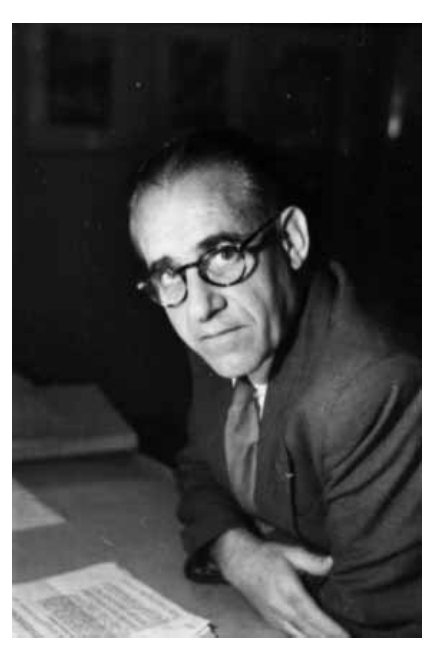

Rino Levi fotografado por Salvador Candia. fonte: arquivo S. Candia. procedimentos construtivos, são atributos que aproximam a obra dos dois arquitetos. Conforme comenta Salvador Candia:

Sempre me emocionou enormemente o lado da pintura, da escultura, da tapeçaria, quer dizer, o lado da matéria, da textura, da transparência, da cor. Mas eu achava que devia aprender, como dizia o Mies, botar um tijolo sobre outro. Certo dia, quando trabalhava no escritório do Rino, que foi um homem a quem todos nós devemos enormemente, tive uma das primeiras lições.

Tinha uma escada que ligava um andar a outro neste prédio do IAB, que estava em construção. No escritório do Rino estava-se desenvolvendo o projeto. Eu disse que se a gente tirasse a escada e ligasse de outro jeito, a planta ficaria melhor, assim como os espaços e a comunicação. Rino Levi me disse: "é, mas isso aí é um projeto feito por seis, sete, oito pessoas". Era um pouco confuso, como vocês podem notar; tem uma parede de tijolos que é o Jacó e o Miguel que inventaram porque eles vinham do Wright; tinha laje que saía, que o Le Corbusier mandava sair a laje; tinha umas paredes retas porque o Mies mandava fazer parede reta.

O Rino quis dizer: "de fato, não se pode consertar o projeto porque agora está em construção". Eu disse: "não, é para consertar porque vai ficar muito melhor". Ele falou: "vai ficar melhor, mas como é que se faz?" Repondi: "Derruba a escada". Então, com aquele jeito dele, disse: "é? Derrubar a escada, hã? Amanhã de manhã você vai na obra, não é? Mas não vai derrubar a escada não".

Levantei cedo, cheguei aqui (naquele tempo não tinha automóvel, nada disso) e disse assim: "olha aí, derruba a escada". Peguei dois camaradas de marreta, de ponteiro, e - pá - começaram a bater no concreto. Depois de meia hora (eu estava espiando), eles tinham desbeiçado um degrau. Aí eu entendi. Eu disse: "olha, pára" "Mas como é que é, doutor?" "Não é nada. Pára”. Aí, quando entrei no escritório, que era no edifício Esther, o Rino olhou para mim, não falou nada, eu também não falei nada. Tratava-se 
Este breve relato evidencia a presença marcante de Levi na formação do arquiteto, e a importância atribuída por Candia ao aspecto material e tectônico da arquitetura.

Além do aprendizado adquirido através de sua colaboração profissional com o grupo de arquitetos a qual faz referência, os registros fotográficos remanescentes da época de sua participação na revista Pilotis atestam o interesse do jovem estudante por certas realizações recentes naquele momento, de arquitetos cujas obras certamente também contribuíram para a sua formação. Registros realizados em fins dos anos 40 e início dos 50 em São Paulo, Rio de Janeiro e Belo Horizonte, demonstram o seu interesse em acompanhar pari passu a realização e a inauguração de obras como a casa Romeu S. Mindlin, de Henrique Mindlin (São Paulo, 1946), Parque Guinle, de Lúcio Costa (Edifícios Nova Cintra, Bristol e Nova Caledônia, Rio de Janeiro, 1948-54), Edifício Anchieta dos irmãos Roberto (São Paulo, 1941), Edifício Prudência (São Paulo,194448,) e o Banco Paulista do Comércio (São Paulo, 1947-50), ambos de Rino Levi.

42 ARQUITETURA e Desenvolvimento Nacional. Depoimentos de arquitetos paulistas. IAB-SP, São Paulo: Editora Pini LTDA, 1979. Depoimento de Salvador Candia.

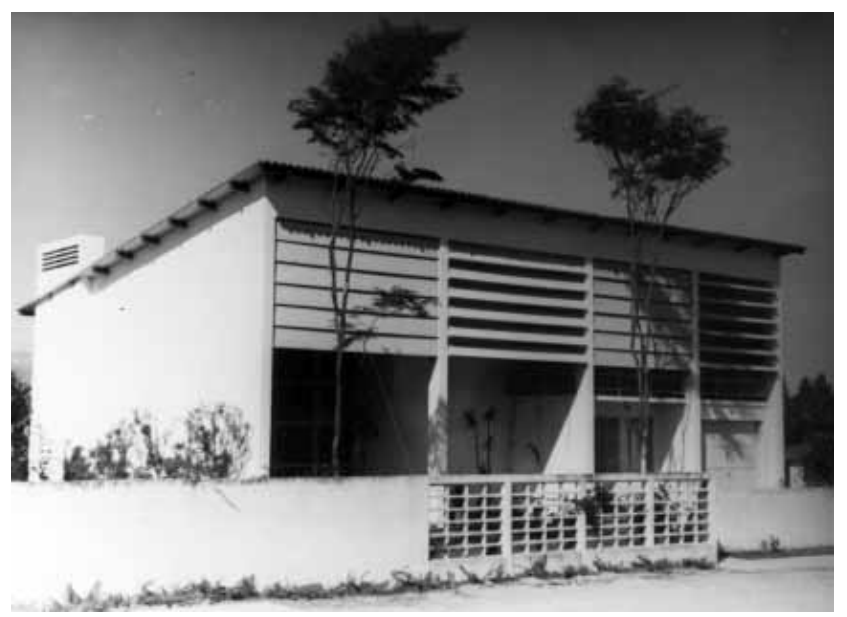

casa Romeu S. Mindlin (Henrique Mindlin, 1946).

Foto de Salvador Candia.

fonte: arquivo S. Candia

\section{à direita acima:}

Edifício Prudência visto a partir da rua Martin

Francisco.

Foto de Salvador Candia.

fonte: arquivo S. Candia

à direita abaixo:

Painel de azulejos de Burle Marx recém instalado.

Edifício Prudência.

Foto de Salvador Candia.

fonte: arquivo S. Candia

à direita extremo:

Edifício do Banco Paulista de Comércio, a partir da rua Boa Vista.

Foto de Salvador Candia.

fonte: arquivo S. Candia. 




\section{parceiros de trabalho: afimmação de um repertório}

Embora Salvador Candia tenha estabelecido escritório próprio em 1950, o início de sua atividade profissional caracteriza-se pela organização de diversas parcerias de trabalho, dentro do círculo de amizades forjadas no Mackenzie. Segundo Sérgio Matera (2005), Candia participou ainda em 1950 no trabalho de assessoria técnica a mutirões habitacionais da Vila Prudente, São Paulo, em associação com os estudantes Ary de Queiroz Barros, Gastão Sandoval Marcondes, Carlos Millan, Sidney da Fonseca e Luiz Roberto Carvalho Franco, no escritório que os três últimos haviam alugado no edifício dos Diários Associados, onde naquele momento se abrigavam o MASP e o MAM. Após sua formatura em 1951, Millan estabeleceu seu novo escritório na rua Barão de Itapetininga, 124, onde já se encontravam instalados os colegas Jacob Ruchti, Galiano Ciampaglia, Miguel Forte, Plínio Croce e Roberto Aflalo. ${ }^{43}$ Este grupo de amigos, aos quais Candia estava fortemente vinculado, passou a empreender diversas frentes conjuntas de trabalho a partir daquele momento. Cumpre notar que devido às suas incursões e pesquisas realizadas em outros campos artísticos de maneira complementar à prática da arquitetura, Candia e Jacob Ruchti representavam uma referência especial para o grupo. Segundo Gasperini (2007):

De fato ele ditava, de uma certa maneira, as regras dentro do grupo de arquitetos que nós freqüentávamos naquela época, que entre outros, tinha o Jacob Ruchti, que também disputava um pouco com o Salvador essa coisa de ser realmente ele o grande promotor das idéias do modernismo, principalmente de todas as idéias do Mies van der Rohe, etc.

43 Note-se que neste mesmo edifício se encontravam também os escritórios de Abelardo de Souza e Zenon Lotufo, com quem Aflalo e Millan haviam colaborado enquanto estudantes.

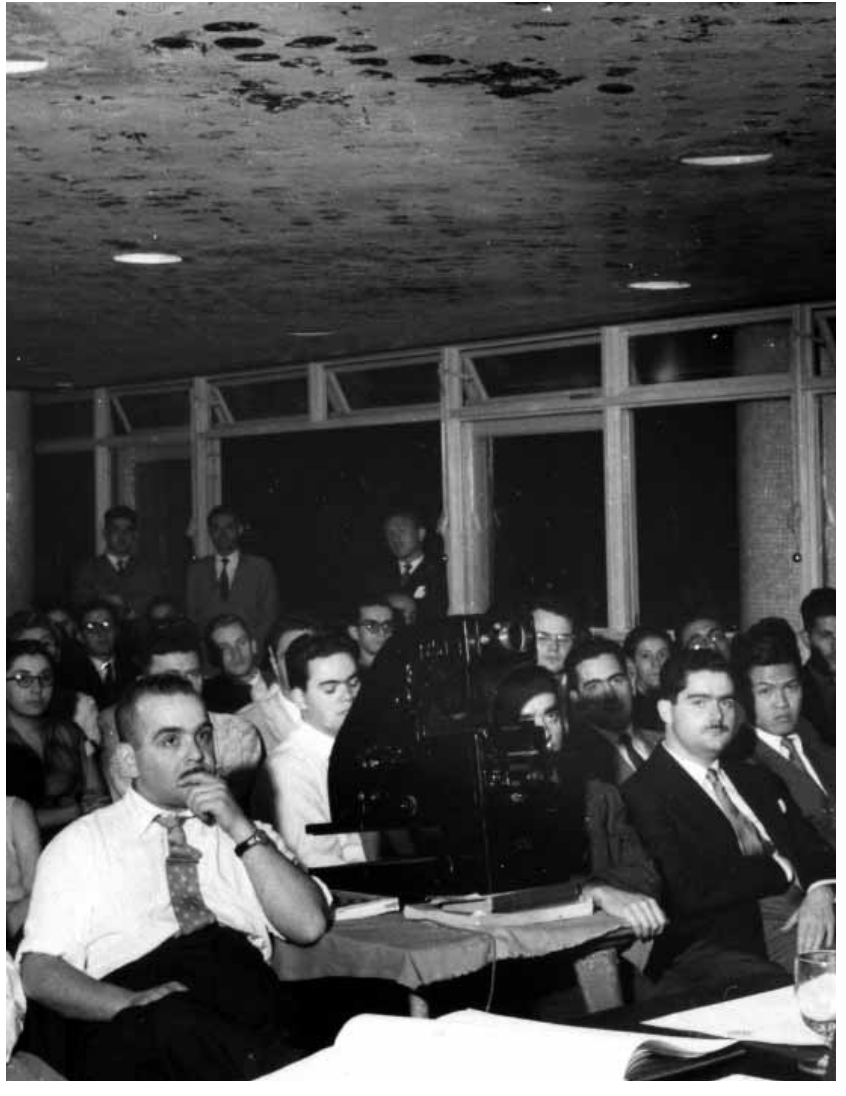


O próprio Candia comenta esta participação em entrevista a Marlene Acayaba (1991. p. 6-4):

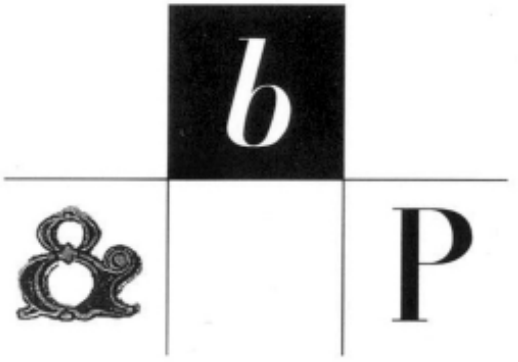

acima:

Logotipo da loja Branco \& Preto. autoria de Jacob Ruchti, 1953 fonte: ACAYABA, 1994, p. 62 .

Conferência no edifício do IAB-SP sobre a Cultura Grega. Na primeira fila, da esquerda para a direita: Plínio Croce, Salvado Candia e Chen Y Hwa. Atrás de Candia está seu irmão Rubens.
foto anônima, Circa 1950.
Nós éramos o grupo moderno: queríamos quebrar o pau e fazer o diabo. Jacob e eu, sugeríamos que era para ver aquela fita, todo mundo ia... que era para gostar da Audrey Hepburn, porque vestia-se bem, era bacana e pertencia a um certo padrão de desenho, então era aquela gamação. Havia, na época, as revistas "Vogue" e "Harper’s Bazaar" que apresentavam trabalhos de fotógrafos artistas que todo mundo imitava. Havia, também, a revista "Interior's". Nesse tempo, no fim dos anos 40, havia para esse grupo de arquitetos e para alguns artistas de São Paulo, uma série de coisas a conquistar e uma delas era uma loja que fizesse móveis e tecidos com tendência moderna e não pseudo-moderna que já começava a existir disfarçadamente no Rio de Janeiro com Tenreiro.

De fato, o empreendimento mais notável realizado pelo grupo naquele momento, sem haver contado no entanto com a participação direta de Salvador Candia e Galiano Ciampaglia, foi a criação da loja Branco \& Preto em 1952, em associação com o arquiteto chinês Chen Y Hua, que havia se formado nos Estados Unidos. Marlene Acayaba percorre em sua Tese de Doutorado (1991) o processo de associação deste grupo de arquitetos em torno da criação da loja. Salvador Candia relata à autora o dia de inauguração:

Quando eles inauguraram a loja, assim ao anoitecer, eu cheguei e ao ver a loja acesa fiquei arrepiado e ao mesmo tempo orgulhoso. Aquilo emocionou-me profundamente: nós tínhamos ganho a primeira loja de móveis e tecidos modernos de São Paulo.

Havia uma coleção linda de tecidos lisos ou com listras, nos quais cores variadas misturavam-se com riscos pretos ou brancos na dosagem certa. A proporção exata do 
risco preto ou das cores era de um bom gosto incrível. Jacob e Miguel “ tripudiaram” neste ponto, porque eles eram os reis do bom gosto. Eles produziram vermelhos, verdes e amarelos lindíssimos. Jacob era um sujeito muito requintado e inventou para as cores nomes associados com arquitetura, cidades italianas, estações do ano etc. $(\ldots)^{44}$

A Branco \& Preto notabilizou-se pelo desenho e produção de móveis modernos, com a criação de novas padronagens de tecidos e estampas a exemplo das experiências da Bauhaus, em um contexto de mercado onde eram raras as iniciativas teste tipo. A experiência do desenho e da produção de móveis viria a influenciar também o processo de projeto dos espaços internos das casas e apartamentos que aqueles arquitetos passavam a realizar, estando presentes como "gabaritos" a indicar o arranjo dos espaços em plantas e perspectivas. Nota-se nos desenhos de Salvador Candia, por exemplo, a presença de peças da Branco \& Preto, junto a móveis conhecidos como a poltrona Barcelona e as mesas de vidro e aço cromado projetadas por Mies van der Rohe. O interesse constante pelo desenho do mobiliário, e também pelo detalhamento dos diversos acabamentos internos de forma compositiva de acordo com a coerência intrínseca à totalidade do projeto, são atributos presentes na obra de Salvador Candia, e o aproximam da idéia de "obra de arte total" difundida por Walter Gropius nos primeiros anos da Bauhaus.

Dentre os projetos de maior escala realizados inicialmente por aquele grupo de arquitetos destaca-se a proposta vencedora do Concurso Nacional para a Estação Ferroviária de Pampulha em 1950, desenhada por Candia em associação com Plínio Croce e Jacob Ruchti. Embora não tenha sido construído, este projeto firmou a base para o desenvolvimento subseqüente de novos trabalhos para este grupo de jovens

44 ACAYABA, Marlene Milan. Branco \& Preto: uma história de design brasileiro nos anos 50. 1991, Tese de Doutoramento - Faculdade de Arquitetura, Universidade de São Paulo, São Paulo. p. 6-7

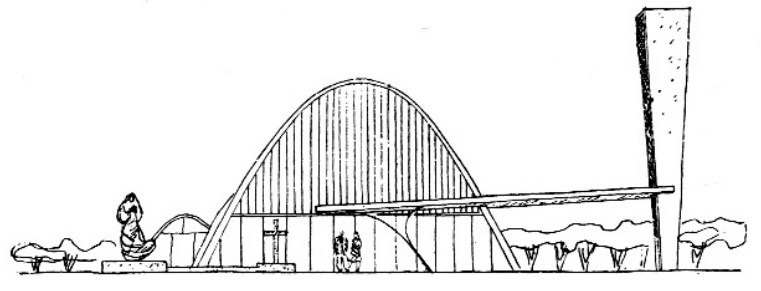

acima:

Igreja de São Francisco de Assis, Pampulha.

Oscar Niemeyer, 1940

fonte: CASTRO, Mariângela; FINGUERUT, Silvia, orgs.

Igreja da Pampulha: restauro e reflexões.

Rio de Janeiro: Fundação Roberto Marinho, 2006

à direita:

Estação Ferroviária de Pampulha, Belo Horizonte.

Candia, Croce e Ruchti, 1950

fonte: Acayaba (1994. p. 58) 


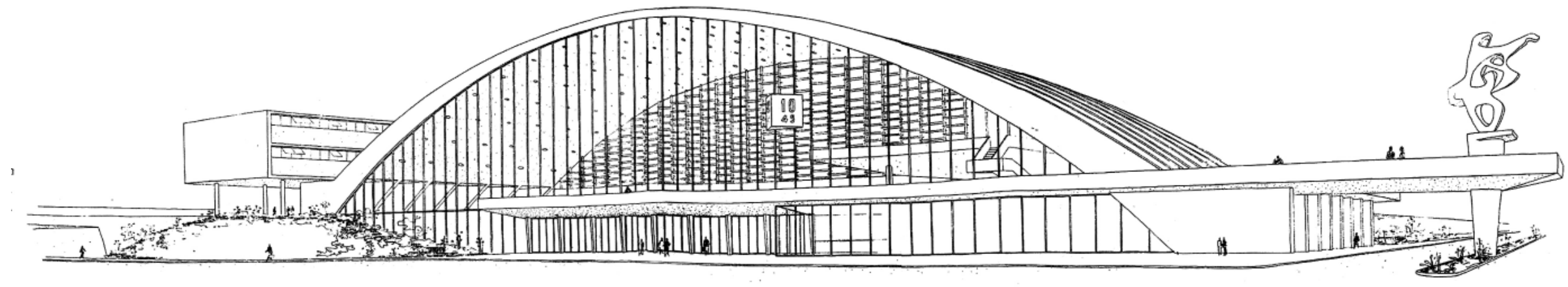


arquitetos. A concepção formal da estação, com seu saguão monumental coberto por uma abóboda de curvatura extremamente abatida, de desenvolvimento longitudinal à sua área de projeção, faz uma menção inversa à aplicação singela das abóbodas empregadas por Oscar Niemeyer (1907) na igreja de São Francisco de Assis (1940), operando desta vez em uma outra escala, de proporções colossais. ${ }^{45}$ Procedendo ainda de forma análoga àquela que havia se tornado a obra símbolo do conjunto da Pampulha, o projeto da estação emprega também uma marquise de acesso superposta ao plano da fachada, com sua saliência assimétrica apoiada no elemento vertical que contrapõe o conjunto. Embora naquele momento este grupo de arquitetos estivesse firmando suas bases em um repertório distinto daquele empregado de forma hegemônica pelos cariocas, indo buscar suas referências nos Estados Unidos através de Wright, Mies, Gropius, Breuer, Neutra, e se aproximando de Oswaldo Bratke, Franz Heep e Rino Levi no Brasil, este projeto procura estabelecer, principalmente em seu aspecto exterior, uma analogia direta com aquela linguagem. O arquiteto Giancarlo Gasperini, que trabalhava então com Jacques Pilon (1905-1962) no Rio de Janeiro, e que começaria a freqüentar o grupo ainda no início da década, comenta este fato: "A gente brincava com ele, por que foi feito com o Plínio, então a gente brincava com o Plínio, dizendo: Puxa, vocês deram uma de 'Arquitetura Brasileira', 'Curvas e etc" ${ }^{46}$ Com efeito, parte destes arquitetos que iniciavam sua atuação profissional na São Paulo dos anos 50, se ressentiam da excessiva representatividade atribuída ao repertório formal da arquitetura carioca, que naquele momento era identificada exclusivamente como sendo arquitetura brasileira. Nas palavras de Salvador Candia:

Pelo menos até o Estado Novo, não sei quando, o centro do Brasil era o Rio de Janeiro

\footnotetext{
45 Tomando-se como base a figura humana na perspectiva de apresentação do concurso, verifica-se que o vão horizontal do arco da abóboda é da ordem de $100 \mathrm{~m}$.

46 GASPERINI, Giancarlo. Depoimento prestado ao autor em 5-12-2007.
} 
e se não era carioca ou partido do Rio por qualquer canal que hoje se chama "mídia" e que naquela ocasião se chamava imprensa - rádio, samba, não sei o quê - então não era brasileiro, se não tinha a chancela carioca. Então, o que aconteceu com o Rio? Apareceu no início que só no Rio de Janeiro é que se fabricava, se fazia, se consumia arquitetura, e que em São Paulo se fazia café, outra coisas, estrada de ferro, mas arquitetura não era paulista. Essa é uma idéia que realmente não tem sentido. $\mathrm{O}$ que tem de verdadeiro nisso, não sei se é uma escola, mas existe um jeito carioca de arquitetura, como em tudo. Se há oposição ou se não há, eu não sei dizer. O carioca, aparentemente, é mais brasileiro porque associou durante muito tempo, erradamente, o que era carioca era brasileiro, definia o Brasil; e se não fosse carioca, não era bem brasileiro $(\ldots)^{47}$

Outro trabalho produzido pelo grupo na época dos encontros na rua Barão de Itapetininga, foi o projeto para as novas instalações das faculdades de Filosofia, Ciências e Letras da USP entre 1952 e 1954. Este projeto integrou a proposta da Comissão de Planejamento da Cidade Universitária Armando Sales de Oliveira elaborada entre 1949-54 por uma equipe de professores da Faculdade de Arquitetura da USP e demais arquitetos convidados, sendo presidida pelos professores Ernesto de Souza Campos e Luiz Inácio de Anhaia Mello. Esta proposta se soma à diversidade de projetos elaborados para o centro universitário desde a década de 30 , tendo sido posteriormente abandonada em favor de uma revisão integral do plano elaborada por Hélio Duarte em 1956. ${ }^{48}$

Entre os arquitetos convidados para integrar o plano de 1949-54 estavam o professor convidado da Escola Politécnica de Milão Gio Ponti, além dos docentes da USP Ícaro Castro

47 Depoimento de Salvador Candia in ARQUITETURA e Desenvolvimento Nacional. Depoimentos de arquitetos paulistas. IAB-SP, São Paulo: Editora Pini LTDA, 1979

48 CABRAL, Neyde Angela Joppert. A universidade de São Paulo : modelos e projetos. 2004, Tese de Doutorado - Faculdade de Arquitetura, Universidade de São Paulo, São Paulo. 
Mello, Ariosto Mila, Plínio Croce e Rino Levi. Este último, que havia realizado o projeto vencedor no concurso da Maternidade Universitária em 1945 com a colaboração de F. Pestalozzi e R. Cerqueira César (projeto premiado na categoria de Edifícios Públicos na I Bienal do MAM em 1951), exerceu um papel de destaque no plano, tendo sido responsável pelo projeto do conjunto residencial para os estudantes e o centro cívico do campus, com a primeira versão da Torre do Relógio dominando a composição entre a Biblioteca Central e o Teatro.

A Plínio Croce coube dirigir o projeto de implantação das unidades acima mencionadas, de acordo com as diretrizes estabelecidas pela comissão de planejamento em 1952. Associou-se para tanto a Gianpaglia, Ruchti, Candia, Millan e Aflalo, sendo que com os dois últimos elaborou também a implantação dos edifícios do Instituto de Pesquisas Técnicas, dentro do mesmo plano geral.

O projeto das unidades da FFCL e do IPT obedece a uma estrita lógica de implantação, baseada em uma retícula ortogonal que organiza a disposição dos edifícios no terreno. Partindo de uma baixa densidade ocupacional, estabelece edifícios de no máximo quatro pavimentos, concebidos sob uma mesma razão modular, com sistema construtivo em estrutura de concreto destacada dos planos de fechamento. ${ }^{49} \mathrm{~A}$ organização funcional dos diversos programas obedece de maneira geral a uma disposição linear de laboratórios e salas de aula organizados em torno de varandas e marquises de circulação, estando as áreas de convívio e atendimento público dispostos preferencialmente no pavimento térreo, conforme as determinações estabelecidas pela comissão de planejamento.

Ao estabelecer um mesmo sistema modular e construtivo para um vasto grupo de edifícios de programas diversos, o grupo pretendia conferir uma identidade uniforme ao conjunto, a exemplo do projeto para o Campus do IIT em Chicago proposto por

49 MATERA, Sérgio. Carlos Milan: um estudo sobre a produção em arquitetura. 2005, Dissertação de Mestrado - Faculdade de Arquitetura, Universidade de São Paulo, São Paulo. p.159.
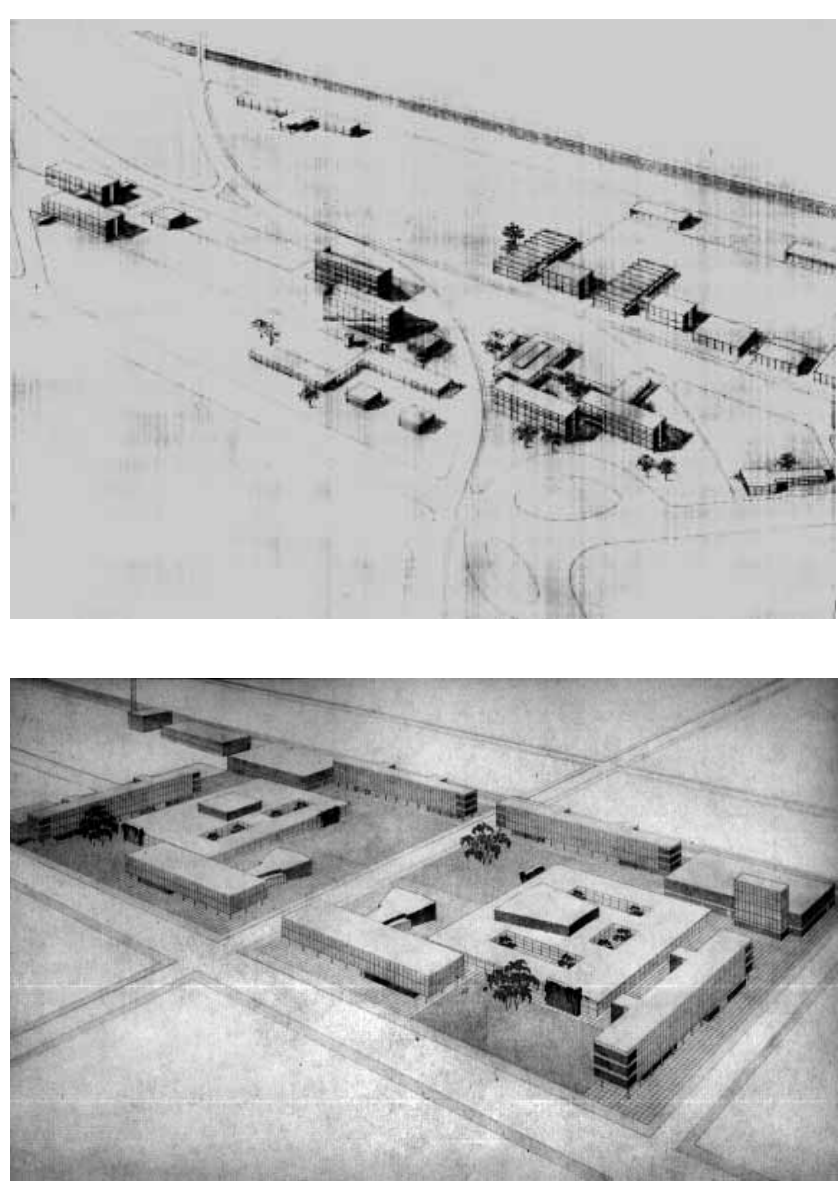

Projeto para o IPT na Cidade Universitária.

Plínio Croce, Roberto Aflalo e Carlos Millan, 1954. fonte:

MATERA, Sérgio. Carlos Millan, um estudo sobre a produção em arquitetura. 2005, Dissertação de mestrado - Faculdade de Arquitetura, Universidade de São Paulo, São Paulo. p. 159.

abaixo:

Projeto para o campus do IIT, EUA. Ludwig Mies van der Rohe, 1930-40.

fonte: LAMBERT, Phyllis. Mies in America. Montreal; New York: Canadian Centre for Architecture; Whitney Museum of American Art, 2001. p. 723. 


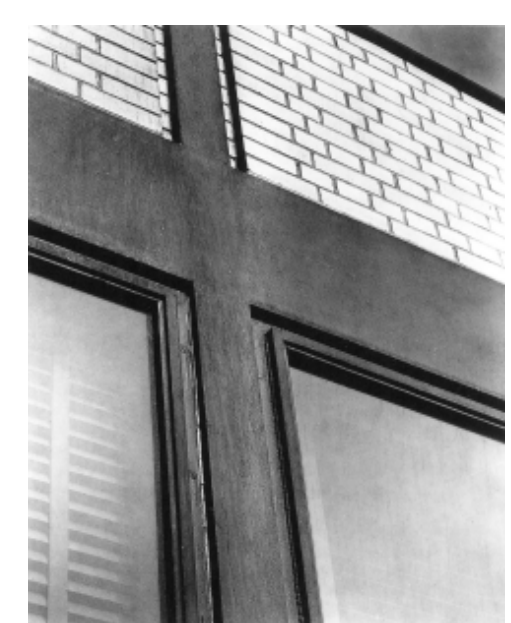

Vista externa das articulações entre tijolos, acima: metálicos e as superfícies envidraçadas. IT Navy Building (Alumni Memorial Hall). Ludwig Mies van der Rohe, 1947. fonte: LAMBERT: 2001, p. 311

à direita:

Projeto para o edifício de Mineralogia e Geologia. fonte: ACAYABA, Madene Milan. Brango \& Proto: uma história de design bra uma historia de design brasileiro nos anos 50.1991 Universidade de São Paulo, São Paulo. p. 5-20.
Mies van der Rohe (1939-40), onde todos os edifícios articulavam-se sobre uma estrita malha cúbica de $7.5 \mathrm{~m}$ de lado. Ali também o sistema construtivo e o módulo foram empregados como denominador comum entre programas diversos. O uso aparentemente $^{50}$ simples dos materiais empregados por Mies nos pavilhões do IIT, onde se evidenciam as articulações entre os montantes metálicos, o vidro e a superfície dos tijolos na construção de prismas elementares regidos por uma grelha estrutural modular, constituiria um exemplo a ser perseguido por Salvador Candia e alguns de seus colegas por um determinado momento. Novamente aqui também se faz presente a influência da obra de Richard Neutra sobre os edifícios educacionais, divulgada através do seu livro publicado em 1948 em São Paulo, conforme comentamos.

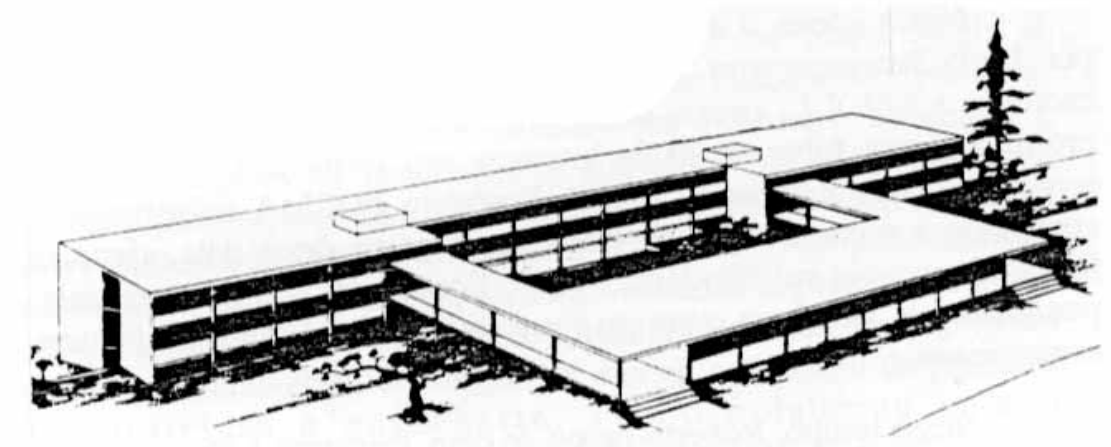

50 Conforme abordado por diversos autores (ver LAMBERT: 2001. p.277), os edifícios construídos por Mies para o IIT são representativos do processo de elaboração de uma linguagem formal aparentemente simples através do emprego de detalhes e procedimentos construtivos complexos. 
Os primeiros anos da década de 50 foram determinantes para a afirmação profissional deste grupo de jovens arquitetos. Entre 1950 e 1951 Croce, Aflalo e Candia participaram de diversos projetos de residências para o Banco Hipotecário Lar Brasileiro. Até o ano de 1953, Candia tinha projetado para esta instituição diversos conjuntos de residências urbanas em Santos (Ponta da Praia), Campinas (Cambuí), e São Paulo (Ana Rosa e Pinheiros). Em Novembro daquele mesmo ano, os três arquitetos realizam para o Lar Brasileiro a proposta de ocupação de uma quadra habitacional em Perdizes, como revisão de um plano anteriormente traçado por Abelardo de Souza. O primeiro dos edifícios propostos, construído pelo Banco em 1954, seria premiado na IV Bienal de São Paulo, em 1957. O reconhecimento dado pelo júri internacional seria decisivo para firmar suas bases profissionais.

Tendo estabelecido seu próprio escritório em 1950, Candia se instala alguns anos depois no oitavo andar do recém concluído Edifício Vicente Filizola, projetado inicialmente por Franz Heep e terminado por Gasperini, nos períodos em que estes haviam colaborado com Jacques Pilon..$^{51}$ Ali estabeleceria então novas parcerias de trabalho.

Em 1958, associa-se ao arquiteto Rubens Meister (1922) para a construção do edifício Barão do Rio Branco em Curitiba-PR, com programa misto de apartamentos e escritórios distribuídos em 23 pavimentos. ${ }^{52}$ Os dois colegas realizariam ainda estudos para outros edifícios e residências naquela cidade. Ainda em 1958 Candia inicia, em parceria com Álvaro Vital Brazil (1909-1997), o projeto para o edifício de escritórios do Banco da Lavoura de Minas Gerais na rua Boa Vista, São Paulo, concluído em 1963. Candia e Brazil cultivariam uma forte amizade, tendo desenvolvido posteriormente outros projetos para a mesma instituição.

51 GASPERINI, Giancarlo. Depoimento prestado ao autor em 5-12-2007

$52 \mathrm{O}$ material referente a este projeto não consta no Arquivo S. Candia.

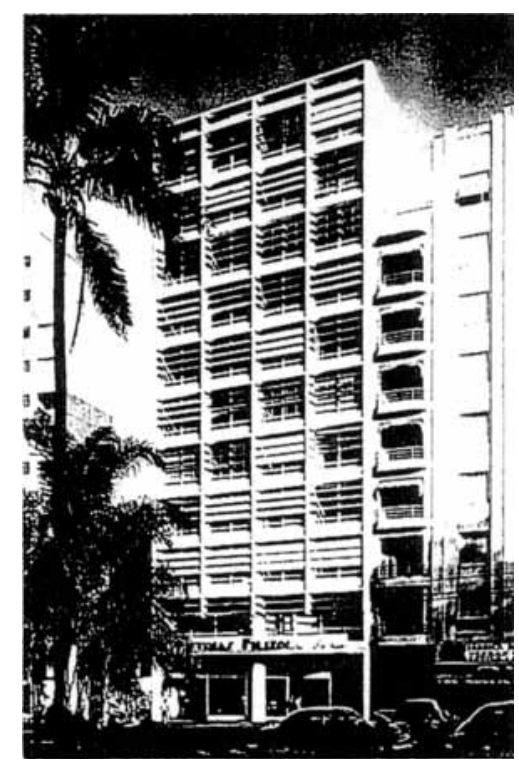

acima:

Edifício Filizola, São Paulo.

Gasperini, Heep, Pilon, 1948-52

fonte: BARBOSA: 2002. p. 40.

próxima página:

Edifício Banco da Lavoura de Minas Gerais. Salvador Candia e

Álvaro Vital Brazil (1958-63). Rua Boa Vista, São Paulo.

fonte: Arquivo S. Candia

à direita acima:

Estudo da elevação da fachada,

com a grelha de quebra-sóis.

à direita abaixo:

Planta dos pavimentos superiores (recuados)

Projeto Executivo, 1959.

à direita extremo:

Fotografia de J. Moscardi, 1963 


Em 1959, após terem ambas as propostas escolhidas em concurso fechado para a construção do Edifício Metropolitano, no Centro Novo de São Paulo, Candia e Gasperini se juntam para desenvolver este projeto que, uma vez inaugurado em 1964, integraria um dos endereços mais significativos na vida cultural paulistana naquele momento.

Em 1961, o arquiteto Japonês Yasuhiro Aida, que havia integrado a equipe vencedora do concurso internacional de estudantes da II Bienal de São Paulo em 1953-54, representando a Universidade de Waseda em Tóquio, e viera após a conclusão dos seus estudos trabalhar no Brasil, junta-se ao escritório de Salvador Candia como colaborador, tendo a ele posteriormente se associado e permanecido durante toda a sua trajetória profissional.

Candia estabeleceria ainda nas décadas seguintes algumas parcerias com o arquiteto José Bina Fonyat (1918), em projetos não executados no Rio de Janeiro e em Salvador, dentre os quais figura o conjunto de apartamentos e galeria comercial Aliança da Bahia, de 1968.

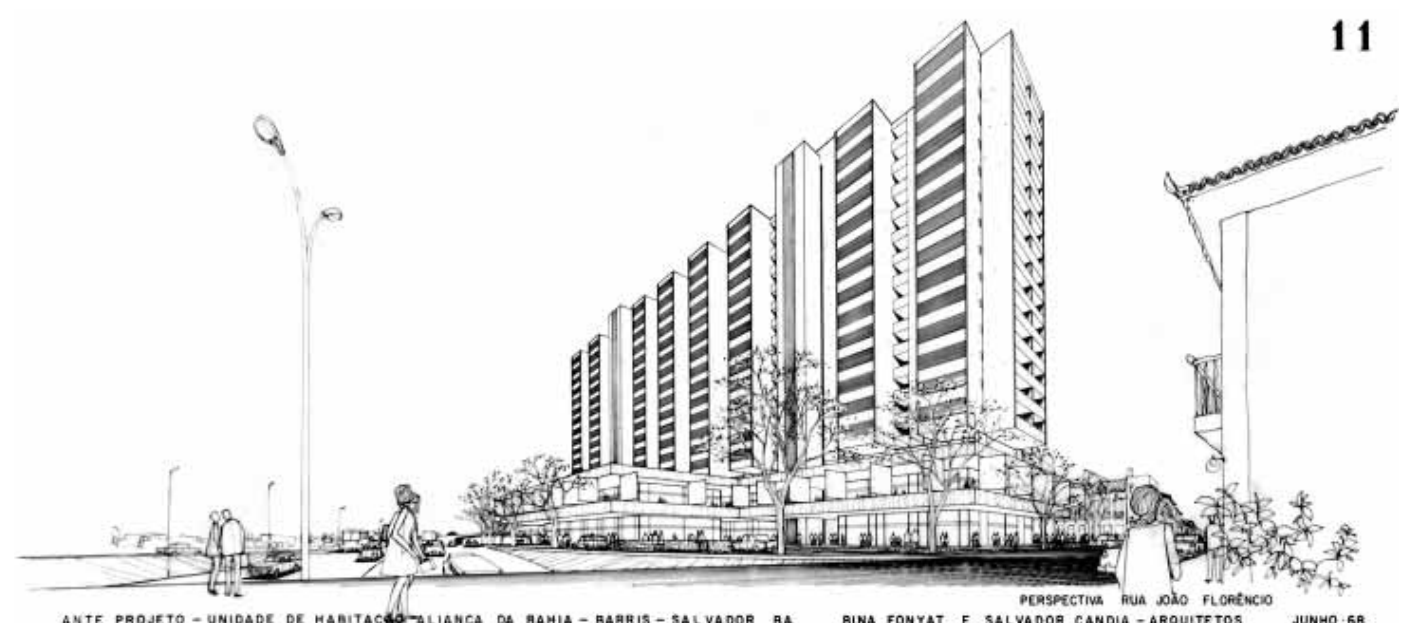

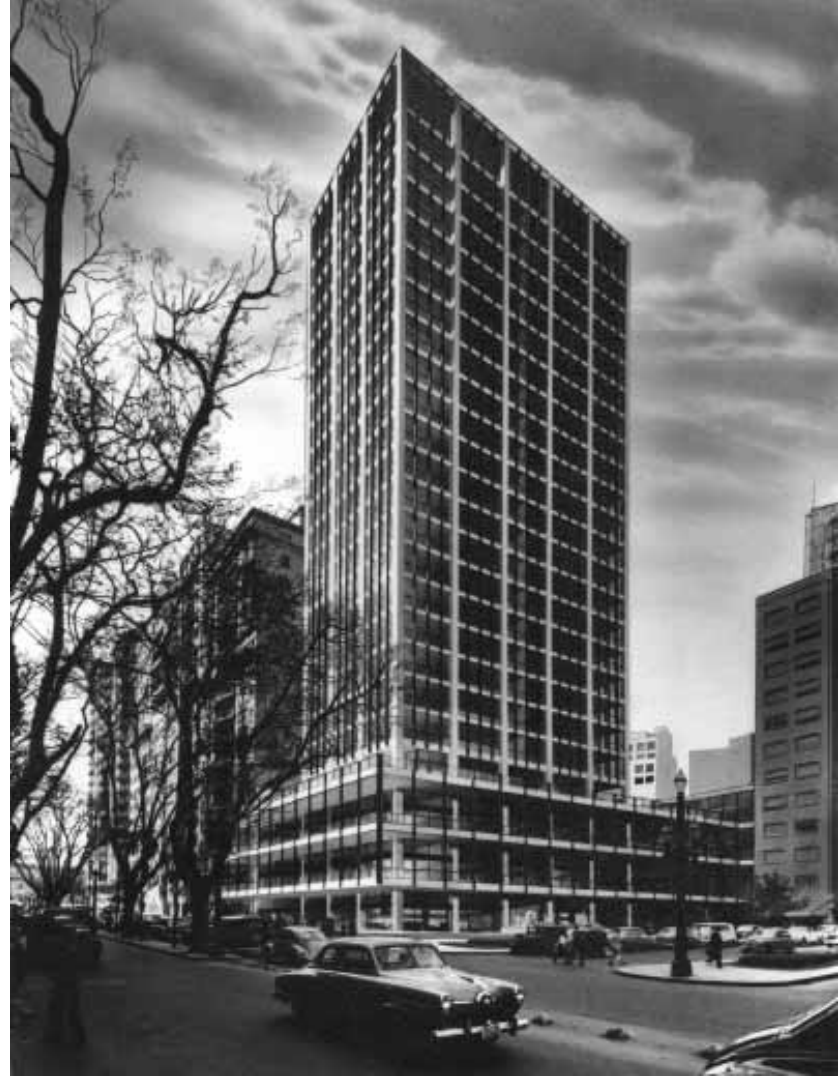

acima:

Edifício Metropolitano, São Paulo.

Salvador Candia e Giancarlo Gasperini (1959-64).

Fotomontagem do modelo.

fonte: Arquivo S. Candia

à esquerda:

Unidade de Habitação Aliança da Bahia, Salvador (BA).

Bina Fonyat e Salvador Candia, 1968.

Perspectiva.

fonte: arquivo S. Candia

na próxima página:
Projeto para Parque Ciqueira Campos, São Paulo

Roberto Burle Marx, Salvador Candia e Clóvis Olga, 1967.

Planta de situação e perspectiva da Praça Alexandre de Gusmão. fonte: arquivo $S$. Candia 

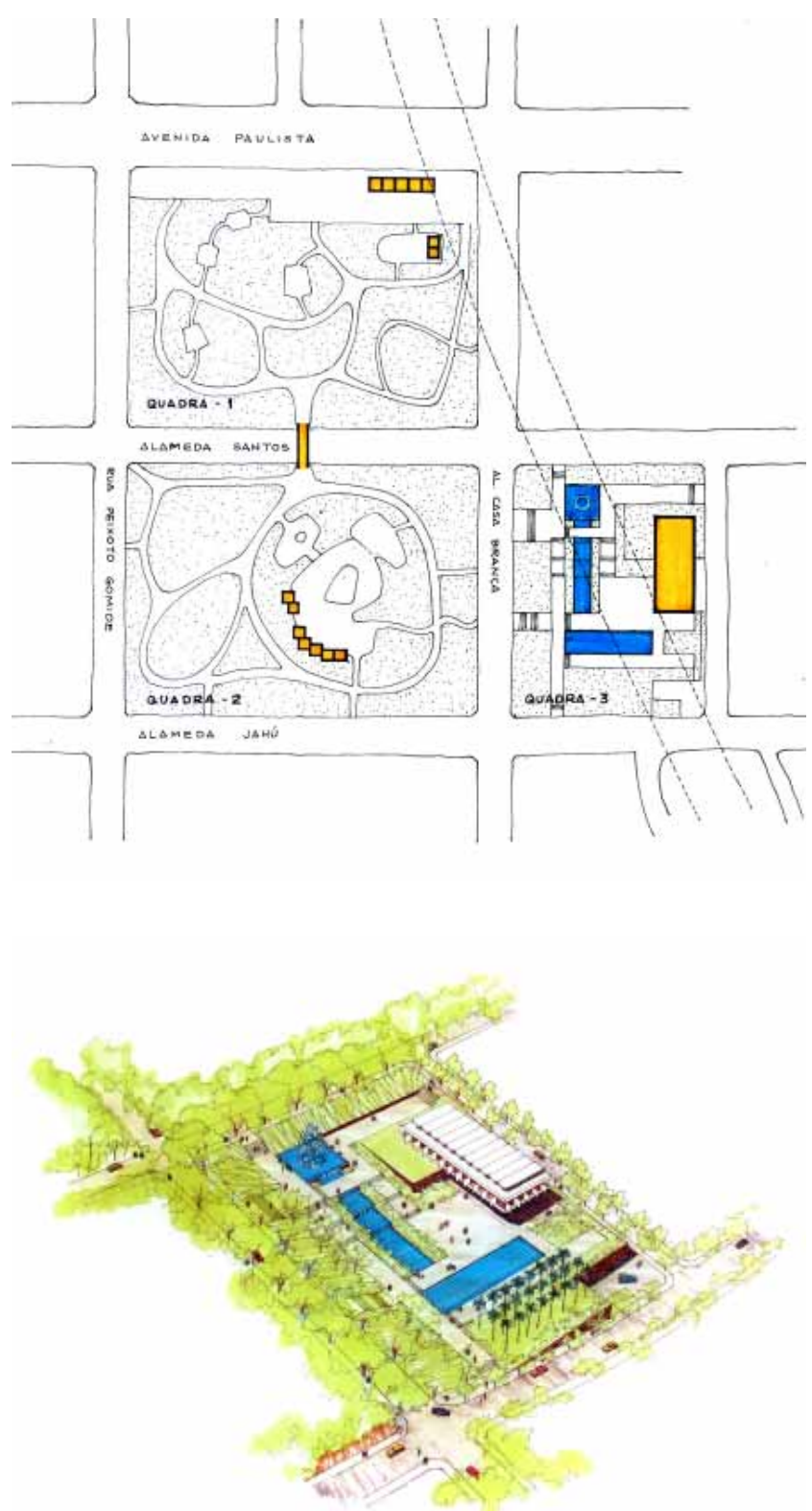

Em 1967, Candia colabora na articulação de uma das equipes que realizariam as propostas para o Plano Diretor de São Paulo, sob a iniciativa do prefeito Faria Lima.

A equipe, que não chegou a realizar o projeto, era integrada por profissionais diversos, dentre os quais estavam os arquitetos José Luis Sert (1901-1983), Walter Gropius (1883-1969), e o paisagista Roberto Burle Marx (1909-1994). ${ }^{53}$

Naquele mesmo ano, o arquiteto colaboraria novamente com Burle Marx, em associação com Clóvis Olga, num projeto não executado de remodelação do parque Ciqueira Campos e da praça Alexandre de Gusmão, para a Prefeitura de São Paulo. O estudo previa para a praça a implantação de um restaurante, integrado a um conjunto de jardins e espelhos d'água dispostos em patamares sucessivos que acompanhavam a declividade do terreno.

Durante os quarenta anos em que manteve suas atividades profissionais, Salvador Candia estabeleceu vínculos de afinidade com um vasto grupo de arquitetos, atuando conjuntamente em diversas cidades brasileiras. Dentre os colaboradores mais freqüentes em seu escritório, estão os arquitetos Yasuhiro Aida, Fernando Arantes, Mário Reginato, Jean Paul Sauver, Fernando Stickel, Luiz Andrade e Roberto Amá. ${ }^{54}$

Desde os primeiros anos de sua atuação como arquiteto, no início da década de 50, Candia se depararia com a emergência de novos programas urbanos que, embora já se mostrassem presentes na cidade de São Paulo há algumas décadas, passariam então a se colocar em uma escala até então inusitada, demandando novas soluções aos arquitetos atuantes naquele período. Partindo deste contexto, e atravessando longo um arco temporal que terminaria no final da década de 80, Salvador Candia desenvolveria uma obra vasta, que soube persistir - ainda que vinculada ao mercado corrente da construção - no rigor construtivo e na clareza funcional de seus projetos; primando por uma atuação discreta porém ativa e transformadora em seu diálogo com a cidade existente, conforme veremos a seguir.

53 Constam apenas as correspondências e documentos referentes à elaboração da proposta (arquivo S. Candia).

54 AIDA, Yasuhiro. Depoimento prestado ao autor em 20-12-2007. 

emergência de novos programas 


\section{novos problemas}

O grande prédio de escritórios apareceu nas nossas cidades como resultado das grandes transações, cuja tendência de se concentrar em pequenas áreas, produziu a super-valorização dos terrenos. Tornou-se assim interessante aumentar o espaço alugável no sentido vertical.

A grande loja de departamentos, agora familiar em quase toda parte, não existia há 80 anos atrás. Hoje, para a conveniência do comprador reúnem-se inúmeras lojas num mesmo edifício e sob a mesma orientação.

O grande prédio de apartamentos também é de desenvolvimento recente. Com os métodos modernos de construção, torna-se mais barato construir um único prédio para cinqüenta famílias do que cinqüenta casas isoladas. Assim, não só os aluguéis são mais baixos, mas também a manutenção da casa mais fácil e econômica.

Eis aí três novos problemas para o arquiteto. Se ele os resolver de maneira eficiente e deixar que a forma se desenvolva naturalmente através da função, seus edifícios não se assemelharão a arquitetura alguma do passado; suas formas serão novas, porque suas funções são novas. Portanto, a atual maneira de viver é a base da nova arquitetura. ${ }^{1}$

No texto "O que é Arquitetura Moderna", publicado pela Pilotis IV em Fevereiro de 1950, seus editores reivindicam uma nova postura a ser adotada pelos arquitetos diante do aporte progressivo de determinados programas que, embora já estivessem presentes no desenvolvimento da cidade há algumas décadas, passam a assumir escala e complexidade inéditas a partir dos anos 40; configurando-se de fato como problemas novos a serem equacionados pelos arquitetos naquele momento.

1 PILOTIS. São Paulo, n. 4, fevereiro 1950. p.8. (Grifo original) 
Dentro deste contexto, programas emergentes como os grandes condomínios residenciais implantados nos bairros e áreas centrais, e os edifícios-conjunto agregando diversas funções no centro da metrópole, irão pautar a atuação dos arquitetos da geração de Salvador Candia desde o início de suas atividades durante a década de 50, determinando em grande parte os seus procedimentos de projeto.

De fato, este período é caracterizado por diversos autores como um momento decisivo no processo de metropolização da cidade de São Paulo, quando essa já lidera o desenvolvimento econômico do país, abrigando desde então o maior centro industrial da América do Sul. ${ }^{2} \mathrm{O}$ vertiginoso processo de crescimento que acompanhou a consolidação deste parque industrial e o seu correspondente aporte migratório produziram, segundo Meyer (1991), dois movimentos opostos e complementares: o crescimento horizontal das periferias e a verticalização do seu centro, aliada ao incremento de novas funções:

Assim, à (relação) de expansão da periferia correspondeu um fortalecimento do centro. O crescimento vertical e a organização de novas funções criou simbólica e concretamente um papel diferenciado, prestigioso e dominante, para o centro da metrópole. Enquanto o desamparo crescia horizontalmente a afluência verticalizavase. Dialeticamente relacionadas estas duas realidades não comportam análises que as isole. Ambas respondem e correspondem a espaços diferenciados e complementares que o capital industrial requer da metrópole. Enquanto a periferia é unifuncional e de certa forma unidimensional, o centro é multifuncional e multidimensional. ${ }^{3}$

A verticalização progressiva das áreas centrais da cidade a partir dos anos 30 foi

2 AZEVEDO, Aroldo (coord.). A cidade de São Paulo. 4 volumes. São Paulo: Companhia Editora Nacional, 1958. p.23.

3 MEYER, Regina M. Prosperi. Metrópole e Urbanismo: São Paulo anos 50. 1991, Tese de Doutoramento - Faculdade de Arquitetura, Universidade de São Paulo, São Paulo. p. 29 
acompanhada, segundo Somekh (1997), por uma legislação baseada no urbanismo normativo da cidade de Nova York. Este processo não pode ser desvinculado, segundo Meyer (1991), das tentativas de transformar urbanisticamente o centro da metrópole através da re-estruturação de sua infra-estrutura viária, contida do Plano de Avenidas de Prestes Maia (1896-1965):

A mais relevante intervenção na área central ocorreu a partir do período 1938-1945 e foi elaborada desde os anos 30 durante a primeira passagem de Prestes Maia pela prefeitura paulistana. Uma das idéias básicas de Prestes Maia, apresentada no Plano de Avenidas de 1930, consistia na construção de um anel de largas avenidas de 33 a 45 metros de largura envolvendo a área central. O perímetro de irradiação deveria sanar as dificuldades produzidas pelo congestionamento e criar áreas de expansão. Prestes Maia acreditava que a conjugação do anel com o Sistema Y que o atravessaria, provocaria o desvio de correntes diametrais fortalecendo uma mais conveniente distribuição perimetral. ${ }^{4}$

A associação direta entre este plano viário, que seria implantado através de versões sucessivas a partir da década de 40, e o estímulo à verticalização como parte integrante da normativa urbanística que o acompanhava, é comentada por Campos (2002):

Percebe-se o estreito vínculo estabelecido por Prestes Maia entre a possibilidade de verticalização e a criação de grandes conexões viárias. Essa relação era explícita no modelo radial-perimetral do Plano de Avenidas, que abria espaço ao crescimento urbano vertical e horizontal por meio da criação de uma malha viária racionalizada:

4 MEYER, Regina M. Prosperi. Metrópole e Urbanismo: São Paulo anos 50. 1991, Tese de Doutoramento - Faculdade de Arquitetura, Universidade de São Paulo, São Paulo. p. 30. 
$\mathrm{O}$ aporte progressivo da indústria automobilística, que passou a criar a partir de então uma preponderância absoluta para as questões associadas ao sistema viário metropolitano, ${ }^{6}$ viria também a se colocar como um novo problema para os arquitetos paulistanos. Propostas de projeto realizadas para a cidade desde fins dos anos 30 demonstram uma preocupação constante em incorporar a presença crescente dos automóveis no espaço urbano através de soluções integradas à arquitetura, conforme demonstra o projeto de Rino Levi para o conjunto comercial do IAPI, que integra a proposta de um novo túnel entre a avenida Anhangabaú e a rua 25 de Março no embasamento daquele grupo de edifícios. $\mathrm{O}$ mesmo arquiteto viria posteriormente a realizar, durante a década de 50, diversos ensaios sobre a questão das garagens urbanas verticalizadas nas áreas centrais da cidade. ${ }^{7} \mathrm{O}$ assunto seria empregado por Levi como mote para o desenvolvimento de exercícios projetuais com os alunos da FAU USP durante este período, além de ter sido experimentado pelo arquiteto em engenhosos projetos de garagens verticais realizados para a iniciativa privada em lotes urbanos em São Paulo e no Rio de Janeiro. 5 CAMPOS, Candido Malta. Os rumos da cidade: urbanismo e metropolização em São Paulo. São Paulo, Editora Senac,
2002. p. 588

6 MEYER, Regina M. Prosperi. Metrópole e Urbanismo: São Paulo anos 50. 1991, Tese de Doutoramento - FAU USP, São Paulo. p. 279.

Meyer oferece os dados referentes ao resultado do crescimento da produção da indústria automobilística em São Paulo (p. 279): Em 1950 circulavam na cidade 63.000 veículos a motor; em 1966 este número passou para 415.000, correspondendo portanto a um aumento de $1.518 \%$ em 16 anos.

7 Segundo Anelli (2001 p.222), Levi propôs em 1955 o programa dos estacionamentos urbanos como tema de reflexão para os alunos do quinto ano da Cadeira de Composicão de Arquitetura da FAU USP. São dessa época os textos: O problema do estacionamento na zona central de São Paulo (1955), O problema do estacionamento e a primeira grande garagem em construção em São Paulo (1955) e Estacionamento e problemas correlatos (1956)

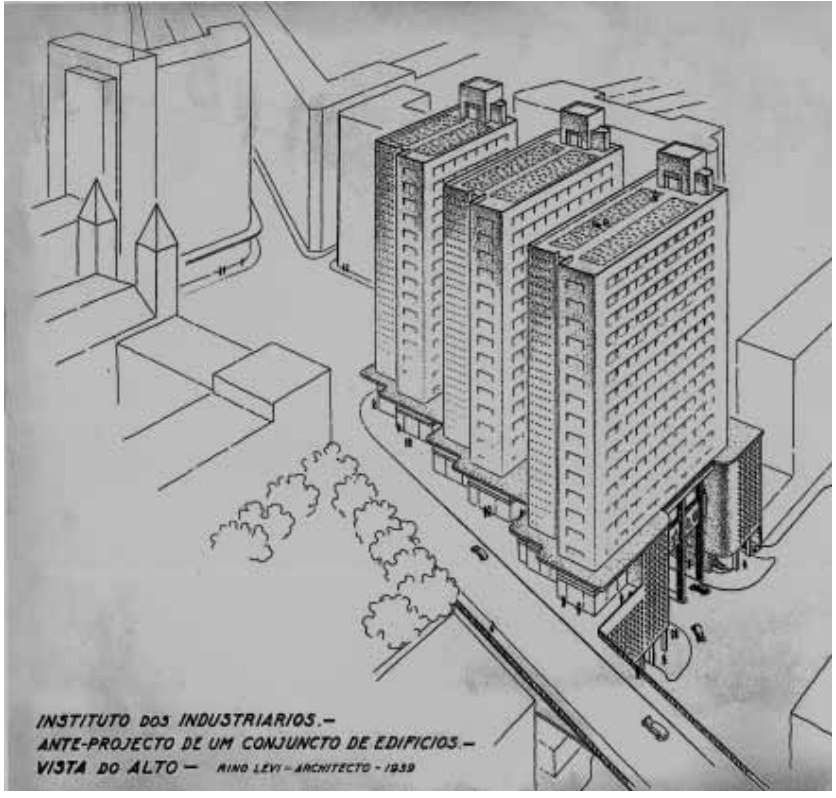

acima:

Projeto para o Conjunto Comercial do IAPI, São Paulo Rino Levi, 1939.

fonte: Anelli (2001. p. 110)

à direita (centro):

Projeto para a Garagem América, São Paulo.

Rino Levi, 1952-58.

fonte: Anelli (2001. p. 194)

à direita (extremo):

Projeto para a Garagem Copana, Rio de Janeiro.

(sistema "polielicoidal" de circulação desenvolvido pelo escritório) Rino Levi, 1956.

fonte: Anelli (2001. p. 194) 


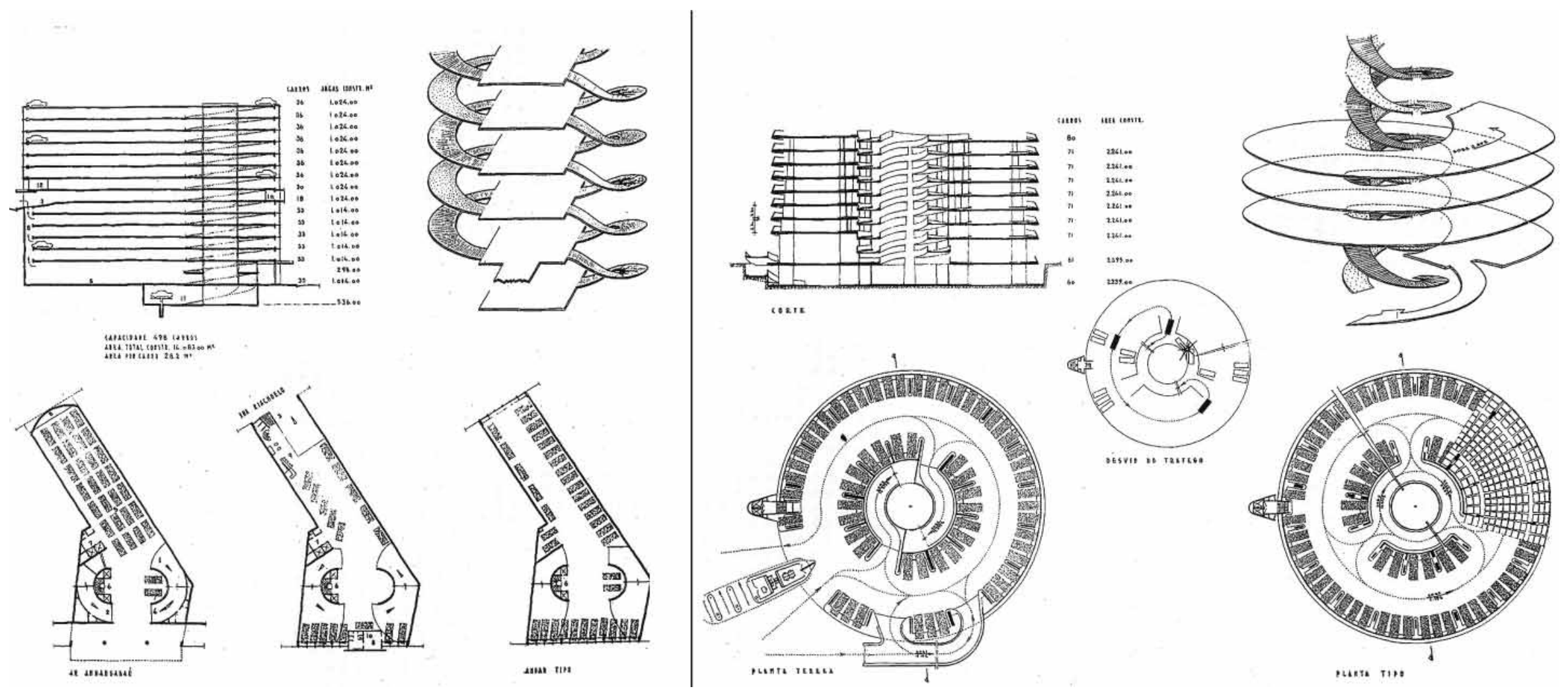




\section{habitação vertical}

Para os arquitetos que iniciavam a sua atividade profissional junto à iniciativa privada no mercado da construção durante os anos 50, o processo de crescimento e compactação $o^{8}$ da metrópole paulistana se tornou visível através do aporte significativo, particularmente em seus bairros mais centrais, de novos empreendimentos habitacionais de grande escala. Segundo Sampaio (2002. p. 26):

O boom imobiliário que caracterizou o pós-guerra foi decorrente do crescimento da oferta de crédito gerada pelos grandes superávits da balança comercial, devido à quebra de importações. A propriedade imobiliária se tornou campo favorito de investimento dos lucros oriundos da indústria, do comércio ou da exportação agrícola. (...)

O uso do condomínio foi também uma novidade que acelerou o mercado imobiliário do pós - guerra. Embora instituído por decreto de 1928, somente no final dos anos 40 começa a ser utilizado pelos construtores paulistanos. A Lei do Condomínio criou a figura jurídica da parcela ideal do terreno, permitindo assim que um imóvel pudesse ter vários proprietários independentes. Carlos Lemos conta que o engenheiro Cipriano Marques Filho começou a construir prédios em Santos, utilizando os mecanismos da incorporação e do condomínio com grande sucesso, o chamado "condomínio pelo preço de custo", que acabou por chamar a atenção de outros construtores da época, que aderiram à solução.

A resolução do problema da habitação coletiva em edifícios verticais, conforme 8 Este termo foi empregado por Langenbuch (1971. p.179) para caracterizar o adensamento das áreas edificadas no interior dos bairros mais centrais, internos aos limites da cidade, principalmente a partir de 1940. acima:

Edifício de Apartamentos, São Paulo.

Júlio de Abreu Júnior, 1927-35.

fonte: Xavier (1983. p. 1)

centro:

Edifício Columbus, São Paulo.

Rino Levi, 1930-34.

fonte: Anelli (2001. p. 60)

abaixo:

Edifício Esther, São Paulo.

Álvaro Vital Brazil e Adhemar Marinho, 34-35.

fonte: Conduru (2000. p. 55) 

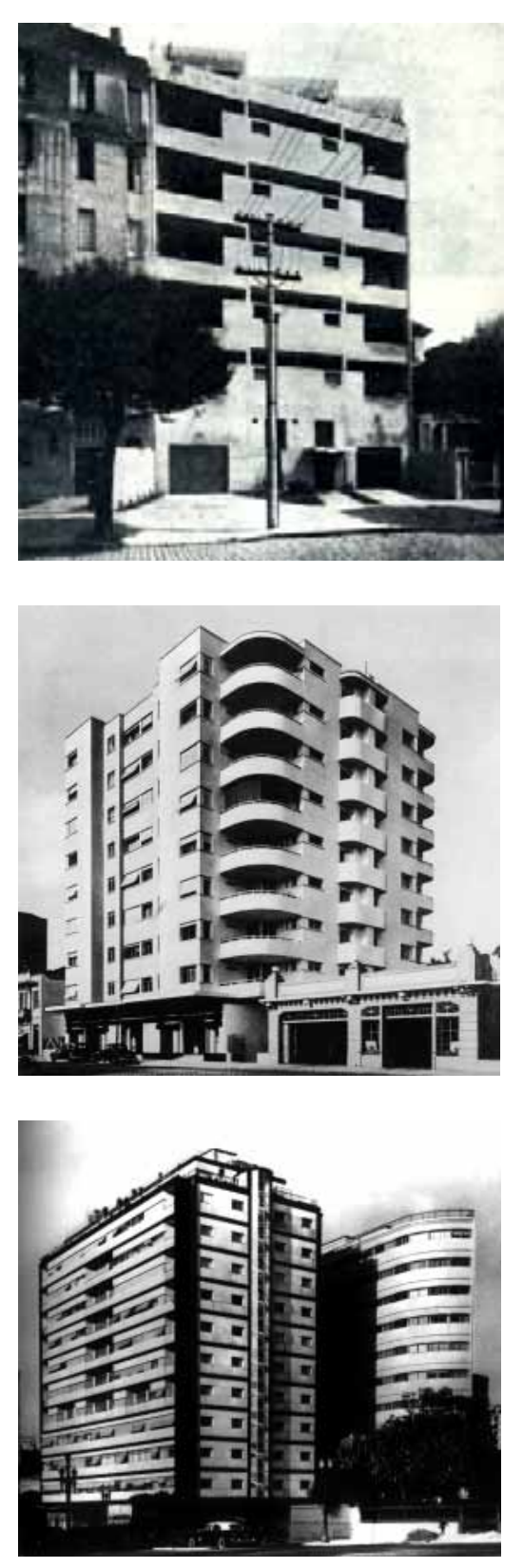

reivindicada pelo grupo editorial da Pilotis, já havia sido ensaiada em São Paulo nas décadas anteriores em menor escala por diversos arquitetos modernos, dentre os quais figuram Júlio de Abreu, com sua solução pioneira para o edifício de apartamentos na avenida Angélica, entre 1927 e 1935, ${ }^{9}$ Rino Levi com o Edifício Columbus (1930), e Álvaro Vital Brazil e Adhemar Marinho com o Edifício Esther (1934-35).

Mas foi no entanto a partir do II pós-guerra que o programa passou a se afirmar em uma dimensão nova, fomentando a adoção de novos paradigmas de verticalização. Segundo Vilariño (2000. p. 90):

O salto na escala dos empreendimentos (de 1950 a 1957) foi possível pela grande atividade imobiliária ocorrida nos anos 40 que propiciou a organização empresarial e desenvolvimento econômico do setor, tornando-o apto a gerenciar obras de maior porte. Nesse período, verifica-se a desassocioação das figuras do construtor e incorporador, revelando a maior complexidade atingida pelo mercado imobiliário. (...) Os condomínios residenciais que antes abrigavam 20, 30 unidades, passaram a comportar 200, 300 unidades, como no caso do Edifício Viadutos, realizado pelas Monções Construtora Imobiliária S.A. em 1955, com 360 apartamentos. Alguns condomínios ocupavam quarteirões inteiros (...).

Cumpre lembrar que a Lei do Inquilinato de 1942, que congelara então o preço dos aluguéis em âmbito nacional, havia contribuído segundo Bonduki (1998 p.209) para transformar radicalmente as formas de provisão habitacional no Brasil e em São Paulo, inviabilizando a produção rentista e estimulando a construção para venda, com o sistema de incorporação dos novos condomínios residenciais. Ao mesmo tempo, o esforço

9 Em sua tese de doutorado, Rosales (2002. p. 65) conclui que este exemplar pioneiro da arquitetura moderna paulistana não poderia ter sido concluído antes do ano de 1935, embora tenha sido projetado em 1927. Vale notar a interessante análise deste projeto realizada pelo autor. 
empreendida pelo poder público de construção de novos conjuntos de habitação coletiva de acordo com os preceitos da arquitetura moderna, havia também contribuído para estabelecer parâmetros de atuação para a iniciativa privada no setor. Segundo Sampaio (2002 p. 24), a produção da habitação de interesse social produzida através dos Institutos de Aposentadoria e Pensões (IAP), embora não tivesse sido implantada numa escala proporcional à demanda (não evitando portanto o incremento das moradias auto-construídas nas áreas periféricas, conforme atesta Bonduki, 1998), procurou imprimir de forma marcante a presença do poder público no campo da habitação, oferecendo um possível modelo a ser seguido. De fato, podemos tomar como exemplo em São Paulo a construção do Edifício Anchieta entre 1941-43 pelo IAPC num contexto urbano de grande visibilidade, no encontro entre a avenida Paulista e a rua da Consolação. Este projeto particularmente inovador realizado pelos irmãos Roberto teve um grande impacto entre seus colegas paulistanos, pelo pioneirismo com que a habitação coletiva é tratada em uma escala até então inusitada. Conta com um arranjo diversificado de apartamentos simples e duplex com prumadas de circulação vertical independentes, e explora de maneira instigante a composição plástica da extensa superfície da fachada com as suas saliências e inflexões características (a exemplo de outras obras realizadas pelos mesmos arquitetos), conforme comentam os próprios autores:

Arquitetura não é uma especulação bidimensional. Não pode se limitar ao mondrianismo, como acontece geralmente, por mais agradável que resulte o brinquedo. Seguindo Borromini, ondulamos docemente uma parte da fachada, pra acusar, sem violência, sua tridimensionalidade. ${ }^{10}$

Significativamente, o Anchieta figura em destaque entre os exemplos da arquitetura

10 "Comentário dos autores (MMM Roberto) sobre as habituais inflexões de fachadas". apud: ROSALES, Mario Arturo Figueroa. Habitação Coletiva em São Paulo 1928>1972. 2002, Tese de Doutorado - FAU USP, São Paulo. p. 108
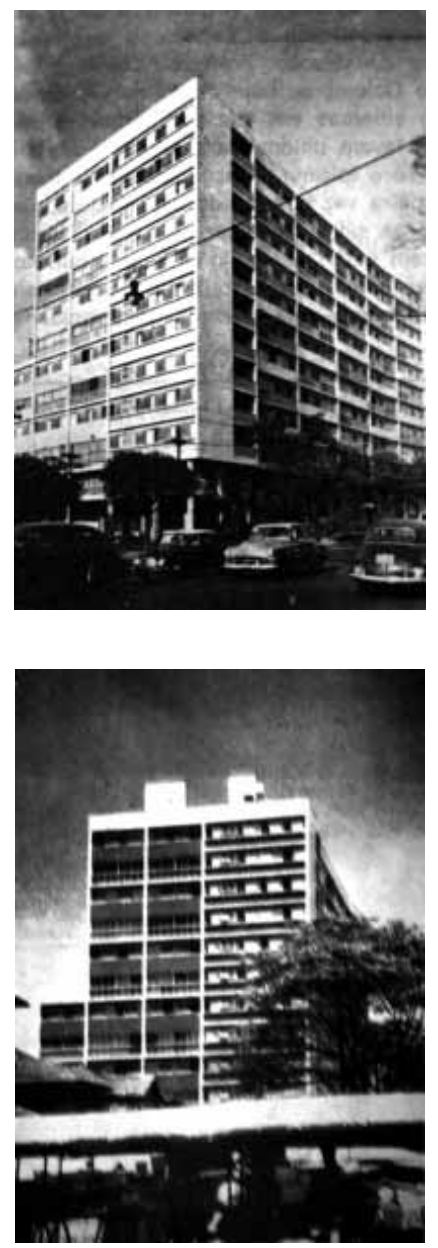

acima: Edifício Anchieta, São Paulo. Irmãos Roberto, 1941-42. fonte: Xavier (1983. p. 8)

abaixo: Edifício Anchieta, São Paulo. Irmãos Roberto, 1941-42.

fonte: PILOTIS. São Paulo, n. 4, fevereiro 1950 

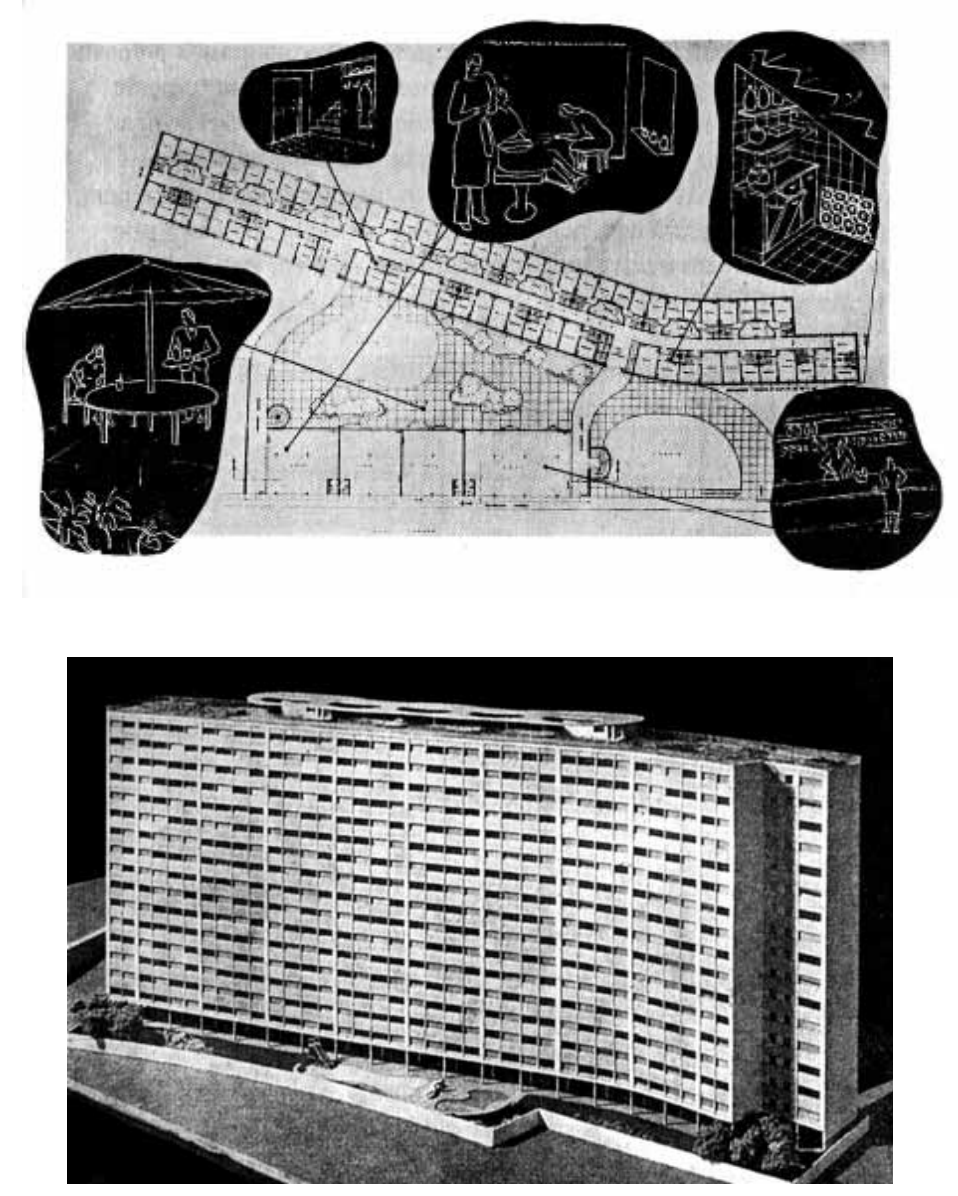

acima: Planta com esquemas de utilização. Eduardo Kneese de Me (1947-57). fonte: Bonduki (1998. p.199) abaixo: Edifício Japurá, São Paulo. Maquete.
Eduardo Kneese de Melo (1947-57). fonte: Bonduki (1998. p.199) moderna brasileira exibidos pelo editorial da Pilotis no texto citado acima, tendo sido objeto recorrente de visitas e estudos "clandestinos" pelos estudantes do Mackenzie durante e logo após a sua construção.

Outra iniciativa marcante promovida em São Paulo pelos IAP foi a construção do edifício Japurá (IAPI, 1947-57) de Eduardo Kneese de Mello. Ali a dimensão do edifício laminar com mais de $110 \mathrm{~m}$ de comprimento assume um caráter monumental, particularmente pela sua posição geográfica. Implantado diante do recém inaugurado viaduto Jacareí (1945), no trecho Sul do Perímetro de Irradiação de Prestes Maia, este edifício veio a substituir o conjunto de cortiços situados em uma área outrora obscura na trama urbana, e que passara - subitamente - a fazer parte do itinerário central da metrópole após a implantação daquela seqüência de viadutos. O Japurá demonstra o interesse do poder público, naquele momento, em associar o conjunto de transformações viárias com a idéia de "melhoramentos urbanísticos".

Entre os promotores privados da arquitetura moderna no mercado habitacional paulistano e em todo o país, destaca-se o Banco Hipotecário Lar Brasileiro, instituição financeira que captava dinheiro por meio de carteiras hipotecárias para investimento no mercado imobiliário, junto à qual Salvador Candia produziu alguns de seus mais significativos projetos no campo da habitação. Segundo Sampaio (2002. p. 27):

O Banco Hipotecário Lar Brasileiro, fundado em 1925, um dos pioneiros na concessão de crédito hipotecário de longo prazo no país, em poucos anos, conseguiu destacar-se por suas atividades de oferta de habitações, incentivando a casa própria, principalmente após a Lei do Inquilinato e no pós-guerra. Na época da construção do conjunto Ana Rosa, o banco já tinha atendido a cerca de 20.000 clientes, contanto com cerca de 80.000 depositantes. O Lar Brasileiro se destacava também pelo apoio que concedia principalmente à arquitetura moderna, contratando jovens arquitetos para desenvolver seus projetos. 
Os edifícios empreendidos pelo Lar Brasileiro desde o início dos anos 40 são representativos da adoção de uma nova escala na construção de condomínios habitacionais. ${ }^{11}$ Empreendimento contemporâneo ao Edifício Anchieta do IAPC, o conjunto "Conceição" (Abelardo de Souza, 1942) na avenida Casper Líbero, centro de São Paulo, reúne em um lote exíguo o programa misto de escritórios e três tipologias de apartamentos, divididos por duas prumadas distintas de circulação vertical em 20 pavimentos. Da mesma forma destaca-se o edifício "Mara” (Eduardo Kneese de Mello, 1944) de comércio e pequenos apartamentos na rua Brigadeiro Tobias, onde o programa hoteleiro foi usado como subterfúgio para a aprovação dos sanitários e cozinhas voltados para o interior do pavimento, conforme se costumou fazer durante um certo período até a legalização deste procedimento ainda na década de $50 .{ }^{12}$ Outro exemplo que reúne um programa misto de lojas, escritórios e apartamentos diversos em um único edifício de grandes dimensões com 23 pavimentos, construído ainda em 1946 pelo Lar Brasileiro, é o "Brasilar" situado na Praça das Bandeiras, Anhangabaú. Implantado de forma compacta sobre um terreno exíguo, este edifício pressupõe o simples prolongamento vertical da quadra urbana típica fechada em seu perímetro, produzindo assim uma extensa fachada de "fundos", constituída por grandes empenas cegas e profundos fossos de ventilação. Sem realizar uma mediação necessária com relação ao contexto urbano onde está inserido, o Brasilar situa-se de maneira desastrosa, demonstrando a dimensão do prejuízo provocado pelo mal equacionamento de um programa de grandes dimen-

11 Para edifícios construídos pelo Banco Hipotecário Lar Brasileiro, consultamos: SAMPAIO, Maria Ruth Amaral de (ed.). A Promoção Privada de Habitação Econômica e a Arquitetura Moderna 1930-1964. São Paulo: Rima/FAPESP, 2002.

12 Vilariño (2000 p. 88) comenta esta questão: "A única dificuldade a superar era a legislação municipal que impedia a utilização de dutos para ventilação dos sanitários, permitidos somente nos programas hoteleiros. Os primeiros edifícios de quitinetes foram aprovados como hotéis, pois a planta ideal em termos comerciais era a que apresentava o quarto-sala olhando a paisagem e o sanitário atrás, ventilado por duto, de forma a aproveitar melhor as áreas nobres das fachadas. Tal situação a paisagem e o sanitário atrás, ventilado por duto, de forma a aproveitar melhor as áreas nobres das fachadas. Tal situação
irregular foi resolvida em pouco tempo, pois os empreendedores imobiliários trataram de providenciar a mudança da lei, e o código Arthur Saboya passou a permitir banheiros ventilados por dutos nos prédios de apartamentos."
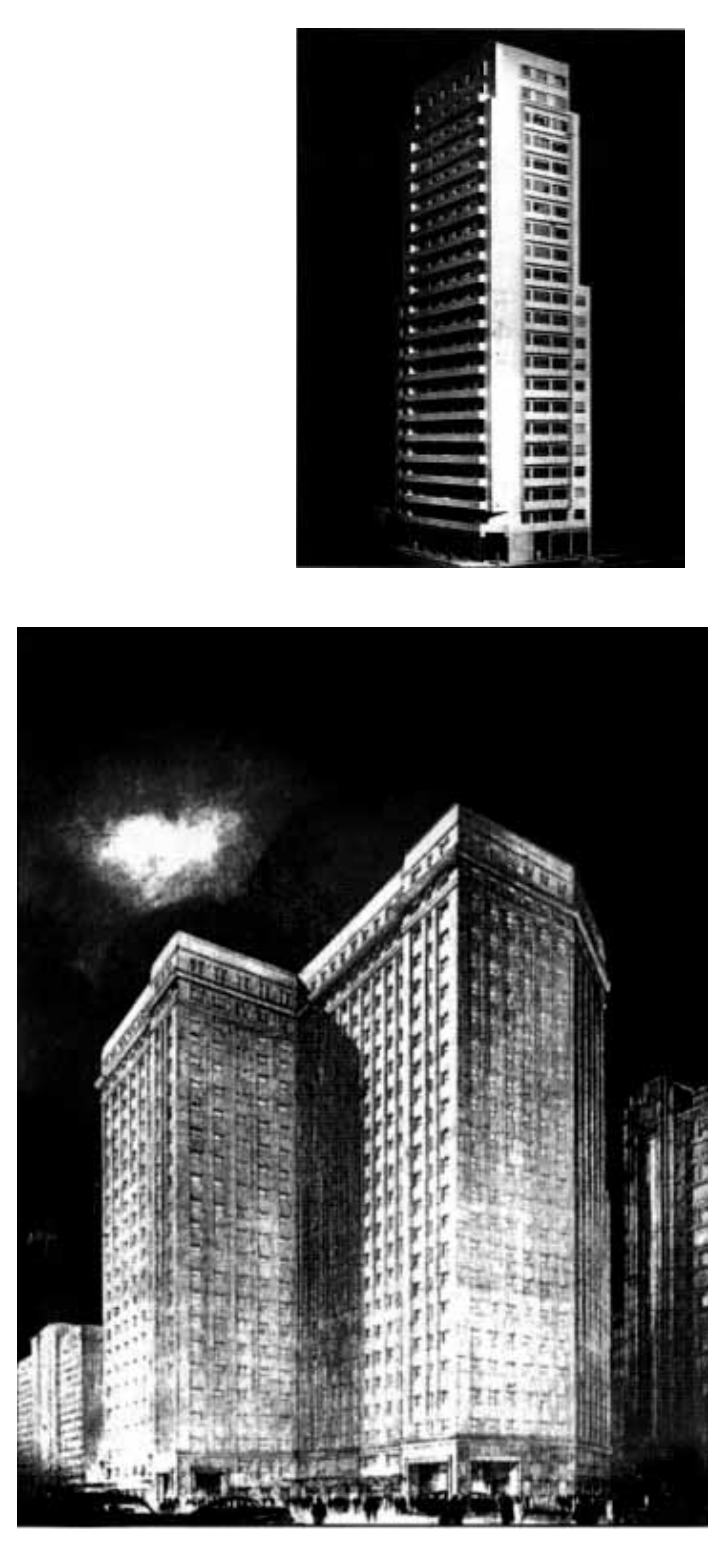
sões, valendo-se da prerrogativa de maior verticalização atribuída às áreas de interesse urbanístico determinadas pelas normas associadas ao Plano de Avenidas.

Seria dentro deste contexto de grandes empreendimentos habitacionais financiados pela iniciativa privada, e mais particularmente pelo Lar Brasileiro, que Candia, Croce e Aflalo realizariam o projeto para a superquadra em perdizes.

Segundo Xavier (1983 p. 36):

O surto imobiliário em São Paulo (...) favoreceu a grande especulação. Aproveitavamse, para tais empreendimentos, terrenos estrategicamente situados em esquinas de ruas comerciais, sempre prevendo edifícios mistos. Somente no começo da década de 50 é que se cogitou a execução de grandes conjuntos residenciais instalados em quarteirões inteiros. O João Ramalho [primeiro edifício daquele plano a ser construído entre 1953 e 1954] é um dos primeiros edifícios concebidos segundo este critério.

à esquerda acima: Edifício Conceição, São Paulo. Abelardo de Souza, 1942 fonte: Sampaio (2002. p. 133)

à esquerda abaixo: Edifício Brasilar, São Paulo. strutora Capua \& Capua, 1946 fonte: Sampaio (2002. p. 141)
A dimensão do empreendimento, tomada pela totalidade de uma quadra urbana de $150 \mathrm{~m}$ de extensão, ofereceu a estes arquitetos a oportunidade de ensaiar uma forma alternativa de ocupação do espaço urbano, aplicando aqui os preceitos urbanísticos da Carta de Atenas de liberação do solo para o transeunte e da implantação dos edifícios de forma independente dos alinhamentos das ruas existentes. A repetição de uma mesma tipologia para os edifícios propostos, haveria ainda possibilitado a experiência da produção industrializada em larga escala dos seus elementos construtivos. Todavia o programa de ocupação estabelecido pelo Banco foi sendo sucessivamente alterado após a implantação do primeiro edifício, o João Ramalho. Os arquitetos ensaiariam posteriormente outras alternativas de ocupação da mesma quadra, com projeto de maior adensamento das unidades habitacionais, tendo sido uma destas versões parcialmente executada somente no início dos anos 60 . Por haver se tratado, naquele momento, de uma experiência significativa de implementação de novos conceitos urbanísticos atra- 
vés do desenho de uma quadra isolada, este projeto será objeto de um estudo específico, conforme veremos adiante.

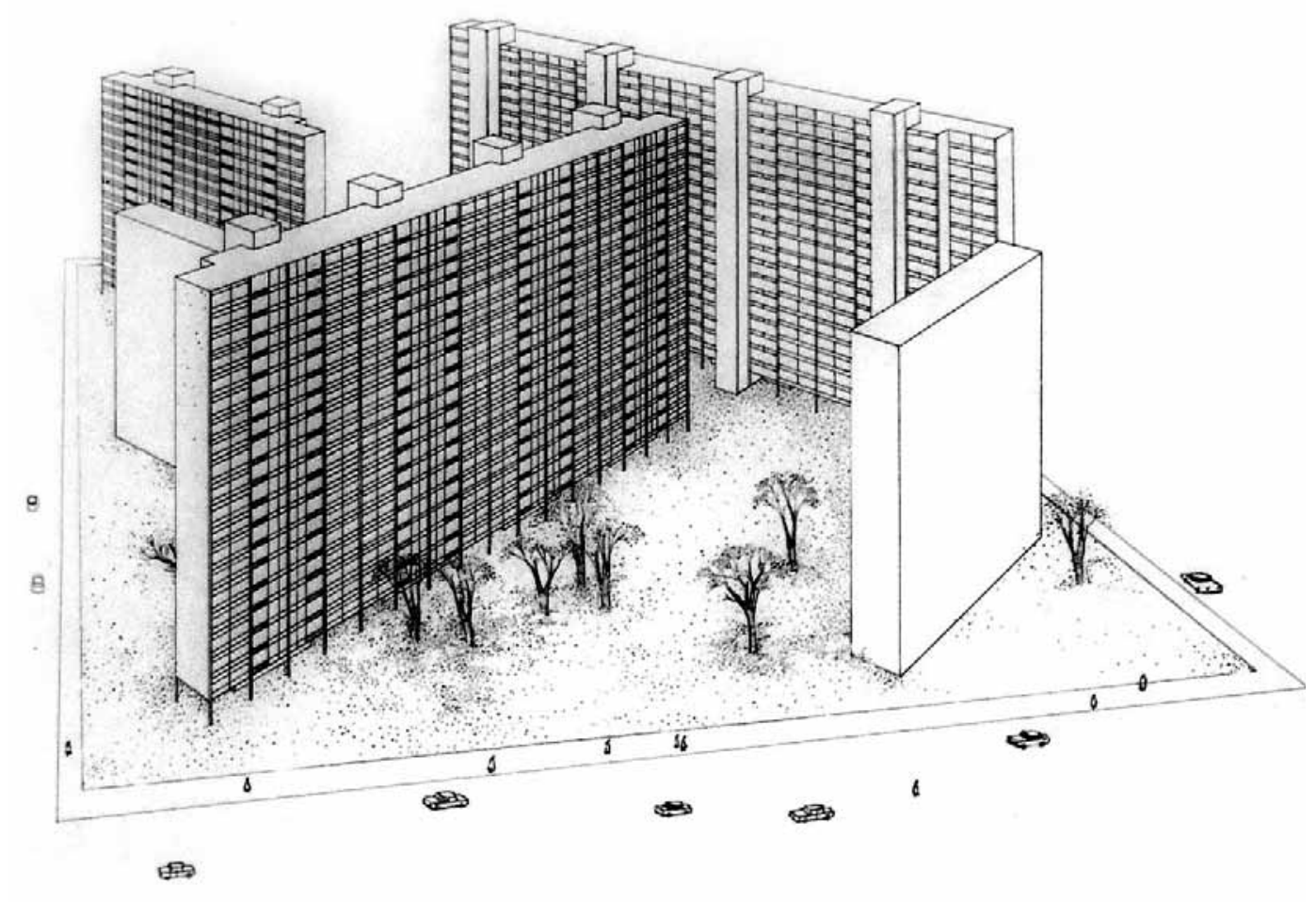

à esquerda:

Superquadra em Perdizes, São Paulo.

Perspectiva de implantação.

Projeto de 1953

Aflalo, Candia e Croce.

fonte: arquivo $\mathrm{S}$. Candia 


\section{galerias comerciais}

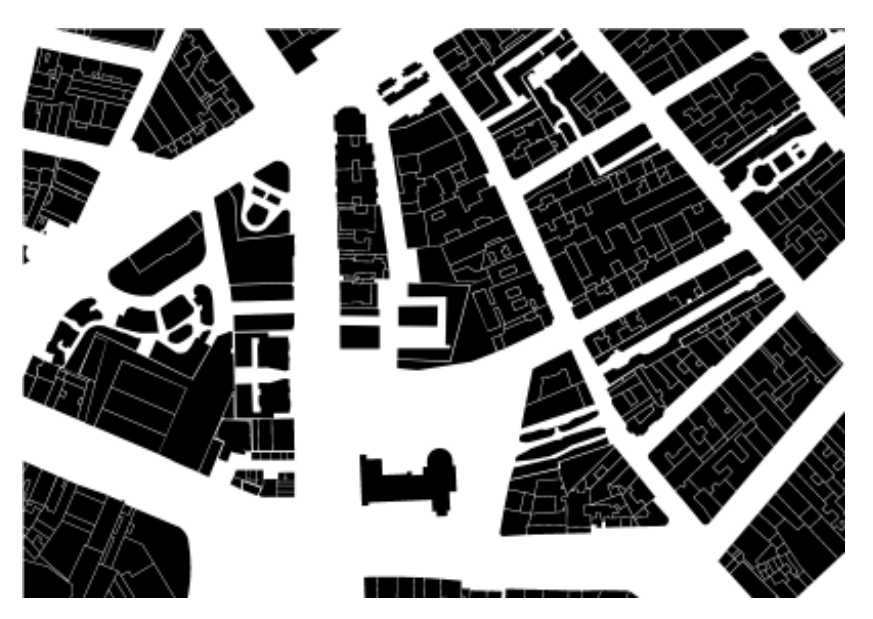

Planta das galerias do Centro Novo em São Paulo, 2008 . desenho realizado com base em fontes diversas
Outro aspecto marcante no panorama cultural paulistano durante a década de 1950 foi a construção do território das Galerias Comerciais no Centro Novo. ${ }^{13} \mathrm{O}$ espaço compreendido entre as praças Ramos, República, Dom José Gaspar e Largo Paissandu configurara-se como um ponto de grande representatividade da burguesia paulistana, concentrando lojas de grifes importadas, bares, livrarias e cafés, onde já se encontravam instalados importantes pontos de referência do itinerário cultural da cidade como o MASP e o MAM, a Biblioteca Pública e o Teatro Municipal. ${ }^{14} \mathrm{O}$ procedimento de ocupação do interior dos lotes para a construção de novas passagens de acesso, desdobrando a sua superfície de aproveitamento para incorporação de novas lojas, já se fazia presente como projeto no imaginário paulistano desde as célebres gravuras de Jules Martin (1832-1906), que inspiradas nas grandes galerias de Milão, Nápoles e Bruxelas, propunham a sua aplicação entre as ruas do centro velho já no final do século XIX.15 $\mathrm{O}$ já citado edifício Esther é um exemplo representativo de uma operação análoga, realizada ainda em 1935: a criação de uma nova rua (Gabos Mendes), que multiplica as fachadas do edifício, e conseqüentemente, suas vitrines. Dois anos antes da construção do Esther, abria-se uma das primeiras galerias comerciais do Centro Novo, através de uma reforma que uniu o pavimento térreo de duas construções pertencentes à Cia. Agrícola

13 O termo "território" foi aqui empregado para designar uma área específica do Centro Novo, situada em torno das praças Ramos, República, Dom José Gaspar e Largo Paissandu, onde as galerias comerciais constituem ao nosso ver o evento urbanístico mais característico.

14 Para o estudo das Galerias Comerciais no Centro Novo consultamos: ALEIXO, Cyntia Augusta Poleto. Edifícios e Galerias Comerciais. Arquitetura e Comércio na cidade de São Paulo, anos 50 e 60. 2005, Dissertação de mestrado - Escola de Engenharia de São Carlos da Universidade de São Paulo, São Carlos.

15 IDEM. p. 74. 
Guatapará (1933) ${ }^{16}$ e possibilitou uma passagem entre as ruas Barão de Itapetininga e 24 de Maio. Esta nova operação, empreendida por motivações estritamente comerciais, acabou por se mostrar extremamente proveitosa, tendo sido então ali empregada sucessivamente por diversos empreendedores durante as décadas de 50 e 60 . O conjunto urbanístico resultante daquela somatória de empreendimentos oferece um traçado alternativo pelo qual se pode caminhar, transpondo o interior das quadras do Centro Novo em uma trama independente do seu sistema viário. Os espaços comerciais que abrigam o passeio pelo interior dos edifícios confundem-se com as praças e as calçadas do logradouro público, multiplicando as suas possibilidades de apropriação.

A incorporação destas novas passagens no interior da trama urbana do Centro Novo teve de vencer os limites impostos pela divisão fundiária daqueles quarteirões. Muitas delas tiveram de utilizar o pavimento térreo de edifícios vizinhos já construídos, estipulando novas conexões através das divisas de fundo dos lotes. Este foi o procedimento empregado no projeto da Galeria Ipê (1949-51), de Plínio Croce. Ali o desenho da passagem acomoda, através de uma suave curvatura, a orientação distinta dos alinhamentos do edifício novo com relação ao existente. No projeto da Ipê, assim como nas demais galerias então implantadas, há uma sobreposição de funções. Enquanto os pavimentos térreos desdobram-se para acomodar o encaminhamento dos percursos existentes na implantação das lojas e dos acessos às prumadas verticais de circulação, os demais andares abrigam programas privativos de escritórios e, de forma menos freqüente, habitações. Alguns dos projetos implantados a partir dos anos 50 ensaiariam maneiras diversas de resolver esta sobreposição funcional: em 1951 Oscar Niemeyer realiza o projeto da Galeria Califórnia, ${ }^{17}$ através do remembramento de um conjunto de lotes situados entre as ruas Barão de Itapetininga e Dom José de Barros. O equacio-

\footnotetext{
16 IBIDEM. p. 172

17 Os projetos realizados por Niemeyer em São Paulo foram desenvolvidos no escritório de Carlos Lemos, arquiteto então recém formado no Mackenzie, colega mais novo da turma de Salvador Candia. (LEMOS: 2005. p. 145)
}
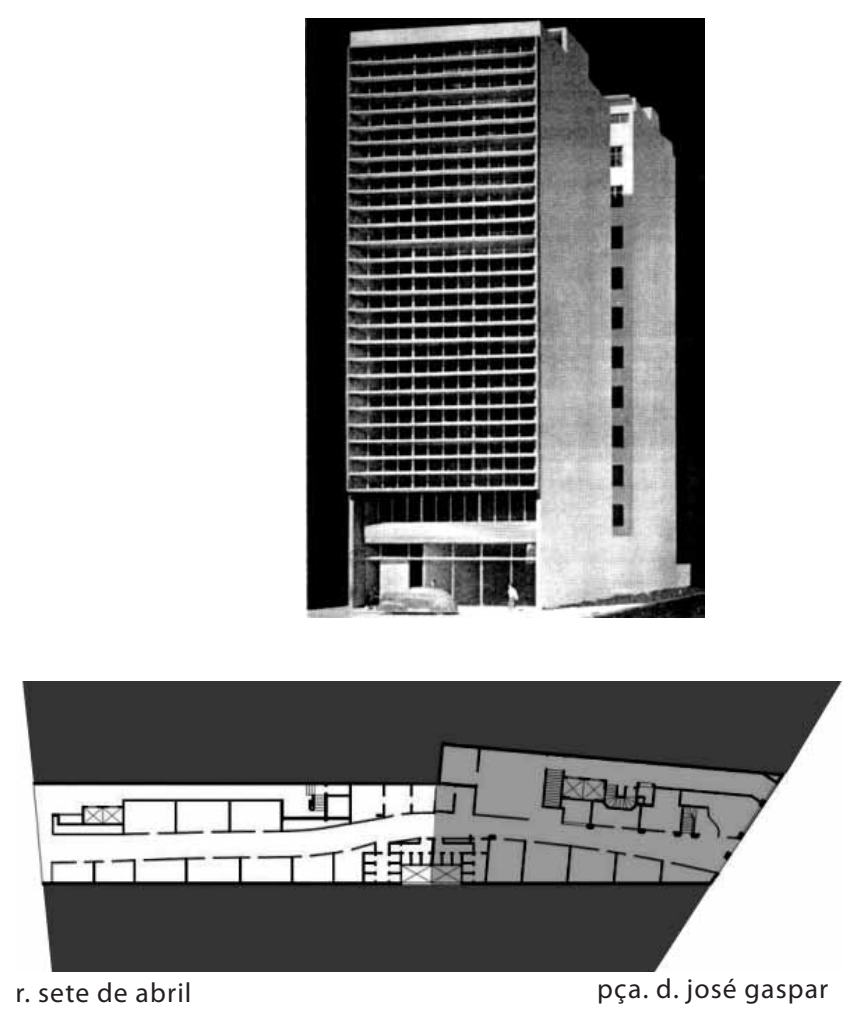

esquerda acima:

Galeria Ipê, São Paulo.Maquete.Plínio Croce, 1949.

fonte: Acayaba (1994. p. 44)

esquerda abaixo:

Galeria Ipê, São Paulo. Planta do pavimento térreo.

Em cinza está marcado o lote vizinho, pertencente ao Instituto de Previdência do Estado de São Paulo.

O desenho foi realizado com base em: Aleixo (2005. p. 181)

à direita:

Galeria Califórnia, São Paulo. Oscar Niemeyer, 1951.

desenhos elaborado com base na planta de prefeitura e nas informações disponíveis em: Aleixo (2005. p. 195)

de cima para baixo:

1. Planta do pavimento térreo

2. Planta do pavimento superior

3. Corte transversal 


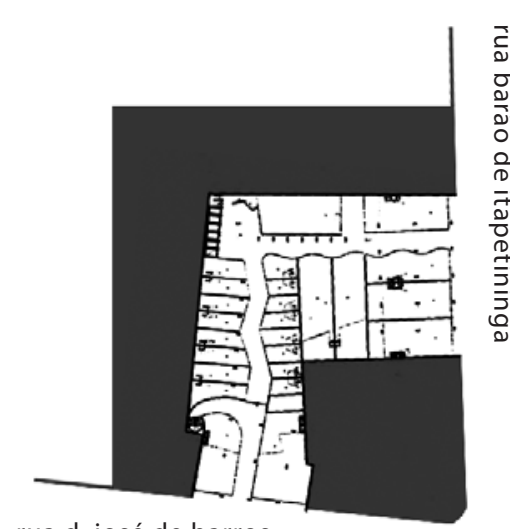

rua d. josé de barros

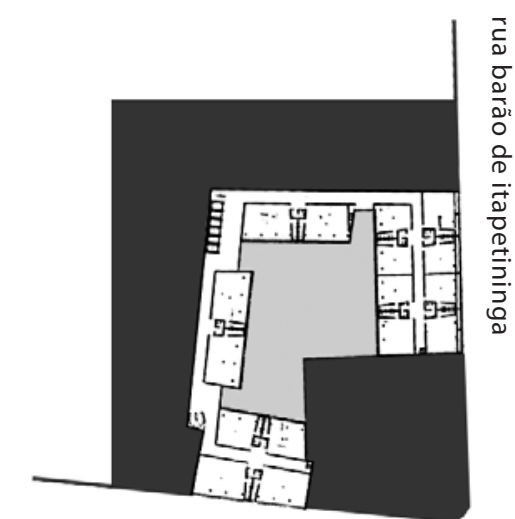

rua d. josé de barros

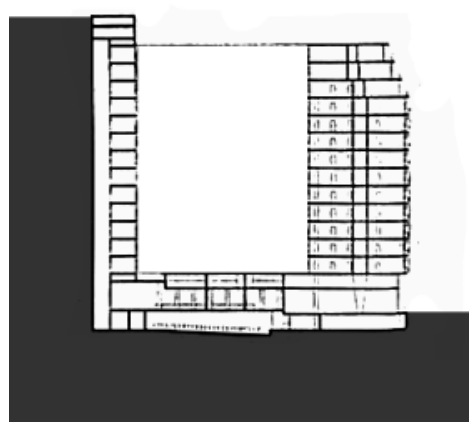

namento do programa levou à criação de um embasamento em toda a extensão do lote para abrigar a galeria no pavimento térreo, e o cinema no subsolo. Para acomodar o volumoso conjunto de escritórios em uma área exígua de geometria irregular, com pouca superfície de contato com as ruas, optou-se pela criação de um grande pátio elevado no miolo da quadra, sobre o qual foi pintado o painel-jardim de Di Cavalcanti (1897-1976), como um inusitado mural para ser visto de cima. ${ }^{18}$ Naquele mesmo ano, Niemeyer inicia o projeto do Edifício Copan, que realiza a sobreposição entre apartamentos e galeria comercial de maneira claramente diferenciada em sua resolução formal, estabelecendo um novo modelo e uma nova escala a serem incorporados posteriormente por outros empreendimentos, conforme veremos adiante.

Dentre as galerias que seriam ainda implantadas no Centro Novo durante as décadas de 50 e 60, destacam-se os diversos edifícios empreendidos pela construtora Alfredo Mathias S.A., realizados em associação com o escritório de arquitetura Siffredi e Bardelli (em conjunto com outros empreendedores diversos). O grupo foi responsável pela construção de notáveis conjuntos comerciais associados aos programas de escritórios como a Galeria 7 de Abril (1959), Centro Comercial Presidente (1962), e Grandes Galerias (1962), incluindo por vezes também o programa habitacional, como na Galeria Nova Barão (1962).

O projeto da Galeria Metrópole, implantado na praça Dom José Gaspar entre 1959 e 1964 por Salvador Candia e Giancarlo Gasperini, insere-se portanto num momento em que o território das Galerias Comerciais já se encontrava idealmente constituído. Este novo edifício se implantaria então de forma coerente com aquele conjunto urbano peculiar, dando-lhe continuidade e contribuindo de forma determinante para a sua consolidação. Salvador Candia iria ainda empregar em vários de seus projetos posteriores o uso das galerias comerciais como forma de interlocução entre o edifício e o "chão" da cidade, promovendo a continuidade do passeio público pelo seu interior.

18 Os estudos originais deste painel se encontram em poder do condomínio da Galeria Califórnia. O artista contribuiu em diversas obras de Niemeyer e Lemos em São Paulo, como o edifício Triângulo (1955) e o Montreal (1950) 
1. EDIFÍCIO COPAN

2. CONDOMÍNIO ZARVOS/ AMBASSADOR

3. EDIFÍCIO LOUVRE

4. EDIFÍCIO ITÁLIA

5. EDIFÍCIO METRÓPOLE

6. EDIFÍCIO ESTHER

7. GALERIA IPÊ

8. GALERIA 7 DE ABRIL

9. GALERIA DAS ARTES

10. GALERIA NOVA BARÃO

11. GALERIA LOUZÃ

12. GALERIA CALIFÓRNIA

13. GALERIA ITAPETININGA

14. GALERIA R. MONTEIRO/ ITÁ

15. GALERIA GUATAPARÁ

16. CONJUNTO PRESIDENTE

GALERIAS DO CENTRO NOVO

PLANTA DO PAVIMENTO TÉRREO

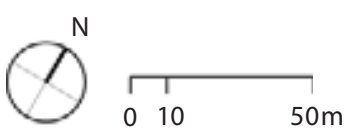









\section{Edifícios-conjunto}

Dentro deste quadro, de novas dimensões e atendendo novos programas funcionais, surgiram na década de 50 obras que marcaram relações novas com o espaço urbano. Os edifícios conjunto, congregando espaço para múltiplas atividades - comércio, restaurantes, cinemas, garagens, ruas internas - tornaram-se marcos da arquitetura do período. ${ }^{19}$

Os edifícios-conjunto representam, dentro daquele contexto estabelecido, o aproveitamento máximo das possibilidades de adensamento e sobreposição de funções em uma única construção. Dos empreendimentos deste vulto realizados em São Paulo entre as décadas de 50 e 60, destacamos como mais representativos o já citado edifício Copan (1951), o Conjunto Nacional (1954) de David Libeskind, e o já citado edifício Metropolitano (1959) de Candia e Gasperini. ${ }^{20}$

Do ponto de vista de seu partido formal, pode-se dizer que estes três conjuntos se aproximam de um mesmo arquétipo: edifício vertical sobre embasamento. ${ }^{21}$ Nos três casos, o embasamento cumpre a função de conciliar o novo conjunto com a cidade

19 MEYER, Regina M. Prosperi. Metrópole e Urbanismo: São Paulo anos 50. 1991, Tese de Doutoramento - Faculdade de Arquitetura, Universidade de São Paulo, São Paulo. p. 42.

20 Dentro dos elementos que levantamos para caracterizar o traço comum entre estes três edifícios, caberia também lembrar entre outros, o projeto do Edifício Itália (1953-56), de Franz Heep. Ali também o arquiteto emprega o uso da galeria no embasamento, que neste caso se desdobra em edifícios intermediários que realizam uma espécie de transição de escala entre o arranha-céu e a galeria comercial. Entendemos entretanto que este edifício assume características particulares em relação aos demais, principalmente pela dimensão exígua do terreno onde está implantado.

21 Em seu curso "Projeto, modernidade e aprendizado" (Escola da Cidade, São Paulo. Setembro de 2007), Hélio Piñon (Universidade Politécnica da Catalunha em Barcelona) comenta este arquétipo do "edifício vertical sobre embasamento", como tendo sido mais propriamente empregado nas cidades do continente americano a partir do II pós-guerra. Além de exemplos norte americanos, como a célebre Lever House de Gordon Bunshaft (1952), encontram-se exemplos notáveis em Bogotá, Caracas e Buenos Aires. Nesta última cidade vale citar o conjunto da rua Florida, 580, de autoria de Mário Roberto Alvarez e Associados (1974)
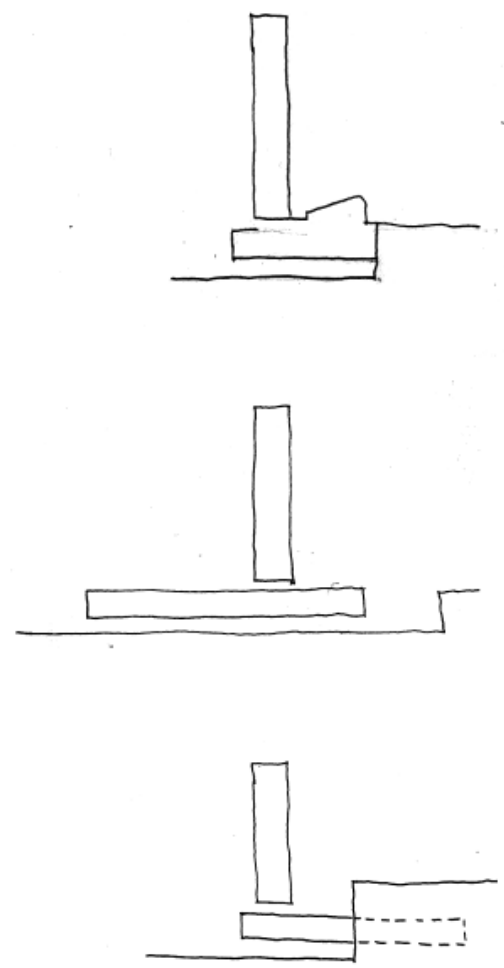

de cima para baixo:

Edifício Copan, Conjunto Nacional, Galeria Metrópole. Diagrama das seções transversais dos três conjuntos.

Forma de articulação entre o edifício vertical, o embasamento e seu entorno imediato

direita acima:

Edifício Seguradora Brasileira, São Paulo.

Planta da galeria no pavimento térreo (projeto original

posteriormente adulterado).

Rino Levi, 1948.

fonte: Barbara (2004. p. 254)

direita abaixo:

Edifício Seguradora Brasileira, São Paulo. Foto do modelo. Rino Levi, 1948.

fonte: Barbara (2004. p. 254) 

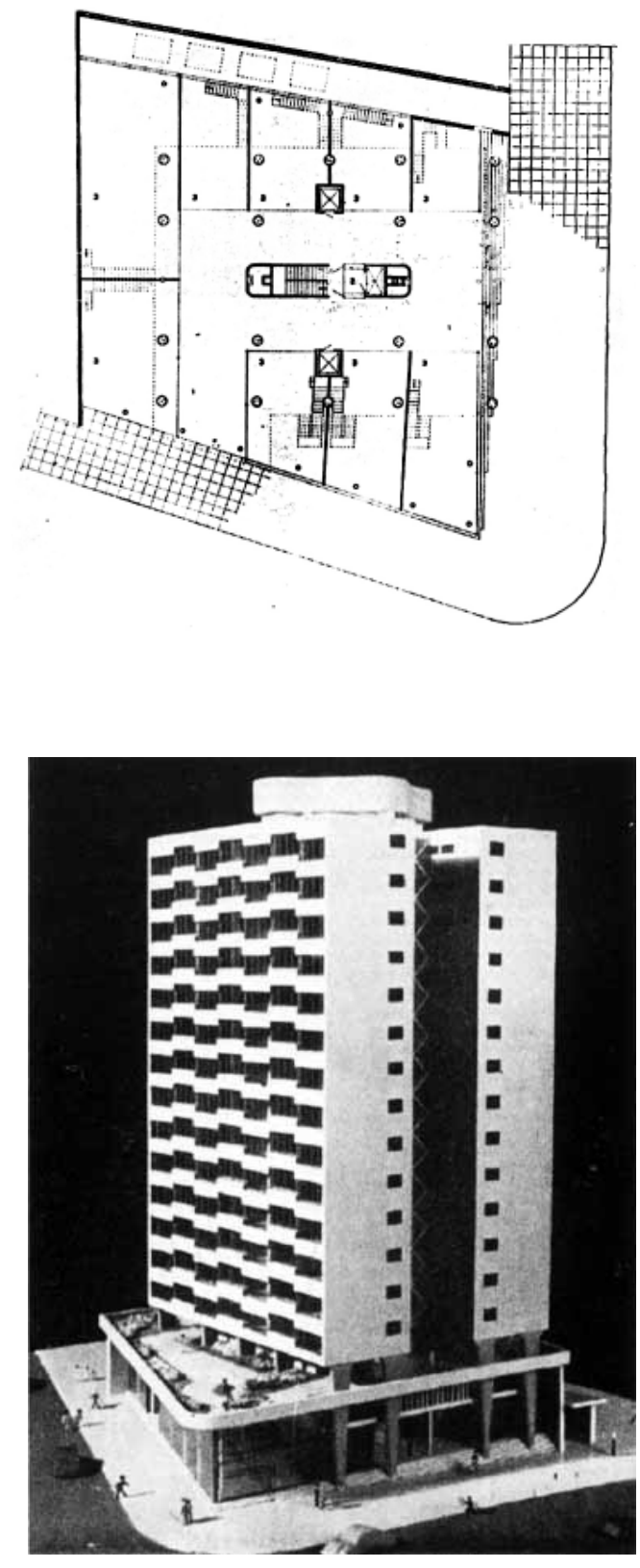

existente, abrigando suas funções de caráter mais público, e submetendo a sua forma às circunstâncias do entorno. Ao volume vertical caberia abrigar as funções mais privativas (ou domésticas) do programa. Estando implantado em uma cota elevada sobre o embasamento, o edifício vertical conquista uma certa independência em relação a seu entorno urbano imediato. À cobertura do embasamento, caberia abrigar os espaços livres, porém destacados do chão da cidade. ${ }^{22}$

Este dispositivo formal de organização do programa já havia sido ensaiado em São Paulo por Rino Levi no projeto de um edifício de lojas e apartamentos para a Cia. Seguradora Brasileira no Largo da Pólvora, Liberdade. ${ }^{23}$ Embora tenha sido projetado em 1948, sua obra foi concluída somente em 1956. A galeria comercial prevista neste edifício dispõe de toda a projeção do lote para a construção do embasamento, alinhando a sua volumetria com as construções vizinhas e oferecendo uma marquise que acolhe os transeuntes na calçada. Situado em um terreno de esquina, o projeto previa originalmente o cruzamento dos pedestres pelo seu interior, oferecendo um percurso alternativo entre as ruas Liberdade e Américo de Campos. O teto jardim sobre o embasamento constitui o espaço livre coletivo dos apartamentos situados no edifício vertical. Outro exemplo análogo que seria realizado por Levi já no início da década de 60, é o Banco Sul-Americano do Brasil S.A., implantado na esquina da avenida Paulista com a rua Frei Caneca. ${ }^{24}$

22 A este modelo ideal do edifício-conjunto correspondem diversas experiências realizadas no Brasil e no exterior, principalmente a partir do II pós-guerra. Em nenhum dos casos que apresentamos, a apropriação posterior dos usuários do edifício correspondeu à aplicação da idéia original do projeto. Em geral, o pavimento intermediário entre o edifício vertical e o seu embasamento apresenta um conflito entre funções de uso público e privativo, como é o caso do edifício Copan e do Conjunto Nacional.

23 BARBARA, Fernanda. Duas Tipologias Habitacionais: O Conjunto Ana Rosa e o Edifício Copan: Contexto e Análise de dois projetos realizados em São Paulo na década de 1950. 2002, Dissertação de Mestrado - Faculdade de Arquitetura, Universidade de São Paulo, São Paulo. p. 252.

24 Há diversos exemplos da utilização deste recurso em São Paulo a partir de meados da década de 50. O movimento de ocupação da avenida Paulista a partir deste momento presenciou a implantação de diversos edifícios com galerias conforme este mesmo arranjo, como seria o exemplo do edifício V Avenida, de Pedo Paulo de Melo Saraiva e Miguel Juliano em 1959 
Embora esta solução arquitetônica tenha sido efetivamente experimentada de forma pioneira em São Paulo a partir do início da década de 50, como atestam os exemplos comentados acima, podemos dizer que a idéia de cidade que alimenta estes projetos esteve presente em diversos planos urbanísticos realizados internacionalmente no II pós-guerra, seja em alguns exemplos europeus, como no plano elaborado - e posteriormente modificado - por Van der Broek \& Bakema para a reconstrução da área comercial central de Rotterdam (1946-1955), onde edifícios laminares habitacionais implantam-se sobre estruturas horizontais que dão abrigo aos programas de comércio e serviços; ou nas prósperas cidades norte americanas, como bem exemplificam os planos realizados pela Chicago Plan Comission durante a segunda metade da década de 40, onde o chão da cidade se desdobra em camadas horizontais sucessivas para a ocupação dos terraços de seu rio urbano. ${ }^{25}$
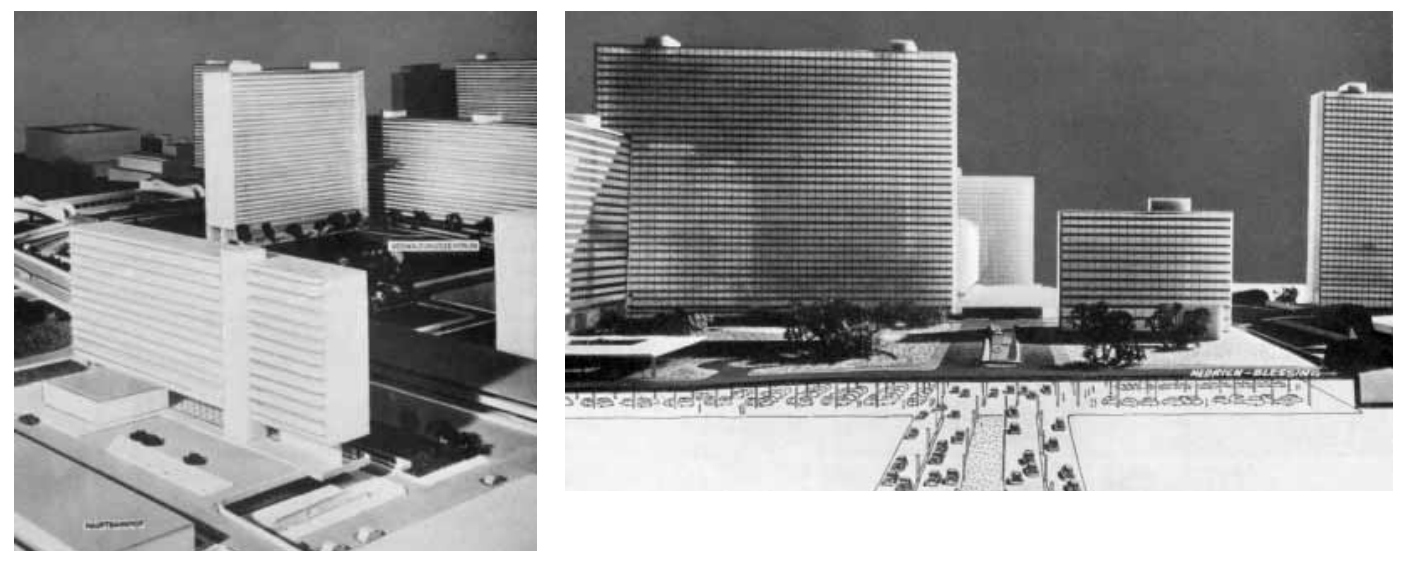

25 Não por acaso, a presença de arquitetos-urbanistas como o alemão Ludwig Karl Hilberseimer (1885-1967) em Chicago, à frente do departamento de planejamento urbano do IIT (Illinois Institute of Technology) e do escritório de planejamento daquela cidade, se faria sentir através de seus estudos precedentes sobre a "Cidade de Arranha-céus" (Hochhausstadt), de 1924. ver: ZUKOWSKY, John (org.). Mies Reconsidered: His Carrer, Legacy, and Disciples. Chicago: Art Institut of Chicago, 1986. p. 111

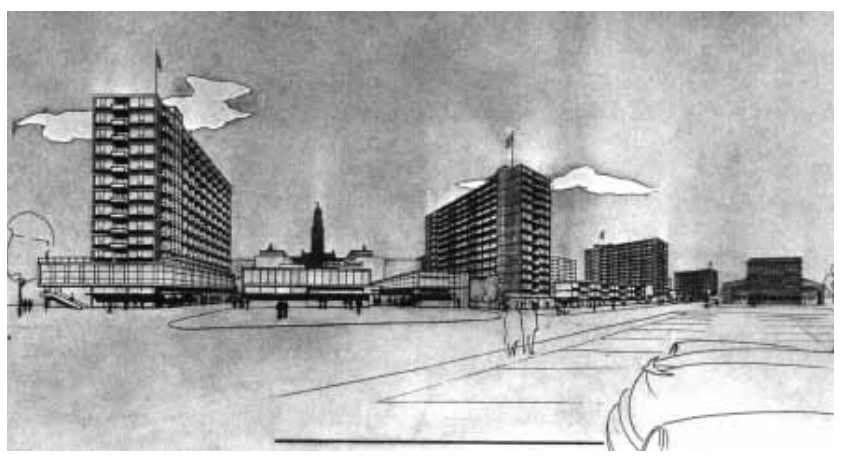

acima:

Schouwburgplein, Rotterdam.

Comércio associado a escritórios e habitação.

Van der Broek \& Bakema e equipe, 1946-53

fonte: Atlas of the Dutch Urban Block (autores diversos)

Rotterdam: THOTH Publishers, 2005. p. 163

esquerda ao lado (duas imagens idem):

Plano de ocupação da margem Leste do rio Chicago.

The Chicago Plan Comission, 1947-51.

fonte: Amerikanische Architektur Seit 1947.

Stuttgart: Gerd Hatje Verlag, 1951. p. 137 

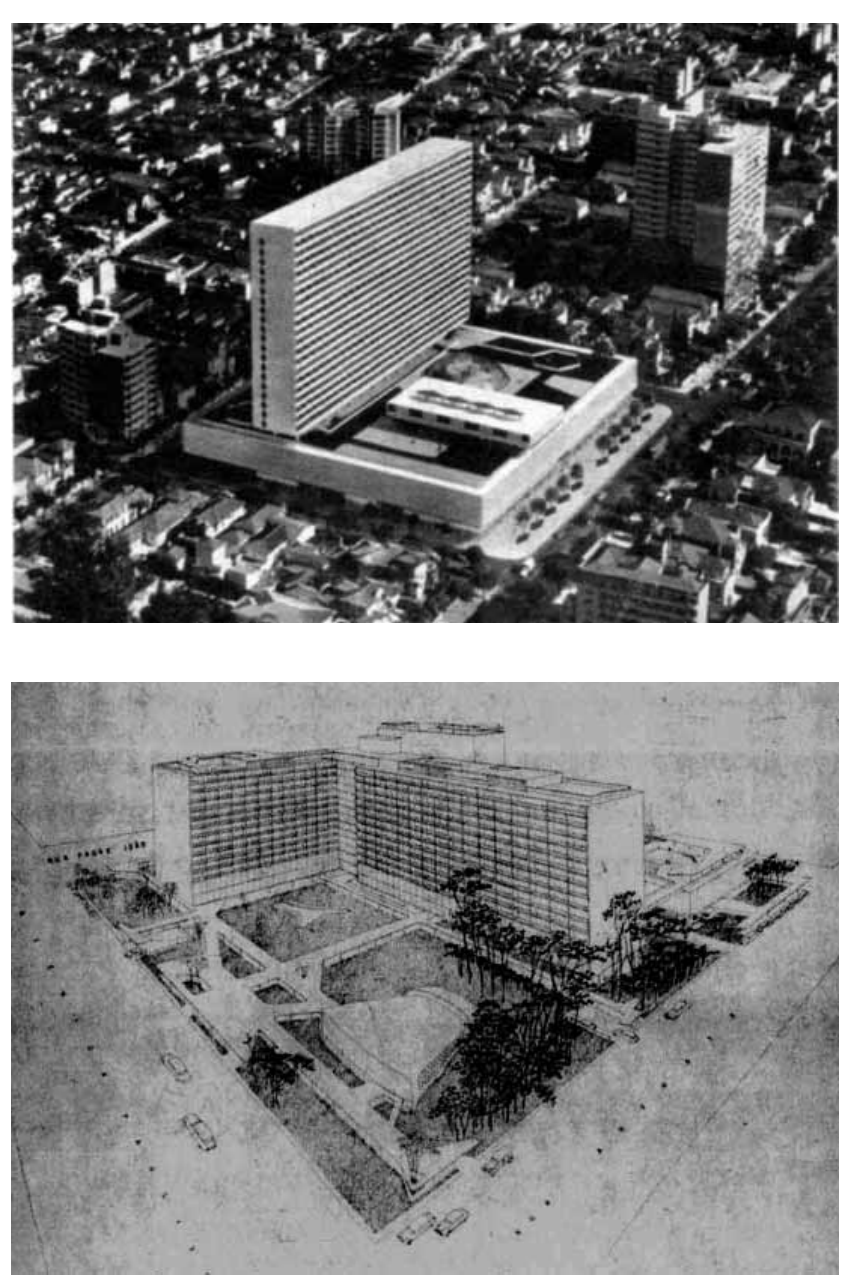

acima:

Conjunto Nacional. São Paulo David Libeskind,1955.

Fotomontagem do modelo.

fonte: Brasil (2004. p.89)

abaixo:

Projeto para o Conjunto Nacional (Hotéis Reunídos S.A.) Perspectiva do conjunto. Gregori Warchavchik, Giancarlo Fongaro, Jacob Ruchti, Salvador Candia e Carlos Lodi, 1952 fonte: Viégas (2003)

\section{experimentando soluções}

Tendo iniciado sua atividade profissional no momento de emergência destes empreendimentos realizados pelo aquecido mercado imobiliário paulistano, Salvador Candia seria diversas vezes convocado a participar de projetos que envolveriam a conjugação de programas complexos (a exemplo dos casos citados), onde procurou ensaiar configurações análogas para a resolução do problema, conforme veremos adiante. Entre 1952 e 1953, participou de duas propostas sucessivas para a ocupação de um quarteirão inteiro na avenida Paulista, a encargo do empreendedor José Tijurs, do grupo "Horsa" (Hotéis reunidos S.A.). Após diversas tentativas elaboradas também por outras equipes, o projeto definitivo do Conjunto Nacional seria (justamente) conquistado em 1954 pelo jovem arquiteto mineiro David Libeskind, ${ }^{26}$ através de concurso fechado.

A proposta de 1952 havia sido elaborada por uma equipe composta por Gregori Warchavchik, Carlos Lodi, Giancarlo Fongaro, Jacob Ruchti e Salvador Candia. Pelas informações de que dispomos, pode-se identificar neste projeto a intenção de setorizar a quadra em duas porções distintas, divididas pela implantação do corpo principal do conjunto. Os demais anexos, cinema e lojas estão dispersos pelo terreno e conjugados por um grupo de marquises, numa trama que se esforça por conquistar, de forma ainda extremamente rarefeita, as dimensões do terreno. ${ }^{27}$

26 Nascido no Paraná em 1928, Libeskind passou toda a sua juventude em Belo Horizonte, tendo se formado em 1952 pela Escola de Arquitetura da Universidade de Minas Gerais. Aos 26 anos, recém chegado em São Paulo, Libeskind elabora aquela proposta decisiva para a construção do Conjunto Nacional. Ver: VIEGAS, Fernando Filippe. Conjunto Nacional: A construção do Espigão Central. 2003, Dissertação de Mestrado - FAU USP, São Paulo.

27 Essa disposição espacial dos edifícios implantados em meio a um conjunto de pátios gramados, articulados por marquises simples para o abrigo do sol e da chuva, se vê concretizada em diversos projetos de Walter Gropius, dentre os quais podemos destacar o conjunto de habitações para universitários em Harvard, 1948. Note-se que o contexto urbanístico condizente com aquela implantação não se aplicaria ao caráter que a avenida Paulista passou a assumir a partir daquele momento. ver: ARGAN, Giulio Carlo. Walter Gropius e a Bauhaus. Rio de Janeiro: José Olympio, 2005. p. 131. 
O segundo projeto, elaborado apenas por Candia, Fongaro e Ruchti, parte de uma proposta de ocupação radicalmente diversa da primeira. A densidade ocupacional prevista então excede a solução final elaborada por Libeskind, antecipando ali a proposta do grande edifício laminar implantado ao longo de toda a extensão do terreno, para abrigar tipos diversos de apartamentos (o projeto propunha apartamentos de quartoe-sala, e também de dois e de três quartos, variando em cinco tipologias). Estes são organizados em prumadas verticais independentes, possibilitando em todos os casos a dupla orientação dos apartamentos. Como forma de equacionar o programa integrado de habitação, galeria comercial e hotel, ${ }^{28} \mathrm{o}$ projeto propõe a setorização da quadra através de uma rua interna exclusiva do conjunto, acessível pela rua Padre João Manuel, onde o movimento de veículos é menor. Esta rua interna sugere a separação funcional entre o programa do hotel, situado em sentido transversal próximo à avenida Paulista, e a lâmina dos apartamentos junto à alameda Santos. O embasamento se divide também em duas porções correlatas, distinguindo assim os serviços do hotel daqueles pertencentes à galeria comercial relacionada às habitações. Na esquina com a rua Augusta, é mantida uma praça arborizada, de forma semelhante ao que se cogitou fazer no projeto com Warchavchik.

O partido de ocupação da quadra ensaiado na versão de 1953 é análogo à implantação originalmente prevista para o edifício Copan, realizada dois anos antes por Niemeyer. ${ }^{29}$ Ali a grande lâmina dos apartamentos também se distingue do edifício do hotel por uma rua interna (rua Inaí). Embora também separado em duas partes, o embasamento do Copan deveria se articular no pavimento de cobertura através de uma "ponte" entre os pisos do teto-jardim, além da continuidade espacial prevista original-

28 É possível que o projeto previsse também o programa de escritórios. Este dado não se encontra todavia disponível nos arquivos de S. Candia.

29 Há também uma relação direta com a implantação Conjunto JK, realizado por Niemeyer em Belo Horizonte, também em 1951

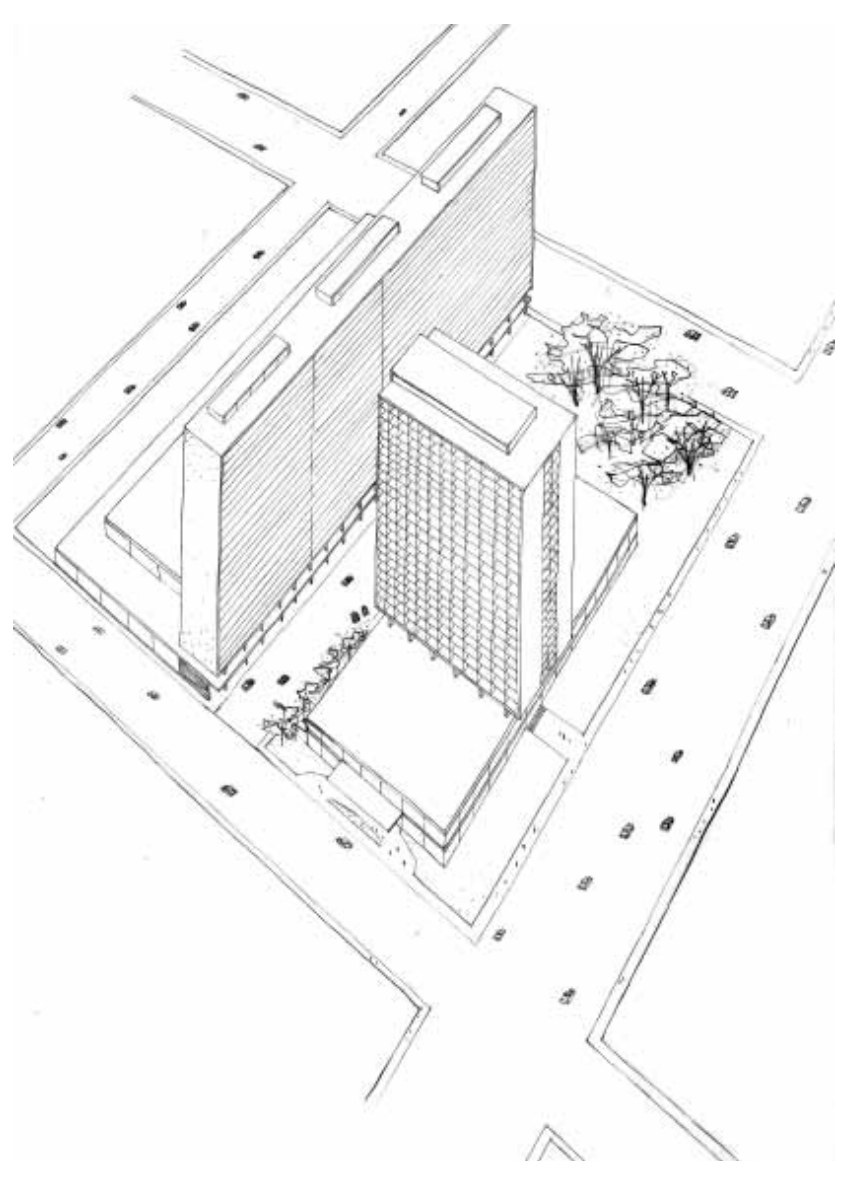

acima:

Projeto para o Conjunto Hotel Nacional

(Hotéis Reunidos S.A.), São Paulo.

Perspectiva.

Giancarlo Fongaro, Jacob Ruchti e

Salvador Candia, 1953.

fonte: arquivo S. Candia 

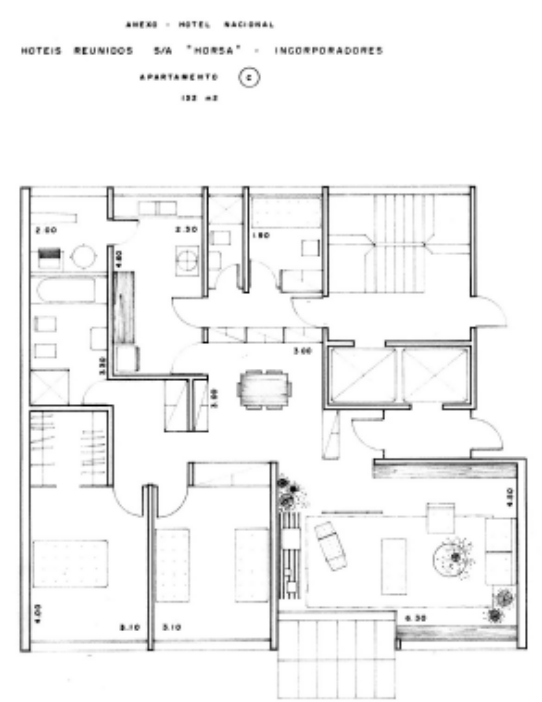

wetels arumioos

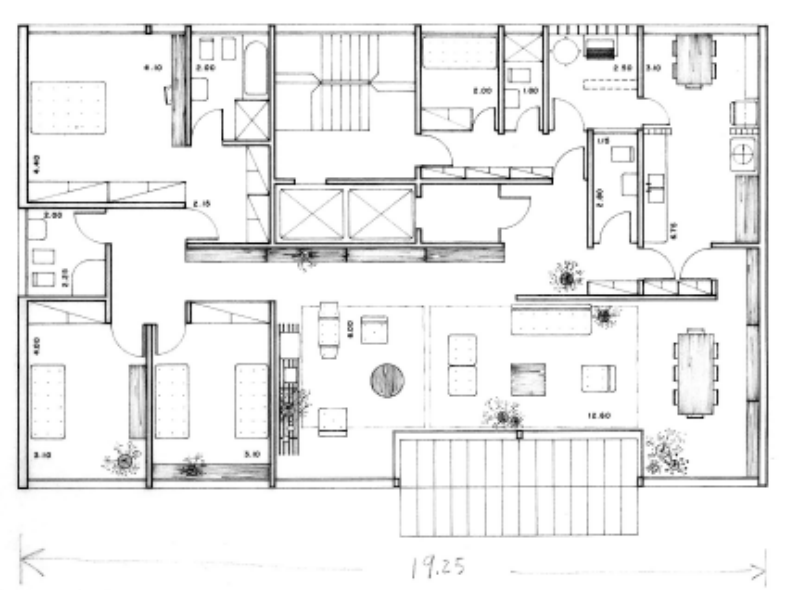

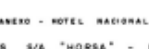

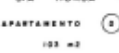

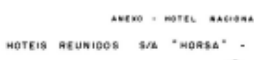

inctions
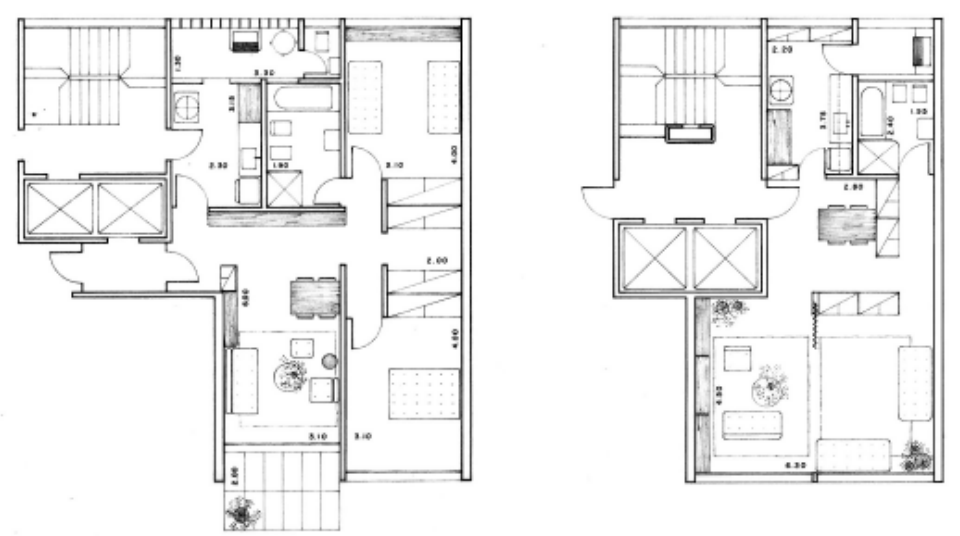

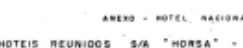

s/4 "Monsa'

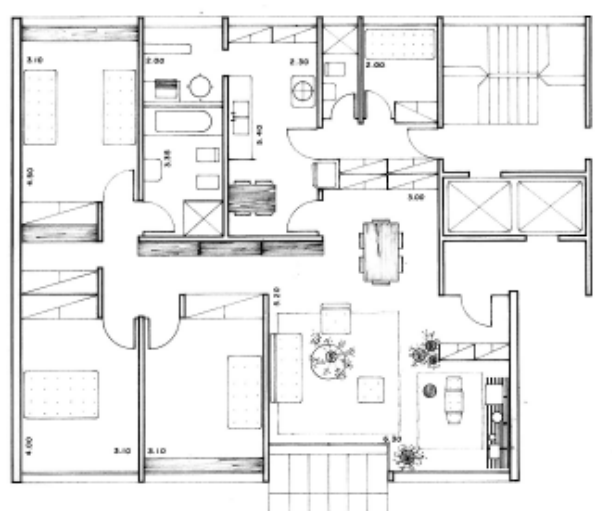

para o projeto do conjunto para o Hotel Nacional (Hotéis Reunidos S.A.), São Paulo.

Giancarlo Fongaro, Jacob Ruchti e Salvador 
mente entre as galerias no pavimento térreo. Neste caso, ao invés de separar o conjunto, a rua assumiria o papel de articulação entre os programas propostos, trazendo o acesso de automóveis para o seu interior (o que certamente enriqueceria as suas possibilidades de uso e apropriação). Esta forma de articulação entre programas de naturezas distintas, como era o caso do hotel e do edifício de habitações, parece haver se mostrado desde aquele momento extremamente oportuna. O lento e conturbado processo de construção do Copan concretizaria uma implantação completamente diversa daquela anteriormente imaginada. Todavia as imagens divulgadas do projeto original a partir de 1951 demonstravam com clareza as vantagens daquela forma de organização.

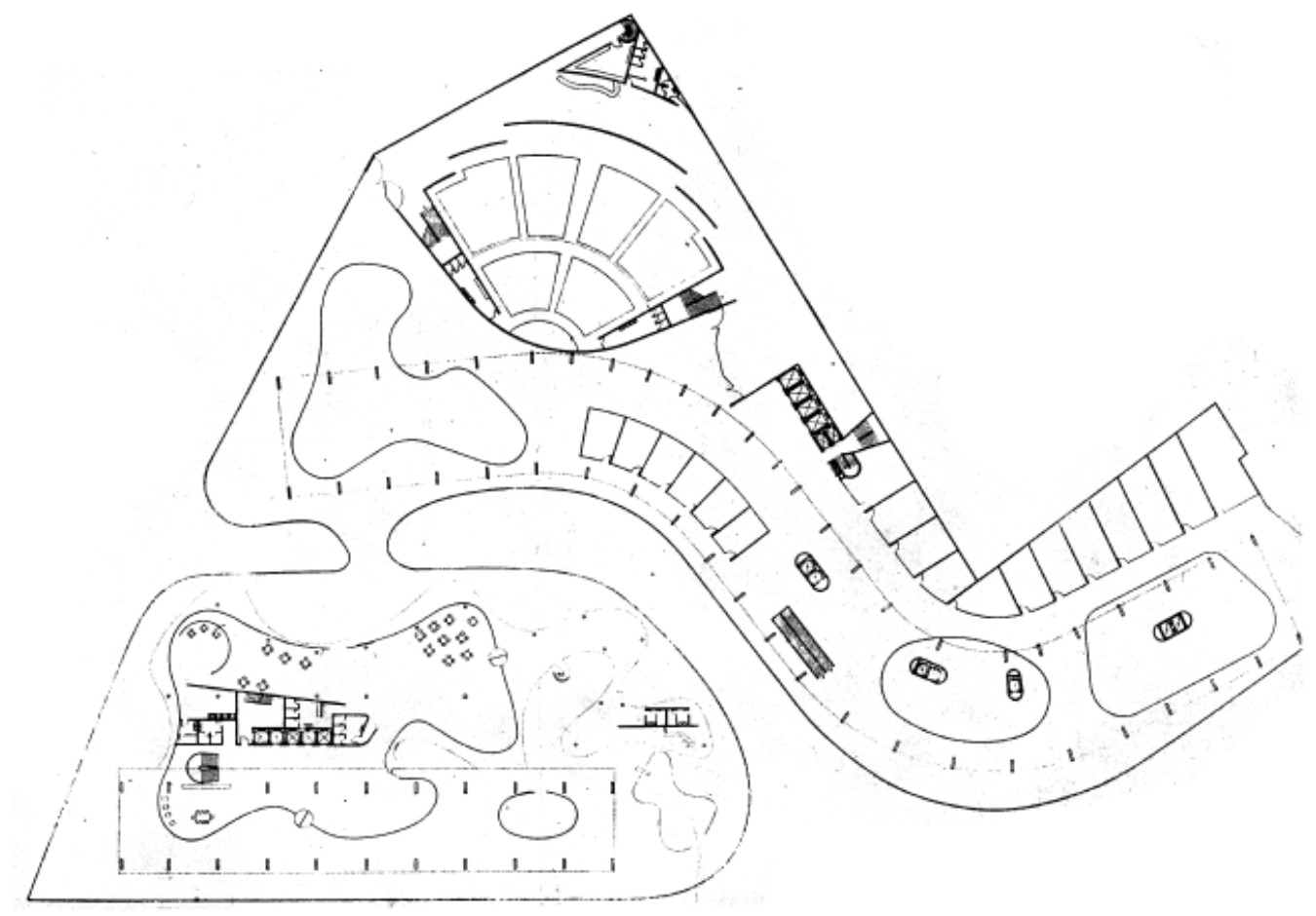

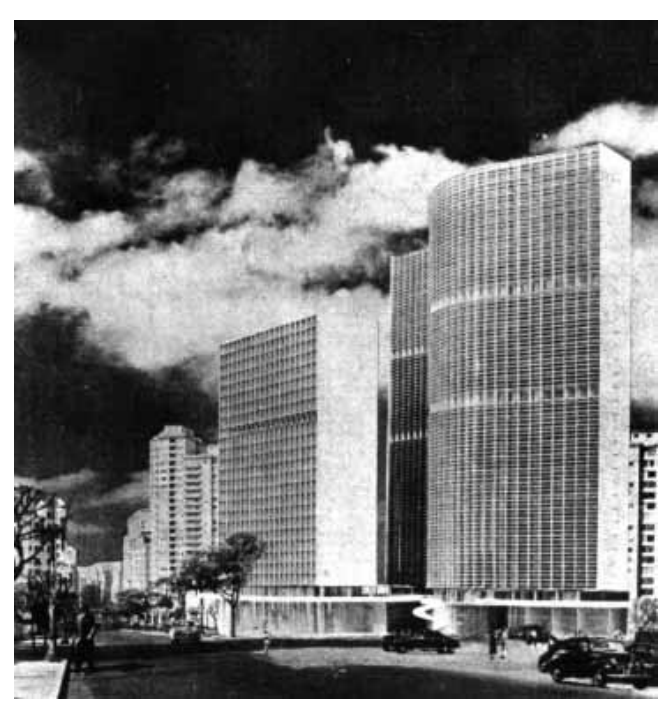

acima:

Edifício Copan (projeto original)

Fotomontagem.

Oscar Niemeyer, 1951

fonte: Barbara (2004. p. 213)

\section{esquerda:}

Edifício Copan (projeto original)

Planta do pavimento de cobertura do

embasamento.

Oscar Niemeyer, 1951

fonte: Barbara (2004. p. 212) 
Em diversos projetos realizados em São Paulo e outras cidades brasileiras principalmente entre as décadas de 50 e 60, Candia experimentaria possibilidades de arranjo entre galerias comerciais e edifícios de habitação ou escritórios. No projeto para a Galeria Metrópole, realizado em 1959-60 em parceria com Gasperini, o embasamento que abriga cinema e lojas realiza claramente a mediação entre o edifício vertical e seu entorno urbano imediato, coadunando-se aos fundos dos lotes vizinhos, e permitindo assim uma livre disposição da torre como marco isolado na paisagem. A trajetória deste projeto será objeto de um estudo mais detalhado, conforme veremos adiante.

No projeto para o edifício Júlio de Castilhos (1960), situado na avenida homônima em Caxias do Sul - RS, o arquiteto realiza para o Banco da Lavoura de Minas Gerais o equacionamento do programa misto de galeria comercial conjugada à agência bancária, sobrepostas pelo edifício de apartamentos. O embasamento que dá abrigo ao programa comercial implanta-se no alinhamento frontal do lote, dando seqüência à escala das lojas e sobrados interioranos, enquanto o volume das habitações se dispõe na transversal da avenida, orientando-se para as áreas internas do terreno. A implantação assimétrica do edifício em relação ao lote sugere uma setorização das aberturas dos apartamentos, com as áreas de convívio e descanso na face mais recuada, e as áreas de serviço na face oposta.

O partido formal experimentado no Júlio de Castilhos sugere uma interlocução distinta no arranjo entre o prisma do edifício de habitações e o seu embasamento. Aqui a transição entre estes dois elementos é tratada como uma fresta, como se um flutuasse sobre o outro. O pavimento de transição existente nos projetos anteriormente comentados é suprimido, sendo tratado apenas como plano de cobertura das lojas. Esta segunda forma de justaposição, presente também em outras obras de Salvador Candia, foi largamente empregada em projetos realizados no mesmo período por diversos arquitetos para solucionar programas semelhantes, tendo-se mostrado no entanto problemática em grande parte dos casos. Ao estabelecer o plano da cobertura do embasamento pra- 


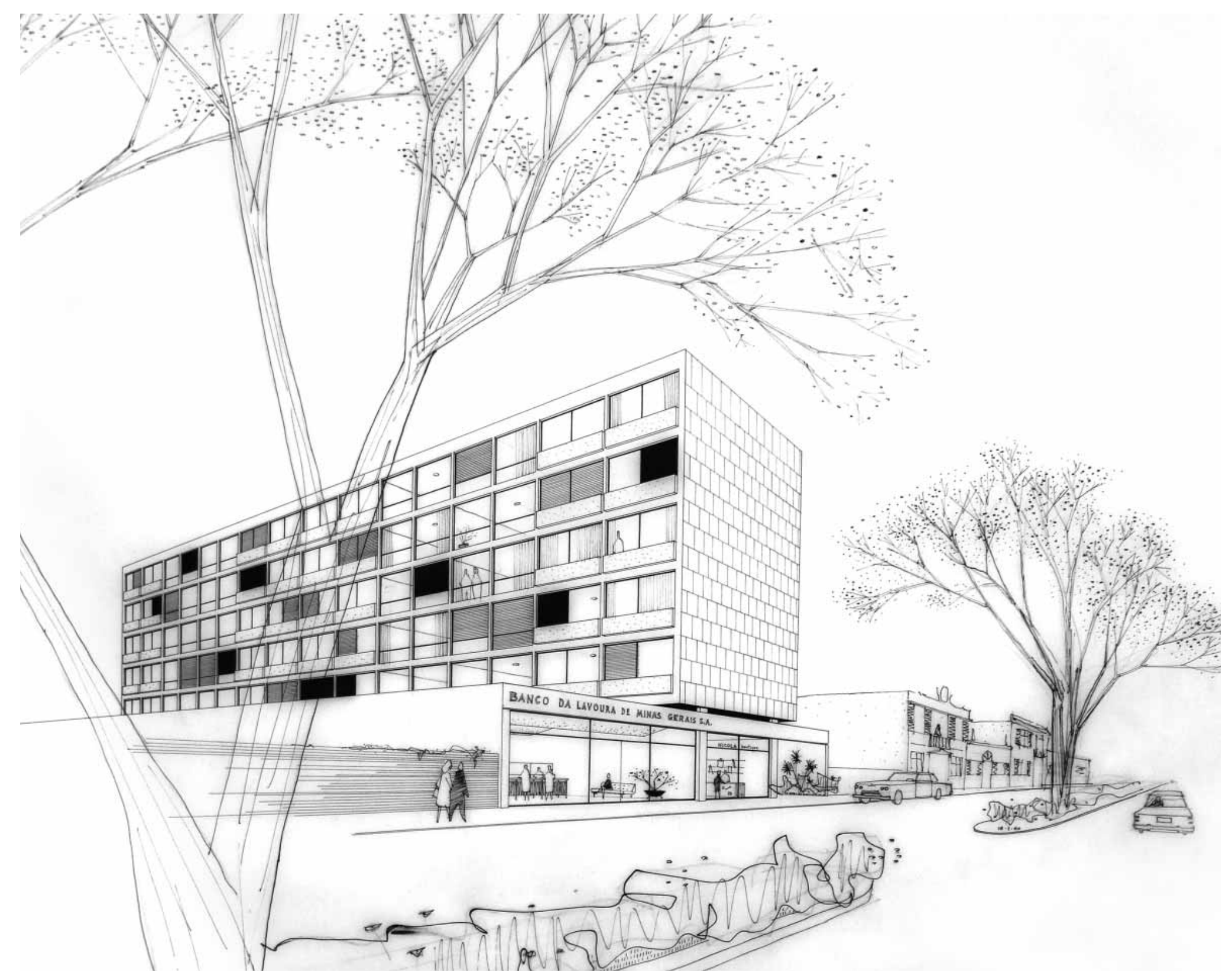



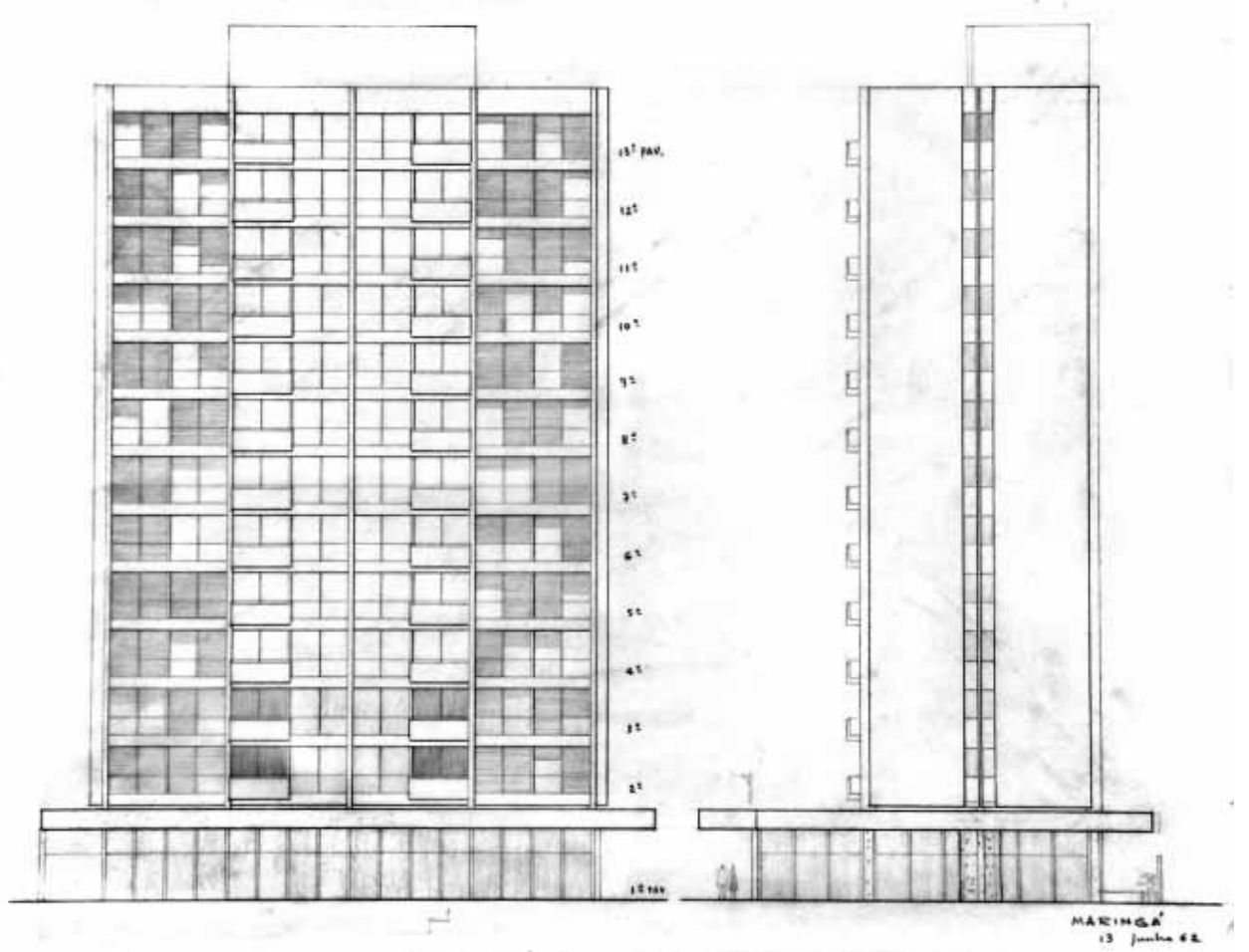

Edifício Maringá, PR.

Salvador Candia, 1962

fonte: Arquivo S. Candia

acima:

Elevações.

direita acima:

Planta da agência bancária no

pavimento térreo.

direita abaixo:

Planta do pavimento tipo.

esquerda:

Edifício Júlio de Castilhos,

Caxias do Sul, RS.

Perspectiva a partir da avenida.

Salvador Candia, Julho de 1960.

fonte: arquivo S. Candia
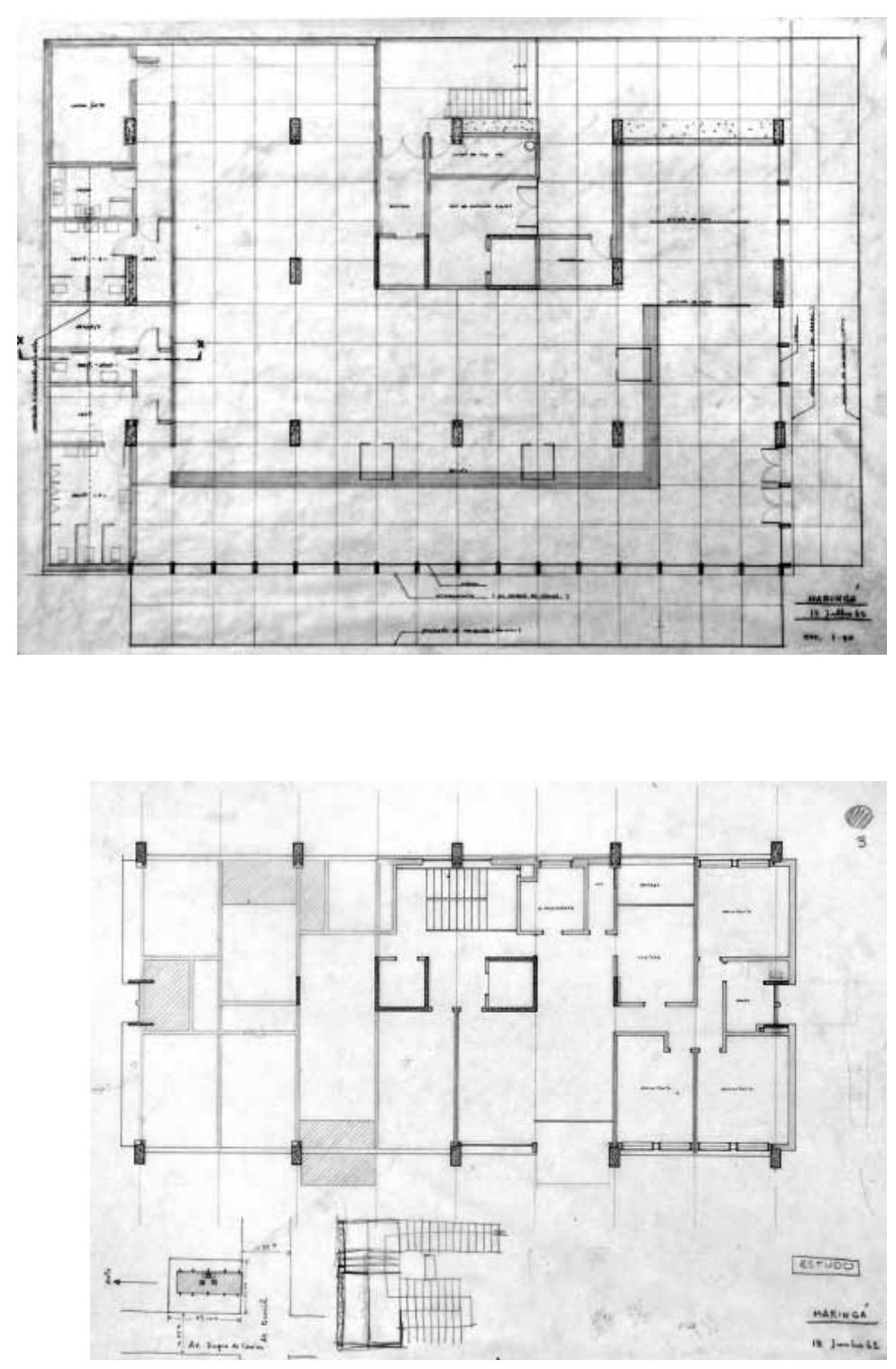
ticamente no mesmo nível que o primeiro pavimento das habitações, o projeto acaba por produzir uma área residual que, embora não seja acessível, participa visualmente do espaço dos apartamentos.

Em 1962, Candia ensaiaria uma solução semelhante para os mesmos empreendedores na cidade de Maringá, PR. O edifício de apartamentos, situado na esquina entre a avenida Brasil e a rua Duque de Caxias, dispõe do pavimento térreo para instalação da agência bancária, oferecendo uma marquise de acolhimento da calçada como prolongamento da laje cobertura do pavimento térreo. Aqui também os apartamentos se encontram ligeiramente destacados em relação ao embasamento, sendo a laje da marquise coberta com telhado de fibrocimento. Embora empreguem uma racionalização rigorosa dos espaços construídos, destinando às áreas coletivas das habitações o dimensionamento estritamente necessário à circulação e ao acesso, estes dois projetos demonstram uma preocupação em prover os apartamentos com amplas aberturas, através do emprego das varandas e dos caixilhos instalados do piso ao teto, modulados por montantes de concreto armado $\mathrm{o}^{30} \mathrm{e}$ protegidos por persianas externas de madeira.

Tratamento idêntico ao Maringá havia sido empregado naquele mesmo ano no projeto para um edifício de lojas e apartamentos empreendido pela Cia. Real Agricultura e Comércio na esquina entre as ruas da Consolação e Marquês de Paranaguá, São Paulo. A semelhança de programa e situação urbana haviam ensejado a repetição do modelo, tendo entretanto somente a segunda versão se concretizado.

30 Os montantes de concreto armado, conforme empregados nos caixilhos do edifício Maringá, são elementos recorrentes na obra de Salvador Candia. Ao mesmo tempo em que contribuem para estruturar os panos de caixilho, estes elementos se destacam na fachada, conferindo-lhe ritmo e profundidade. A sua aplicação é análoga, sob este ponto de vista, ao uso dos perfis "I" metálicos empregados nas cortinas de vidro consagradas por Mies van der Rohe nos Estados Unidos. 

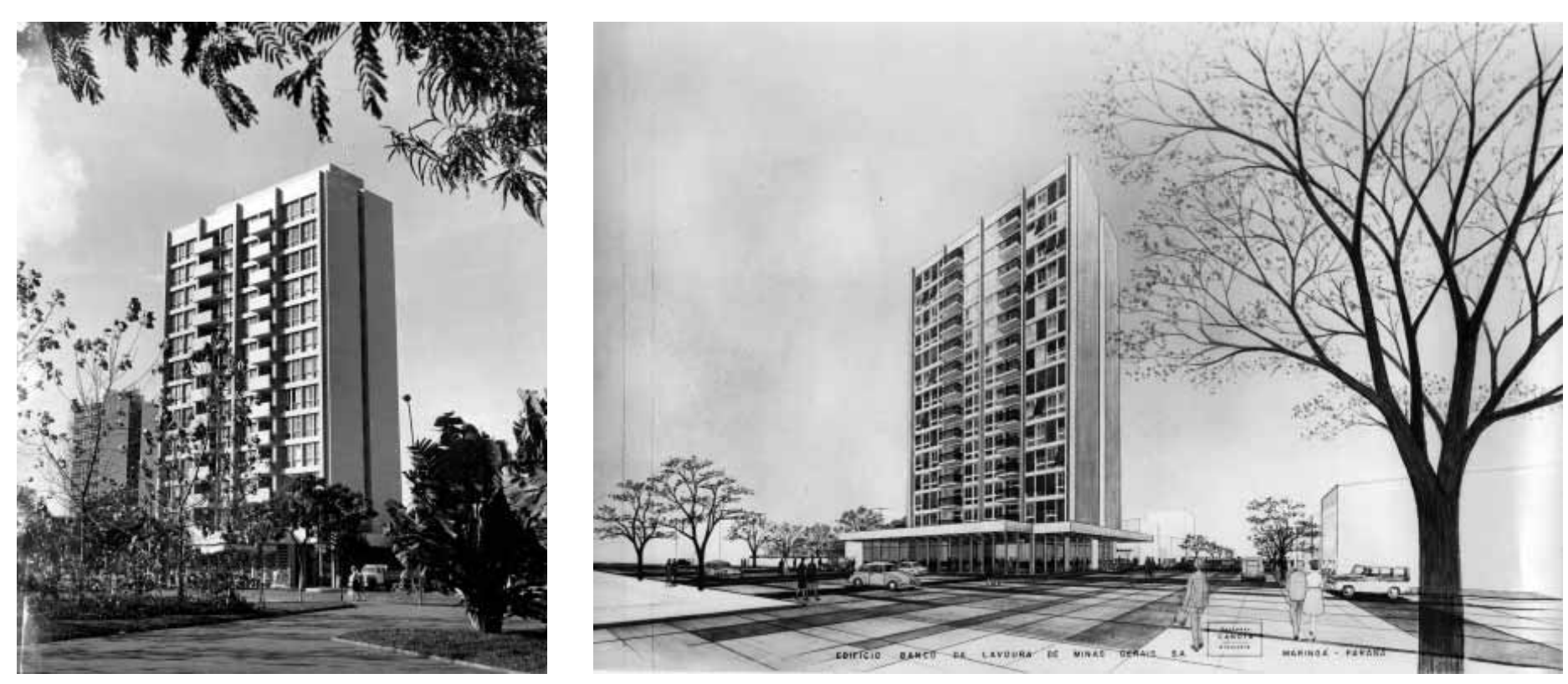

acima:

Edifício Maringá, PR.Salvador Candia, 1962.

Foto sem data. arquivo S. Candia

à direita acima:

Edifício Maringá, PR.Salvador Candia, 1962

Perspectiva.arquivo S. Candia

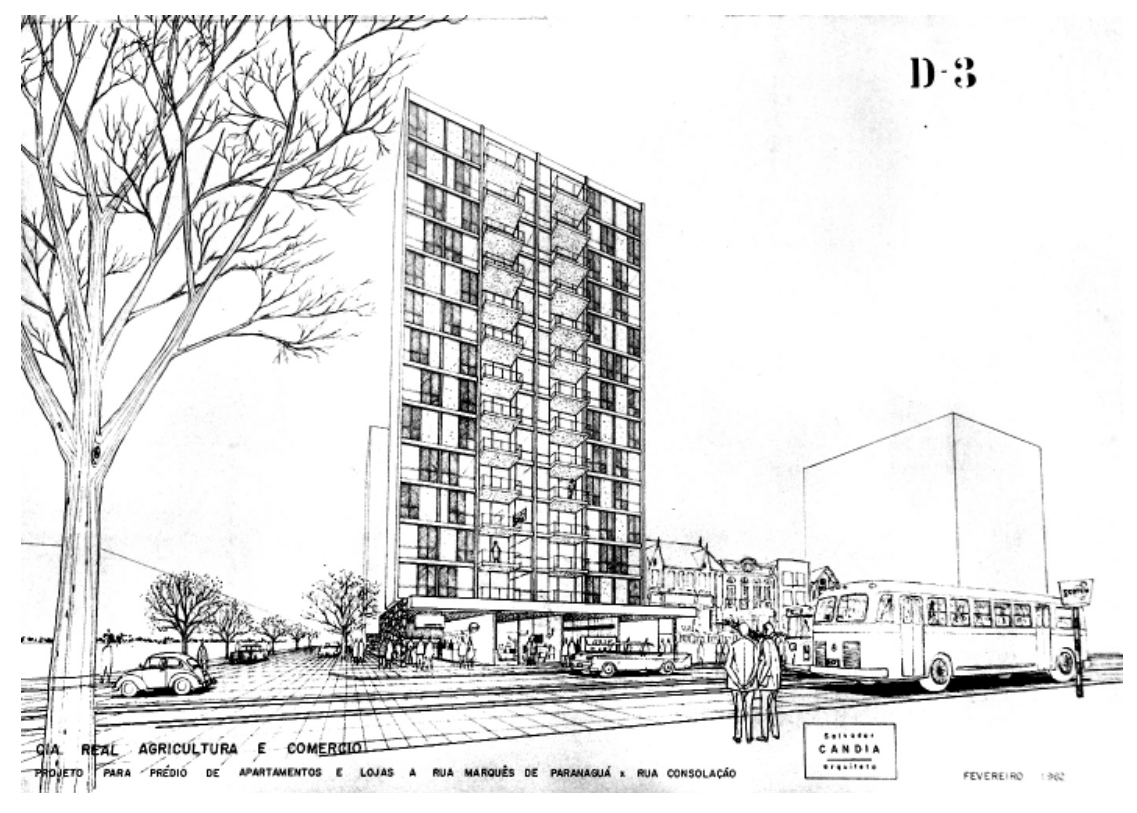

Projeto de edifício para a Cia. Real

Agricultura e Comércio, São Paulo.

Salvador Candia, 1962. Perspectiva.

fonte: Arquivo S. Candia 
Entre 1964 e 1972, o arquiteto realizaria diversas versões para um mesmo projeto de maior escala, empreendido pela construtora Gomes de Almeida Fernandes. Tendo sido implantado na intersecção entre as avenidas Paulista, Brigadeiro Luis Antônio e a rua Manuel da Nóbrega, o edifício Barão do Ouro Branco acompanhou o movimento de migração do eixo econômico da cidade, a partir do Centro Novo rumo a Sudoeste, em direção à Avenida Paulista.

A exemplo do célebre edifício Nações Unidas, implantado em 1953 na esquina oposta por Abelardo de Souza, este projeto previa inicialmente um programa habitacional verticalizado, associado a um conjunto de lojas no pavimento térreo. Uma das versões do projeto ensaia a resolução do programa habitacional em duas torres de vinte pavimentos assentadas sobre o embasamento das galerias. Estando os apartamentos organizados numa planta em "L", o arranjo entre os dois edifícios volta-se para o seu interior, conformando dois vértices de um retângulo incompleto. A alta densidade ocupacional do terreno prevista nestes desenhos seria paulatinamente reduzida nas demais versões.

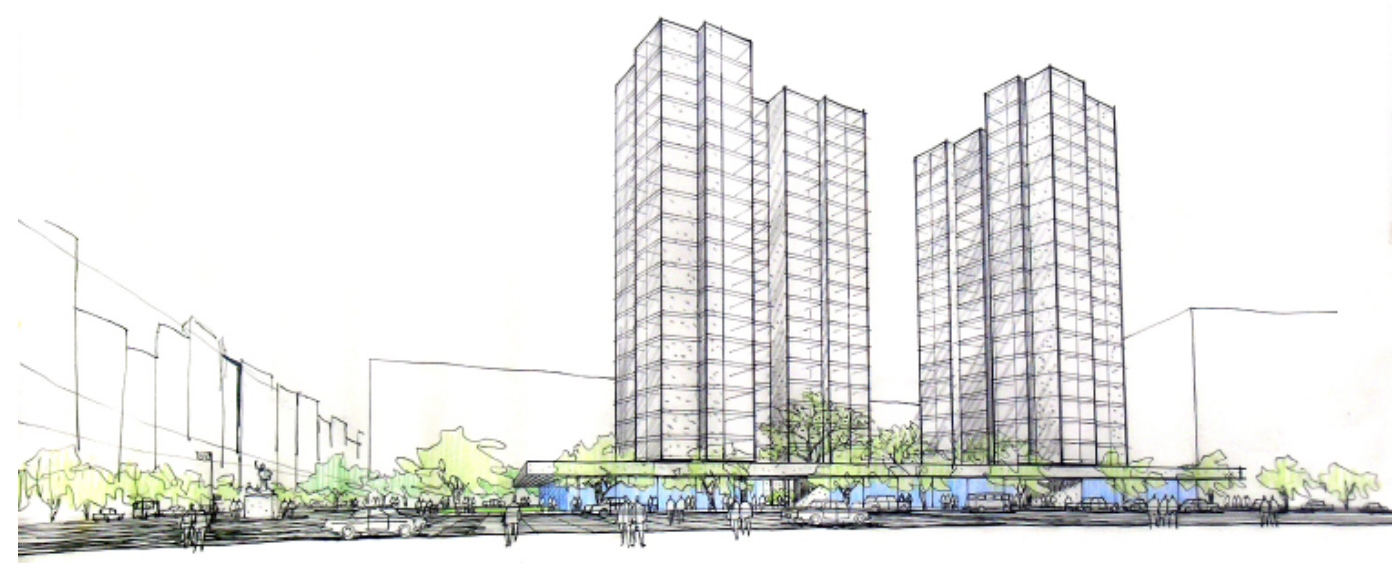

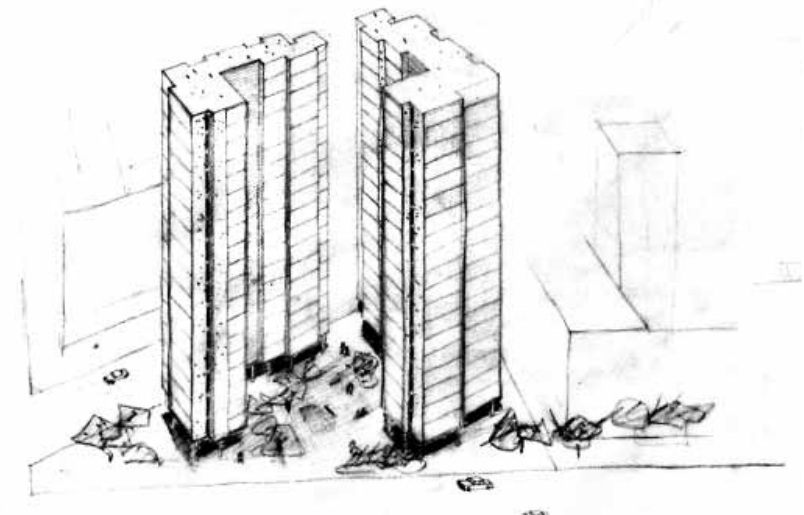

\$4

acima:

Edifício Barão do Ouro Branco, São Paulo.

Proposta da implantação das torres de apartamentos

diretamente sobre o solo, sem o embasamento das

galerias comerciais.

fonte: arquivo S Candia

à esquerda:

Edifício Barão do Ouro Branco, São Paulo.

Perspectiva do conjunto com as duas torres de

apartamentos implantadas sobre a galeria de

comércio e serviços.

fonte: arquivo S. Candia 

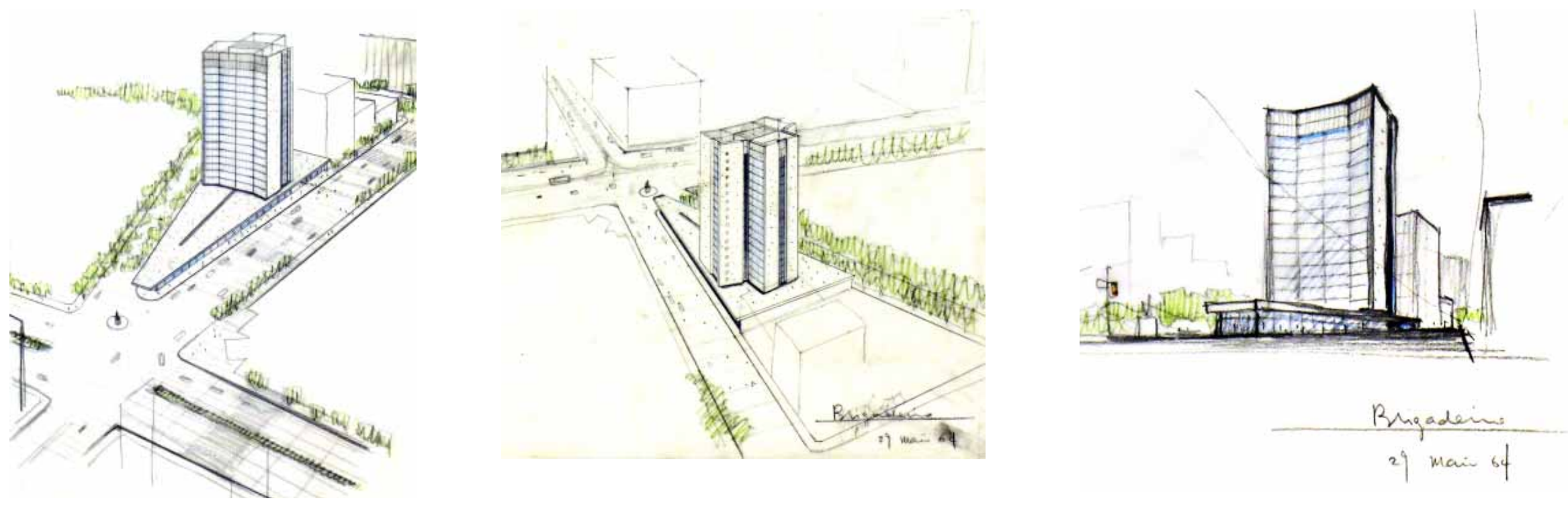

acima:

três estudos de implantação do Edifício

Ouro Branco, São Paulo.

Salvador Candia, 1964.

abaixo:

Corte Perspectivado da galeria comercial e

acesso à prumada vertical do edifício.

Salvador Candia, sem data.

fonte: arquivo S. Candia.

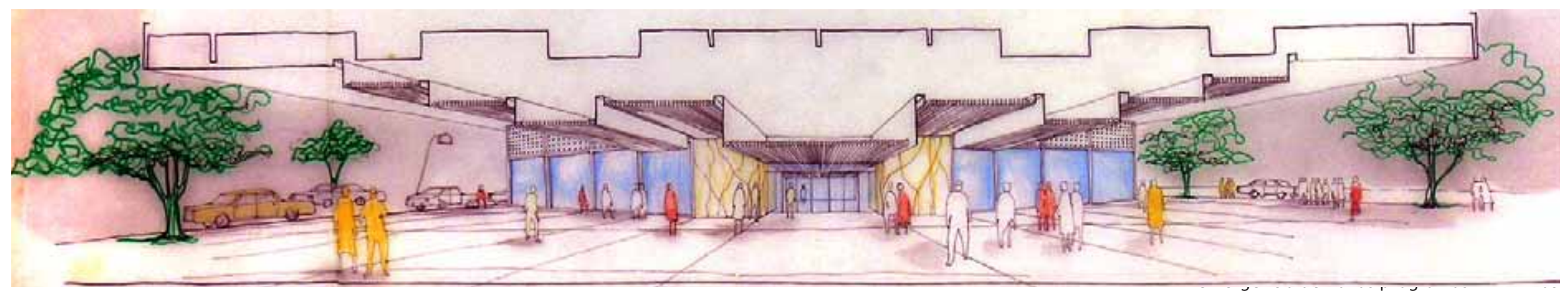


Uma outra versão, que mantém ainda o uso predominantemente habitacional para o conjunto, dispõe de cinco apartamentos de dois quartos organizados simetricamente em torno da prumada de circulação vertical em uma única torre, conformada à geometria triangular do lote. Em uma solução variante prevista anteriormente para este mesmo partido, invertia-se a posição da escada e elevadores, voltando assim a face côncava do edifício para o vértice do terreno. Este arranjo remetia a um tratamento já empregado em situações semelhantes por Franz Heep no edifício O Estado de São Paulo (1946), e Oscar Niemeyer no edifício Eiffel (1953).

Em todas as versões do projeto, prevê-se a construção do embasamento ocupando quase a área integral do lote. As lojas são dispostas ao longo dos passeios, recuadas em relação à projeção da cobertura, para abrigo dos transeuntes. No lado menor do triângulo, próximo à divisa com o lote vizinho, é prevista uma passagem que interliga os passeios, dando acesso à prumada de circulação vertical do edifício.

Na versão final do projeto, realizada em 1972, o programa habitacional é abandonado, dando lugar a uma torre mais compacta de planta em cruz com aproximadamente $600 \mathrm{~m}^{2}$, para a instalação de pequenas salas de escritório de $25 \mathrm{~m}^{2}$ a $50 \mathrm{~m}^{2}$. A exemplo dos projetos anteriormente comentados, a galeria comercial é tratada com simplicidade, dando maior atenção às situações de esquina, onde as lojas têm uma maior dimensão. O acesso ao estacionamento no subsolo é posicionado junto à divisa do terreno, na rua de menor freqüencia de veículos. O pavimento de transição entre a torre comercial e seu embasamento é também aqui tratado somente como plano de cobertura das lojas.

Os estudos preliminares de implantação realizados para este projeto, onde a disposição dos elementos construídos é experimentada sob diversos pontos de vista a partir das ruas e construções vizinhas, demonstram uma preocupação constante do arquiteto em estabelecer a interlocução precisa do novo edifício com relação à cidade existente, através do arranjo compositivo dos novos volumes. Há também um cuidado especial na relação do embasamento do edifício com o "chão" da cidade, promovendo a continui-
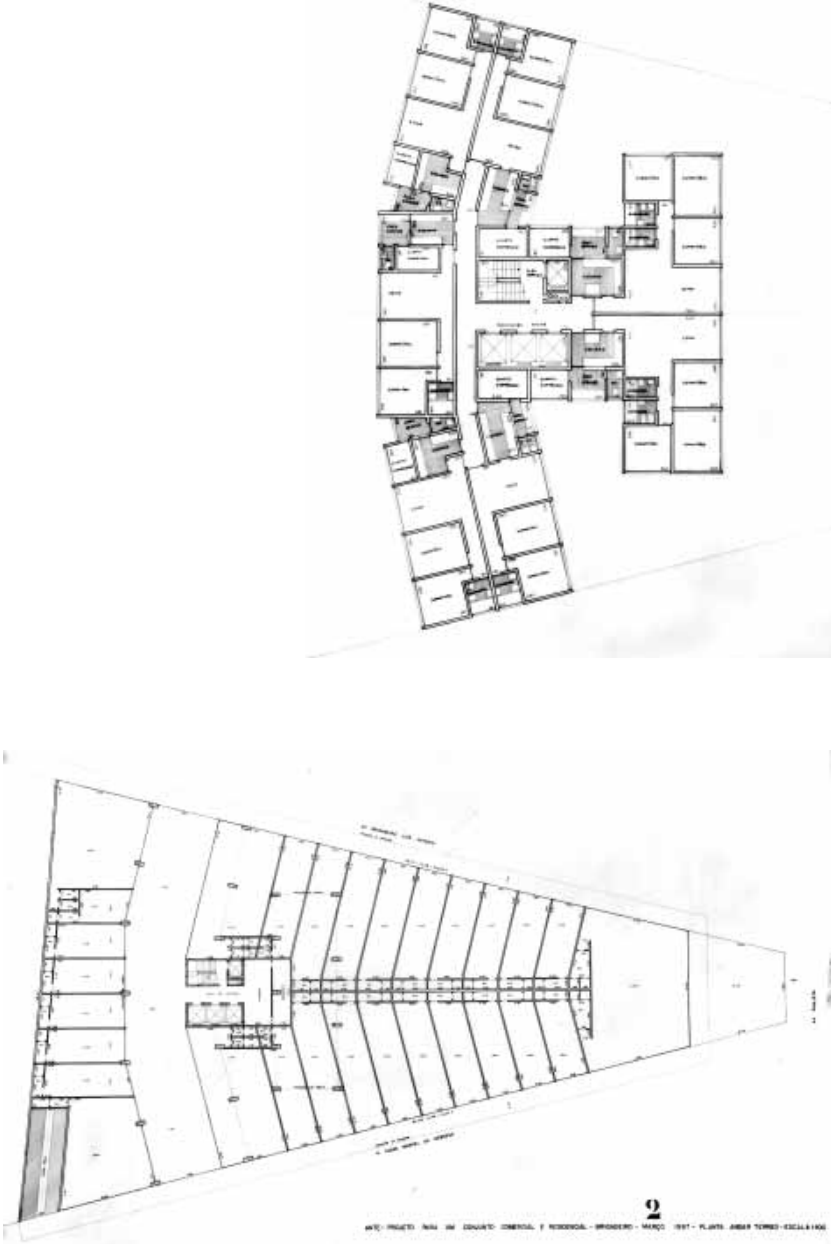

acima:

Planta do pavimento tipo, torre de apartamentos.

Salvador Candia, 1967.

fonte: arquivo S. Candia.

abaixo:

Planta da Galeria comercial no pavimento térreo.

Salvador Candia, 1967.

fonte: arquivo S. Candia 




Fotografo Branco. fonte: arquivo S. Candia

à direita:

Planta do pavimento tipo da torre de escritórios conforme foi construída (sugestão do arquiteto para o arranjo interno dos escritórios). Salvador Candia, 1972 fonte: arquivo S. Candia dade do passeio público para o seu interior através da Galeria Comercial.

Este aspecto presente nos projetos de Salvador Candia, da preocupação constante com a inserção do edifício na cidade existente, será abordado adiante, por constituir um dos aspectos mais significativos em sua obra. 

questões recorrentes 


\section{o sentido urbano do edifício}

Um dos traços de maior relevância na obra de Salvador Candia, claramente presente nos projetos abordados por esta pesquisa, é a interlocução direta do edifício com relação ao meio urbano onde ele é implantado. Esta relação verifica-se a partir de duas dimensões distintas de abordagem: a primeira refere-se à presença do edifício na paisagem, na forma como este vincula-se à sua situação geográfica e urbana num contexto mais abrangente. A segunda diz respeito à forma como o edifício se relaciona com o "chão" da cidade, vinculando-se aos percursos existentes na trama urbana.

Conforme vimos anteriormente, grande parte dos programas que o arquiteto seria convocado a projetar, partem da adoção de altos índices de aproveitamento do solo, incorporando eventualmente a combinação de programas múltiplos em um mesmo conjunto. Seria então recorrente a necessidade de se equacionar o arranjo de grandes volumes implantados em situações urbanas diversas, em lotes por vezes extremamente exíguos. O tema do edifício vertical para escritórios ou habitação surge como um problema constante, tendo sido objeto de investigações sucessivas, tanto no que diz respeito a seus aspectos formais e construtivos, quanto em relação à sua presença como marco na paisagem. A torre será tratada, sempre que possível, como um volume prismático puro, destacado em relação aos demais programas que eventualmente compõe o conjunto. Nas palavras do próprio arquiteto:

O espírito da torre livre em todas as suas faces e com estrutura desimpedindo completamente a área de trabalho, havia sido implantado em 1960 nos 20 pavimentos de escritórios do "Centro Metropolitano" na praça Dom José Gaspar, tendo continuado 
Nos dois projetos comentados acima, assim como em outros que se realizarão posteriormente como o edifício Joelma (1968-72) implantado na praça das Bandeiras, e o edifício das Nações (1974) situado na avenida Eusébio Matoso, ambos em São Paulo, as torres de escritórios associam-se necessariamente a um segundo elemento que, conforme comentamos anteriormente, teria a função de realizar a sua mediação com as construções vizinhas. Este procedimento refere-se principalmente aos casos onde a trama urbana existente é caracterizada por um conjunto contínuo de construções ocupando as divisas do lote. Neste sentido, caberia lembrar o já citado exemplo do Esther, que dispõe de um edifício anexo para arrematar os vizinhos da quadra urbana construída em seu perímetro, liberando as suas quatro faces do contexto urbano imediato. Conforme comenta Salvador Candia:

(...) o edifício "Esther" que se ergue na praça da República paulista comove ainda hoje, apesar da dinamicidade do período. Lá estão, desde 1936, a janela em comprimento, a estrutura independente, o pilotis, a planta livre e o jardim suspenso de Le Corbusiana memória que aqui chegaram nos livros que o mestre escrevera nos anos 20. O que surpreende não é só o uso apropriado do novo vocabulário, mas a maneira primorosa, elegante, e racional como foram usados, além do tratamento dado ao espaço e ambiente circunstante, desvinculando o edifício do "lote" paulistano da época. ${ }^{2}$

1 CANDIA, Salvador. Curriculum Vitae e Obras Executadas, São Paulo, Arquivo Salvador Candia, [1980]

2 CANDIA, Salvador. A Ordem Construtiva Arquitetônica em Vital Brazil. Brazil, Vital. 50 Anos de arquitetura/ Álvaro Vital Brazil. Nobel, São Paulo, 1986. p. 9. 

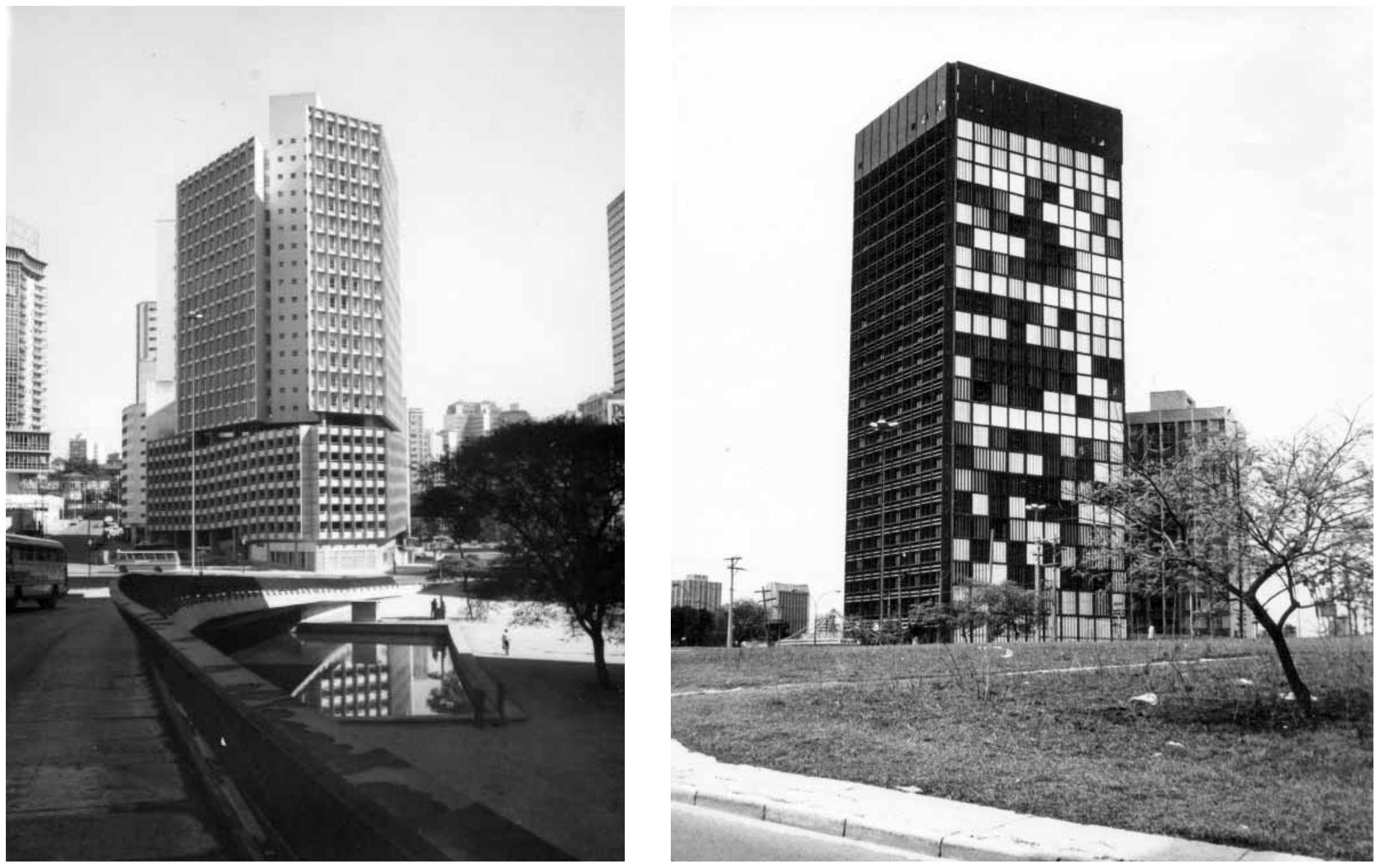

à esquerda acima:

Edifício Villares, São Paulo.

Salvador Candia, 1961.

fonte: arquivo S. Candia.

à esquerda abaixo:

Edifício Metrópole, São Paulo.

Salvador Candia, 1959-60.

fonte: arquivo S. Candia. nesta página à esquerda:

Edifício Joelma, São Paulo.

Salvador Candia, 1968.

fonte: arquivo S. Candia.

nesta página à direita:

Edifício das Nações. São Paulo.

Salvador Candia, 1973-74.

fonte: arquivo $S$. Candia. 
No caso da torre da Aços Villares implantada na avenida do Estado, São Paulo (1961), o segundo edifício que compõe o conjunto abriga os depósitos da indústria de aços perfilados, adaptando sua planta à geometria do terreno. Assim como no caso do Esther, o anexo atua como fundo ou contraponto em relação à torre principal. Os depósitos do Villares constituem um plano cego horizontal sobre o qual a torre de escritórios se destaca. Há também neste caso uma interlocução com o seu recinto urbano em uma escala mais abrangente: implantado junto ao parque industrial da várzea do rio Tamanduateí, zona Sudeste da cidade, onde os galpões horizontais de fábricas e depósitos se espraiam por longas extensões do território associados ao rio e à ferrovia, este edifício figura como um marco vertical na paisagem. Aproxima-se então, sob este ponto de vista, da torre de torrefação da Cia. de Café Finos, implantada por Rino Levi em 1942, 400m a jusante do rio. Há ali uma interlocução que se realiza tanto no partido formal e compositivo dos elementos horizontais e verticais - porque o conjunto implantado por Levi também reforça a horizontalidade de seus galpões anexos, utilizando em sua fachada um renque de quebra-sóis horizontais - quanto no tratamento dado às torres, na acentuação de sua verticalidade através do emprego da grelha vertical de quebra-sóis.
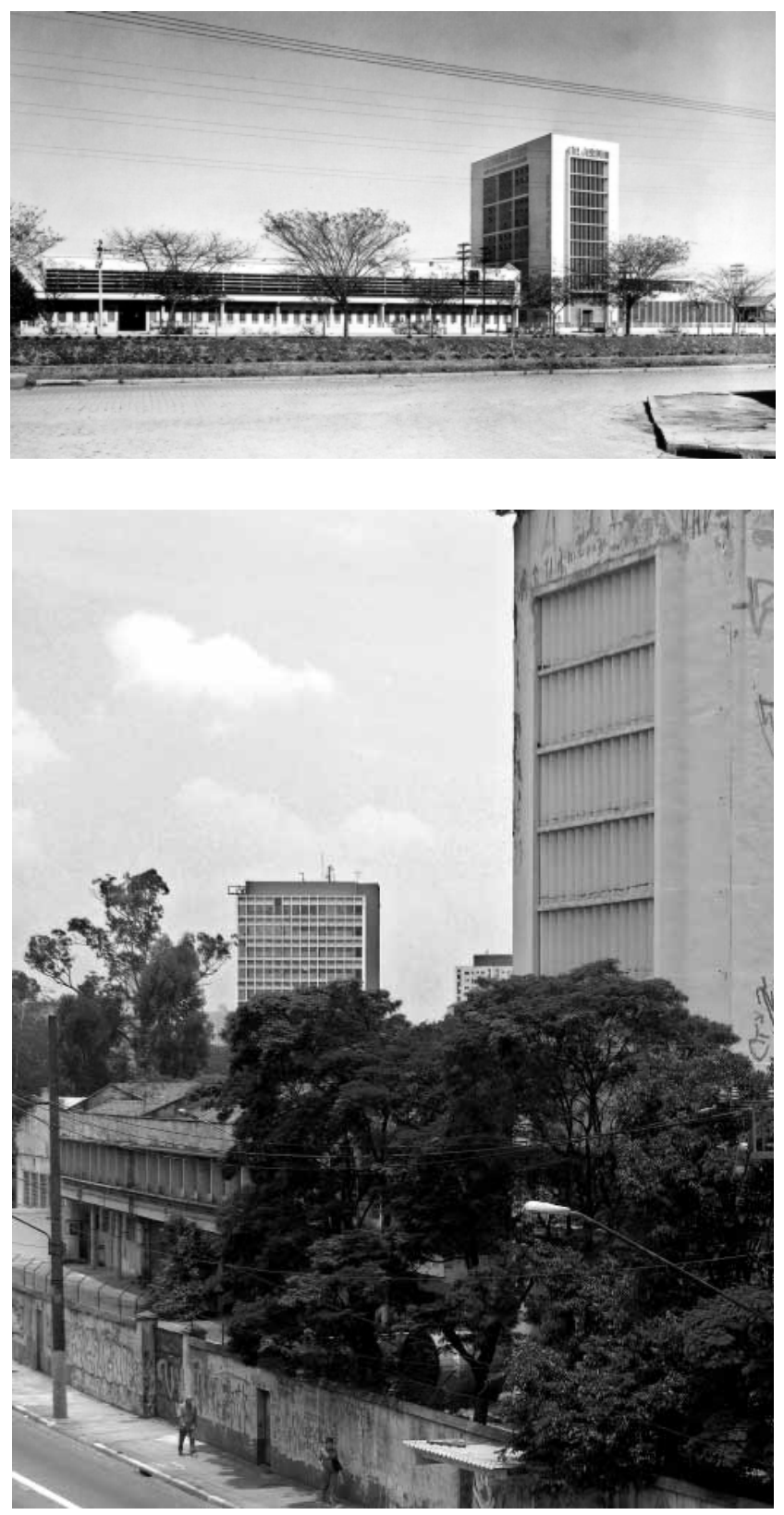

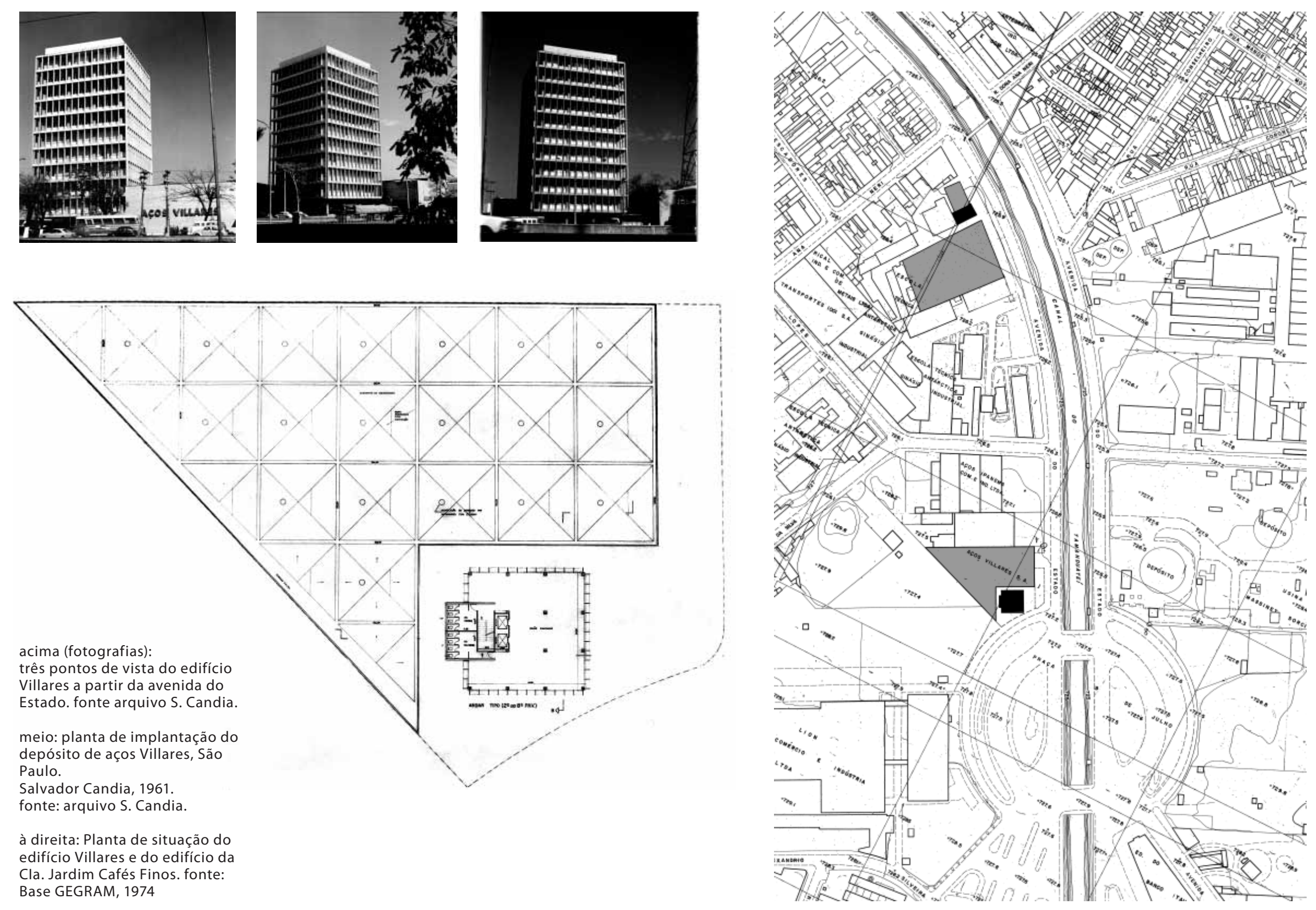
Há também determinados projetos onde a implantação do volume edificado parte de uma composição conjunta dos espaços constituídos entre o novo edifício e os existentes: na primeira versão do projeto realizado para o edifício de escritórios Triton (1973), situado na esquina entre a avenida Paulista e a alameda Ministro Rocha Azevedo, a torre de escritórios proposta com 25 pavimentos implanta-se diretamente sobre uma praça aberta, a exemplo das duas torres gêmeas situadas na esquina oposta, pertencentes ao conjunto Centeco Plaza, projetado alguns anos antes por Carneiro Viana (1914), Norton Sievers (1922) e Rubio Morales (1924). Na divisa posterior do lote onde se situa o Triton, Candia implanta um volume anexo, o salão de serviços que tem a função de abrir uma nova frente para o que seriam os "fundos" da praça, dotando os espaços externos com programas que propiciam a sua utilização. A disposição da torre em meio à praça projetada justifica-se através da relação compositiva que este novo edifício estabelece com os seus vizinhos da Centeco Plaza, sugerindo assim a constituição de um conjunto contínuo de espaços livres públicos junto à avenida Paulista. O posicionamento da torre recuado em relação à avenida, abrindo o espaço vazio na esquina, permite o distanciamento visual do transeunte em relação ao conjunto, além de conceder um alargamento do espaço pertencente à torre vizinha (Centeco torre Sul), implantada de forma marcante junto ao alinhamento na esquina oposta. Este procedimento remete à implantação do edifício Seagram (Nova York, 1954-8) de Mies van der Rohe, onde a decisão de se recuar o volume edificado com relação à esquina, para permitir uma rara abertura das visuais em meio à paisagem vertical de Manhattan, antecipou a criação das pequenas praças secas que caracterizariam posteriormente os conjuntos urbanos daquela cidade. ${ }^{3}$

3 LAMBERT, Phillis (1994). Segundo Phillis Lambert, a implantação do edifício Seagram, que estabelece um recuo em relação à avenida principal, influenciou posteriormente a legislação de Nova York: “(...)after the Seagram building was completed the planning legislation for New York City was revised in order to encourage street-level open space in association with high-rise buildings." In: MERTINS, Detlef (ed.). The Presence of Mies. New York: Princeton Architectural, 1994. p. 34.
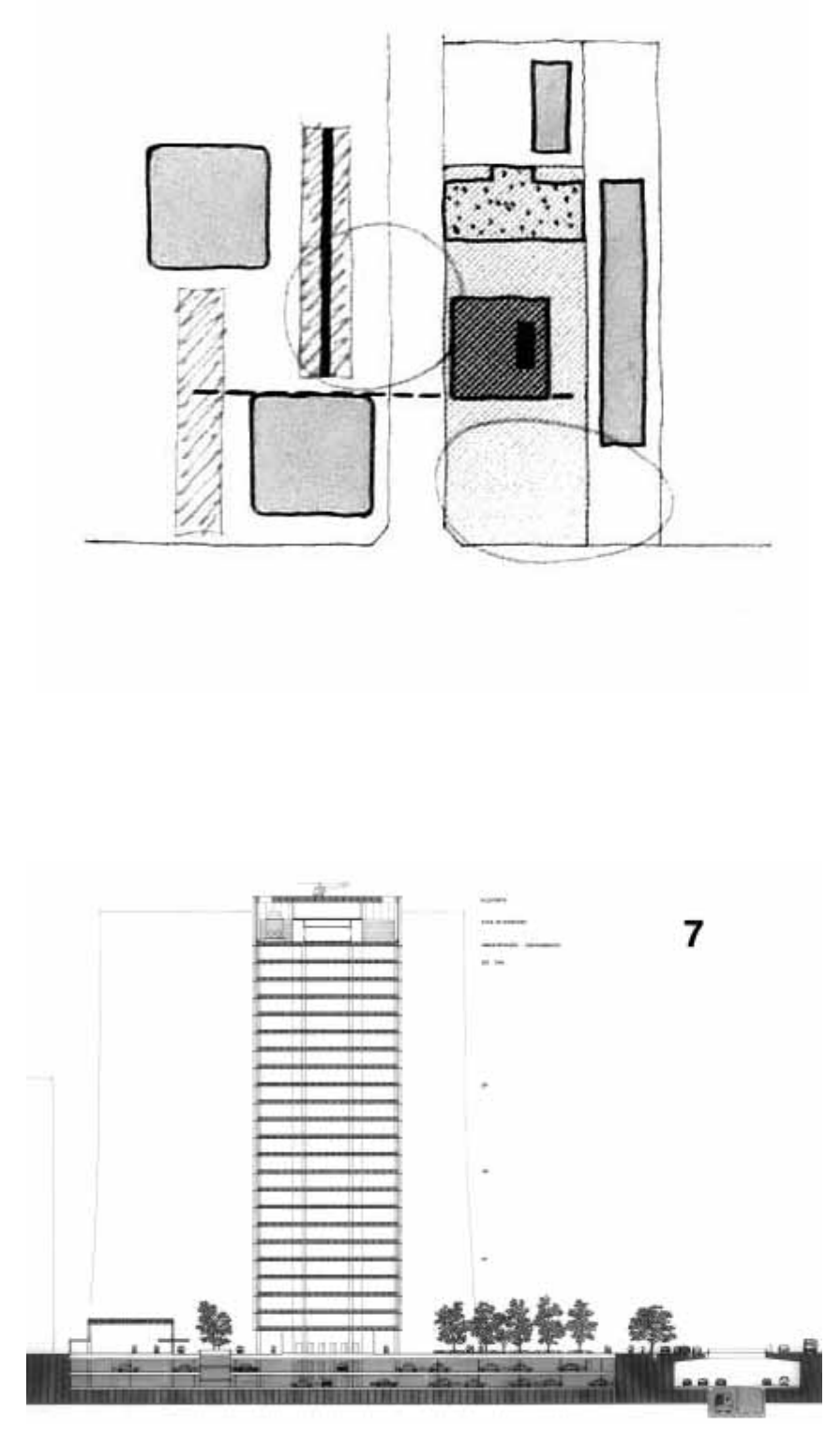


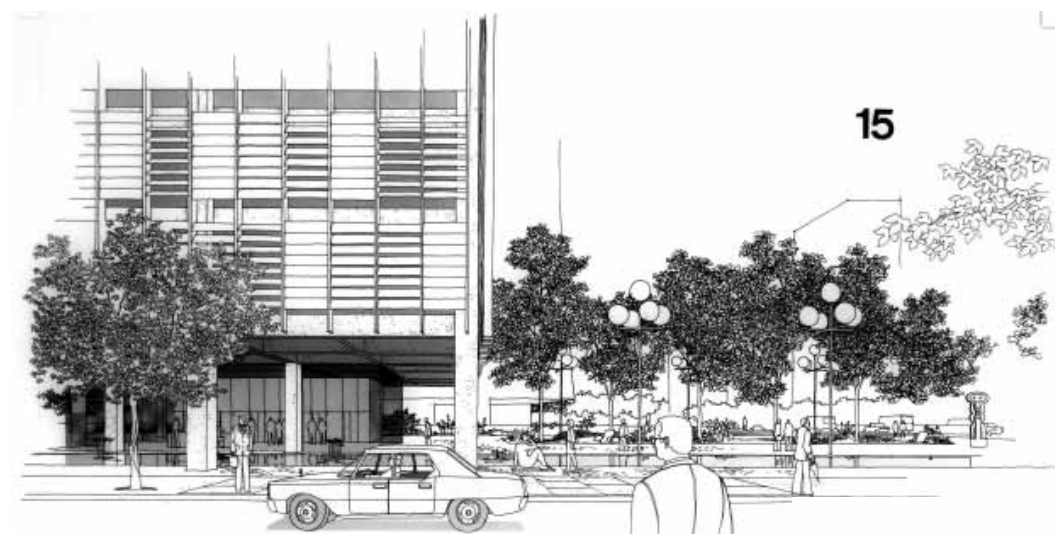

nesta página acima:

Edifício Triton, São Paulo.

Perspectiva.

Salvador Candia, 1973.

fonte: arquivo S. Candia.

nesta página à direita:

Edifício Triton, São Paulo.

Planta de situação.

Salvador Candia, 1973.

fonte: arquivo S. Candia.

à esquerda acima:

Edifício Triton, São Paulo.

Estudo de implantação.

fonte: arquivo S. Candia

à direita abaixo:

Edifício Triton, São Paulo.

Corte Longitudinal.

Salvador Candia, 1973.

fonte: arquivo S. Candia

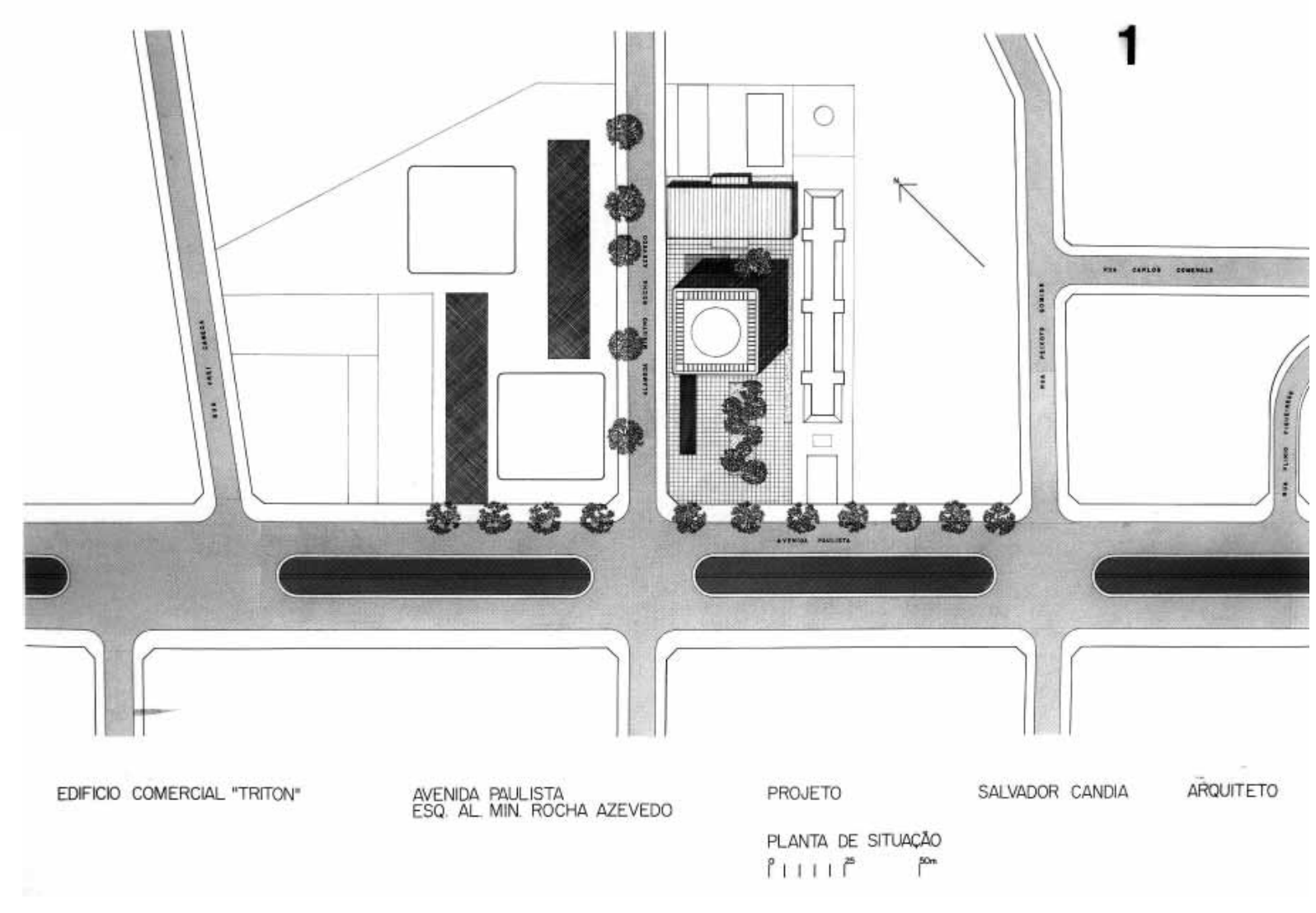




\section{O desenho do chão: ruas que se desdobram no interior dos edifícios}

Nos edifícios Metrópole, Nações e Joelma o embasamento abriga funções diversas e proporciona novas conexões entre a circulação vertical e os planos de acesso ao edifício, seja em relação aos percursos de pedestres, ou em relação às vias de acesso para automóveis. Assim é que na implantação da Galeria Metrópole, as lojas no pavimento térreo e as circulações verticais do conjunto estão diretamente associadas aos percursos de pedestres existentes no entorno urbano. A nova conexão proposta entre a rua Basílio da Gama e a praça Dom José Gaspar serve como eixo estruturador do projeto, organizando a disposição dos equipamentos de circulação que darão acesso aos pavimentos superiores da galeria comercial.

Na primeira versão para o projeto do edifício das Nações em 1973, o embasamento que abriga a garagem no primeiro pavimento estabelecia uma galeria comercial no pavimento térreo, como prolongamento do passeio público a partir do alargamento das calçadas, formando uma loggia sob a grelha da estrutura. O projeto previa ainda uma passagem de pedestres pelo interior do embasamento no pavimento térreo, que percorreria o perímetro da projeção da torre de escritórios, dando acesso às duas avenidas que formam a esquina. Esta nova passagem estabeleceria ainda uma interligação com o pavimento térreo do edifício vizinho, na divisa de fundos do terreno. Embora não tenha sido realizada, esta proposta demonstra a intenção de se extrapolar os limites impostos pelo loteamento das quadras urbanas, tornando-as permeáveis ao pedestre, a exemplo do que se realizara, dentro de um contexto urbano completamente distinto, no Centro Novo da cidade durante as décadas de 50 e 60 , conforme comentamos anteriormente. ${ }^{4}$

4 No momento em que se realizava o projeto do edifício das Naç̃es, em 1973, a região onde o edifício está situado ainda não tinha uma ocupação consolidada, embora já houvesse um conjunto de edifícios implantados, como por exemplo o prédio de apartamentos vizinho. Observando-se os desenhos de implantação do projeto original do edifício das Nações, pode-se intuir que os arquitetos imaginaram um contexto urbano distinto daquele que viria a prevalecer no lugar.
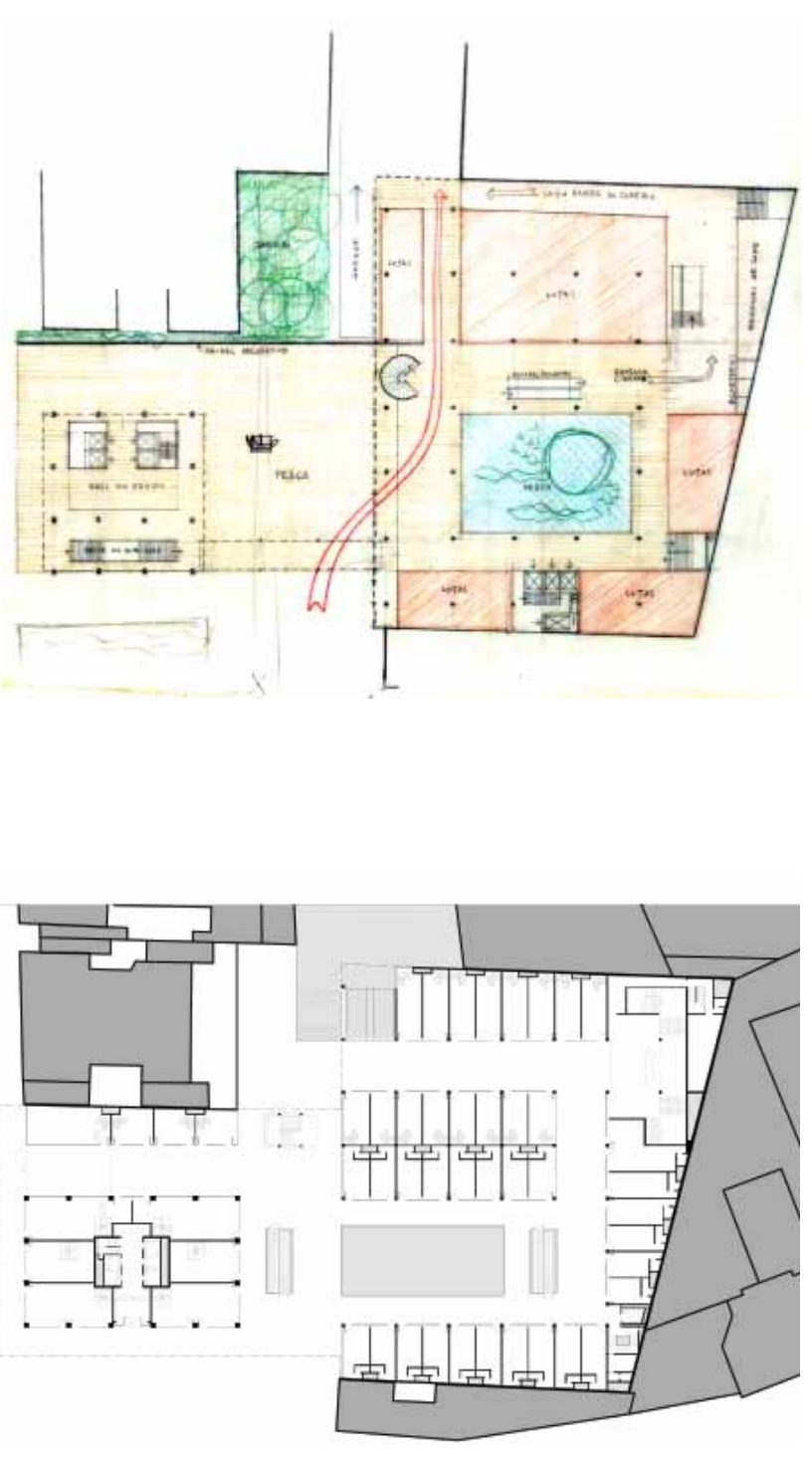


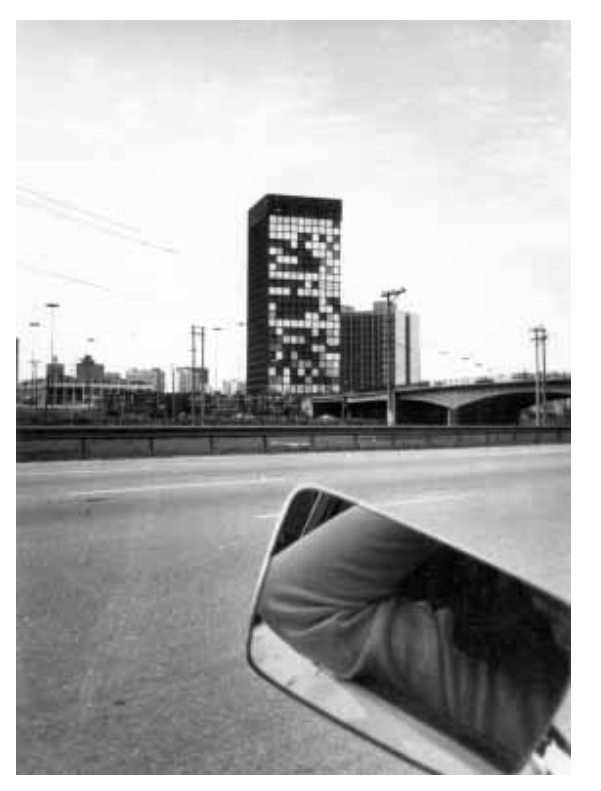

nesta página acima:

Edifício das Nações, São Paulo.

Salvador Candia, 1973-74.

Foto da finalização da obra, a partir da avenida das Nações (Marginal Pinheiros).

fonte: arquivo S. Candia.

à direita:

Edifício das Nações, São Paulo.

Salvador Candia, 1973-74.

Planta de Implantação com galeria anexa.

fonte: arquivo S. Candia.

à esquerda acima:

Edifício Metrópole São Paulo.

Salvador Candia e Giancarlo Gasperini, 1959-60.

Croqui de implantação, 1959.

fonte: arquivo S Candia

à esquerda abaixo:

à esquerda abaixo:

Giancarlo Gasperini, 1959-60.

Planta definitiva de implantação.

fonte: Redesenho feito sobre bases diversas.

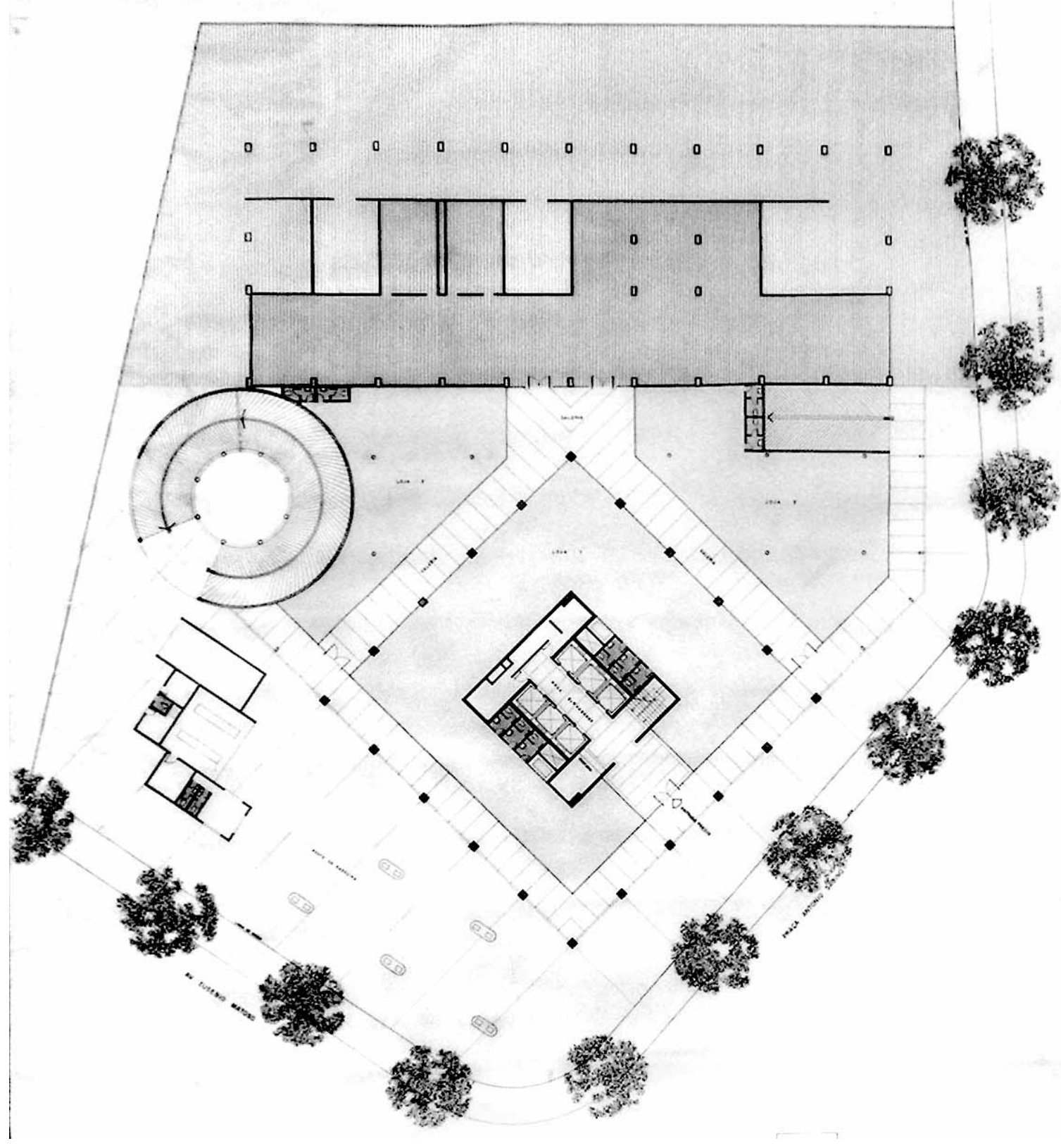


Numa operação análoga de interlocução entre o edifício vertical e o chão da cidade, o embasamento do Joelma, que dá abrigo a um estacionamento resolvido através de uma rampa helicoidal suave, dispõe em seu pavimento térreo de duas passagens internas que comunicam a avenida 9 de Julho à rua Santo Antônio pelo seu interior. Uma primeira passagem para pedestres comunica a prumada de circulação vertical da torre aos passeios públicos. A segunda passagem, exclusiva de automóveis, desdobrase para dentro do edifício no desenvolvimento das rampas do estacionamento. O que confere interesse a estes percursos incorporados ao seu embasamento, é que eles estão visualmente articulados através do desenho do edifício, e compõe entre si um conjunto plasticamente expressivo.
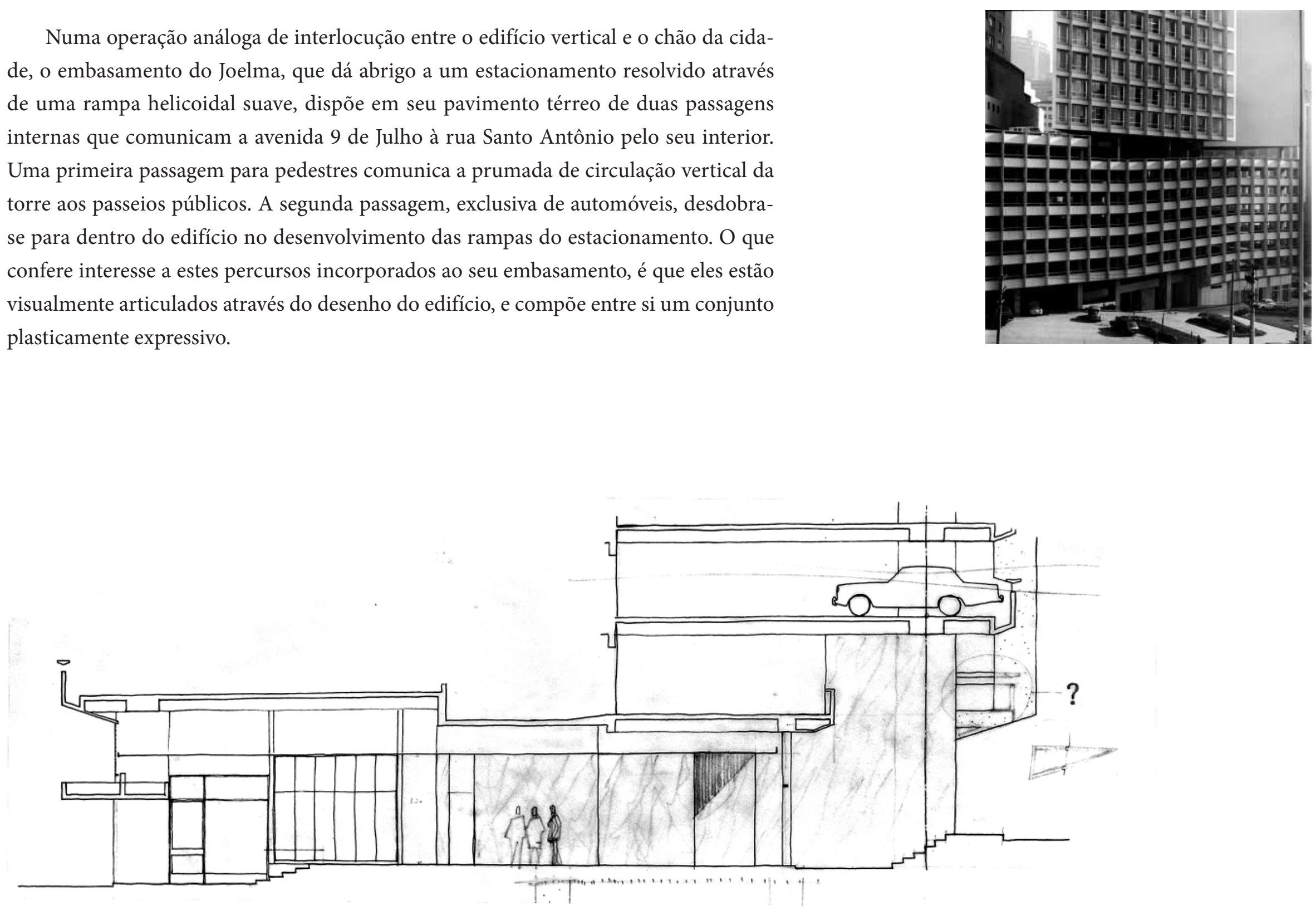


\section{razão construtiva e expressão plástica}

e praça de acesso.

fonte: arquivo $\mathrm{S}$ Candia.

à direita abaixo:

Edifício Joelma, São Paulo.

Salvador Candia, 1968.

Estudo da galeria de acesso.

fonte: arquivo S. Candia

Como dizia há pouco, eu "inventei" o Mies. Como gostava de mexer nas coisas e o Brasil era todo de curvas etc. e tal, todo barroco, o Mies tinha ensinado que era para construir. Ele falava de construção e ao mesmo tempo de requinte. Vocês todos conhecem, pelo menos, a poltrona, o pavilhão de Barcelona. Mies era um homem requintado, que falava em construção mas no fundo era um artista plástico fabuloso, usava mármores, inventou o aço inox na arquitetura, coisas assim. Nós não tínhamos isso, já éramos subdesenvolvidos.

Então, achei que estava na hora de entrar o Mies. E deu prêmio da Bienal (de arquitetura). O pessoal que veio achou que naquele Brasil, assim solto, o prêmio da Bienal dado pelo prédio das Perdizes foi por se tratar de uma primeira tentativa de pegar uma quadra e botar blocos em relação a ela, os automóveis todos para baixo, o verde aparecendo (isso era o Corbusier do la royaume du pietón que tinha sobrado em mim), mas as linhas dos prédios eram um negócio diferente, Mies.

Isso poderia ser generalizado sobre o estado melancólico da arquitetura de hoje. O que aconteceu com o Mies, que fui eu que inventei, é o seu mau uso, porque ele era muito mais simples. Ele tinha inventado aquela estrutura simples, modulada, aquela história de transportar com guindastes o caixilho inteiro; ele tinha inventado, enfim, o método de não fazer a construção, mas de montar o edifício.

Essa era a sua mensagem final: não vamos mais construir, mas juntar as partes, fazer as formas, montar. E em São Paulo todo mundo começou a fazer “miesinho". Eu ainda era suficientemente jovem para dizer: "bom, se é para fazer miesinho, então vamos mudar outra vez". Mas ficou claro que não era tão fácil. É que não se faz arquitetura a 
Em depoimento prestado ao IAB em 1979 sobre a sua atuação profissional, Salvador Candia demonstra claramente a relação que procuraria estabelecer com a linguagem formal e construtiva empregada por Mies van der Rohe, particularmente na obra desenvolvida pelo mestre alemão em sua fase norte americana, a partir do II pós guerra. Embora sejam diversas as referências a Mies e à arquitetura norte americana daquele período na obra de Candia, conforme procuraremos demonstrar, elas se mostram com maior evidência na resolução de alguns dos edifícios verticais de escritórios e habitações que o arquiteto projetaria em São Paulo, a partir do início dos anos 50.

No edifício João Ramalho, Perdizes, projetado entre 1953-54 em parceria com Plínio Croce e Roberto Aflalo, encontra-se um paralelo com os procedimentos construtivos empregados alguns anos antes por Mies para o edifício de apartamentos Promontory (1946-49) em Chicago.

Estes dois projetos guardam todavia diferenças significativas na maneira como se articulam os apartamentos e as prumadas de circulação vertical: no João Ramalho este arranjo pôde se realizar de maneira mais simples e proveitosa, dispondo somente de dois apartamentos por prumada, e possibilitando uma orientação desimpedida de suas aberturas. No Promontory os apartamentos se organizam formando uma planta de duplo "T", tipicamente utilizada nas construções daquela cidade. ${ }^{6}$

Há no entanto uma relação direta na forma como se organiza a estrutura de concreto e os planos independentes de fechamento nos dois edifícios. No Promontory, onde o concreto armado havia substituído o emprego do aço conforme previsto nos

5 ARQUITETURA e Desenvolvimento Nacional. Depoimentos de arquitetos paulistas. IAB-SP, São Paulo: Editora Pini LTDA, 1979. Depoimento de Salvador Candia.

6 GIEDION (2004. p. 630). Significativamente, as diversas publicações que divulgaram este primeiro edifício vertical de Mies mostram sempre a sua fachada "frontal", omitindo a situação conformada pelo desdobramento da planta na face posterior (Nota do autor).
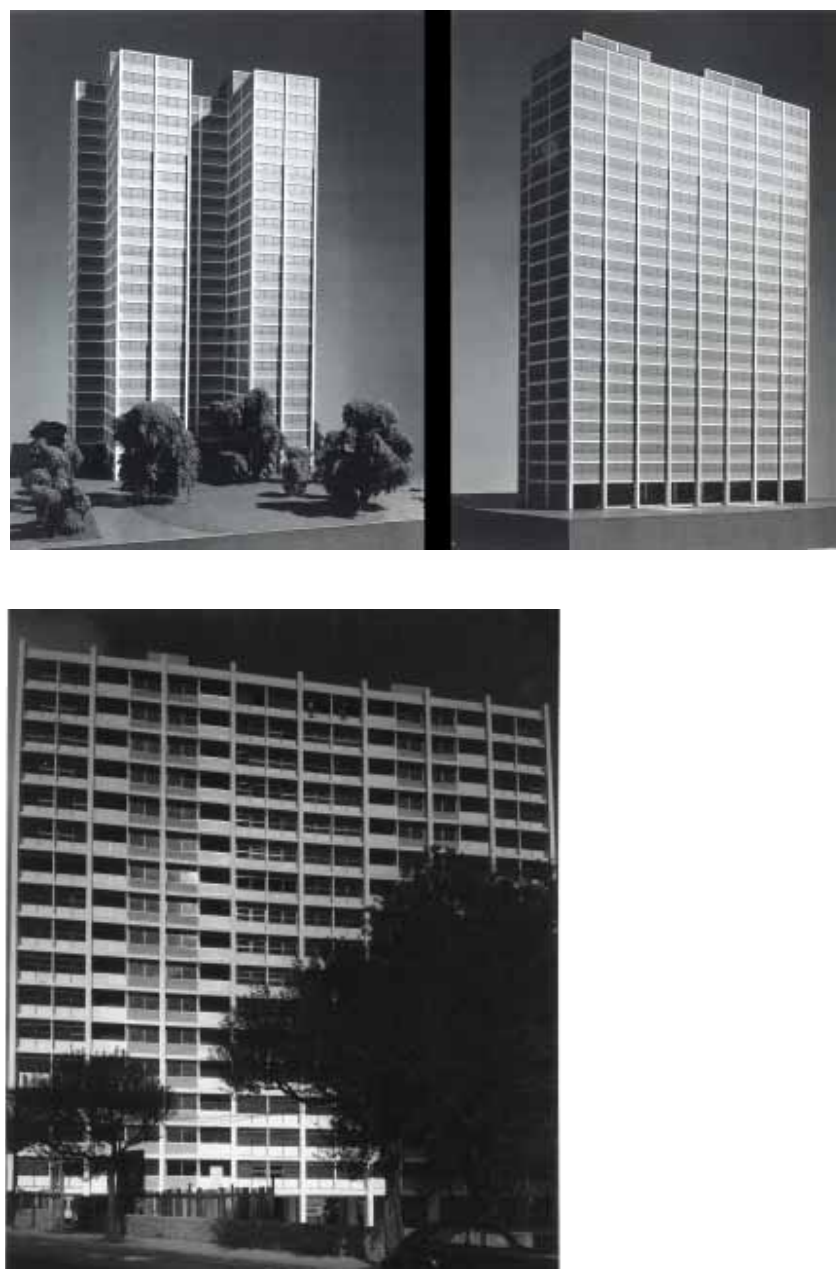

acima:

Edifício Promontory, Chicago.

Mies van der Rohe, 1946-49.

fonte: LAMBERT (2001)

abaixo:

Ed. João Ramalho, São Paulo.

Aflalo, Candia e Croce, 1954.

fonte: arquivo S. Candia 

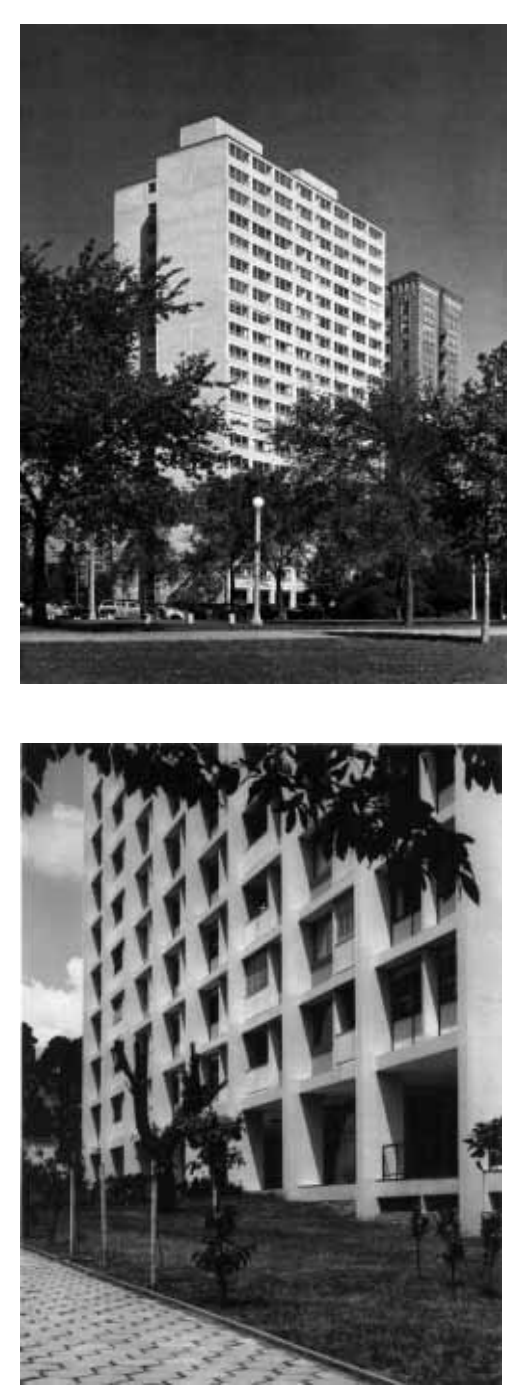

acima:

Edifício Promontory, Chicago. Mies van der Rohe, 1946-49. fonte: SCHULZE (1989) abaixo:

d. João Ramalho, São Paulo. Aflalo, Candia e Croce, 1954 fonte: arquivo S. Candia primeiros estudos por conta dos reflexos da guerra na economia norte americana, Mies experimenta uma de suas primeiras hipóteses no arranjo entre a grelha estrutural e os planos de fechamento para o arquétipo do edifício vertical, dando continuidade a um processo que caracterizaria fortemente a sua obra norte americana.

Neste primeiro caso os apoios se destacam do plano compreendido pela grelha estrutural da fachada, alternando a sua dimensão em função da variação dos carregamentos verticais da estrutura. Destacados em relação aos demais elementos, os pilares do Promontory marcam o ritmo da modulação estrutural, e determinam a subdivisão dos caixilhos e peitoris.

O João Ramalho emprega linguagem semelhante no partido de organização da estrutura e dos planos de fechamento, embora o perfil dos pilares destacados na fachada seja contínuo, acentuando ainda mais o ritmo da modulação e a sua verticalidade. Há também outra diferença fundamental no desenho da estrutura e dos fechamentos destes dois edifícios. Enquanto que no Promontory as vigas que constituem os pórticos da fachada formam um plano contínuo com os peitoris de alvenaria e caixilhos, dando maior destaque à variação de profundidade empregada nos pilares, e criando dois planos claramente diferenciados; no João Ramalho a grelha que organiza o plano da fachada oferece diversas variações de profundidade. Estabelece-se assim uma hierarquia entre os diversos elementos que compõe esta trama: os pilares destacados em primeiro plano, as bordas das lajes em segundo, os montantes verticais em terceiro, os caixilhos em quarto, e finalmente, a varanda recuada em quinto lugar (ver planta adiante).

Os materiais empregados na composição dos fechamentos, embora guardem em alguns casos uma certa semelhança com o Promontory, apresentam no João Ramalho uma rica variação que se vincula ao programa dos ambientes internos, obedecendo a uma mesma subdivisão modular de aproximadamente um metro e meio. Desta forma, embora a sala de estar dos apartamentos ofereça uma variação de profundidade, alternando entre o caixilho sobre peitoril de alvenaria - semelhante ao empregado no 

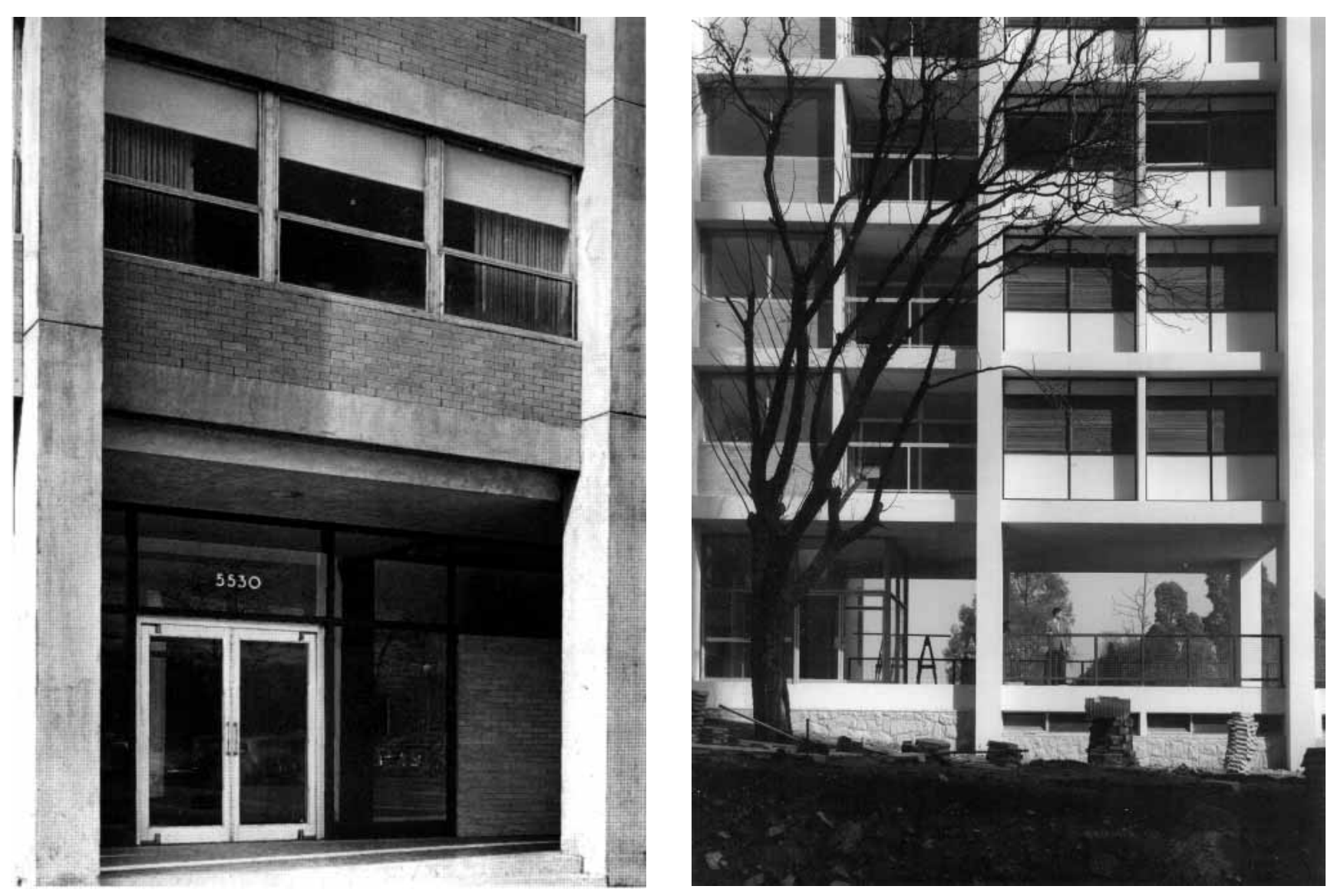

\section{nesta página}

esquerda:

Edifício Promontory, Chicago.

Mies van der Rohe, 1946-49.

fonte: CARTER (1999)

direita:

Ed. João Ramalho, São Paulo.

Aflalo, Candia e Croce, 1954.

foto da conclusão da obra. (o guarda-corpo

ainda não estava concluído).

fonte: arquivo S. Candia

página seguinte

acima:

Edifício João Ramalho, São Paulo.

Aflalo, Candia e Croce, 1954.

1. Planta parcial do pavimento tipo.

2. Ampliação da linha de pilares

e fechamentos.

fonte: arquivo S. Candia.

abaixo:

Edifício João Ramalho, São Paulo.

Aflalo, Candia e Croce, 1954

Perspectiva de implantação.

fonte: arquivo S. Candia 

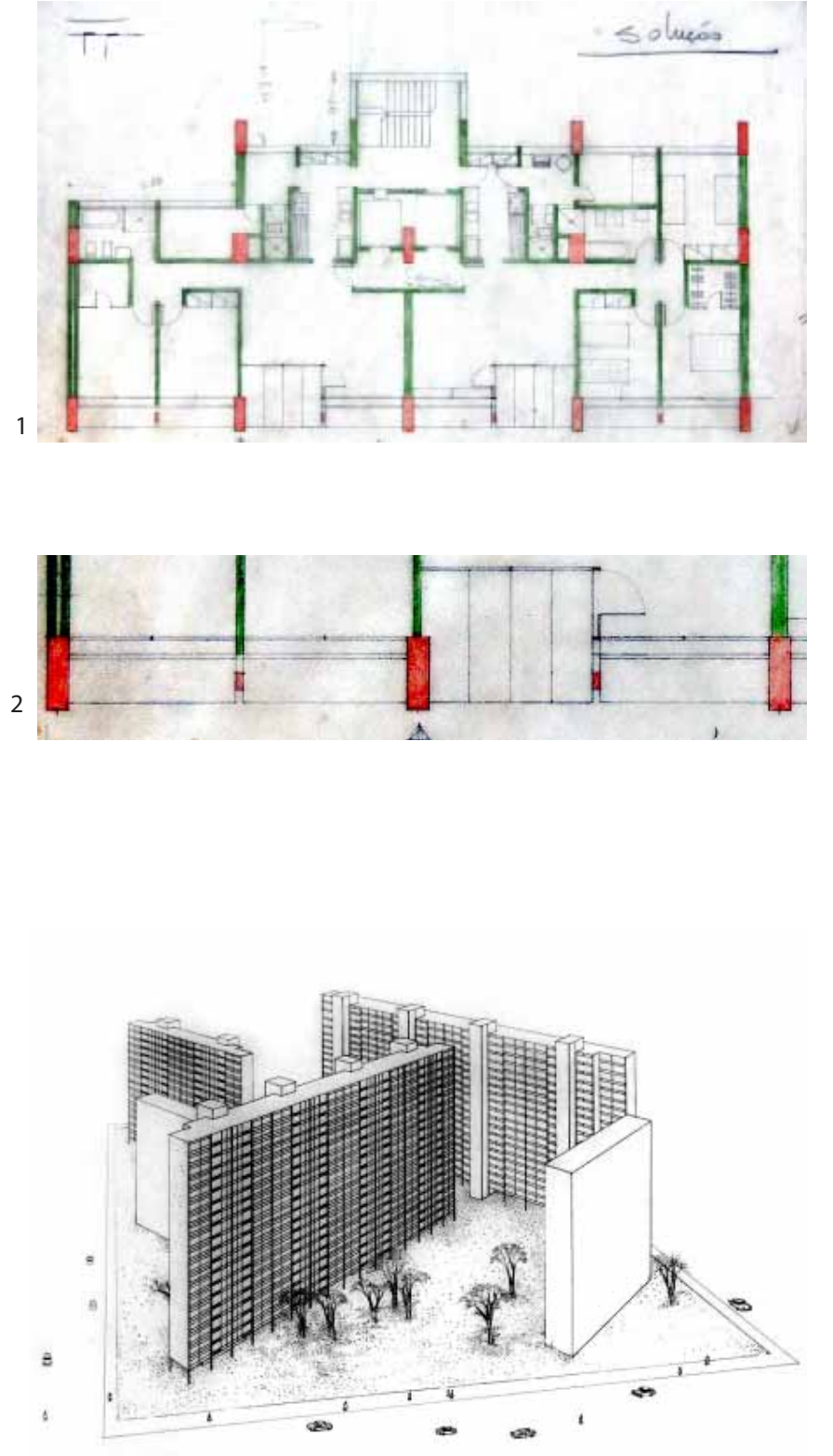

Promontory - ocupando um duplo módulo de três metros, e a varanda recuada com caixilhos de piso a teto ocupando o duplo módulo subseqüente, esta variação se acusa apenas discretamente na fachada, estando encoberta pelo destaque dado ao ritmo dos elementos estruturais.

Os caixilhos dos dormitórios oferecem ainda uma terceira variação dos materiais empregados na fachada. Fabricadas pela indústria dos Irmãos Collavini em São Paulo, as janelas contrapesadas tipo "Ideal", empregadas já anteriormente em grande escala no edifício Louveira (1946-48) de Vilanova Artigas, representavam naquele momento uma tentativa de se promover a industrialização dos elementos da construção, se aproximando da idéia de "montagem do edifício" defendida por Salvador Candia em seu depoimento. No memorial do projeto apresentado à IV Bienal, os arquitetos comentam a idéia:

A estrutura é em concreto armado e participa, seja pelo seu volume, seja pelo seu espírito, como elemento conjugado à arquitetura (...).

O mesmo intercolúneo da estrutura em ambas as faces de ambos os edificios, permitiu o emprego de caixilhos estandardizados de alumínio, persianas de madeira e chapas de fibrocimento. ${ }^{7}$

Estando vinculada ao projeto de um conjunto de três edifícios que empregavam elementos idênticos em seus fechamentos, a industrializalção deste e dos demais elementos de fachada poderia ter se tormado de fato uma experiência oportuna, caso o plano tivesse sido integralmente implantado.

À exceção do edifício Louveira, onde haviam sido feitos em chapa de aço, os caixilhos contrapesados eram comumente fabricados em madeira ou chapas de fibrocimento.

7 Memorial descritivo do projeto, datado de 26 de Julho de 1956 (Arquivo S. Candia) 
Com o intuito de protegê-los das intempéries e oferecer-lhes uma maior sustentação, os caixilhos do João Ramalho foram instalados com recuo em relação ao plano das lajes e das alvenarias externas. Em outras obras posteriores, como os edifícios para o conjunto Ana Rosa (1954), onde irá empregar os mesmos caixilhos, Salvador Candia fará uso de um montante vertical de concreto armado para estruturar o plano de fechamento, e empregará este mesmo elemento para marcar visualmente a sua modulação.

Outro elemento que diferencia o edifício João Ramalho do Promontory é o tratamento dado às empenas laterais. Nos dois exemplos, o fechamento lateral do edifício constitui o arremate das fachadas principais, sendo tratado como plano cego. Enquanto que no caso norte americano o edifício mantém a regularidade de seu volume demonstrando a sua espessura através do fechamento lateral, no João Ramalho os apartamentos situados nas extremidades do edifício correspondem a uma planta menor, com apenas dois quartos. Esta variação possibilita o estreitamento do último módulo estrutural, reduzindo assim a sua volumetria aparente.

Cabe notar que, além das qualidades comentadas acima, a questão a nosso ver mais relevante no projeto das Perdizes é a dimensão urbanística de sua implantação, que merecerá por isso uma leitura mais específica adiante. O que nos parece entretanto importante em relação aos procedimentos plásticos e construtivos empregados no João Ramalho, é que eles partem de uma interpretação ativa da linguagem empregada por Mies van der Rohe, e que aponta para o desenvolvimento de um vocabulário próprio.

Numa revisão do plano de ocupação da quadra de Perdizes realizada posteriormente em 1959-60, os três arquitetos experimentaram uma outra tipologia para a habitação coletiva. Partindo de um maior adensamento populacional, propuseram agrupar os apartamentos em torres compactas de planta quadrada, com quatro apartamentos servidos por uma única prumada de circulação vertical, dando origem aos edifícios Barão de Laguna e Barão de Ladário.

Neste novo projeto a estrutura perimetral das torres se destaca novamente do plano
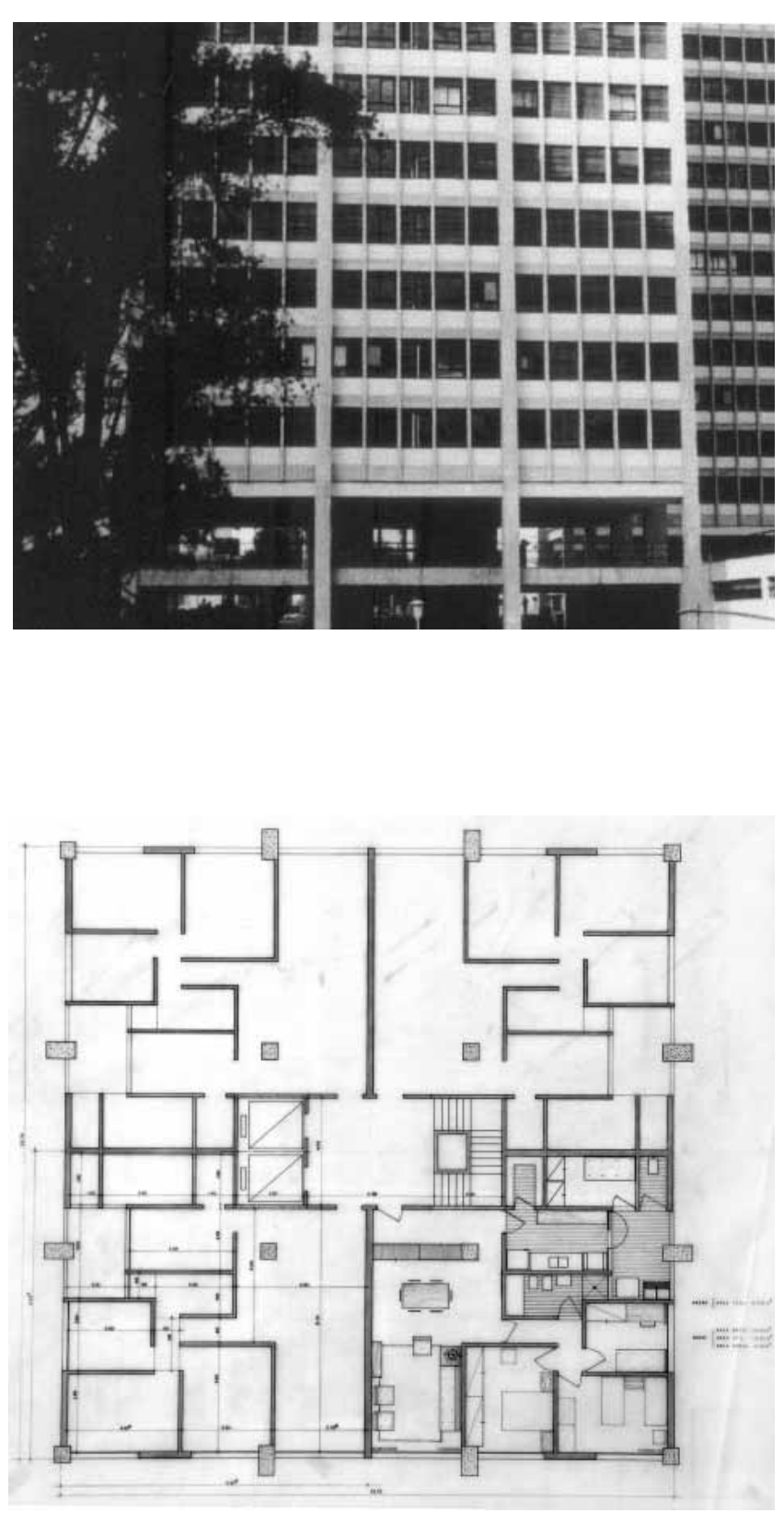


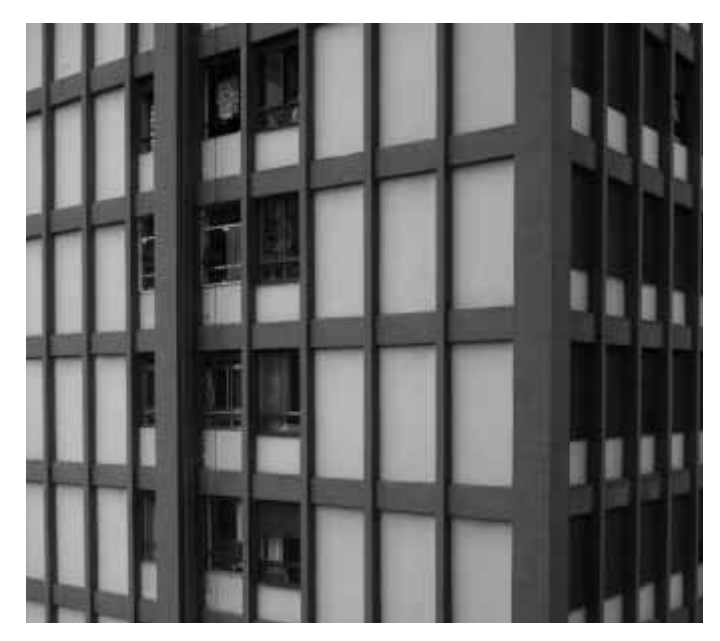

nesta página

acima:

Ed. Barão de Laguna, São Paulo

Aflalo, Candia e Croce, 1959-60

fonte: foto do autor

direita: :

Ed. Barão de Laguna, São Paulo

Aflalo, Candia e Croce, 1959-60

estudo alternativo para os fechamentos

fonte: Aruivo S. Candia

\section{página anterior}

acima:

Ed. Barão de Laguna, São Paulo

Aflalo, Candia e Croce, 1959-60

foto da obra recém concluída

fonte: Arquivo S. Candia

abaixo:

Ed. Barão de Laguna, São Paulo

Aflalo, Candia e Croce, $1959-6$

fonte: foto do autor de fechamento, assim como se fizera no edifício anterior, prevendo ainda nos estudos iniciais a adoção de um sistema análogo para a construção dos fechamentos, imprimindo uma mesma identidade construtiva ao conjunto. Esta proposta foi no entanto posteriormente abandonada para dar lugar a um sistema mais simplificado na construção das novas fachadas, com uma área maior de alvenaria utilizada como fechamento externo, intercalada com planos de caixilho sobre peitoris. A alternativa então empregada conta com a construção de um renque de montantes verticais em concreto armado que, embora sirvam de módulo e suporte para a instalação dos caixilhos, não guardam uma correspondência direta com os métodos construtivos da fachada, servindo antes para conferir ritmo e unidade ao conjunto aleatório de aberturas.

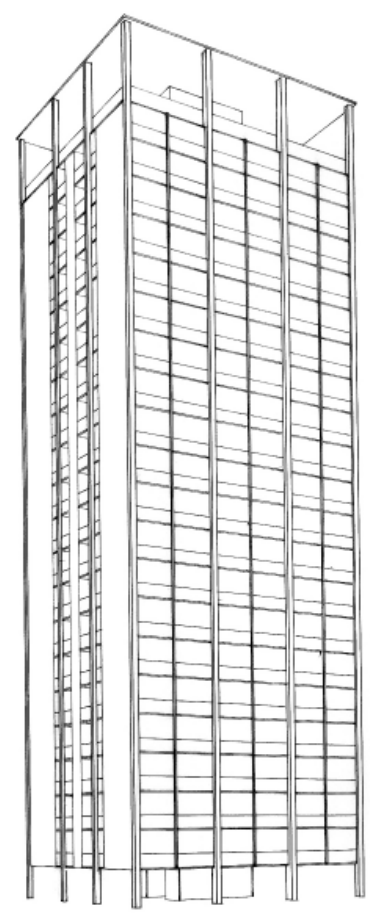




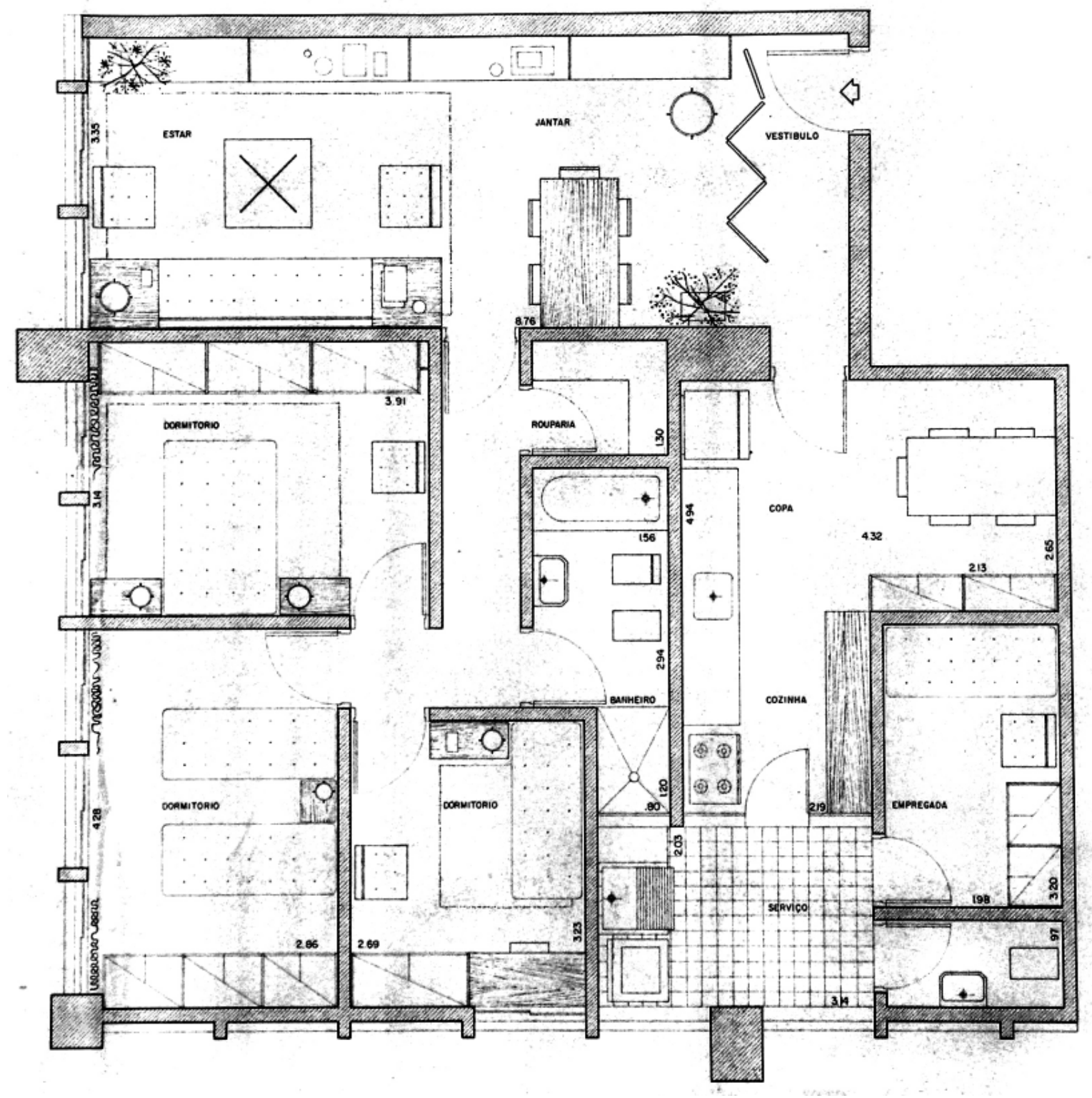

à direira

Lake Shore Drive 860/880, Chicago

Mies van der Rohe, 1948-51

foto da grelha sendo içada para baixo

fonte: CARTER (1999)

nesta página:

Ed. Barão de Laguna, São Paulo

Aflalo, Candia ecroce, 1959-60

fonte: arquivo S. Candia 


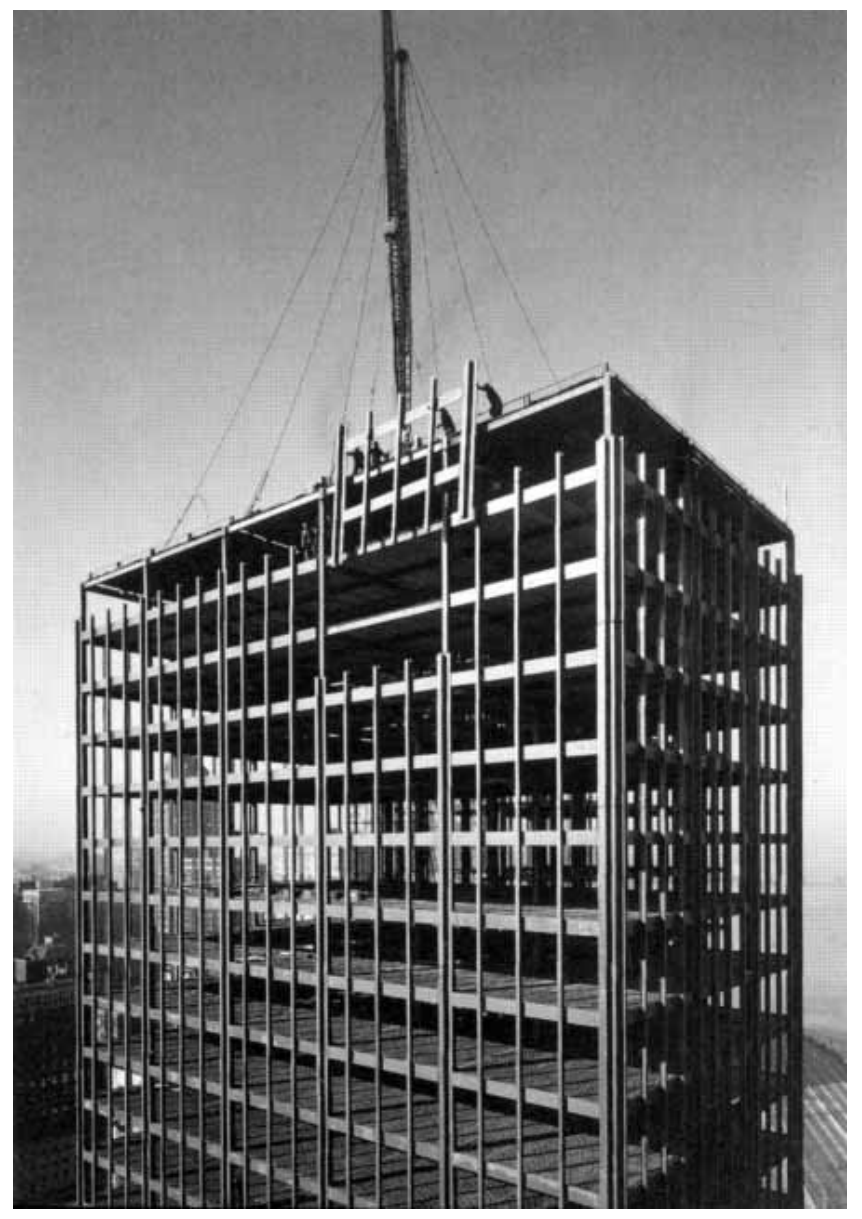

O desenho que resulta deste procedimento remete ao uso dos perfis "I" metálicos empregados primeiramente por Mies nas torres de apartamentos em Lake Shore Drive 860/880 em Chicago (1948-51). Ainda que a aplicação desta nova malha metálica sobreposta à grelha estrutural do Lake Shore Drive resulte de uma determinação de ordem plástica, destacando o plano de fechamento daquele conformado pela estrutura, marcando externamente o seu módulo e conferindo-lhe profundidade, há também ali uma forte implicação construtiva: os montantes metálicos são agrupados em maiores módulos, com dois pavimentos e pré-fabricados no próprio canteiro, tendo sido posteriormente montados sobre a estrutura. ${ }^{8}$

A interpretação daquela linguagem construtiva teria necessariamente que partir do emprego de um material diverso, pois o uso em larga escala do aço no mercado nacional da construção não seria uma prática corrente naquele momento. No projeto das Perdizes, além do uso dos frisos de concreto percorrendo toda a fachada, os arquitetos experimentam também uma maneira diversa para a resolução do problema da construção da esquina resultante do encontro ortogonal de duas fachadas iguais (novamente uma questão levantada por Mies van der Rohe), reduzindo simplesmente a seção do pilar de concreto nos quatro cantos do edifício. ${ }^{9}$

Salvador Candia experimentaria ainda por um certo período diversas formas de tradução desta linguagem para as circunstâncias construtivas locais. Nas torres do Barão de Laguna e Barão de Ladário, a própria repetição do mesmo edifício - que neste caso tratava-se de um conjunto de quatro torres idênticas - e sua disposição no terreno, guardam uma interlocução com o projeto do Lake Shore Drive e também com as demais implantações que Mies realizara subseqüentemente.

8 CARTER (1999 p. 46). Peter Carter comenta os diversos processos construtivos empregados nos edifícios verticais de Mies van der Rohe a partir das primeiras torres Lake Shore Drive 860/880 em 1948-51. Neste primeiro caso, os módulos de pédireito duplo da fachada foram fabricados em canteiro no topo do edifício, e içados para baixo para a montagem da fachada.

9 Este detalhe foi comentado por Abílio Guerra no Exame de Qualificação deste mestrado, realizado em 27-07-2007. O mesmo detalhe foi também lembrado por Giancarlo Gasperini, em depoimento concedido ao autor em 05-12-2007. 


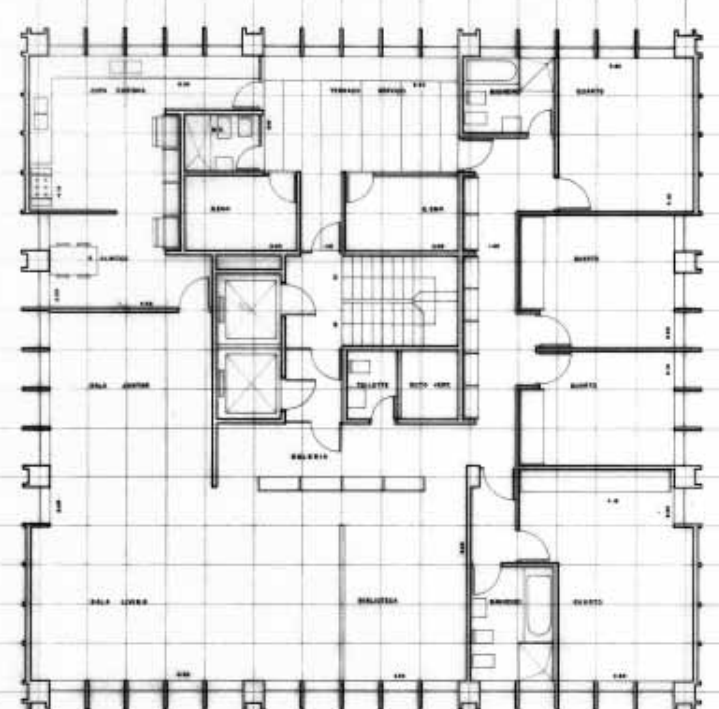

noso , . n n nos
(1)

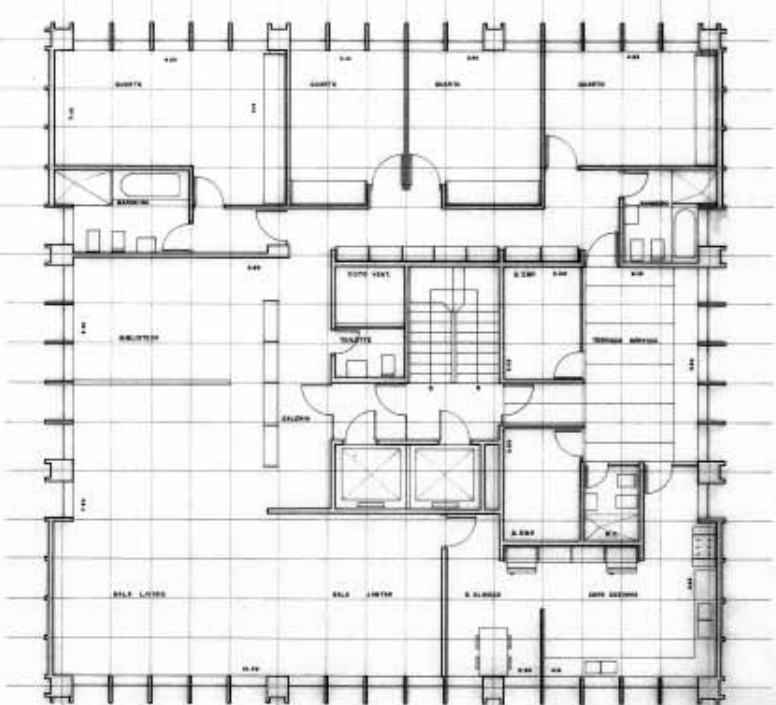

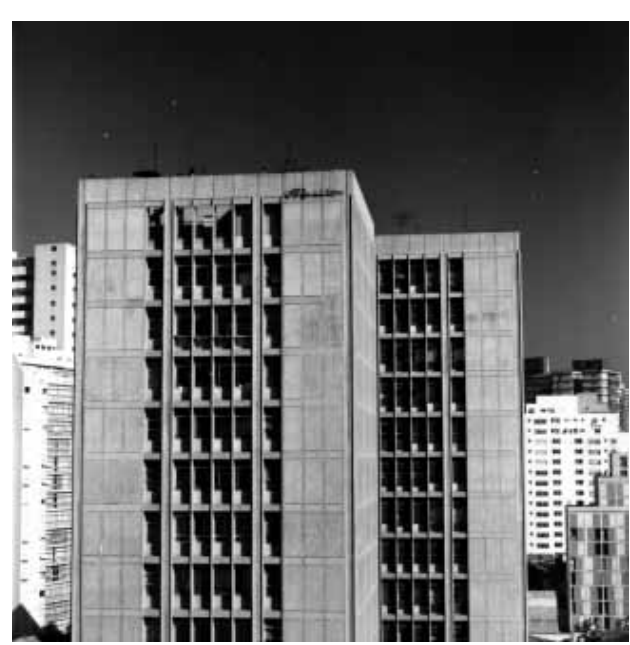

nesta página

acima:

Ed. Santa Cândida e Santa Francisca,

São Paulo.

Salvador Candia, 1961-63.

fonte: arquivo $\mathrm{S}$. Candia.

à esquerda

Ed. Santa Cândida e Santa Francisca,

São Paulo.

Salvador Candia, 1961-63.

fonte: arquivo S. Candia. 

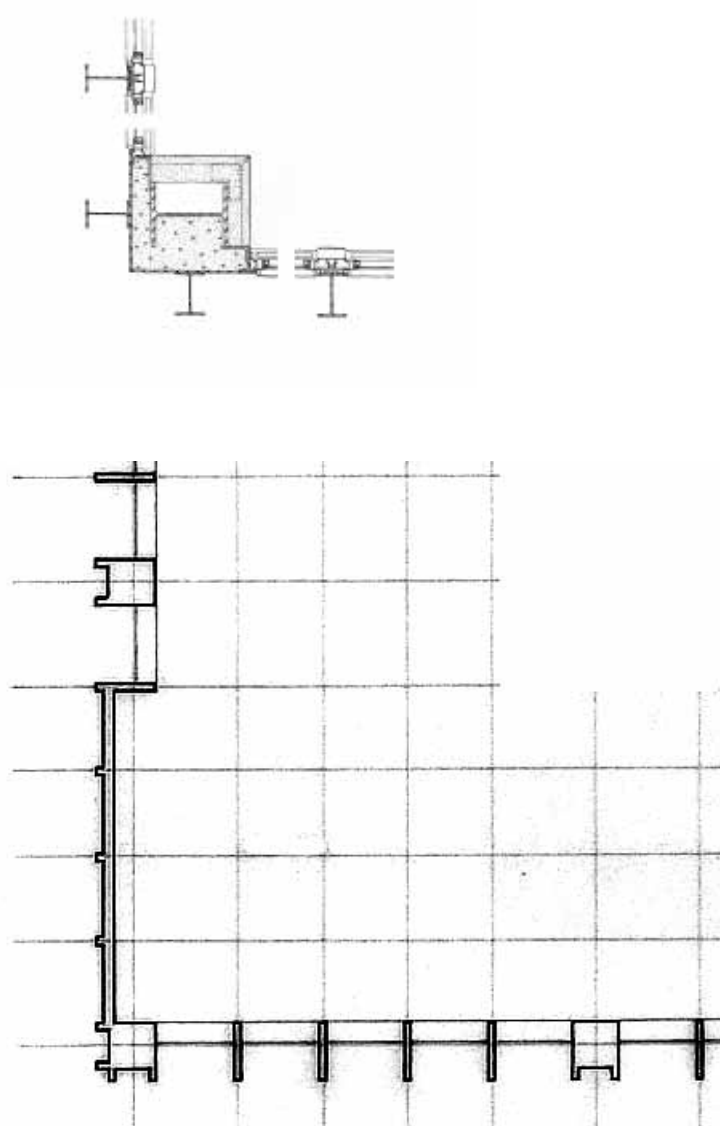
ke Shore Drive 860/880, Chicago Mies van der Rohe, 1948-51
detalhe da esquina entre as fachadas iguais. Os perfis metálicos são anexados ao pilar de forma a sobrepor o ritmo da modulação sobre a superficie da estrutura.
fonte: CARTER (1999)

abaixo:

Ed. Santa Cândida e Santa Francisca, São Paulo: Salvador Candia, 1961-63. Detalhe da modulação da fachada e da resolução da esquina.
fonte: arquivo S. Candia.
Em um projeto análogo realizado em 1960-63 para um conjunto de apartamentos no bairro de Higienópolis em São Paulo, as torres Santa Cândida e Santa Francisca, o arquiteto desenha um conjunto de septos verticais na fachada que, além de marcarem o módulo de 1.05 metro que organiza o pavimento tipo, dão sombra e proteção aos caixilhos, colocando-os em segundo plano. Variando em relação à face do edifício e à incidência do sol, as aberturas ganham aspecto de simples rasgos na fachada, de forma semelhante ao que ocorre com as janelas do já citado edifício de Júlio de Abreu Jr. na avenida Angélica, de 1927. Este efeito se reforça no último pavimento, onde embora não existam mais caixilhos e a cobertura seja vazada, o desenho das aberturas permanece o mesmo.

O uso da modulação neste projeto está diretamente vinculado à linguagem construtiva empregada na fachada. Nos planos cegos de alvenaria, o módulo é marcado com frisos rebaixados, diferentes daqueles empregados nas torres Laguna e Ladário (embora nos desenhos do ante-projeto os frisos sejam salientes). O ritmo da modulação é dado entretanto sempre no intervalo entre dois pilares, fazendo com que o friso se duplique nas laterais de cada pilar. 

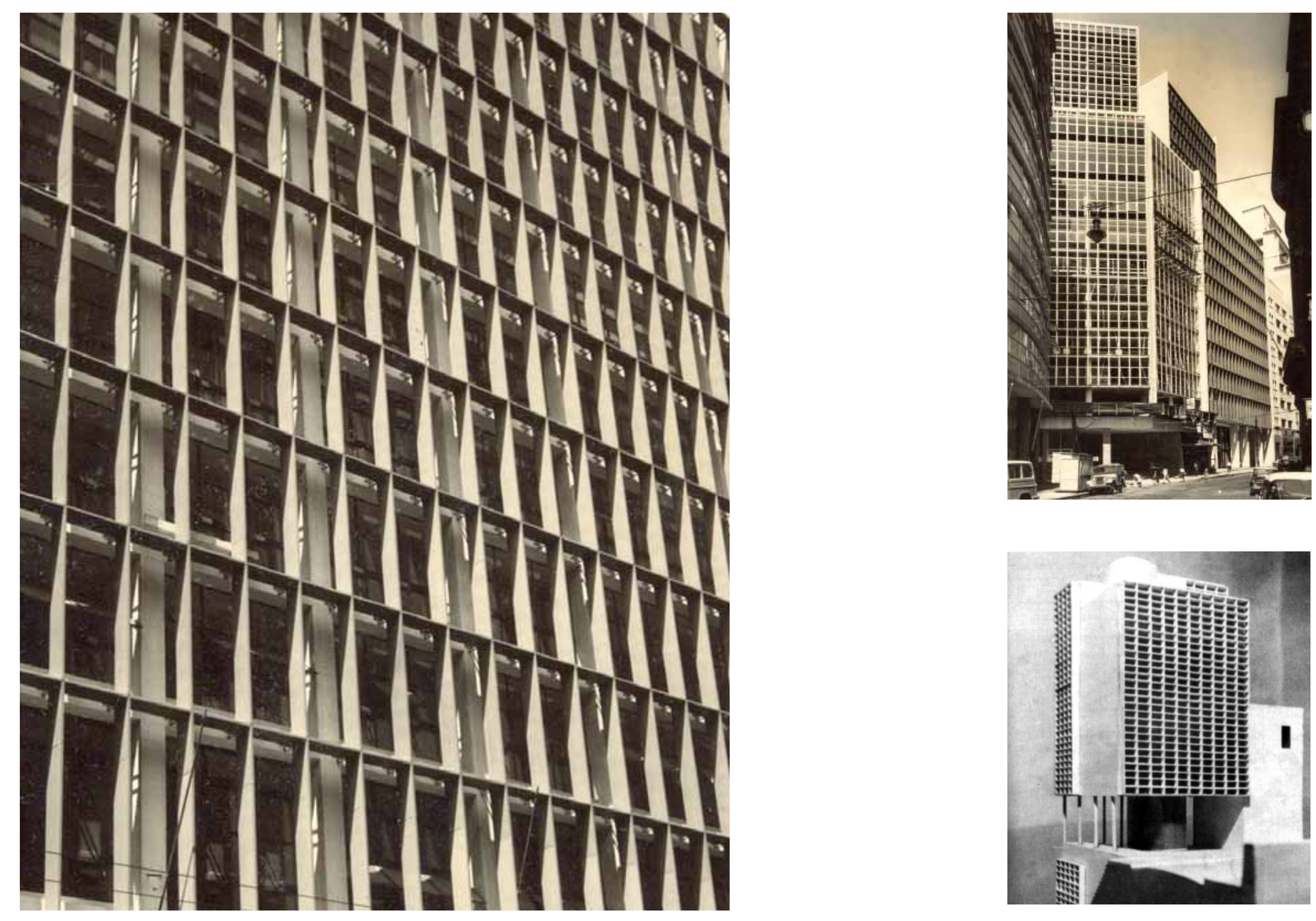
fonte: arquivo $\mathrm{S}$. Candia

esquerda acima:

Banco da Lavoura de Minas Gerais, São Paulo. Salvador Candia e Álvaro Vital Brazil, 1958-61 detalhe da grelha de quebra-sóis.

fonte: arquivo $\mathrm{S}$. Candia

esquerda abaixo:

Edifício Para apartamentos de aluguel

(Projeto Posnik), Alger.

Le Corbusier, 1933.

fonte: MONTEYS (2005)

Em projetos realizados posteriormente, o arquiteto utilizaria procedimentos construtivos mais simples e diretos para a obtenção de efeitos análogos, particularmente através do uso das grelhas de quebra-sóis destacados das fachadas. Ainda em 1958, Candia e Vital Brazil haviam empregado no projeto para o Banco da Lavoura de Minas Gerais na rua Boa Vista em São Paulo, uma grelha contínua de quebra-sóis verticais e horizontais destacados do plano de fechamento. Além de proteger a cortina de vidro do edifício da incidência de sol em sua face Oeste, e permitir uma plena ventilação pelo vão que se interpõe entre a grelha e os caixilhos, este elemento proporcionaria novamente a unidade, a profundidade e o ritmo modular da fachada.

Esta grelha ortogonal de brises, cujo uso pioneiro se atribui aos projetos de Corbusier em Argel no início da década de 30, e que no Brasil se inaugura com o Ministério da Educação, foi largamente empregada em São Paulo por arquitetos como Levi, Heep e Korngold a partir dos anos 40.

Candia faria por várias vezes o uso destes elementos, através de seguidas experimentações, como se pode verificar nos projetos para os edifícios Villares (1961), Joelma (1969) e Nações (1974), que serão apresentados com mais detalhe adiante. Neste sentido, a atuação de Candia demonstra um desenvolvimento gradual que se dá através de aproximações sucessivas, e que relaciona-se, por sua concisão e racionalidade, à postura projetual de Rino Levi em São Paulo. Nas palavras do próprio arquiteto:

O desenvolvimento cada vez mais apurado de um conceito é uma filosofia que gostamos de adotar, até porque não se cria uma arquitetura, e como conseqüência um sistema construtivo, um plano de iluminação, etc. - a cada segunda feira.

A arquitetura deve expressar sempre imaginação e tanto quanto possível conter um elemento de magia, mas é sempre a resolução de problemas construtivos, e portanto, não deve cair em excentricidades de efeito fácil ${ }^{10}$

10 CANDIA, Salvador. Curriculum Vitae e Obras Executadas, São Paulo, Arquivo Salvador Candia, [1980] 


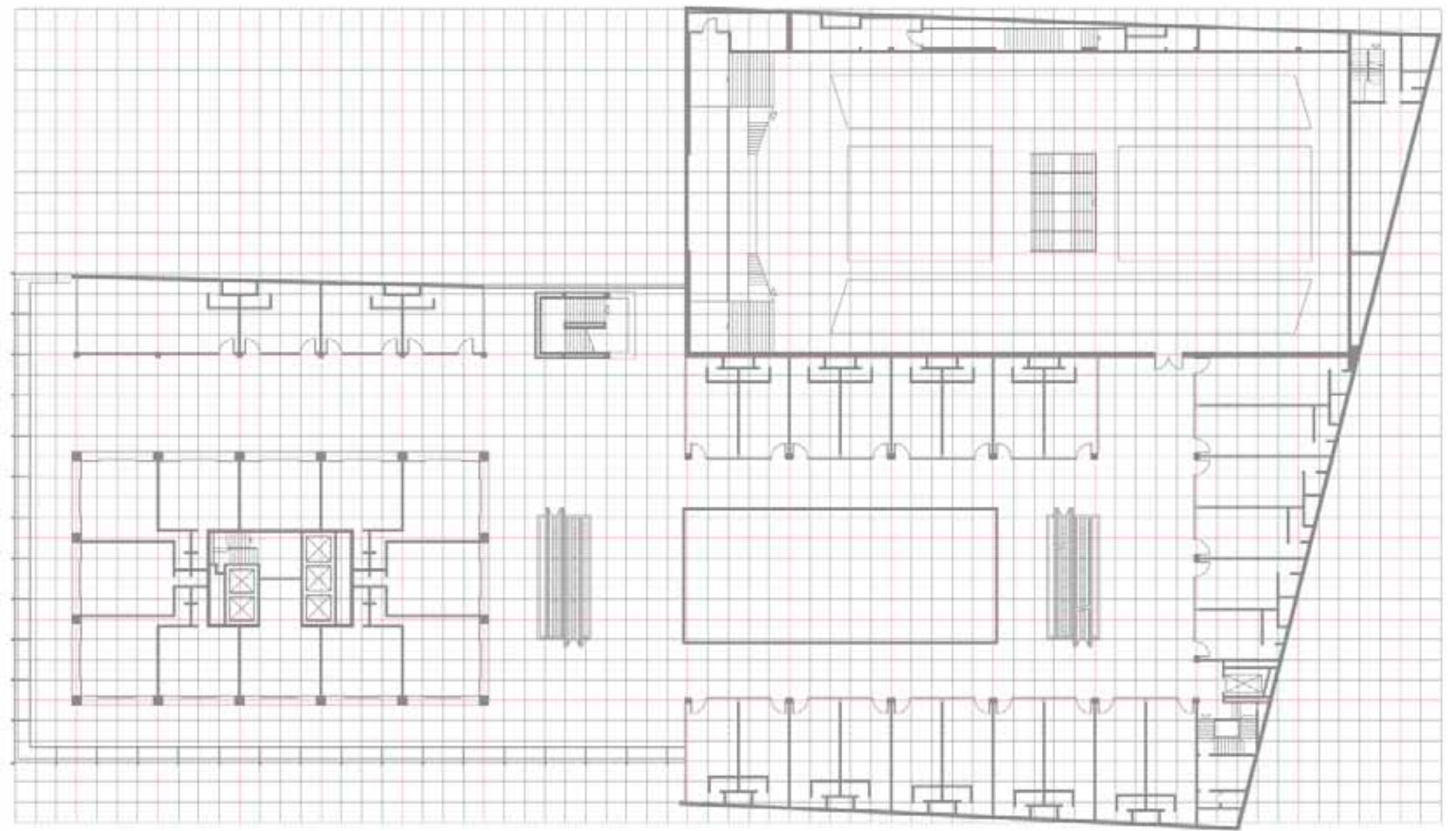




\section{O emprego do módulo}

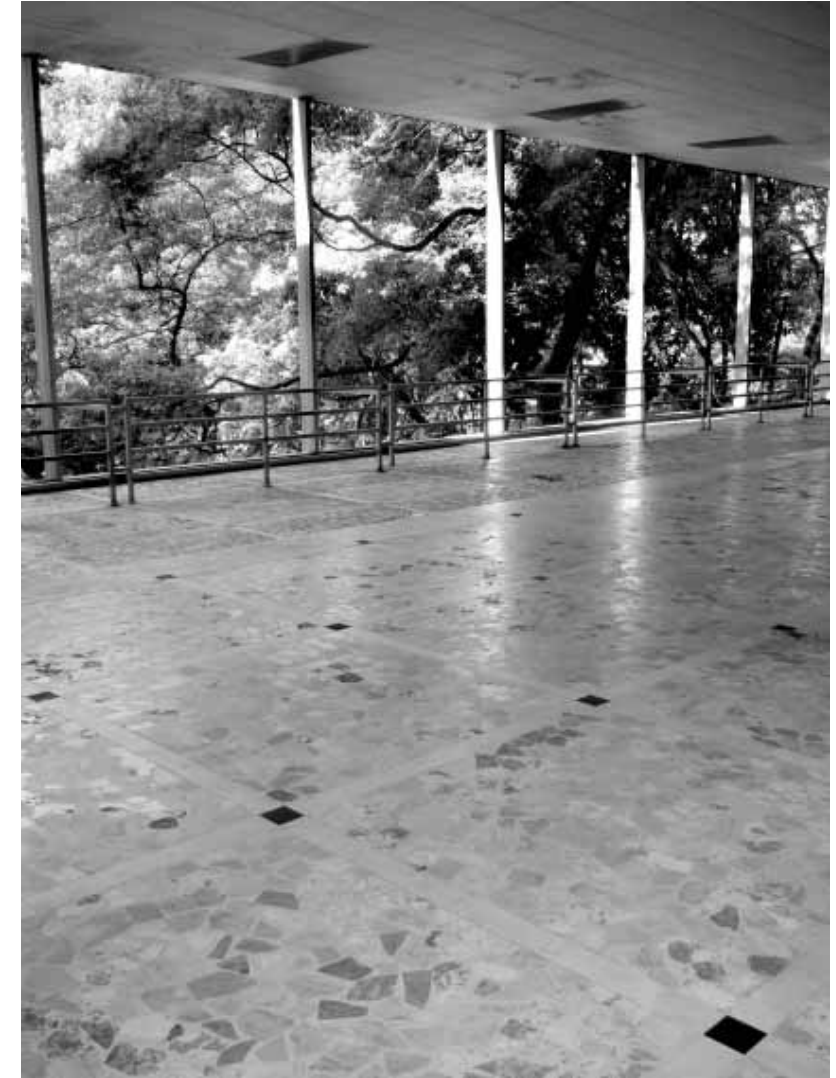

Edifício Metrópole, São Paulo.Salvador Candia e Gima: Edificio Metrópole, São Paulo.Salvador Candia e Giancarlo Gasperini, 1959. Foto da varanda da galeria comercial. (ver detalhe do piso e da fachada). fonte: foto do autor Edifício Metrópole, São Paulo. Salvador Candia e Giancarlo Gasperini, 1959 Planta com a grelha de modulação. fonte: desenho realizado sobre bases diversas
Conforme comentamos em relação ao projeto das torres Santa Cândida e Santa Francisca, o uso da modulação se faz presente na composição da fachada, através da modenatura empregada nos septos e nos frisos verticais dos pilares e das alvenarias. Embora as técnicas construtivas empregadas na obra, como a alvenaria revestida com argamassa e as estruturas de concreto moldadas in loco pudessem eventualmente prescindir desta subdivisão, ela confere unidade às variações dos planos cegos e vazados. A mesma modulação está também fortemente presente no arranjo espacial interno do apartamento.

No projeto realizado para o edifício Metrópole, a planta do conjunto que compreende torre de escritórios e galeria comercial está inteiramente organizada conforme o módulo de um metro e meio. Os vãos estruturais de seis metros da estrutura periférica da torre compatibilizam-se aos vãos de sete metros e meio das lojas da galeria através deste múltiplo. Aqui também o uso desta medida não teria uma implicação construtiva direta, porque não corresponde a um sistema modular de construção. Neste caso verifica-se novamente que, para muito além das razões de ordem prática e construtiva, o módulo é empregado na concepção espacial do edifício, tornando-se um elemento que confere unidade e coerência a um conjunto diversificado de programas e ambientes.

Esta intenção se torna clara através da aplicação de determinados elementos que a evidenciam, e que funcionam como uma referência de medida do espaço: as juntas no piso na galeria marcam o módulo do edifício e o ressaltam através do "cabochão" de granito preto no seu cruzamento. Da mesma forma, os perfis verticais aplicados na extremidade das varandas constituem um desdobramento daquela medida sobre o espaço. 


\section{planta funcional}

My attack is not against form, but against form as an end in itself.

I make this attack because of what I have learned.

Form as an end inevitably results in mere formalism.

This effort is directed only to the exterior. But only what has life on the inside has a living exterior.

Only what has intensity of life can have intensity of form. ${ }^{11}$

Este trecho do artigo publicado originalmente por Mies van der Rohe em 1927 na revista Die Form, e reproduzido vinte anos depois por Philip Johnson no catálogo da exposição do arquiteto alemão no MOMA, ao qual Candia teve acesso ainda quando estudante, reivindica uma determinada abordagem sobre o projeto, que iria conduzir em parte a atuação do arquiteto brasileiro: mais do que uma interlocução direta entre a forma e a função, o procedimento empregado por Candia no desenho dos espaços em determinadas obras toma partido expressivo da articulação funcional entre os diversos programas, tornando-os visíveis no seu exterior. Podemos verificar este procedimento através da leitura de alguns de seus edifícios residenciais.

Para além da simples resolução funcional no arranjo entre os diversos espaços que compõe a habitação, alguns de seus projetos demonstram um dado diverso na organização da planta dos apartamentos. Num primeiro estudo realizado em 1961 para o mesmo terreno onde posteriormente seriam implantadas as torres Santa Cândida e Santa Francisca, situado na esquina das ruas Marquês de Itu e Aureliano Coutinho em

11 ROHE, Ludwig Mies van der. "1927: A letter on form in architecture." Philip C. Johnson, Mies van der Rohe. Nova York, The Museum of Modern Art, 1947. p. 187. A parte grifada corresponde às notações feitas por Salvador Candia no texto original. 


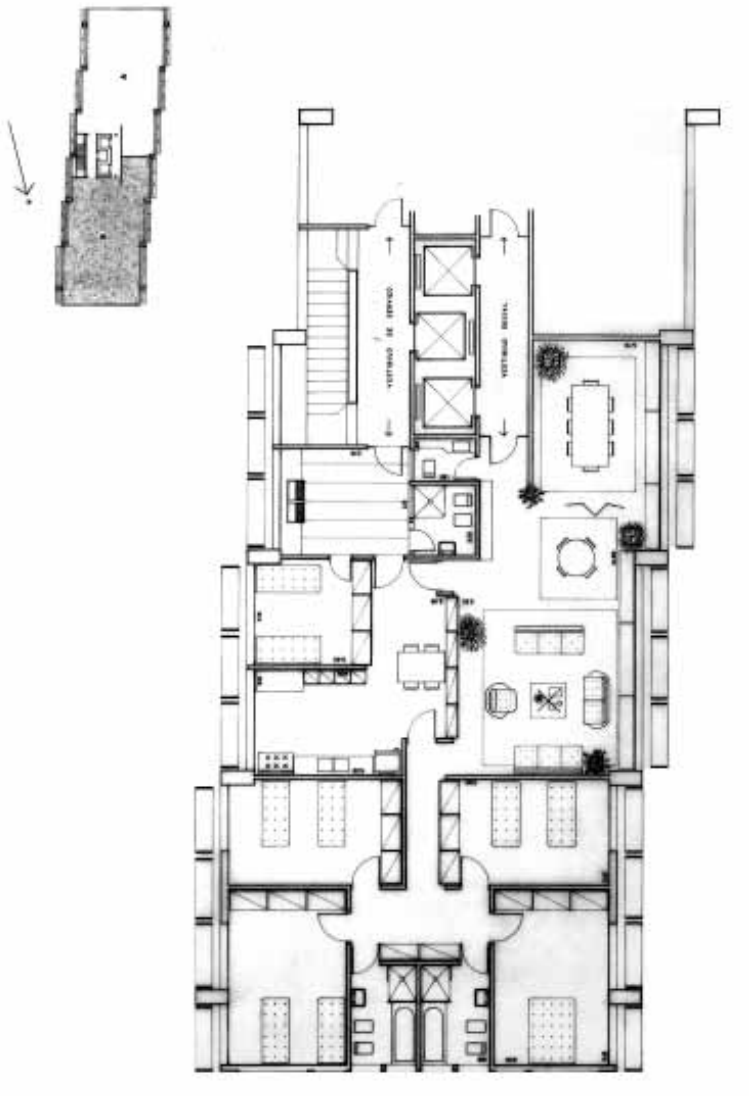

acima:

Conjunto à Aureliano Coutinho $x$ Marquês de Itu, São Paulo. Salvador Candia 1961. Planta parcial do pavimento tipo fonte: arquivo S. Candia

à direita:

Conjunto à Aureliano Coutinho Marquês de Itu, São Paulo. Salvador Candia 1961. Planta Candia 1961. fonte: arquivo S. Candia
Higienópolis, Candia distribui os apartamentos em um único bloco laminar ocupando toda a largura do terreno. Ao invés entretanto de dispor esta lâmina no alinhamento ortogonal das divisas do lote, ele acompanha a ligeira inclinação da rua Aureliano Coutinho, acomodando a geometria ortogonal do edifício a esta inflexão através de um escalonamento sucessivo dos módulos estruturais. Este escalonamento se reflete também na organização interna dos apartamentos, fazendo com que os deslocamentos internos encontrem correspondência na setorização funcional da habitação, como se pode notar no desenho da planta. ${ }^{12}$

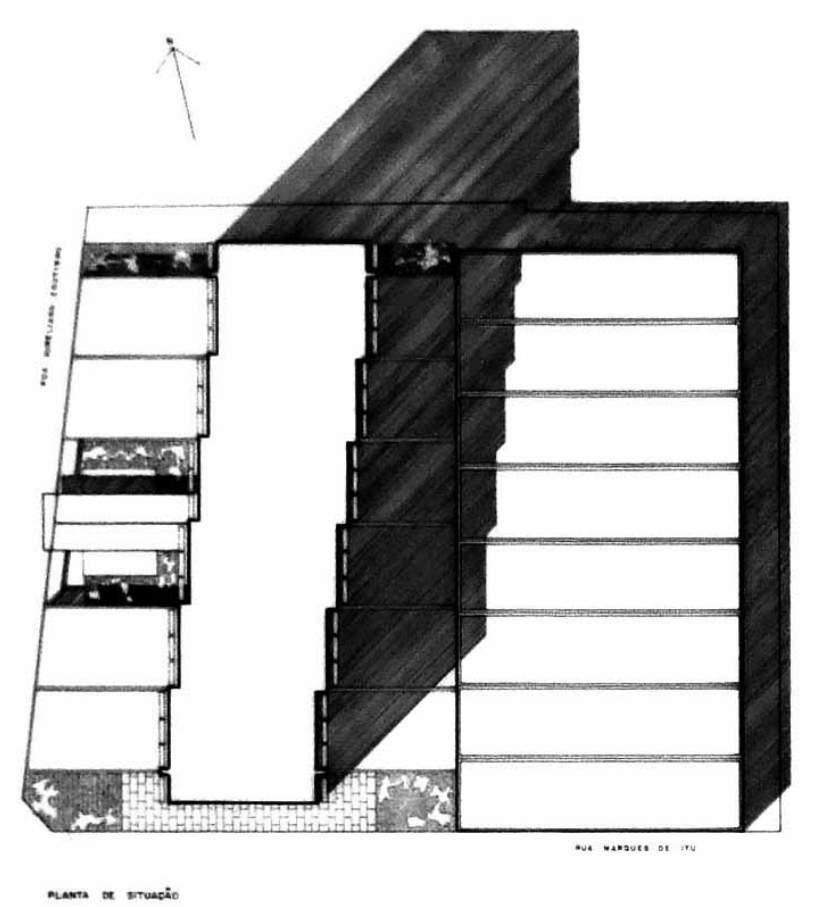

12 Esta correspondência foi comentada pelo professor Luis Antonio Jorge na Banca de Qualificação desta dissertação, realizado em 27-7-2007. 


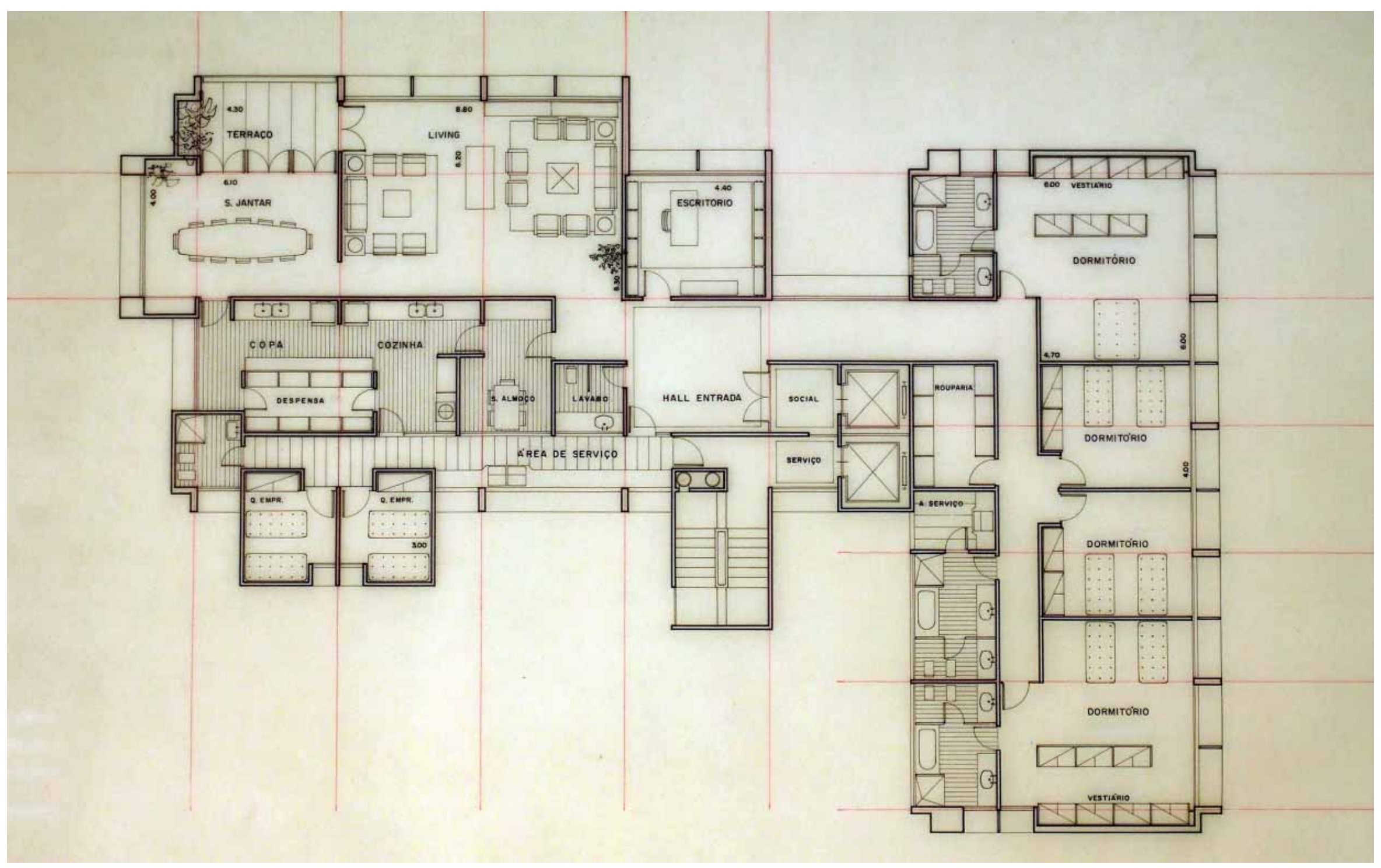




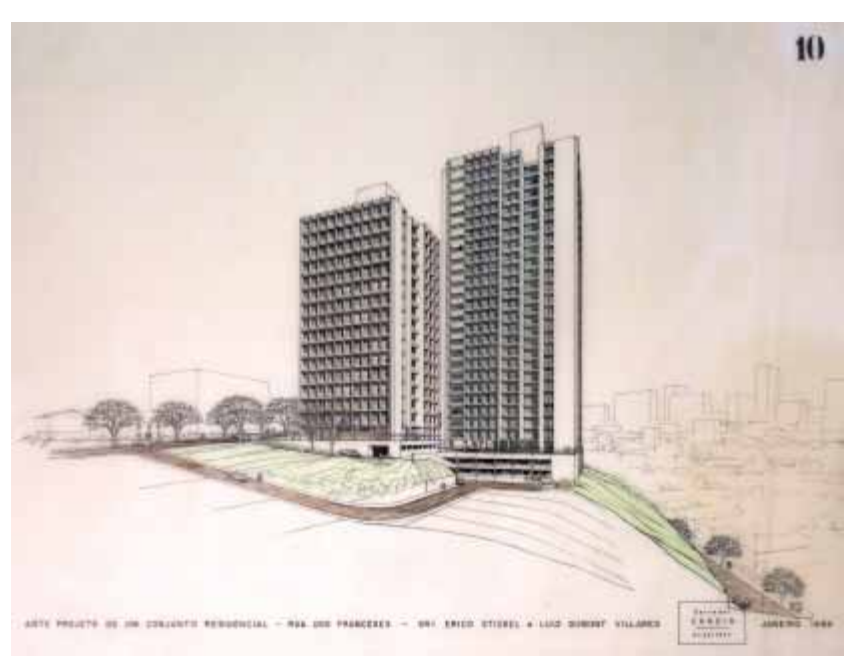

acima: Condomínio rua dos Franceses, São Paulo. Salvador Candia, 1969 Perspectiva do Conjunto. fonte: arquivo S. Candia à esquerda: dos Franceses, São Paulo. Salvador Candia, 1969 Planta do pavimento tipo. fonte: arquivo S. Candia
Operação análoga se verifica no estudo realizado em 1969 para incorporação de um lote situado na rua dos Franceses, São Paulo, na encosta Leste da Grota do Bixiga. Neste segundo caso, o arquiteto propõe a construção de duas torres iguais, dispondo de um apartamento por andar em cada edifício.

O arranjo proposto para os apartamentos parte de um eixo central de circulação, em torno do qual se agregam os diversos ambientes. A forma como estão dispostos não se define entretanto por uma geometria regular externa ao edifício, mas se organiza livremente em torno dos espaços de circulação, gerando uma figura recortada. Esta disposição sugere o destaque do setor dos quartos com relação aos espaços de estar e serviço, como se fossem dois edifícios diferentes vinculados por uma ponte. A volumetria externa dos edifícios reflete o seu arranjo funcional interno, formando um prisma irregular cuja forma não se apreende visualmente de um único ponto de vista, mas que sugere uma justaposição de diversos volumes.

Formas análogas de setorização dos espaços da habitação, e sua articulação através de pátios e galerias, foram experimentadas em alguns estudos para residências realizados pelo arquiteto, como na Dr. H. Bastos (Campinas, 1963), e na Soubihe (1968).

Estes e diversos outros exemplos (ver fichas de projetos) remetem a experiências realizadas por Rudofsky e Rino Levi em São Paulo, além das casas realizadas por Marcel Breuer nos Estados Unidos a partir dos anos $40{ }^{13}$

O projeto para a residência Dr. H. Bastos (próxima página) sugere através de seu desenho de implantação, a composição de um espaço contínuo, a exemplo dos estudos sobre a "Casa de tijolos" de Mies van der Rohe (1924), onde os planos construídos se estendem infinitamente.

13 Embora não tenham sido diretamente abordados nesta dissertação, há diversos projetos de residências realizados por Salvador Candia que mereceriam um estudo mais aprofundado, conforme se pode verificar nas fichas organizadas em anexo neste volume. 


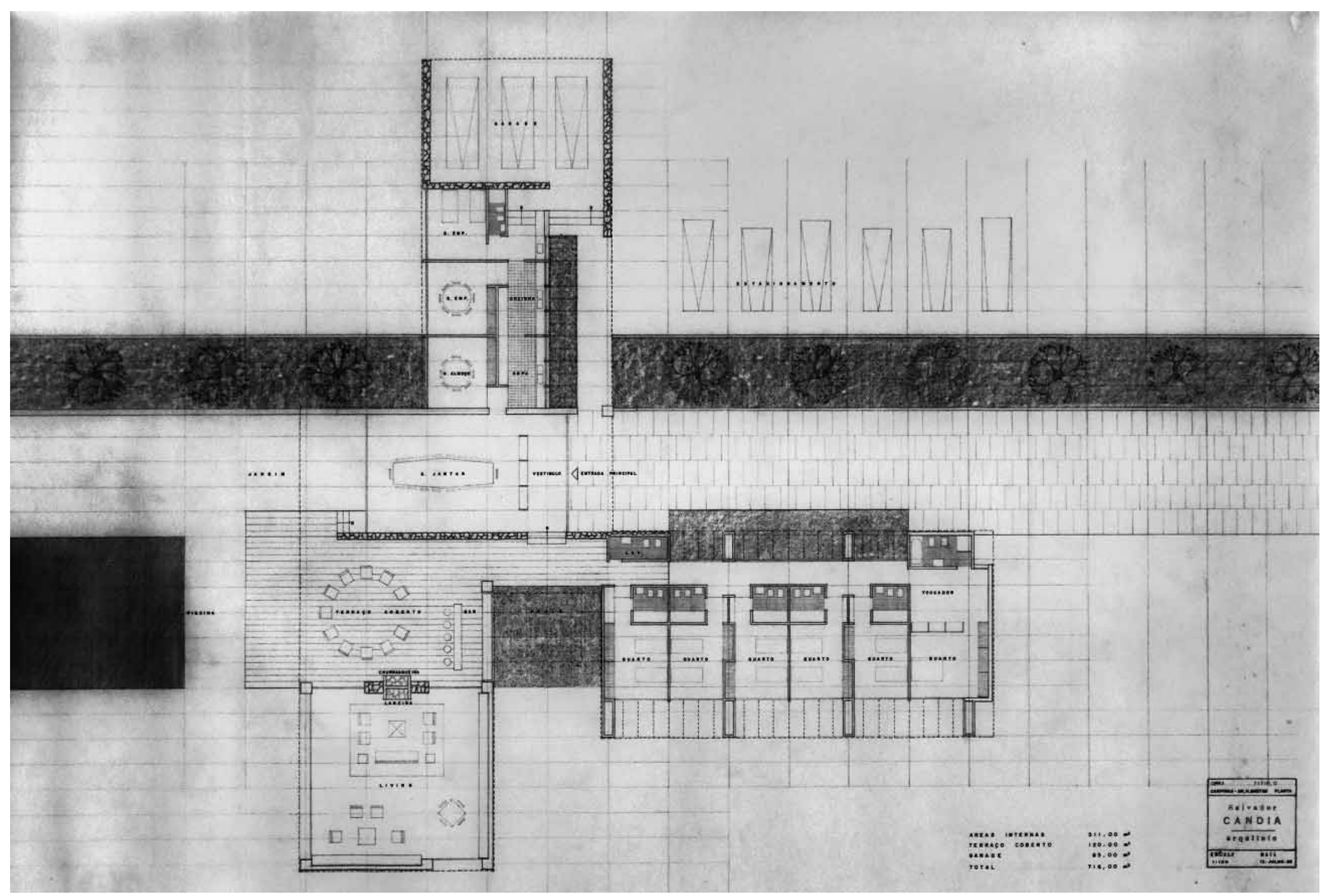




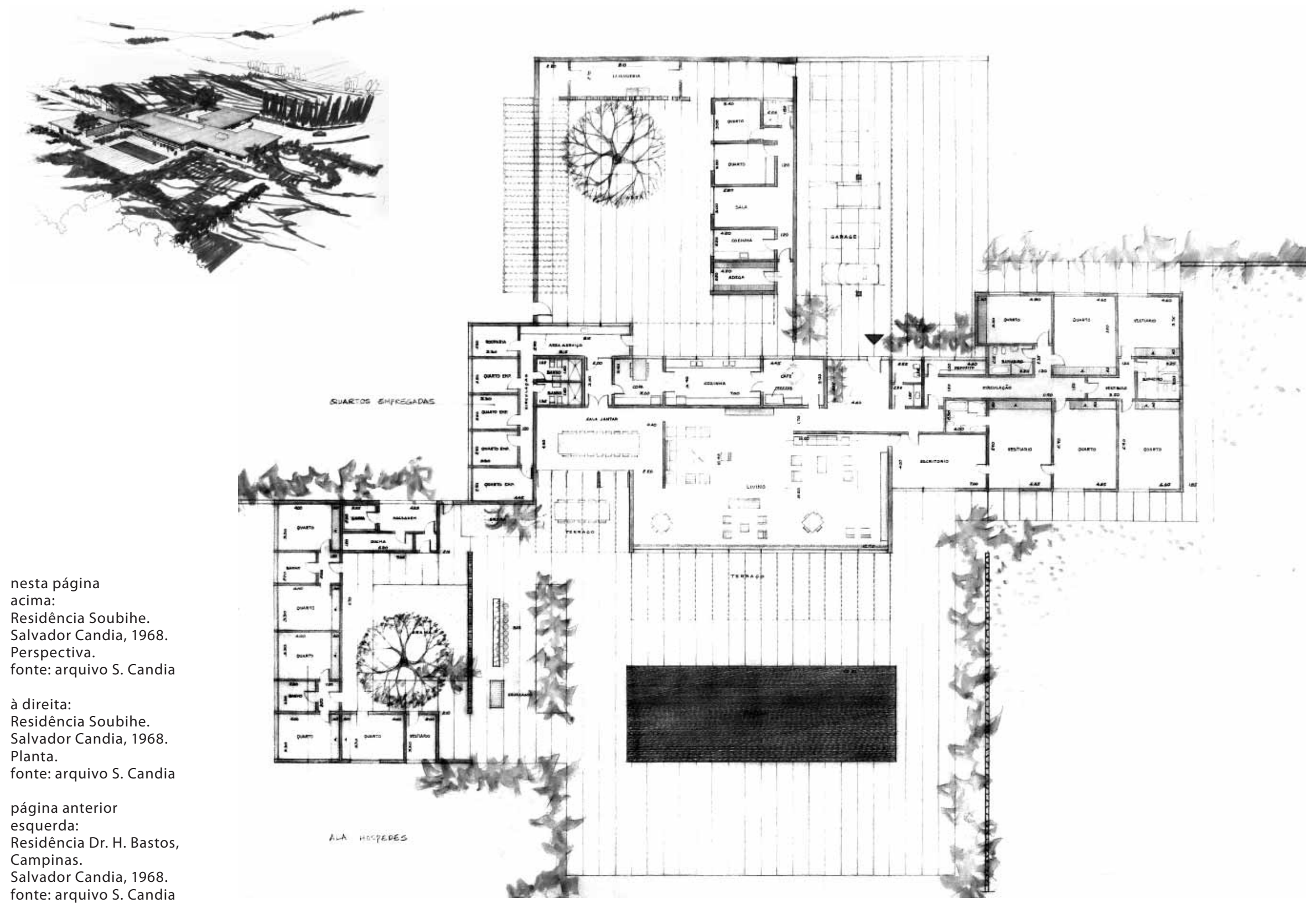


Em outros exemplos na resolução de apartamentos menores, onde o programa demandava uma solução mais compacta, Candia experimenta formas mais diretas de organização da planta (ver fichas de projetos). Em projetos como o já citado João Ramalho e o edifício de apartamentos em São Vicente, ambos de 1953, vê-se uma clara distinção entre os espaços de circulação, serviço, estar e repouso, mantendo variações nas tipologias dos apartamentos dentro de uma volumetria mais contida e regular.

Há certas soluções recorrentes, como por exemplo o recuo das portas de acesso dos dormitórios em relação aos corredores, conformando um pequeno vestíbulo que caracteriza a entrada dos quartos, conforme havia realizado Corbusier no Pavilhão Suíço da Universidade de Paris (1930-32), para distinguir os acessos daquele conjunto de dormitórios. A escada compacta com os degraus chanfrados no patamar, utilizada em quase todos os edifícios verticais de Candia, já se vê também presente nas torres do Lake Shore Drive, de Mies.

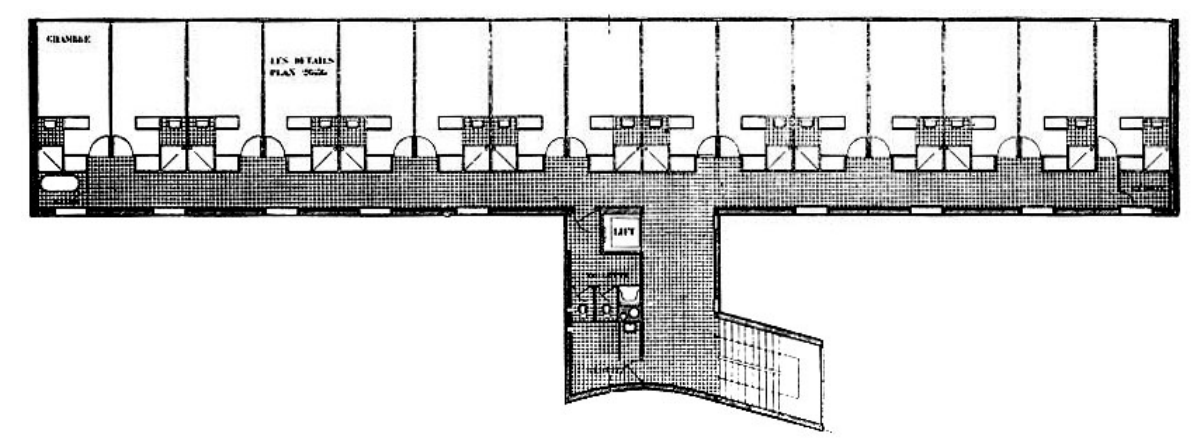

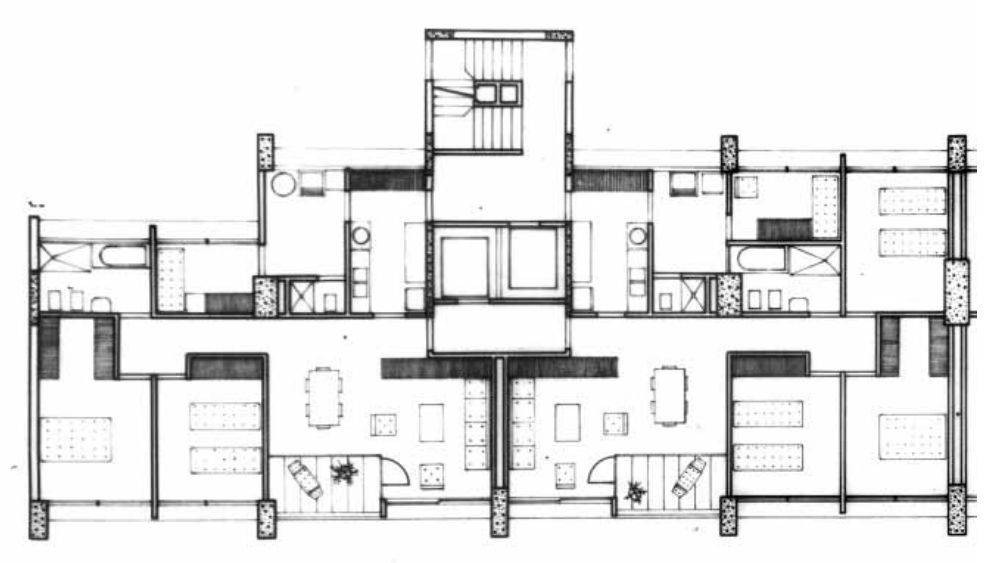

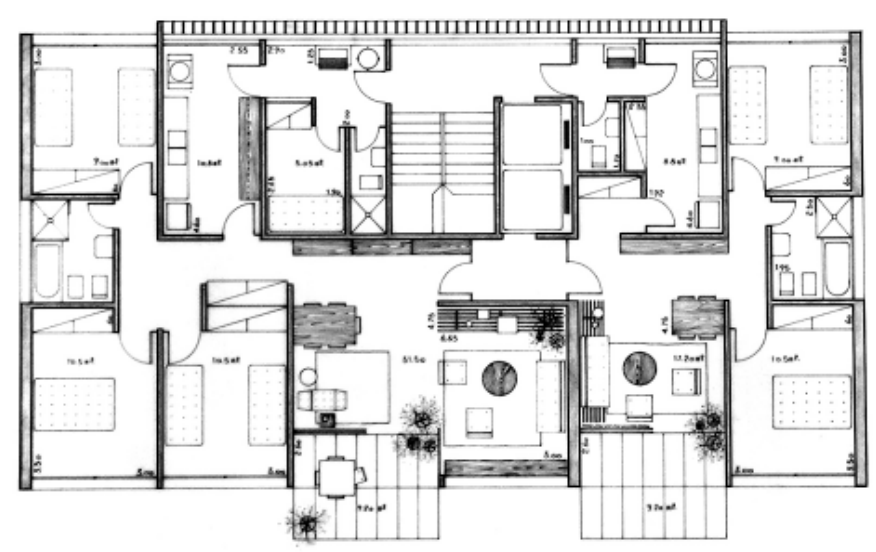

acima:

Edifício João Ramalho, São Paulo. Aflalo, Candia e Croce, 1953-4. Planta parcial do pavimento tipo. fonte: arquivo S. Candia

abaixo:

Edifício de apartamentos em São Vicente-SP. Salvador Candia, 1953. Planta do pavimento tipo. fonte: arquivo $S$. candia

à esquerda:

Pavilhão Suíço da Universidade de Paris. Le Corbusier, 1930-32. Detalhe do pavimento tipo. fonte: MONTEYS (2005) 


\section{integrar as artes}

Salvador Candia inicia sua atuação como arquiteto num momento onde o tema da integração das artes plásticas na arquitetura figurava entre as questões mais relevantes no debate internacional entre os arquitetos modernos, tendo sido abordado, entre diversas outras ocasiões, nos Congressos Internacionais de Arquitetura Moderna entre 1947 e 1951. Entre os arquitetos brasileiros, a atuação de Corbusier no Ministério da Educação em 1936 teria um forte impacto, estimulando o emprego dos painéis de azulejo, das pinturas murais e esculturas em diversas obras arquitetônicas a partir dos anos 40. A divulgação das obras do próprio Ministério e do conjunto da Pampulha em 1943 através do livro Brazil Builds influenciaria fortemente a geração que iniciava sua atuação profissional a partir daquele momento, conforme atesta o editorial da revista Pilotis $n^{\circ}$ III, de 1949:

Quando em 1943 Phillip Goodwyn e Kidder Smith, enviados pelo "Museum of Modern Art" de Nova York, descobriram a arquitetura moderna brasileira, publicando "Brazil Builds" (hoje um clássico na história da arte deste país), não foi só a nossa arquitetura que se tornou mundialmente famosa. Associados aos nomes de arquitetos que atravessaram também as fronteiras pátrias, os de pintores, paisagistas, escultores - isto é, de artistas que se realizavam através da arquitetura. Daquela data, o mundo culto está atento às nossas manifestações artísticas - e daí as visitas de personalidades e as publicações cada vez mais freqüentes, dedicadas à arquitetura e à arte no Brasil.

Cumpre-se mais uma vez o ciclo histórico da arquitetura liderando e integrando as outras artes. 

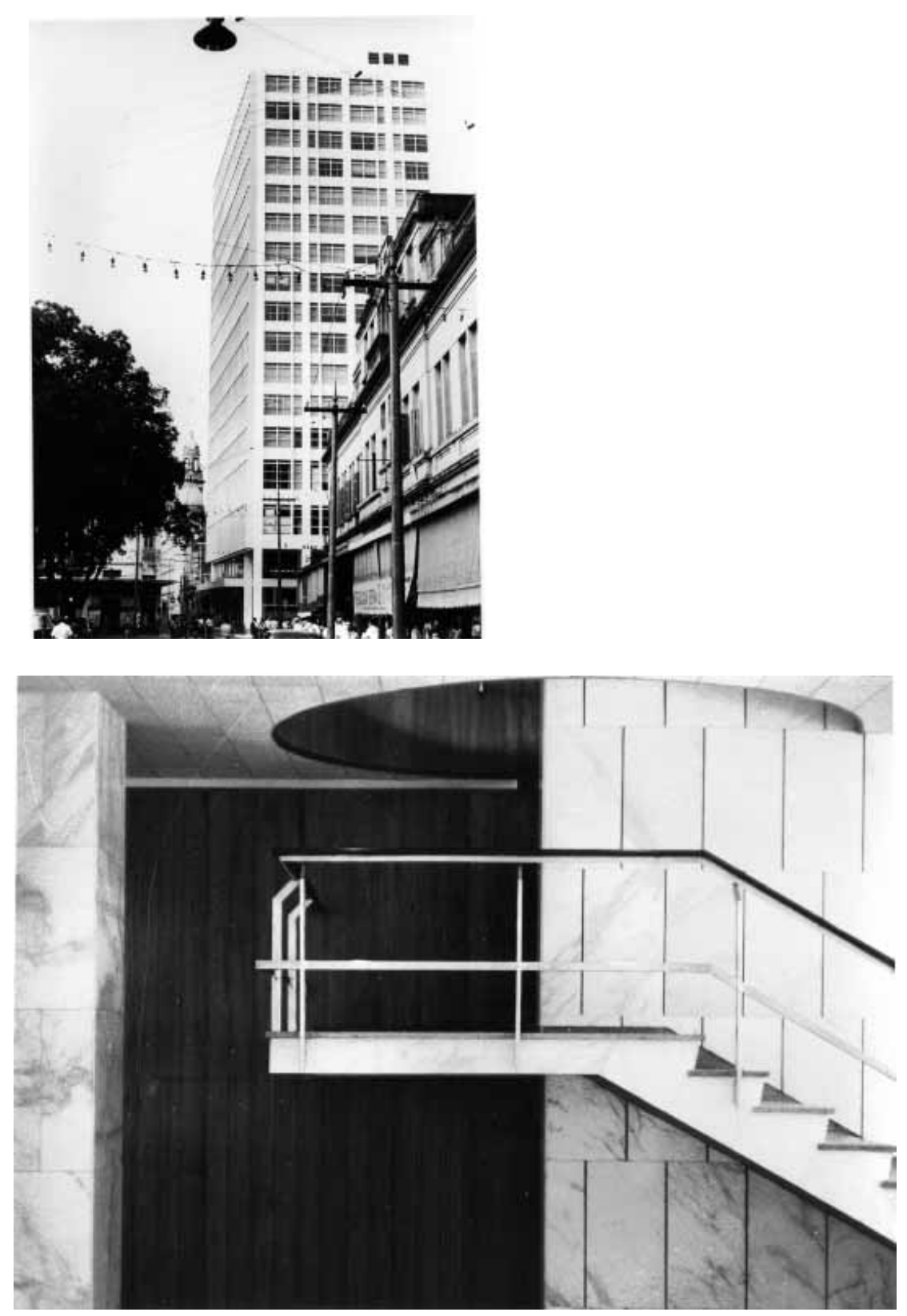

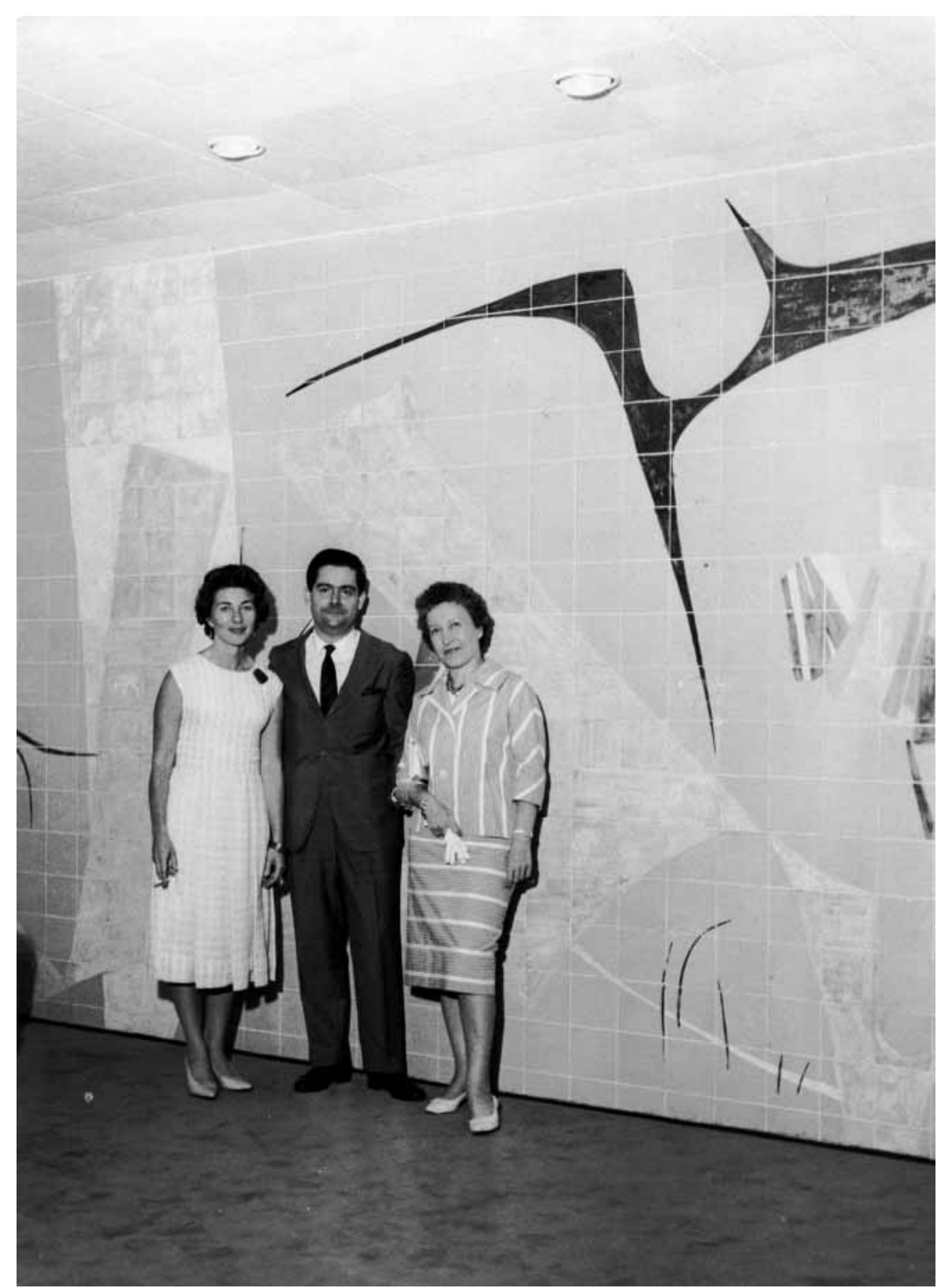




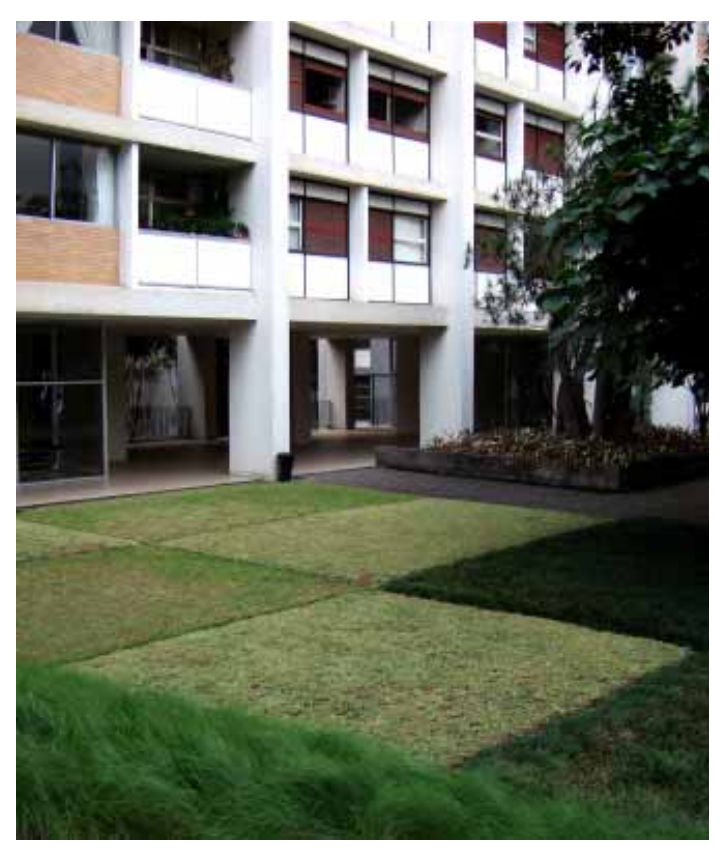

acima:

Edifício João Ramalho, São Paulo.

Paisagismo de Waldemar Cordeiro.

fonte: foto do autor

página anterior:

Edifício Itatiaia, Santos-SP

Salvador Candia, 1957.

fonte: arquivo S. Candia

direita (extremo acima):

Foto do edifício a partir da praça.

direita (extremo abaixo):

Detalhe da escada de acesso ao segundo

pavimento da agência bancária

direita:

Inauguração do painel de azulejos.

da esquerda para a direita:

1.Fayga Ostrower

2.Salvador Candia
Movido por este mesmo espírito, Candia contaria com a colaboração de artistas em alguns dos projetos de sua autoria ainda na década de 50. O que caracterizaria entretanto posteriormente a sua obra com maior freqüência, seria o uso de elementos gráficos realizados pelo próprio arquiteto através da composição dos materiais construtivos em pisos e painéis diversos.

O edifício João Ramalho, cuja obra se concluiu em meados daquela década, foi desenhado em suas áreas externas pelo artista concreto Waldemar Cordeiro (19251973), que tivera uma participação intensa no debate em torno das Bienais alguns anos antes, e foi posteriormente membro do Conselho Artístico do MAM-SP. Cordeiro realizaria obras significativas em sua atividade como paisagista, como o playground do clube Espéria em São Paulo, de 1966. No João Ramalho, os jardins foram tratados com uma quadrícula de cores que se vincula ao módulo estrutural do edifício, associada a pisos secos construídos em blocos de concreto intertravado e ao uso de vegetações arbustivas.

Em 1957, Candia realiza para o Banco Lar Brasileiro um edifício de escritórios de dezoito pavimentos implantado na praça Rui Barbosa, em Santos. Para o tratamento de uma das paredes de destaque no interior da agência bancária situada no pavimento térreo, Candia convida a artista plástica polonesa radicada no Brasil Fayga Ostrower (1920-2001) ${ }^{14}$. Além do emprego do grande painel de azulejos, o interior da agência foi tratado com um exaustivo detalhamento de revestimentos internos em mármore e madeira, guarda-corpos em aço cromado e elementos diversos, que indicam a intenção de se compor um espaço desenhado em sua totalidade.

14 Esta informação nos foi confirmada pelo arquiteto Fernando Arantes em depoimento prestado em 10-1-2008. 

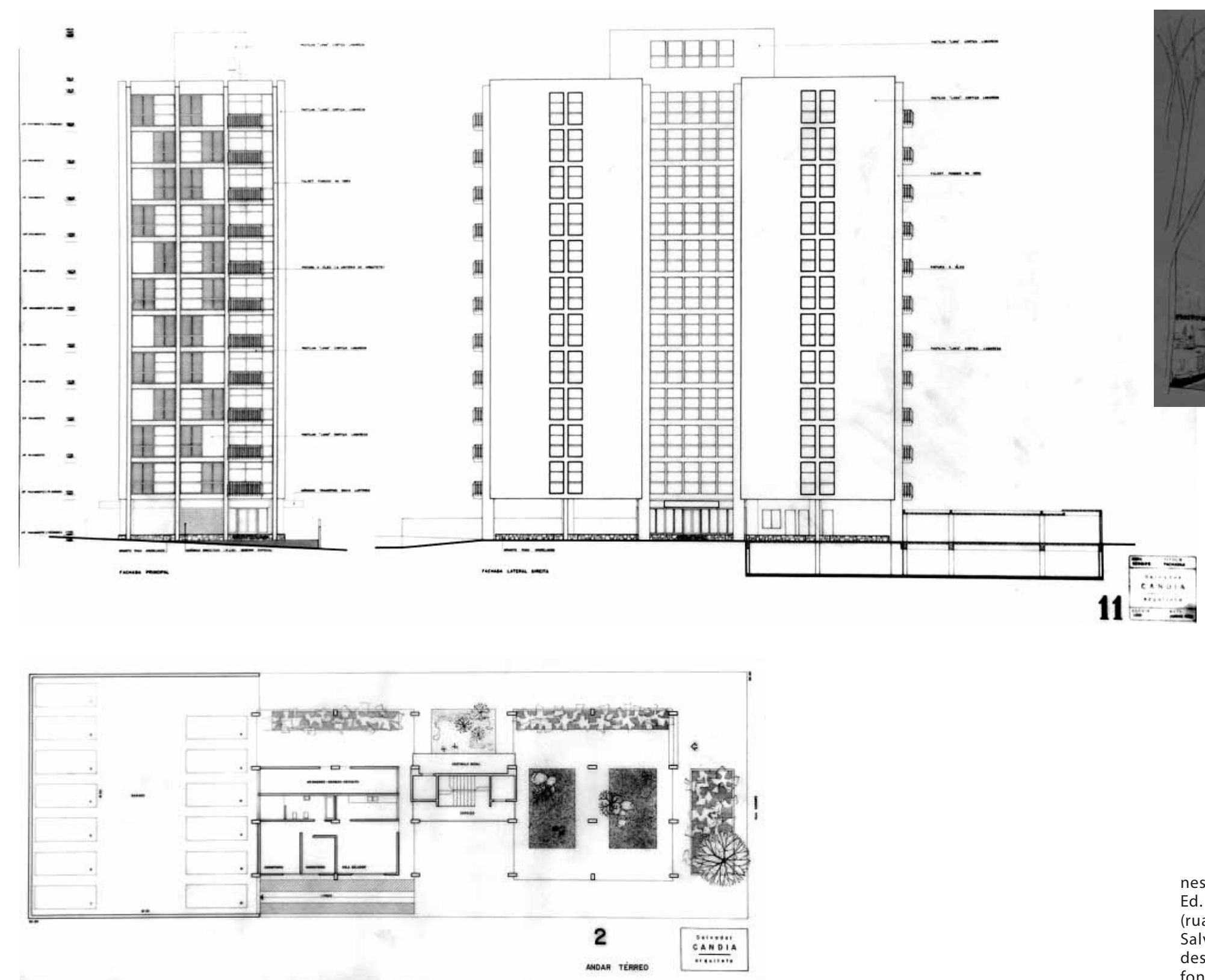

nesta página:

Ed. São Vicente

(rua Sergipe-São Paulo)

Salvador Candia, 1963

:

fonte: arquivo S. Candia 

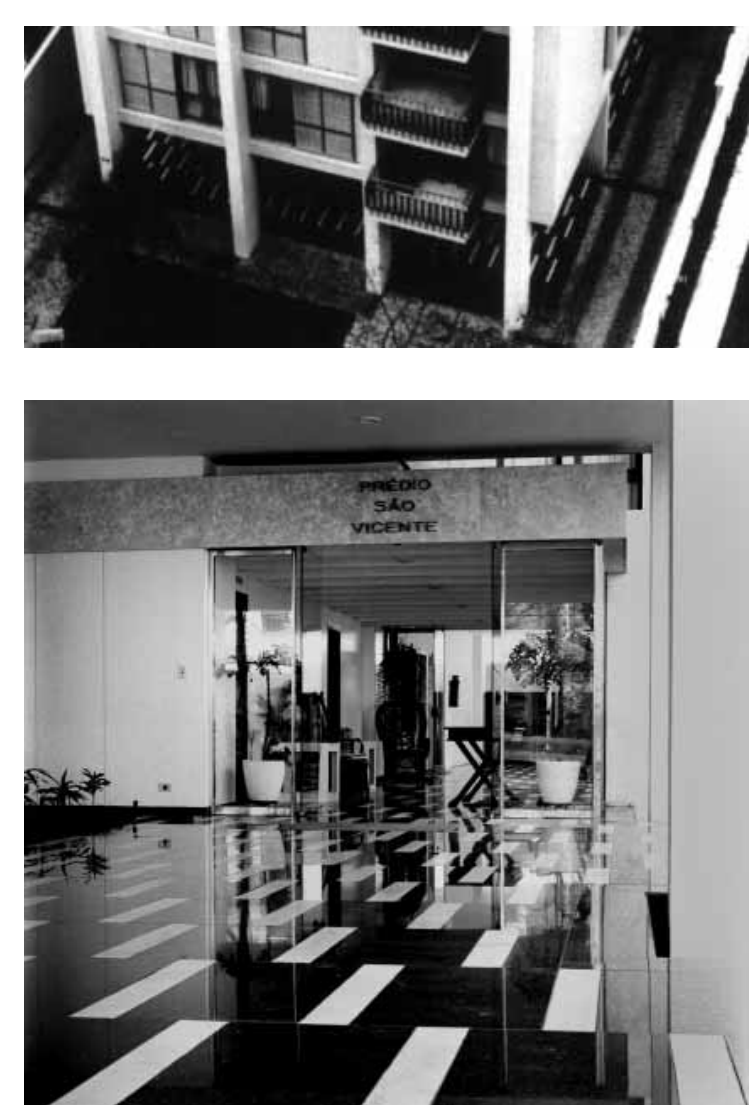

acima: Ed. São Vicent (rua Sergipe-São Paulo) Salvador Candia, 1963 fotos do piso de acesso fonte: arquivo S. Candia à direita: Casa na rua Suécia, São Paulo. Oswaldo Bratke, 1956 Sala de estar com decoração e tapete de autoria de Fongaro. Áreas externas com uma variação sobre o mesmo grafismo. fonte: SEGAWA (1997)
No edifício de apartamentos construído na rua Sergipe em Higienópolis, São Paulo (1963), Candia eleva em três degraus o plano de acesso ao edifício, constituindo um patamar destacado em relação ao declive suave da rua em direção à avenida Angélica. Este elemento é tratado como um pesado bloco de granito preto, sobre o qual é aplicado um tema gráfico semelhante ao que Oswaldo Bratke empregara nos pisos externos da residência na rua Suécia, Jardim Europa (1956). ${ }^{15}$ Este padrão fora também utilizado em um tapete para a sala de estar da mesma casa, desenhado por Giancarlo Fongaro, colega de Candia que realizava parcerias freqüentes com Jacob Ruchti, e com quem juntos haviam empreendido a proposta para o Conjunto Nacional em 1953. O mesmo desenho de piso seria também posteriormente empregado em obras de Rino Levi como a galeria R. Monteiro, no Centro Novo (1959).
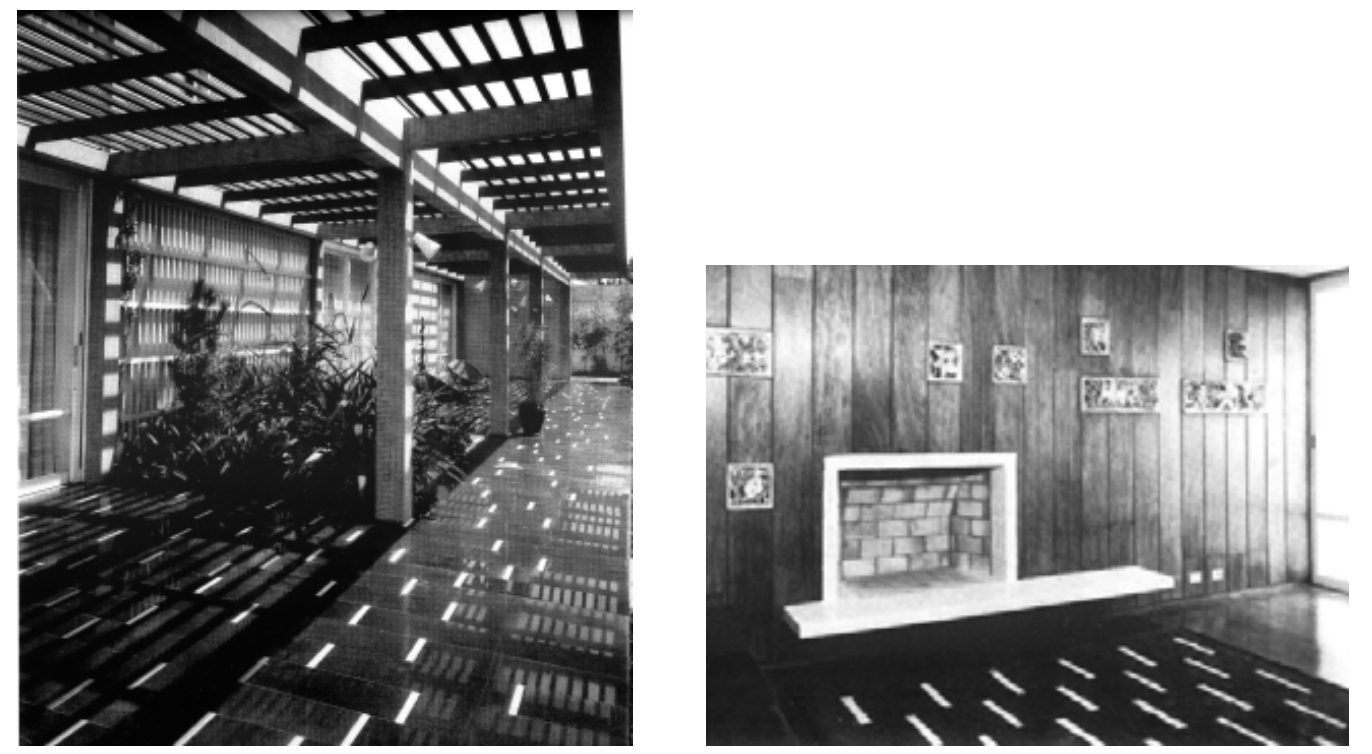

15 KUNNI, Mariana (2000. p. 34) 


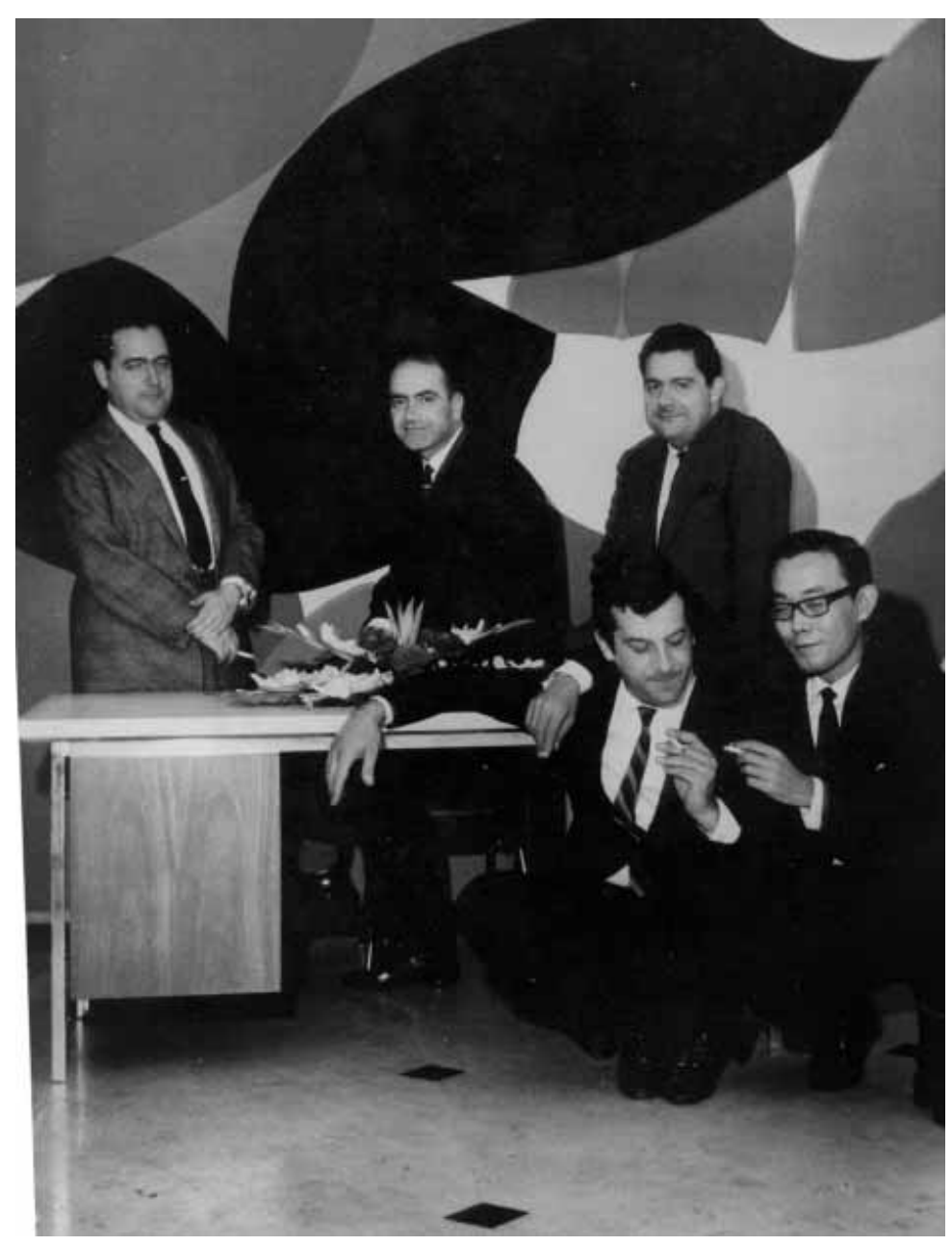

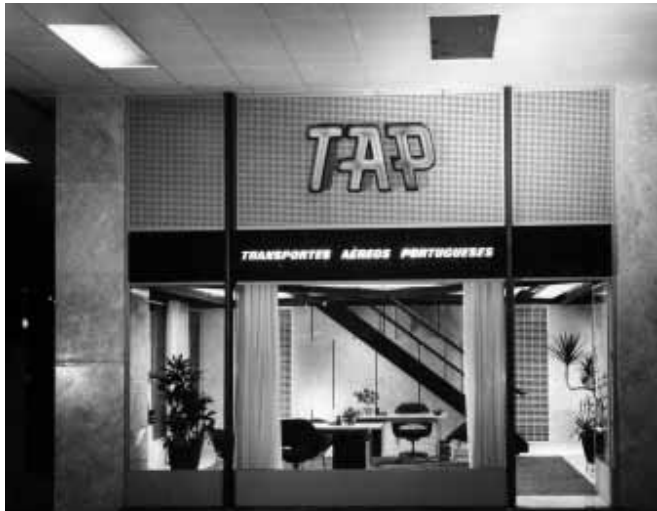
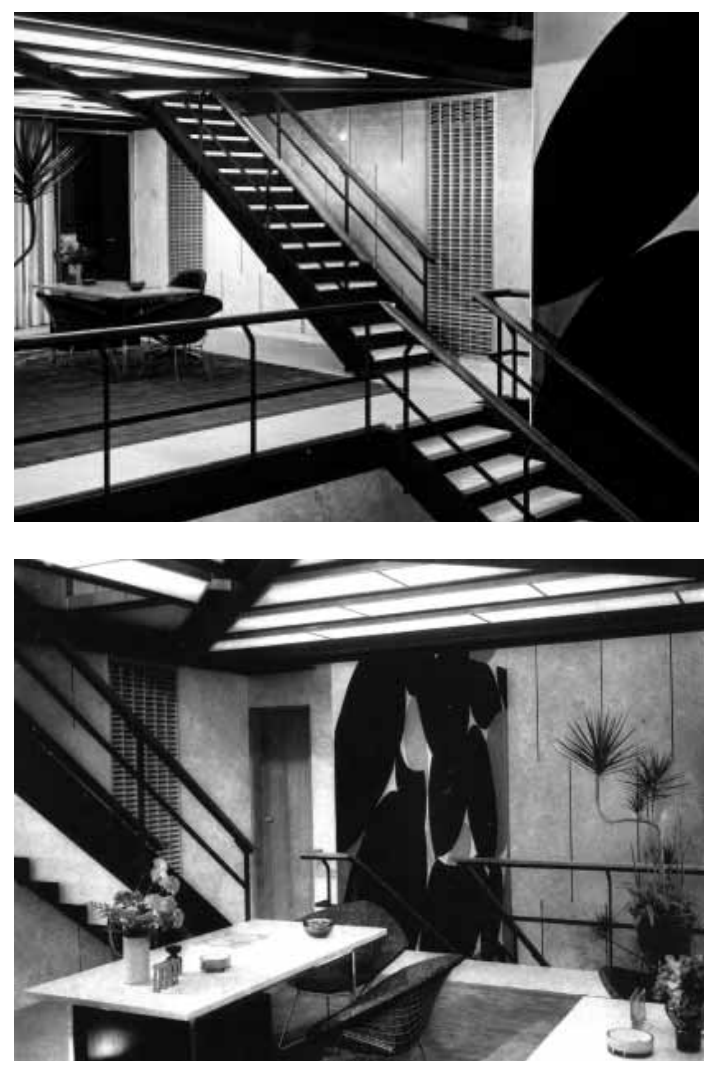

nesta página:

oja da TAP, São Paulo

Galeria Metrópole).

Salvador Candia, 1963-64.

Salvador Candia, $1963-64$.

foto maior:

inauguraçăo da loja

atrás da mesa (da esquerda para a direita):

Rubens Candia, Sr. Godinho (TAP),

e Salvador Candia.

agachados (da esquerda para a direita):

Fernando Lemos e Yasuhido Aida.

fotos menores:

inauguração da loja.

Fachada (praça Dom José Gaspar) e interiores. 

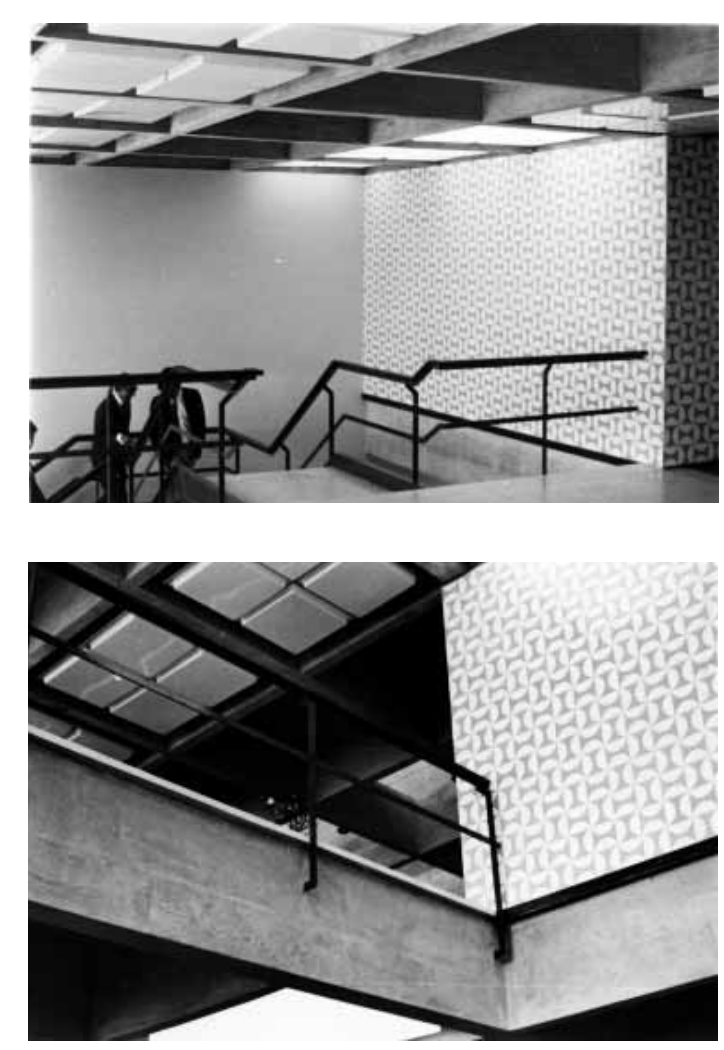

nesta página: Agência do Banco do Brasil em Suzano. Salvador Candia, 1970. fonte: arquivo S. Candia

acima: fotos do painel de azulejos
Ainda em 1963 Candia realizaria o projeto para instalação da loja dos Transportes Aéreos Portugueses (TAP) na esquina da recém concluída Galeria Metrópole. O maior interesse neste projeto está na idéia de retirar um trecho da laje de piso em frente à praça Dom José Gaspar, repetindo em menor escala a operação realizada no jardim interno da galeria, onde a vista se abre para o subsolo. Para marcar este vazio de pédireito duplo criado no interior da loja e visível a partir da praça, o arquiteto instalaria a obra de tapeçaria do artista português Fernando Lemos (1926). Ali também Candia detalharia a totalidade dos materiais empregados no interior da loja, compreendendo luminárias, escadas metálicas, guarda corpos e balcões, fazendo uso compositivo de materiais diversos como mármore, madeira e tecidos.

No projeto para uma agência do Banco do Brasil em Suzano-SP (1970), Candia desenha um padrão de azulejo que aplicaria em um painel junto ao vazio de pé direito duplo no interior da agência. Naquele mesmo ano, o arquiteto realiza uma composição de triângulos para a fachada do edifício Barão de Iguatemi, na avenida Faria Lima. Estas experiências demonstram sua afinidade com a obra desenvolvida pelos artistas concretos em São Paulo.

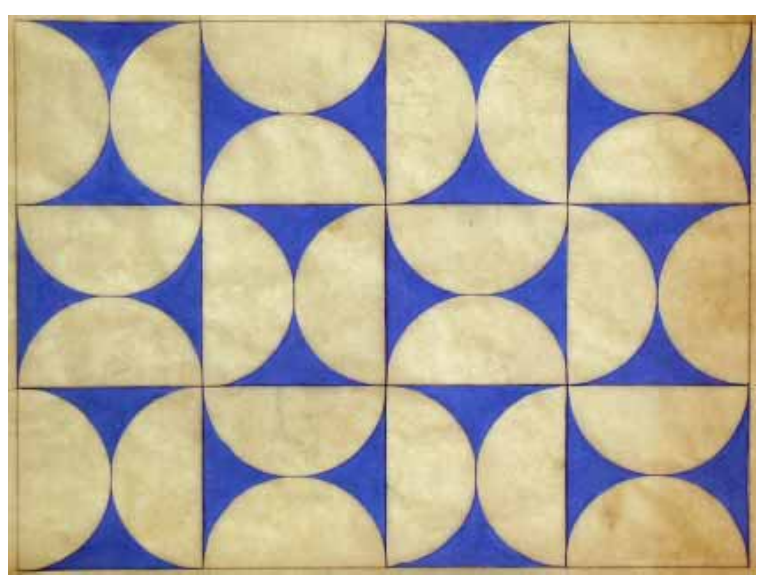



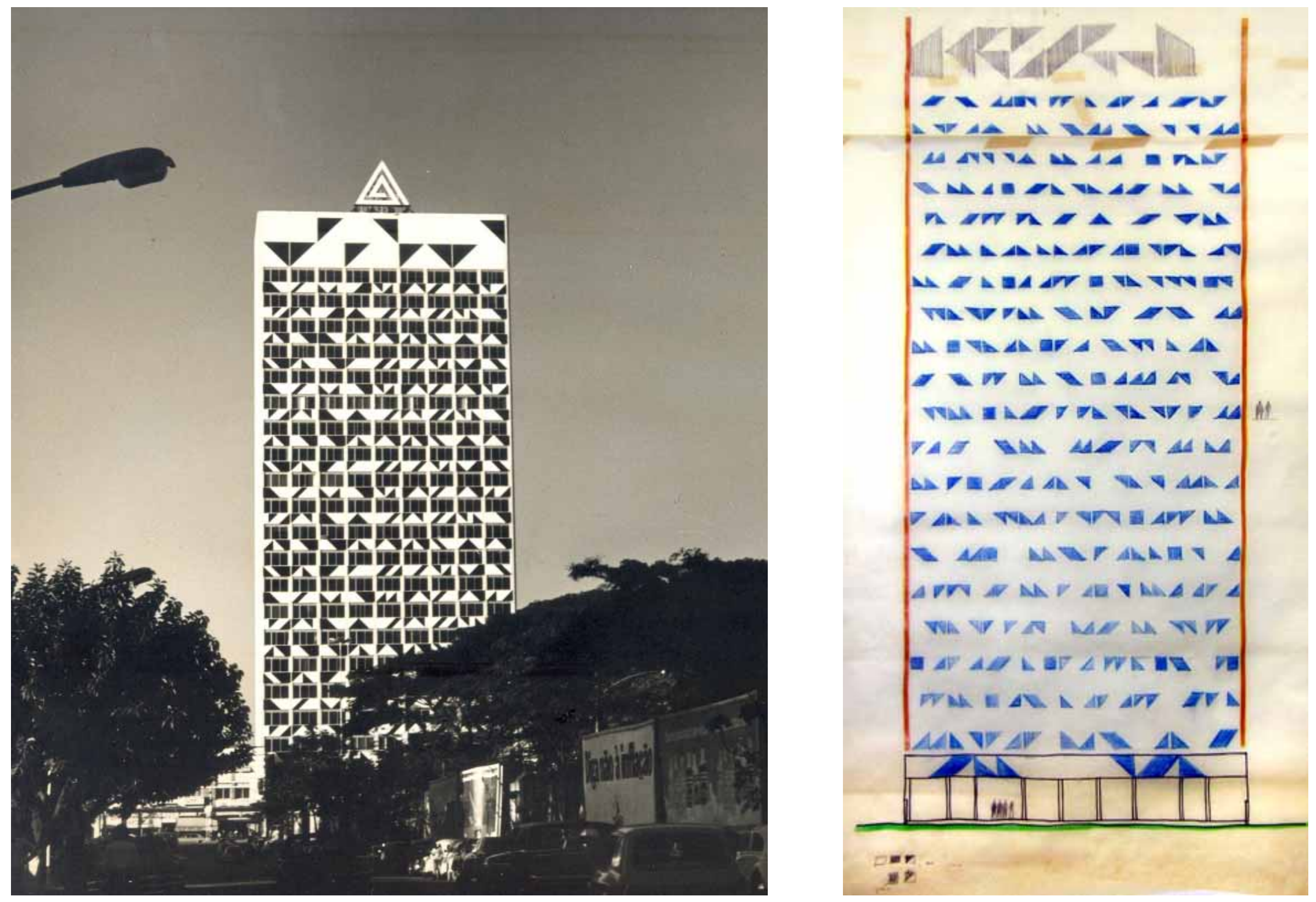


\section{arquiteto/professor}

Candia retorna ao Mackenzie como professor na cadeira de Composição aos quarenta anos em 1964, no momento em que a Universidade vivia os reflexos negativos provocados pelo golpe militar de Abril daquele ano com a demissão de parte do corpo docente, dentre os quais estavam Alfredo Paesani, Fábio Penteado e Eduardo Corona. ${ }^{16}$ Este último havia tido, juntamente com Carlos Milan, um papel importante na tentativa de realizar mudanças no conteúdo didático e nos métodos empregados nas aulas de composição, tendo ensaiado por um curto período a realização de um Atelier Vertical, onde alunos de períodos diversos realizavam projetos integrados. Havia ainda naquele momento uma certa reação à arquitetura moderna entre os professores ideologicamente vinculados a Stockler das Neves, que se aposentara somente em 1956.

Candia aproximou-se de Franz Heep durante o período em que lecionaram juntos até a saída do arquiteto alemão do Mackenzie em 1965. Alguns de seus colegas de estudos e de trabalho se juntariam também posteriormente ao grupo de professores, como Miguel Forte e Fernando Arantes.

Tendo lecionado nas disciplinas de Composições e posteriormente História da Arte, Candia procurava, segundo relatos de ex alunos, conduzir o aprendizado da arquitetura através da leitura e análise crítica de projetos exemplares, como neste caso comentado pelo próprio arquiteto ${ }^{17}$ :

Em 1960 e pouco, quando eu já era professor do Mackenzie, a meninada não sabia

16 BREIA (2005. p. 268)

17 LOTUFO, Vitor. Depoimento prestado ao autor em 4-12-2007 
coisas, porque o pessoal não sabia ir à biblioteca, não sabia procurar. Tinha uma coisa fantástica feita poucos anos antes, que é aquela serpentina, aquele dormitório que o Aalto fez no M.I.T., lembram? Era muito bonita, tinha até um jeito brasileiro porque era toda sinuosa. Aquilo que se chama de brasileiro, de carioca. Eu disse: olha, aqui está o projeto, vocês não sabem como partir, vamos examinar esse projeto. E o pessoal ficou admirado de ver a análise que fiz (que para mim era fácil) de como o projeto era diferente, como se podia fugir de uma série de coisas e fazer um dormitório que não fosse essa coisa boba que em geral a gente associa a dormitório colegial. ${ }^{18}$

Após três anos atuando como professor no Mackenzie, Candia torna-se diretor do curso de arquitetura daquela instituição, em 1967. Dos registros que se têm disponíveis sobre este período, infere-se que o arquiteto procurou promover transformações nos procedimentos didáticos do curso, convocando novos professores entre arquitetos e artistas plásticos para comporem o corpo docente. ${ }^{19}$ A extensão das mudanças propostas o teria levado, entre outras razões, a desentender-se com a reitora da instituição, Esther de Figueiredo Ferraz. Um dos motivos do desentendimento teria surgido em torno da gestão do acervo da biblioteca da universidade, conforme lembraria o arquiteto:

Bom, dois ou três anos depois, eu já não lecionava, fui para uma função administrativa no Mackenzie e alguém veio me procurar, me falando na revista e no dormitório do Aalto, não sei por quê. Então eu disse: tem aí na biblioteca. "Não, na biblioteca não tem”, me respondeu. Então, fui lá, eu era rápido em biblioteca e disse: tem, esta biblioteca eu conheço desde que era aluno, sei o que tem. Fui lá. A revista era uma "Architetural Forum" e o Mackenzie tinha coisas preciosas. Digo tinha - vejam

18 ARQUITETURA e Desenvolvimento Nacional. Depoimentos de arquitetos paulistas. IAB-SP, São Paulo: Editora Pini LTDA, 1979. Depoimento de Salvador Candia.

19 ARANTES, Fernando. Depoimento prestado ao autor em 10-01-2008 
o tempo do verbo - tinha o recorde desde 1898, quer dizer, no Mackenzie estava documentada toda a arquitetura moderna desde a Escola de Chicago, enfim, tudo o que aconteceu. Alguém, nesse intervalo, por falta de espaço, mandou jogar fora todas as revistas. Isso é a burrice em nível universitário. ${ }^{20}$

Apesar de haver lecionado por um curto período de tempo, entre 1964 e 1969, acreditamos que esta experiência tenha relevância no contexto de sua atuação como arquiteto. Candia seria lembrado posteriormente por ex-alunos pela sua vasta erudição, e pela coerência com a qual procurava empregá-la efetivamente na resolução dos problemas projetuais, valendo-se constantemente de seu conhecimento como uma ferramenta prática de trabalho. 

leitura de três projetos 


\section{Edifício Metrópole}

180 lojas, 80 escritórios (26 pavimentos), cinema para 1200 pessoas e garagens para 150 automóveis $\left(35,151 \mathrm{~m}^{2}\right)$

colaboração Giancarlo Gasperini

localização Praça Dom José Gaspar, São Paulo

cliente Cia. Santista de Administração e Comércio

material Concurso/ Estudos Preliminares/ Projeto Executivo 1959-1961

fonte Arquivo S. Candia

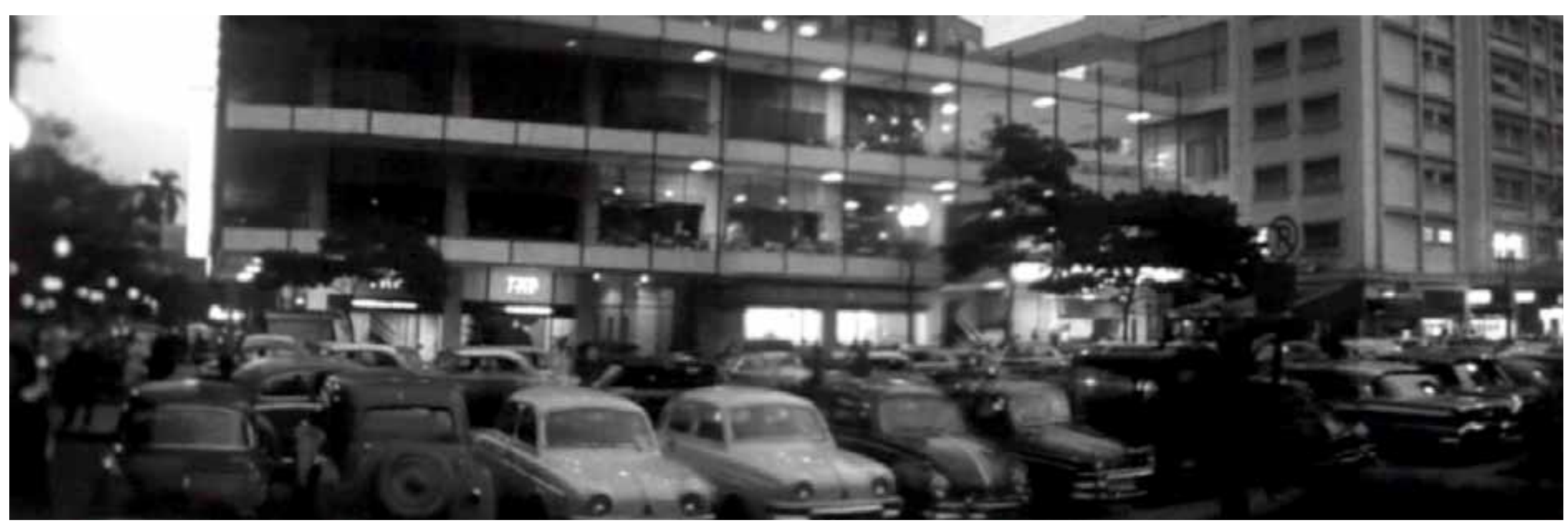

Montagem fotográfica feita a partir de documentário exibido em: O PRÍNCIPE. Direção o roteiro: Walter Hugo Khoury, São Cia Cire, Produça: Kamera Khllmes e DVD (98min) 


\section{Visão de São Paulo à noite}

Poema Antropófago sob Narcótico

Na esquina da rua São Luís uma procissão de mil pessoas acende velas no meu crânio

há místicos falando bobagens ao coração das viúvas

e um silêncio de estrela partindo em vagão de luxo

fogo azul de gim e tapete colorindo a noite, amantes

chupando-se como raízes

Maldoror em taças de maré alta

na rua São Luís o meu coração mastiga um trecho da minha vida

a cidade com chaminés crescendo, anjos engraxates com sua gíria

feroz na plena alegria das praças, meninas esfarrapadas

definitivamente fantásticas

há uma floresta de cobras verdes nos olhos do meu amigo

a lua não se apoia em nada

eu não me apoio em nada

sou ponte de granito sobre rodas de garagens subalternas (...)

\section{Roberto Piva}

1 PIVA, Roberto. Um estrangeiro na legião, Obras reunidas volume I. Roberto Piva, organização Alcir Pécora - São Paulo: Globo, 2005 Poema originalmente publicado no livro Paranóia, 1963. 


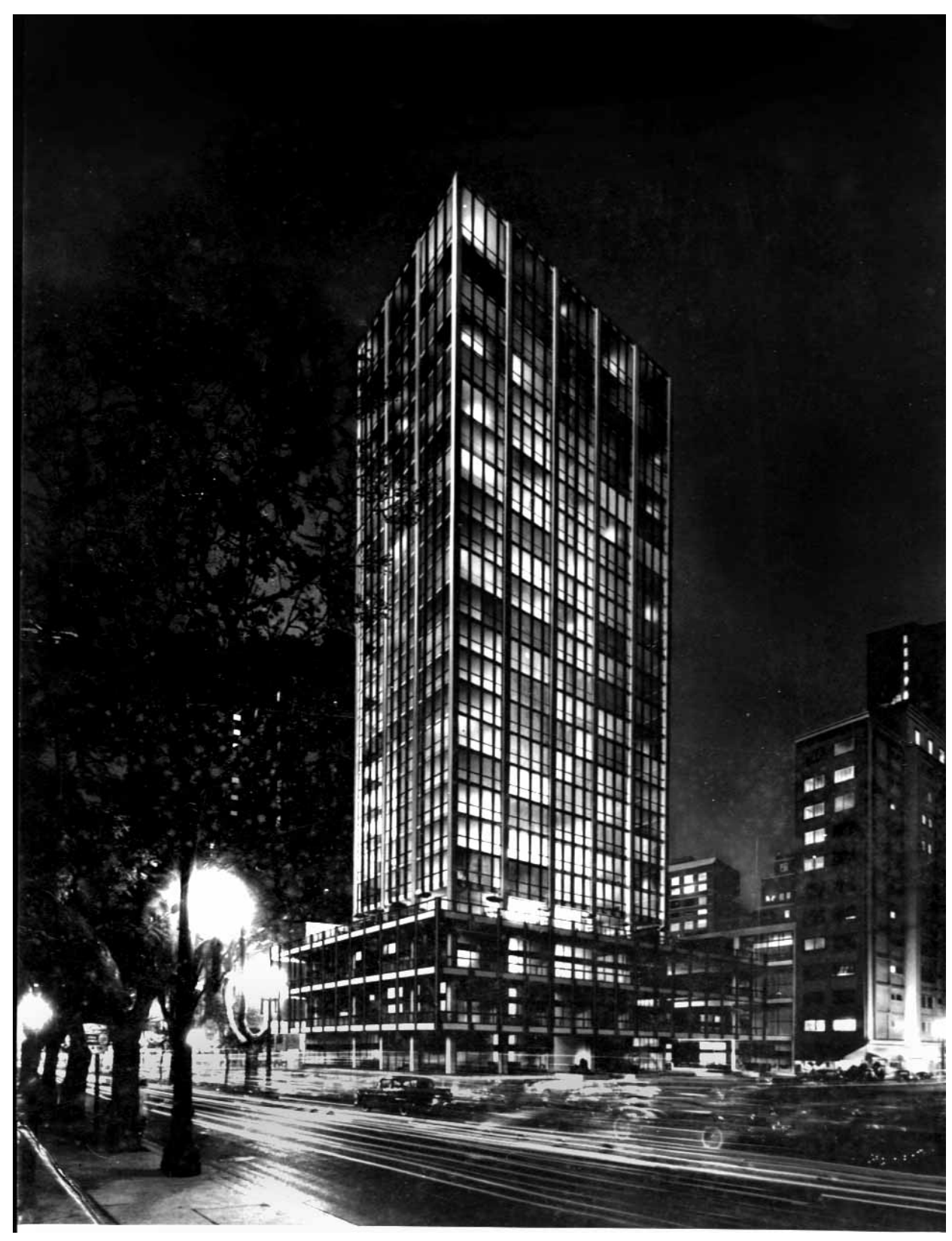

Edifício Metropole, São Paulo.

Salvador Candia e Giancarlo Gasperini

Foto-montagem noturna.

fonte: arquivo S. Candia 
Situado num dos pontos focais do perímetro de irradiação de Prestes Maia, na esquina da avenida São Luiz com a praça Dom José Gaspar, o edifício Metrópole - originalmente denominado "Conjunto Máximus" - integrou a partir de sua inauguração em 1964 um dos endereços mais significativos daquele momento na vida cultural e boêmia de São Paulo - conforme atesta a imagem descrita pelo poeta Roberto Piva - publicada em seu livro Paranóia de 1963, quando as obras da Galeria estavam sendo concluídas. Segundo o depoimento da dramaturga Maria Adelaide do Amaral, uma vez implantada, a galeria passou a abrigar diversos pontos de encontro de destaque na noite paulistana:

(...) Havia o Jogral. Não era o único barzinho. Tinha outros. E tinha também umas casas de chá que faziam sessões de Jazz. "Jam sessions". Tinha o chá Moon. Tinha o Ponto que era uma livraria e ao mesmo tempo era um espaço onde você via desde "pocket shows" até gente recitando poesia, poetas recitando a sua obra (...) Havia os [poetas] novíssimos. E alguns dos novíssimos se apresentavam lá no Ponto. Eduardo Alves da Costa, Lindolf Bell. ${ }^{2}$

Dentre os bares mais significativos situados nas imediações, destacava-se o famoso Paribar:

No Antológico Paribar, na praça Dom José Gaspar, encontrava-se, sem necessidade de agenciamentos prévios, figuras singulares como Sérgio Milliet ou Antônio Cândido. Espécie de "ante-sala da noite", o Paribar engurgitava-se nos fins de tarde com muitos jornalistas e publicitários, empregados ou à procura de um fichamento. ${ }^{3}$

2 Depoimento da dramaturga e novelista Maria Adelaide do Amaral. Sobre o Príncipe (Making-off) in: O PRÍNCIPE. Direção: Ugo Georgetti, São Paulo, Produção: SP Filmes, São Paulo, 2002, DVD (102min.). Transcrição extraída de: CUNHA, Jaime. Edifício Metrópole: um diálogo entre arquitetura moderna e cidade. 2007, Dissertação de Mestrado - Faculdade de Arquitetura e Urbanismo da Universidade de São Paulo, São Paulo.

3 ARRUDA (2000. p. 47). 
Somando-se a estes eventos, havia ao redor a Biblioteca Municipal, o MAM e o MASP, e a sede do jornal O Estado de São Paulo, com suas rotativas expostas em vitrines na calçada da rua Martins Fontes.
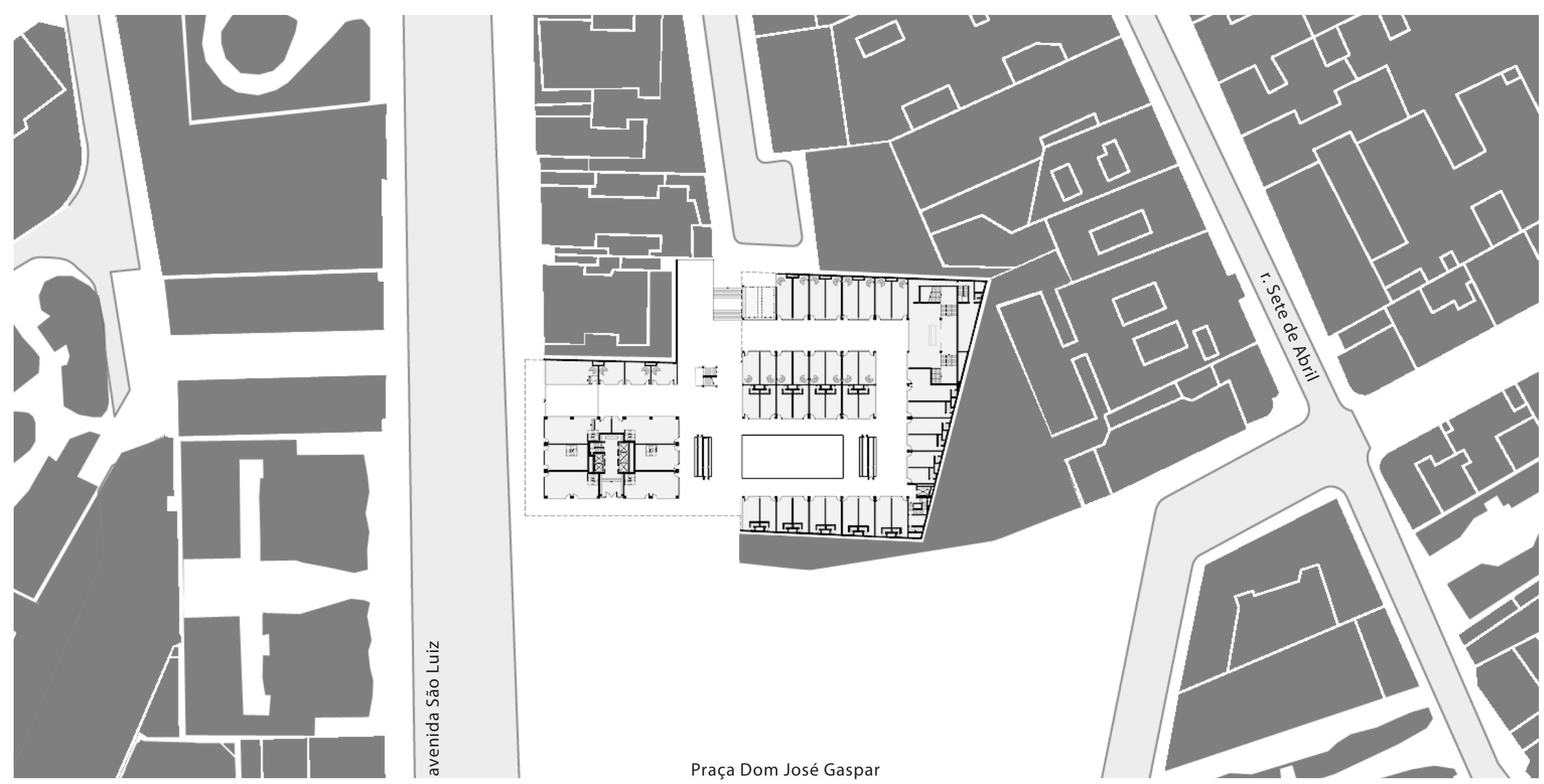


\section{o projeto}

Tendo sido objeto de um concurso fechado, organizado pela Cia. Santista de Administração e Comércio em 1959, o projeto do edifício Metrópole nasceu da conciliação entre duas propostas concorrentes realizadas por Giancarlo Gasperini e Salvador Candia, ambas escolhidas pelo júri para comporem um novo projeto. As duas propostas, embora contivessem diferenças significativas em seu partido de ocupação do terreno, se mostraram complementares no desenvolvimento posterior do projeto. $\mathrm{O}$ vasto programa de escritórios, cinema, lojas e garagens resolvido conjuntamente pelos dois arquitetos, se caracterizaria por uma implantação fortemente vinculada ao seu contexto urbano.

\section{implantação}

O lote de 5.095 metros quadrados destinado à construção do conjunto é resultante da incorporação de um terreno de grandes dimensões pertencente ao Laboratório Paulista de Biologia, fronteiriço ao prolongamento da rua Marconi junto à avenida São Luiz e à praça da Biblioteca; e ainda um segundo terreno menor localizado nos fundos do Laboratório, cujo projeto de ocupação havia sido ensaiado por Gregori Warchavchik para o Automóvel Clube de São Paulo em 1950. ${ }^{4}$ 
A anexação deste segundo terreno possibilitou a incorporação de uma frente ao lote junto à rua Basílio da Gama, estabelecendo assim uma nova possibilidade de acesso ao seu interior. A geometria resultante do terreno divide-se em duas partes distintas: Uma primeira parte situada na esquina entre a avenida São Luiz e a praça D. José Gaspar é franqueada em quase todo o seu perímetro pelas áreas externas da praça e da avenida, tendo diante de si os espaços mais abertos. A segunda parte volta-se para o interior da quadra, diante das empenas cegas das construções vizinhas.

O partido de implantação do conjunto emprega dois elementos básicos para o equacionamento do programa proposto: Uma torre de 19 pavimentos de 570 metros por andar, com uma prumada autônoma de circulação vertical para servir os escritórios, e um embasamento de 5 pavimentos de 4.400 metros quadrados para abrigar os demais programas, mais próximos do nível do chão e franqueados ao acesso público.

A disposição destes dois elementos no terreno corresponde também a duas operações distintas: a torre é situada no vértice da praça, de modo a marcar a esquina com a avenida São Luiz e determinar o encerramento da quadra construída junto à avenida, enquanto que o embasamento alinha-se às construções vizinhas ocupando integralmente toda a superfície do lote. No interior da quadra, onde as suas lajes são delineadas pela geometria irregular das empenas cegas existentes, determina-se a construção de um espaço vazio de 11 x 22 metros em posição análoga à da torre. Este grande espaço vazio, que em certa medida reproduz as proporções da torre em planta, estabelece um contraponto à massa construída daquele edifício, como um volume em negativo.

\section{vínculos com o chão da cidade}

A disposição destes elementos na planta do pavimento térreo favorece a constituição de determinados percursos, em continuidade com os caminhos potenciais a

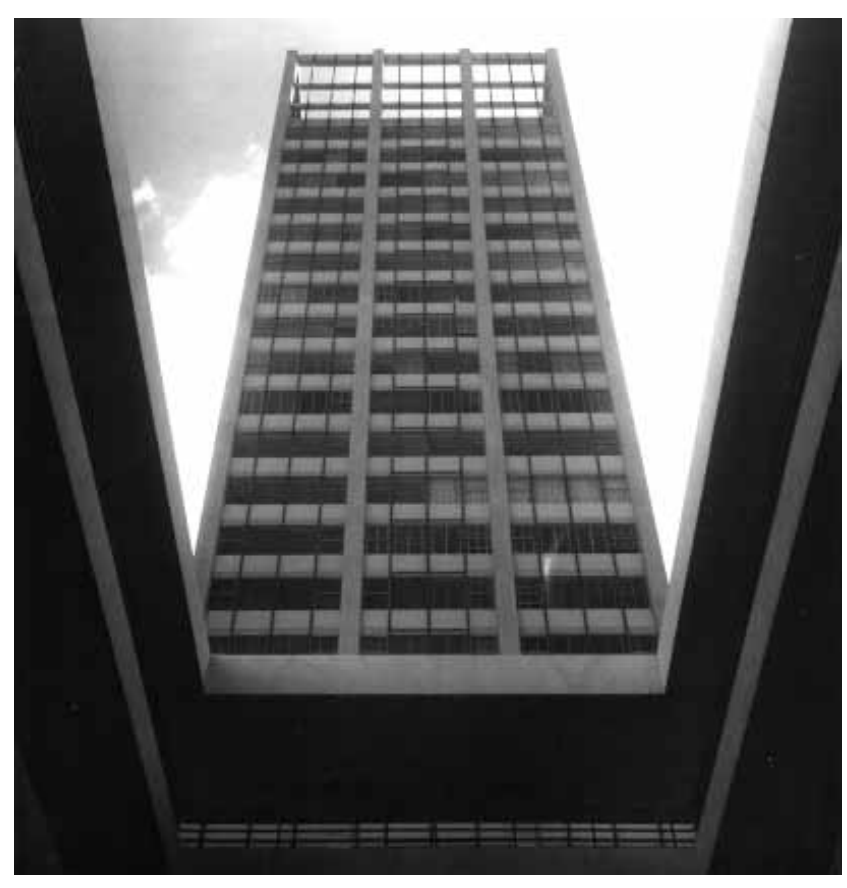

Edifício Metropole, São Paulo.

Salvador Candia e Giancarlo Gasperini

Foto da obra recém concluída.

fonte: arquivo S. Candia.

à direita:

Edifício Metropole, São Paulo.

Salvador Candia e Giancarlo Gasperini

Foto do modelo.

fonte: arquivo S. Candia 


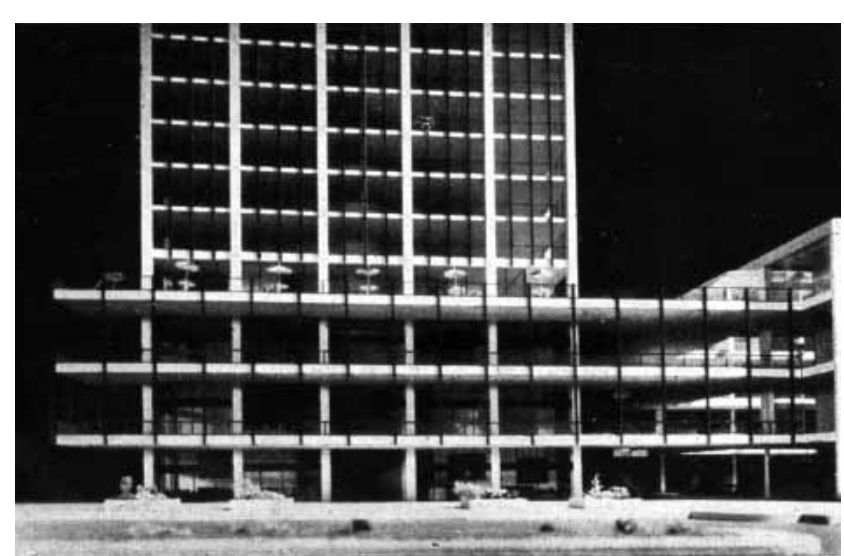


o acesso de automóveis e serviços mais adequado ao menor movimento da rua. $\mathrm{O}$ primeiro pavimento em subsolo é oferecido como piso associado à galeria comercial, comunicando-se através das prumadas de circulação vertical e da continuidade do vazio interno. $\mathrm{O}$ arvoredo que ocupa a projeção do vazio no nível do primeiro subsolo estabelece um deslocamento intrigante em relação à praça Dom José Gaspar, sugerindo uma continuidade dos seus jardins, porém num nível inferior.

A despeito da intenção inicial dos arquitetos e empreendedores em fechar o vazio com uma cobertura translúcida, observada no Projeto Executivo de 1961, ${ }^{6}$ podemos considerar que o vazio interno com caráter de implúvio, sujeito às intempéries, empresta um significado mais rico àquele espaço, comunicando-o diretamente com o exterior.

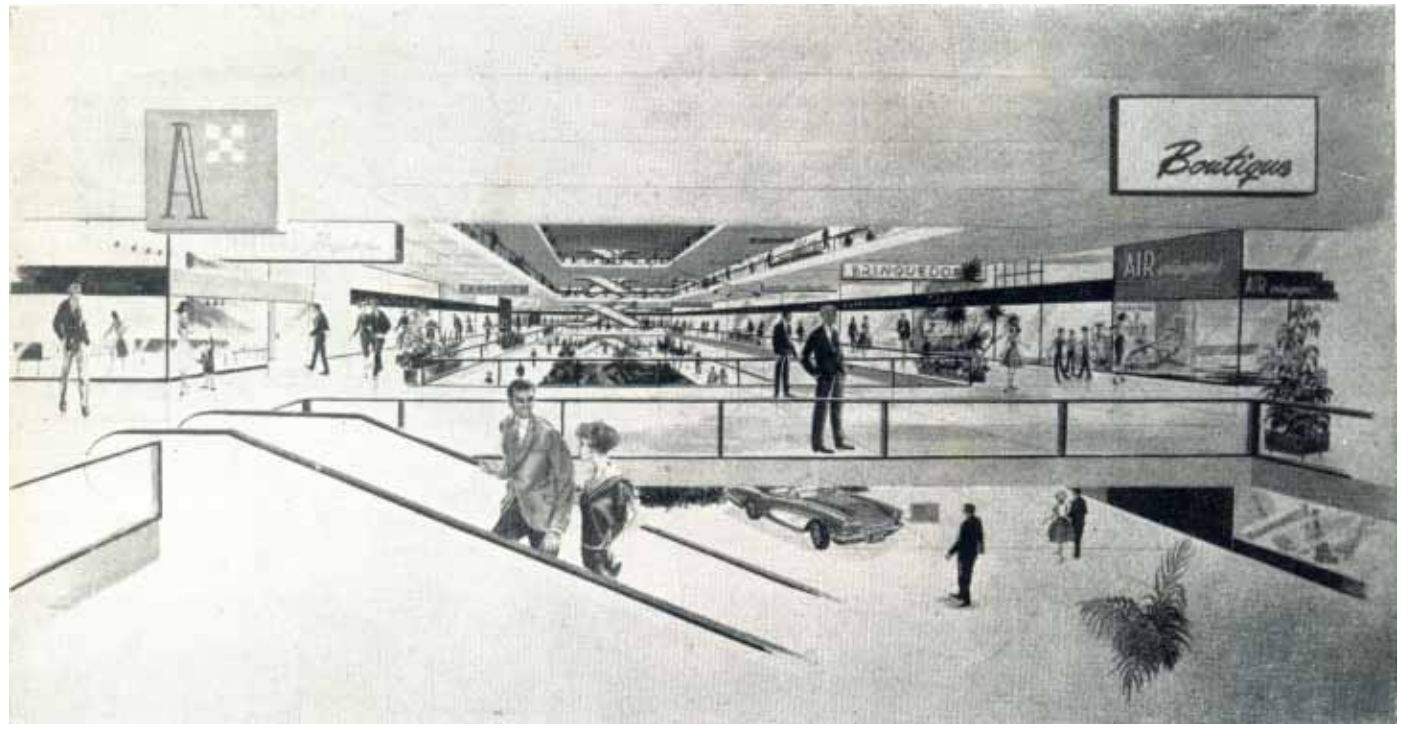

6 As folhas originais em papel vegetal do Projeto Executivo do Conjunto Metropolitano que constam no Arquivo Salvador Candia foram dobradas após a construção do edifício. Para que sejam novamente abertas, será necessária a aplicação de uma técnica específica de restauro. O projeto original prevê o fechamento da última laje com vigamento de concreto e dómus de fibra de vidro.

164

capítulo IV

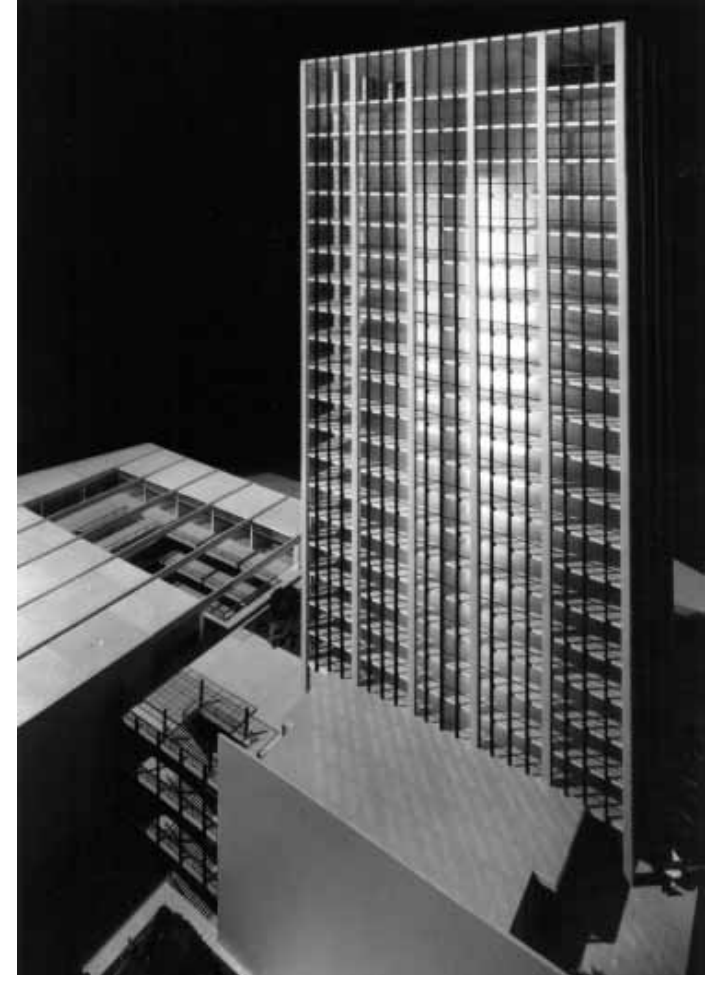

acima:

Edifício Metrópole, São Paulo.

Salvador Candia e Giancarlo Gasperini

Foto do modelo.

fonte: arquivo S. Candia.

à esquerda:

Edifício Metrópole, São Paulo.

Salvador Candia e Giancarlo Gasperini

Perspectiva interna.

fonte: arquivo S. Candia

à direita (próxima página):

Edifício Metrópole São Paulo.

Salvador Candia e Giancarlo Gasperini

Foto da obra recém concluída.

fonte: arquivo S. Candia 


\section{Cobertura}

O terceiro pavimento das galerias deveria, de acordo com o projeto original, estabelecer uma transição espacial entre a torre e o embasamento, através da constituição de um pavimento mais livre na projeção do edifício vertical, destinado a abrigar restaurante e terraço-jardim. Este pavimento foi entretanto transformado em salas de escritórios logo após a inauguração da obra. Segundo Giancarlo Gasperini:

O meu escritório era na Barão de Itapetininga, e o do Salvador era na rua da Consolação, num prédio que eu tinha projetado com o Jacques Pilon (...). E aí nos encontrávamos sempre, por que embaixo do nosso prédio estava uma confeitaria e bar, que era o famoso Fasano. E era aí que nos encontrávamos e discutíamos, etc. E propusemos transferir o Fasano para o último piso da Galeria. E chegamos a desenhar isso, ocupando a projeção da torre. Depois veio a época de vendas, e tudo o mais, e se alterou $(\ldots) .^{7}$

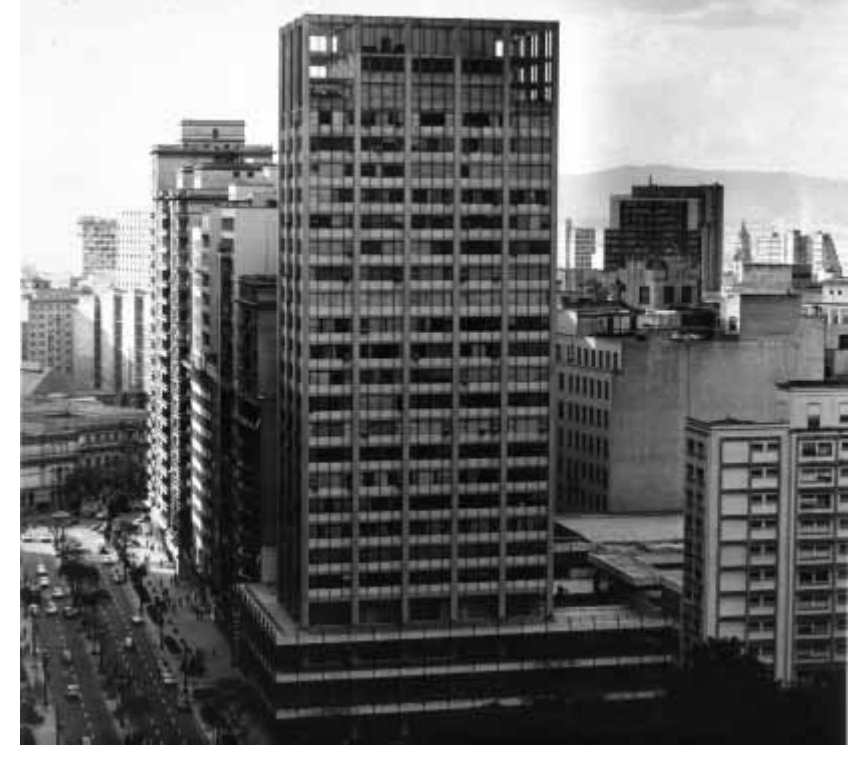


A torre destaca-se entretanto do bloco constituído pelos demais edifícios no alinhamento da avenida, marcando a esquina com a praça Dom José Gaspar.

Em relação ao espaço da praça, sua implantação estabelece um contraponto com a torre dos livros da Biblioteca Municipal projetada por Jacques Pilon em 1935.

Seu partido estrutural adota o já consagrado modelo da prumada central para apoio, contraventamento e instalações, e a segunda linha de pilares perimetrais à fachada. Os desenhos originais do projeto indicam a instalação de quebra-sóis horizontais e verticais nas fachadas Norte e Oeste, os quais não foram executados. A incorporação destes e de outros dispositivos de controle das fachadas como elementos de expressão na linguagem construtiva dos edifícios, seria experimentada por Salvador Candia em obras posteriores, como no edifício das Nações (1973-74).

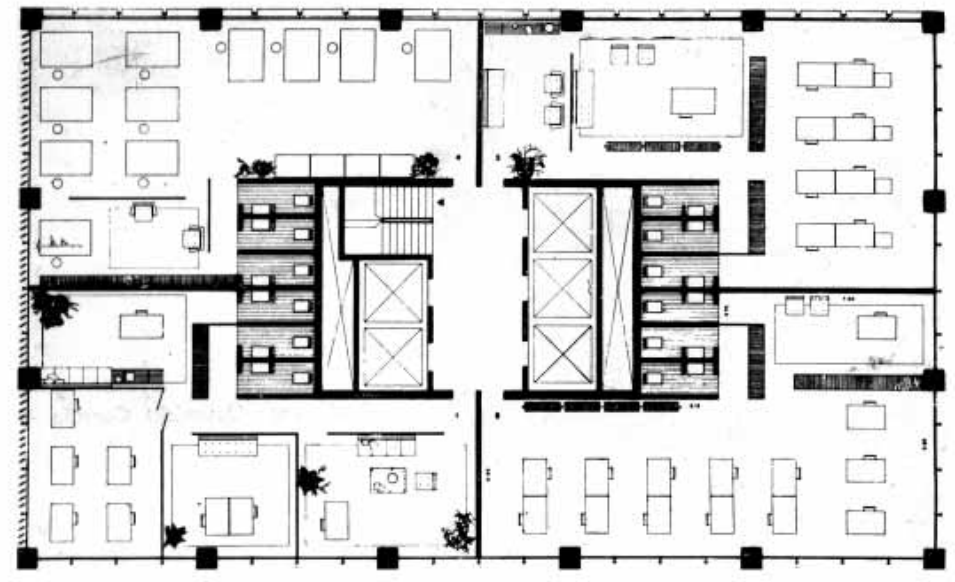

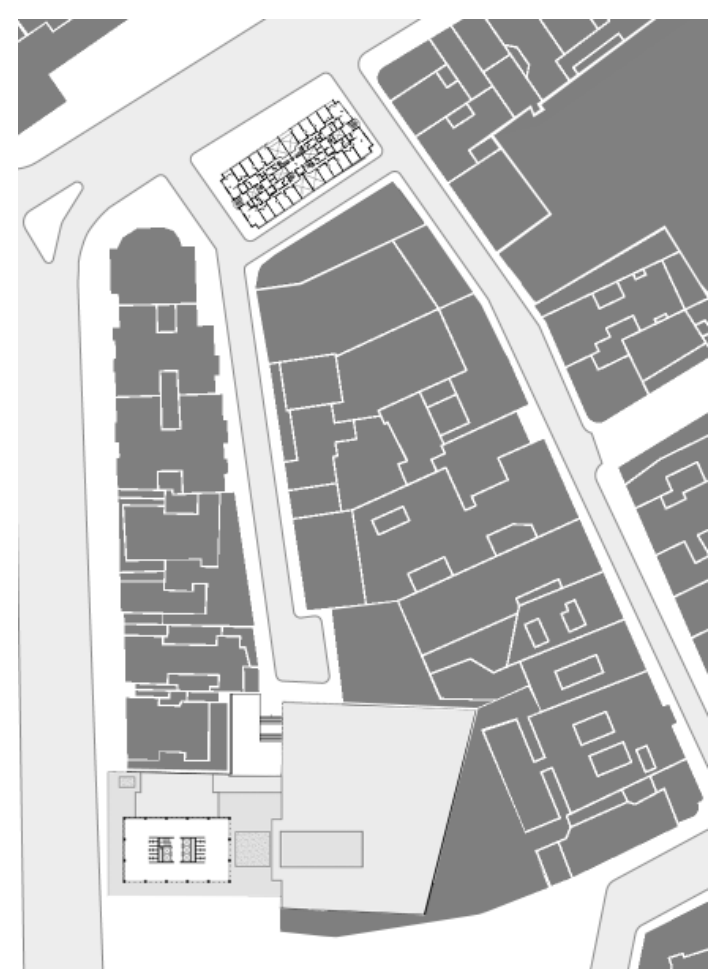

acima:

Desenho de situação da torre com relação aos edifícios vizinhos. Na ponta oposta do quarteirão, situa-se o edifício Esther, que se "solta" dos vizinhos, de forma análoga à que os arquitetos procuraram fazer.

à esquerda:

Edifício Metrópole, São Paulo.

Salvador Candia e Giancarlo Gasperini

Planta do pavimento tipo, Ante-Projeto

fonte: arquivo S. Candia

à direita (próxima página):

Edifício Metrópole, São Paulo.

Salvador Candia e Giancarlo Gasperini

Corte Longitudinal com torre seccionada,

Ante-Projeto.

fonte: arquivo S. Candia 


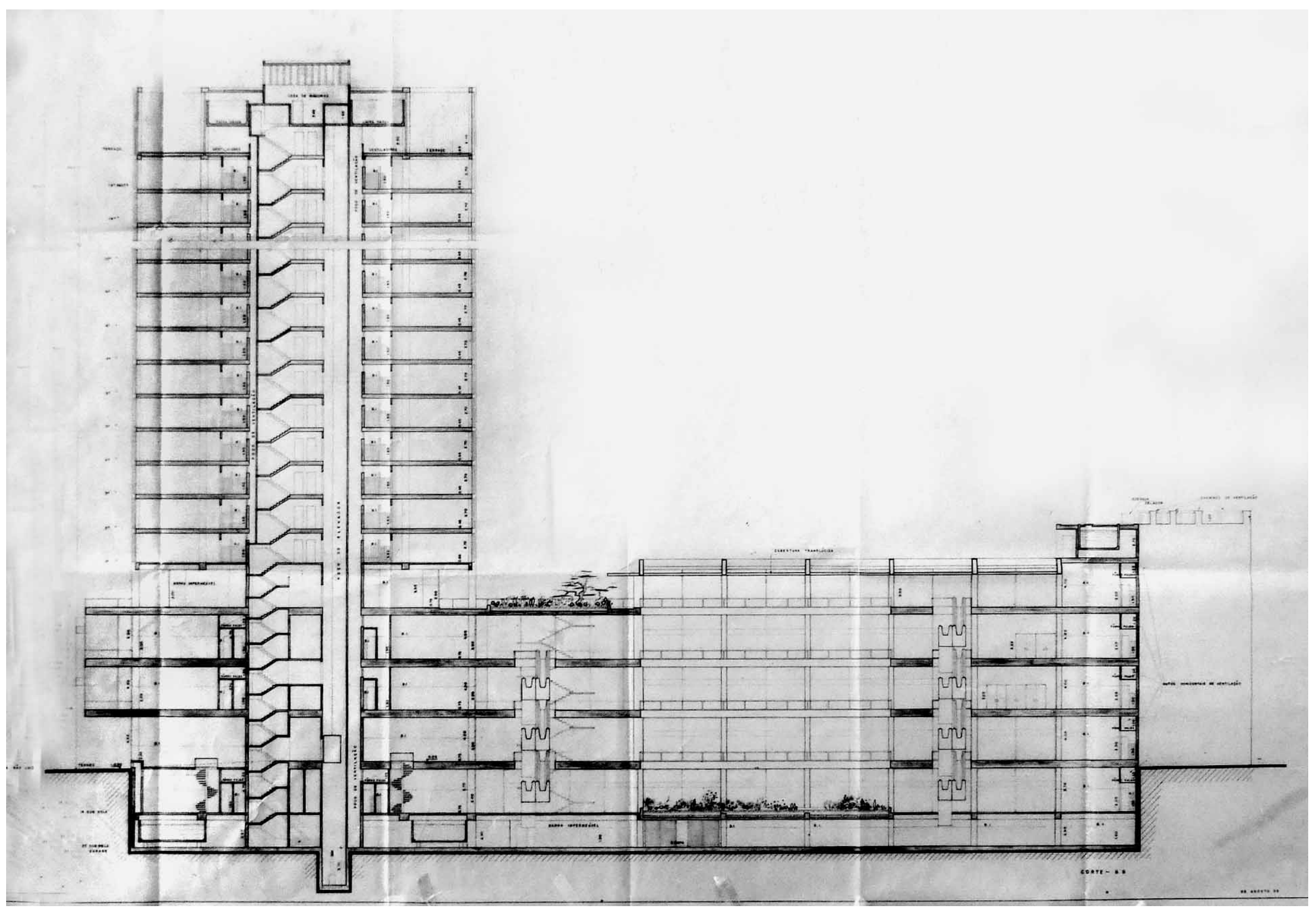




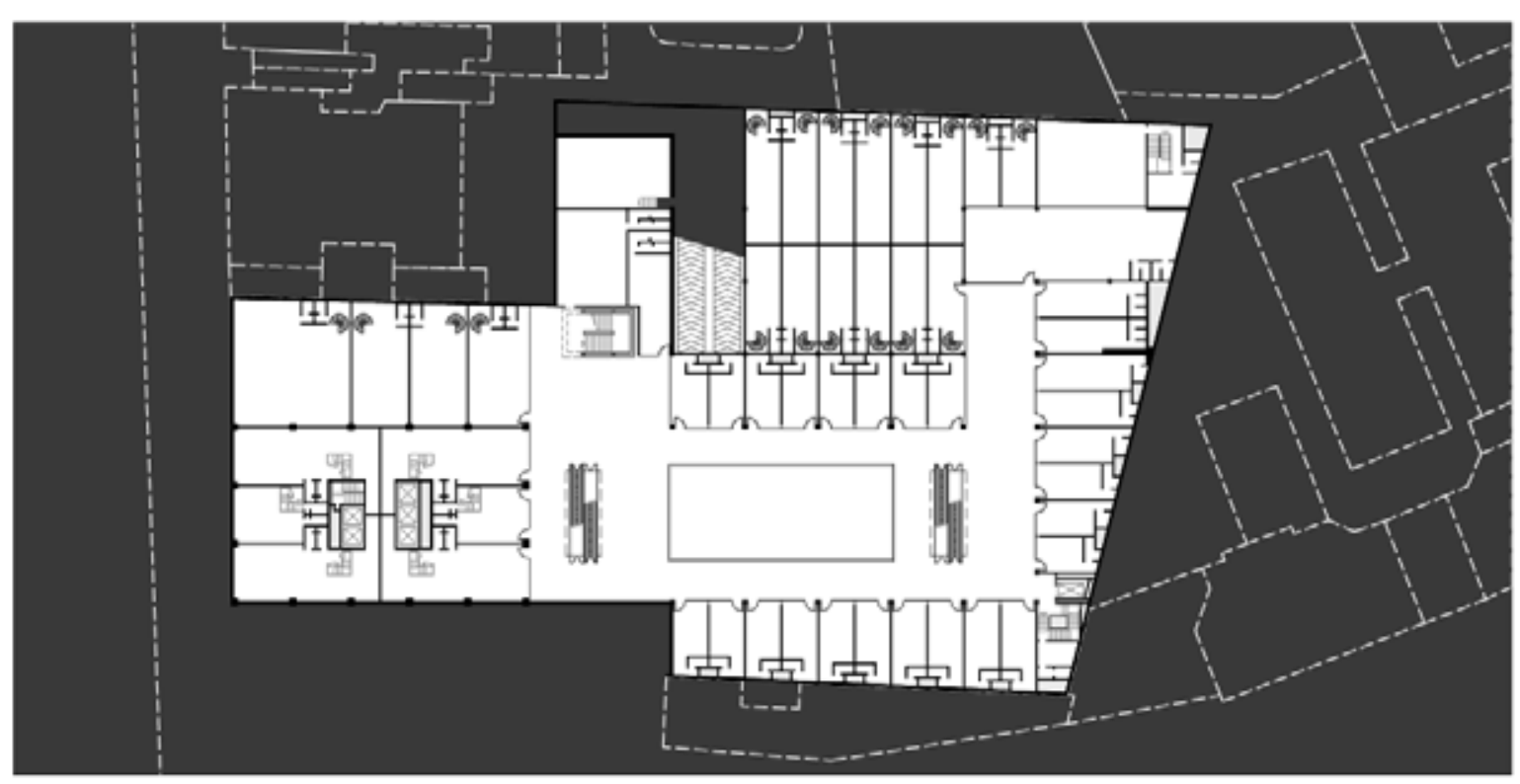

EDIFÍCIO METRÓPOLE

PLANTA DO PAVIMENTO TÉRREO
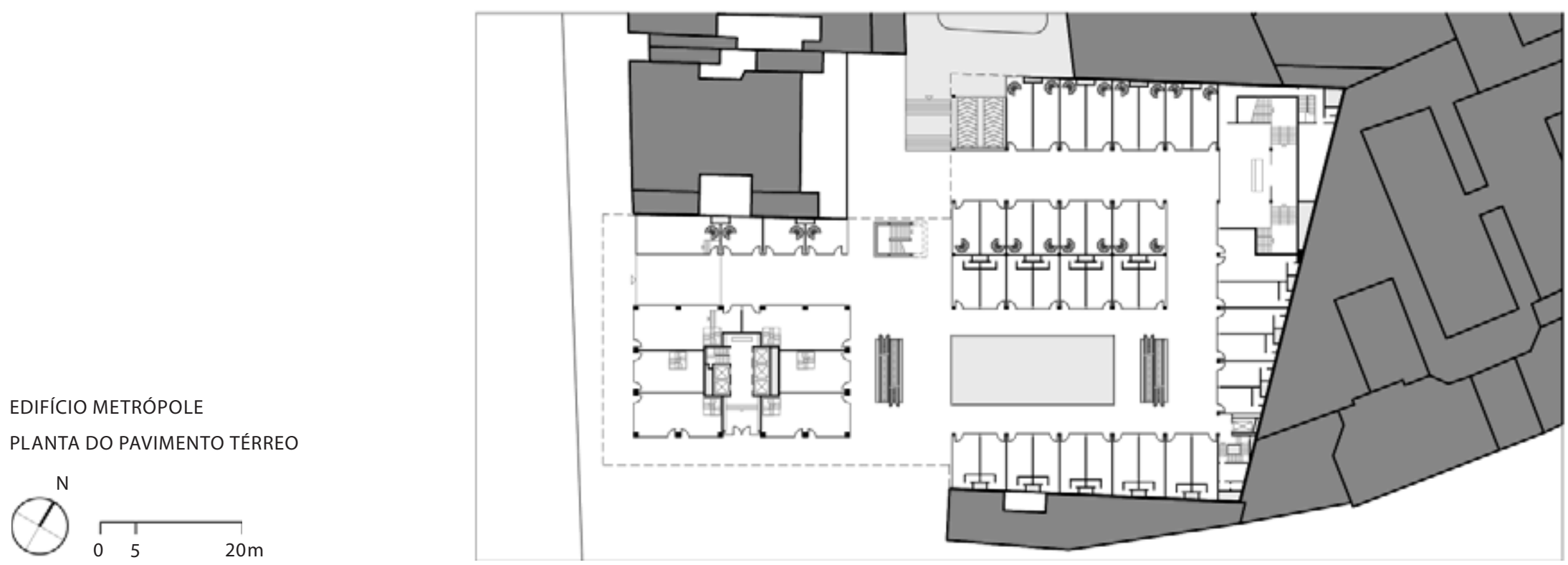
EDIFÍCIO METRÓPOLE

PLANTA DO PRIMEIRO PISO

EDIFÍCIO METRÓPOLE

PLANTA DO SEGUNDO PISO

$\bigodot_{0}^{N} \Gamma_{5}^{1} 20 \mathrm{~m}$
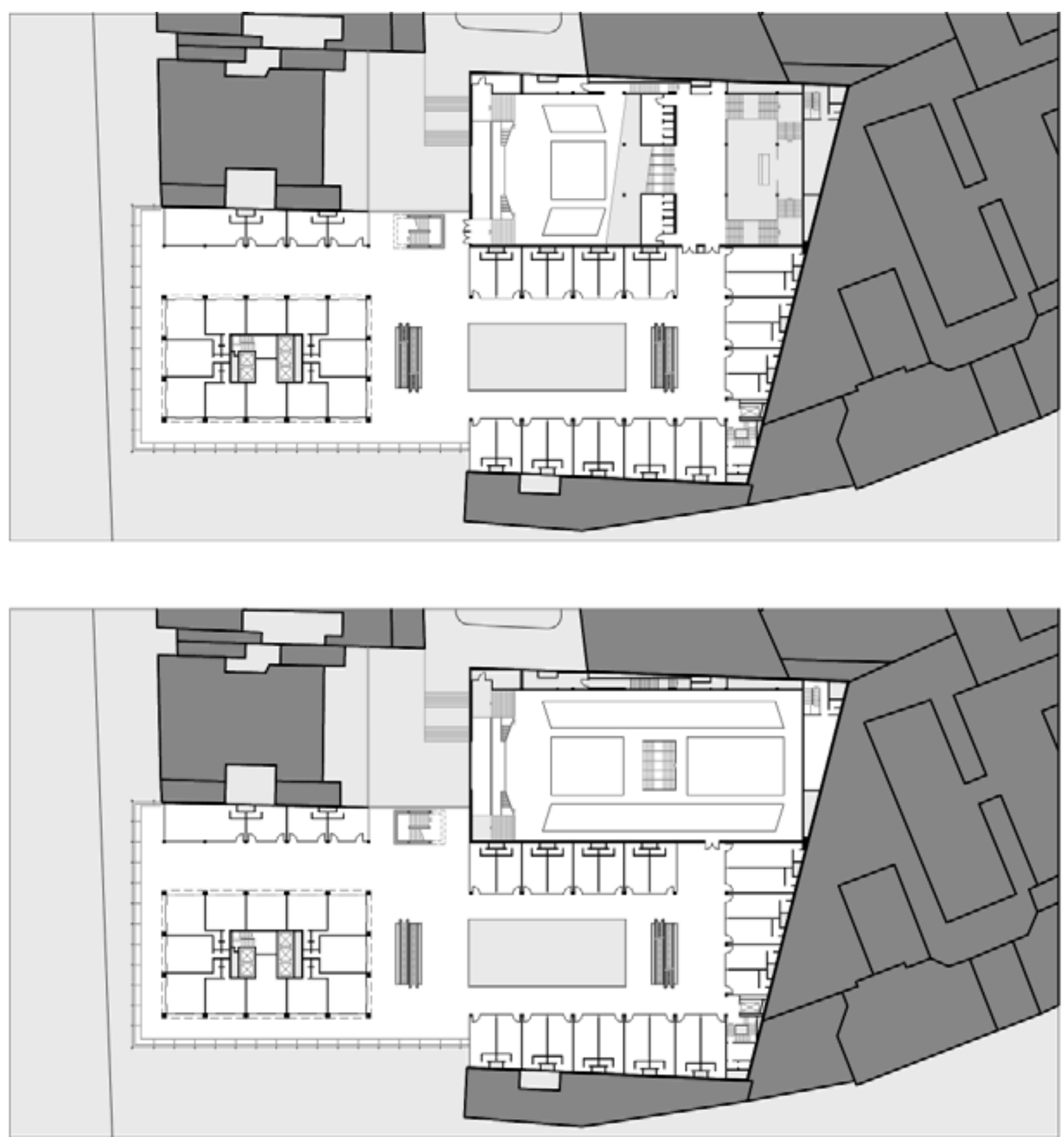

leitura de três projetos 
EDIFÍCIO METRÓPOLE

PLANTA DO TERCEIRO PISO

EDIFÍCIO METRÓPOLE

PLANTA DO PAVIMENTO TIPO DA TORRE

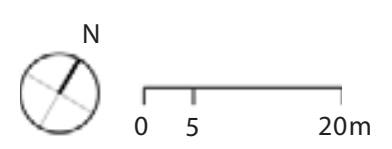

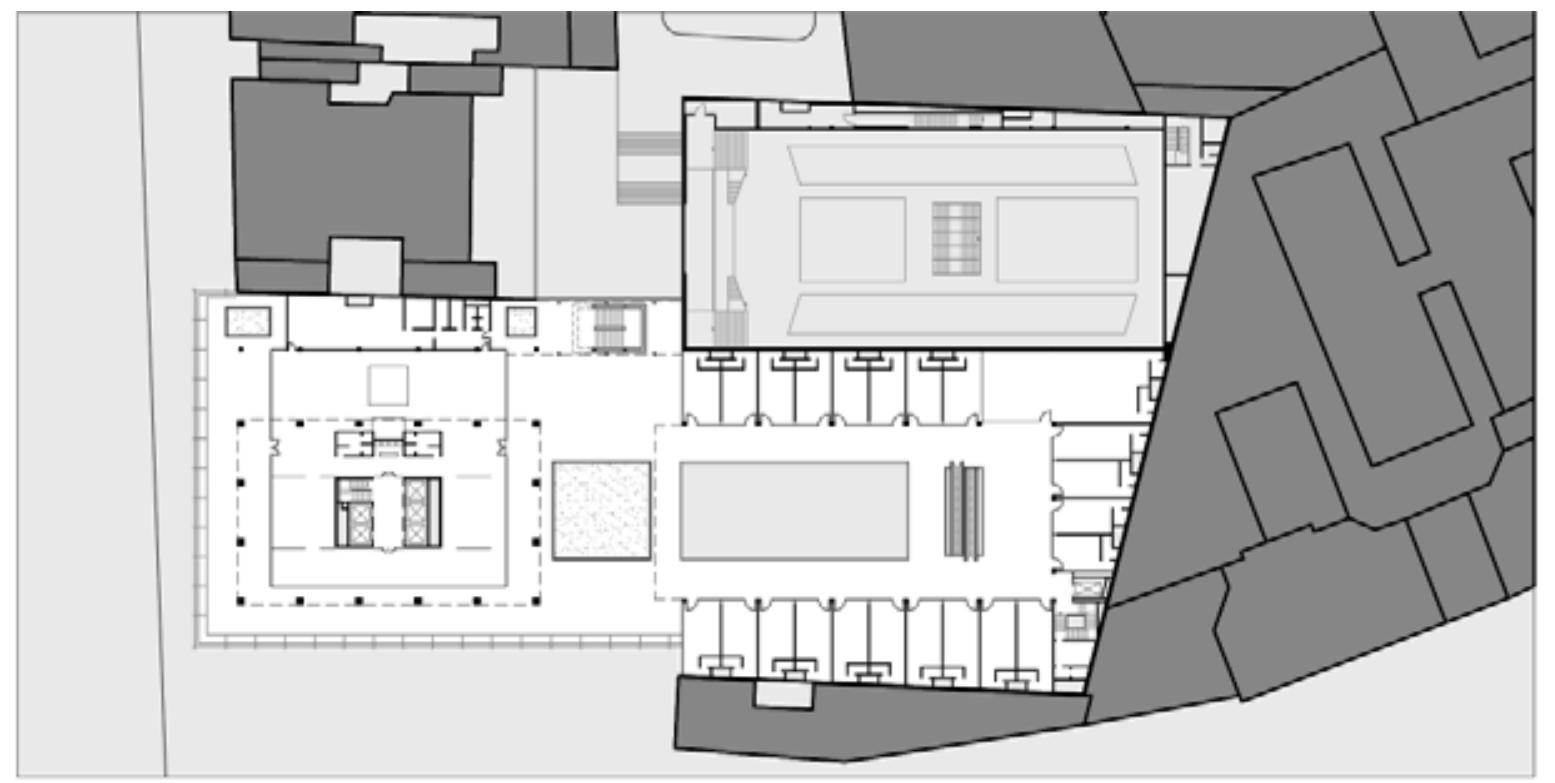

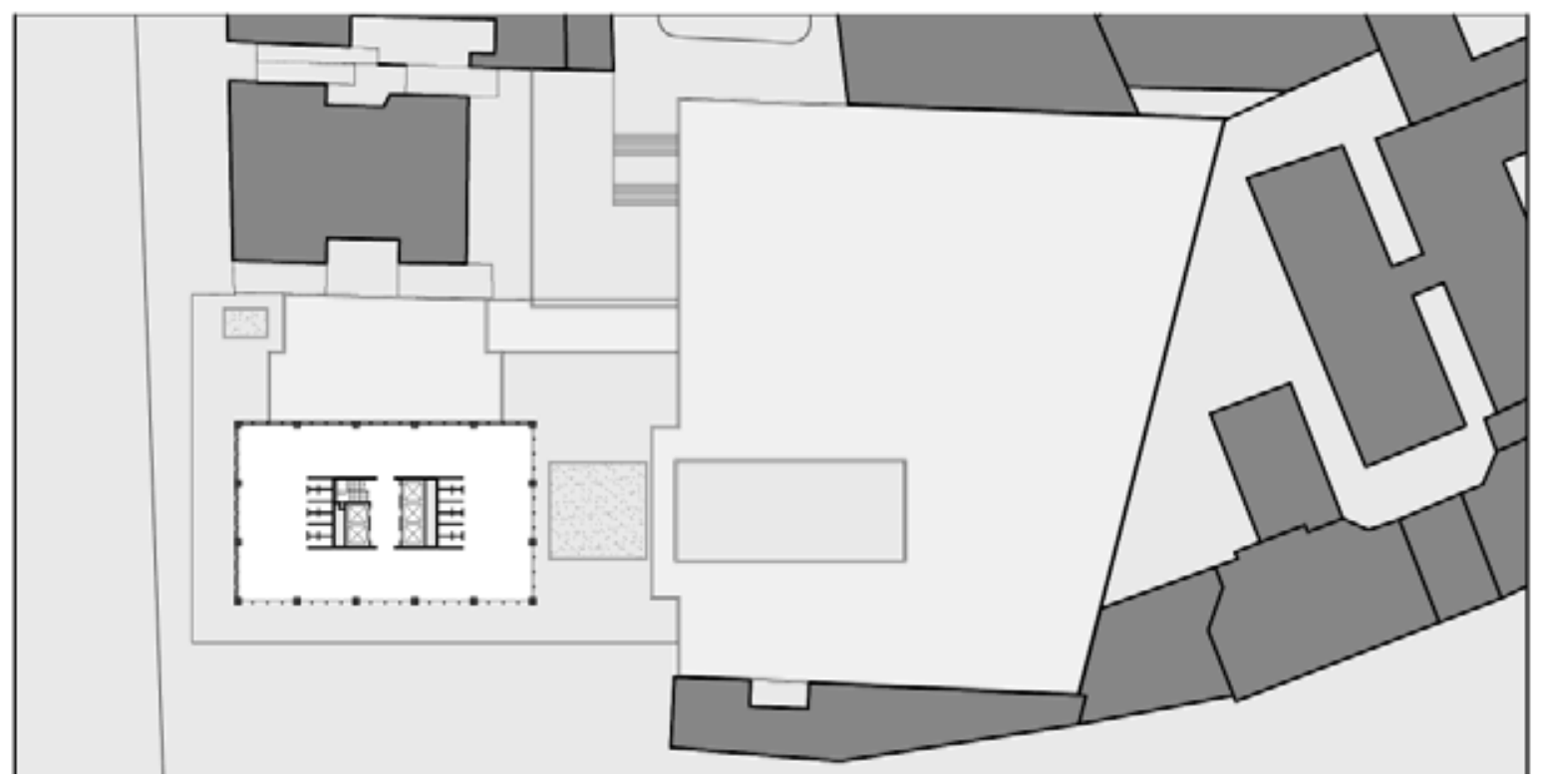


Edifício Metropole, São Paulo. Salvador Candia e Giancarlo Gasperini Foto-montagem.

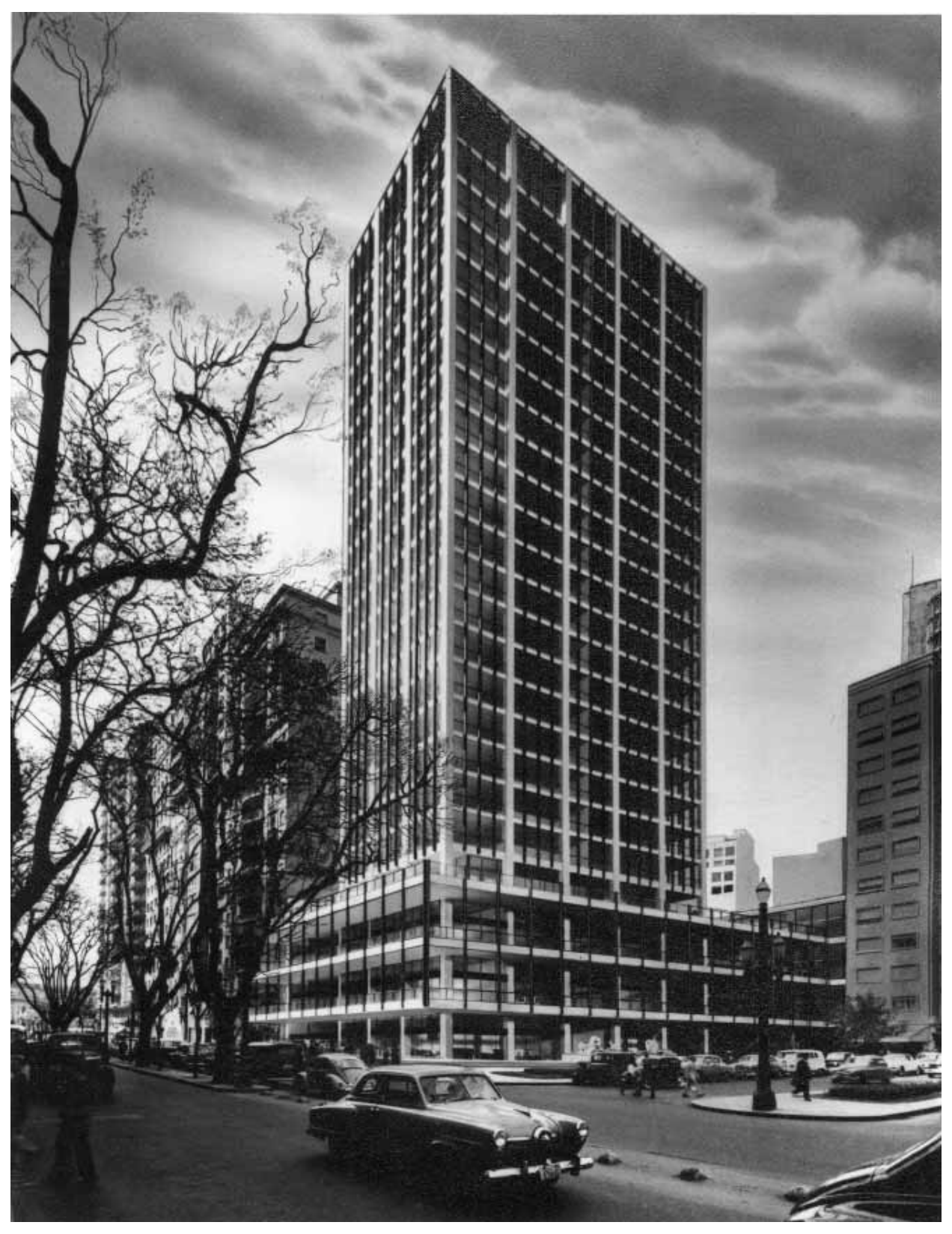
fonte: arquivo S. Candia 

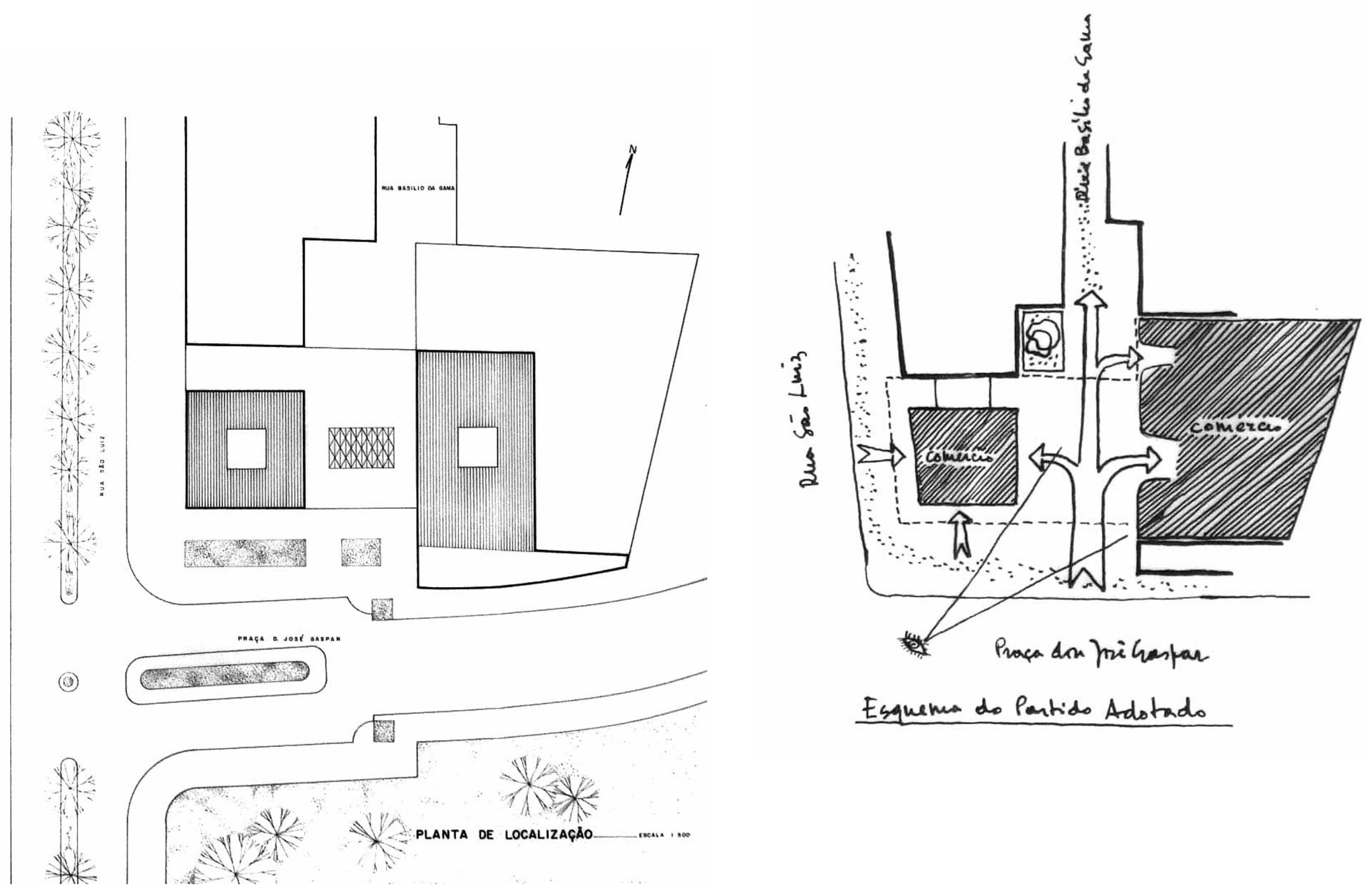

Esquema do Pentids Adotado 


\section{As duas propostas para o concurso.}

página anterior (direita extremo): Edifício Metrópole,

Proposta para o concurso.

Salvador Candia, 1959

Implantação

fonte: arquivo S. Candia/Giancarlo Gasperin

página anterior (direita):

Edifício Metrópole,

Proposta para o concurso.

Glancarlo Gasperini, 195

fonte: arquivo S. Candia/Giancarlo Gasperini
Dos quatro projetos elaborados para o concurso, do qual também participaram David Libeskind e Jorge Wilheim, tivemos acesso somente às propostas vencedoras, gentilmente cedidas pelo arquiteto Giancarlo Gasperini.

Embora haja diferenças significativas nos partidos de ocupação do terreno, os dois projetos compartilham de uma mesma postura em relação à disposição dos principais elementos que compõe o programa: em ambos os casos, a torre principal de escritórios implanta-se de forma semelhante, junto à avenida São Luiz. Outro elemento que caracterizaria fortemente as duas propostas seria a abertura da passagem de pedestres entre a rua Basílio da Gama e a praça Dom José Gaspar, que em ambos os casos serve como elemento estruturador do projeto, destacando a implantação da torre de escritórios com relação ao embasamento das lojas voltadas para o interior da quadra, junto aos lotes vizinhos.

As principais diferenças entre os dois projetos residem justamente na ocupação do miolo da quadra. O projeto de Gasperini aproxima-se da solução final, ao nosso ver, partindo da criação de um volume baixo de cinco pavimentos que se acomoda à geometria do terreno junto ao fundo do lote, e abrindo vazios em seu interior para iluminação das lojas.

Candia parte por sua vez da construção de um embasamento de dois andares para o abrigo do cinema e das galerias comerciais, sobre as quais é implantado outro edifício de escritórios com onze pavimentos, que acompanha o gabarito das construções vizinhas. O edifício proposto por Candia cumpriria a função de arrematar parte das empenas cegas junto às divisas remanescentes do lote, completando a volumetria do quarteirão junto à praça conforme o alinhamento da rua Basílio da Gama. Esta operação se aproximaria da solução empreendida por Brazil e Marinho para o edifício Esther, situado 


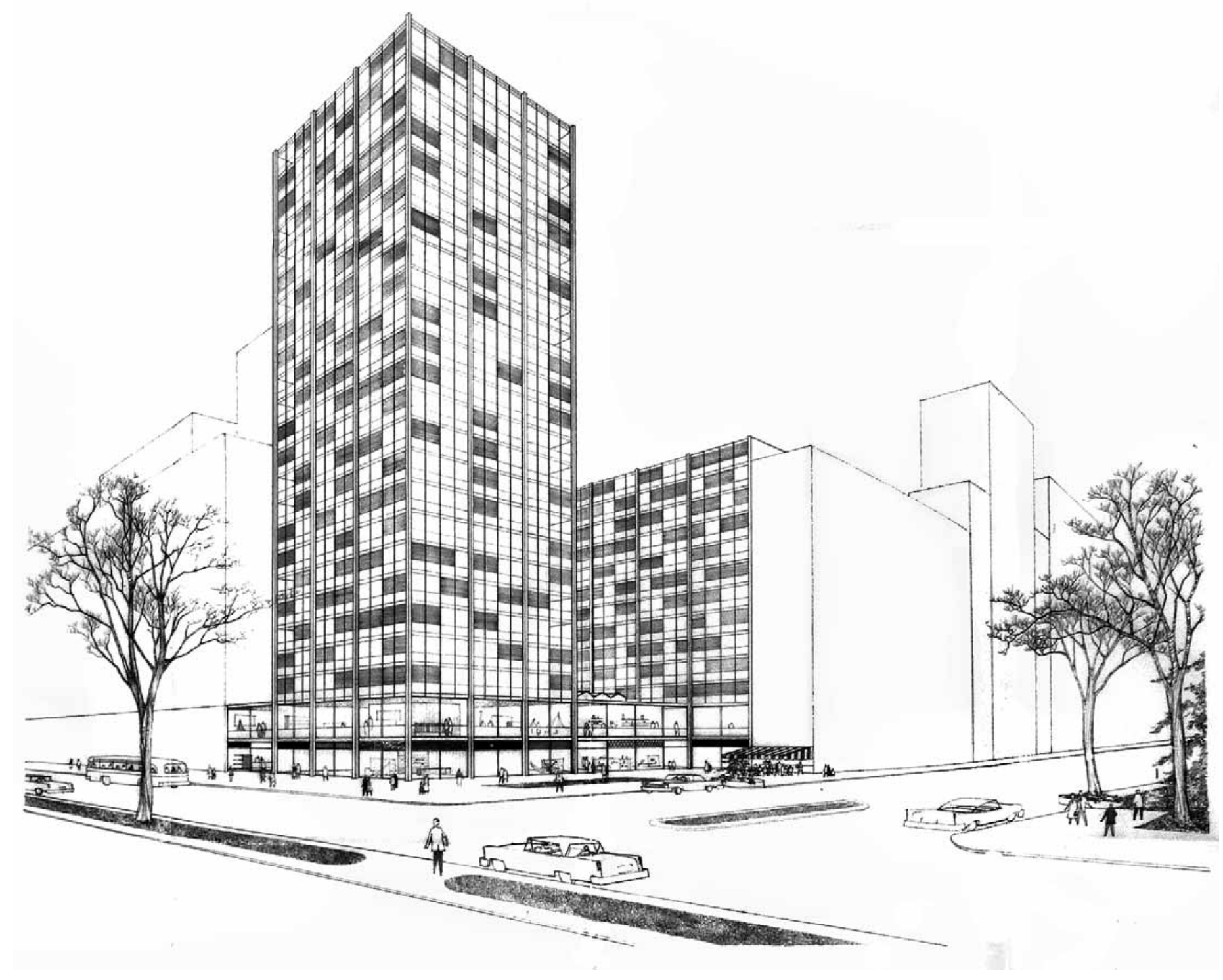

Nesta página:

Edifício Metrópole,

Proposta para o concurso.

Salvador Candia, 1959

Perspectiva.

fonte: arquivo S. Candia/

Giancarlo Gasperini

Próxima página:

Edifício Metrópole,

Proposta para o concurso.

Proposta para o concurso.

Perspectiva.

fonte: arquivo S. Candia/

Giancarlo Gasperini 


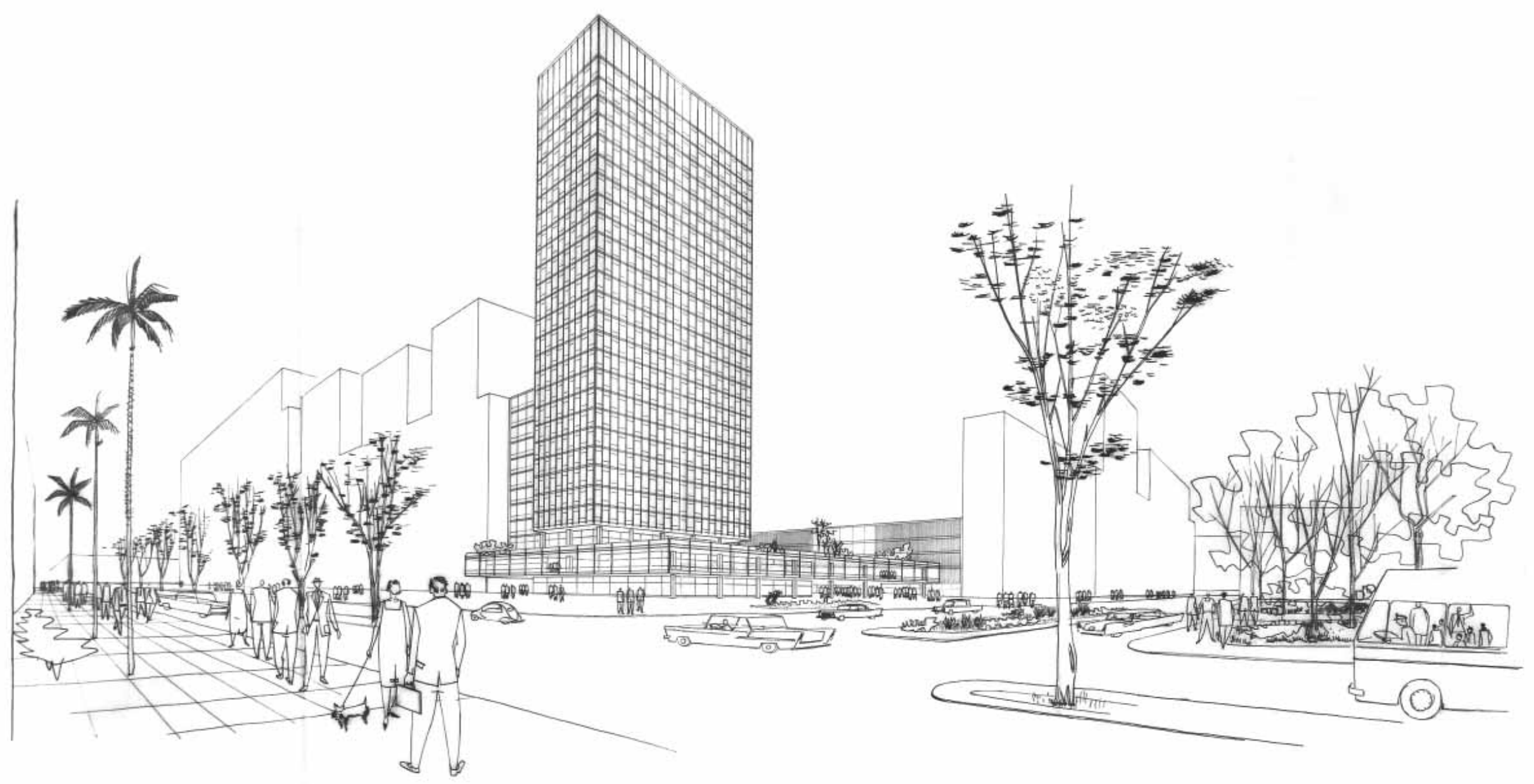


na outra extremidade da rua. A disposição do edifício anexo completando em parte a volumetria do quarteirão, contribuiria para dar maior destaque à torre implantada na esquina oposta, estabelecendo uma relação de fundo e figura. Todavia a solução empregada para o novo edifício ocuparia apenas parcialmente o perímetro do terreno, interrompendo-se junto à rua Basílio da Gama para dar lugar à cobertura do cinema. Este partido de ocupação acabaria também por produzir uma extensa área de "fundos" no interior da quadra, para onde se abriria uma das fachadas do novo edifício.

Um dos argumentos levantados para adoção deste partido seria, além de prover uma quantidade maior de conjuntos de escritórios, a possibilidade de sua execução por etapas, talvez influenciada pela constatação das dificuldades de se empreender um conjunto daquelas dimensões, com base nos processos descontínuos de construção do edifício Copan e do Conjunto Nacional.

Tendo partido de uma densidade ocupacional menor, a solução posteriormente adotada para ocupação do miolo da quadra resolve de forma mais simples e eficiente o problema da ocupação dos "fundos" do terreno, através da abertura de um grande pátio central para o qual se voltam as galerias comerciais.

Outro elemento que diferencia as duas propostas apresentadas é o tratamento empregado à torre de escritórios. Gasperini propõe uma torre retangular de vinte e quatro pavimentos recuada em relação ao terraço do embasamento, aproximando seu desenho de implantação da célebre Lever House de Gordon Bunshaft em Nova York (SOM, 1952). A sua planta dispõe da prumada de circulação vertical anexa a uma das laterais, assimétrica em relação às salas de escritórios. Estando implantada próxima à divisa posterior do lote, a torre acomoda-se ao perfil dos edifícios vizinhos, que - em obediência ao código vigente - estão recuados das divisas laterais somente a partir do décimo segundo pavimento, resultando em uma volumetria escalonada.

Candia intencionava destacar a torre de escritórios dos demais elementos que configuravam o conjunto. Por isso, o volume das galerias é mais baixo e não se sobressai em
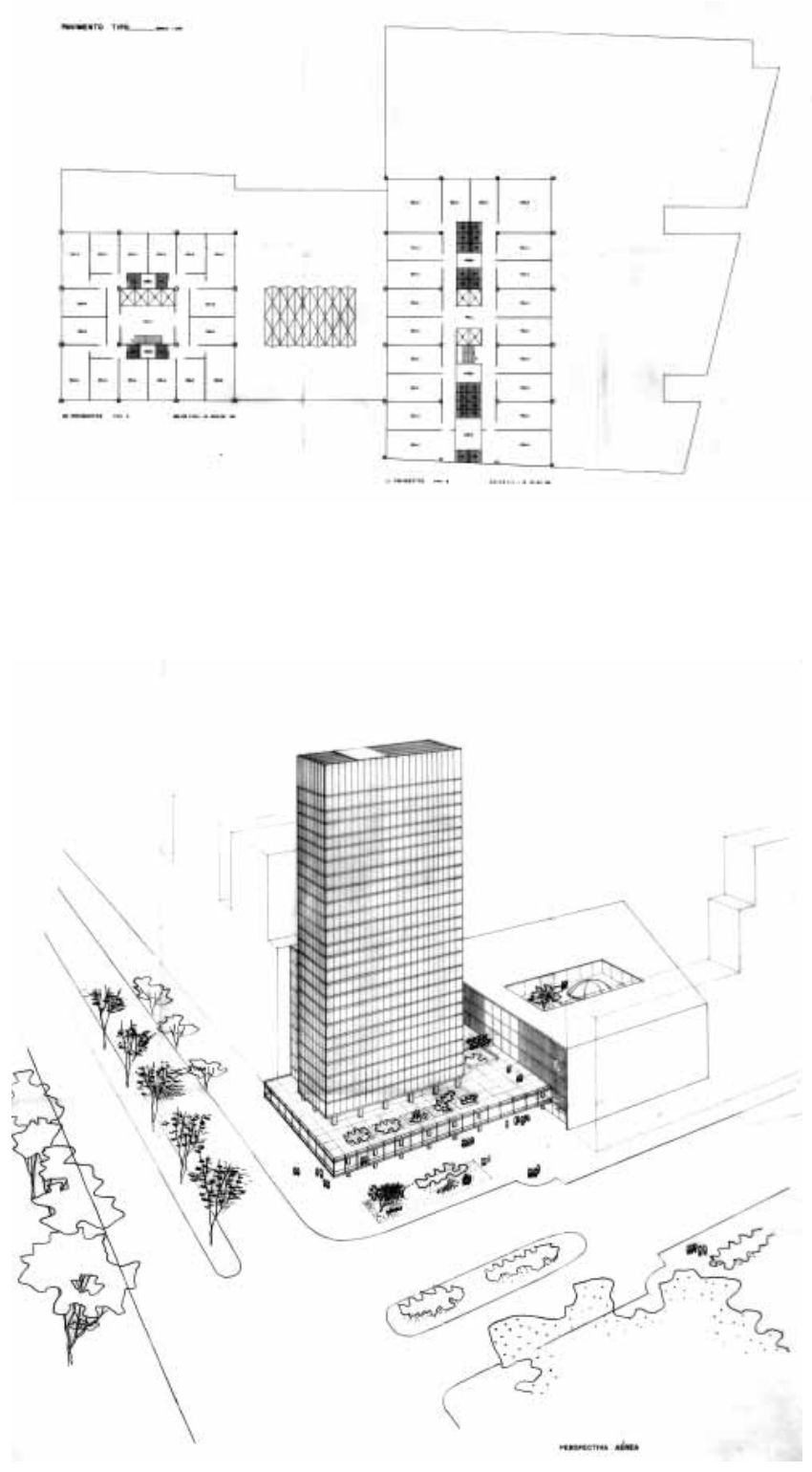
relação ao volume do edifício principal. A planta da torre, que prevê uma área maior para o pavimento tipo $\left(625 \mathrm{~m}^{2}\right.$, frente aos $550 \mathrm{~m}^{2}$ previstos no outro projeto) organizase conforme o clássico arranjo de prumada central de circulações verticais e estrutura periférica na fachada, mantendo os salões livres em suas quatro faces. Nas palavras do próprio arquiteto:

Foi um concurso e o Gasperini e eu, com projetos diferentes, ganhamos. Na hora de executar, o projeto que parece que respondia mais às implicações não só econômicas, não só materiais, mas inclusive apresentava uma abordagem nova, era o meu. O que ele tinha de novo? Tinha torre solta, foi a primeira torre solta que se fez em São Paulo. Isto pode parecer uma coisa vulgar, mas não era na época.

Fazer no meio do centro urbano uma torre solta com quatro fachadas mais ou menos iguais, porque eu achava que elas devam ter uma diferença devido à incidência do sol, com a estrutura toda nas pontas e no centro, hoje se tornou uma fórmula. Acho que isso foi uma lição do Mies que eu também introduzi, bem como todo o salão livre e o uso tanto quanto possível do vidro para dar aos salões uma iluminação mais eficiente possível. $^{8}$

Página anterior:

Edifício Metrópole,

Proposta para o concurso.

Salvador Candia, 1959

Planta do pavimento tipo.

fonte: arquivo S. Candia/

Giancarlo Gasperini

Página anterior:

Edifício Metrópole

Proposta para o concurso.

Glancarlo Gasperini, 1959

Perspectiva.

fonte: arquivo S. Candia/

Giancarlo Gasperini

8 CANDIA, Salvador in Arquitetura e desenvolvimento nacional: depoimentos de arquitetos paulistas. São Paulo: Instituto de Arquitetos do Brasil - departamento de São Paulo e editora Pini, 1979 


\section{Proposta de Giancarlo Gasperini, 1959}

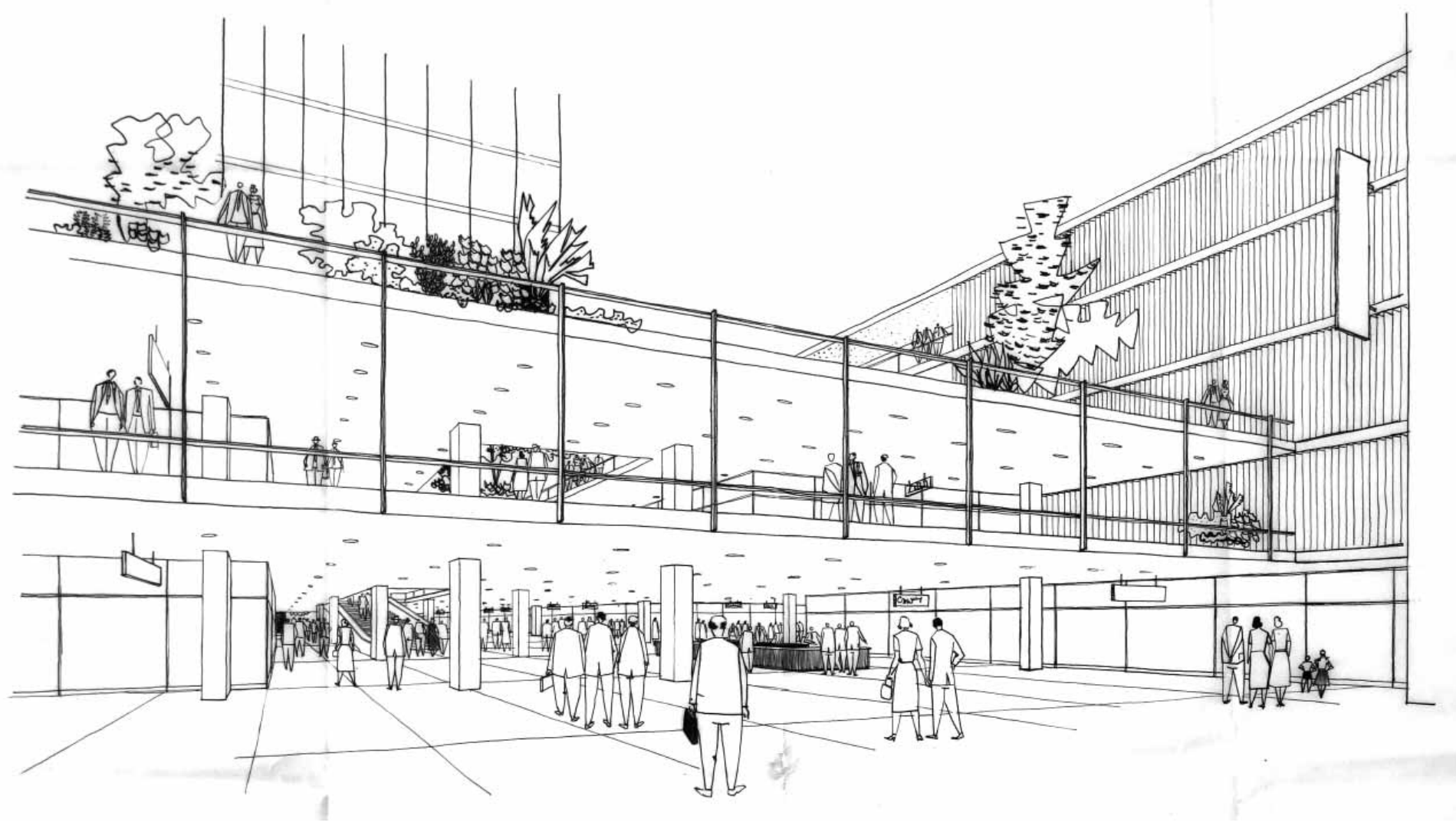

Edifício Metrópole,

Proposta para o concurso.

Giancarlo Gasperini, 1959

fonte: arquivo S. Candia/

Giancarlo Gasperini

Nesta página:

Perspectiva.

Página Seguinte: 

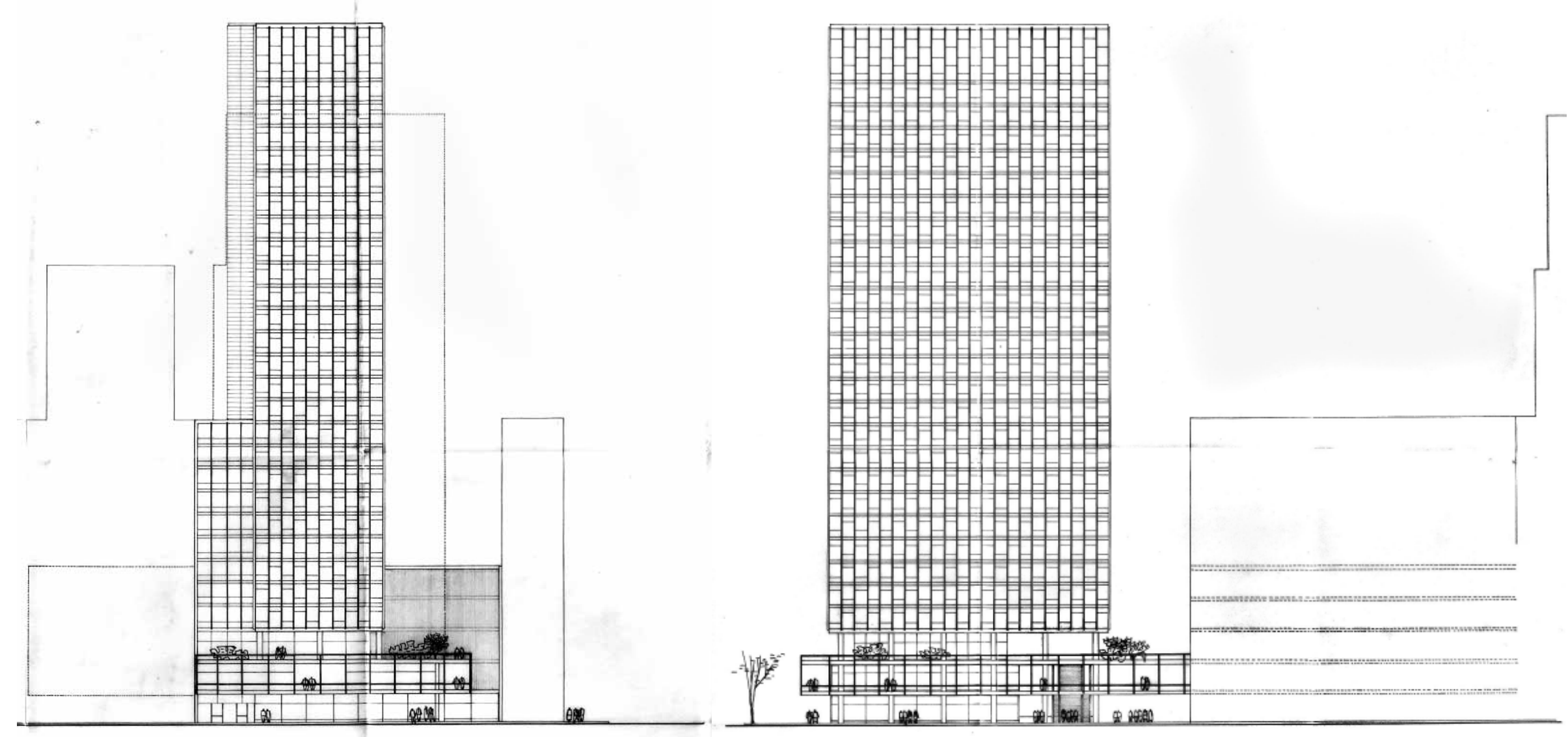

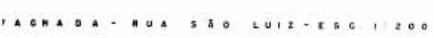




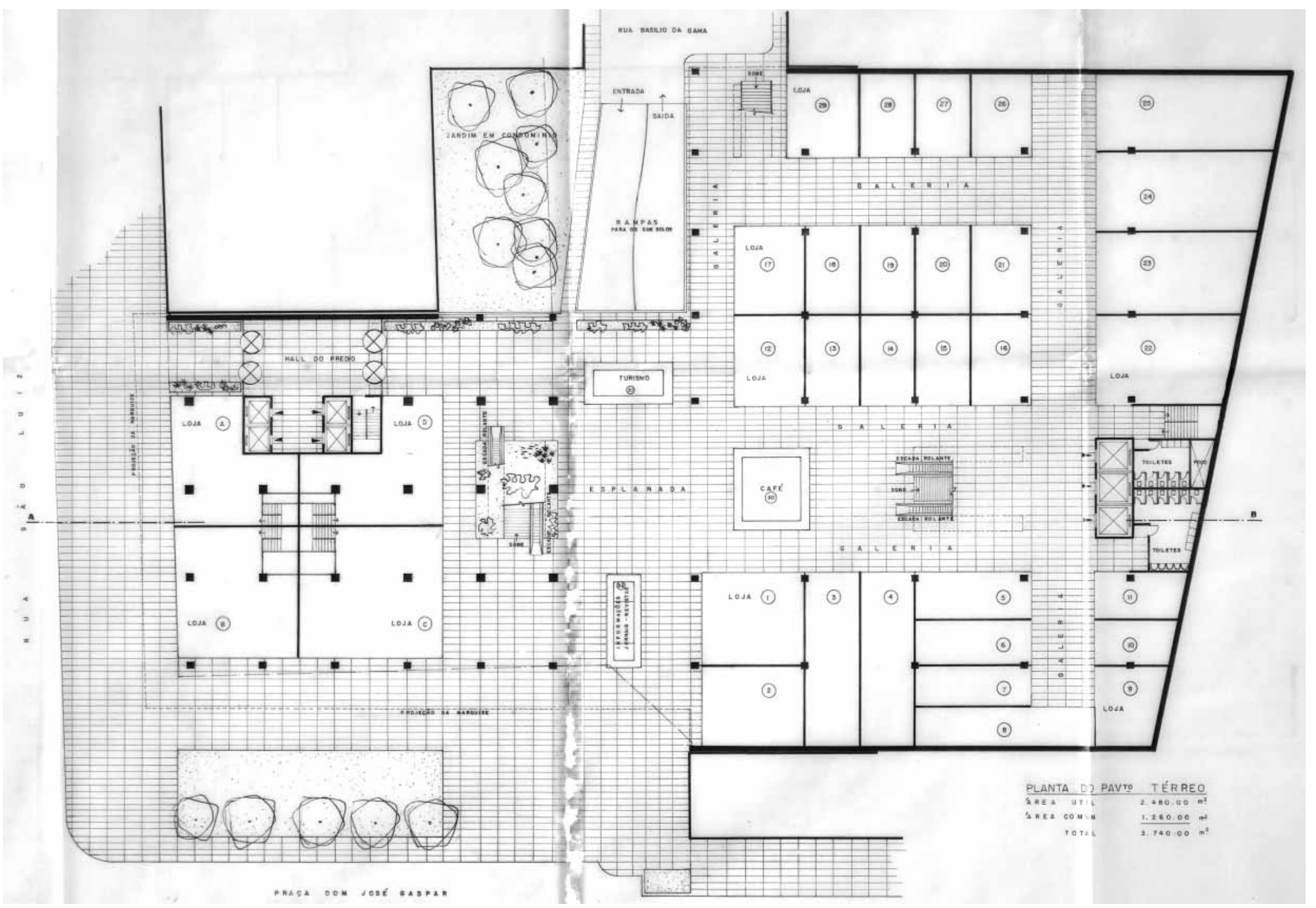


Edifício Metrópole Proposta para o concurso. Giancarlo Gasperini, 1959

fonte: arquivo S. Candia/ Giancarlo Gasperini.

Nesta página à direita: Corte Longitudinal.

Nesta página à direita (extremo):
Plantas da torre de escritórios.

Página Anterior: Planta do pavimento

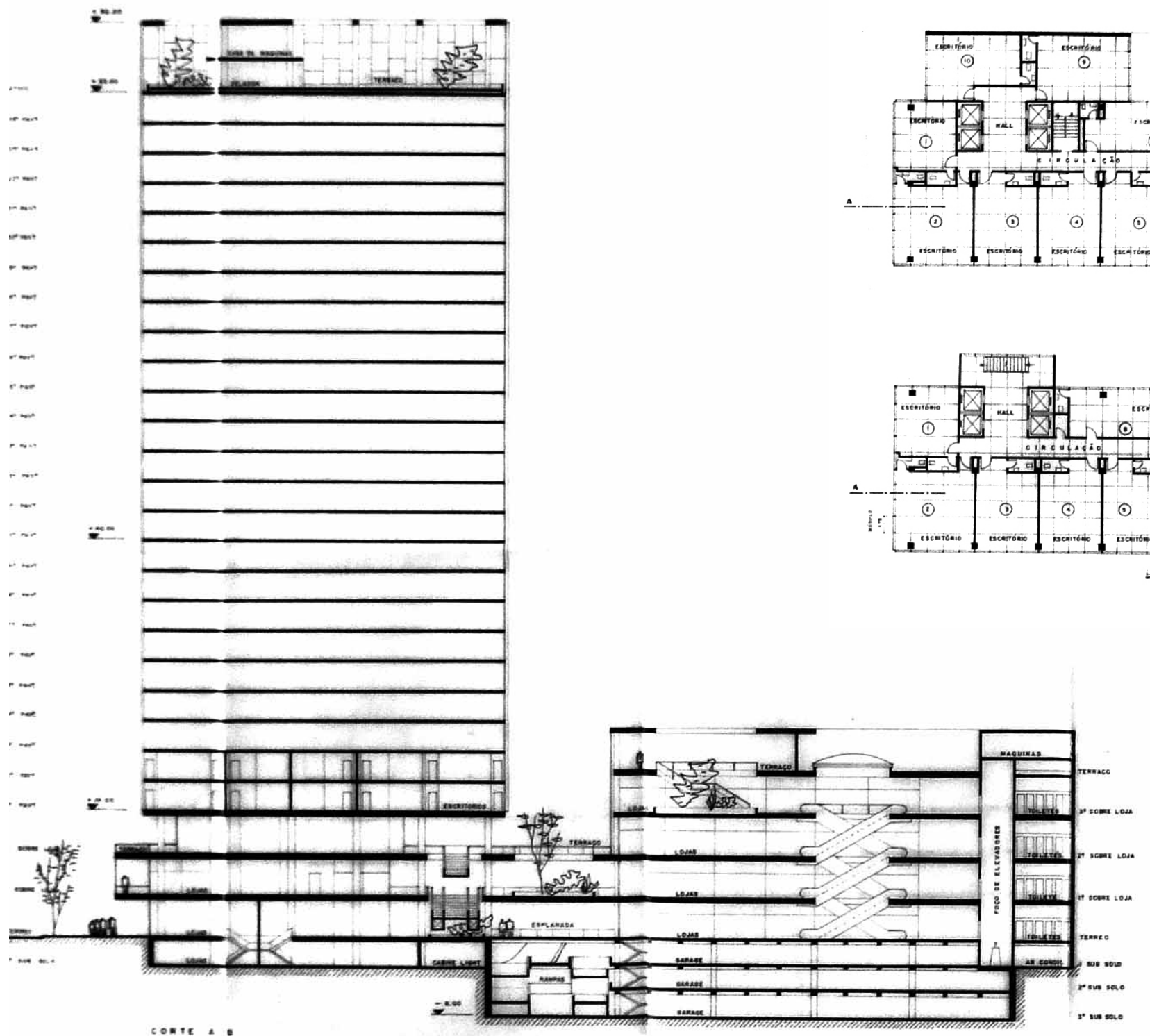


Proposta de Salvador Candia, 1959
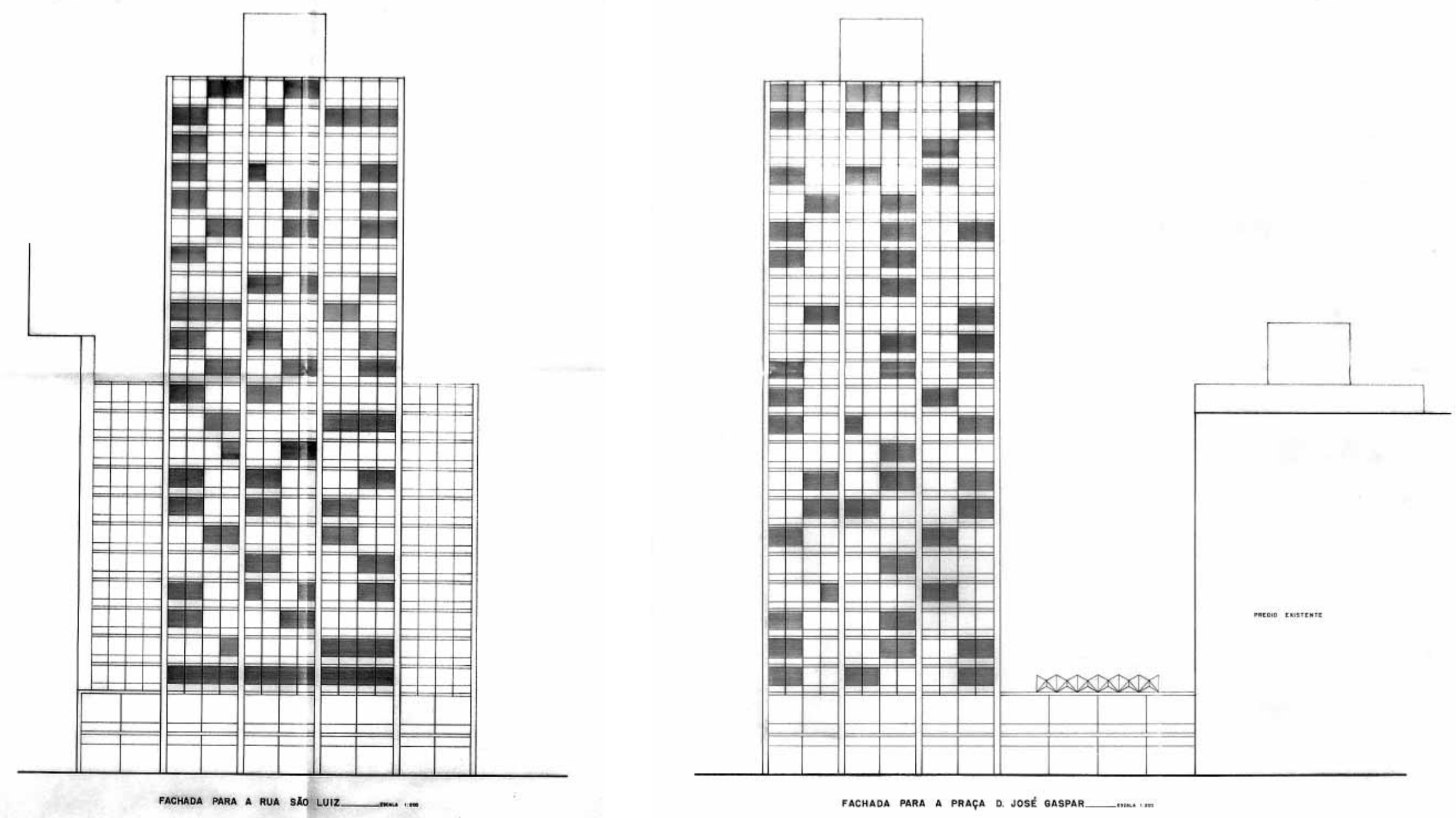
Nesta página: Edifício Metrópole Proposta para o concurso.

Salvador Candia, 1959

Corte Longitudinal.

fonte: arquivo S. Candia/

Giancarlo Gasperin

Página anterior:

Edifício Metrópole,

Proposta para o concurso.

Salvador Cancurso.

Elevações.

fonte: arquivo $\mathrm{S}$. Candia/

Giancarlo Gasperini

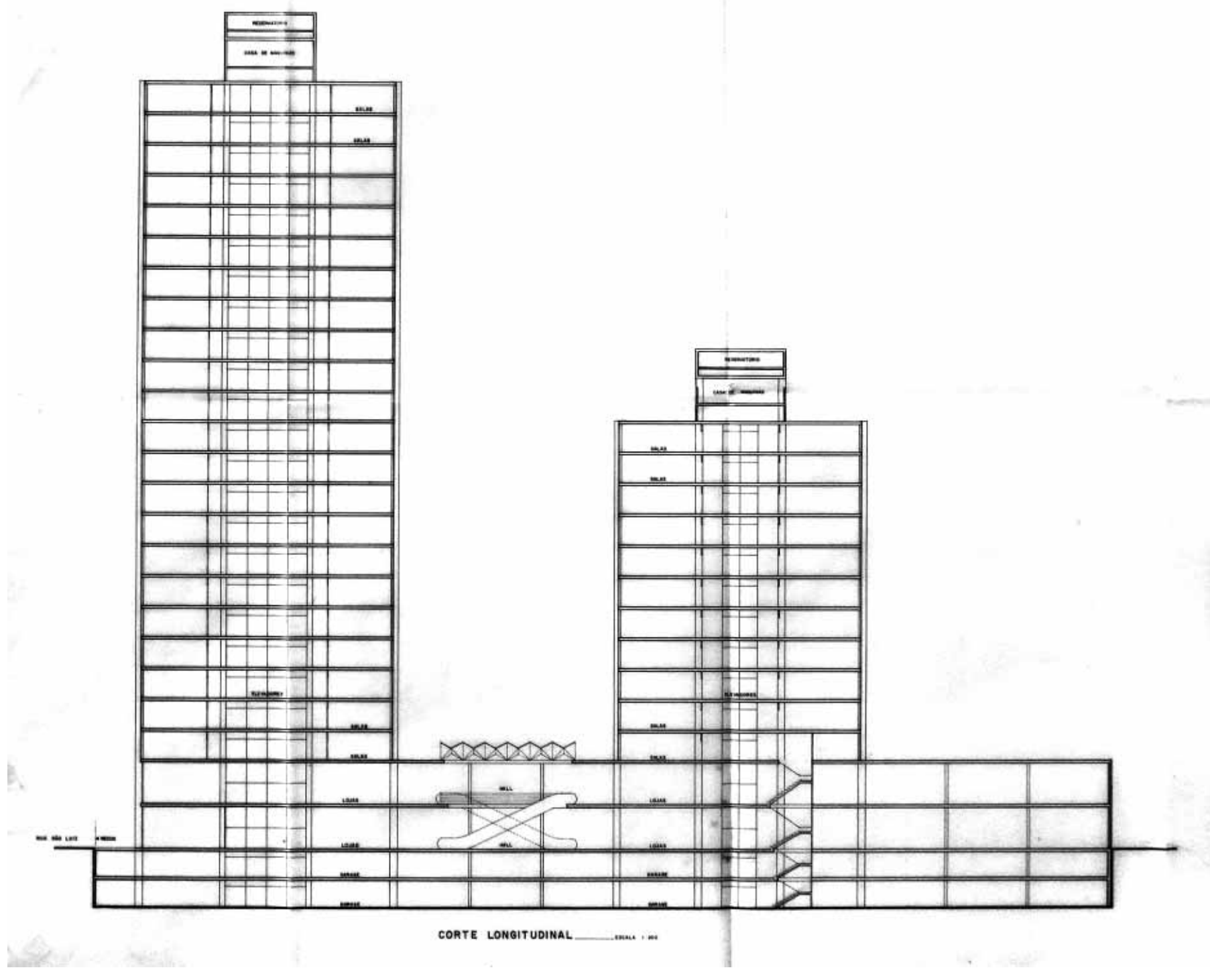

leitura de três projetos 


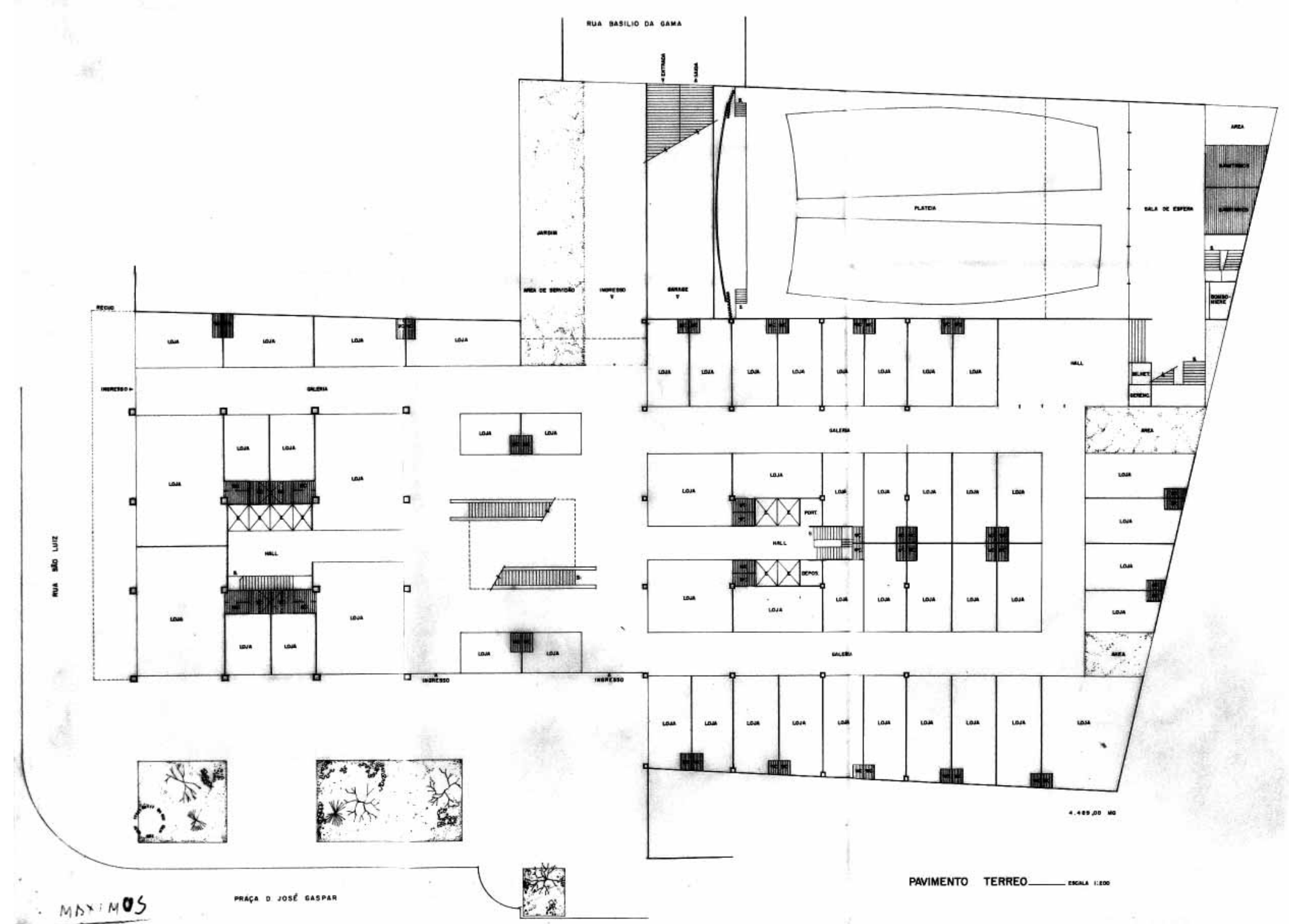




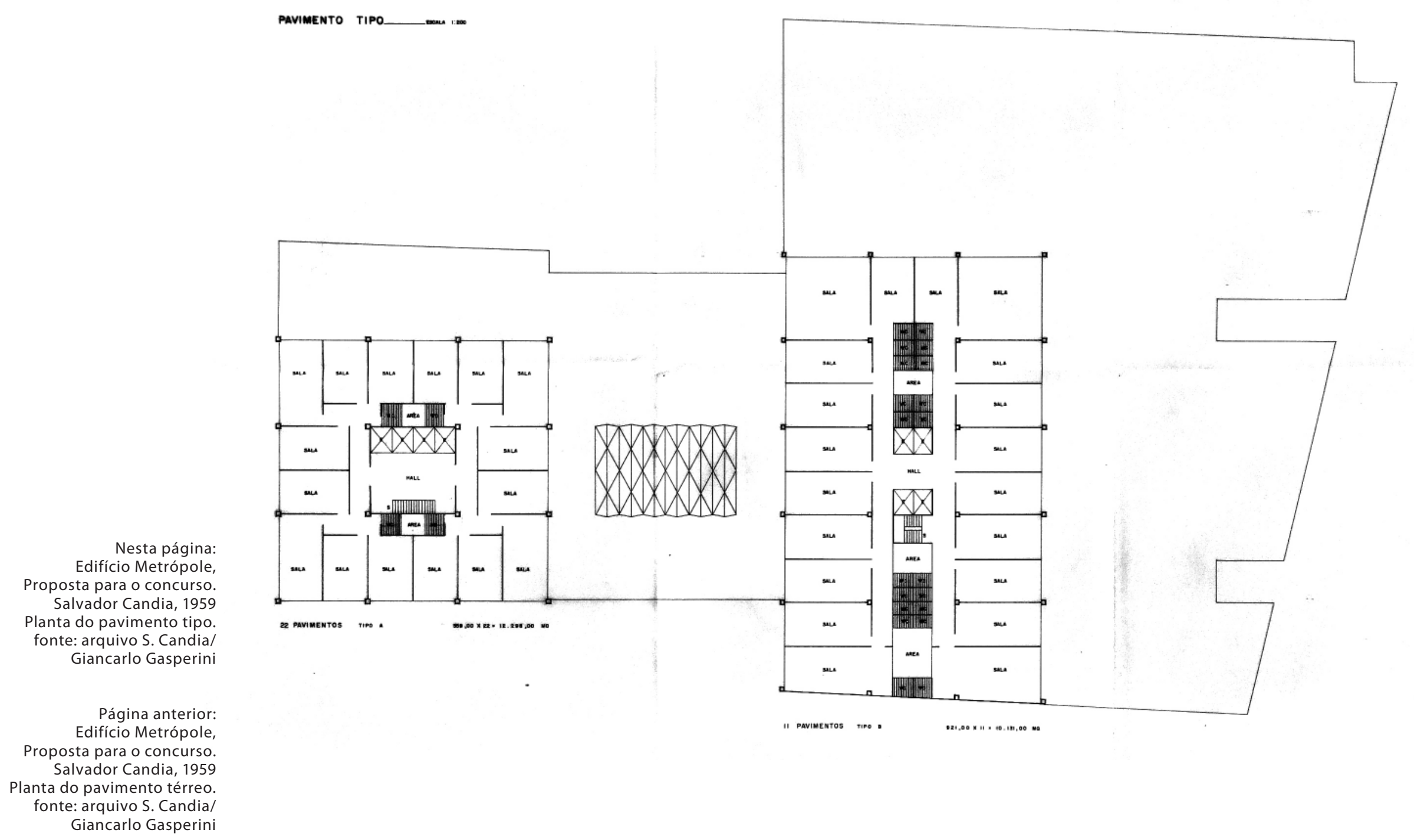




\section{Construção}

O projeto sofreria inúmeras alterações durante a sua construção. Havia originalmente uma proposta interessante, contida no primeiro projeto de Gasperini, para a abertura do recuo do edifício vizinho junto à rua Basílio da Gama, para a criação de um jardim comum aos dois edifícios. Embora ainda esteja contida no desenvolvimento posterior do projeto, ela foi abandonada durante a sua construção.

Há também alterações principalmente em relação aos materiais empregados na construção. Os estudos realizados pelos arquitetos para as alternativas de composição dos fechamentos indicam a tentativa de se implementar elementos industrializados, tentando novamente empregar as janelas contrapesadas, desta vez projetadas em chapa de aço. ${ }^{9}$ A versão finalmente adotada é a mais simples, com peitoris de alvenaria revestidos com pastilhas e os caixilhos de ferro. Os perfis metálicos aplicados externamente à torre remetem às diversas tentativas de se estabelecer uma linguagem associada à construção modular da fachada, conforme comentamos anteriormente.

No espaço das varandas da galeria junto à praça e à avenida São Luiz, os arquitetos foram obrigados a recuar o posicionamento dos guarda-corpos associados aos perfis das fachadas, reduzindo em um terço a largura das varandas, pois a legislação em vigor permitiria apenas a construção de marquises projetadas sobre o alinhamento do recuo, tendo sido necessário negociar o seu uso com a prefeitura. ${ }^{10}$

O coroamento do edifício teria recebido, segundo o projeto original, um conjunto de perfis verticais que criariam um véu de fechamento nos vãos da grelha estrutural dos últimos pavimentos, de modo a manter íntegra a sua volumetria. Este fechamento não

9 CUNHA (2007. p.189)

10 CUNHA (2007. p.198).

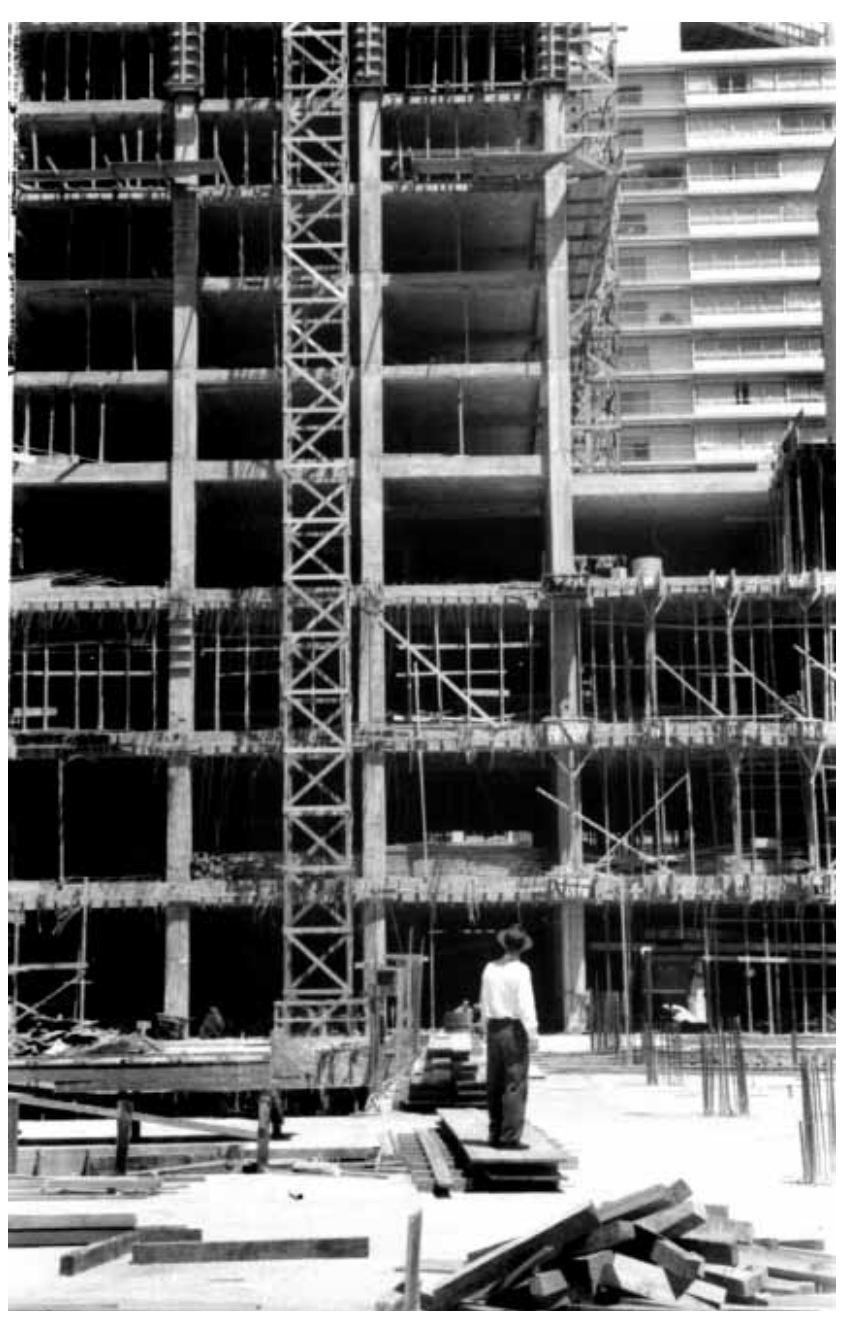


foi no entanto concluído. Nas palavras de Salvador Candia:

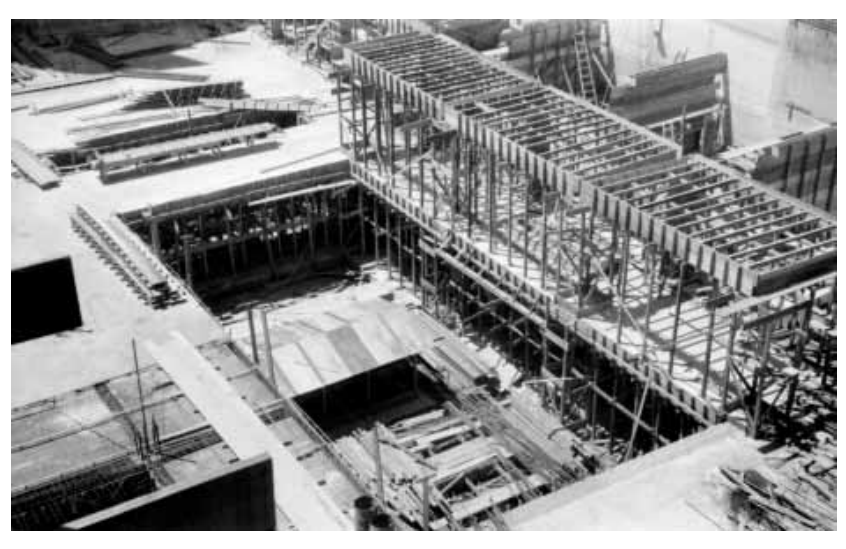

Nesta página:

Edifício Metrópole

Canteiro de obras

Cimbramento do piso das
galerias.

fonte: arquivo S. Candia

Página anterior:

Edifício Metrópole,

Canteiro de obras.

Vista da torre em construção. Ao fundo, o edifício "Louvre", na

avenida São Luiz.

fonte: arquivo S. Candia
Não posso olhar para o prédio da rua São Luís porque nós o detalhamos até os mínimos detalhes e ele foi feito com cores diferentes, com proporções diferentes, com materiais diferentes, não foi terminado em cima, os forros não são aquilo que tínhamos imaginado. Mas alguma coisa sobra. O que sobrou é aquele vazio de pavimentos superpostos onde também devia haver uma espécie de Calder. Eu imaginava que devia ter umas fontes para mostrar a comunicação dos andares e, ao mesmo tempo, a situação de esquina. Como acontece que lá no fundo tem um cinema, eu achava que devia ter ali um certo espaço para ligar os vários pavimentos e inclusive o exterior. Isso está feito lá, muito mal feito, mas está. Foi uma intervenção no sentido urbano. ${ }^{11}$

Apesar de todas as alterações realizadas durante e após a sua construção, o edifício Metrópole mantém a sua integridade pela força de seu partido de implantação. A forma como se associa à praça Dom José Gaspar, formando uma sucessão de espaços públicos, confere a este edifício um sentido marcadamente urbano, conforme a definição do próprio arquiteto. 11 CANDIA, Salvador In Arquitetura e desenvolvimento nacional: depoimentos de arquitetos paulistas. São Paulo: Instituto de
Arquitetos do Brasil - departamento de São Paulo e editora Pini, 1979 


\section{Edifício J oelma}

Conjunto de Garagens, escritórios e lojas. Área construída: 19.280m2 - 23 Pavimentos

localização Praça das Bandeiras, São Paulo

material Projeto Executivo, 1968-69/ Projeto de reforma, 1979

fonte

Arquivo S. Candia

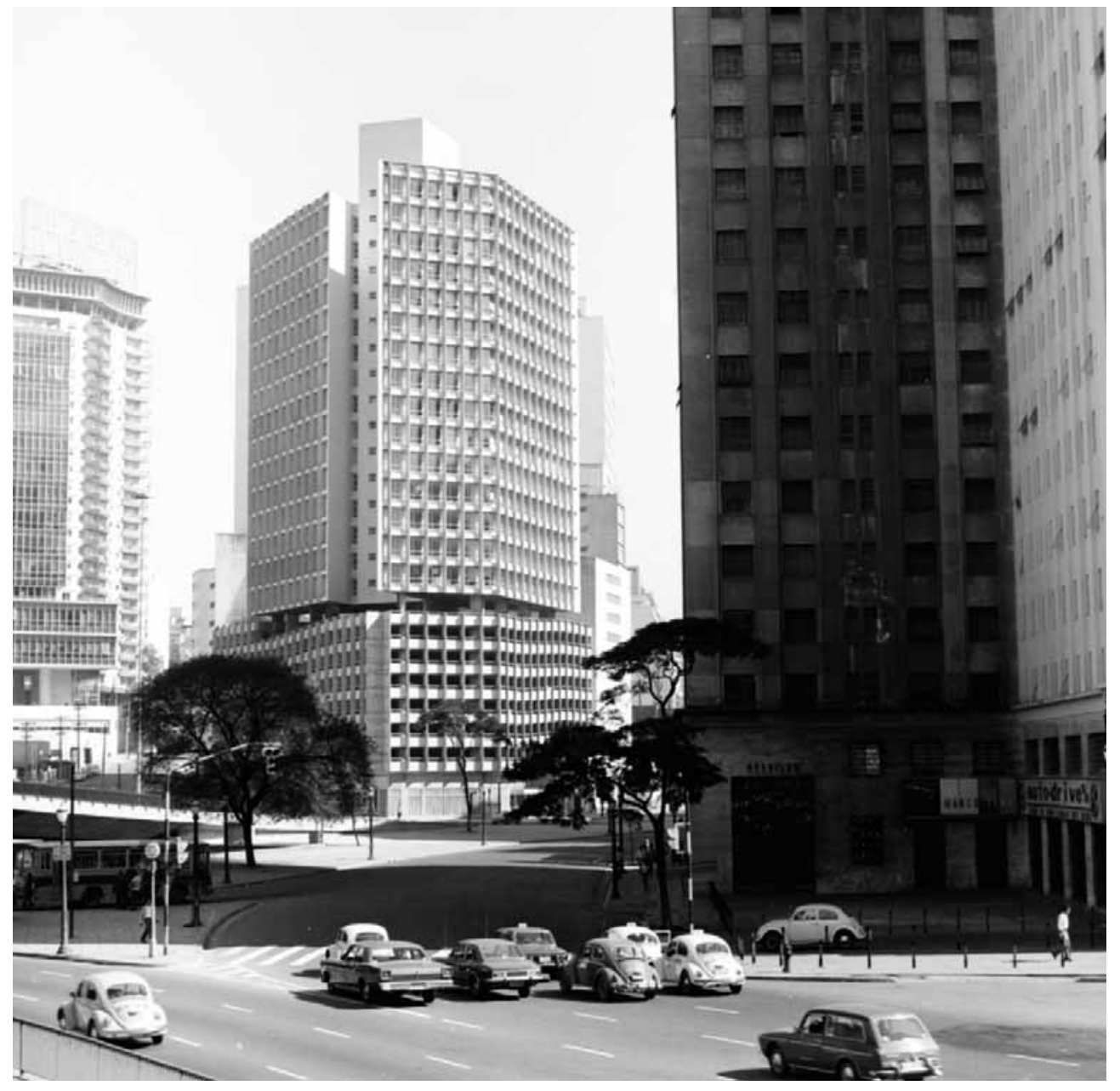

O edifício Joelma, como "Ponto Focal" visto a partir da Avenida Anhangabaú. fonte: arquivo S. Candia 
O Joelma é uma coisa muito difícil, um pentágono esquisito, é uma espécie de triângulo. Tinha que ter uma garagem em baixo, dois prédios de escritórios em 1.500 metros quadrados de terreno. É um problema extremamente difícil, mas acho que foi razoavelmente bem resolvido, principalmente porque ele tem um pouco daquilo que eu gostaria que fosse minha arquitetura. E também porque acho que aí reencontrei - não é que reencontrei o Brasil -, fiz uma síntese daquilo que acho que tem de ser arquitetura brasileira, com as coisas todas que eu li, sobre as quais conversei, que eu vi nos Estados Unidos, na Inglaterra, com aquelas bolsas, com aqueles prêmios e tudo o mais que eu não contei. ${ }^{1}$

O edifício Joelma caracteriza-se pela acomodação de um conjunto complexo de garagens, escritórios e lojas com uma área que excede em 15 vezes a superfície do seu terreno. $^{2}$

Situado em uma esquina de grande importância simbólica na área central da cidade, encerrando a frente Sudoeste do recinto do vale Anhangabaú, o edifício pontua o desfecho da avenida 9 de Julho junto à praça das Bandeiras, no encontro das vertentes sul do sistema "Y" de avenidas proposto por Prestes Maia. O terreno define-se pelo encontro oblíquo entre a avenida 9 de Julho e a rua Santo Antônio, formando um triân-

\footnotetext{
1 CANDIA, Salvador. Arquitetura e desenvolvimento nacional - depoimentos de arquitetos paulistas. São Paulo: Pini/IABSP, 1979

2 O edifício Joelma abriga aproximadamente $7.000 \mathrm{~m}^{2}$ de escritórios, $8.000 \mathrm{~m}^{2}$ de garagens, $1.300 \mathrm{~m}^{2}$ de lojas e acessos, servidos por um núcleo de circulação vertical de $3000 \mathrm{~m}^{2}$, perfazendo $19.300 \mathrm{~m}^{2}$ implantados sobre um terreno de $1.300 \mathrm{~m}^{2}$
} 


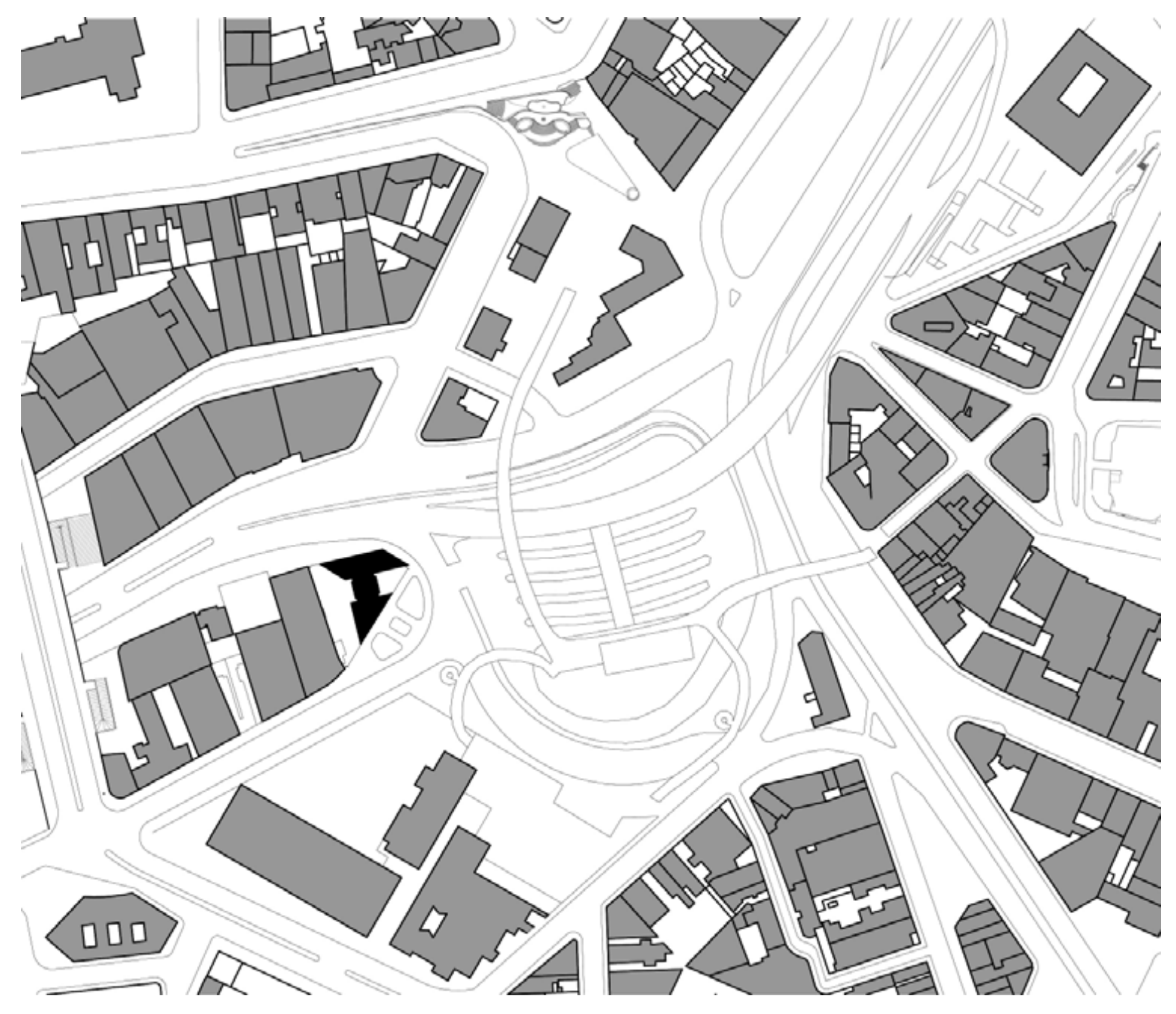


gulo incompleto com desnível suave de aproximadamente 4 metros em direção ao vale do córrego Saracura, situado sob a avenida.

O edifício é dividido em duas partes funcionais autônomas: os escritórios estão dispostos em uma dupla torre de quinze andares que ocupa a frente do terreno, marcando a esquina. $\mathrm{O}$ estacionamento desdobra-se em rampas helicoidais sucessivas até o sétimo pavimento, conformando o embasamento do edifício. Enquanto a torre se destaca dos vizinhos e faz frente ao Anhangabaú, o embasamento ocupa todo o perímetro do lote e dá continuidade às construções vizinhas.

à direita: Edifício Joelma São Paulo. Salvador Candia, 1968 Candia

página anterior: desenho realizado sobre bases diversas.

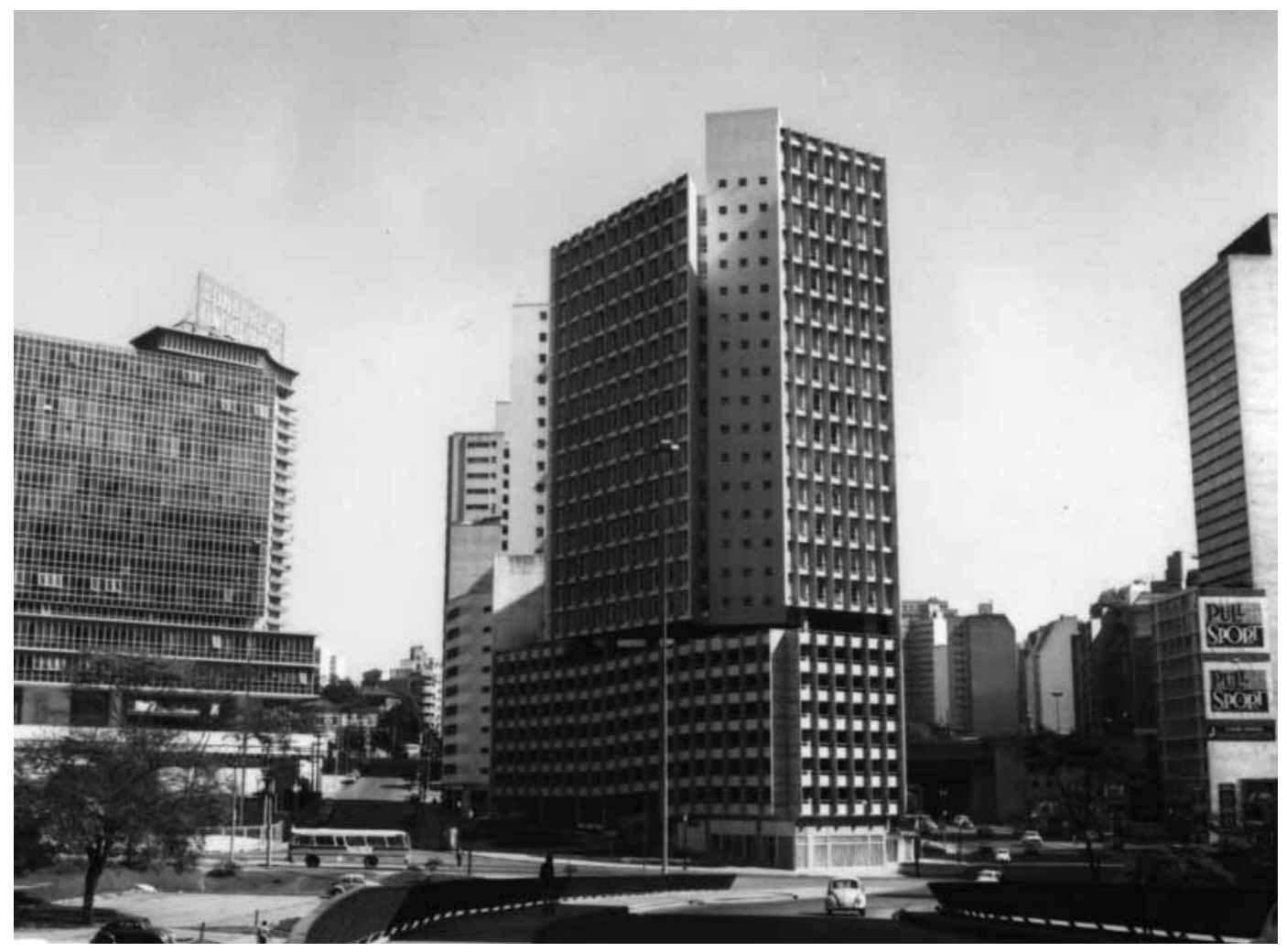




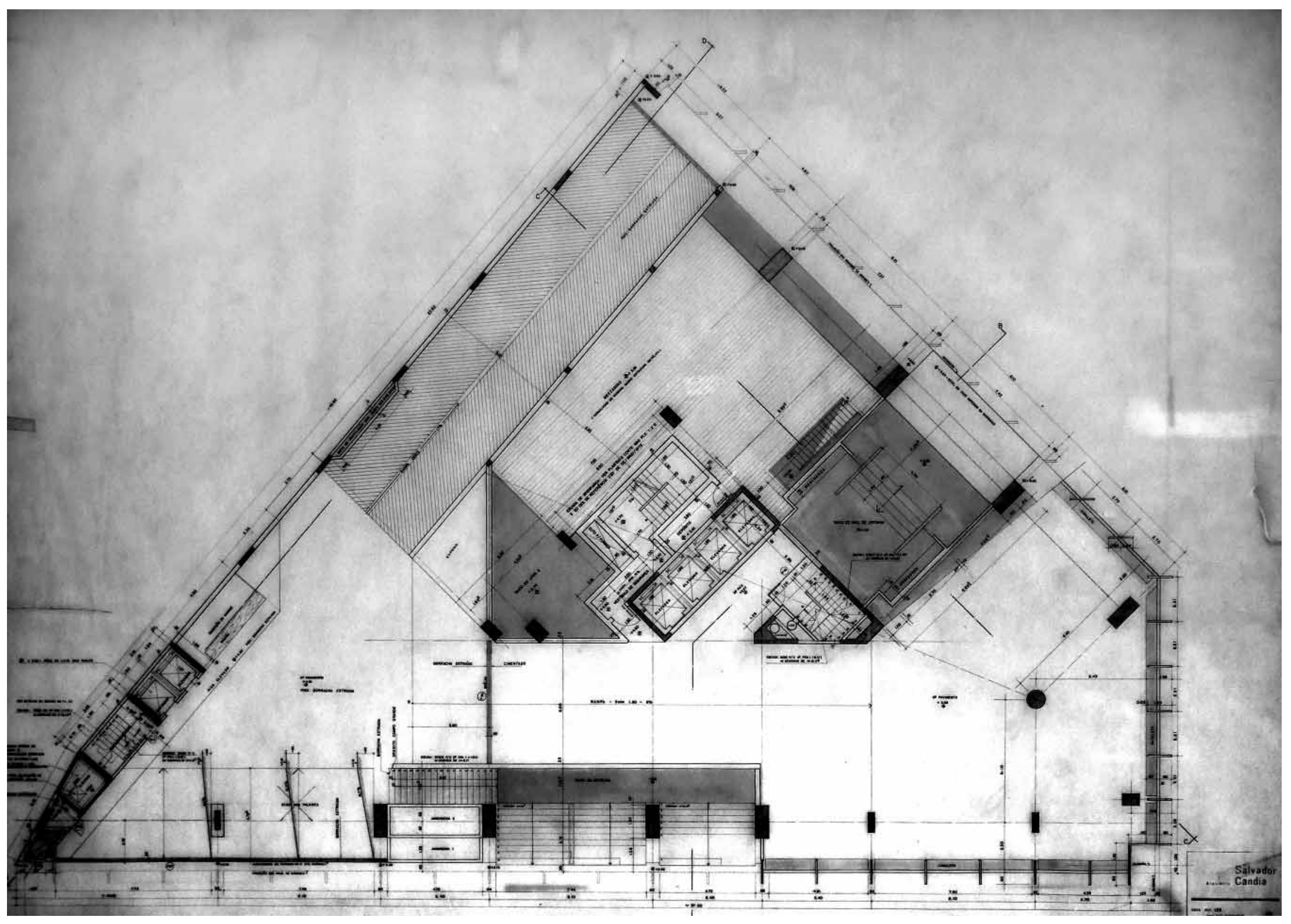



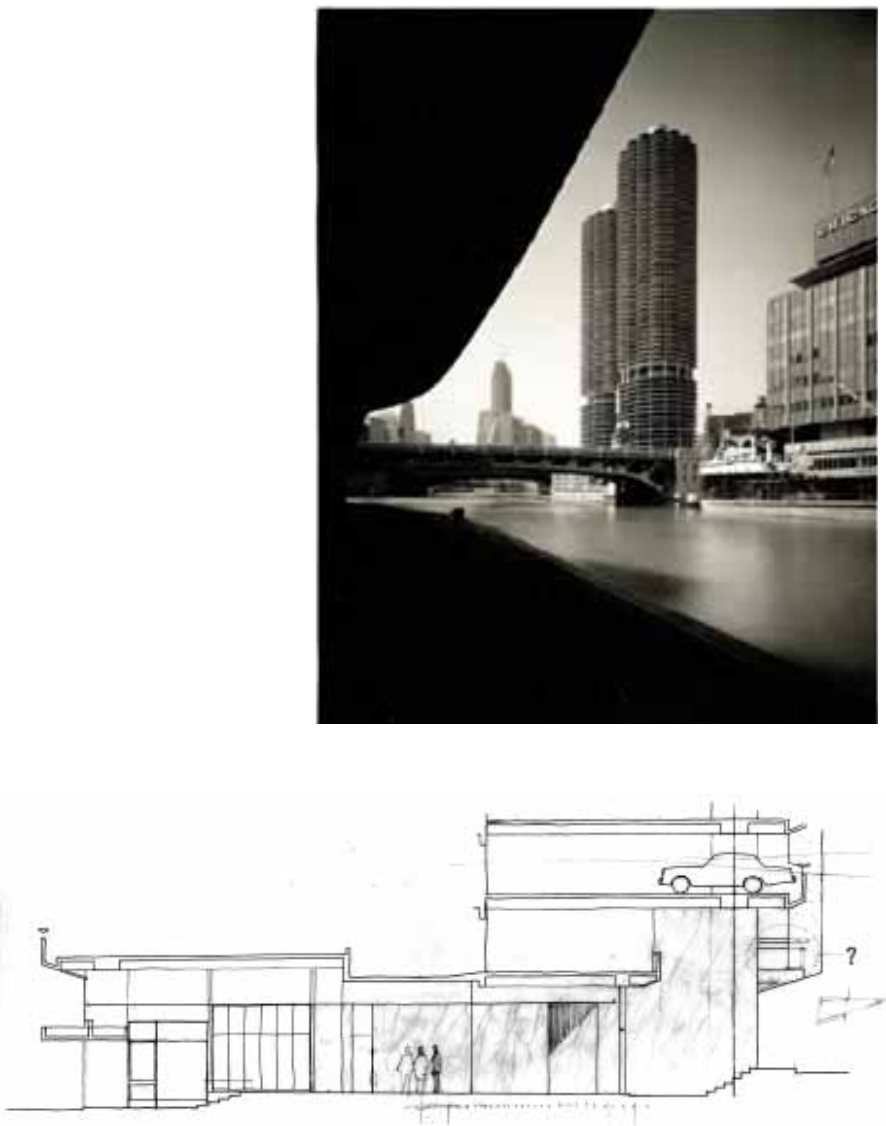

acima:

Conjunto "Marina City", Chicago

Bertrand Goldberg, 1959.

fonte: idem (nota de rodapé)

em baixo:

Edifício Joelma, Estudo do acesso sob o embasamento. fonte:

arquivo S. Candia

página anterior:

Edifício Joelma, São Paulo.

Planta do Mezanino sobre o pavimento de acesso. Notar a rampa

de acesso de automóveis e a galeria para pedestres que dão

acesso às duas ruas.

\section{Embasamento: o problema das garagens}

O programa das garagens urbanas havia sido objeto de estudo por Rino Levi nas décadas anteriores, tendo sido proposto como problema didático aos seus alunos da FAU USP em 1955. ${ }^{3}$ Anos depois, como professor no Mackenzie, Candia viria a empregar o mesmo programa como tema de reflexão aos seus alunos. ${ }^{4}$

A solução das rampas do Joelma é análoga ao projeto da Garagem Copana (1956), de Levi. ${ }^{5}$ Um sistema semelhante de garagens helicoidais, constituindo o embasamento de um edifício vertical de programa misto fora também empregado no célebre conjunto de "Marina City" em Chicago (1959), pelo ex-aluno da Bauhaus Bertrand Goldberg. ${ }^{6}$ Este edifício tornou-se um modelo de ocupação das áreas centrais de cidades norteamericanas por um determinado período após a sua construção.

No Joelma as garagens são dispostas em um conjunto trapezoidal de rampas e patamares sucessivos, perfazendo um embasamento funcionalmente autônomo em relação ao restante do edifício, com uma prumada de circulação vertical independente. Duas passagens de acesso distintas, uma para automóveis e outra de pedestres, atravessam os pavimentos térreos do edifício de uma face a outra, vencendo o desnível de quatro metros existente entre a rua Santo Antônio e a avenida 9 de Julho. As lojas ocupam todo o perímetro restante da fachada junto às calçadas.

\footnotetext{
3 Ver Capítulo II

4 LOTUFO, Vitor. Depoimento prestado ao autor em 4-12-2008.

5 ANELLI (2001. p. 194)
}

6 Bertrand Goldberg's speech about Marina City presented at the seminar on "Architectural Aspects of Edmonton Civic Centre Plan," Edmonton, Alberta, Canada. September 27, 1959, Disponível em: <http://www. marina citylMarina City, Chicago - Bertand Goldberg.mht> . Acesso em: 28 maio 2007. 


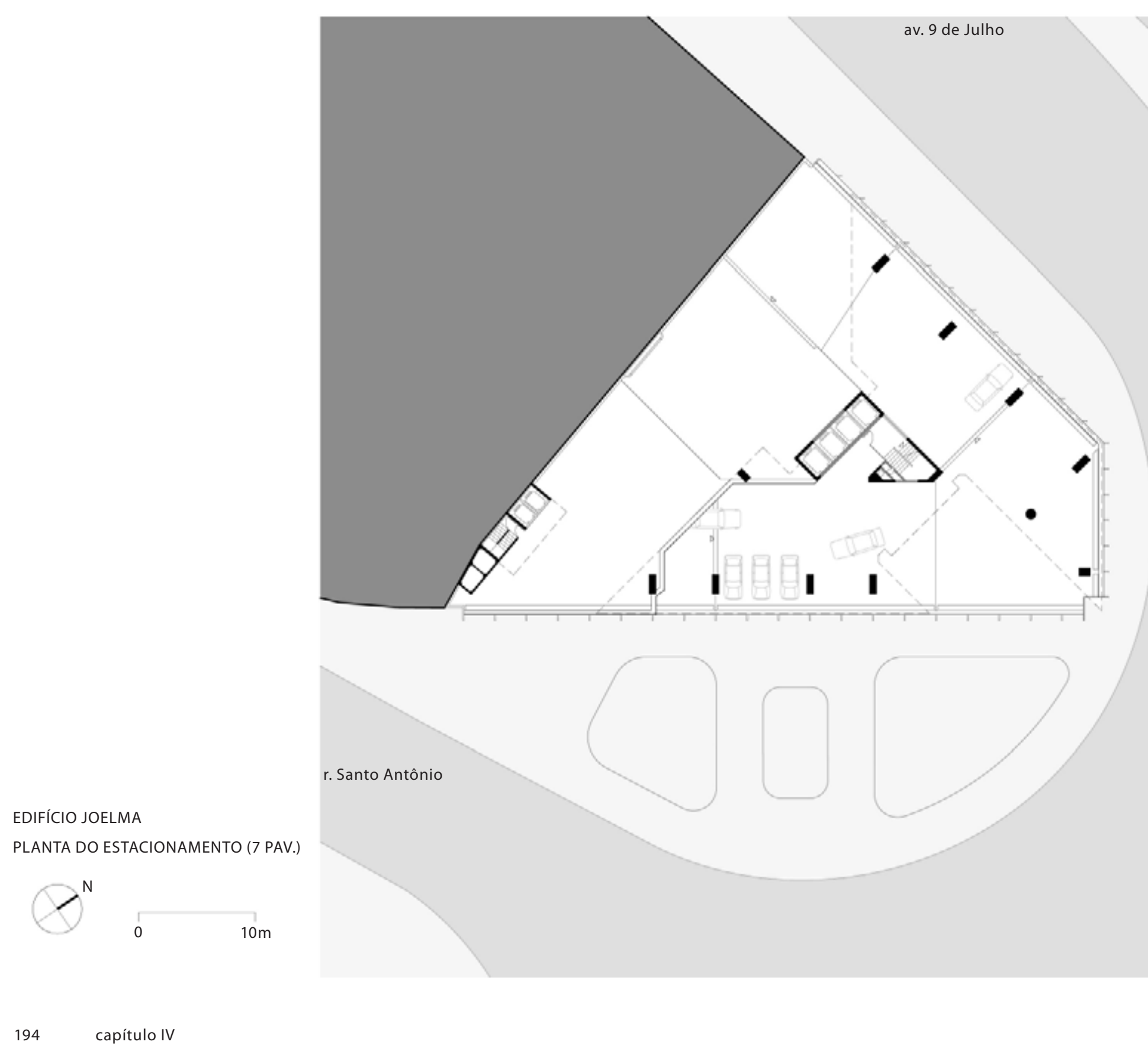




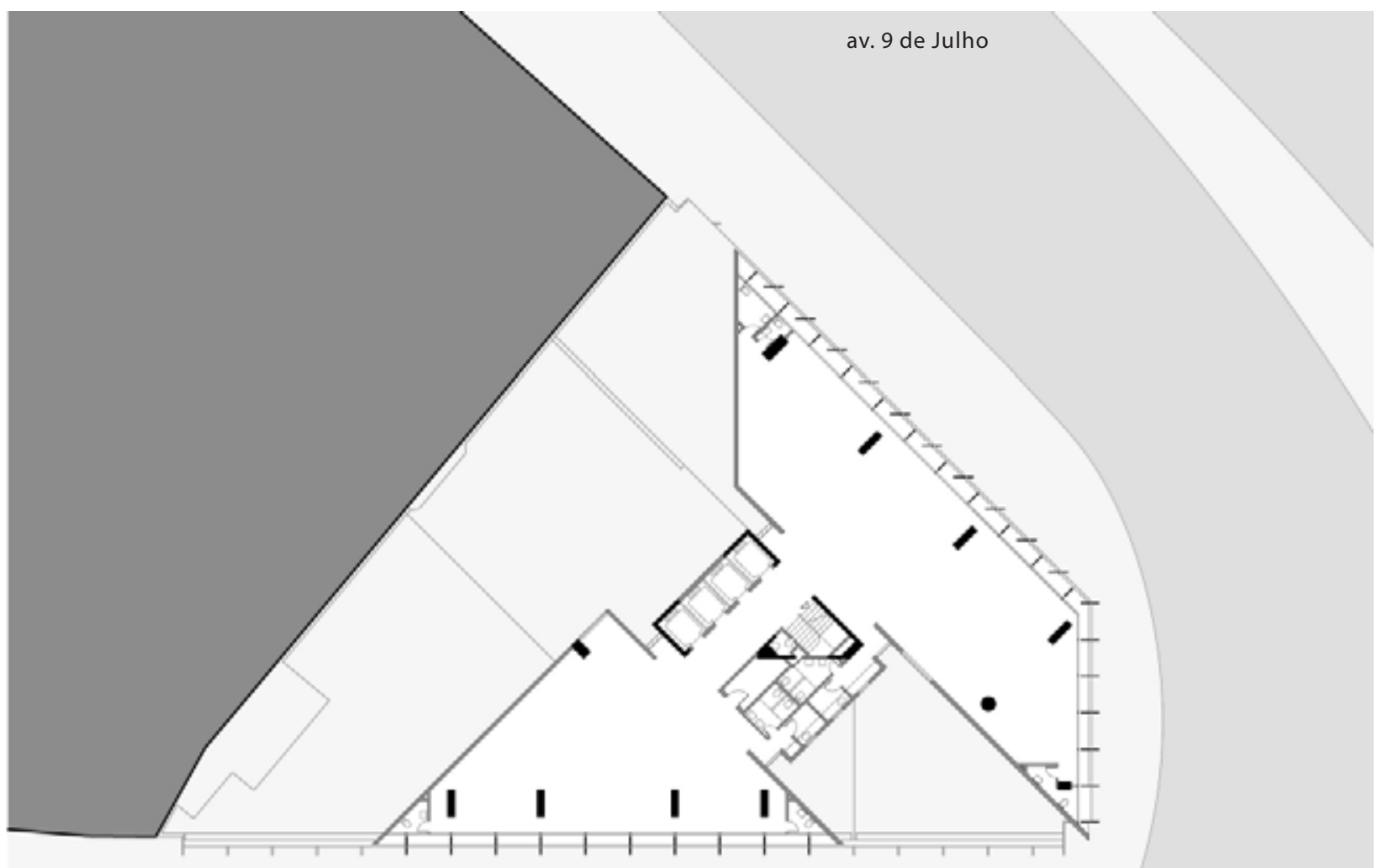

EDIFÍCIO JOELMA

PLANTA DO PAVIMENTO TIPO

N
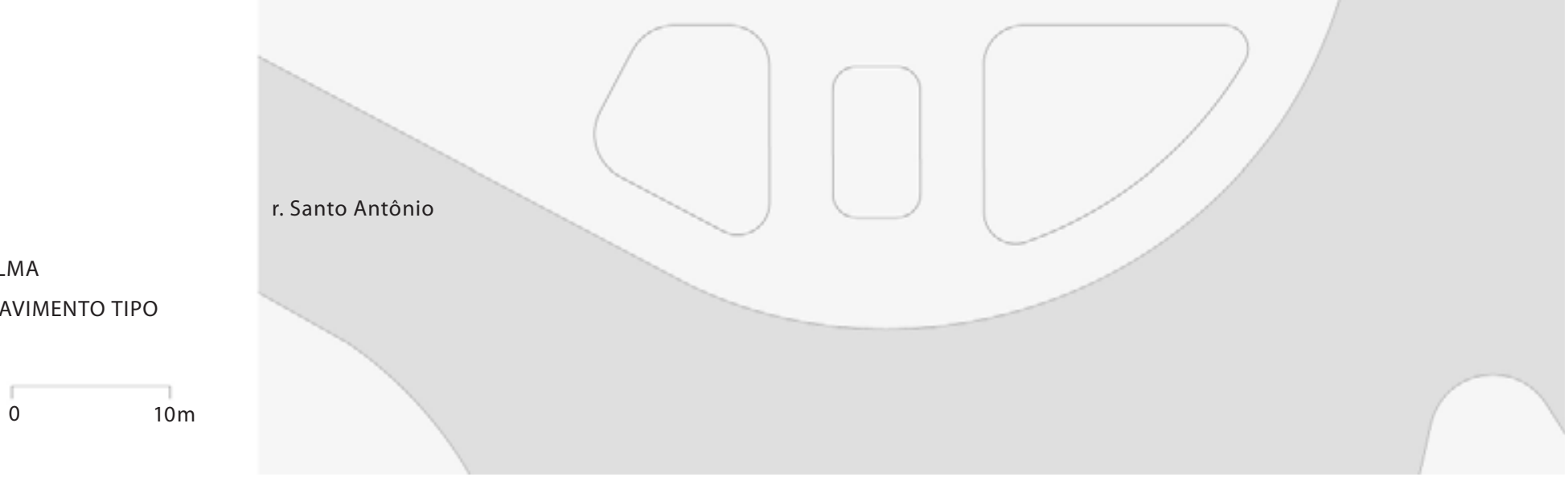

leitura de três projetos

195 

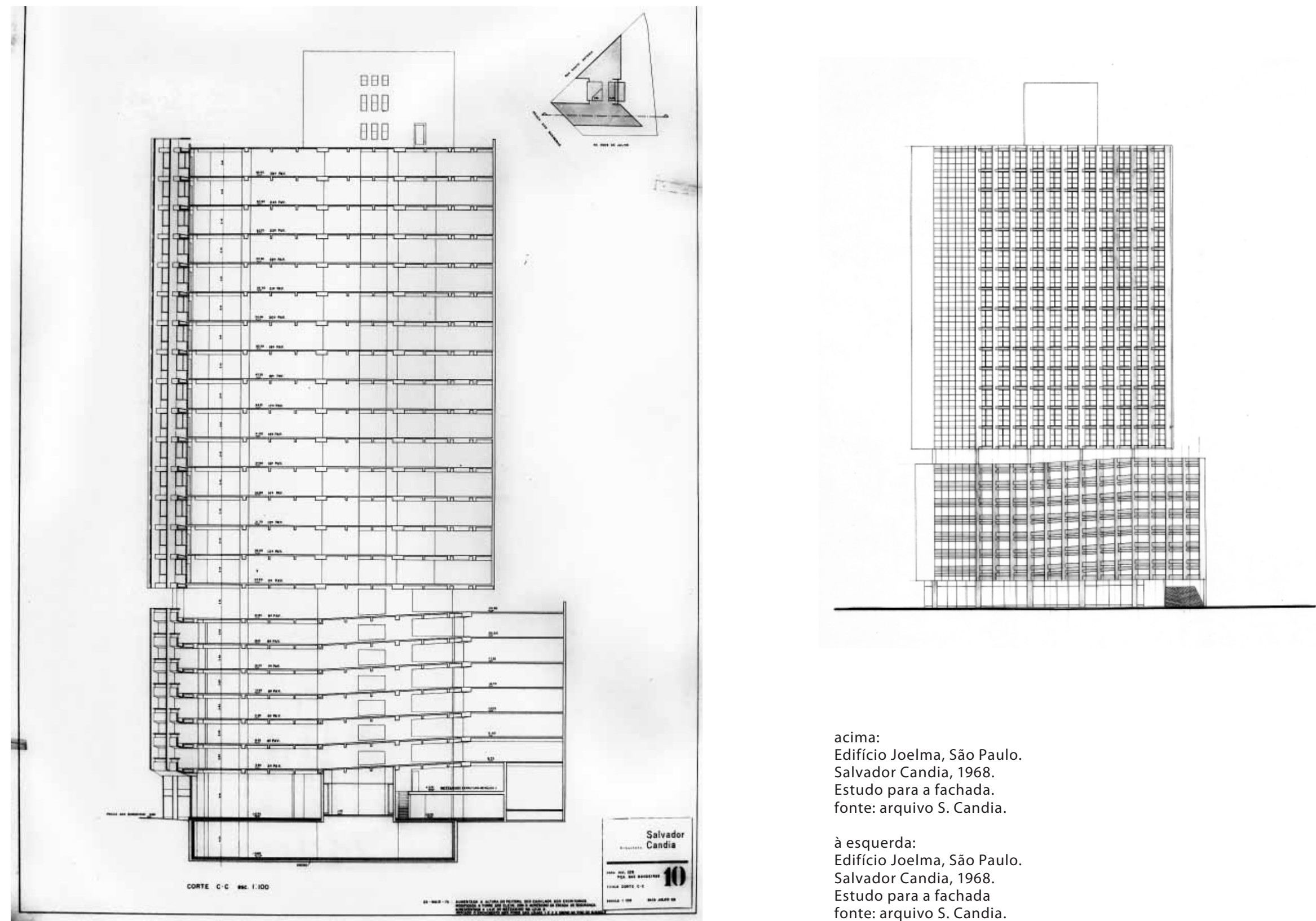

acima:

Edifício Joelma, São Paulo.

Salvador Candia, 1968.

fonte: arquivo S. Candia.

à esquerda:

Edifício Joelma, São Paulo.

Salvador Candia, 1968.

Estudo para a fachada

fonte: arquivo S. Candia. 


\section{Duas torres solidárias}

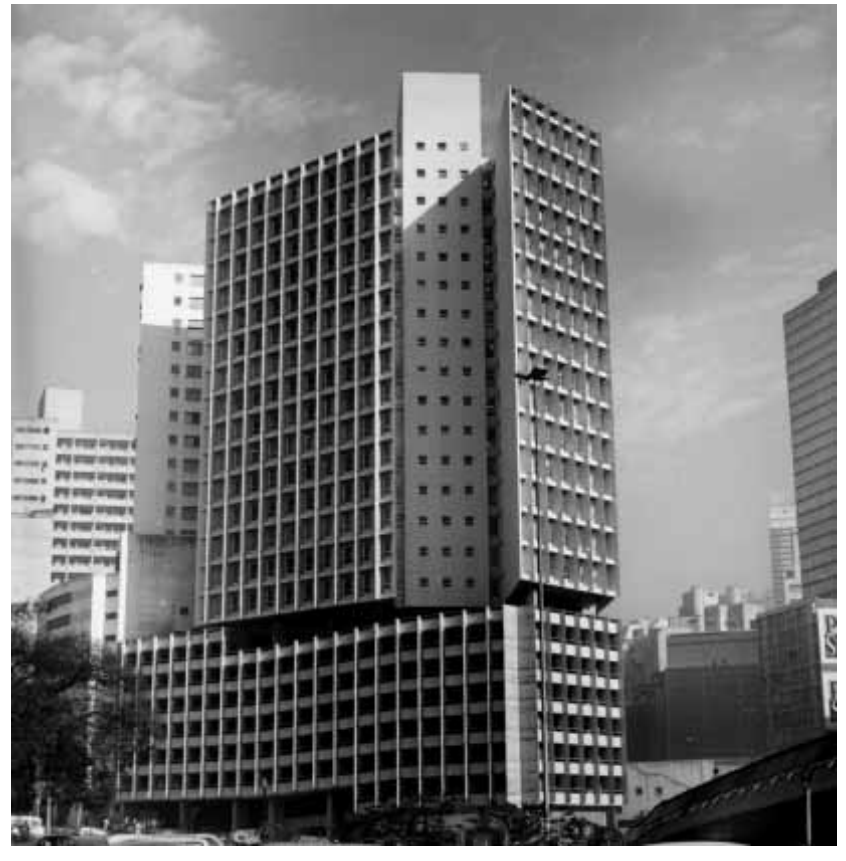

acima: Salvador Candia, 1988 fonte: arquivo S. Candia.
Duas torres de 15 pavimentos de escritórios se acomodam na proa do terreno e são servidas por uma única prumada de circulação vertical e de áreas de apoio (copas, sanitários e depósitos). A geometria destes volumes se destaca dos lotes vizinhos, constituindo um elemento autônomo que pontua o desfecho da quadra perante à praça, em cumprimento às diretrizes urbanísticas sugeridas por Prestes Maia para o arremate dos pontos focais estabelecidos pelos grandes eixos viários. Nas palavras de Salvador Candia:

Os desenhos destacam as dificuldades de relacionar níveis, acessos, espaços de estacionamento e trabalho, estrutura e um detalhamento delicado a fim de harmonizar os volumes diversos em funções e formas através de uma "unidade expressiva" compatível com o ponto focal da Praça das Bandeiras.?

O desenho das plantas adota os ângulos de $45^{\circ}$ e $135^{\circ}$ existentes na figura trapezoidal do lote. A geometria resultante, associada ao ritmo dos quebra-sóis verticais modulados a 2.70 metros, proporciona um volume que varia radicalmente a partir da mudança do ponto de vista do observador. O vazio criado entre a torre de escritórios e os edifícios vizinhos é parcialmente encerrado pelas faces angulares do novo edifício, criando situações inesperadas para o observador em movimento a partir da avenida 9 de Julho.

7 CANDIA, Salvador. Curriculum Vitae e Obras Executadas, São Paulo, Arquivo Salvador Candia, [1980] 

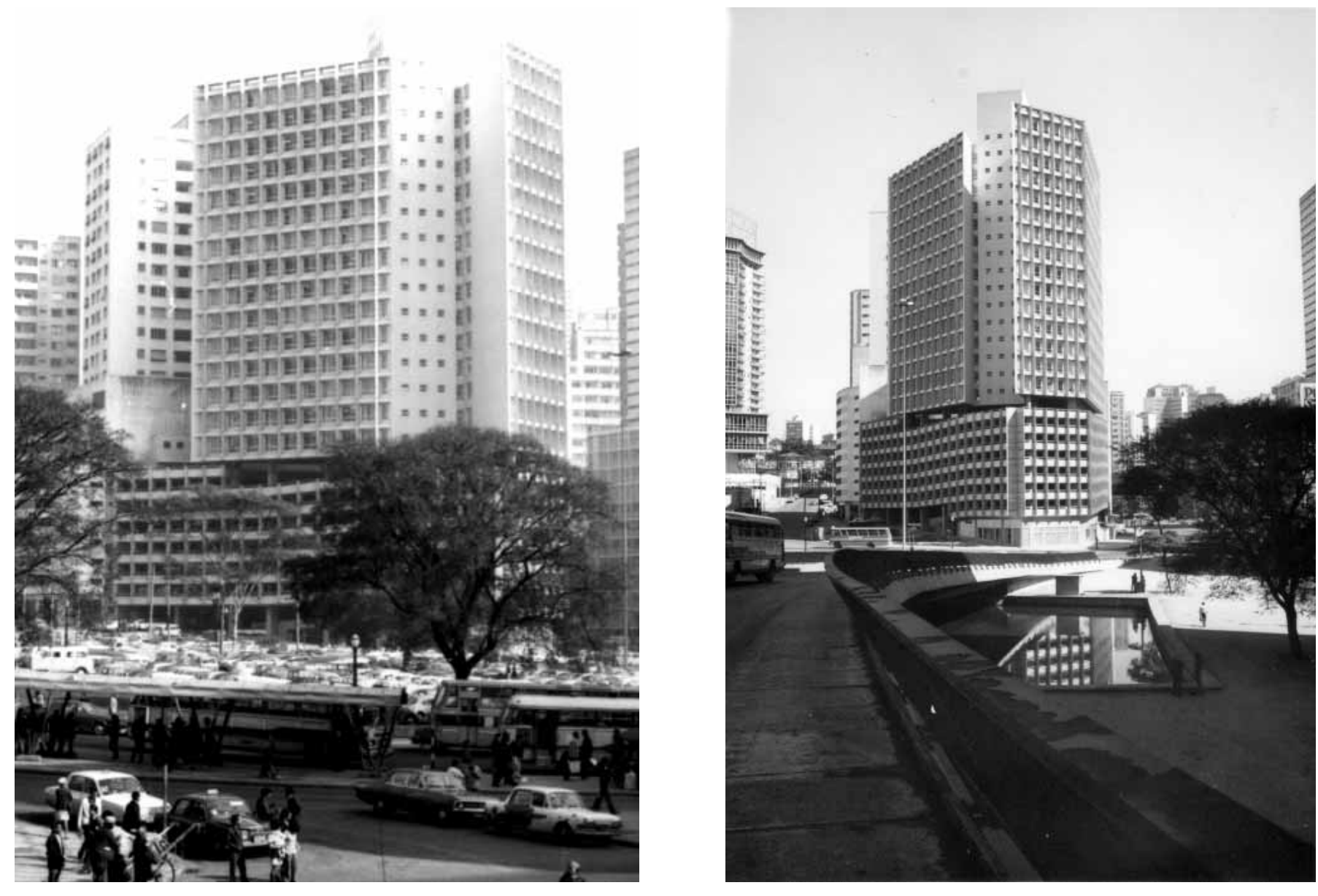

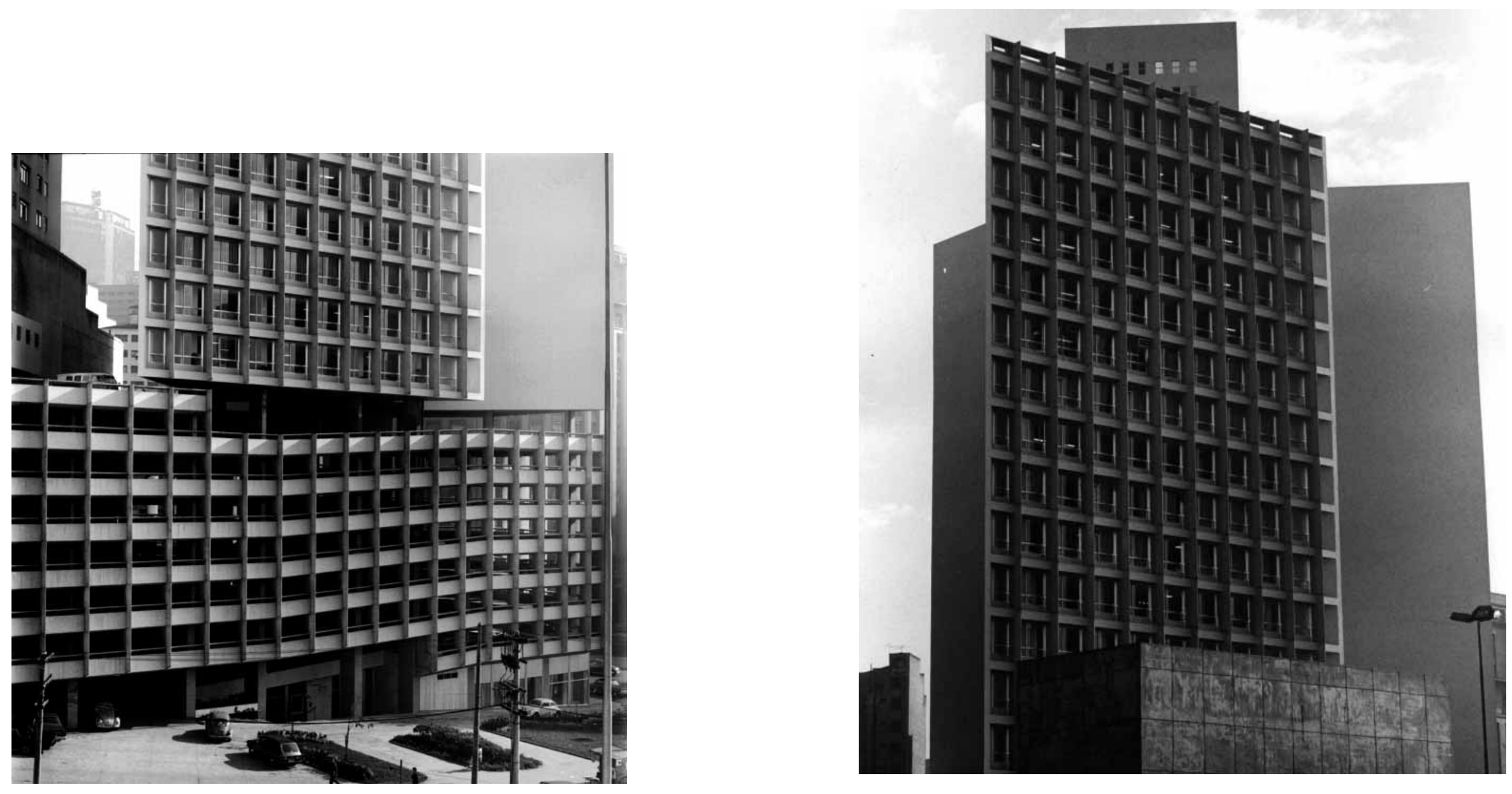


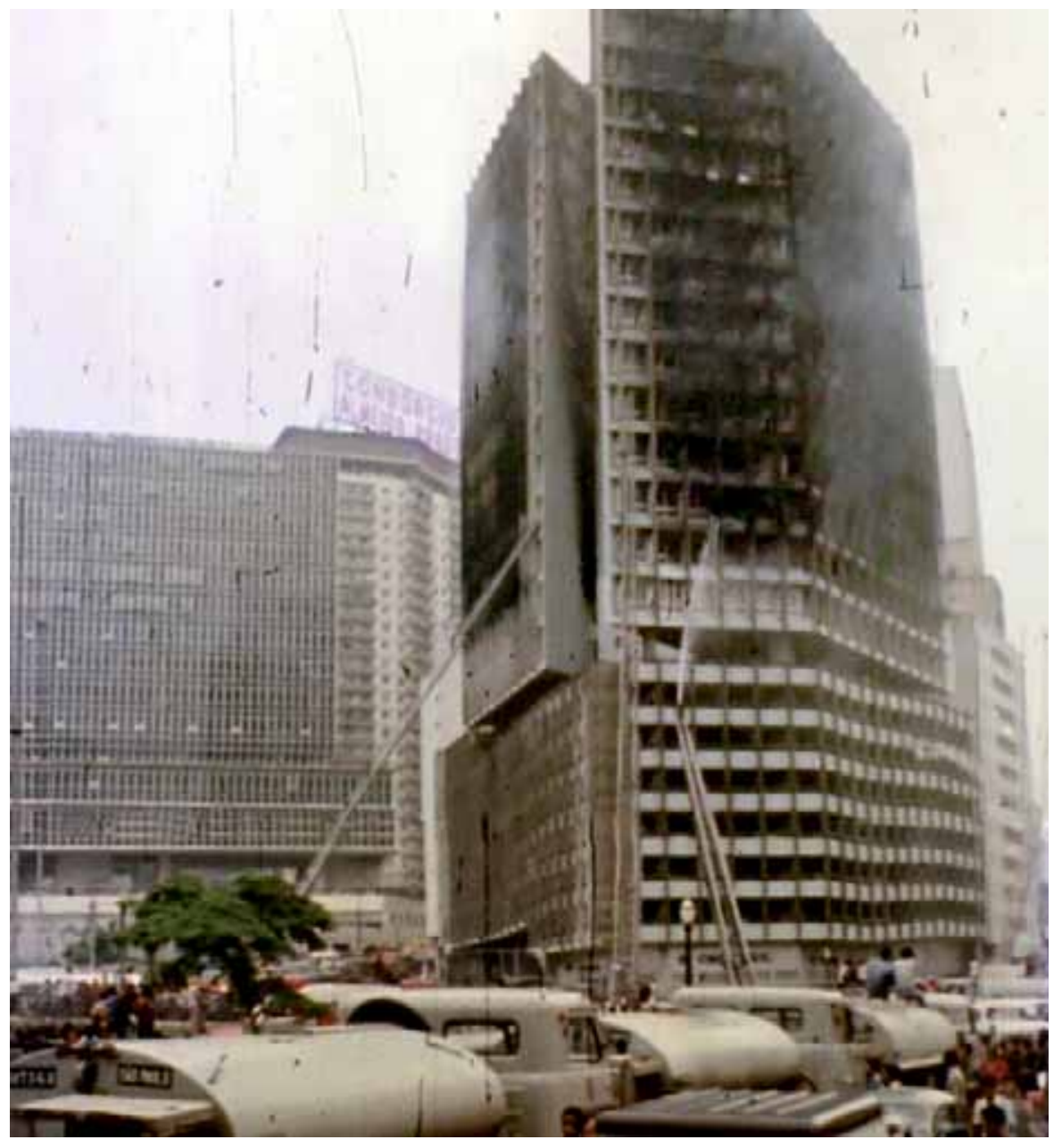

Montagem fotográfica

feita a partir da

filmagens originais

exibidas em:

A $23^{\circ}$ ANDAR

Direção: Clery Cunha,

São Paulo, 1980.

DVD (80 mim.). 


\section{Incêndio}

No dia primeiro de Fevereiro de 1974, cerca de três anos após a sua inauguração, o edifício sofreu um incêndio que resultou na maior tragédia vivida pela cidade até aquele momento, onde 179 pessoas morreram em um período de cinco horas. ${ }^{8}$ A causa do incêndio foi uma pane elétrica provocada pela instalação irregular de um conjunto de aparelhos de ar condicionado no segundo pavimento da torre de escritórios.

Tendo inicialmente consumido a estrutura de madeira do forro, o fogo se alastrou instantaneamente no momento em que rompeu a sua superfície e entrou em contato com o oxigênio. A prumada de circulação vertical, que até aquele momento se fazia comumente aberta, conduziu a fumaça e as chamas para os pavimentos superiores.

Ocorrido dois anos após o incêndio do edifício Andraus na avenida São João, São Paulo, o desastre do Joelma provocou o debate público em torno da necessidade de uma nova legislação e de um controle mais efetivo por parte da prefeitura, que passou então a adotar novas normas de segurança.

Em 1979, o Joelma passou por uma reforma de adaptação às novas normas, projetada pelo mesmo arquiteto. A nova escada de segurança foi anexada à parte posterior da prumada dos elevadores, ocupando parcialmente o vazio entre a torre e as construções vizinhas. ${ }^{9}$

8 Inferno no Joelma, Diário de São Paulo. 1 de Fevereiro de 2004, página A4

9 Há uma mudança na postura projetual do arquiteto no período que se sucedeu imediatamente ao incêndio do Joelma, que se pode constatar nas duas versões do projeto para o edifício Triton (1973-74). A segunda versão deste projeto organiza-se a partir de cinco escadas de segurança, e prevê paredes de isolamento entre os salões do pavimento tipo (ver ficha de projetos) 


\section{Conjunto em Perdizes}

\section{Conjunto de edifícios para apartamentos e garagem}

colaboração Plínio Croce e Roberto Aflalo

localização Rua João Ramalho, Perdizes

cliente Cia. Santista de Administração e Comércio

material Primeira Versão (João Ramalho): Estudo Preliminar/ Projeto Executivo 1953-54

Segunda Versão (Barão de Laguna e Barão de Ladário): Ante-Projeto, 1959-60

fonte

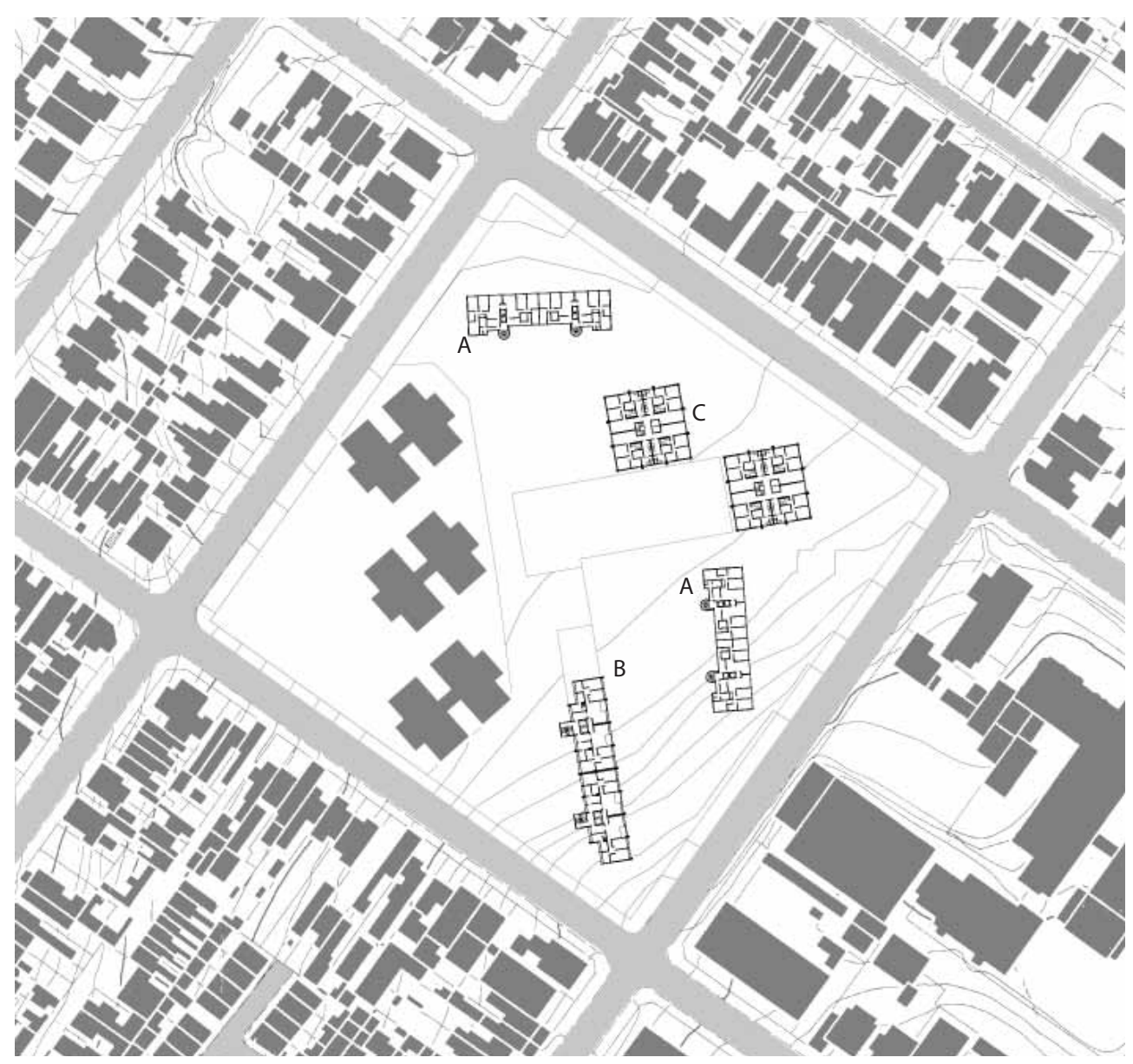

\section{LEGENDA}

A - VERSÃO I: ABELARDO DE SOUZA

Edifícios Ministro Godoy e Franco da Rocha

B - VERSÃO II: AFLALO, CANDIA E CROCE

Edifício João Ramalho

C - VERSÃO III: AFLALO, CANDIA E CROCE

Edifícios Barão de Laguna e Barão de Ladário

fonte: desenho realizado sobre bases diversas

CONJUNTO EM PERDIZES

PLANTA PAVIMENTO TIPO

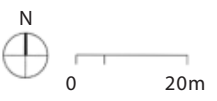



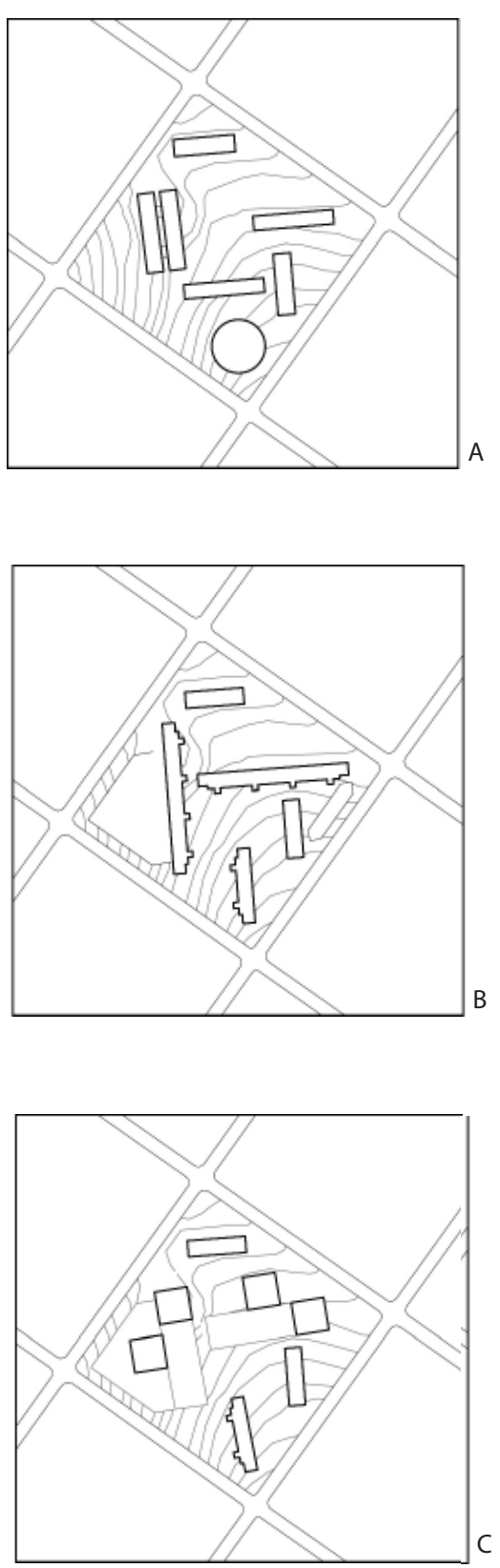

Este conjunto resultou de uma sucessão de projetos propostos para uma mesma quadra de 21.700 metros quadrados situada no bairro das Perdizes em São Paulo, entre as ruas Dr. Homem de Mello, Franco da Rocha, João Ramalho e Ministro Godoy, incorporada pelo Banco Hipotecário Lar Brasileiro no início dos anos 1950.

As tentativas iniciais de se incorporar o quarteirão integralmente em um único projeto atestam a pertinência da dimensão empreendedora desta instituição, responsável pela promoção de uma série de realizações importantes no campo habitacional, que contribuíram para a afirmação da arquitetura moderna entre a iniciativa privada naquele momento.

Situado em um bairro estruturado a partir de um parcelamento típico para residências unifamiliares, este empreendimento representou uma oportunidade de se experimentar uma ocupação urbana de caráter distinto, propondo em seus estudos iniciais um conjunto de edifícios habitacionais implantados sobre pilotis em meio a uma quadra aberta. Todavia o projeto foi sendo sucessivamente modificado através de novas versões, que atenderam às mudanças de orientação comercial de seus empreendedores, principalmente em relação à densidade ocupacional da quadra e à tipologia do apartamento comercializado.

Após a implantação parcial de quatro versões sucessivas, esta quadra acabou por perder aquelas qualidades previstas inicialmente, tendo sido posteriormente loteada em cinco condomínios distintos. Partindo-se dos projetos a que tivemos acesso, verificamse as seguintes fases de ocupação:

A primeira versão de Abelardo de Souza prevê a implantação de seis lâminas de apartamentos de treze pavimentos sobre pilotis totalizando 312 apartamentos, um edifício-garagem e um pequeno pavilhão comercial. Deste conjunto, somente dois edifícios foram construídos: o "Ministro Godoy" e o "Franco da Rocha”. A segunda versão, realizada por Plínio Croce, Roberto Aflalo e Salvador Candia, parte de uma maior densidade ocupacional para a quadra, prevendo lâminas maiores de dezenove pavimentos sobre 
pilotis totalizando 472 apartamentos (incluindo nesta soma os edifícios já construídos). Esta nova versão prevê o estacionamento implantado em semi-subsolo, além de uma área comercial de dimensões semelhantes à primeira proposta. A esta fase corresponde a construção do edifício João Ramalho (1953-54).

A terceira versão, realizada novamente pelos mesmos arquitetos do projeto anterior, prevê uma ocupação menos densamente construída, com quatro torres mais compactas em relação aos edifícios anteriores, totalizando 424 apartamentos. Neste projeto, os estacionamentos estão novamente dispostos em semi-subsolo, constituindo em sua cobertura um plano de acesso que comunica o conjunto no pavimento térreo. Desta versão foram construídas somente as torres Barão de Ladário e Barão de Laguna.

Na quarta etapa de construção da quadra, o projeto anterior foi novamente abandonado para dar lugar a mais três novas torres e uma área comercial maior, projetadas por outros arquitetos.

\section{Primeira versão do Projeto: arquiteto Abelardo de Souza}

O primeiro estudo de implantação da quadra, realizado pelo arquiteto Abelardo de Souza ${ }^{1}$ prevê a disposição de seis edifícios laminares implantados segundo a orientação Norte-Sul e Leste-Oeste, de modo a expor as áreas de longa permanência dos apartamentos predominantemente a Norte, sendo uma destas fachadas voltada exclusivamente ao poente, e duas ao nascente. A disposição dos edifícios na diagonal da quadra, rompendo claramente com os alinhamentos das ruas circundantes, deve-se ao nosso ver a dois fatores: em primeiro lugar, ao afastar a frente dos edifícios do alinhamento

1 Para a análise do projeto de Abelardo de Souza tomamos como base as publicações nas revistas: Arquitetura e Engenharia n. 31 -1954, e Acrópole n. 200, ano 17. Junho de 1955. 

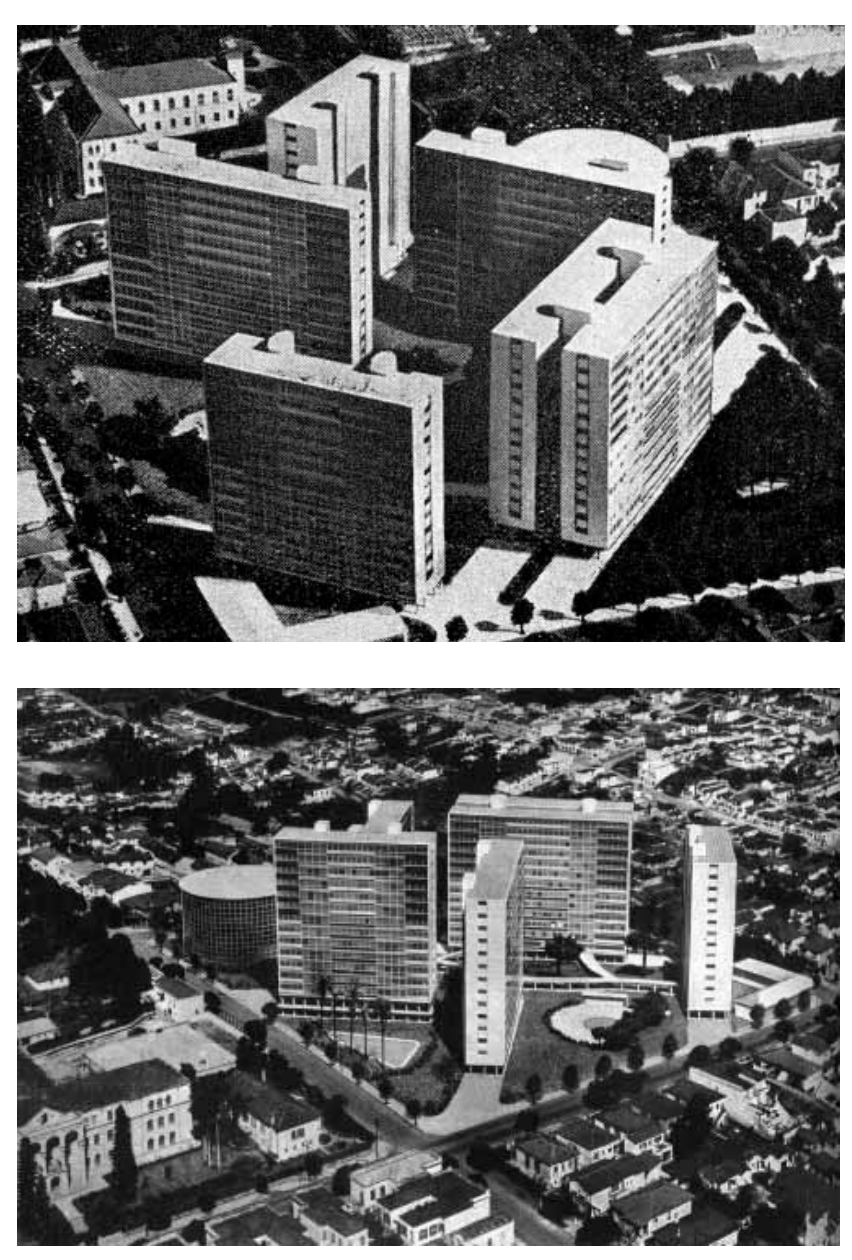

acima (duas imagens): Conjunto em Perdizes, São Paulo. Abelardo de Souza. Foto-montagem do modelo sobre o bairro. e Engenharia n.31 - 1954 do lote, o arquiteto pôde ultrapassar os gabaritos previstos, pois estes se aferiam pelo ponto médio da fachada. Em segundo lugar, esta disposição promove uma maior permeabilidade visual ao interior da quadra, com os edifícios sempre oblíquos em relação ao transeunte.

Cada edifício é servido por duas prumadas de circulação vertical dispostas a cada dois apartamentos, possibilitando a construção de unidades com dupla fachada. Como uma exceção no conjunto, dois edifícios estão associados em paralelo, conjugando as prumadas de circulação vertical de modo a atenderem a quatro apartamentos por andar.

O programa habitacional é complementado por uma pequena construção anexa destinada ao comércio, localizada na esquina entre as ruas Dr. Homem de Mello e Franco da Rocha, e um edifício vertical de garagens para 250 vagas de estacionamento, com acesso pela rua João Ramalho. Este edifício garagem - que está organizado através de rampas helicoidais sucessivas - se destaca do conjunto, implantado junto à rua João Ramalho na esquina mais elevada do terreno (cota $778.4 \mathrm{~m}$ ). O forte desnível de vinte metros existente entre esta esquina e o cruzamento com a rua Franco da Rocha é absorvido pelas áreas ajardinadas do terreno. Uma marquise determina o percurso de acesso entre os edifícios, vinculando-se a uma piscina implantada diretamente sobre o solo numa das áreas remanescentes na porção Nordeste da quadra. O conjunto conta ainda com uma área fechada destinada à recreação infantil em meio aos jardins no pavimento térreo.

Considerando o modo como este e os demais equipamentos condominais foram dispostos no terreno, podemos inferir que esta implantação supõe uma clara delimitação das áreas a serem franqueadas ao pedestre, sem a qual não seria possível distinguir as diversas áreas condominais daquelas de acesso inteiramente público. 


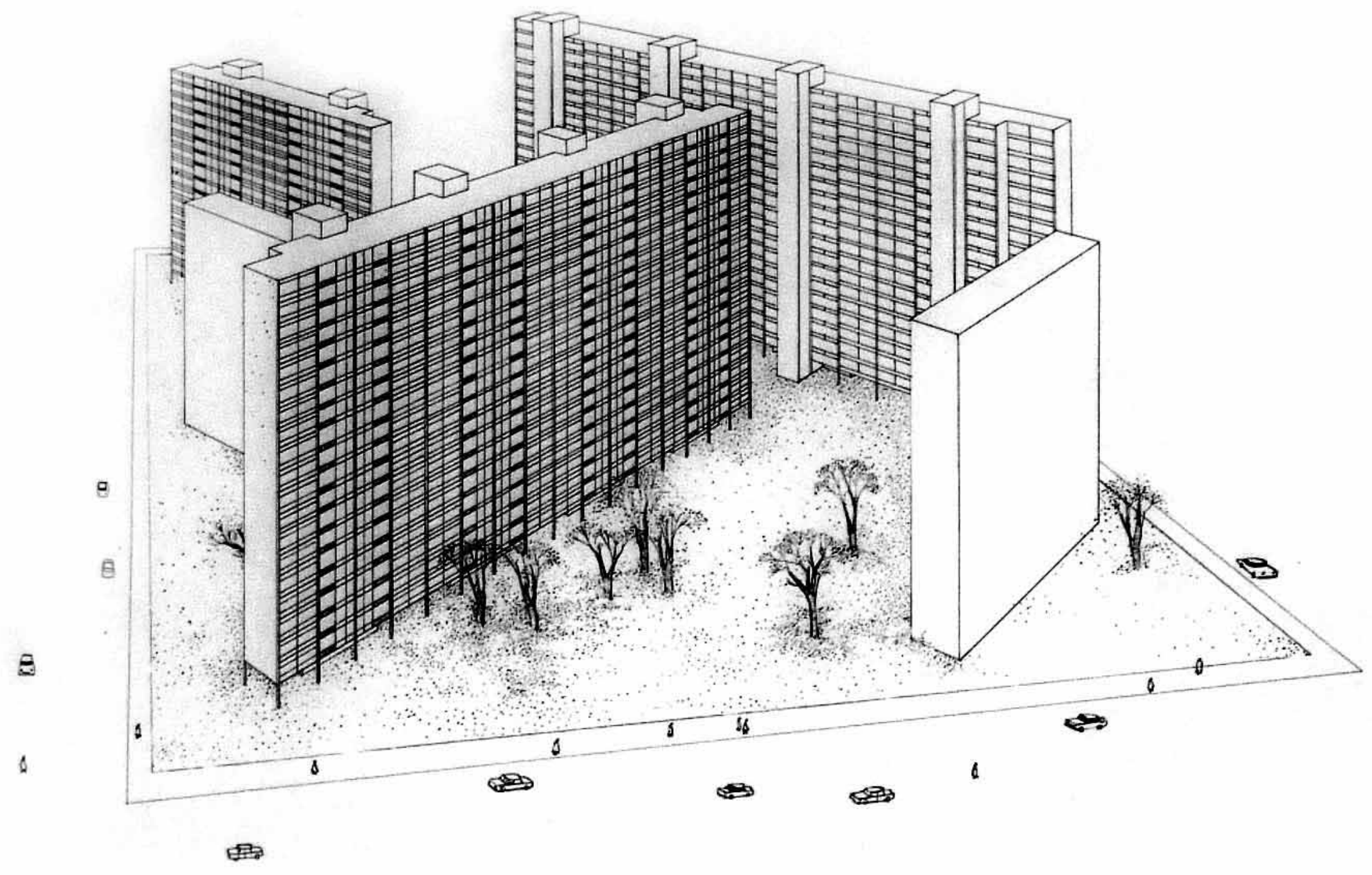




\section{Segunda versão: Aflalo, Candia e Croce}

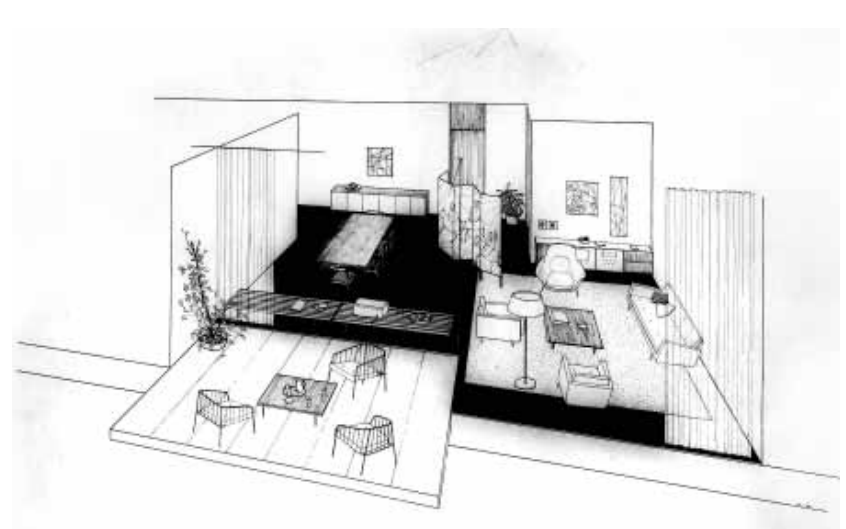

acima:

Conjunto em Perdizes, São Paulo.

Aflalo, Candia e Croce, 1953.

Perspectiva interna de um

apartamento-tipo.

fonte: arquivo S. Candia

página anterior:

Conjunto em Perdizes, São Paulo.

Aflalo, Candia e Croce, 1953.

Perspectiva do conjunto.

fonte: arquivo $S$. Candia
Este projeto apresentado por Aflalo, Candia e Croce consiste numa intervenção sobre a quadra parcialmente construída, com os edifícios Franco da Rocha e Ministro Godoy já implantados por Abelardo de Souza. O estudo parte de um acréscimo sobre o número de apartamentos previsto no plano anterior, o qual justificam:

(...) em função do alto custo do terreno, situado numa zona de transição, até agora constituído de residências individuais, mas que rapidamente são substituídas por edifícios de múltiplos andares $(. . .)^{2}$

O novo plano incorpora a matriz de orientação Norte-Sul inaugurada por Abelardo de Souza, inserindo três novos edifícios laminares organizados a partir de um mesmo sistema de distribuição das circulações verticais. Os novos edifícios propostos assumem, entretanto, uma escala mais compatível com as dimensões da quadra, e a sua implantação atenua a excessiva fragmentação dos espaços externos provocada pelo plano anterior. Os dois blocos principais propostos, contendo cada um 104 metros de extensão com 152 apartamentos dispostos em 19 pavimentos e servidos por quatro prumadas de circulação vertical, organizam os amplos espaços remanescentes, em conjunto com os dois edifícios existentes. A proposta conta ainda com um terceiro bloco de menores dimensões, implantado na porção mais elevada do terreno. Este terceiro edifício - o João Ramalho - foi o único bloco deste plano a ser implantado.

2 Memorial descritivo do projeto, datado de 26 de Julho de 1956 (Arquivo Salvador Candia) 


\section{PERDIZES}

BANCO HIPOTECARIO LAR BRASILEIRO S. A.

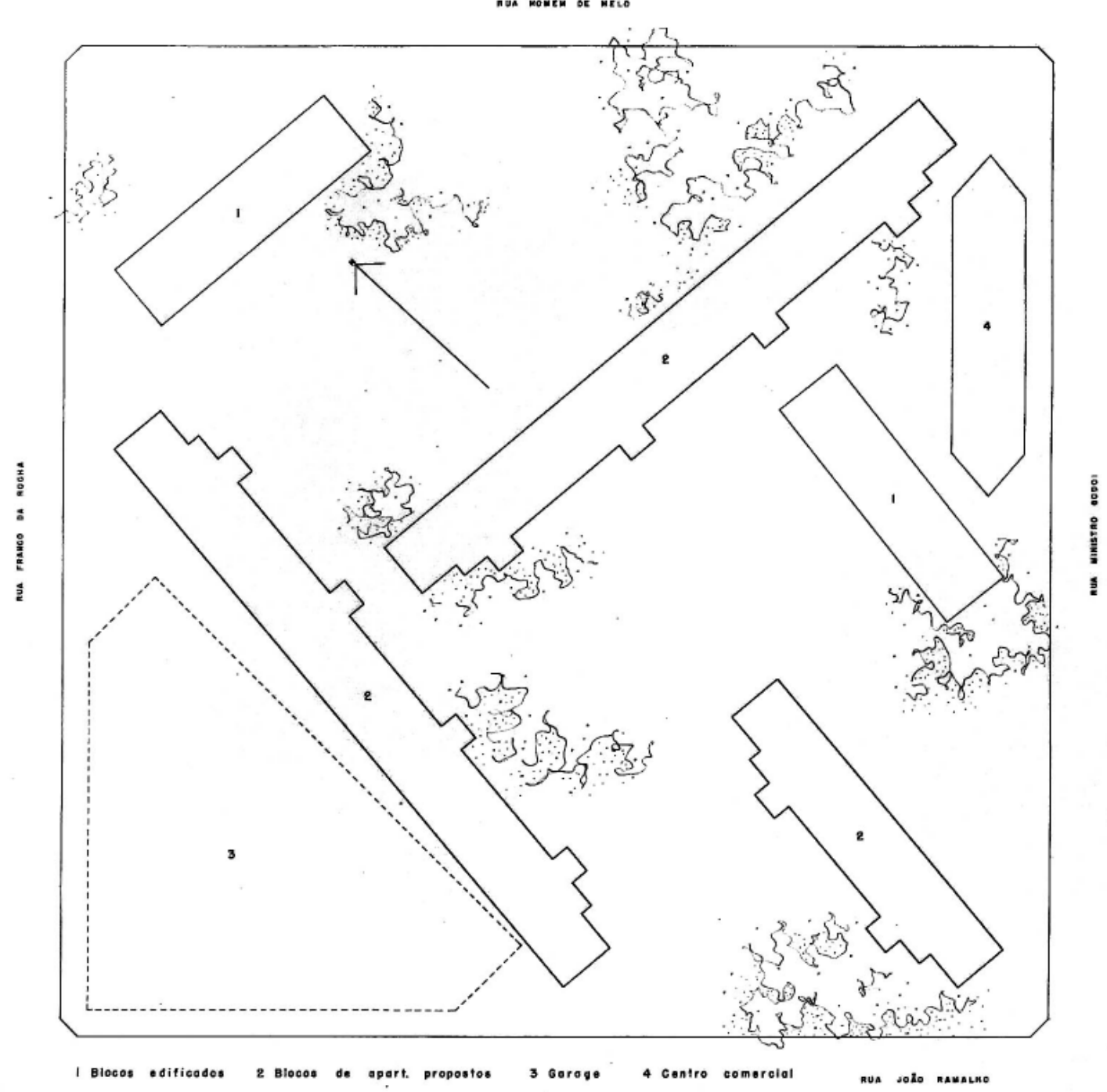

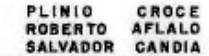




\section{Programas complementares: garagem e pequeno comércio}

O programa anteriormente previsto para estacionamento de 250 automóveis é atendido nesta versão do projeto através de um edifício que incorpora o desnível existente na esquina mais baixa do terreno (cota 757,5m), inserindo um conjunto de planos horizontais sucessivos como prolongamentos do declive:

Os pavimentos das garagens, estão localizados em uma esquina em desnível com o resto do terreno, que os projetistas utilizaram, para que os automóveis tivessem fácil e própria maneabilidade, com saídas e entradas localizadas em ruas e níveis diversos permitindo assim um tráfego fácil. O pavimento superior da garagem é um jardim suspenso, continuação do existente entre os blocos residenciais. ${ }^{3}$

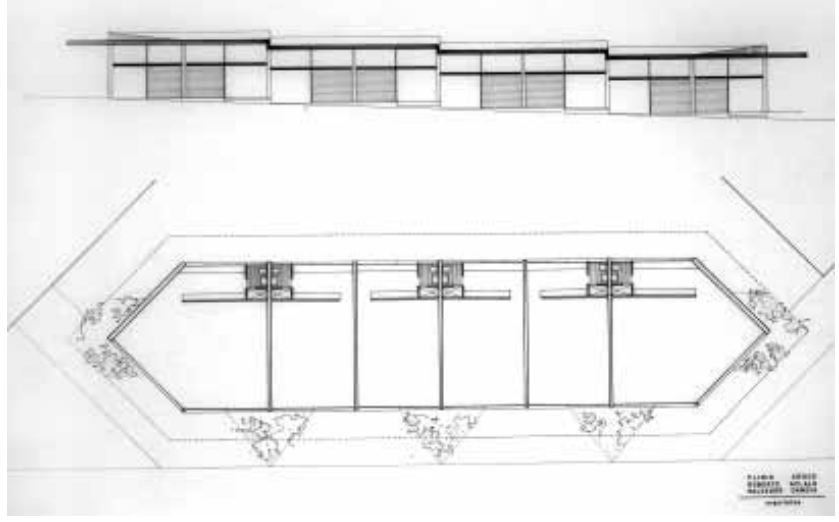

acima:

Conjunto em Perdizes, São Paulo.

Aflalo, Candia e Croce, 1953.

Planta e elevação do Pavilhão do

Comércio

fonte: arquivo S. Candia

página anterior:

Conjunto em Perdizes, São Paulo.

Aflalo, Candia e Croce, 1953.

Planta de Implantação.

3 Memorial descritivo do projeto, datado de 26 de Julho de 1956 (Arquivo S. Candia) 


\section{PERDIZES}

BANCO MIPOTECARIO LAR BRASILEIRO S. A.

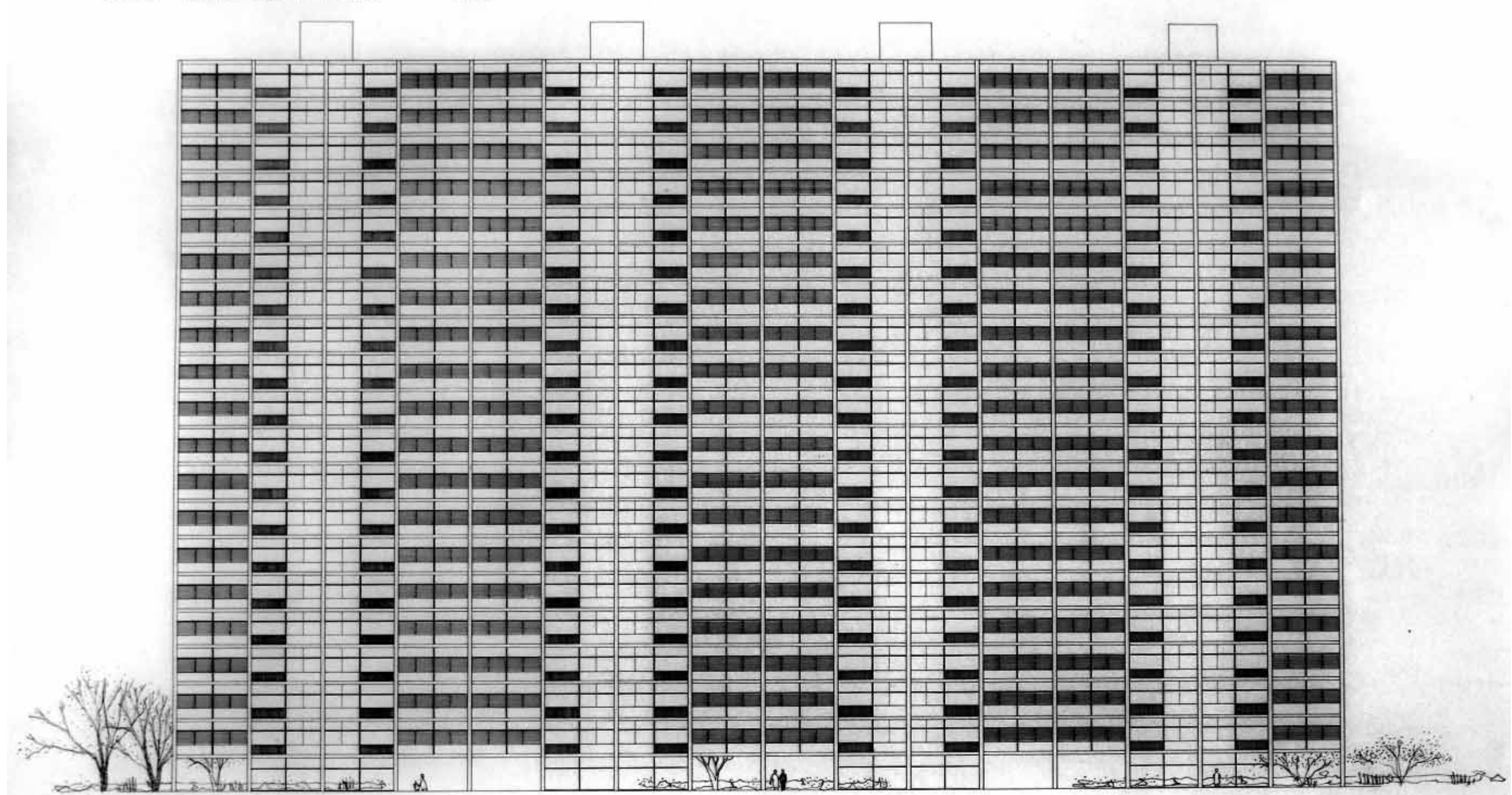

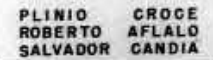

orquitetes 


\section{Desenho do chão}

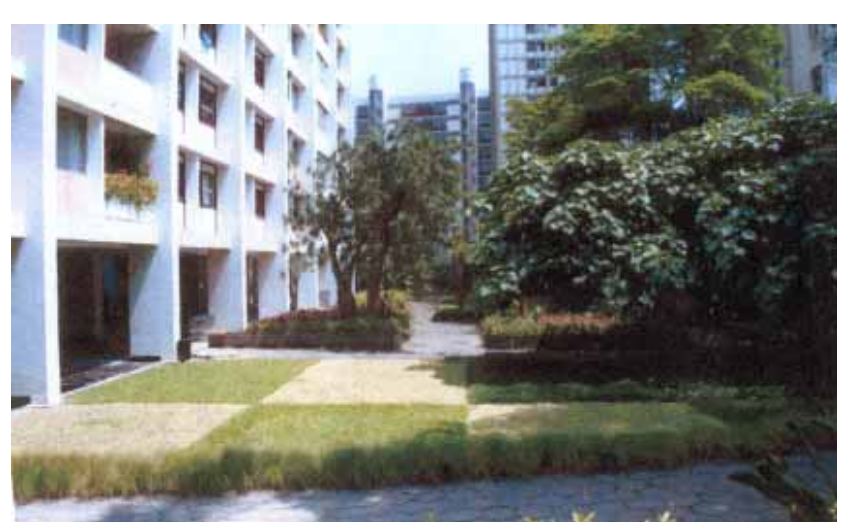

A organização do pavimento térreo proposto nesta versão do projeto indica uma quadra inteiramente aberta ao pedestre. Equipamentos condominais como piscina e área de recreação infantil, que haviam sido propostos no desenho de Abelardo de Souza em meio aos jardins no pavimento térreo, são eliminados desta nova implantação. Diversamente, o chão do edifício João Ramalho seria posteriormente tratado com um desenho de caráter fortemente urbano com os jardins de Waldemar Cordeiro, constituindo largos planos acomodados à topografia e ao passeio com muretas baixas de arrimo.

acima:

Paisagismo de Waldemar Cordeiro.

Fotografia extraída de HERBST (2002)

à direita:

Conjunto em Perdizes, São Paulo.

Aflalo, Candia e Croce, 1953.

Elevação do estacionamento

em semi-subsolo

fonte: arquivo S. Candia

página anterior:

Conjunto em Perdizes, São Paulo.

Aflalo, Candia e Croce, 1953.

Elevação de um dos edifícios maiores.

fonte: arquivo $\mathrm{S}$. Candia

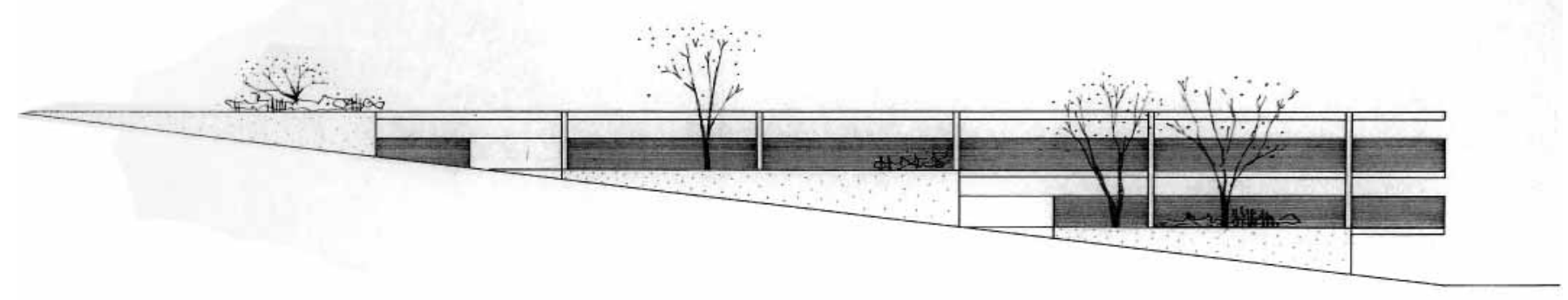




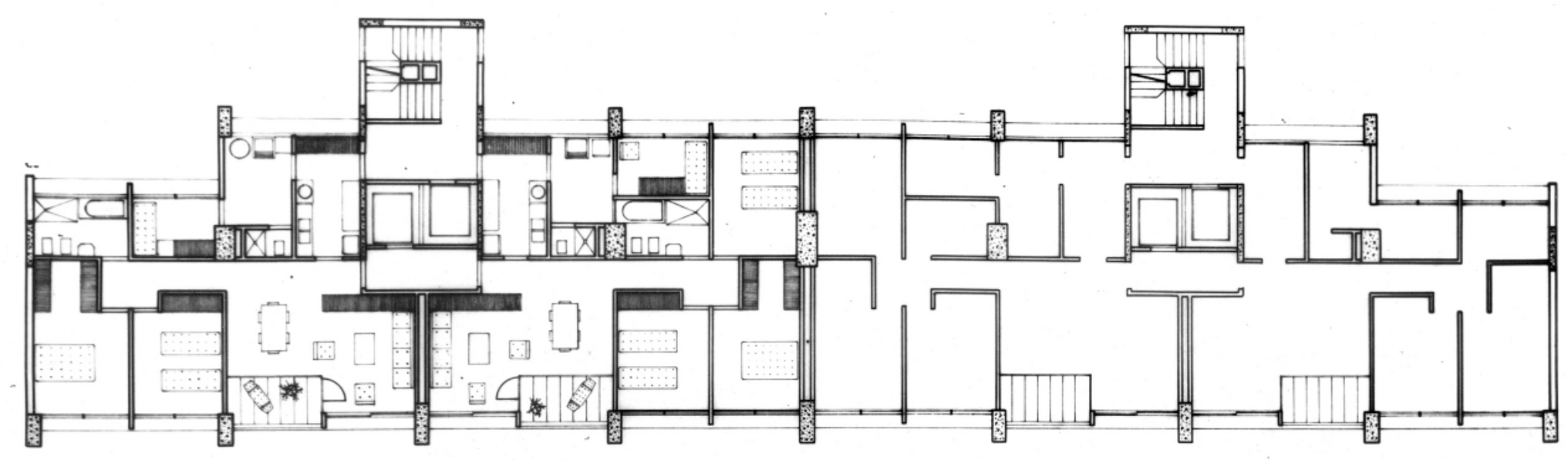

pavimento tipo
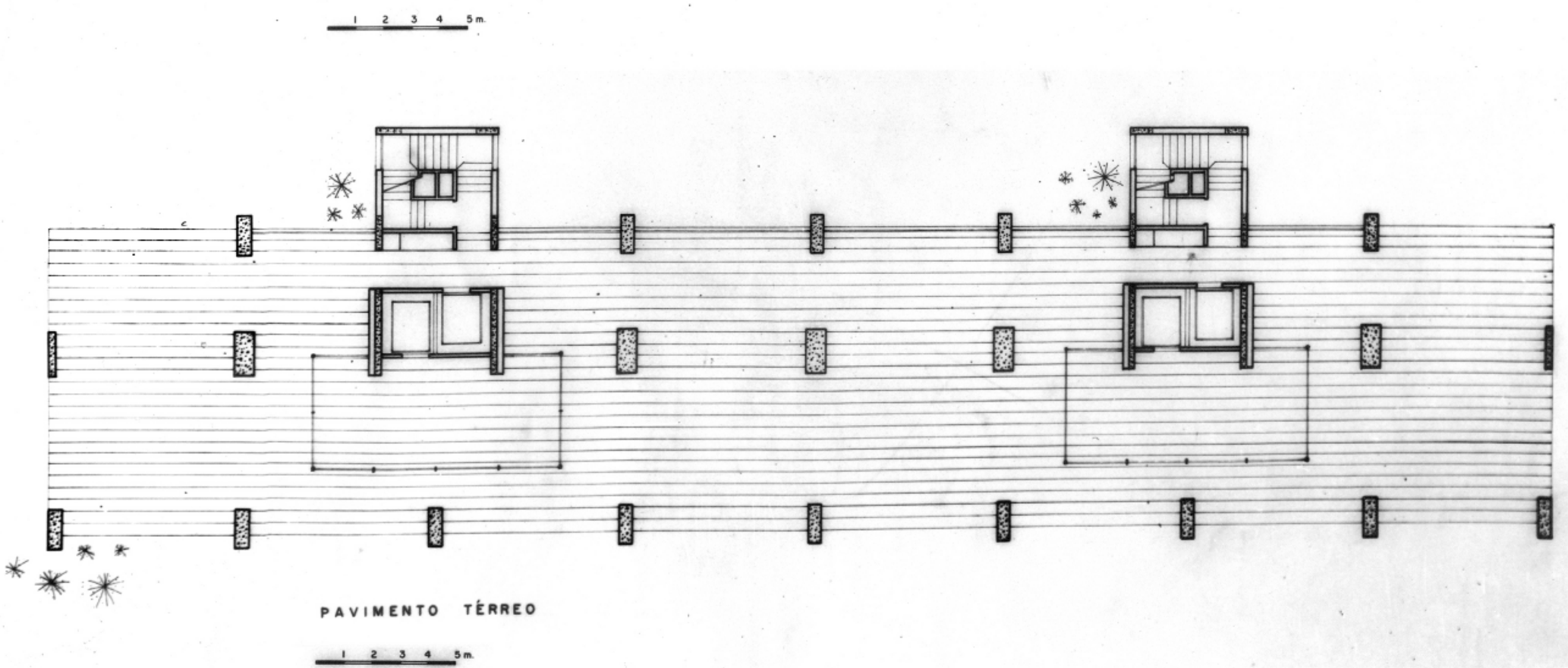


\section{Edifício João Ramalho}

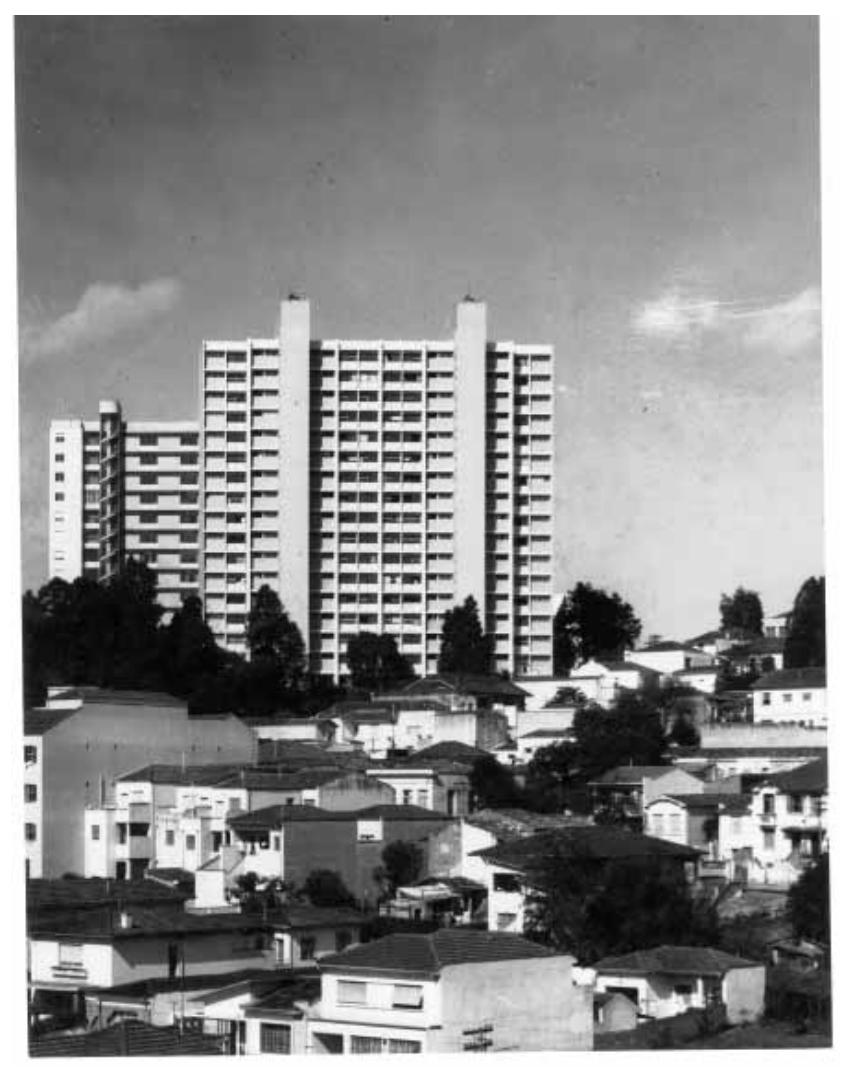

acima: João Ramalho e edifício de Abelardo de Souza no bairro das

Perdizes. fonte: arquivo S. Candia

página anterior: Edifício João Ramalho.

Plantas de apresentação do projeto.

fonte: arquivo S. Candia
Tendo sido executado entre 1954 e 1956, o edifício João Ramalho representou para Aflalo, Candia e Croce uma experiência significativa em sua atividade profissional, conforme comentamos anteriormente. Uma vez construído, ele haveria de se tornar uma importante referência para os arquitetos paulistanos a partir daquele momento. Nele morou Carlos Millan ${ }^{4}$ até a sua morte prematura em 1964, e também Salvador Candia durante um certo período até a década de 1970.

Nas fotografias realizadas por J. Moscardi logo após a conclusão das obras do edifício, verifica-se a coerência da primeira proposta realizada pelos três arquitetos para ocupação desta quadra. A intenção de se constituir uma implantação diversa daquela que comumente caracteriza as cidades brasileiras se evidencia nestas imagens, onde o edifício é mostrado contra o plano do bairro. Fica clara a intenção em se registrar a transparência e continuidade espacial do edifício ao nível do chão, através da qual se enxerga em contraste a morfologia típica do entorno. 

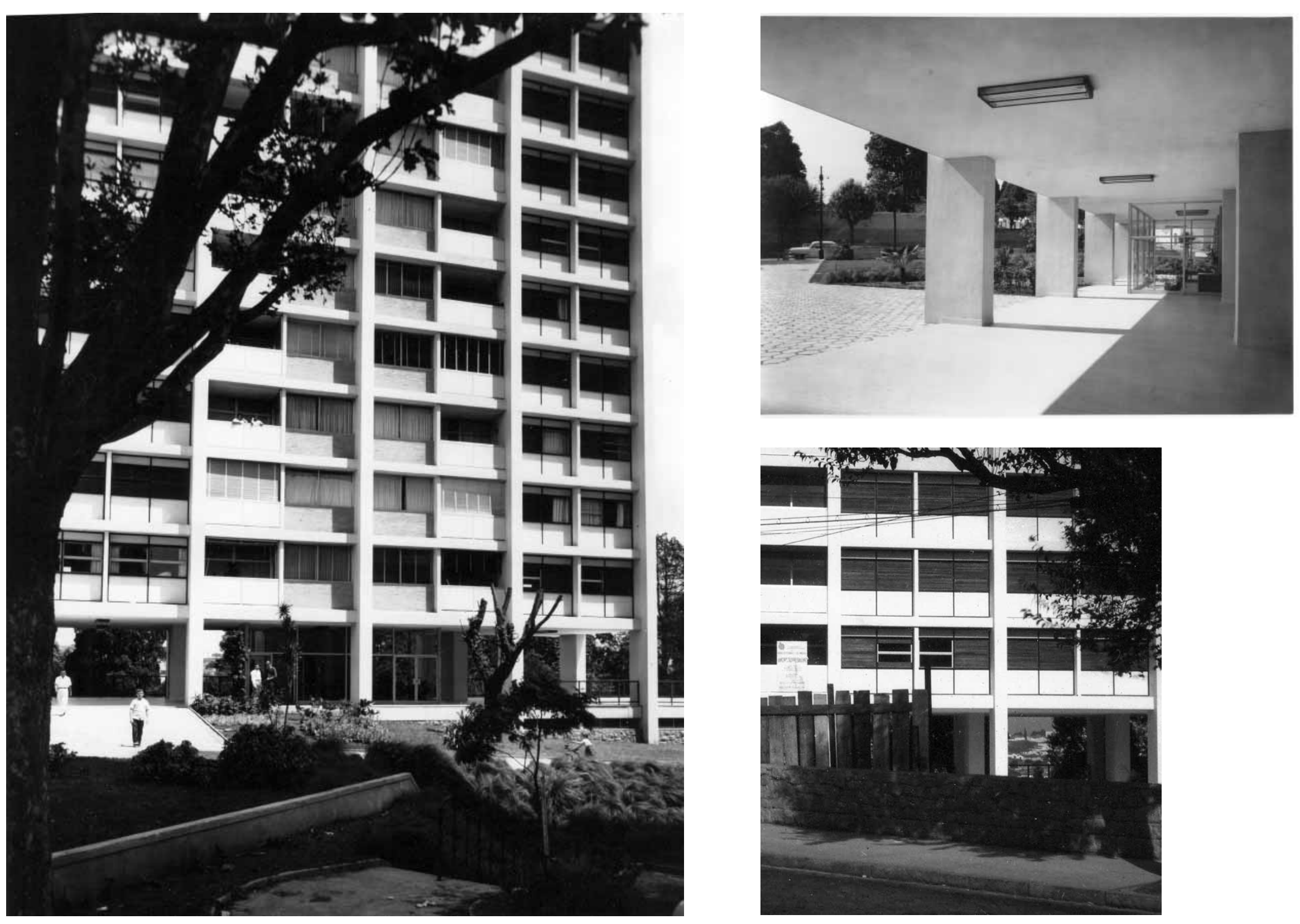


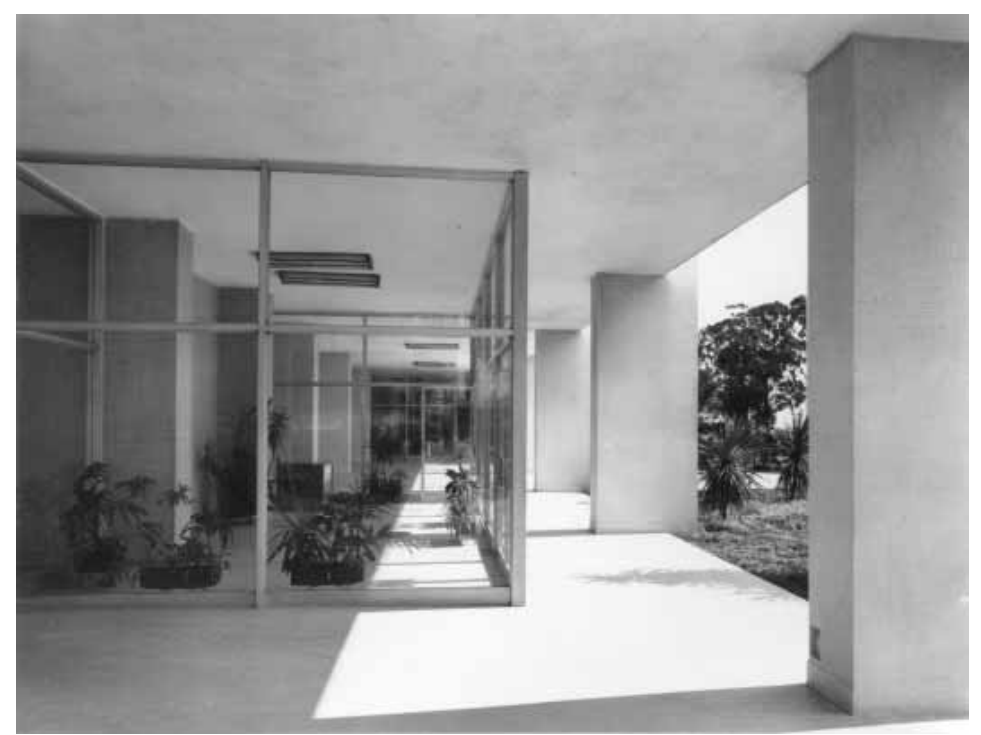

国四

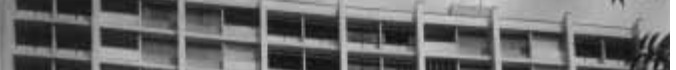

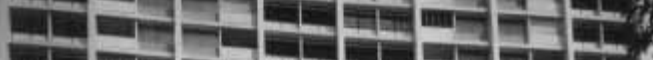

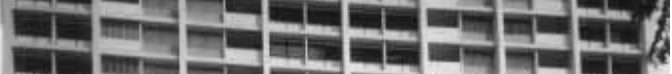

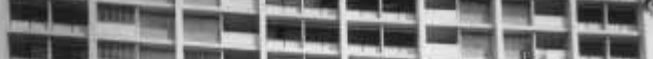

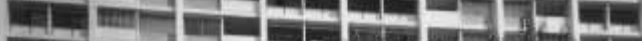

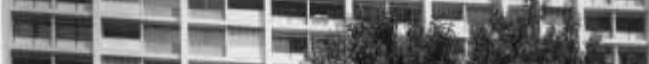
물

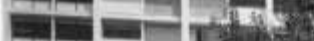

물

En Evis

and

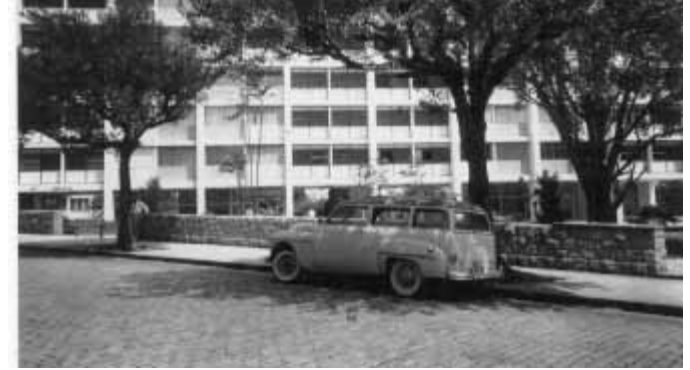

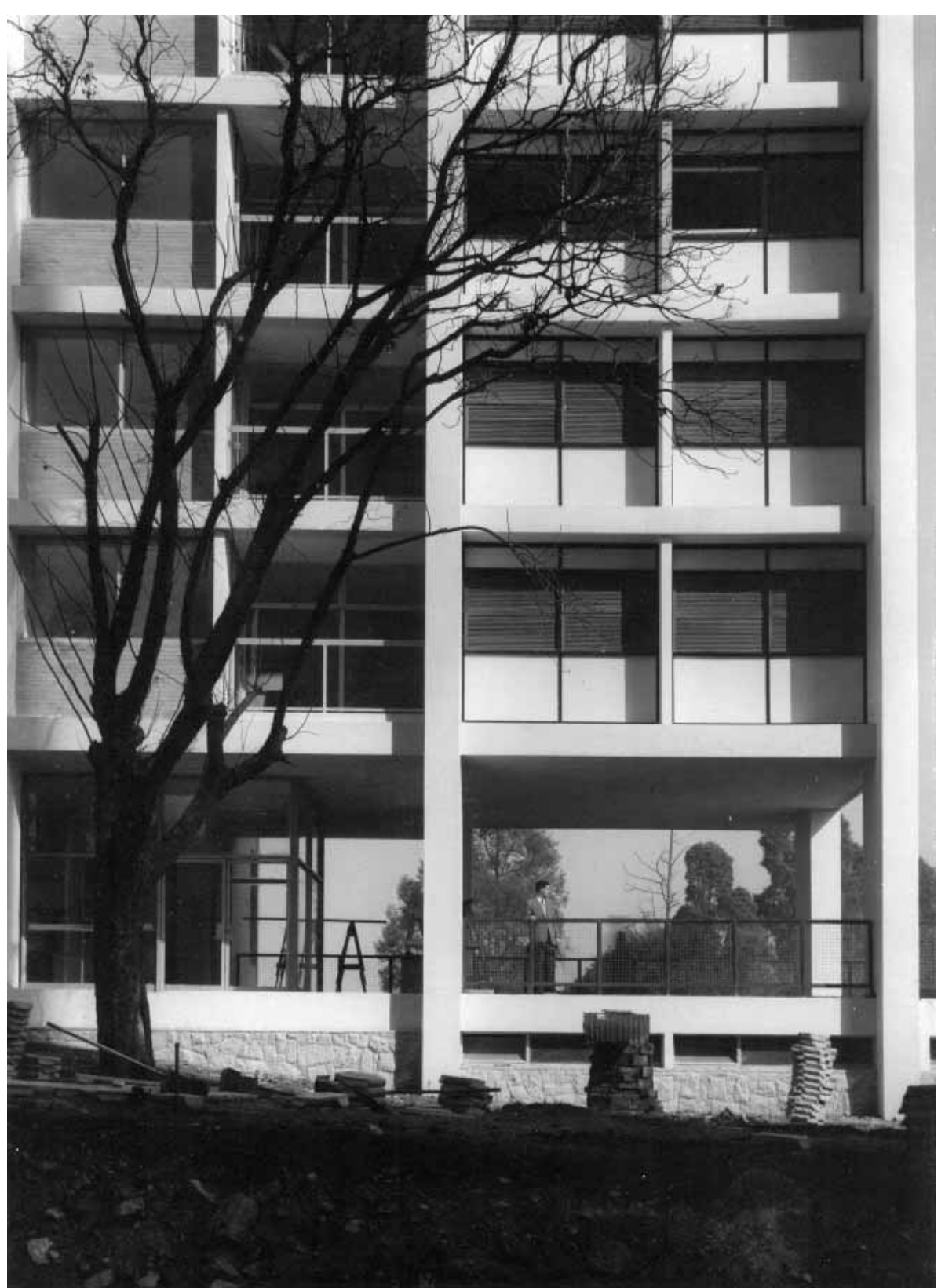

leitura de três projetos 


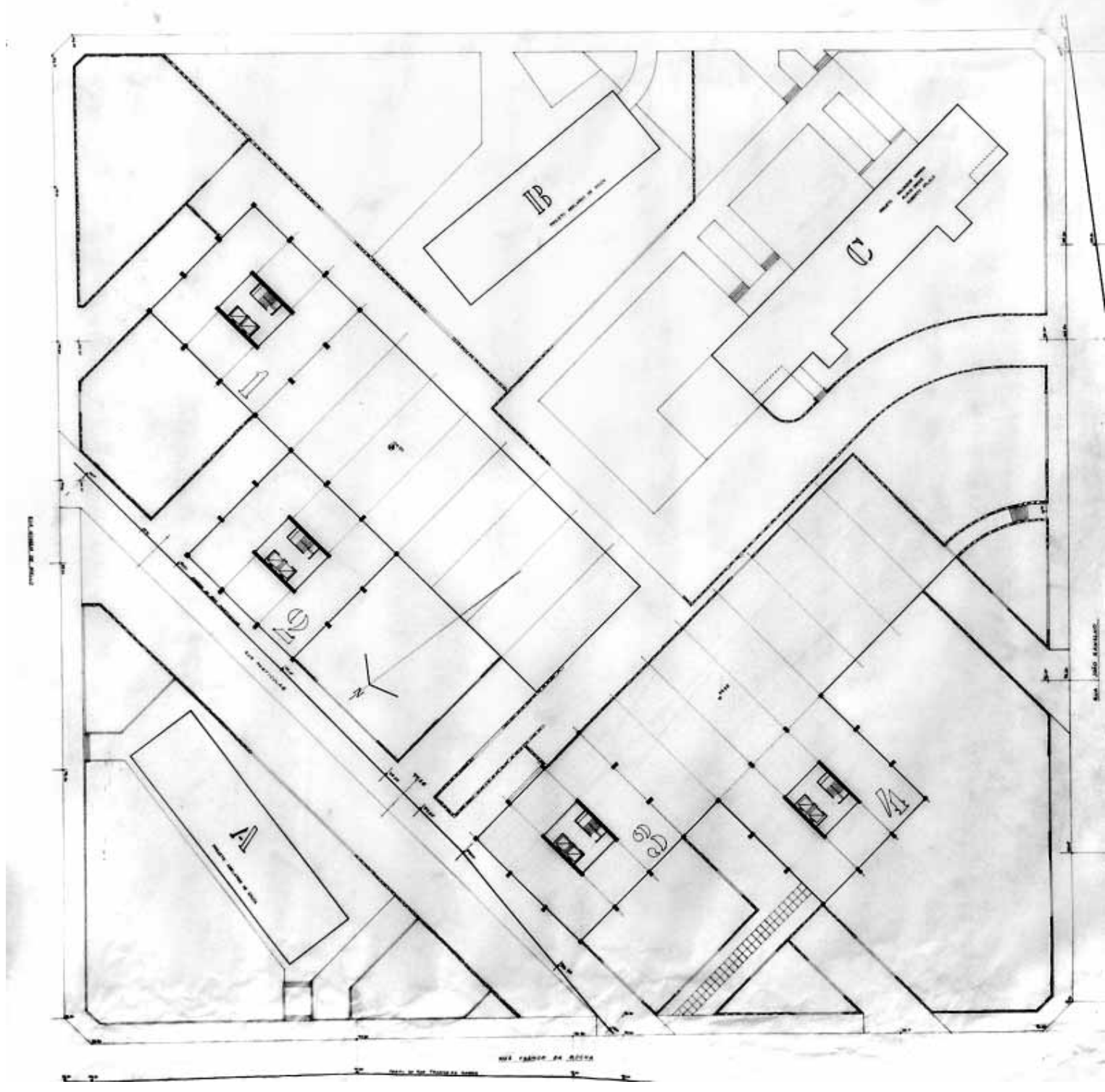

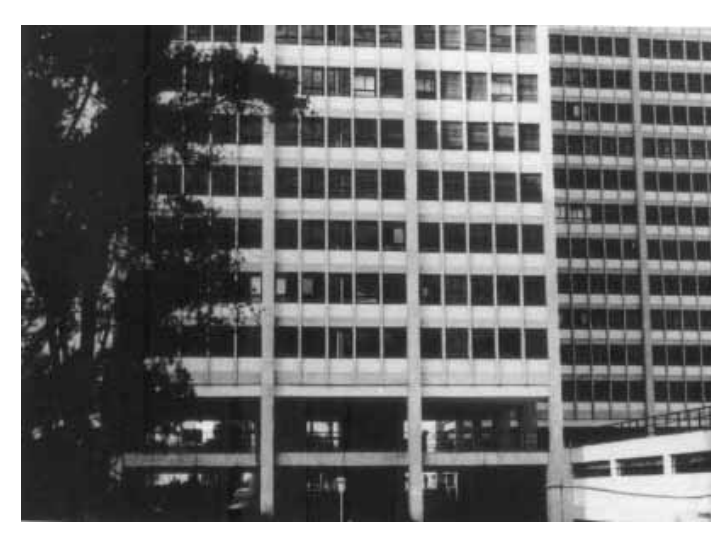

nesta página acima:

Edifícios Barão de Laguna e Barão de

Ladário, São Paulo

Aflalo, Candia e Croce, 1959.

fonte: arquivo S. Candia

nesta página à esquerda:

Conjunto em Perdizes, Verão III

Aflalo, Candia e Croce, 1959.

Planta de Implantação

fonte: arquivo S. Candia

próxima página acima:

Edifícios Barão de Laguna e Barão de Ladário, São Paulo

Elevação do conjunto.

Aflalo, Candia e Croce, 1959.

fonte: arquivo S. Candia

próxima página acima:

Edifícios Barão de Laguna e Barão de

Ladário, São Paulo

Planta do pavimento tipo

Aflalo, Candia e Croce, 1959

fonte: arquivo S. Candia 

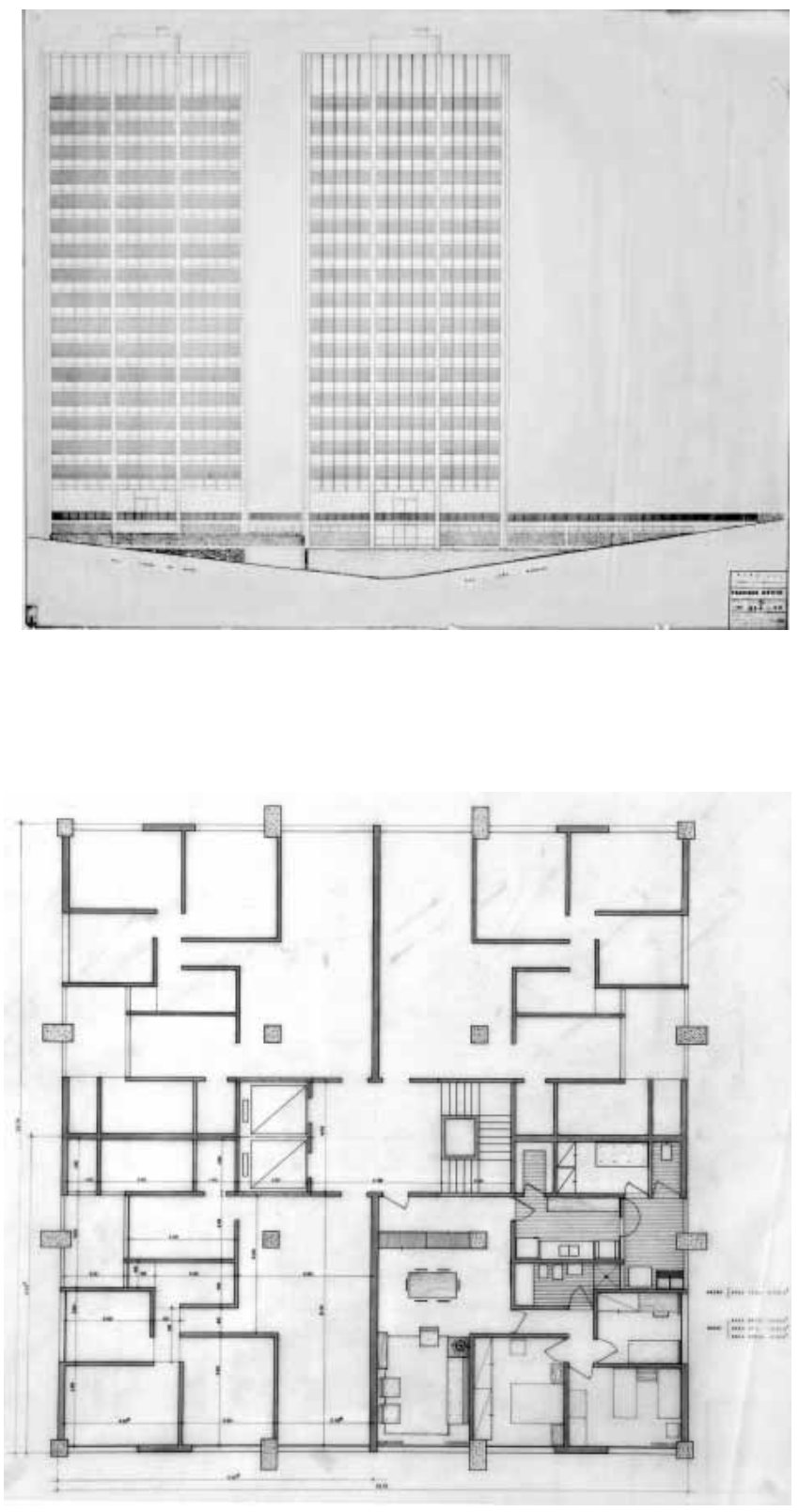

\section{Terceira versão: Aflalo, Candia e Croce:}

edifícios Barão de Laguna e Barão de Ladário (1959-60)

A última versão do projeto realizada por Aflalo, Candia e Croce parte de um novo arranjo formal para as habitações, propondo quatro torres idênticas de quatro apartamentos por andar, servidas por um núcleo central de circulação vertical. A implantação dos novos edifícios favorece a divisão da quadra em lotes separados, estabelecendo dois planos distintos de acesso, um pela rua Franco da Rocha, e outro pela rua Dr. Homem de Mello. As torres articulam-se duas a duas em torno de um embasamento comum que abriga os estacionamentos em semi-subsolo. A sua laje de cobertura constitui o pavimento comum de acesso, que descola-se gradualmente dos declives do terreno e caracteriza claramente as áreas pavimentadas com relação aos jardins nos níveis inferiores.

Implantadas dentro da matriz estabelecida pelos projetos anteriores, as torres resultam em uma orientação desfavorável, voltando uma de suas faces inteiramente ao Sul. Este problema é atenuado através do arranjo interno dos apartamentos, que dispõe predominantemente as áreas de serviço para esta fachada. 

considerações fínais 


\section{considerações finais}

Durante os quarenta anos em que manteve suas atividades profissionais, entre as décadas de 1950 e 1980, Salvador Candia conduziu uma obra que, embora situada de maneira discreta no panorama da arquitetura moderna em São Paulo, destaca-se pelo cuidado constante com a inserção dos edifícios no contexto urbano, e pela rigorosa coerência formal, associada à clareza do arranjo dos espaços, à coordenação modular e à expressão plástica própria dos elementos construtivos e estruturais do edifício.

Tendo iniciado sua atuação num momento em que a metrópole paulistana demandava novas soluções dos arquitetos no aporte crescente de determinados programas arquitetônicos e urbanísticos sob uma nova escala de abordagem, como os condomínios de habitação vertical e os grandes conjuntos comerciais, Candia experimentou através de seus projetos formas diversas de interlocução entre o edifício e a cidade, como demonstram as soluções desenhadas para a Superquadra em Perdizes e o Edifício Metrópole.

Em sua postura profissional, diante dos problemas de ordem construtiva e funcional presentes na arquitetura, Candia aproxima-se fundamentalmente dos exemplos de Rino Levi, Franz Heep e Vital Brazil.

Sua obra procura ainda estabelecer uma interlocução com a arquitetura moderna produzida nos Estados Unidos no segundo pós-guerra, notadamente a realizada pelos arquitetos da Bauhaus, como Breuer, Gropius, e Mies van der Rohe. Procurando traduzir estas influências, Candia realizaria experiências de grande força expressiva, como os edifícios Aços Villares, Joelma e das Nações.

Embora tenha sido pouco divulgada e publicada, a obra de Salvador Candia contribuiu de maneira significativa para os encaminhamentos da cultura arquitetônica em 
São Paulo.

Antes de procurar estabelecer conclusões definitivas, esta pesquisa busca apresentar a obra do arquiteto sob uma perspectiva mais abrangente, disponibilizando as informações levantadas de forma a contribuir para futuras aproximações. 
bibliografía 


\section{Bibliografia Geral}

ÁBALOS, Iñaki. A boa-vida: Visita guiada às casas da modernidade. Tradução Alícia Duarte Penna. Barcelona: Editorial Gustavo Gili, 2003.

ACAYABA, Marlene Milan. Branco \& Preto: Uma história de design brasileiro nos anos 50. São Paulo: Instituto Lina Bo e P. M. Bardi, 1994.

AMARAL, Aracy. Arte para quê?: A preocupação social na arte brasileira, 1930-1970: subsídeos para uma história social da arte no Brasil. São Paulo: Estúdio Nobel, 2003.

AMERIKANISCHE Architektur seit 1947. Stuttgart: Verlag Gerd Hatje, 1951.

ARQUITETURA e desenvolvimento nacional: depoimentos de arquitetos paulistas. São Paulo: Instituto de Arquitetos do Brasil - departamento de São Paulo e editora Pini, 1979.

ARTIGAS, João Batista Vilanova. Caminhos da arquitetura/ Vilanova Artigas (organização José Tavares Correia de Lira, Rosa Artigas). São Paulo: Cosac Naify, 2004.

ASSOCIAÇÃO DOS GEÓGRAFOS BRASILEIROS. A Cidade de São Paulo: Estudos de geografia urbana. São Paulo: Companhia Editora Nacional, 1958. (Série Brasiliana: Grande Formato, V. 14)

ATIQUE, Fernando. Memória Moderna: a trajetória do Edifício Esther. São Carlos: RiMa, 2004.

BONDUKI, Nabil. Origens da habitação social no Brasil. São Paulo: Estação Liberdade/FAPESP, 1998.

BRITO, Ronaldo. Neoconcretismo: Vértice e ruptura do projeto construtivo brasileiro. $1^{\mathrm{a}}$ reimpressão. São Paulo: Cosac \& Naify, 2002.

BRUAND, Yves. Arquitetura contemporânea no Brasil. São Paulo: Perspectiva, 1981.

CASTRO, Mariângela; FINGUERUT, Silvia, (Org.). Igreja da Pampulha: restauro e reflexões. Rio de Janeiro: Fundação Roberto Marinho, 2006.

COSTA, Helouise; BOEHRINGER, Vivian. Waldemar Cordeiro e a fotografia: Arte Concreta Paulista. São Paulo: Cosac \& Naify, 2002.

CROCE, Aflalo; Gasperini Arquitetos. 25 Anos depois: Uma retrospectiva da obra de Croce, Aflalo \& Gasperini Arquitetos. São Paulo: CVS-Artistas Associados/ Ed. Pau Brasil, 1986.

GIEDION, Sigfried. Espaço, Tempo e Arquitetura: O Desenvolvimento de uma Nova Tradição. Tradução 
Alvamar Lamparelli. $1^{a}$ ed. São Paulo: Martins Fontes, 2004.

GOODWIN, Philip. Brazil Builds: Architecture new and old 1652 -1942. Nova York: The Museum of Modern

Art, 1943.

GROPIUS, Walter; et al. (Ed.). The Architects Collaborative. Teufen (Suíça): Arthur Niggli, 1966.

HITCHCOCK, Henry-Russell; JOHNSON, Philip. The International Style. Nova York: W. W. Norton, 1995.

DREXLER, Arthur (Ed.). Built in USA: Post-war Architecture. Nova York: The Museum of Modern

Art.

. Latin American Architecture since 1945. Nova York: The Museum of Modern Art, 1955.

KOMOSSA, Susanne; et al. (Ed.). Atlas of the Dutch Urban Block. Bussum: Thoth, 2005.

LEFÈVRE, José Eduardo de Assis. De Beco a Avenida: A História da Rua São Luiz. São Paulo: Edusp, 2006.

LEMOS, Carlos Alberto Cerqueira. Viagem Pela Carne. São Paulo: Edusp, 2005.

MINDLIN, Henrique. Arquitetura Moderna no Brasil. Tradução Paulo Pereira. São Paulo: Aeroplano/IPHAN, 2000.

MUSEU DE ARTE MODERNA. II Bienal: Catálogo Geral. São Paulo: EDIAM, 1953.

III Bienal: Catálogo Geral. São Paulo: EDIAM, 1955.

IV Bienal: Catálogo Geral. São Paulo: EDIAM, 1957.

PIVA, Roberto. Obras reunidas volume 1: Um estrangeiro na legião. 1a ed. São Paulo: Globo, 2005.

SAMPAIO, Maria Ruth Amaral de (ed.). A Promoção Privada de Habitação Econômica e a Arquitetura Moderna 1930-1964. São Paulo: RiMa/FAPESP, 2002

SARAIVA, Roberto (Org.). Calder no Brasil. São Paulo: Cosac \& Naify, 2006.

SCULLY JR., Vincent. Arquitetura moderna: a arquitetura da democracia. Tradução Ana Luiza Dantas Borges. São Paulo: Cosac \& Naify, 2002.

SMITH, Elizabeth A.T. Case Study Houses. Köln: Taschen.

WOLFE, Tom. From Bauhaus to Our House. Nova York: Pocket Books, 1982.

XAVIER, Alberto (ed.). Depoimentos de uma geração: Arquitetura Moderna Brasileira. São Paulo: Cosac \& Naify, 2003.

XAVIER, Alberto; LEMOS, Carlos; CORONA, Eduardo. Arquitetura Moderna Paulistana. São Paulo: Pini, 1983. 


\section{Monografias sobre Arquitetos}

ANELLI, Renato; GUERRA, Abílio. Rino Levi: Arquitetura e Cidade. Fotos Nelson Kon. São Paulo: Romano Guerra, 2001.

ARGAN, Giulio Carlo. Walter Gropius e a Bauhaus. Rio de Janeiro: José Olympio, 2005.

BENCLOWICZ, Carla Milano (Coord.). Alvaro Vital Brazil: 50 Anos de Arquitetura. São Paulo: Nobel, 1986. CAMARGO, Mônica Junquiera de. Joaquim Guedes. São Paulo: Cosac \& Naify, 2000.

CARTER, Peter. Mies van der Rohe at work. London: Phaidon, 1999.

CONDURU, Roberto. Vital Brazil. São Paulo: Cosac \& Naify, 2000.

FERNÁNDEZ-GALIANO, Luis (ed.). Mies van der Rohe: Berlin/Chicago. Madrid: Arquitectura Viva, 2001.

(AV Monografías 92).

GIEDION, Sigfried. Walter Gropius: L'uomo e l'opera. Milão: Edizioni de Comunità, 1954.

JOHNSON C., Philip. Mies van der Rohe. Nova York: The Museum of Modern Art, 1947.

KAMITA, João Masao. Vilanova Artigas. São Paulo: Cosac \& Naify, 2000.

KRINSKY, Carol Herselle. Gordon Bunshaft of Skidmore, Owings and Merrill. Nova York: Architectural History Foundation MIT, 1988.

LAMBERT, Phyllis. Mies in America. Montreal; Nova York: Canadian Centre for Architecture; Whitney Museum of American Art, 2001.

MARCEL Breuer: Casas Americanas. Barcelona, Editora Gustavo Gili, No 17, 2001/I.

MERTINS, Detlef (Ed.). The Presence of Mies. Nova York: Princeton Architectural, 1994.

MONTEYS, Xavier. Le Corbusier: Obras y Proyectos. Barcelona: Editorial Gustavo Gili, 2005.

NEUMEYER, Fritz. The artless word: Mies van der Rohe on the Building Art. Tradução para o inglês Mark Jarzombek. Cambridge, Massachusetts: MIT, 1991.

PUENTE, Moisés (Ed.). Conversas com Mies van der Rohe: Certezas americanas. Tradução Maria Luíza Tristão de Araújo. Barcelona: Gustavo Gili, 2006.

QUETGLAS, Josep. Fear of glass: Mies van der Rohe’s Pavilion in Barcelona. Tradução John Stone e Rosa Roig. Basel: Birkhäuser, 2001. 
RILEY, Terence; BERGDOLL, Barry (Org.). Mies in Berlin. Nova York, The Museum of Modern Art, 2001.

SCHULZE, Franz (Ed.). Mies van der Rohe: Critical Essays. Nova York: The Museum of Modern Art, 1989.

. Mies van der Rohe: A Critical Biography. Nova York: University of Chicago, 1985.

SEGAWA, Hugo. Oswaldo Arthur Bratke. São Paulo: ProEditores, 1997.

WISNIK, Guilherme. Lúcio Costa. São Paulo: Cosac \& Naify, 2001.

ZUKOWSKY, John. Mies Reconsidered: His Career, Legacy, and Disciples. Chicago: Art Institue of Chicago;

Rizzoli, 1986.

\section{Teses e Dissertações}

ACAYABA, Marlene Milan. Branco \& Preto: uma história de design brasileiro nos anos 50. 1991, Tese de Doutoramento - Faculdade de Arquitetura, Universidade de São Paulo, São Paulo.

ALEIXO, Cyntia Augusta Poleto. Edifícios e Galerias Comerciais: Arquitetura e Comércio na cidade de São Paulo, anos 50 e 60. 2005, Dissertação de mestrado - Escola de Engenharia de São Carlos da Universidade de São Paulo, São Carlos.

BARBARA, Fernanda. Duas Tipologias Habitacionais: O Conjunto Ana Rosa e o Edifício Copan: Contexto e Análise de dois projetos realizados em São Paulo na década de 1950. 2002, Dissertação de Mestrado - Faculdade de Arquitetura, Universidade de São Paulo, São Paulo.

BARBOSA, Marcelo Consiglio. A obra de Adolf Franz Heep no Brasil. 2002, Dissertação de Mestrado - Faculdade de Arquitetura, Universidade de São Paulo, São Paulo.

BIANCHI, Ronaldo. MAM, Uma história sem fim. 2006, Dissertação de Mestrado - Pontifícia Universidade Católica, São Paulo.

BRASIL, Luciana Tombi. A obra de David Libeskind: Ensaio sobre as Residências unifamiliares. 2003, Dissertação de Mestrado - Faculdade de Arquitetura, Universidade de São Paulo, São Paulo.

BREIA, Maria Teresa de Stockler e. A transição do ensino da arquitetura Beaux-Arts para o ensino da arquitetura moderna na Faculdade de Arquitetura Mackenzie - 1947-1965. 2005, Tese de Douturado 
- Faculdade de Arquitetura, Universidade de São Paulo, São Paulo.

CABRAL, Neyde Angela Joppert. A universidade de São Paulo: modelos e projetos. 2004, Tese de Doutorado - Faculdade de Arquitetura, Universidade de São Paulo, São Paulo.

CAPPELLO, Maria Beatriz Camargo. Arquitetura em revista: Arquitetura moderna no Brasil e sua Recepção nas Revistas francesas, inglesas e italianas $(1945$ - 1960). 2005, Tese de Doutoramento - Faculdade de Arquitetura, Universidade de São Paulo, São Paulo.

COMO PAISAGEM URBANA, São Paulo é de uma tristeza absoluta. Entrevista de Fábio Penteado concedida a A. Mendelez e F. Serapião. Projeto Design. Edição 290. Abril 2004. In <http://www.arcoweb.com. br/entrevista/entrevista55.asp>. Acessado em 13-01-2008.

CUNHA, Jaime. Edifício Metrópole: um diálogo entre arquitetura moderna e cidade. 2007, Dissertação de Mestrado - Faculdade de Arquitetura, Universidade de São Paulo, São Paulo.

FORTE, Miguel. Diário de um jovem arquiteto: minha viagem aos Estados Unidos em 1947. São Paulo: Editora Mackenzie, 2001.

GOLDBERG, Bertrand. Speech about Marina City. In Seminar "Architectural Aspects of Edmonton Civic Centre Plan". Edmonton, Alberta, Canada. 27 setembro 1959. Disponível em: http://www.marinacity/Marinacity,Chicago-BertrandGoldberg.mht. Acessado em 28-05-2007.

HERBST, Hélio. Promessas e Conquistas: Arquitetura e Modernidade nas Bienais. 2002, Dissertação de Mestrado - Faculdade de Arquitetura, Universidade de São Paulo, São Paulo.

IMBRONITO, Maria Isabel. Três edifícios de habitação para a Formaespaço: Modulares, Gemini e Protótipo. 2003, Dissertação de Mestrado - Faculdade de Arquitetura, Universidade de São Paulo, São Paulo.

INFERNO NO JOELMA. Folha de S. Paulo, São Paulo, 1 de Fevereiro de 2004.

JUNQUEIRA, Monica. Porta Retratos: Miguel Forte. In <http://www.docomomo.org.br/portaretratos\%20M\%2 0Forte.htm>. Acessado em 13-12-2007.

KUNNI, Mariana Limeira. Salvador Candia. 2000. Trabalho de Graduação Interdisciplinar - Faculdade de Arquitetura e Urbanismo, Universidade Mackenzie, São Paulo.

MATERA, Sérgio. Carlos Millan: um estudo sobre a produção em arquitetura. 2005, Dissertação de mestrado - Faculdade de Arquitetura, Universidade de São Paulo, São Paulo. 
MENDONÇA, Denise Xavier de. Arquitetura Metropolitana: São Paulo década de 50. 1999, Dissertação de Mestrado - Escola de Engenharia de São Carlos, Universidade de São Paulo, São Carlos.

MEYER, Regina M. Prosperi. Metrópole e Urbanismo: São Paulo anos 50. 1991, Tese de Doutoramento - Faculdade de Arquitetura, Universidade de São Paulo, São Paulo.

NEUTRA, Richard. Arquitetura social em paises de clima quente / Architecture of social concern in regions of mild climate. São Paulo: Gerth Todtmann, 1948.

NEVES, Christiano Stockler das. “Comunismo architectônico: Vaticínios de Keyersling para o Brasil” In: Architetura e Construcções n. 13, V. I, 1930.

PEREIRA, Gustavo. Christiano Stocker das Neves e a formação do curso de Arquitetura do Mackenzie College: Um estudo sobre a disseminação dos métodos da "École de Beaux-Arts de Paris" e das "Fine Arts Schools” norte-americanas. 2005, Dissertação de Mestrado - Faculdade de Arquitetura e Urbanismo - Universidade Presbiteriana Mackenzie, São Paulo.

ROSALES, Mario Arturo Figueroa. Habitação Coletiva em São Paulo 1928-1972. 2002, Tese de Doutorado Faculdade de Arquitetura, Universidade de São Paulo, São Paulo.

SANOVICZ, Abrahão. Sistematização Crítica da Obra de Arquitetura para Obtenção do Título de Livre Docente. 1997, Tese de Livre Docência - Faculdade de Arquitetura, Universidade de São Paulo, São Paulo.

VIEGAS, Fernando Filippe. Conjunto Nacional: A construção do Espigão Central. 2003, Dissertação de Mestrado - Faculdade de Arquitetura, Universidade de São Paulo, São Paulo.

\section{Filmes}

JOELMA 23ํADAR, Direção Clery Cunha, São Paulo, 1980. DVD (80min).

O PRÍNCIPE. Direção e roteiro Walter Hugo Khoury, São Paulo, Produção Kamera Filmes e Cia. Cinematográfica Vera Cruz, 1964. DVD (98min). 


\section{Artigos Publicados de Salvador Candia}

ARQUITETURA e Desenvolvimento Nacional. Depoimentos de arquitetos paulistas. IAB-SP, São Paulo: Editora Pini LTDA, 1979. Depoimento de Salvador Candia.

CANDIA, Salvador. Marcel Breuer: De Bauhaus à Casa no Jardim. Pilotis, São Paulo, n. 4, fev. 1950.

Projeto Para Dois Edifícios de Apartamentos. Revista de Engenharia Mackenzie, São Paulo, ano XLII,

n. 132, fev./mar. 1957.

. A Ordem Construtiva Arquitetônica em Vital Brazil. Brazil, Vital. 50 Anos de arquitetura/ Álvaro Vital Brazil. Nobel, São Paulo, 1986.

. O caso Gregori. Folha de S. Paulo, São Paulo, 18 jun. 1986.

ESPECIALISTA CRITICA CATEDRAL. Folha de S. Paulo, São Paulo, Caderno Cidades, 1987.

CANDIA, Salvador. Na Arquitetura, novo estilo trouxe uma alegre mistura. Folha de S. Paulo, São Paulo, 13 aug. 1987.

Roteiro de um arquiteto. Folha de S. Paulo, São Paulo, 19 set. 1987.

Antepassado do teatro paulista localizado na França. Folha de S. Paulo, São Paulo, [19--].

\section{Textos de Salvador Candia não publicados}

CANDIA, Salvador. Principais Projetos e Obras Executadas A Partir Do Início Das Atividades Professionais Em Escritório: 1950, São Paulo, Arquivo Salvador Candia, [1954]

Projetos contratados e em fase de desenvolvimento, São Paulo, Arquivo Salvador Candia, maio 1959

SALVADOR CANDIA ARQUITETOS ASSOCIADOS S/C LTDA. Curriculum Vitae e Obras Executadas, São Paulo, Arquivo Salvador Candia, [197-]

CANDIA, Salvador. Curriculum Vitae e Obras Executadas, São Paulo, Arquivo Salvador Candia, [1980]

. Memorial Descritivo do projeto Parque Lar Brasileiro, São Paulo, Arquivo Salvador Candia, 26 jul. 1956. 
Memorial Justificativo de Conjunto Residencial à rua dos Franceses em terreno de propriedade dos Srs. Érico Stickel e Luiz Dumond Villares, São Paulo, Arquivo Salvador Candia, jan. 1969.

Edital de Concorrência para Ante-Projto Arquitetônico para o edifício da Administração Geral, São Paulo, Arquivo Salvador Candia, Junho de 1977.

\section{Publicações sobre Salvador Candia e seus projetos}

GRUPO DE RESIDÊNCIAS À RUA TUCUMAN. Acrópole, São Paulo, n. 15, p. 50, jun. 1951.

CONJUNTO RESIDENCIAL: Bairro das Perdizes. Arquitetura e Engenharia, São Paulo, n. 31, p. 52, 1954. RESIDÊNCIA DO SR. ELISEU MELLONI

Arquitetura e Decoração, São Paulo, n. 3, dez. 1953/jan. 1954.

Arquitetura e Decoração, São Paulo, n. 10, mar./abr. 1955.

EDIFÍCIOS DE APARTAMENTOS. Acrópole, São Paulo, n. 242, p. 55-7, dez. 1958.

CONJUNTO DE EDIFÍCIOS “MAXIMUS”. Habitat, São Paulo, ano 11, n. 59, p. 3-9, mar./abr. 1960.

L'Architecture d'aujourd'hui, Paris, ano 31, n. 93, dez. 1960/jan. 1961.

ACAYABA, Marlene Milan. Dois arquitetos, duas experiências. Projeto, São Paulo, n. 85, p. 72, 1986.

FERNANDO SERAPIÃO, Edifício das Nações. Projeto Design, São Paulo, n. 324, fev. 2007. Suplemento. 

anexo A

lista de obras construídas até 1980 


\section{Relação de Obras Construídas até 1980}

com base nos arquivos remanescentes do esctitório

\section{Conjuntos Residenciais}

- Conjunto residencial "Nova Campinas" - Campinas - SP.

- Conjunto residencial "Jardim Ana Rosa” - Capital, com 64 unidades 2.095m².

- Conjuntos “Corsário" e "Caravela” - Praia da Enseada, Guarujá - SP, com 48 unidades

- Conjunto residencial “Jardim Estoril” - Bauru - SP.

- Conjunto residencial “Jardim Figueiras” - Jundiaí - SP, com 155 unidades e 13.290 $\mathrm{m}^{2}$.

\section{Prédios de apartamentos}

- Edifício “Ministro Godoy” ã Rua Ministro Godoy - Perdizes, São Paulo com 64 apartamentos (prêmio Internacional na V Bienal São Paulo)

- Conjunto "Barão de Laguna” e "Barão de Ladário" à Rua Dr. Homem de Mello Perdizes, São Paulo, com 132 unidades e $22.080 \mathrm{~m}^{2}$.

- Edifício "Júlio de Castilhos" - Caxias do Sul, RS, com 20 apartamentos e diversas lojas com $4.814 \mathrm{~m}^{2}$

- Edificio "Maringá” - cidade de Maringá - Paraná, com 13 pavimentos e 24 apartamentos e $4.100 \mathrm{~m}^{2}$.

- Edifício à Rua Sergipe, São Paulo, com 13 pavimentos, 22 apartamentos e $5.370 \mathrm{~m}^{2}$

- Conjuntos "Santa Cândida" e "Santa Francisca" - Rua Marques de Itú esquina com Rua Aureliano Coutinho, São Paulo, com 18 pavimentos e 30 apartamentos e $12.300 \mathrm{~m}^{2}$. - Edificio a Rua Otávio Nébias - São Paulo, com 28 apartamentos e 4.650 m².

- Edifício à Rua Caetés - Capital, com 14 pavimentos e $2.930 \mathrm{~m}^{2}$.

- Edifício a Rua Pedroso Alvarenga - Capital, com 14 pavimentos e $5.370 \mathrm{~m}^{2}$.

- Edifício à Rua Argentina - Praia da Enseada - Guarujá - SP, com 24 apartamentos e 
$3.063 \mathrm{~m}^{2}$

- Edifício à Rua Capitão Messias, 56, São Paulo, com 17 pavimentos e 7.613 m².

- Edifício à Rua Joaquim Antunes, 557, São Paulo, com 19 pavimentos e $9.700 \mathrm{~m}^{2}$.

- Edifício à Rua Bandeira Paulista, 86, São PAulo, com 21 pavimentos e 9.774 m².

- Edificio à Rua Manoel da Nóbrega - São Paulo, com 60 apartamentos e $9.967 \mathrm{~m}^{2}$

- Edifício à Rua Haddock Lobo, 1.327 - Capital, com 12 pavimentos e 3.700 m² $^{2}$

(data da obra -).

- Edificios de apartamentos a Rua Sóror Angélica, São Paulo, com 3 blocos de 15 e 18 pavimentos e área total de $21.734 \mathrm{~m}^{2}$ (data da obra -).

\section{Bancos e Edifícios de Escritórios}

- Edifício "Rio Branco" - Curitiba - Paraná, com 20 pavimentos para o Banco Lar Brasileiro SA.

- Edifício "Itatiaia” - Santos - SP, com 18 pavimentos e $8.370 \mathrm{~m}^{2}$.

- Banco Real SA, à Rua Boa Vista - São Paulo, com 20 pavimentos e 30.474 m² $^{2}$

- Banco do Estado do Rio de Janeiro, ex-Banco de Minas Gerais AS, entre as Ruas São Bento e Libero Badaró - Capital, com 12 pavimentos e $3.500 \mathrm{~m}^{2}$.

- Edifício para o Banco Real SA à Rua XV de Novembro -Pelotas - RS, com 9 pavimentos, lojas e $4.330 \mathrm{~m}^{2}$.

- Banco do Brasil SA., agência Suzano - SP, à Rua General Francisco Glicério, 472, com 2 pavimentos e $1.000 \mathrm{~m}^{2}$.

- Edifício "Barão do Ouro Branco", com lojas, garagens, e escritórios, com 21 pavimentos e $16.630 \mathrm{~m}^{2}$ à Av. Brigadeiro Luiz António, confluência com Av. Paulista e Rua Padre Manoel da Nóbrega - Capital.

- Edifício "Barão do Amparo", com lojas, escritórios e garagens, com 21 pavimentos e $15.980 \mathrm{~m}^{2}$ à Av. Paulista, 2006, São Paulo. 
- Edifício "Joelma”, com Lojas, garagens e escritórios, com 23 pavimentos e $19.280 \mathrm{~m}^{2}$ à Praça das Bandeiras confluência com Av. Nove de Julho e Rua Santo Antônio, São Paulo

- Edifício da Cia. de Seguros “Brasil”, com lojas e escritórios de 21 pavimentos e 8.020 $\mathrm{m}^{2}$. à Av. Paulista 2040 - São Paulo

- "Edifício das Nações", com escritórios, lojas, garagens, à Av. Nações Unidas esquina com Av. Eusébio Matoso, com $31.500 \mathrm{~m}^{2}$ São Paulo

- Edifício de escritórios, à Rua Coronel Lisboa, 286 -Vila Mariana - São Paulo (data da obra - ).

- UNIBANCO - agência Belo Horizonte à Av. Afonso Pena, / 737 - Belo Horizonte MG, com 10 pavimentos e $2.600 \mathrm{~m}^{2}$ (data da obra-)

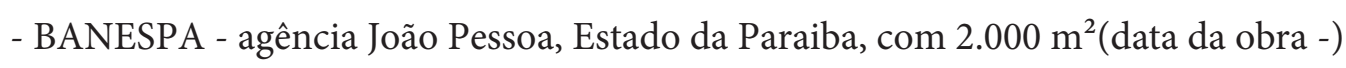

- UNIBANCO - agência Santo Amaro â Av. América do Sul (antiga Rua Campos Salles), 139, Bairro de Santo Amaro com $1.678 \mathrm{~m}^{2}$ (data da obra -)

\section{Edifícios Industriais}

- COFAP - Fábrica de Peças, ampliação do escritório de administração - Santo André - SP.

- Aço Villares SA., depósito, e escritório com 12 pavimentos à Av. do Estado, 6116 São Paulo.

- Kentinha SA.- Indústria e Comércio - Fábrica de Embalagens para refeições, à Margem da Rodovia dos Imigrantes Km. 20,5 - Diadema - SP, com $5.000 \mathrm{~m}^{2}$.

- Aço Minas - Edifício para Resfriamento e circulação de água para uso indireto dos sopradores; uso indireto da coqueria e uso direto da coqueria.

\section{Edifícios Hospitalares}

- Instituto Paulista de Psiquiatria “Dr. Joy Arruda” Ltda., construído em 1974/75 à Av. 
Engenheiro Armando de Arruda Pereira, 2.979 -São Paulo, constando de: vários pavilhões interligados distribuídos em 5 pavimentos com área total de $8.685 \mathrm{~m}^{2}$, para 403 leitos.

- Hospital Nossa Senhora da Penha SA., à Rua Arnaldo Vallardi Portilho, 100 - Penha de França - São Paulo, em construção. Hospital geral, com ambulatório, cirurgia, maternidade etc. para 352 leitos, distribuídos em 5 pavimentos e área total de 8.300 $\mathrm{m}^{2}$.

- Edifício do "C L A M" Clube de Assistência Médica, à Rua Augusta esquina com Alameda Santos, São Paulo, com 2.700 m2.

\section{Escolas}

- Escola - Hotel para Banco Real SA. - Edifício para treinamento administrativo e moradia temporária -Pampulha - Belo Horizonte - MG.

- Escola de $1^{\circ}$ grau realizadas nas cidades deTanabi, Ourinhos, Campinas, Itapeva.

- Conjunto Didático e Esportivo da Escola Normal de Marilia - SP.

- Escolas de $1^{\circ}$ grau realizadas para CONESP no Estado de São Paulo, nas cidades de: Americana, Aparecida,Indiaporã, Pedreira, Ribeirão Pires, Sorocaba, Taboão da Serra e São Paulo (Jabaquara, Itaquera, Perus, Vila Carrão).

\section{Edificações para problemas específicos}

- Asilo de Velhos, para a Sociedade Beneficente Alemã, a Via Raposo Tavares, Km. 11, São Paulo.

- Fórum de Adamantina - Adamantina, SP.

- Cinema em Atibaia, SP.

- Sede campestre e conjunto recreativo para "UNIBANCO ESTANCIA CLUBE DE AMPARO" - Amparo,SP. 
- Conservatório Dramático e Musical "Dr. Carlos de Campos" na cidade de Tatuí - SP., da Secretaria de Esta do da Cultura, Ciência e Tecnologia com 2 pavimentos e 2.300 $\mathrm{m} 2$.

\section{Planejamento físico}

- Planejamento físico de 130 alqueires no Município de Itú neste Estado, com Campo de Golf e loteamento, em colaboração com o escritório Robert Trent Jones, Inc. (Paio Alto, Califórnia U.S.A.).

- Planejamento físico "Nova São Paulo" para Município de Itapeví - SP, com serviços completos de medição, traçado de ruas "grades", captação e distribuição de água, divisão de lotes, projeto de água pluviais, rede elétrica e locação de edifícios para super mercado, hotel, edifício de administração, clube e igreja em terreno de 500.000 $\mathrm{m}^{2}$.

- Planejamento físico de loteamento para Mairiporã,

"Jardim Lago da Cantareira", com serviços completos de medição, traçado de ruas, e "grades", divisão de lotes, projeto de águas pluviais, captação e distribuição de água, rede elétrica e locação de edifício para clube.

- Planejamento físico de 237 alqueires, Amparo - SP, com serviços completos de medição, traçado de ruas "grades", divisão de lotes, projeto de águas pluviais, captação e distribuição de água, rede elétrica.

- Planejamento físico para "Fazenda Moinho Velho", Município de Cotia, de 62 alqueires - com serviços completos de medição, traçado de ruas e "grades", divisão de lotes, projeto de águas pluviais, captação e distribuição de água, rede elétrica e locação para condomínios horizontais, blocos de prédios e comércio.

- Condomínio horizontal para 60 casas, com projetos completos de infra-estrutura e equipamentos sociais e lazer, para Gomes de Almeida Fernandes SA (data da obra). 


\section{Projetos de Interiores}

- Banco do Brasil SA. Reinstalações de Restaurante e planejamento de cozinha para 1.000 refeições em uso no $2^{\circ}$ pavimento do edifício da Av. São João - Praça António Prado - Libero Badaró - Capital.

- Instalações de agências bancárias, companhias de aviação, etc. 
Anexo B

fichas de projetos e obras levantados 


\section{Conjunto de 48 residências em Santos}

localização Ponta da Praia, Canal 6 (projeto construído).

cliente Banco Hipotecário Lar Brasileiro S.A.

material Projeto Executivo, 1950.

fonte $\quad$ Arquivo S. Candia.

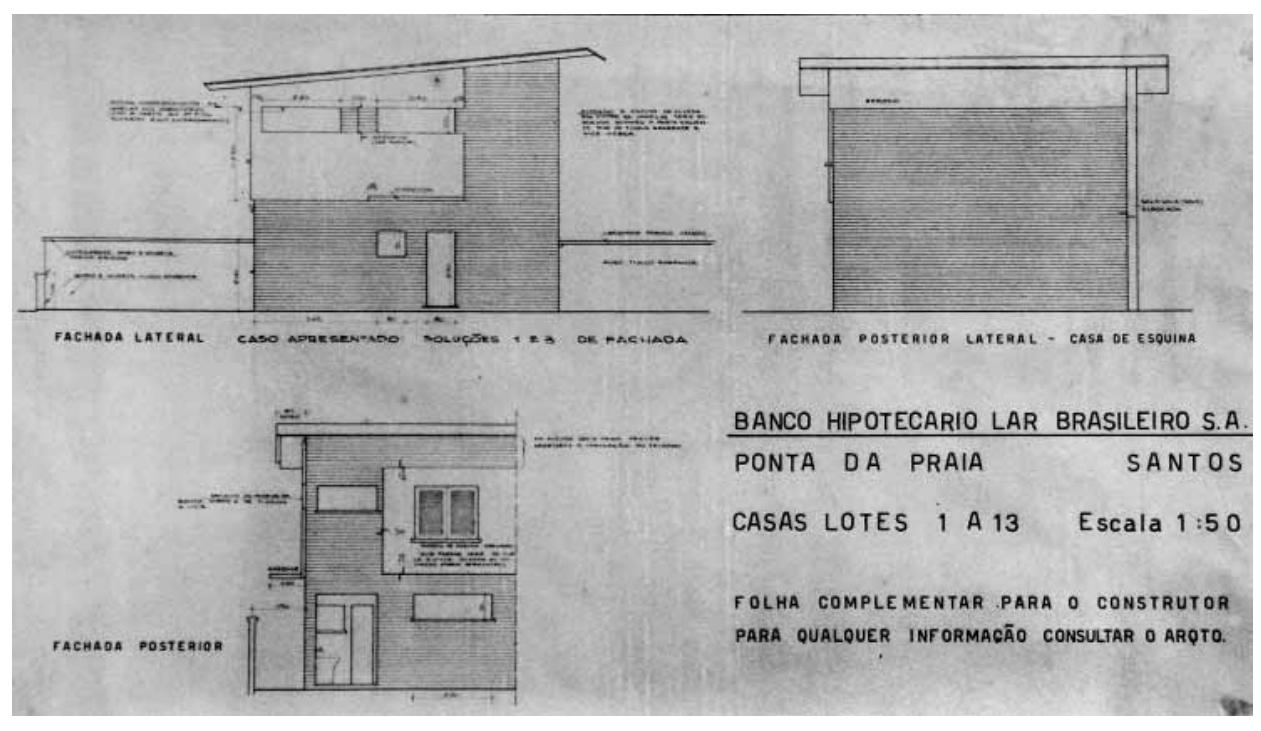

\section{Estação Ferroviária de Pampulha}

Projeto vencedor de Concurso Nacional

colaboração Plínio Croce e Jacob Ruchti

localização Pampulha, Belo Horizonte (projeto não construído).

material Perspectiva, 1950.

fonte Acayaba (1994. p. 58)

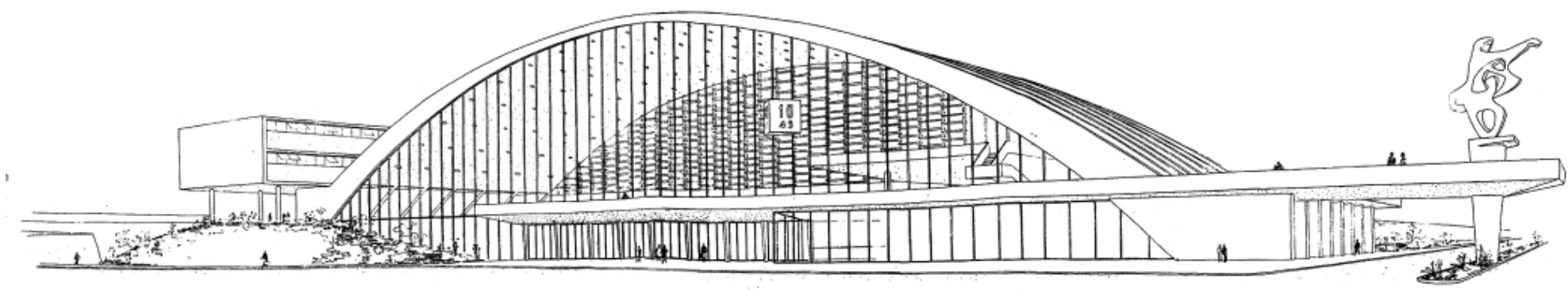




\section{Residências à rua Tucuman}

Grupo de 7 residências para o conjunto de 48 unidades no Jardim Europa

localização rua Tucuman, São Paulo.

cliente Banco Hipotecário Lar Brasileiro S.A.

material Perspectiva do conjunto e plantas da residência

fonte $\quad$ Revista Acrópole n. 158, Junho de 1951

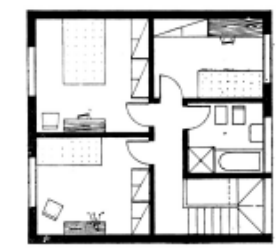

PAVIMENTO SUPERIOR
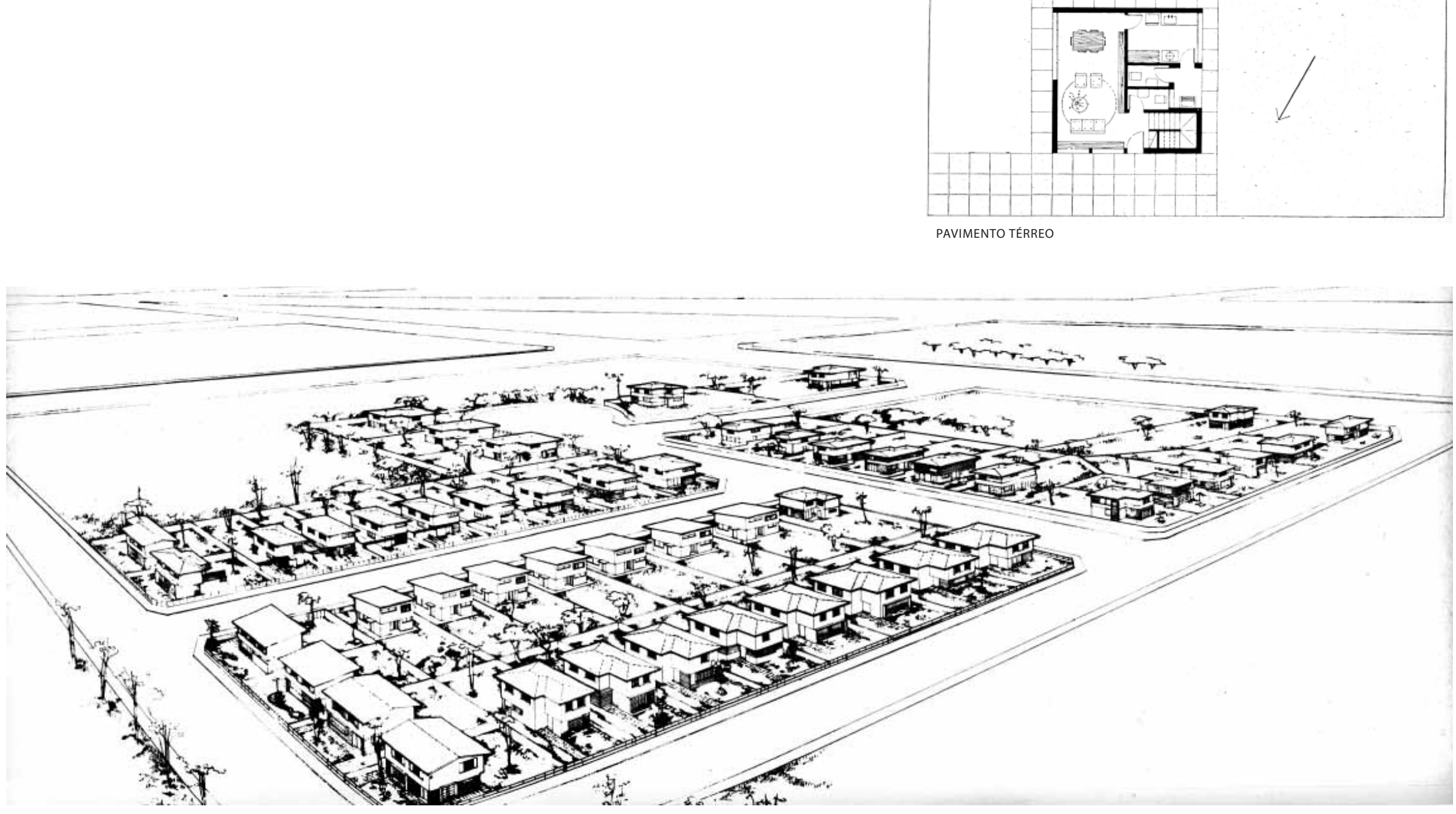


\section{Residência à rua Antonina}

localização rua Antonina, 38. São Paulo (projeto construído).

cliente Sr. Eliseu Meloni

material Fotografias da casa recém construída, 1952-53

fonte

Revista Arquitetura e Decoração n.10, Março/Abril 1955
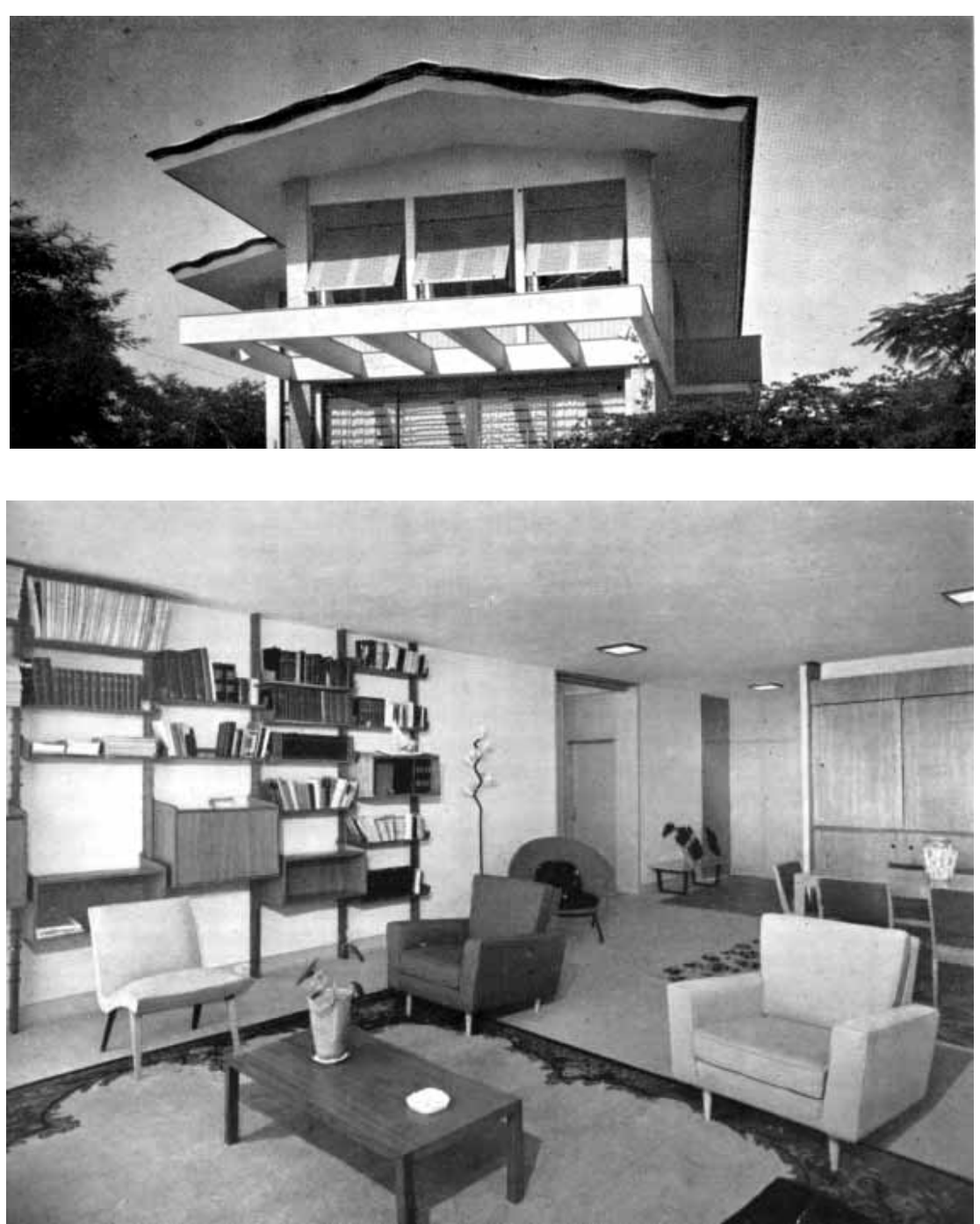


\section{Conjunto Ana Rosa - Residências}

Primeira versão do projeto, realizada em 1950 em conjunto com diversos arquitetos

localização rua Senador José de Queirós Aranha, São Paulo

cliente Banco Hipotecário Lar Brasileiro S.A.

material Plantas de duas residências, 1950

fonte Revista Acrópole n.58, jun 1950

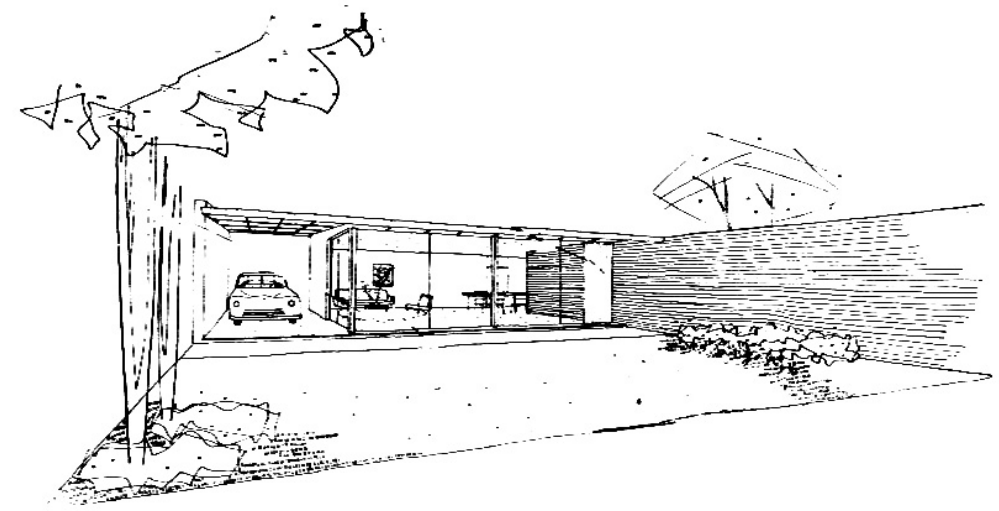

PERSPECTICA CASA A

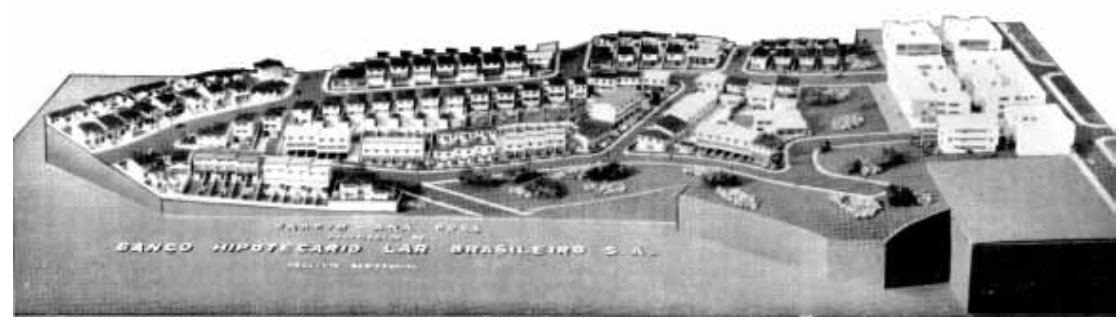

MODELO DO CONJUNTO

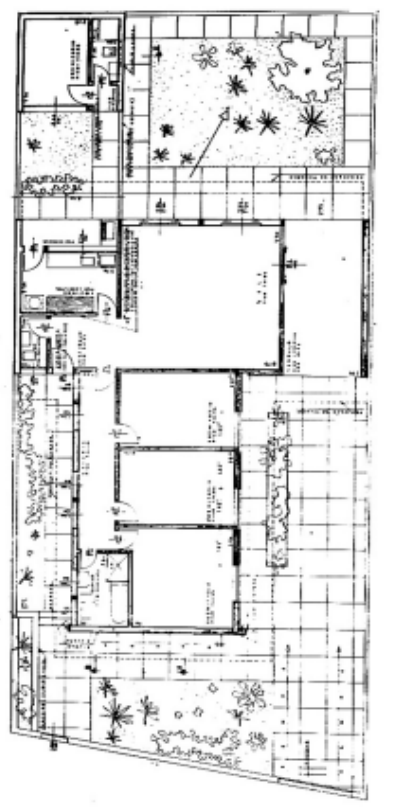

PLANTA CASA A

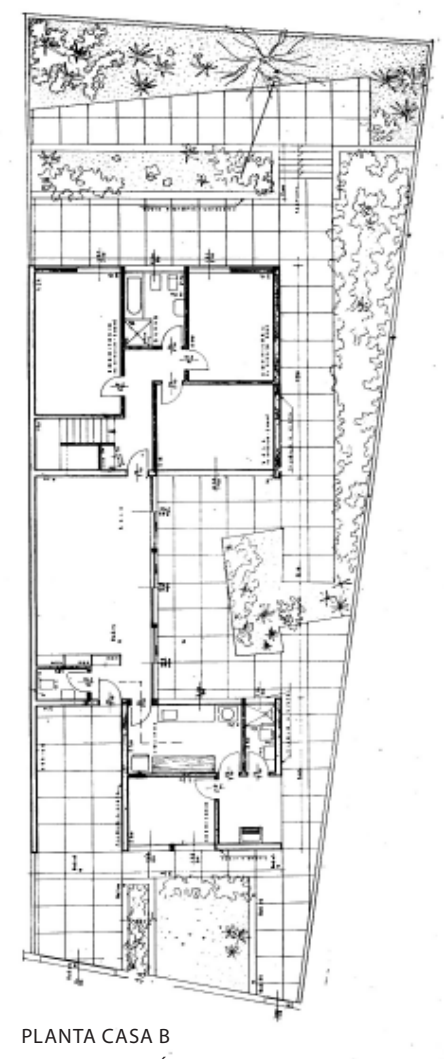

(PAVIMENTO TÉRREO) 
fonte

\section{Hotel Nacional e edifício de apartamentos}

localização Avenida Paulista, São Paulo (projeto não construído)

cliente Grupo Horsa (Hotéis Reunidos S.A.), José Tijurs

material Pranchas de apresentação do projeto, 1952

Arquivo S. Candia

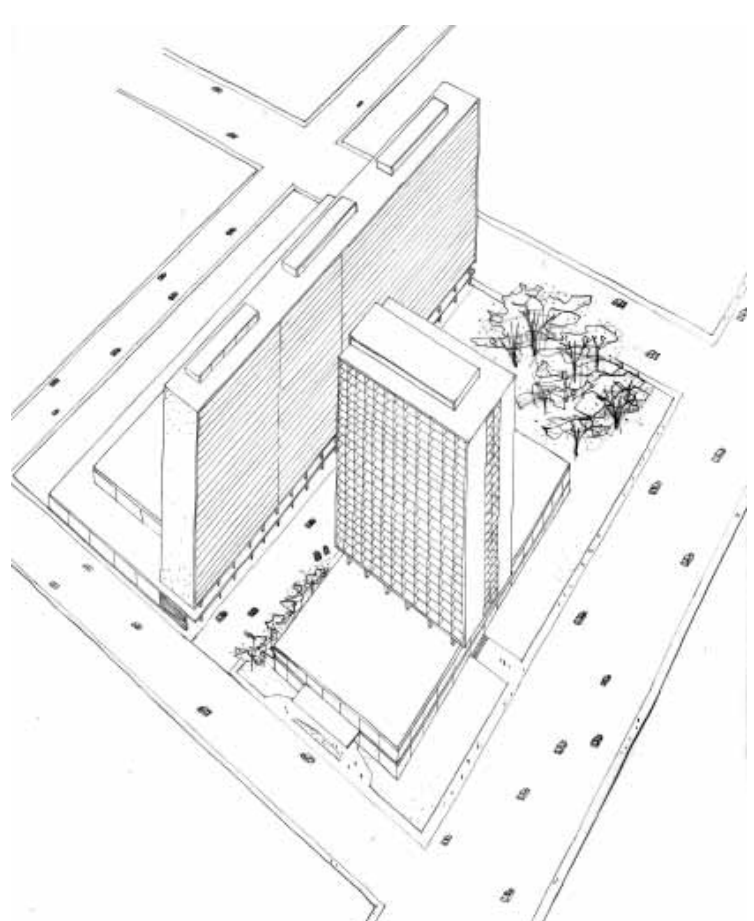

PERSPECTICA DE IMPLANTA;ÁO
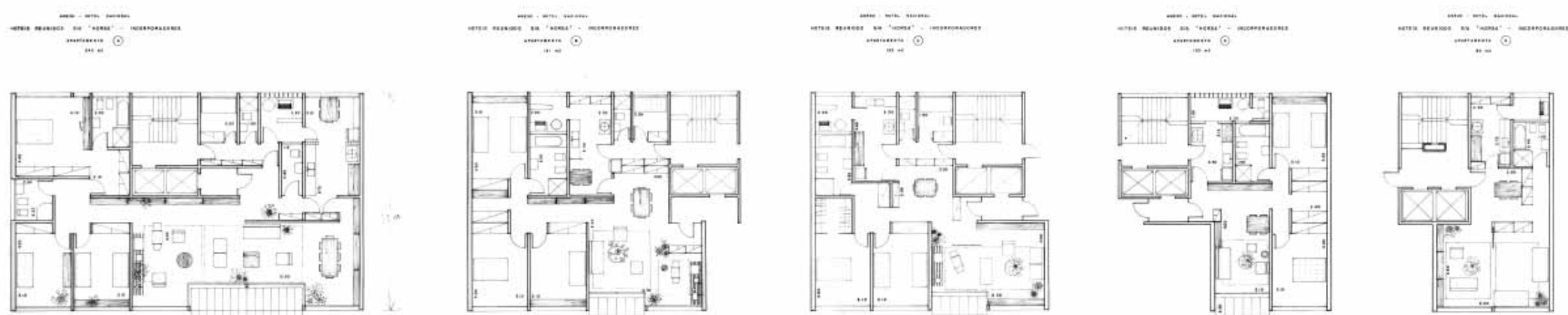

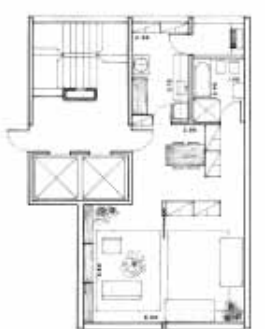

PLANTAS DOS APARTAMENTOS 


\section{Edifício de apartamentos em São Vicente}

localização

cliente

material

fonte rua Jacob Emerich

Dr. Ademar de Morais

Ante-projeto, 1953

Arquivo S. Candia

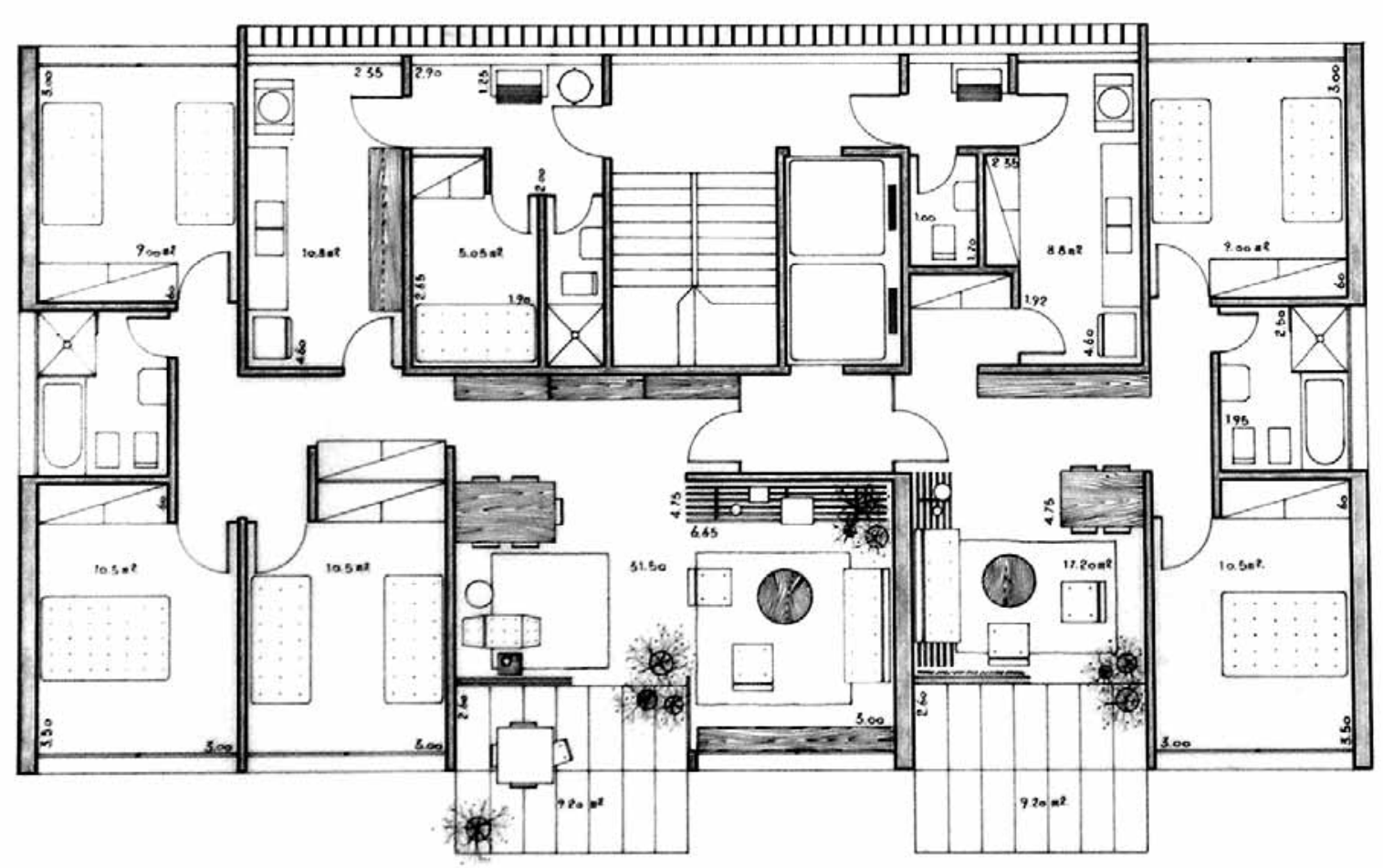

PLANTA PAVIMENTO TIPO 


\section{Residências em Campinas}

localização

cliente

materia

fonte

Cambuí, Campinas

Banco Hipotecário Lar Brasileiro

Ante-projeto, Jun.1953

Arquivo S. Candia
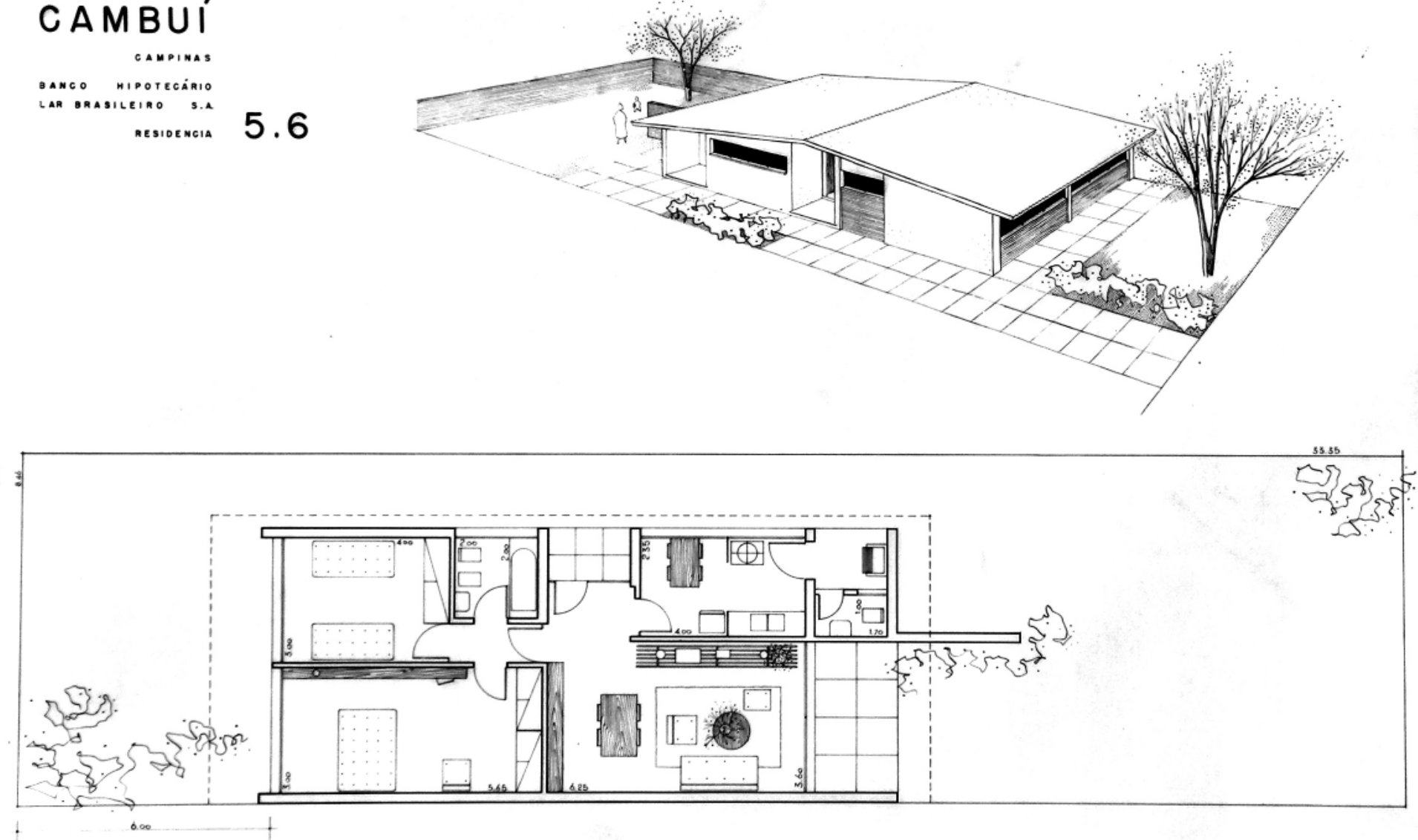


\section{CAMBUÍ}

caupina

LAR BRABILEIRO S.A.

nesioencia 2.3

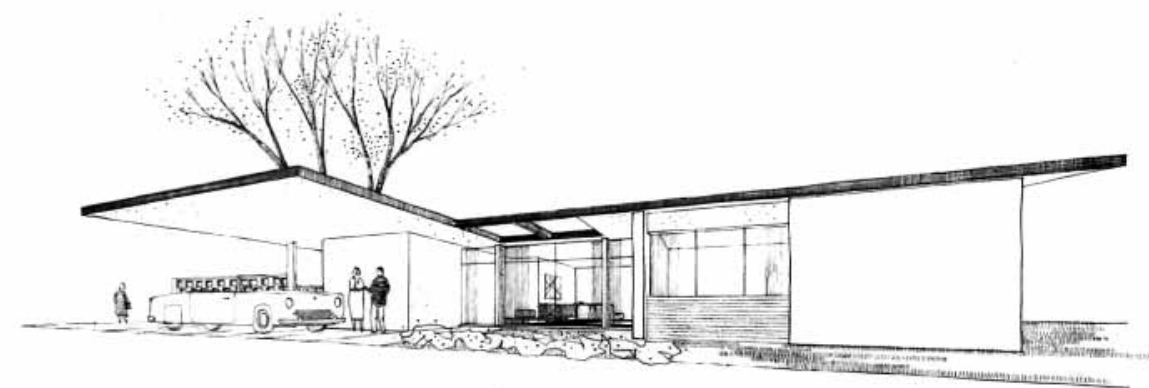

AnEEA

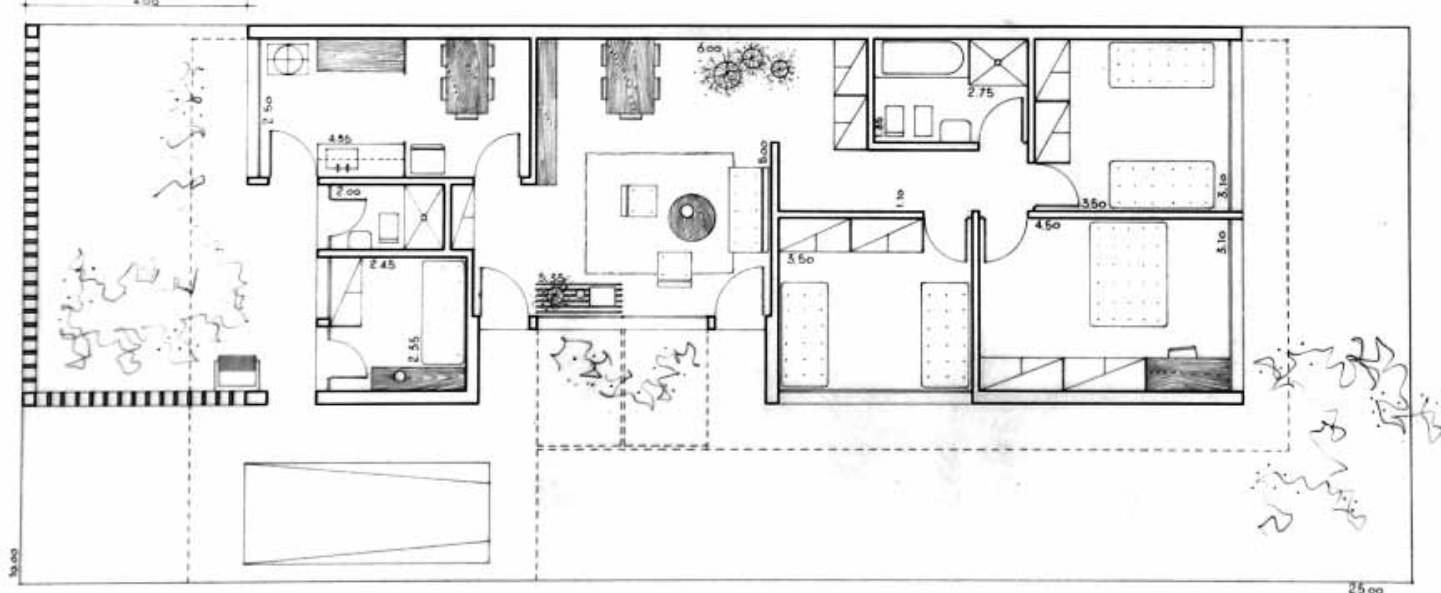




\section{Quadra habitacional em Perdizes e Edifício J oão Ramalho}

Revisão do plano de ocupação originalmente realizado por Abelardo de Souza

colaboração Plínio Croce e Roberto Aflalo

localização Perdizes, São Paulo (parcialmente construído)

cliente Banco Hipotecário Lar Brasileiro

material Estudo Preliminar, Nov.1953/ estudos diversos

fonte $\quad$ Arquivo S. Candia

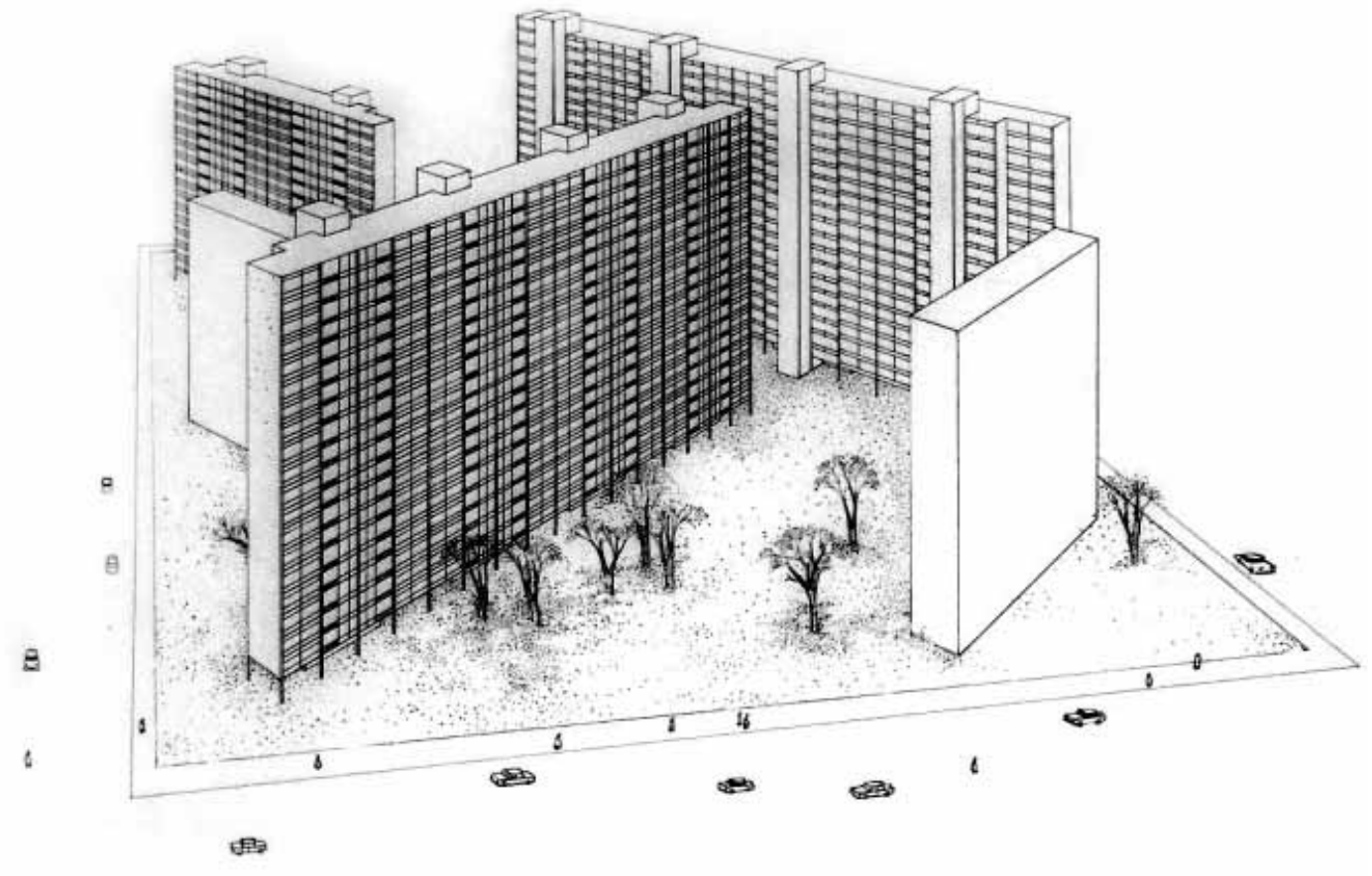

PERSPECTIVA DE IMPLANTAÇÃO

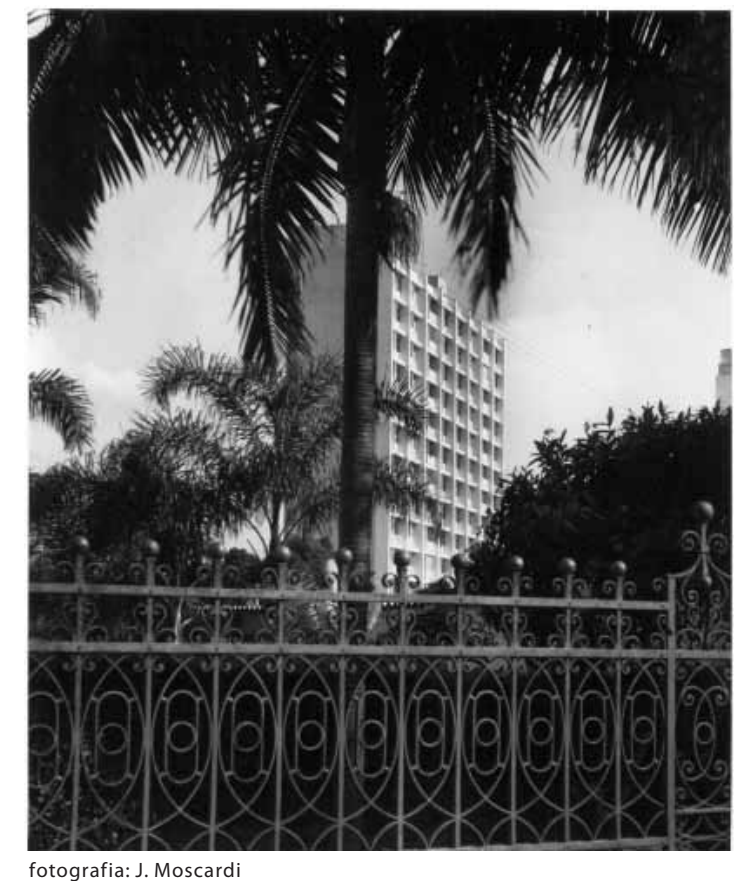

Moscardi 


\section{Edifício de apartamentos}

localização Praça do Ouvidor, Centro - São Paulo

cliente

material

Sr. Érico Stickel

Estudo Preliminar Mar. 1954

Arquivo S. Candia

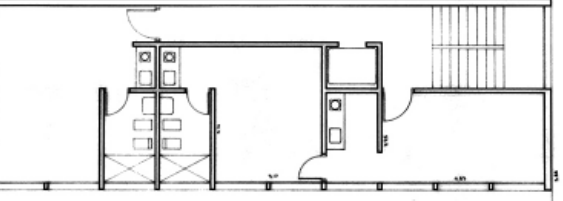

PLANTA DO $10^{\circ}$ PAVIMENTO (ANDARES RECUADOS)

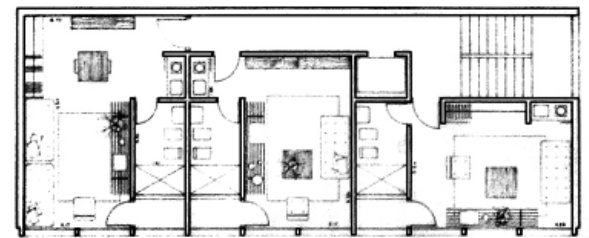

PLANTA DO PAVIMENTO TIPO

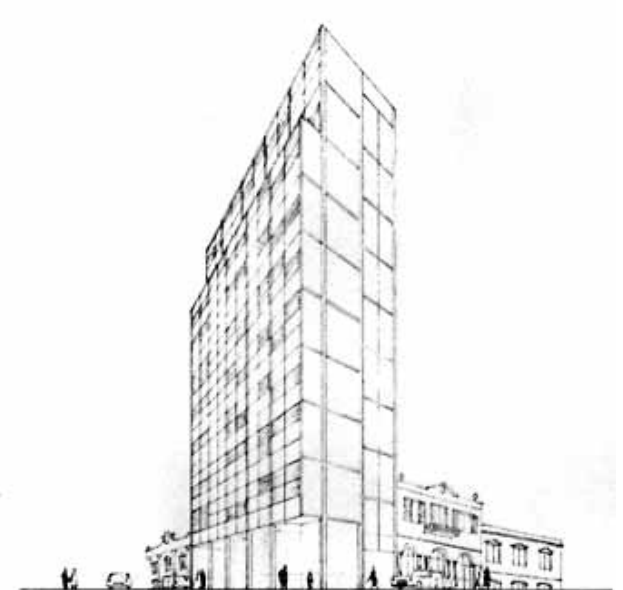

PERSPECTIVA

\section{Residência Erico Sticke}

\section{cliente Sr. Érico Stickel}

material Croquis, 1954

fonte Arquivo S. Candia
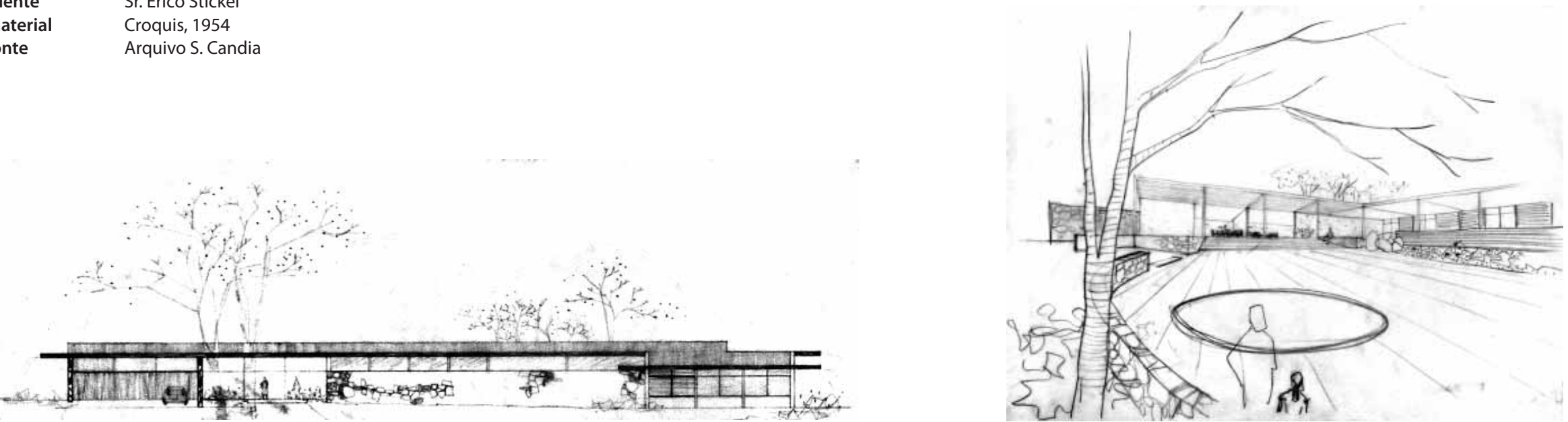


\section{Edifício à rua General Jardim}

\section{localização Rua General Jardim, s/n.}

material

Ante Projeto, 1955

fonte

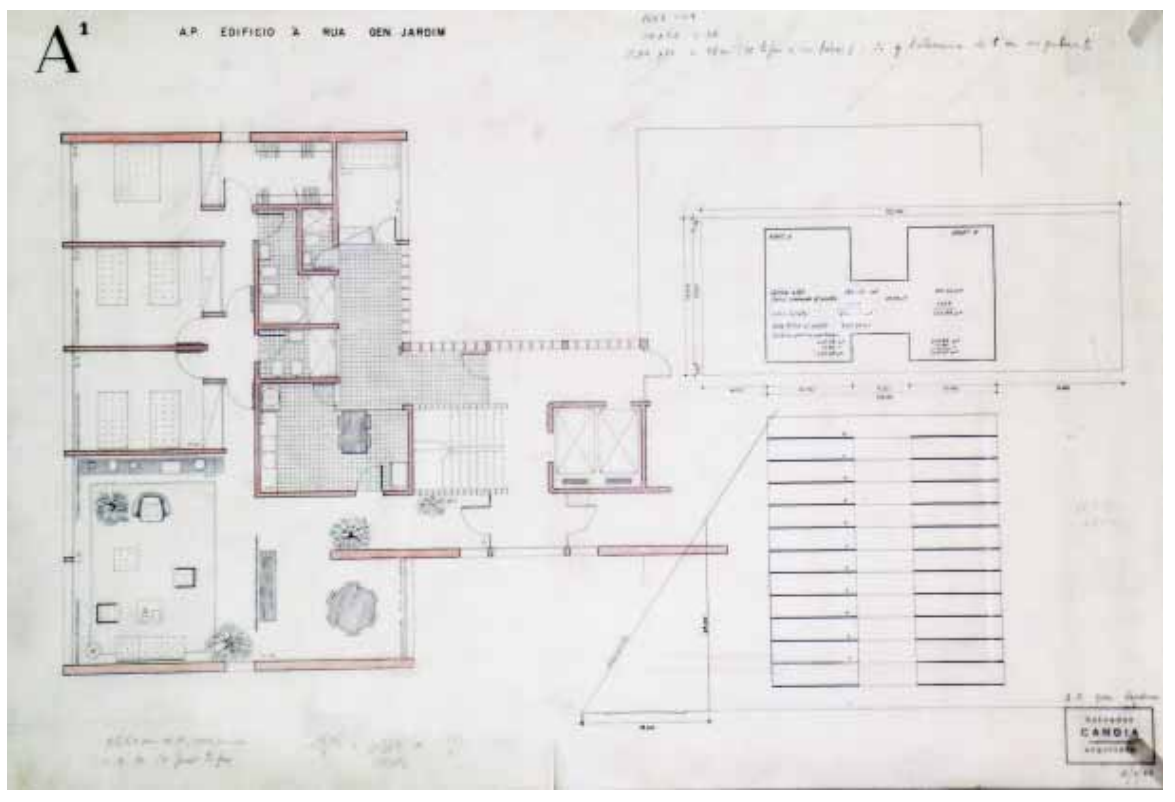

\section{Edifício à rua 7 de Abril}

$\begin{array}{ll}\text { localização } & \text { Rua } 7 \text { de Abril, s/n. } \\ \text { material } & \text { Ante Projeto, } 1955\end{array}$

material

Arquivo S. Candia

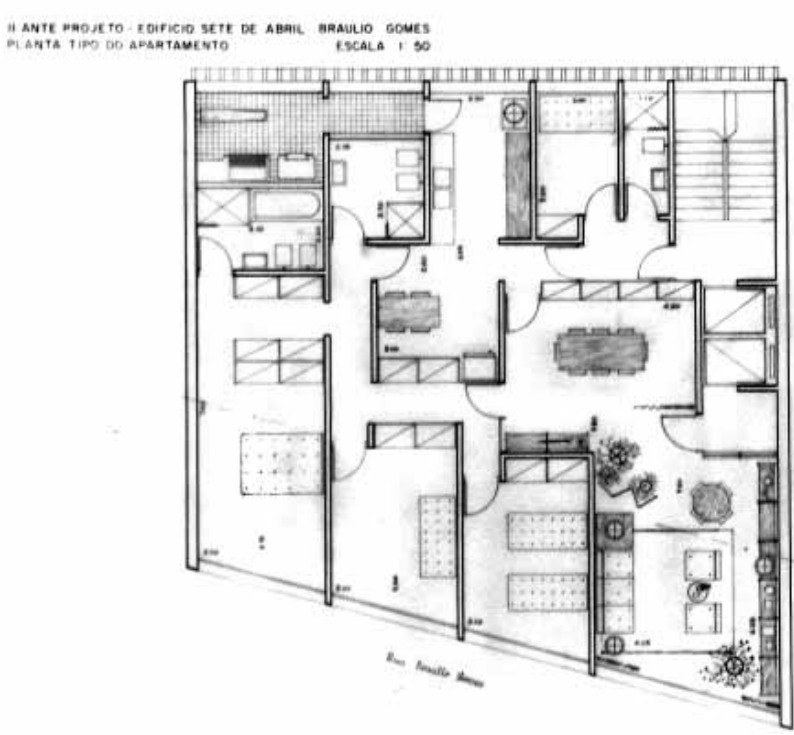




\section{Edifício Itatiaia}

18 pavimentos e $8.3270 \mathrm{~m}^{2}$

localização Praça Rui Barbosa, Santos - SP

cliente Banco Lar Brasileiro SA

material Fotografias da inauguração da obra, projeto de (1957-58)

fonte

Arquivo S. Candia

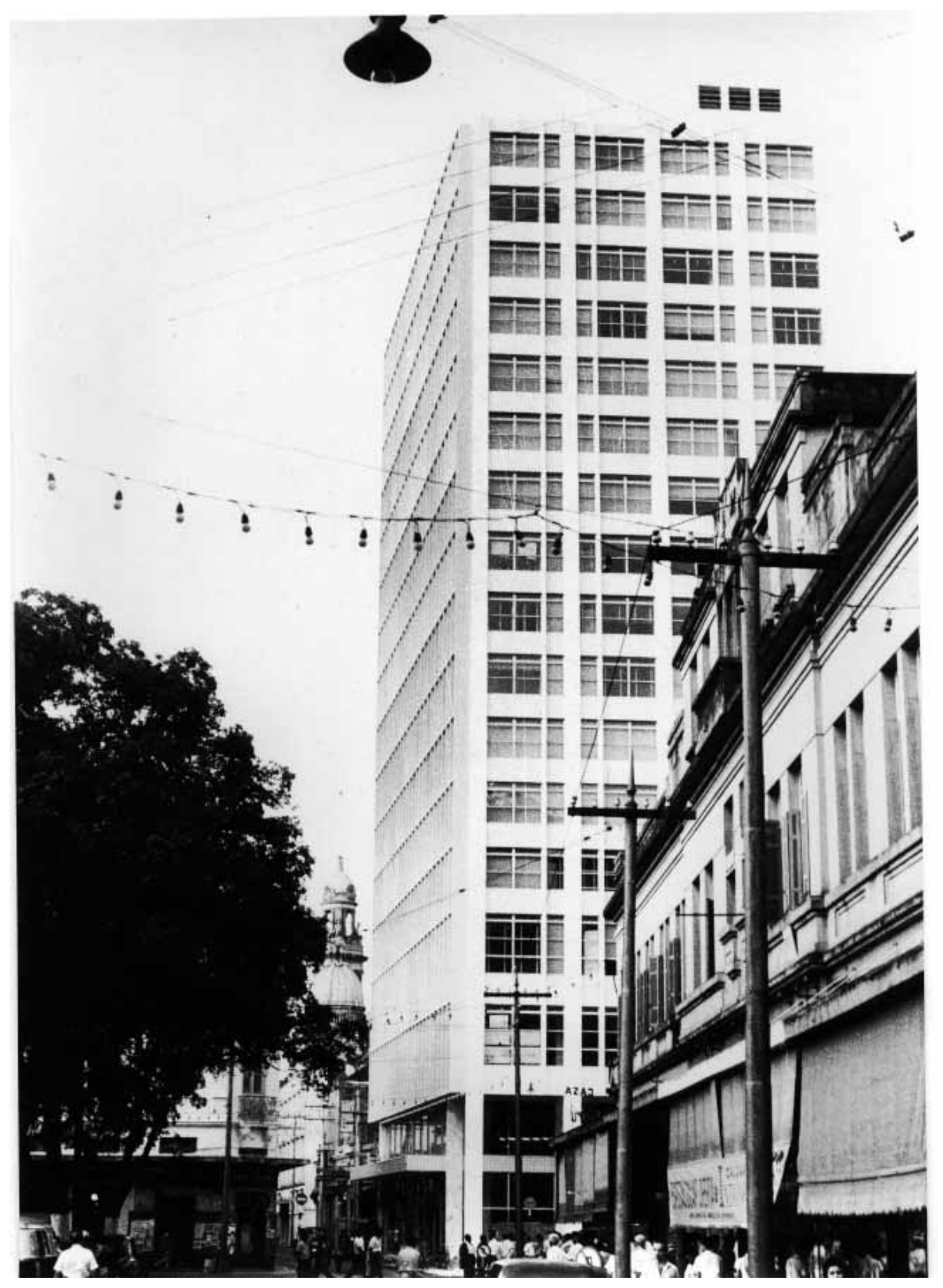




\section{Dois edifícios de Apartamentos para oJ ardim Ana Rosa: versão I}

localização rua Dr. José Queiroz Aranha, São Paulo (projeto construído)

cliente

material

Banco Hipotecário Lar Brasileiro

Projeto Executivo Versão Preliminar, 1956-57

fonte

Arquivo S. Candia/ Revista de Engenharia do Mackenzie n.132, Fevereiro/Março de 1957
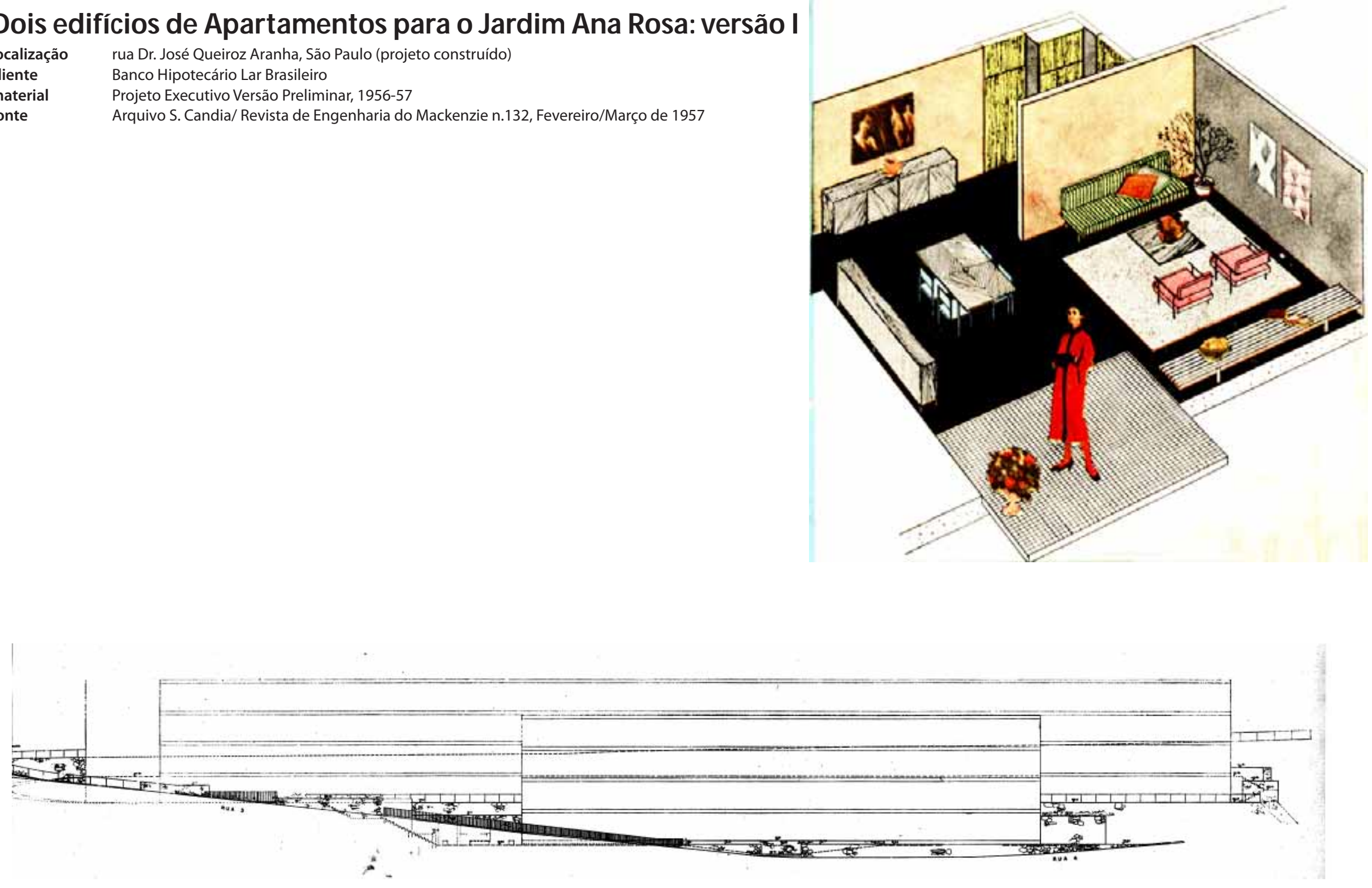

Elevação do conjunto 

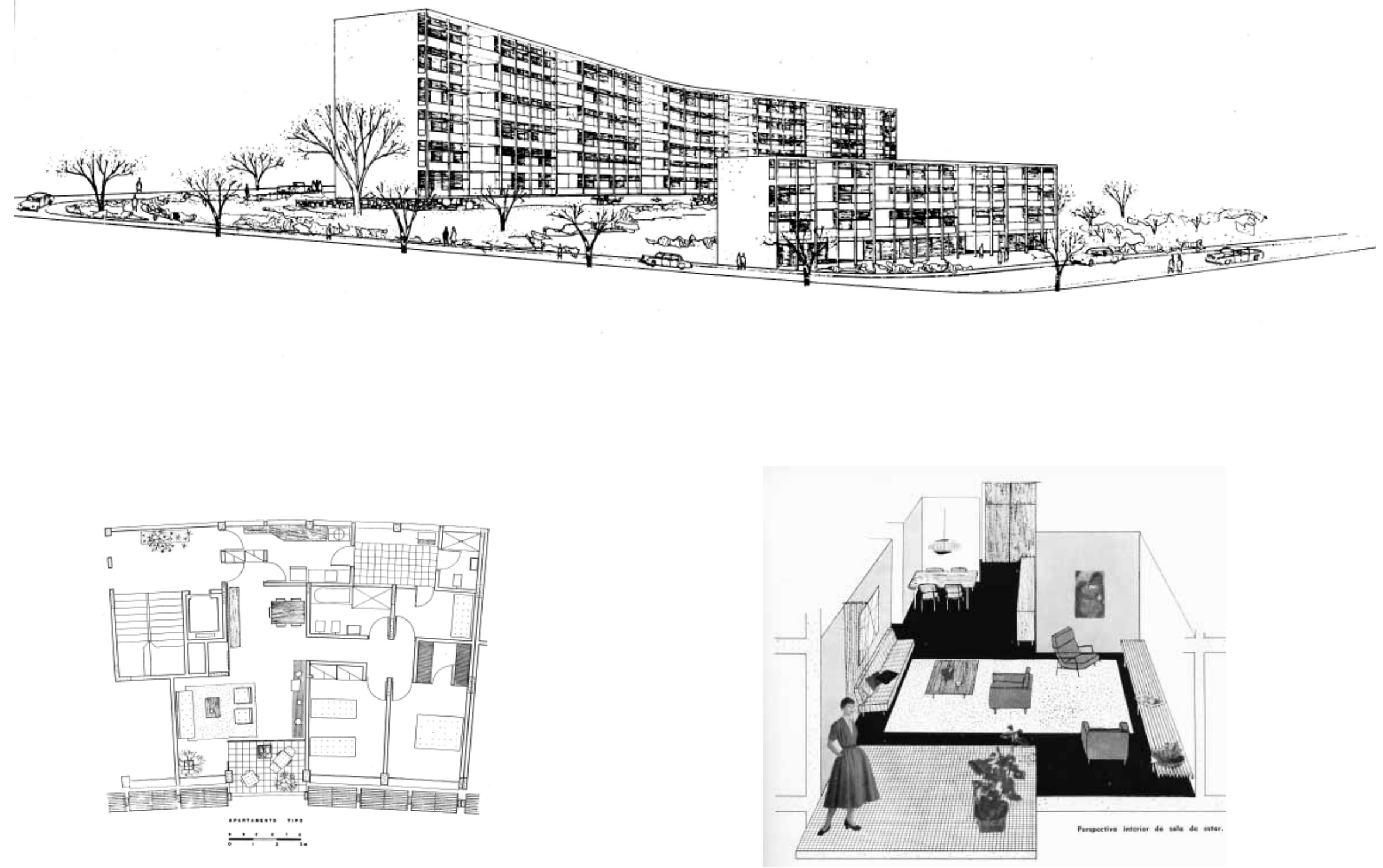


\section{Dois edifícios de Apartamentos para oJ ardim Ana Rosa: versão II}

\section{localização rua Dr. José Queiroz Aranha, São Paulo (projeto construído)}

cliente

Banco Hipotecário Lar Brasileiro

material

Ante Projeto (parcial) s. data

fonte

Arquivo S. Candia

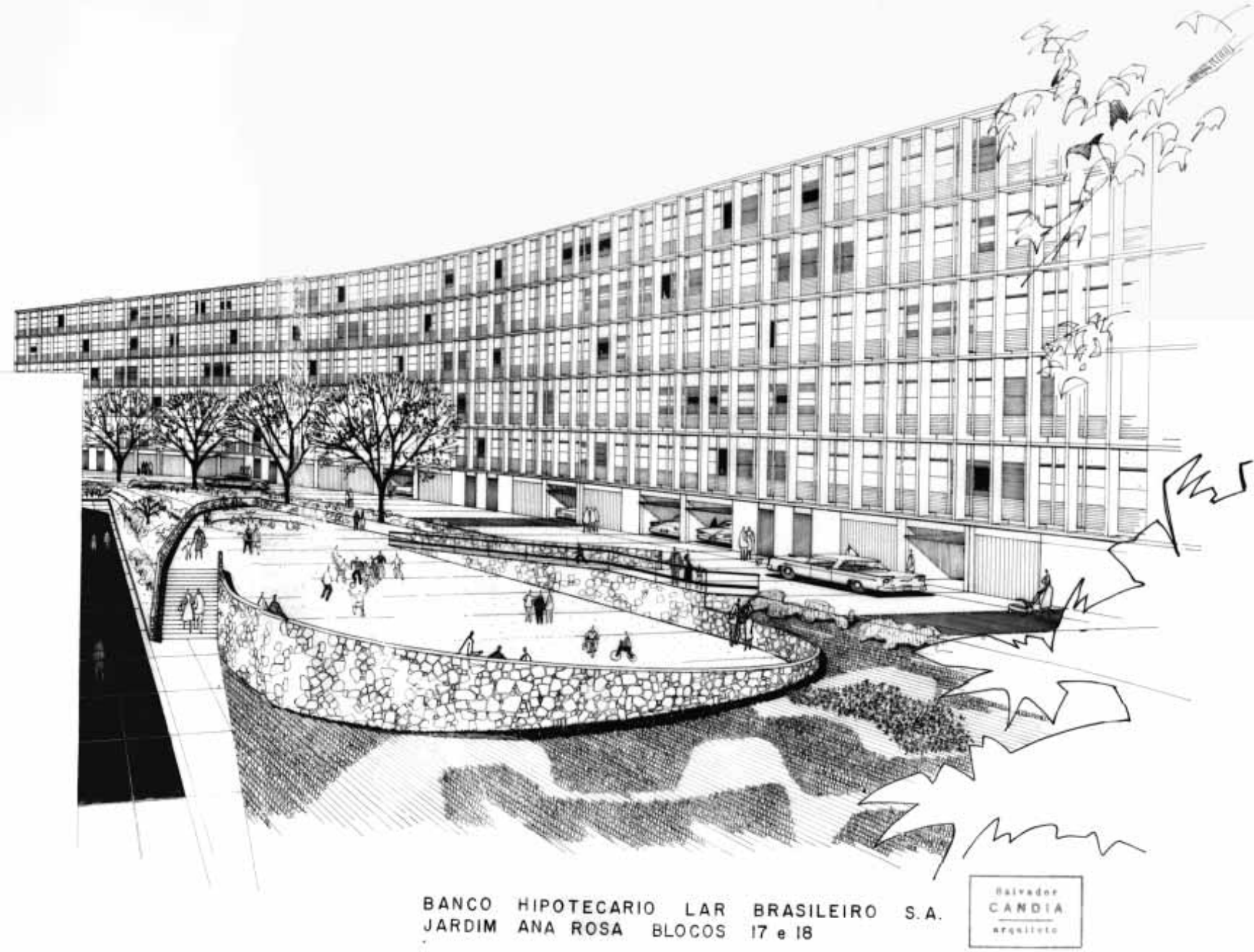




\section{Banco Lavoura de Minas Gerais}

colaboração Álvaro Vital Brazil

localização Rua Boa Vista, São Paulo

cliente Banco Lavoura de Minas Gerais

material Projeto Executivo 1958/ Fotografias da obra concluída 1963

fonte

Projeto Executivo
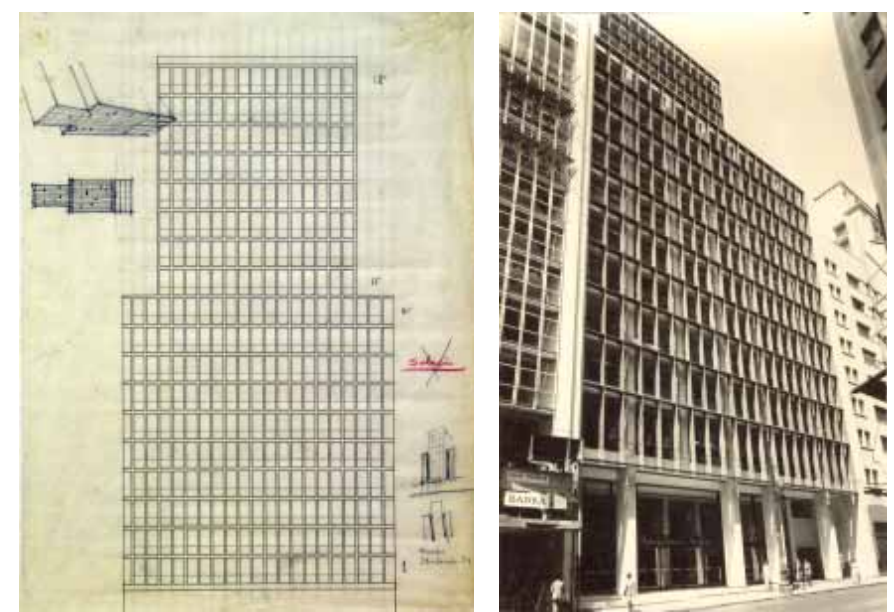

\section{Edifício Roosevelt}

\section{localização}

cliente

material

Santos, SP

Banco Lar Brasileiro

fonte

Ante Projeto 1958

Arquivo S. Candia

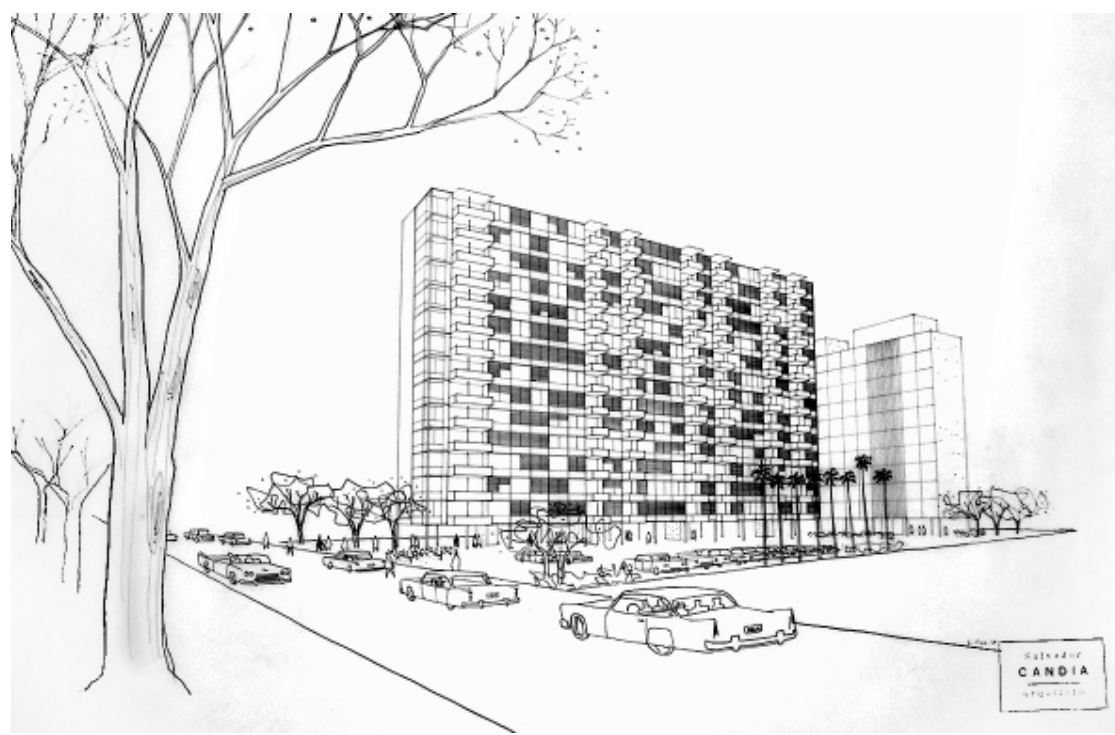




\section{Edifícios Barão de Laguna e Barão de Ladário}

colaboração Plínio Croce e Roberto Aflalo

localização Perdizes, São Paulo

cliente Banco Hipotecário Lar Brasileiro

material Estudos, Ante Projeto e Projeto Executivo, 1959

fonte

Estudos, Ante Proje
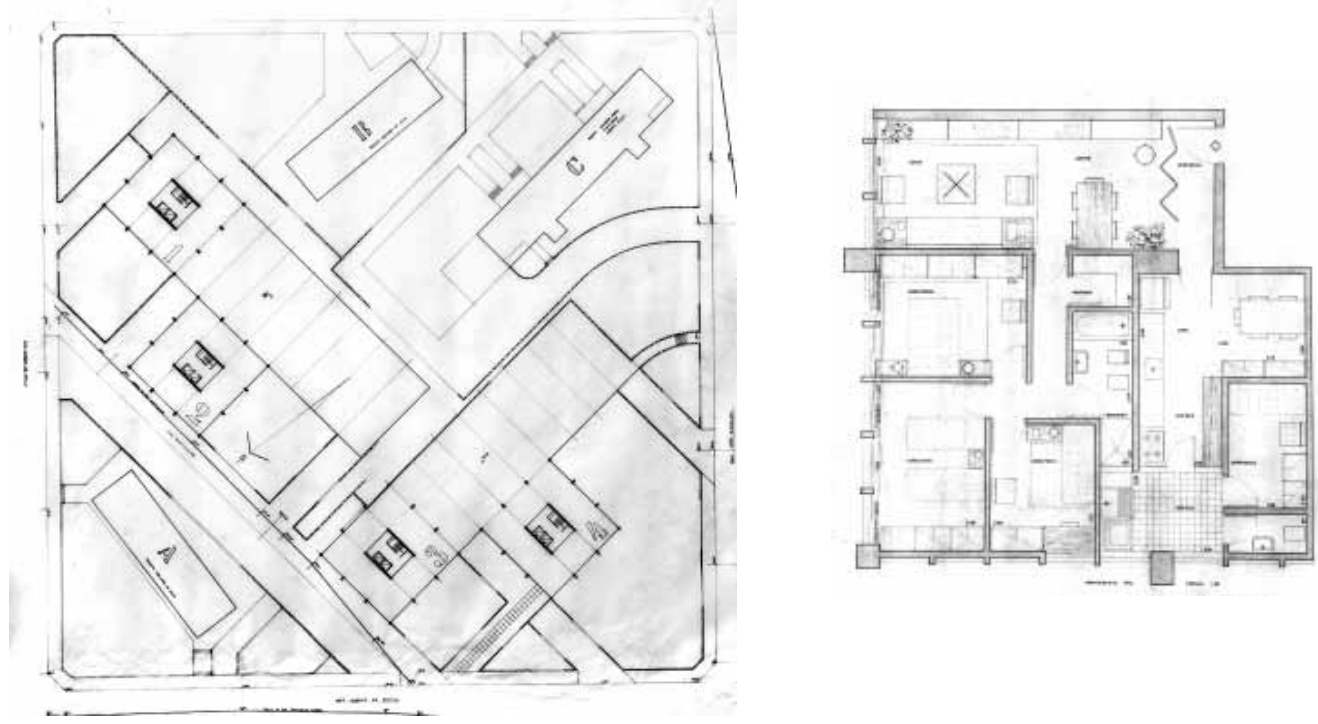

\section{Conjunto de edifícios de apartamentos em Curitiba}

Grupo de 11 ed de apartamentos cinema

localização Avenida Getúlio Vargas x Avenida Iguassú, Curitiba

material Estudo Preliminar 1959

fonte $\quad$ Arquivo S. Candia

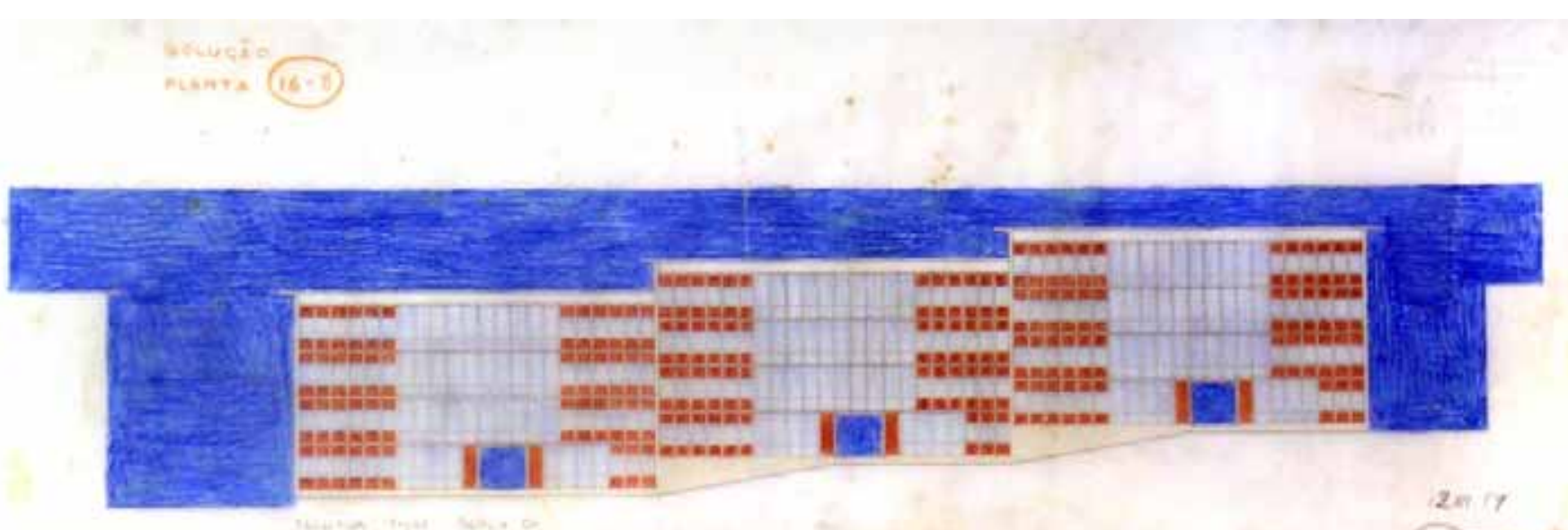




\section{Escola IPESP Itapira}

\section{localização Itapira, SP}

cliente IPESP

material Ante Projeto, 1959

fonte

Arquivo S. Candia

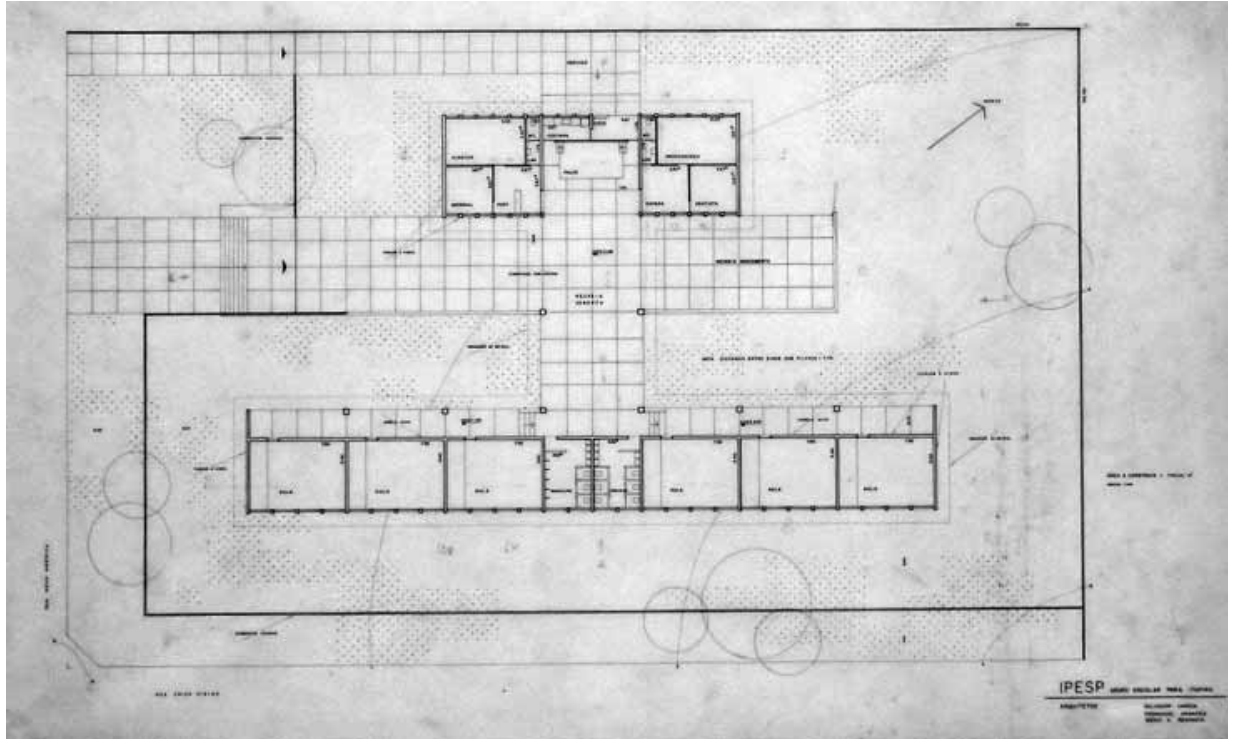

\section{Edifício Metrópole}

180 lojas, 80 escritórios (26 pavimentos), cinema e garagens $\left(35,151 \mathrm{~m}^{2}\right)$

colaboração Giancarlo Gasperini

localização Praça Dom José Gaspar, São Paulo

material Estudos diversos, 1959/ Projeto Executivo, 1960-61

fonte

Arquivo S. Candia/ Giancarlo Gasperin

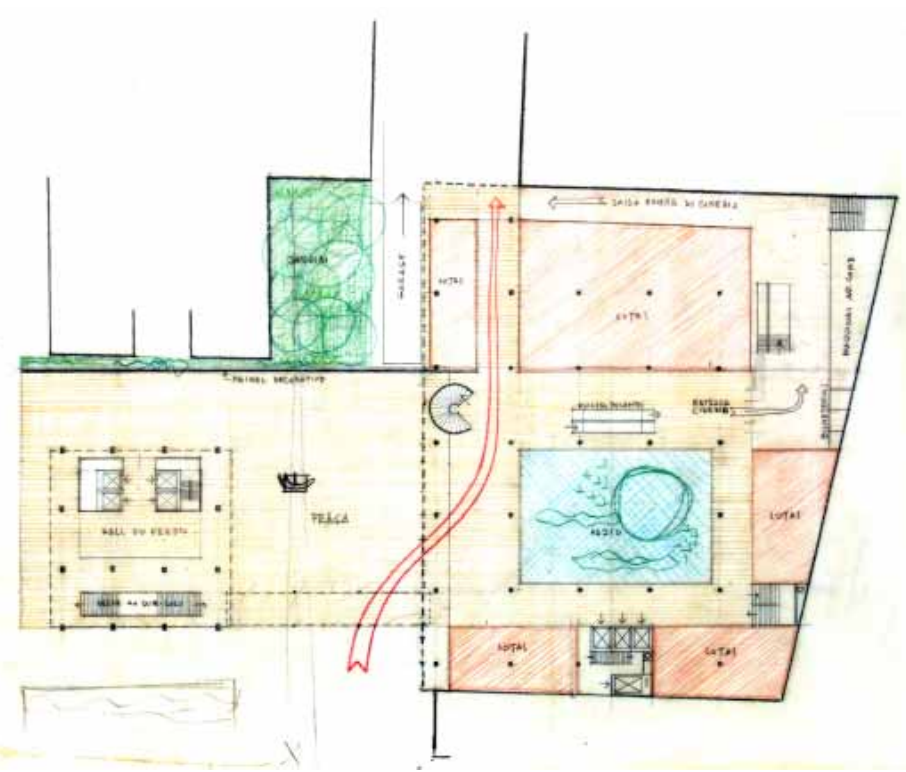




\section{Edifício J ulio de Castilhos}

20 apartamentos e diversas lojas $\left(4.814 \mathrm{~m}^{2}\right)$

localização avenida Julio de Castilho, Caxias do Sul - RS (obra construída)

cliente

Banco da Lavoura de Minas Gerais

material Ante-Projeto (arquivo S. Candia) Julho, 1960

fonte

Arquivo S. Candia/ Revista de Engenharia do Mackenzie n.132, Fevereiro/Março de 1957

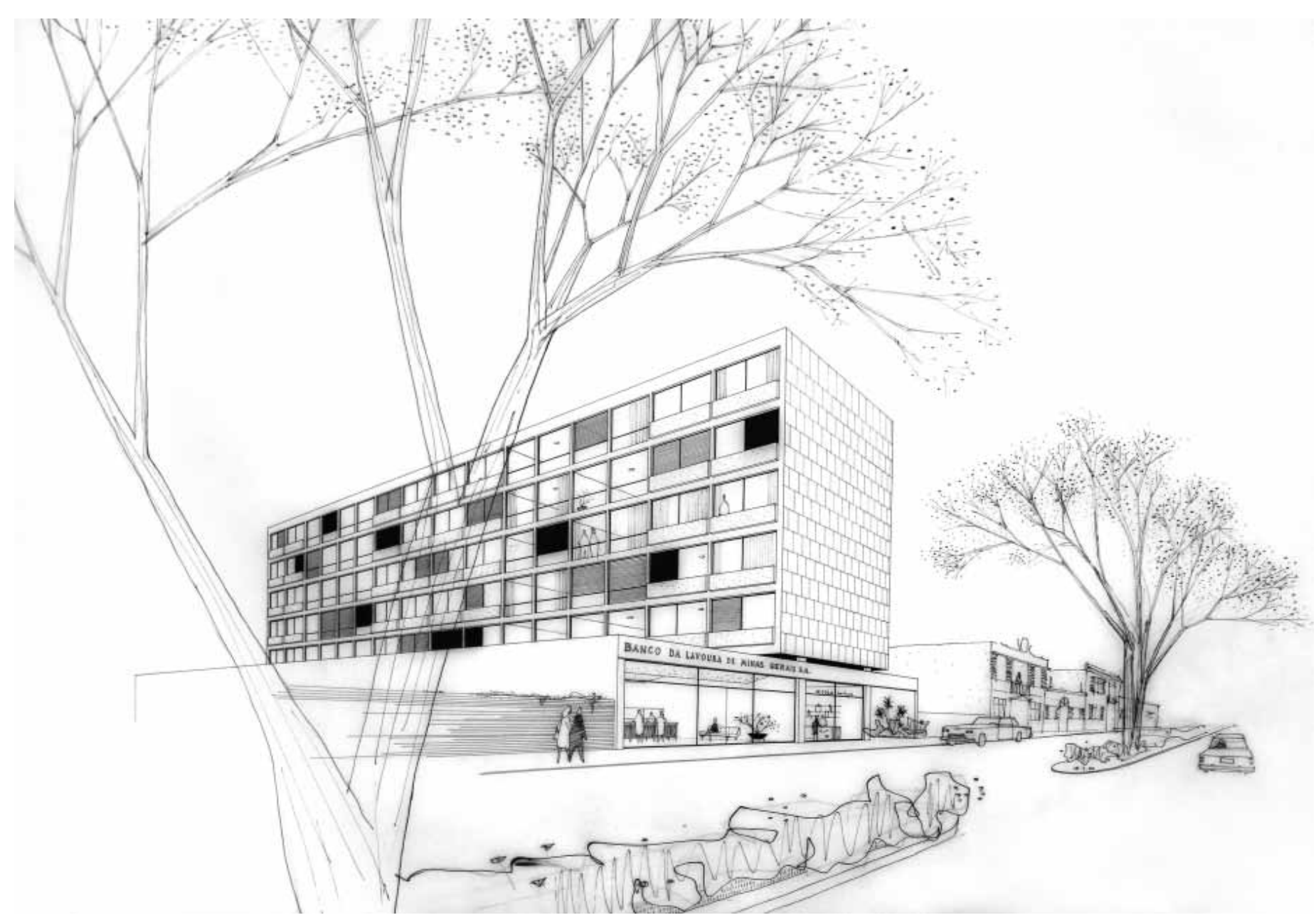




\section{Edifício Aços Villares}

Edifício de 12 pavimentos de escritórios e depósito

localização Avenida do Estado 6.116, São Paulo

cliente Aços Villares S.A.

material Ante Projeto/ Projeto Executivo, 1961

fonte
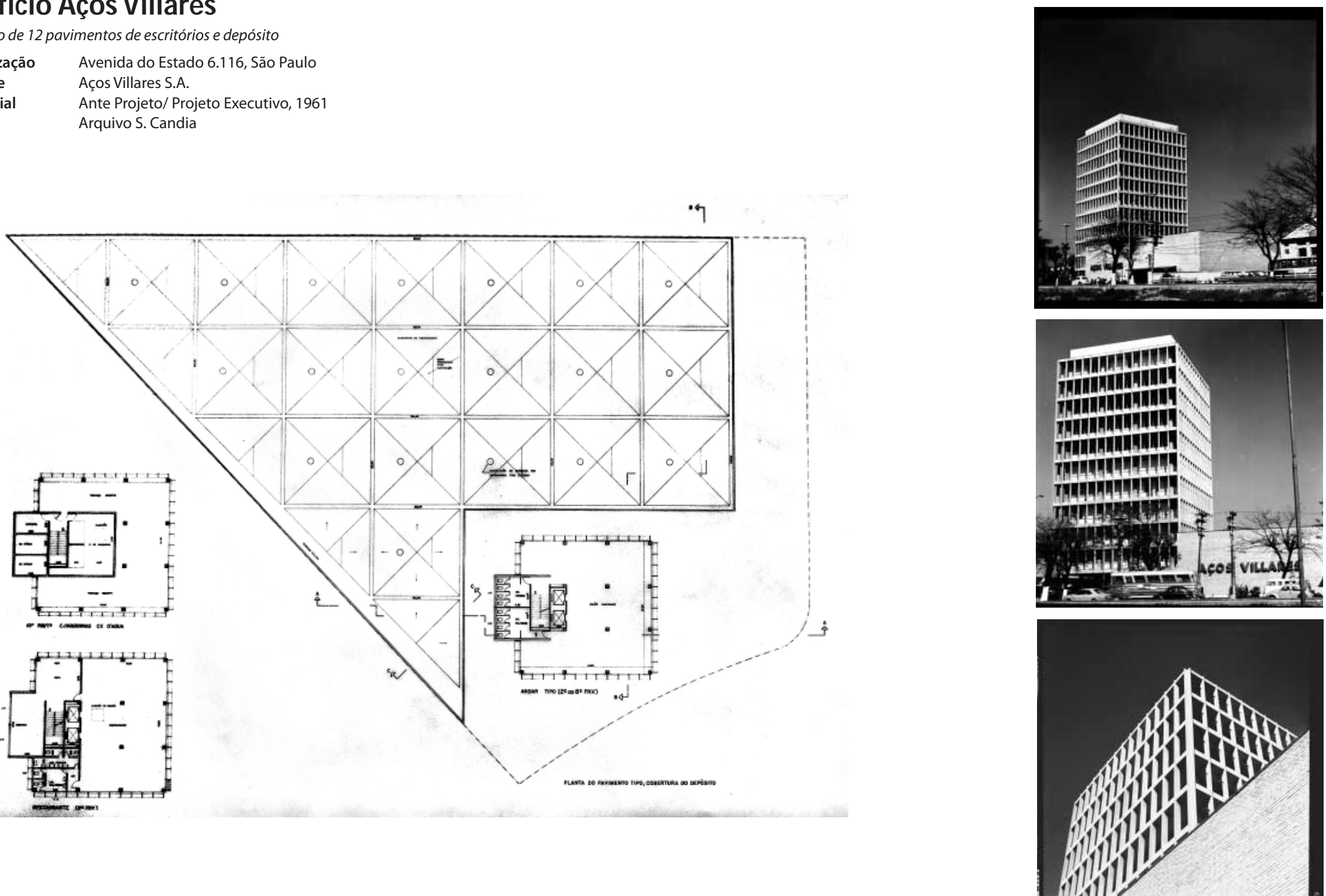


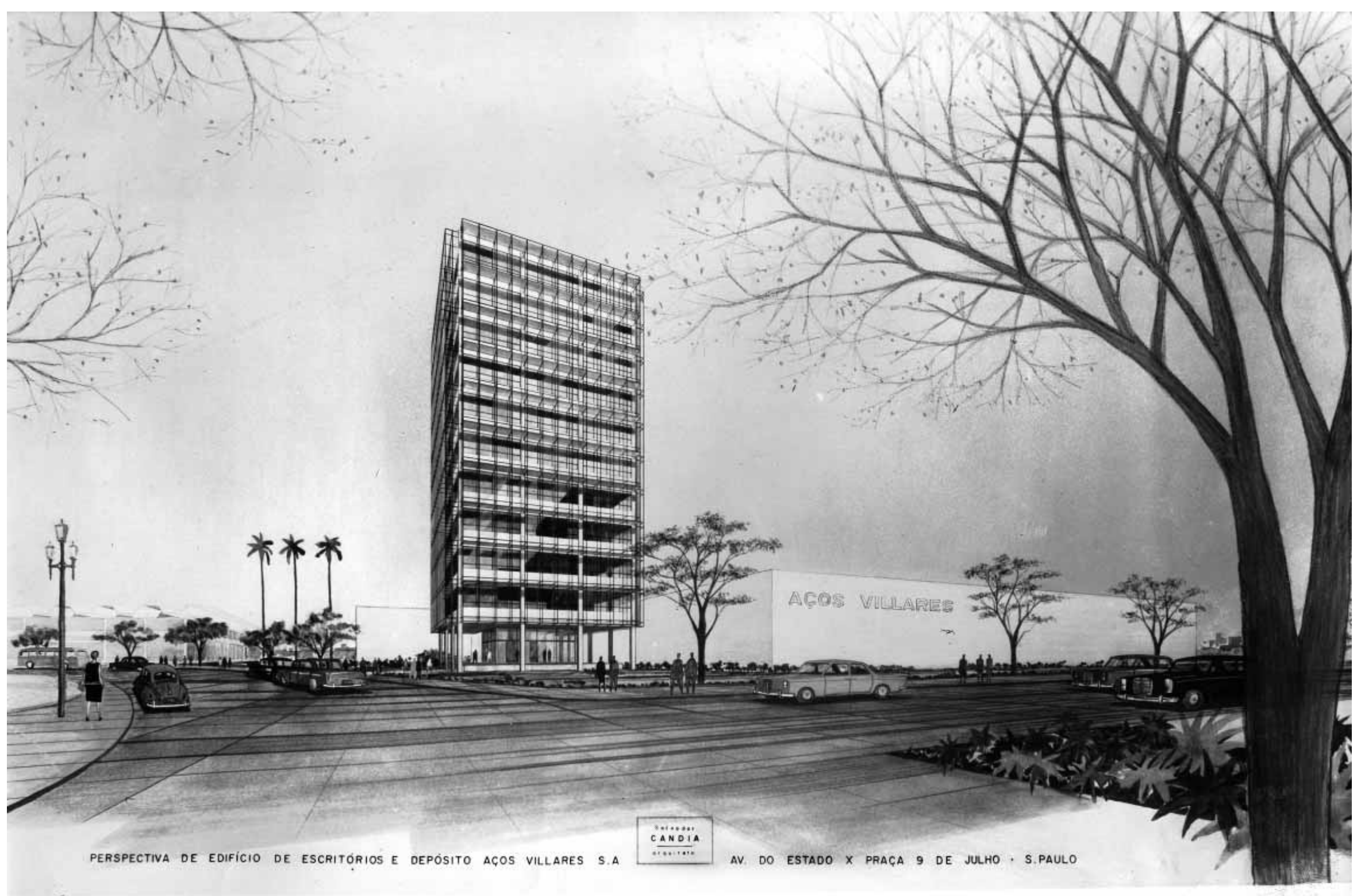


Edifícios à rua Marquês de Itu x Aureliano Coutinho - versão I

localização Higienópolis, São Paulo

material

Ante Projeto, 196

fonte

Arquivo S. Candia
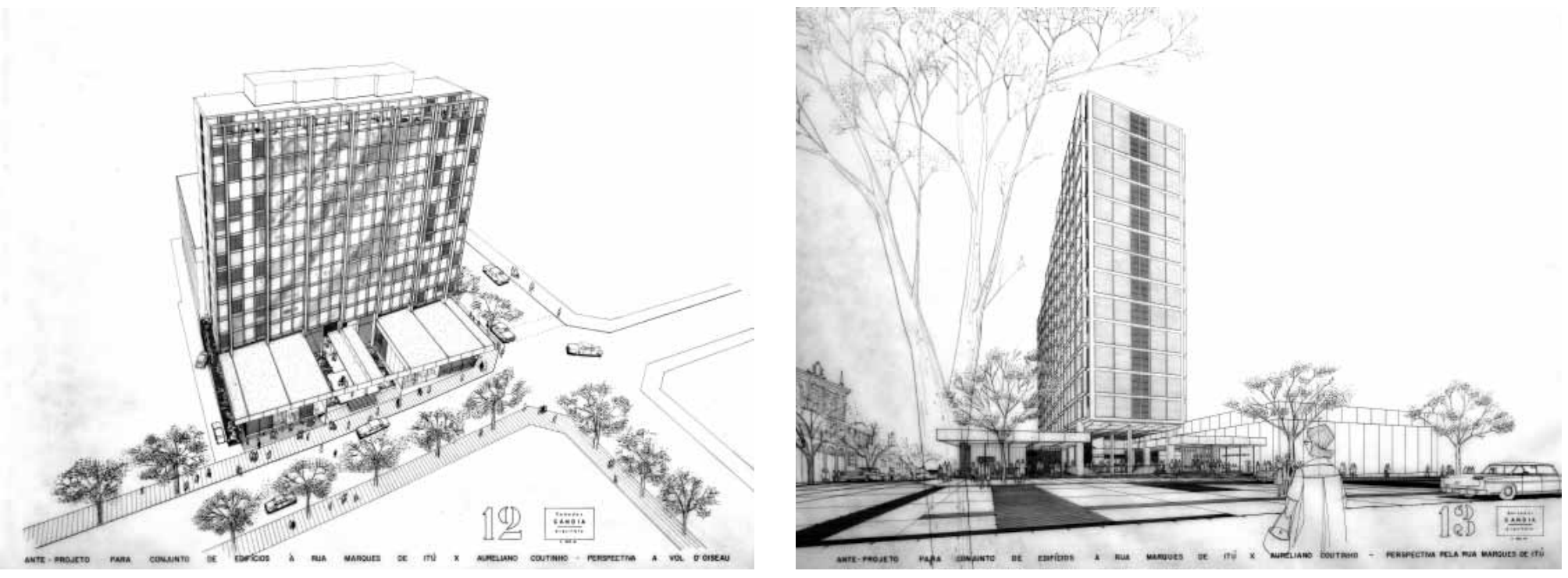


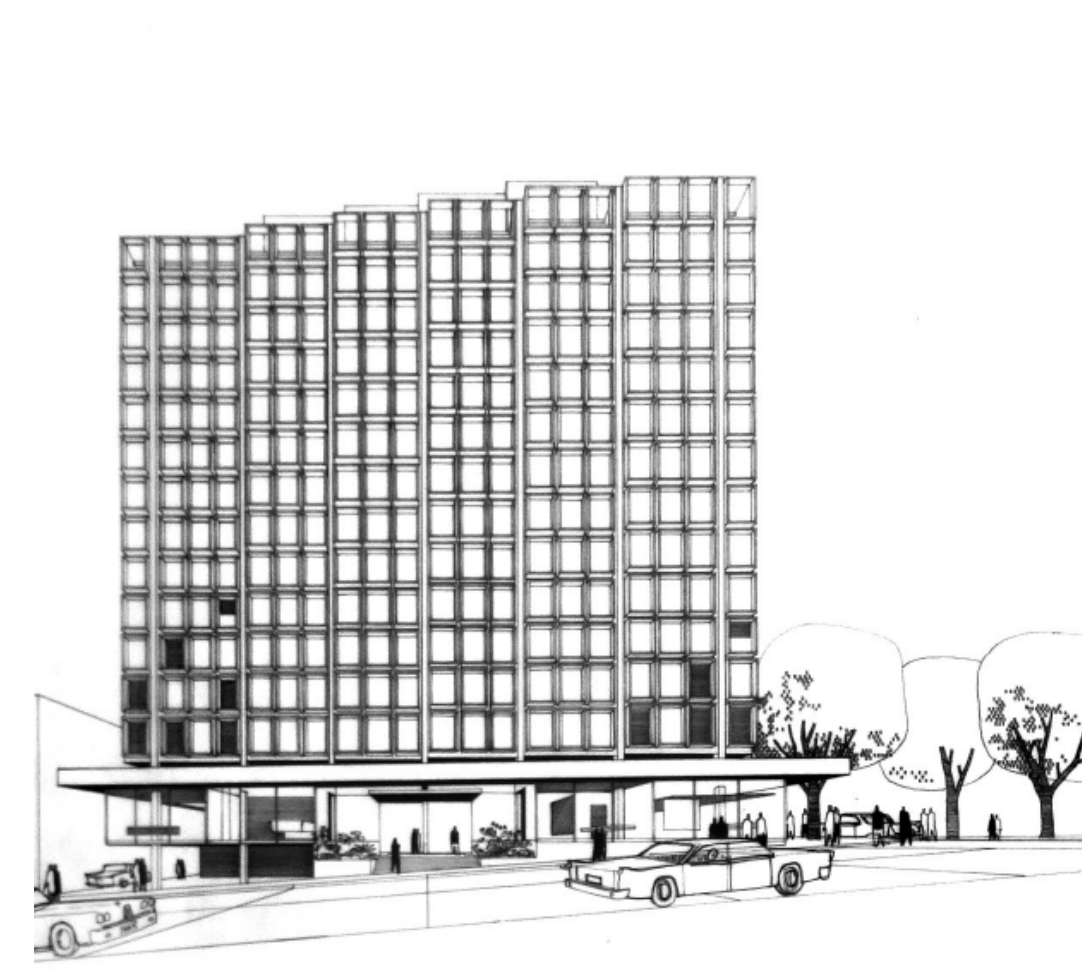

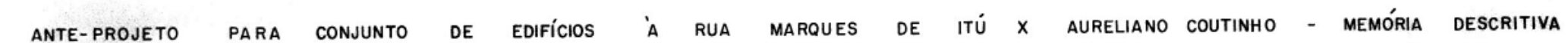

\section{Orsiduastoess Prois}

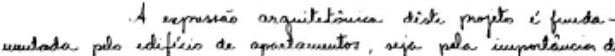

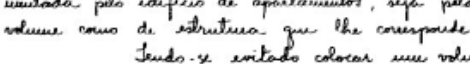

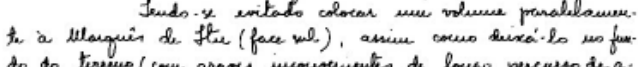

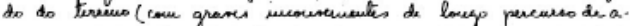

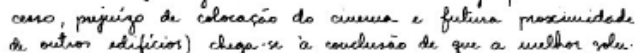

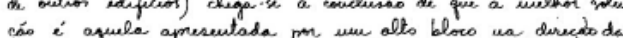

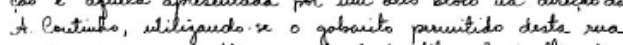

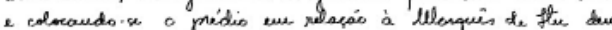

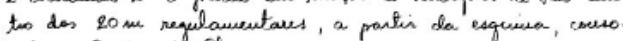
arte O Qidino de Olras

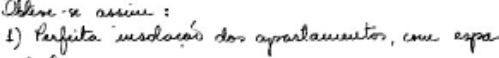

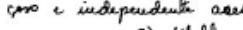

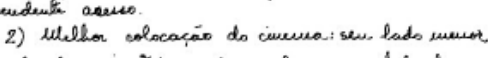

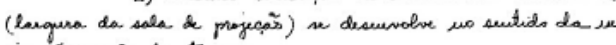
pole pópis can'ter de funcior lualidade.

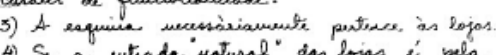

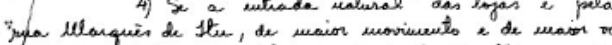

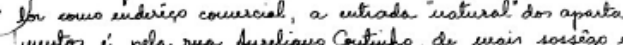

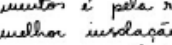

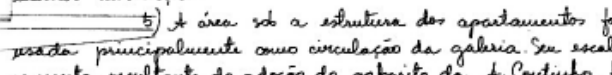

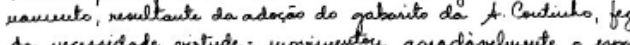

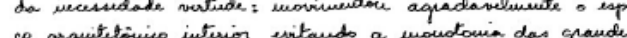

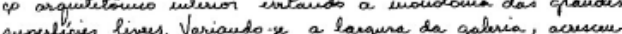

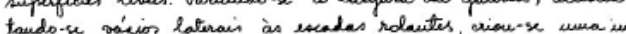

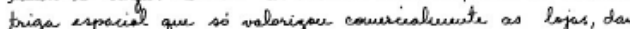
do. Vles sucion evidiecia

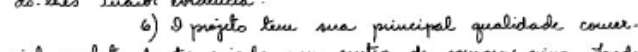

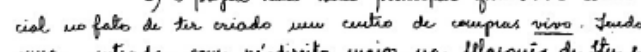

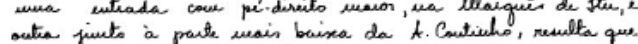

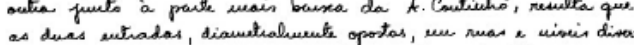

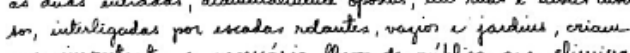

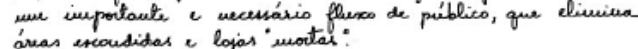

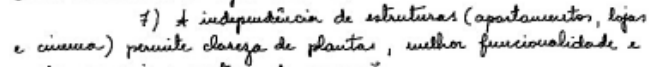

Crasidersciés Eospecifices is folles do progto

Father 3 : garague us vibsols

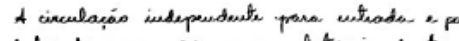

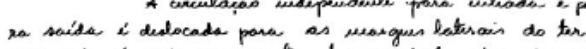

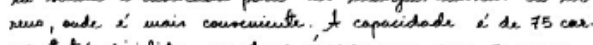

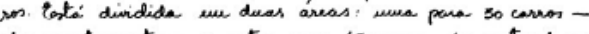

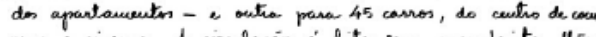
pras ine

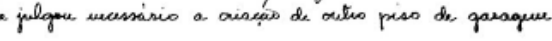

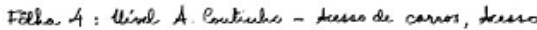

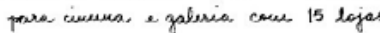

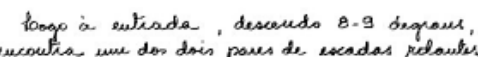

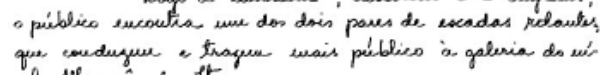
vel lllarquin de" the.

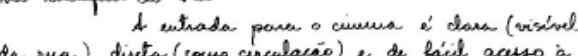

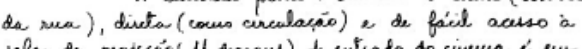

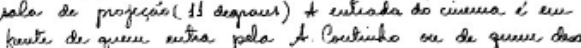

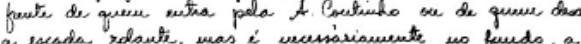

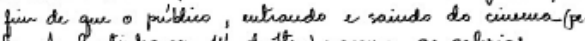

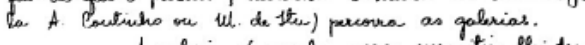

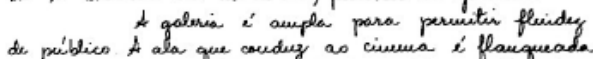
por sur grande couthiro de plantas, já do lado exter. wo, was cont visublidade do intrior. furportante, is ter a billeteria fora do ci

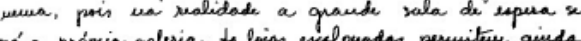
vaion visibibildade de vitrines.

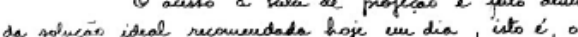
píblico ativarindo a platíia ua sua jous cartál.

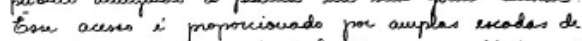

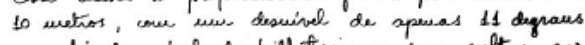

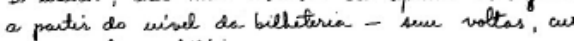
vas oce outtos antifíciors

do do partido tirado do dravinal do terrewar.

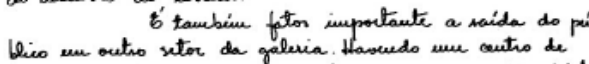

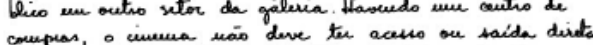
pera as reas sua fruçäo é foge o píblice circular vas plevicas de acries is lojas.

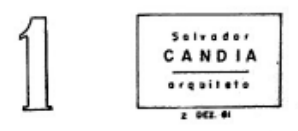




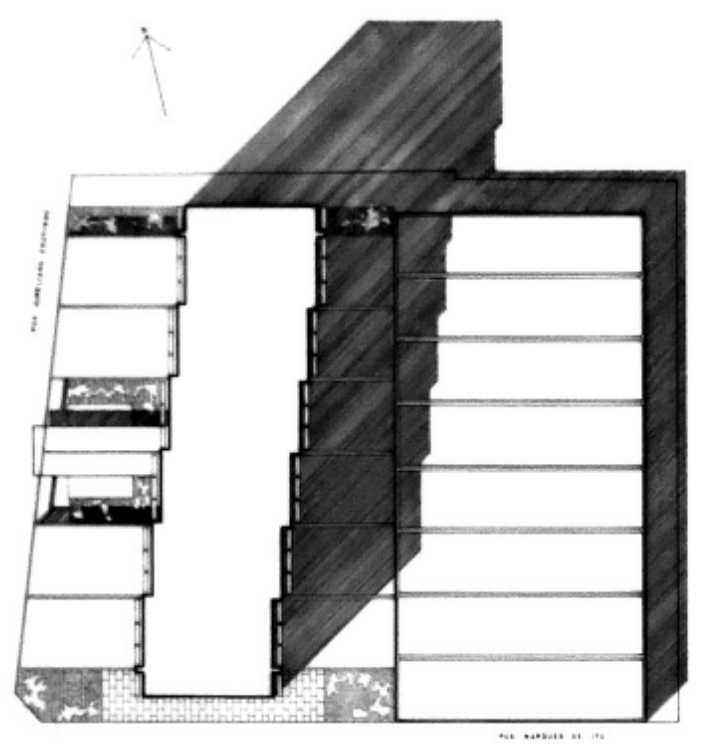

nom. $x$ mate

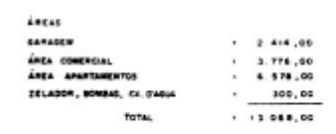

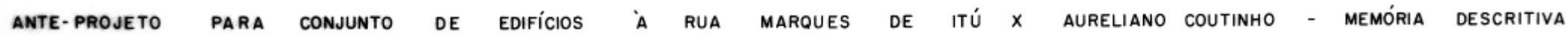

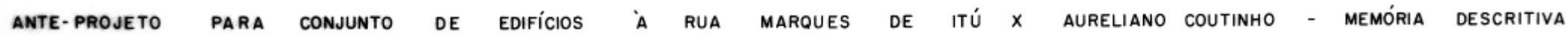

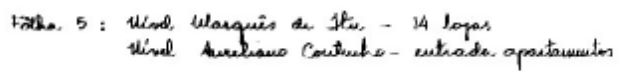

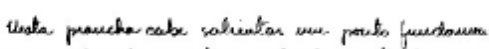

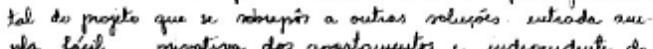

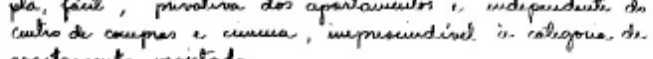
apastancurto projetado.

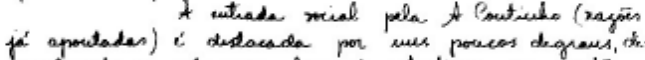

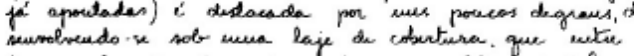
deas esplavedas de verde oreduy an vestibuto visal.

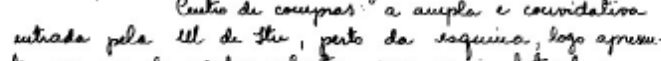

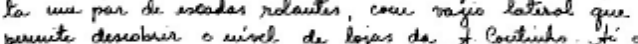

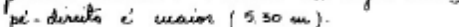

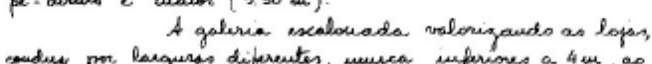

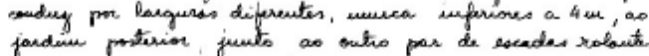

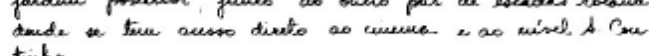

$$
\text { Fillas } 6 \text { e } 7 \text { spartamentor. }
$$

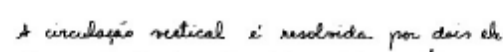

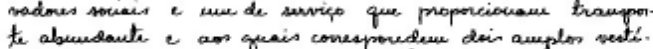

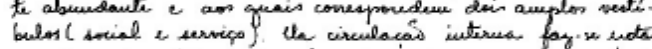

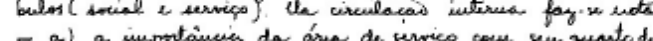

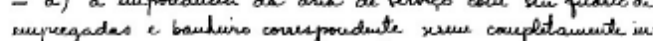

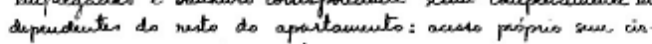

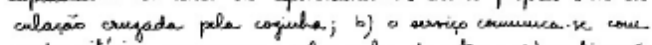

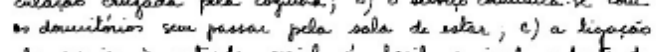
do serrices à

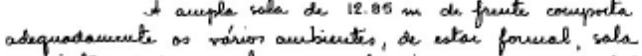

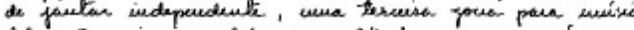

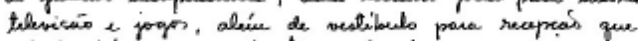

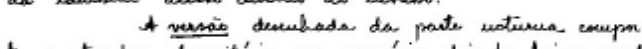

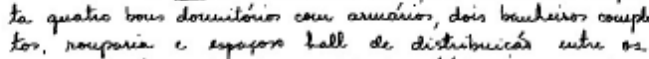

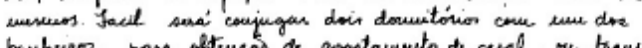

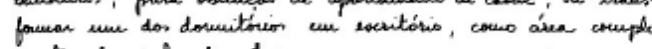

vertar da sala de stas.

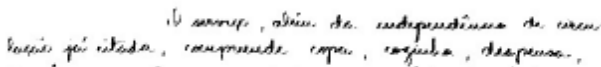

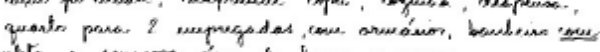

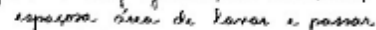

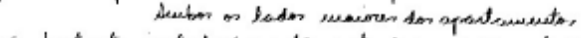

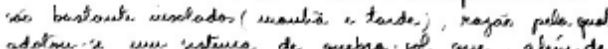

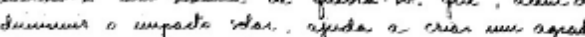

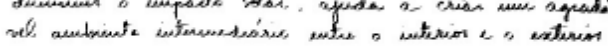

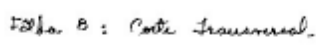

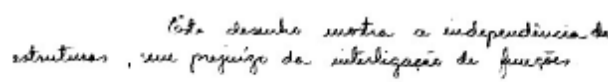

Folhe 9: Pineno

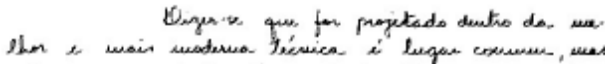

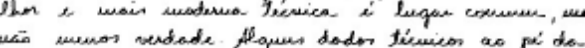

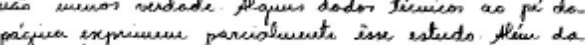

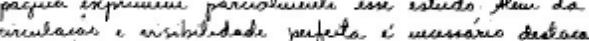

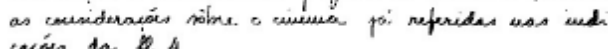
cocises da fo $A$

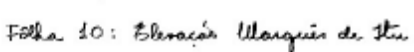

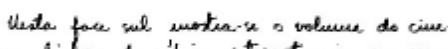

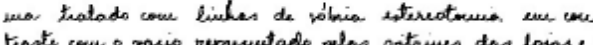

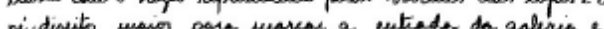

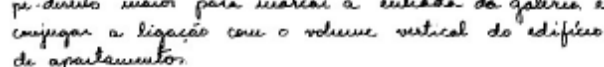

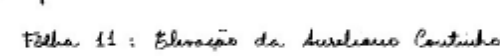

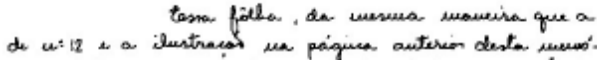

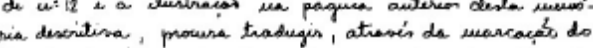

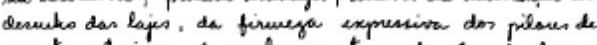

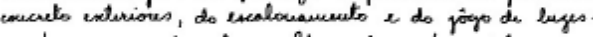

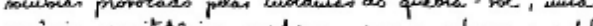

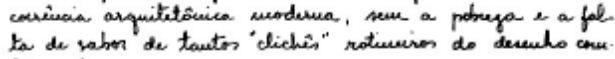
teriponamen.

Une aprovertamento wairs sue área riprife.

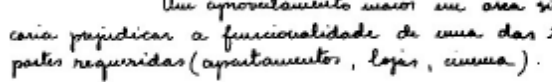

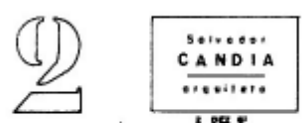


Edifícios à rua Marquês de Itu x Aureliano Coutinho - versão II

localização Higienópolis, São Paulo

material Projeto executivo e fotografias, 1961

fonte $\quad$ Arquivo S. Candia
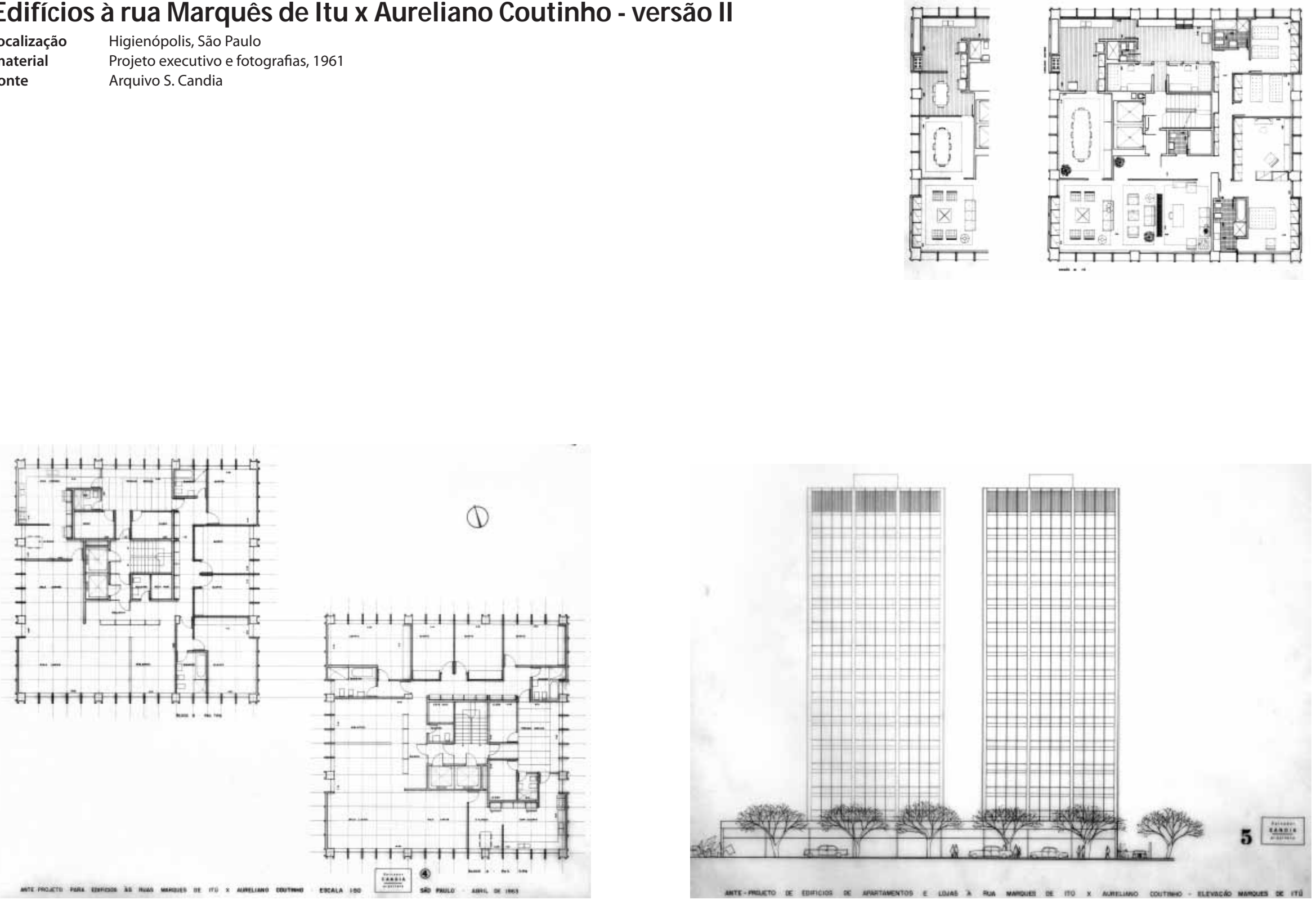


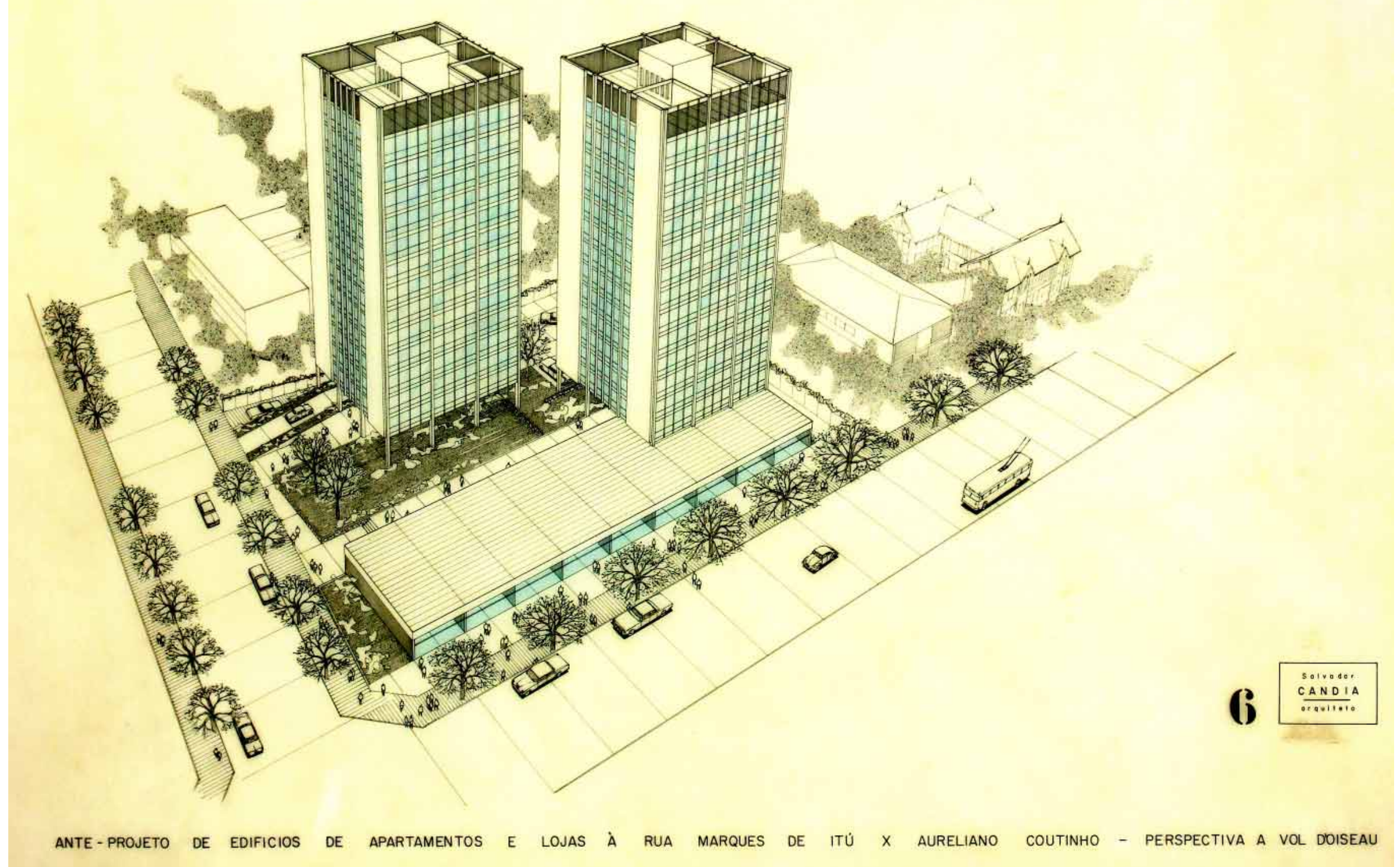




\section{Tenis Clube de Santo André}

\section{localização Santo André, São Paulo}

material Ante Projeto, 1962

fonte Arquivo S. Candia

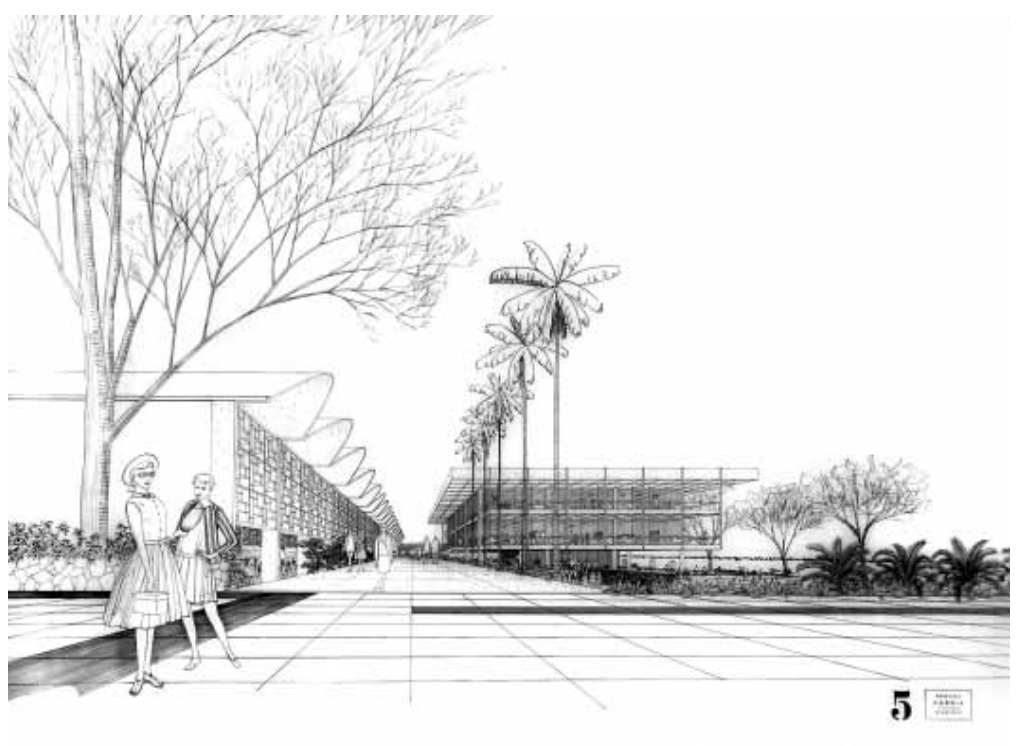

\section{Instituto de Educação}

localização Marília, São Paulo

material Fotos do modelo, 1961

fonte Arquivo S. Candia

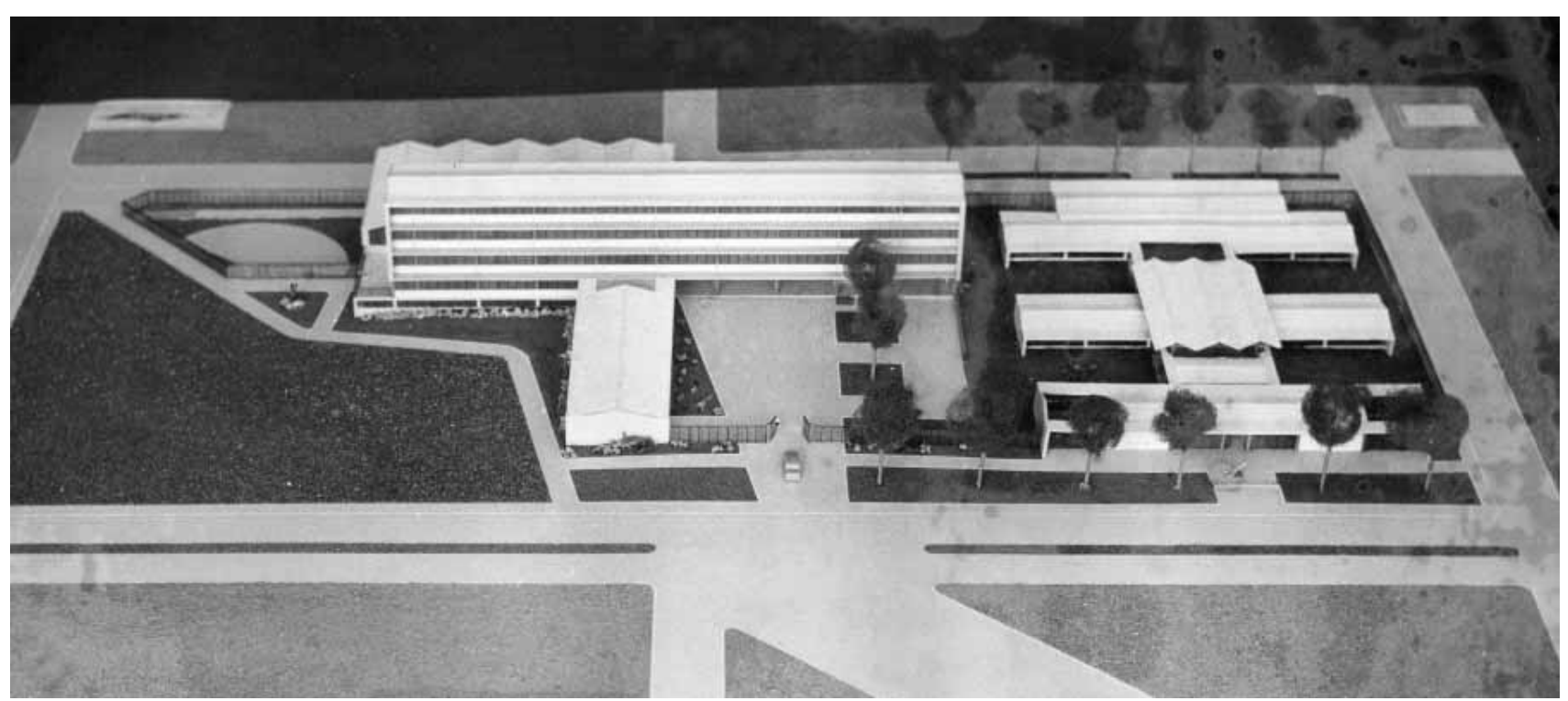




\section{Clube Sírio Libanês}

\section{colaboração Halim Soubihe}

localização Bauru, São Paulo

material Ante Projeto, 1963

fonte

Arquivo S. Candia

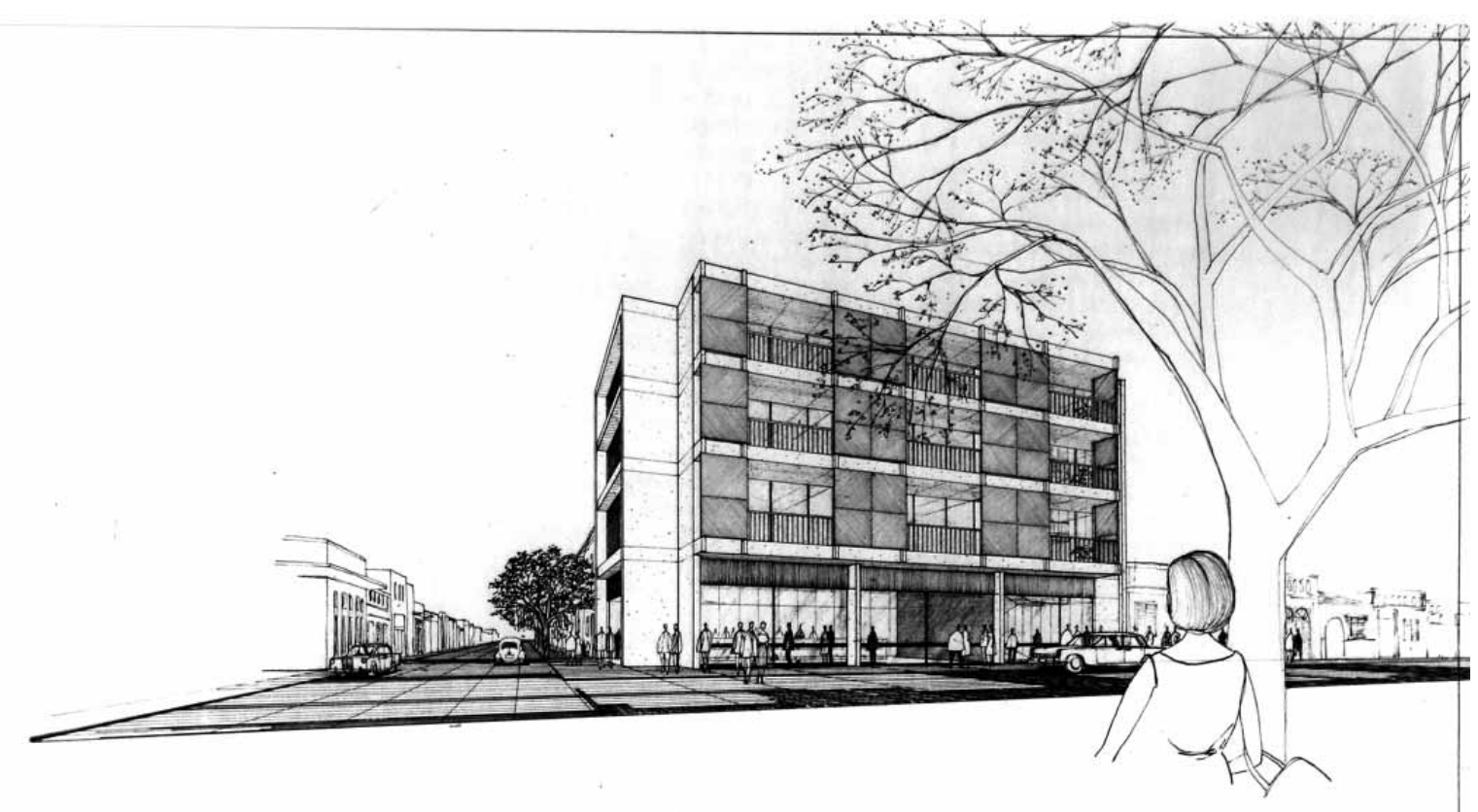

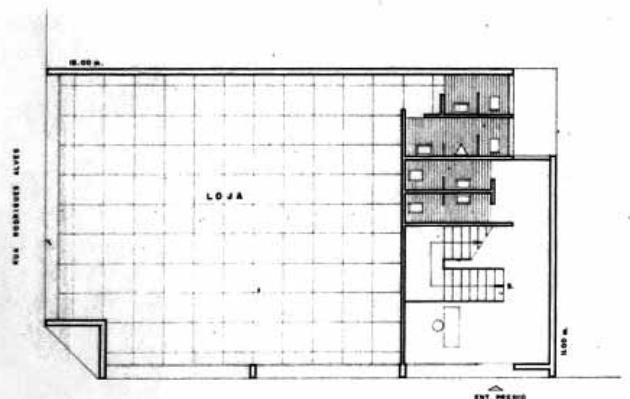

andAR TÉrREo

esc. t:100

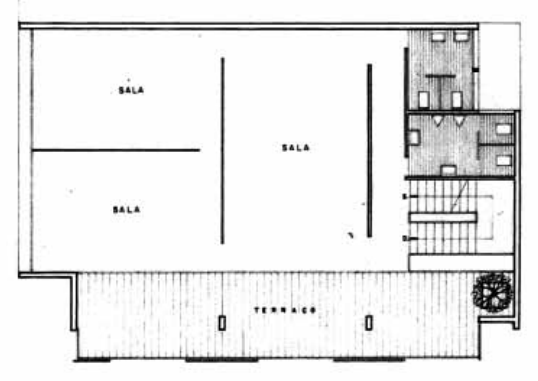

AMOAR IPO EsC. 1::00

ANTE PROJETO CLUB - RECREATIVO - SírIO LIBANÊS dE bauRU PROJETO: HALIM SOUBIHE E SALVADOR CANOIA

DEZEMBRO 


\section{Edifício São Vicente}

\section{localização Rua Sergipe, São Paulo}

material

Ante Projeto, 1963

fonte

Arquivo S. Candia

\section{Edifício Ouro Branco}

localização Avenida Paulista, São Paulo

material Projetos diversos, 1964-72

fonte

Arquivo S. Candia

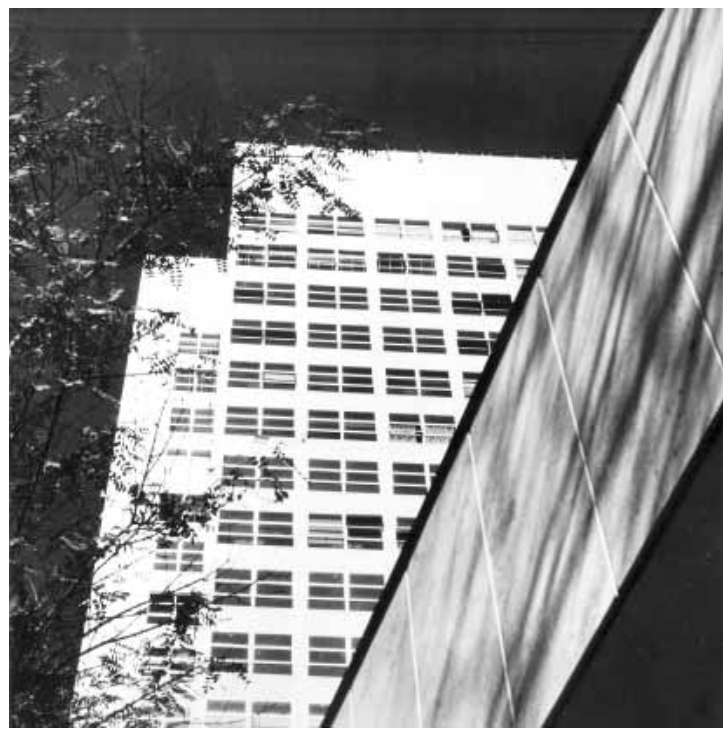




\section{Condomínio Astúnias}

\section{localização Guarujá, São Paulo}

cliente Construtora Sodraga

material Ante Projeto, 1965

fonte
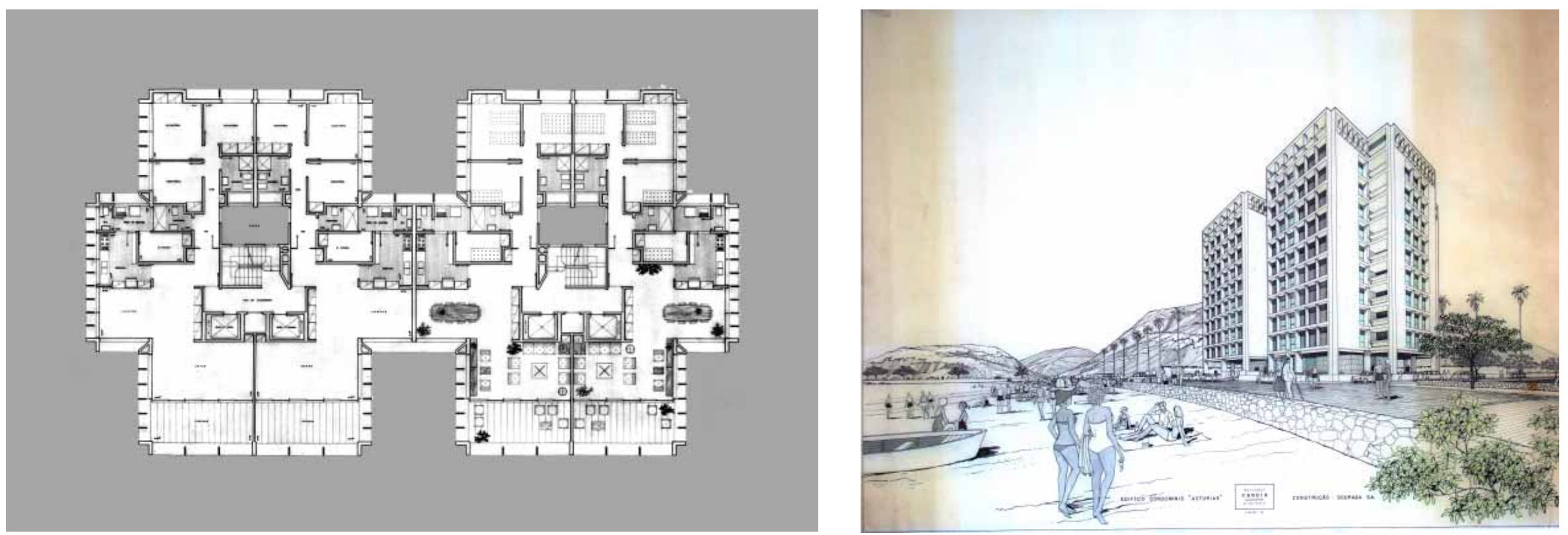


\section{EdifícioJ oelma}

localização Praça das Bandeiras, São Paulo

material Projetos diversos 1968/1979 (projeto de adaptação)

fonte

Arquivo S. Candia

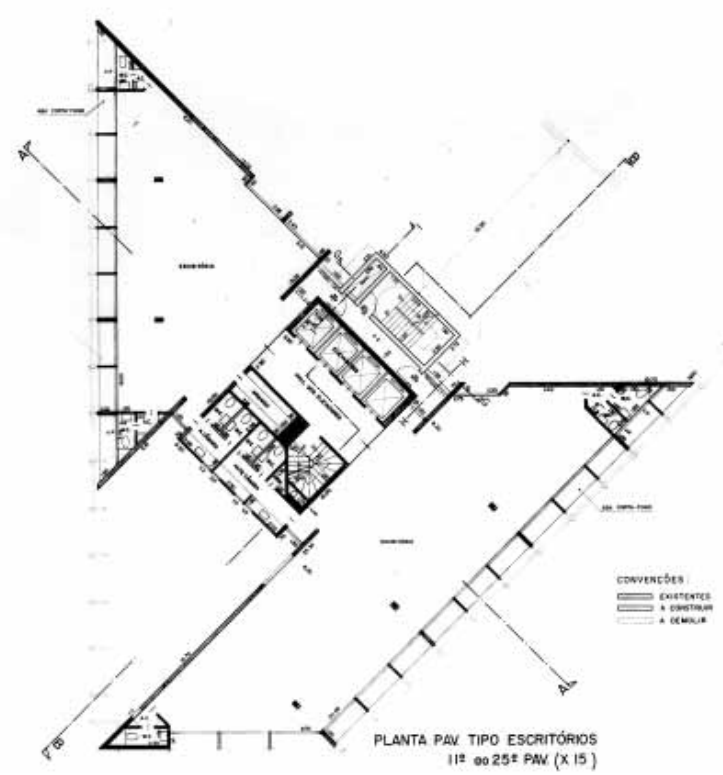

\section{Edifício Iguatemi}

localização

Avenida Faria Lima, São Paulo

material

Projetos diversos, 1972

Arquivo S. Candia

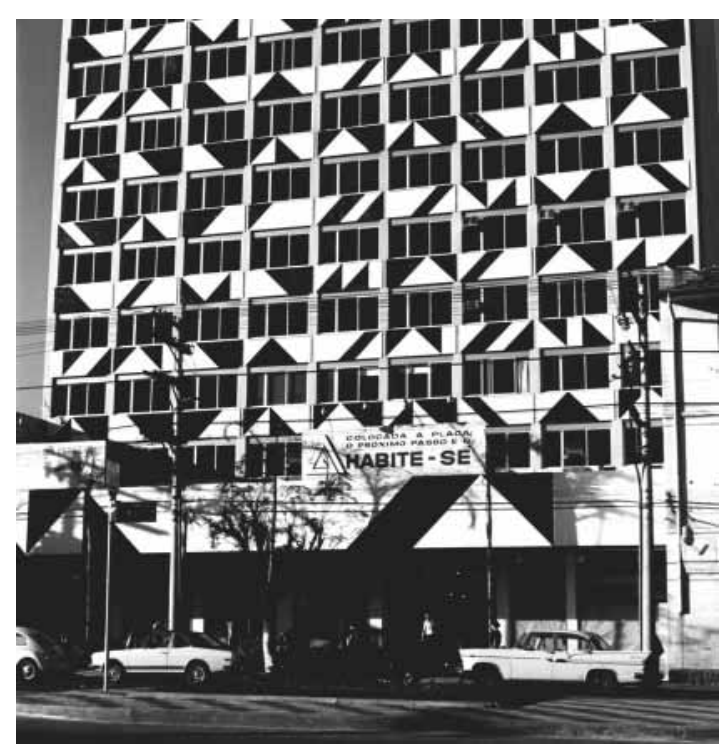




\section{Edifício OFAL}

localização Alameda Santos x Alameda Campinas, São Paulo

material

Ante Projeto 1969

fonte
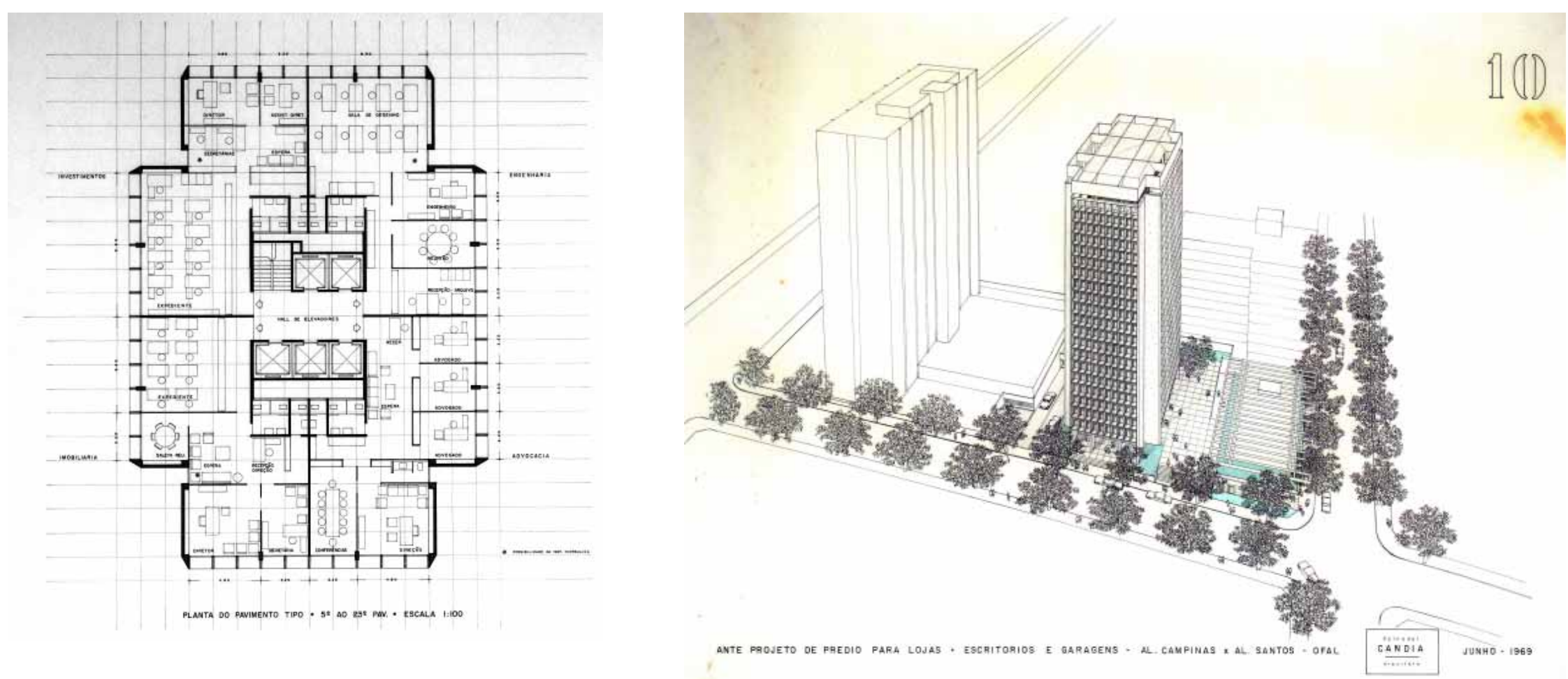


\section{Condomínio J ardim Figueiras}

\section{localização Jundiaí, São Paulo}

material Projetos diversos 1970/72

fonte $\quad$ Arquivo S. Candia

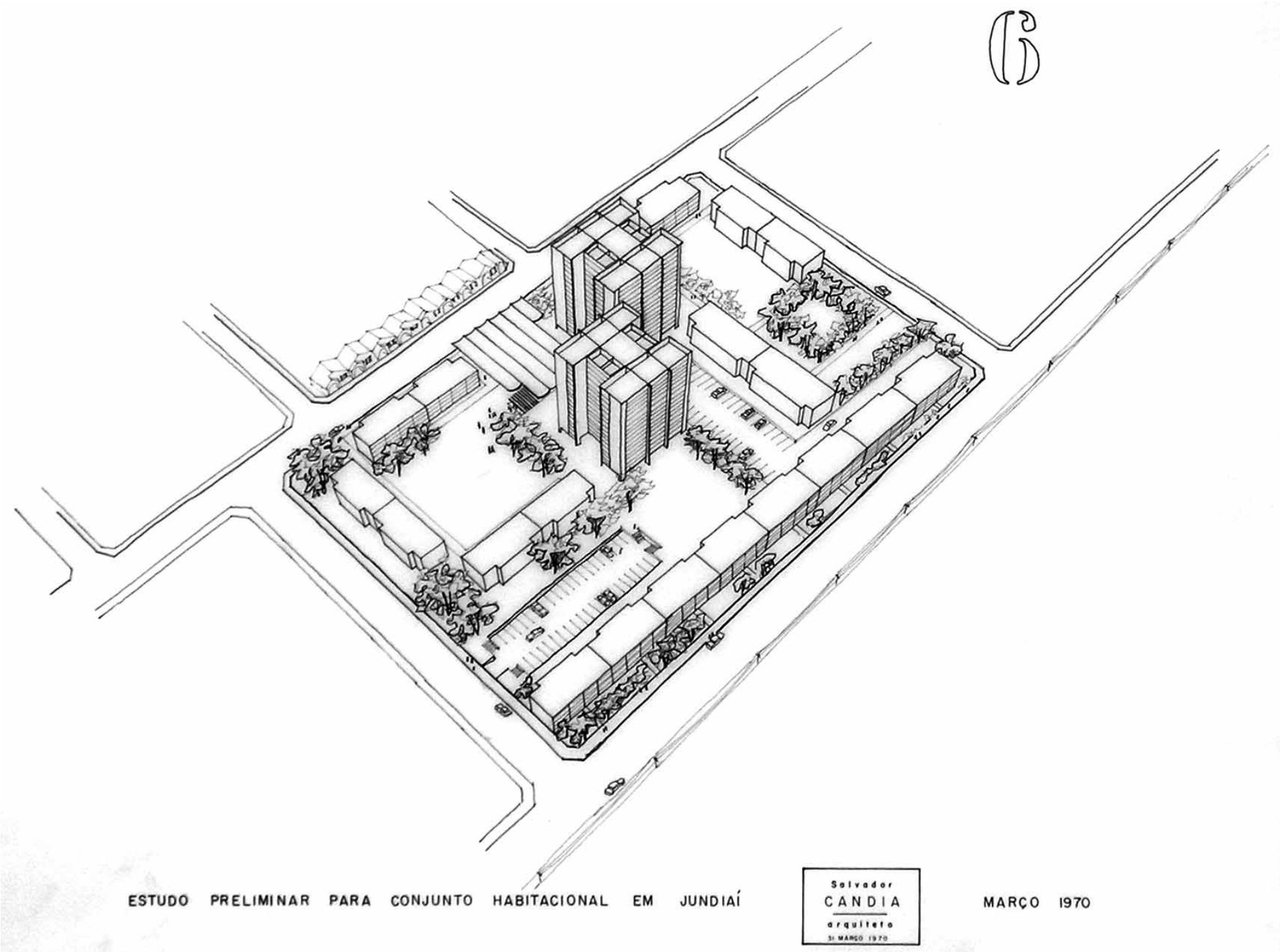




\section{Edifício Comercial Triton - versão I}

\section{Edifícios de loja, escritórios e estacionamento}

localização Avenida Paulista, 1804

cliente Triton-Equipamentos Agrícolas

material Ante Projeto 1973

fonte Arquivo S. Candia

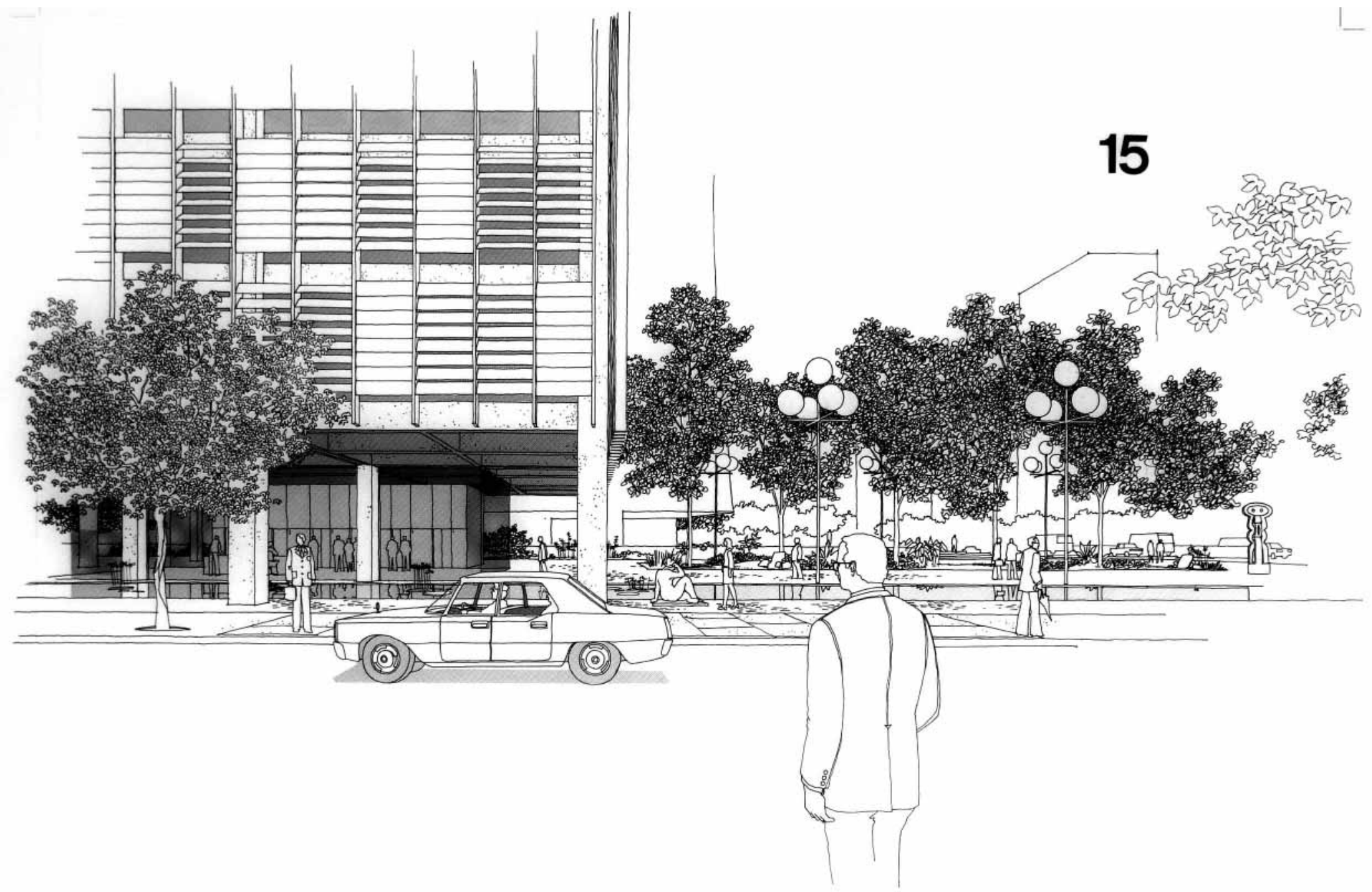




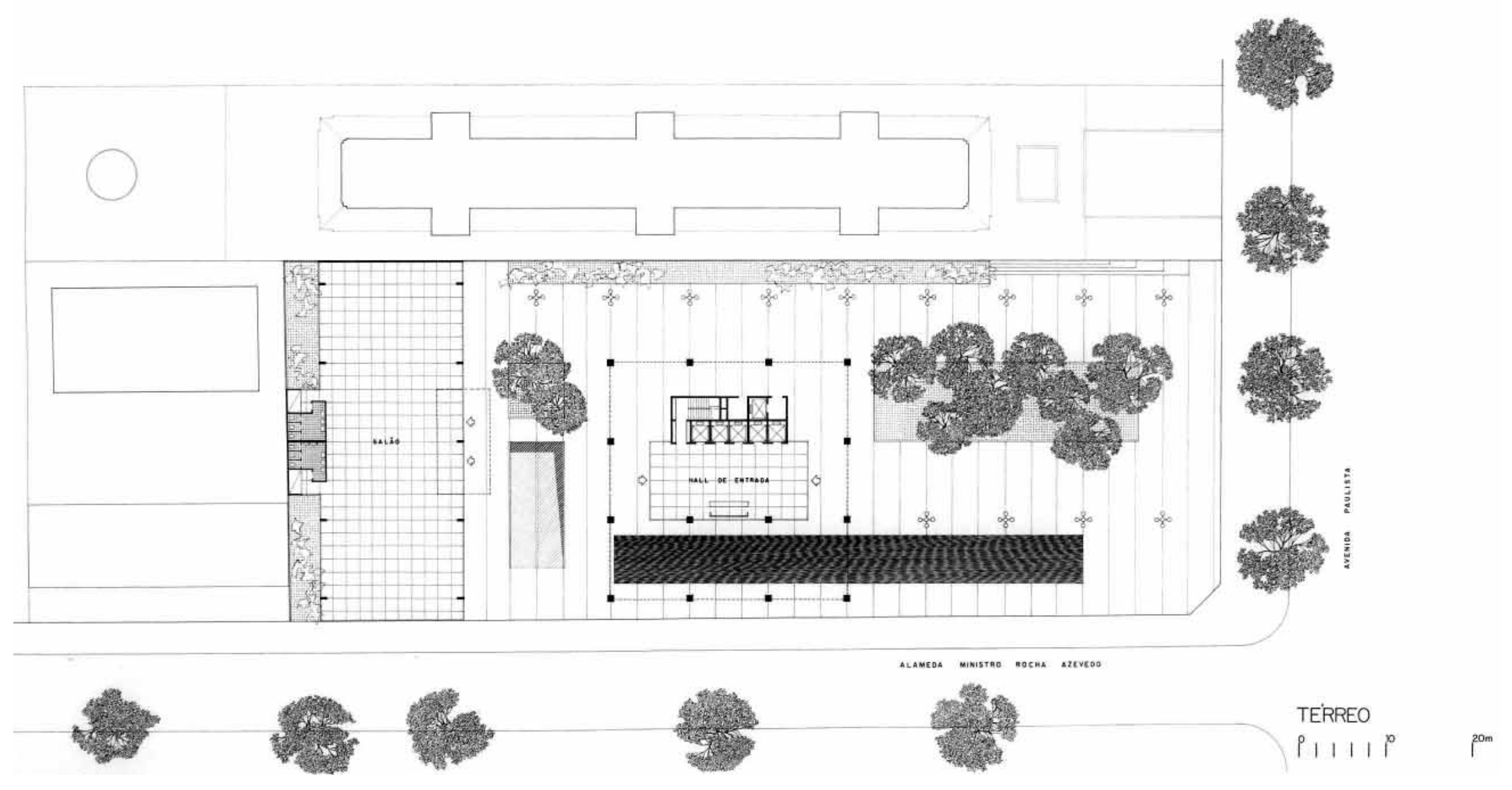




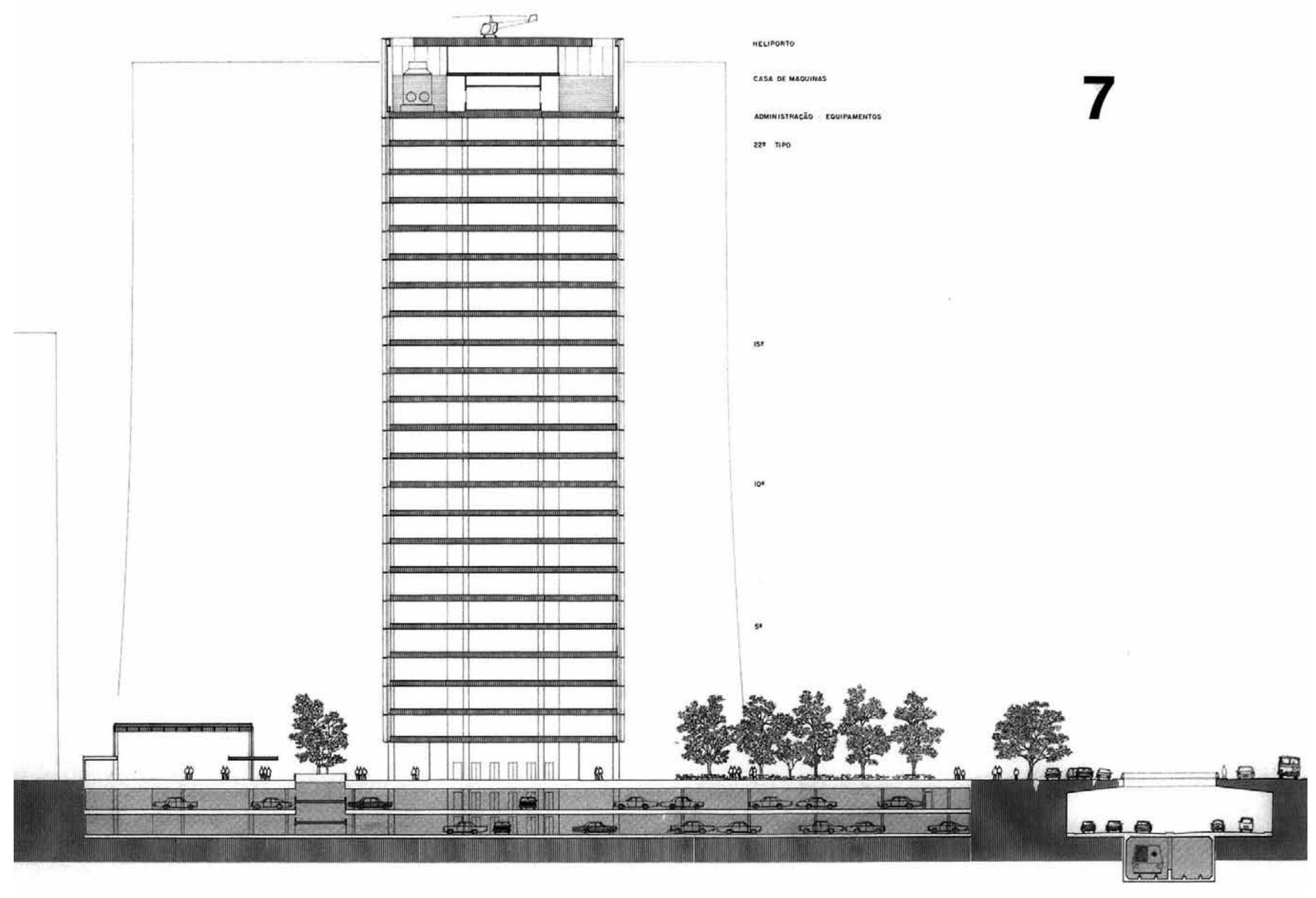



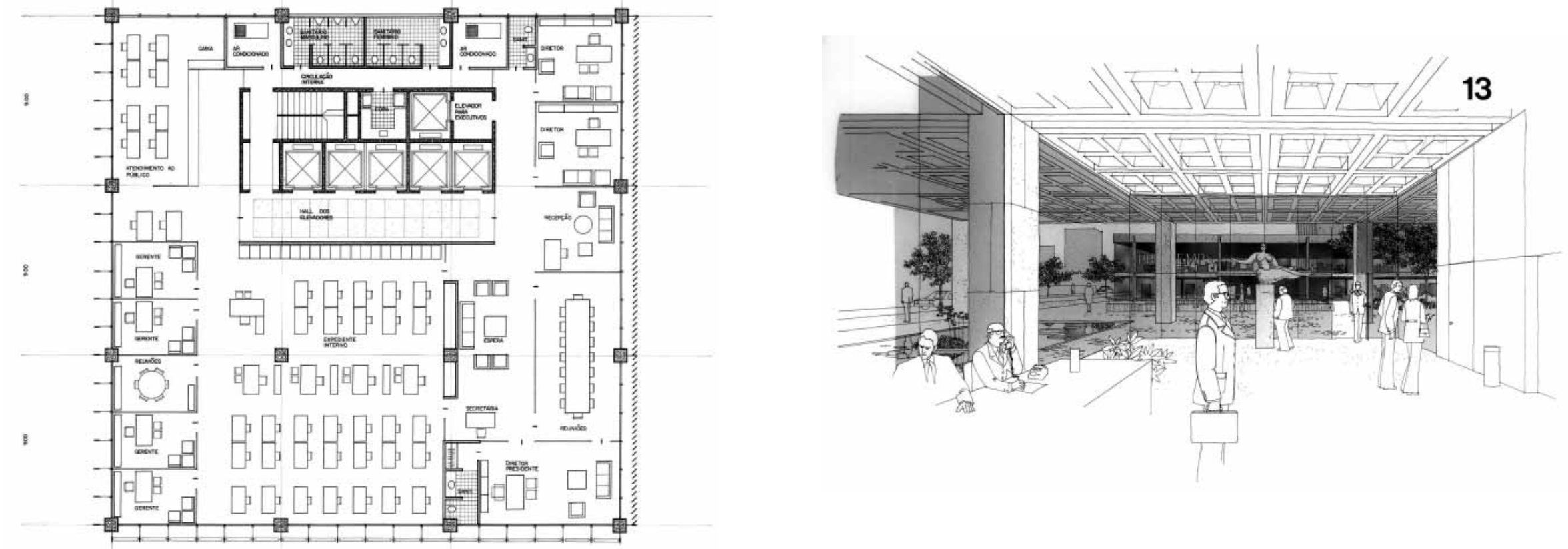


\section{Edifício Comercial Triton - versão II}

\section{Edifícios de loja, escritórios e estacionamento}

localização Avenida Paulista, 1804

cliente Triton - Equipamentos Agrícolas

material Projeto de aprovação 1974

fonte $\quad$ Arquivo S. Candia
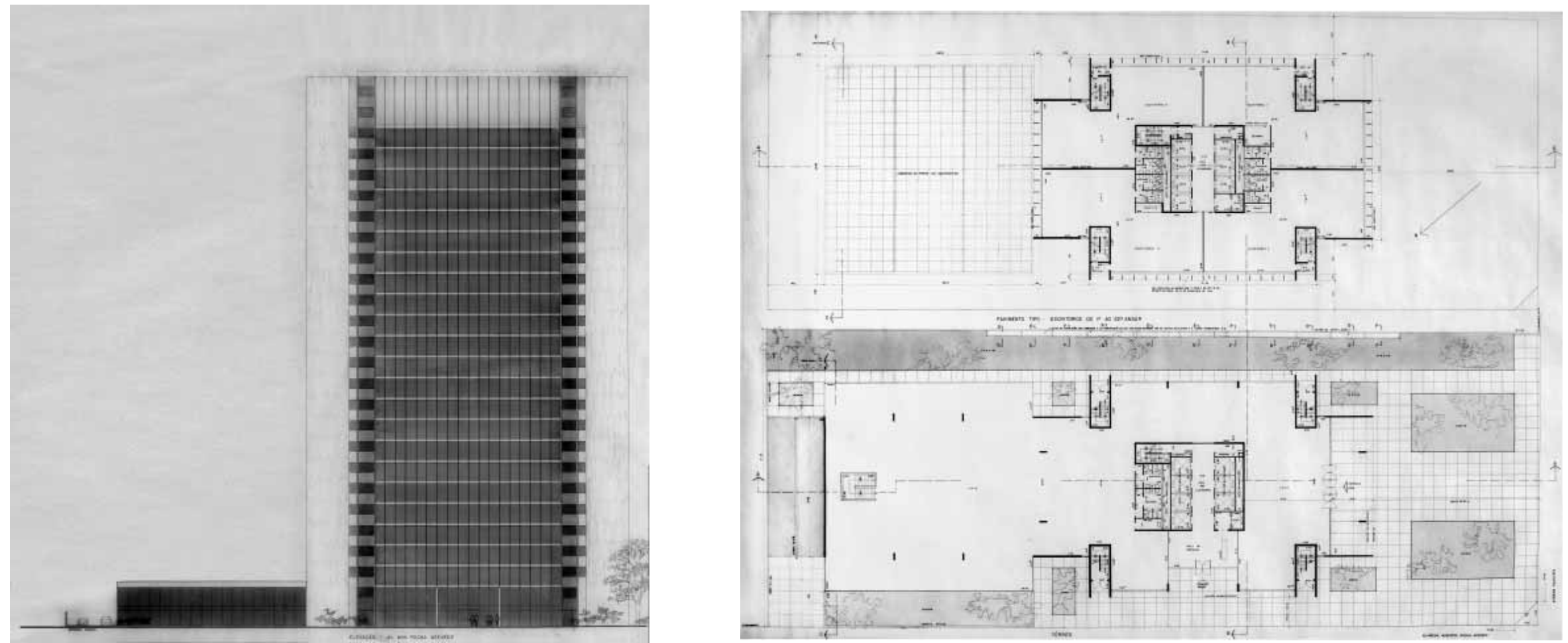


\section{Edifício das Nações}

localização Avenida Eusébio Matoso, São Paulo

material

Arquivo diversos
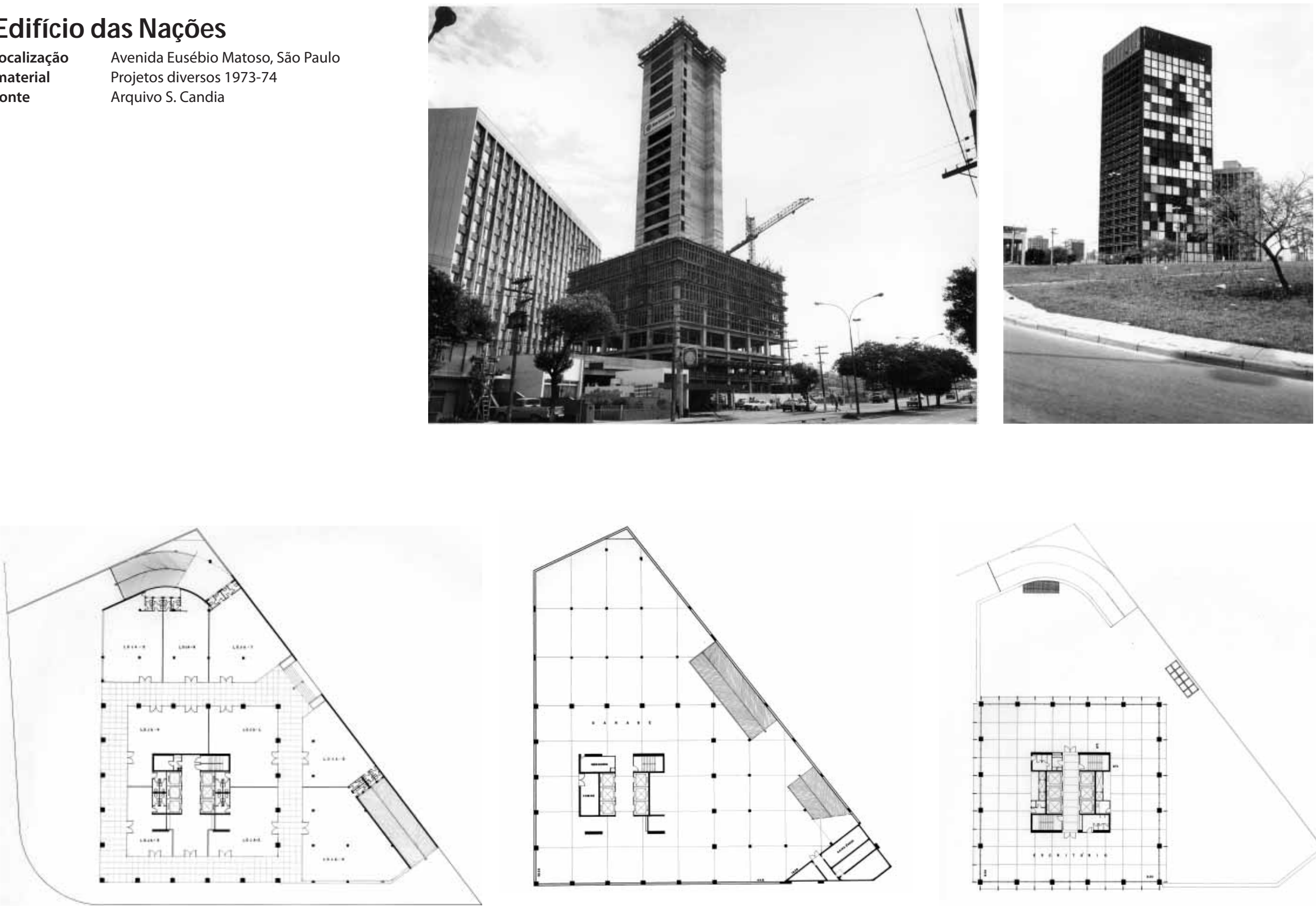

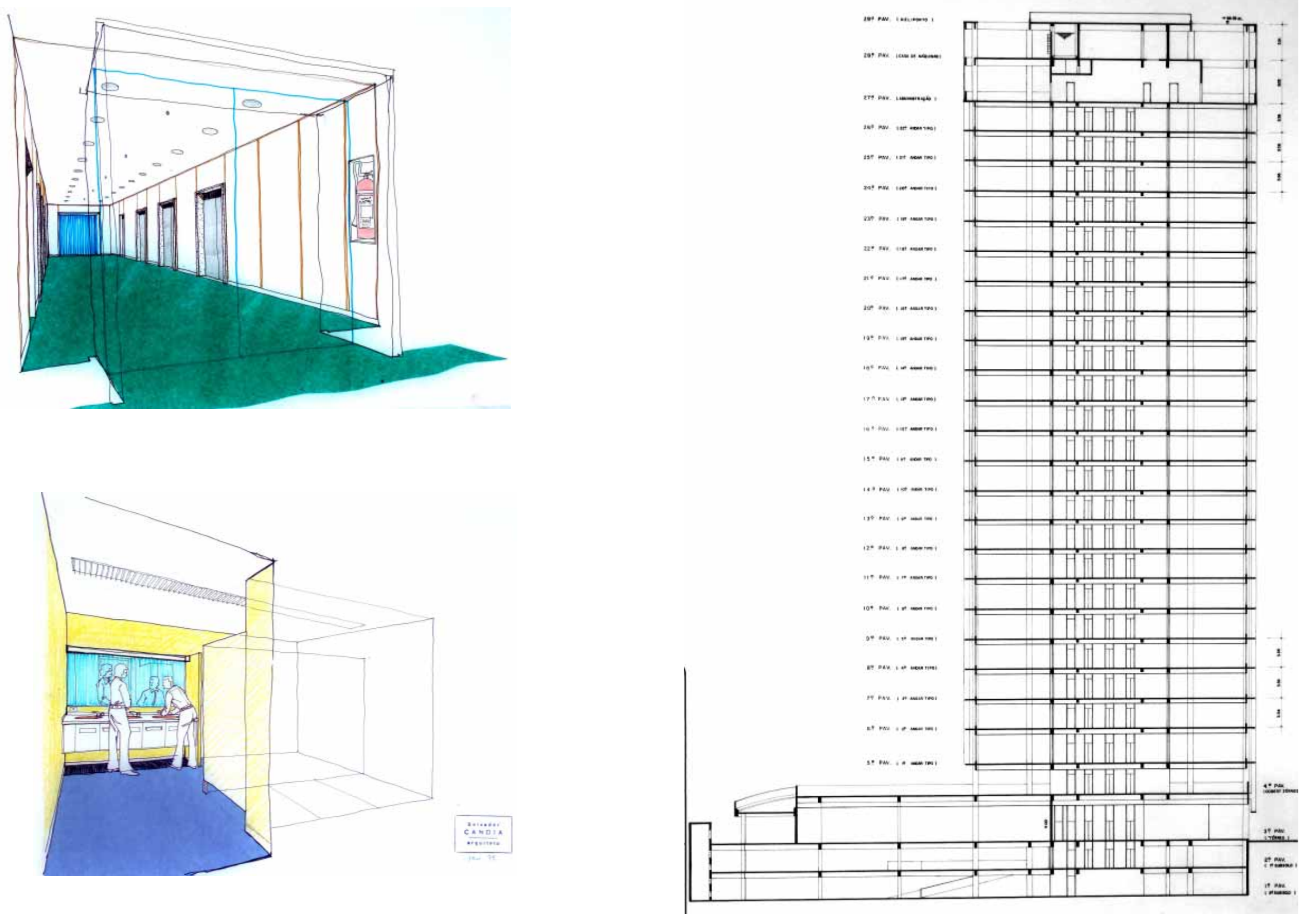


\section{Agência Unibanco Campo Grande}

\section{localização Campo Grande, MS}

material Projeto Executivo 1984

fonte

Arquivo S. Candia
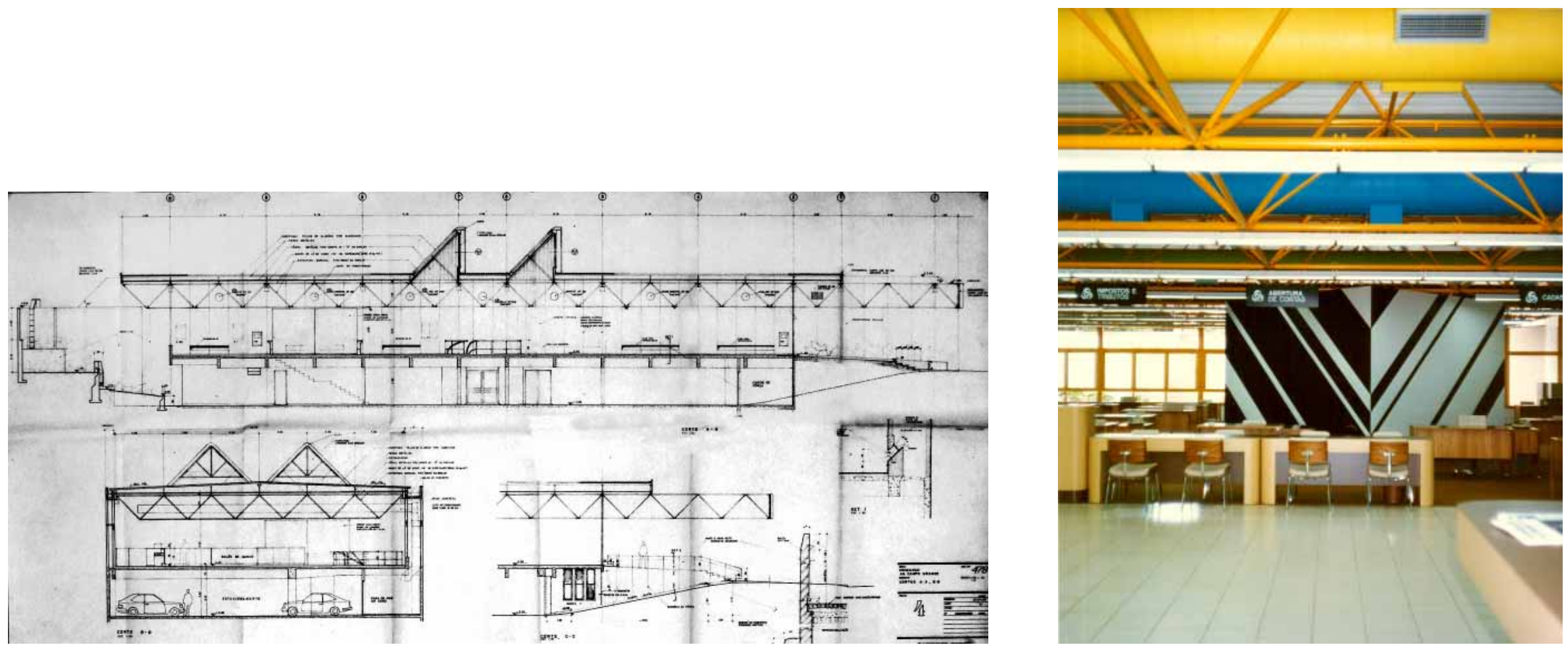
Anexo C

artigos publicados de Salvador Candia 


\section{O Caso Gregori}

Folha de S. Paulo, São Paulo, 18 jun. 1986

(Este artigo está sendo republicado, na versão original e completa, uma vez que no último domingo, por falha técnica, faltaram os últimos parágrafos.)

Afinal quais são os anos dourados?

Depende da geração ou de cada enfoque que a história destaca. Parece certo, nesta altura do sanos 80 , que o douradoro está no passado - já que os tempos atuais não permitem grande entusiasmo pelo "brave new world" que ai está

Houve época em que o futuro era encarado com sadio otimismo. Na história da arte brasileira, a década dos 20 produziu a Semana de Arte Moderna, a poesia também chamada moderna, Tarsila, Bandeira, o turbulento Oswald. Aparecem nomes estrangeiros, Malfatti, Segall, Nery, Brecheret e, em arquitetura, temos o caso Warchavchik.

Por que a polémica a respeito deste arquiteto? Em síntese, trata-se da história de uma brilhante personalidade que inicia o processo de renovação da arquitetura brasileira, e vai encerrar a carreira assinando melancólicos projetos. Há várias subhistórias, que não cabem numa notícia como esta, mas um pouco de cronologia vai ajudar.

No Brasil dos anos 20, chega o moço de Odessa, via faculdade de Roma, com o figurino da Bauhaus na bagagem. Solta manifesto no Rio, e associa-se a Lúcio Costa. Há uma fotografia histórica dos dois juntamente com Frank Lloyd Wright, para não deixar dúvidas sobre quem já estava agindo. Em São Paulo, além de sua própria casa (1927, rua Santa Cruz), acontece a casa da rua Itápolis - "modernista", usando um termo já aplicado a Otto Wagner e companheiros na Viena do início do século. Da capital austríaca ainda ecoava o grito de Loos, "o ornamento è um crime". As edificações passaram a ser cubos, rasgados por longas janelas na horizontal ou decididamente verticais, em seus volumes despojados. 
Que foi ? Que não foi ?

São Paulo industrializava-se, a nação tinha vontade de renovar suas estruturas políticas e sociais, os artistas também proclamavam, muda Brasil.

Para ver quadros é preciso ir até eles; para ler livros, ter vontade de fazê-lo. As figuras e paisagens da pintura modernista, a linguagem das "Memórias de João Miramar", exigiam erudição, sensibilidade para apreciá-las, mas a arquitetura da rua Itápolis estava lá, passava-se em frente e foi demais para a mentalidade paulista. Bons tempos, eram tão dourados que ainda havia escândalos. O processo continuou com a casa na rua Bahia até hoje conservada mais ou menos no original ; a rua Estados Unidos, destruída ; a sequência das casas operárias geminadas da Mooca que tanto maravilhavam os estudantes de arquitetura até os anos 60. Foram, depois, grotescamente modificadas.

Na São Paulo, e no Rio de Janeiro da época, onde iria o arquiteto buscar os móveis, as luminárias, os tapetes, as obras de arte contemporânea, para exprimir uma maneira nova de viver? Aí revela o arquiteto outra faceta de importante contribuição: os móveis começaram a ser desenhados especificamente para as ocasiões que se apresentavam; assim como a iluminação artificial foi adaptada à arquitetura, objetos de arte foram encontrados, quando não importados.

John Graz, sua mulher Regina e outros, começaram a trabalhar num vocubaluário condizente com a arquitetura contemporânea e Warchavchik teve a decisiva atuação em deflagrar o processo do desenho "modernista". Suas casas dos anos 20 e 30 não definiram nem criaram uma casa "brasileira" condizente com o meio ambiente e nossa maneira de viver.

Sua obra estava ainda impregada de forte impulso polêmico que caracterizava o projetar e construir europeu.

Seu desempenho foi, porém, importante não só nas obras em si, mas nos discípulos e nas indústrias afins à arquitetura que gerou, e que haveriam de frutificar logo em seguida. 
Paralelamente há casas no Rio de Janeiro e outras aqui, na Vila Mariana. A partir do edifício da alameda Barão de Limeira, começa uma diluição da força original, que vai se moldar a uma moral duvidosa.

E havia o personagem, homem fino, de poucas palavras, introvertido, sempre elegantemene vestido, retrato aliás não só dos arquitetos modernistas mas da época de gravata e paletó imprescendíveis. Componente desse homem e do decór do período eram as festas do casal na casa e jardim por eles desenhados.

O que aconteceu? O que não aconteceu?

Paulicéia desvairada. Escândalos. O caso. "Travelling" até a década seguinte, surgem Portinari e Sérgio com "Raízes". O desdobramento do modernismo. Agite. Ponha música. Daria um filme.

Salvador Canida, 61, è arquiteto ex-diretor da Faculdade de Arquitetura da Universidade Mackenzie. 


\section{A Ordem Construtiva Arquitetônica em Vital Brazil.}

Brazil, Álvaro Vital, 1909 - 50 anos de arquitetura / Álvaro Vital Brazil. São Paulo: Nobel, 1986

Nos últimos cinquenta anos, o tempo em que opera o autor das obras deste livro, a arquitetura contemporânea passou da maturidade a que chegara nos anos 30 e no imediato pós-guerra, à atual perplexidade e até mesmo uma nostálgica e artificial volta ao passado, nos quatro cantos do mundo.

A arquitetura ocidental viveu, grosso modo, até meados do século passado com o vocabulário herdado da antiguidade clássica. Como consequência da revolução industrial, passa a se exprimir com um espírito que as novas técnicas e a nova mentalidade começam a permitir.

Nesse sentido entenda-se por arquitetura contemporânea, como atrás escrito, ao período que vai aproximadamente da época do Palácio de Cristal em Londres até os anos 50 deste século, quando começa a crise que a envolve.

O Brasil participa desse movimento a partir da década dos anos 20 e mais intensamente a partir dos anos 30, com as novas edificações que começam a surgir em São Paulo e no Rio.

A atuação e a entrada em cena de Álvaro Vital Brazil tem qualquer coisa do mirabolismo que Manuel Bandeira viu na entrada de Mozart no céu em 1791.

Isto porque o edifício "Esther" que se ergue na Praça da República paulista comove ainda hoje, apesar da dinamicidade do período. Lá estão, desde 1936, a janela em comprimento, a estrutura independente, o pilotis, a planta livre e o jardim suspenso de Lê Corbusiana memória que aqui chegaram nos livros que o mestre escrevera nos anos 20. O que surpreende não é só o uso apropriado do novo vocabulário, mas a maneira 
primorosa, elegante e racional como foram usados, além do tratamento dado ao espaço e ambiente circunstante, desvinculando o edifício do "lote" paulistano da época.

Acrescente-se também o uso da dualidade do preto e branco para ordenar as fachadas na expressão de um programa esdrúxulo.

Com esse edifício Vital Brazil entrou no céu dos arquitetos sugerido pelo poeta e teve decidida participação na criação da nova arquitetura brasileira.

A essencialidade da ideia construtiva do recém-formado arquiteto e engenheiro civil que criou o "Esther" vai permanecer através dos seus cinquenta anos de carreira, independentemente das dificuldades que enfrentou para impor a nova maneira, sem concessões ao cliente ou ao gosto comum vigente.

A partir desse movimento que foi o moderno de então, o racional, o estilo internacional, como foi sendo etiquetado até meados deste século, o autor menciona no seu esboço histórico o descontentamento dos alunos que entravam para as escolas de arquitetura do Brasil por volta de 1929/30 e a necessidade de mudanças na orientação daquele ensino e da luta que foi a implantação das novas ideias.

Nas páginas seguintes, uma fotografia de São Paulo, durante a execução do "Esther", mostra qual era o meio ambiente que circundava a construção do prédio. Outros pioneiros desse tempo, Warchavchik, Flávio de Carvalho, haviam iniciado a "guerrilha" do modernismo, assim como Rino Levi que além de casas também já edificara o "Columbus".

Logo a seguir, a obra do Berço, o Ministério da Educação no Rio, a Pampulha de Niemeyer e a obra dos irmãos Roberto, davam corpo ao movimento.

A residência do arquiteto em Santa Teresa no Rio de Janeiro, um cubo de vidro e concreto suspenso no ar para a mata que o circundava, as escolas públicas de Niterói, o Instituto que leva o nome do ilustre pai, na mesma cidade, mostram o desenrolar da filosofia racional do arquiteto, sem malabarismos expressivos.

Da época da guerra é o trabalho de alojamento de trabalhadores na mata amazô- 
nica, com o uso de materiais e sistemas construtivos da zona, mas com uma clareza de planta e de estrutura típica do autor.

Os projetos das estações de aeroportos em Manaus e Belém de meados dos anos 40 dizem bem da maneira de ser da arquitetura brasileira da época, assim como o edifício "Clemente Faria" em Belo Horizonte e o projeto vencedor do concurso para a nova sede do Jockey Club Brasileiro na Av. Rio Branco, e posteriormente o novo projeto para o terreno da Av. António Carlo

A partir de 1949, nota-se uma influência da obra de Mies van der Rohe que tanto adere ao espírito do autor. Os edifícios de escritórios e apartamentos passam a usar uma caixilharia modulada de alto a baixo da fachada que a indústria nacional começava a fornecer. O edifício da Rua Prudente de Morais no Rio inicia esse tipo de aplicação e acabamento que prossegue o espírito do "Esther" e do cubo bauhausiano da residência de Santa Teresa e se desenvolve na obra subsequente.

Destacam-se então a residência com pátio interno de Cabo Frio, as casas da Tijuca, da Ilha do Governador e de Itaipava e a singeleza na técnica de edificação e de locação das partes que compõem a casa "Rondon".

Há edifícios para estaleiros, projeto para companhia de gás do Rio, mais edifícios de apartamentos, garagens, que levam até os anos mais recentes essa marca de ordenação construtiva, partindo de plantas simples que constituem o traço essencial da sua obra.

O conjunto de sua obra com a estrutura clara, a planta equilibrada, as elevações que refletem um cuidadoso estudo harmonizam-se com os detalhes, escadas, esquadrias, e as especificações para vedação e acabamento: o emprego desde o início de materiais novos que melhor representavam o espírito que se queria mutante e representativo da época nova que ajudou a criar.

Um "tranquilo purista no manejo da expressão arquitetural", como o chama Henrique Mindlin no atento estudo que lhe dedicou. O modo de projetar suas obras relaciona-se com o seu procedimento, comedido nos gestos, parcimonioso nas palavras 
e na elegância discreta do vestir - uma extensão de comportamento não como modo assumido, mas como jeito espontâneo de ser.

Dos arquitetos pioneiros da arquitetura contemporânea no Brasil, talvez o único de quem faltava uma monografia era Vital Brazil, que nos dois primeiros anos de seu exercício profissional trabalhou associado a Adhe-mar Marinho.

Bem-vinda, pois, achegada deste livro. Que as novas gerações de estudantes e os que se debruçam sobre nossa história recente, possam meditar nesta lição de equilíbrio, serenidade e amor à ordem construtiva arquitetônica. 


\section{Especialista Critica Catedral}

Folha de S. Paulo, Caderno Cidades, 1987

\section{Especialista critica catedral}

Convidado pela Folha, o arquiteto Salvador Candia, 62, também ex-pro fessor de História da Arte, passeou anteontem por São Paulo comentando alguns exemplos da arquitetura eclética. Segundo ele, o ecletismo é uma volta a estilos do passado corque "depois trial os arquitetos descobriram tinham arites não sabiam usá-las como expressão apareceu neo-qualquer-coisa".

O primeiro prédio visitado foi a catedral da Sé (projeto neogótico de Maximiliano Hehl, em 1911/1912) que para Candia "é uma das piore coisas" "da cidade. Diante do prédio disse: Todo mundo sabe o que uma catedral. Quem foi projetá-la não sabia no que se apoiar. Daí o falso gotico. A cupula é esdruxula porque não existe no gótico. Fo criada na renascença italiana. Um estilo nasce de muitas gerações, como o moderno hoje. A catedra acabou descaracterizada. A cupula tem um lanternim, ainda por cima, numa estrutura gotica. Ja o portico com santos e anjos e coisa tipica do gótico. O resultado não é bom, particularmente nesta catedral."

Ainda na Sé, Candia citou o palácio de Justiça, "tipicamente do início do século, inspirado no palácio de Justica de Roma". Deteve-se brevemente diante do prédio da Caixa Econômica Federal, "exemplo de obra inspirada no neoclassicismo", e chamou atenção para a falta de "unidade entre a parte de baixo (colunas neoclássicas de granito preto) e a parte superior".

\section{Foi em seguida ao Pátio do Colégio} para mostrar o prédio do $1^{\circ}$ Tribunal de Alcada Cível, pelo qual demonstrou imenso entusiasmo e respeito: "Não sei quem construiu, mas é um exemplo de arquiteto que sabia juntar, desenhar, trabalhar com grande imaginaçâo. Teve uma imaginação louca, enorme. 0 prédio, assim como o Teatro Municipal e o palácio dos Campos Elíseos, é muito construído.

Candia passou a descrever o pré dio, todo em granito rosa, de baixo para cima: "Vê-se a ordem dórica já estilizada (as colunas com três andares de altura); há a cornija (ornamento sobre o friso acima das colunas), também estilizada, que vem longinquamente dos gregos. 0 prédio tem as caras, que começam a aparecer na renascença, com a estilização de guerreiros, trabalha dores. Depois fica um semi-arranhaceu, com oito pavimentos. Tem festōes (ornatos com forma de grinalda), colunas estilizadas (peque nas, nas janelas centrais). Termina numa grande festividade de mansardas, coisa tipicamente francesa. $\mathbf{E m}$ cima temos arquitraves (vigas assentadas sobre colunas) até egípcias. No apagar das luzes do ecletismo (década de 30), desenhou este prédio." Segundo Candia - que visitou ainda o predio do banco Sudameris (rua Quinze de Novembro, centro), outro exemplo de ecletismo arquite tônico na cidade- "São Paulo aind tem coisas interessantíssimas. melhor que Jânio não ouça". 


\section{$\mathrm{Na}$ arquitetura, novo estilo trouxe uma alegre mistura}

\section{SALYADOR CANDIA}

Especial pora o Folho

Por volta do fim da década de 50 , Louis Kahn, da geração dos arquitetos que tinham contribuido na primeira metade do século para implantar o moderno, começou a trabalhar em edificaçôes numa linha diferente da linguagem até então usada na época. Pouco depois Robert Venturi, outro americano com estágio na Academia Americana de Roma, escreveu um livro em que não só aproximava as diversas correntes do moderno mas apelava para o antigo que deveria se incorporar a elas com o renascimento de conceitos $e$ expressōes que o moderno repudiava. Posteriormente, chegou mesmo a ridicularizar alguns dos monstros sagrados do modernismo, "less is bore", em contraposiçāo ao "less is more" de Mies van der Rohe, e foi juntando num proselitismo que comecou a tomar corpo outros arquitetos que desconfiavam que o moderno comecara a trincar: era por demais racional, seco, asséptico.

Enfim o eterno conflito de geraçōes, com os novos contestando os mestres de cabelos brancos. Houve mesmo gente de cabeça grisalha como Philip Johnson e num certo sentido Paul Rudolph que aderiram. Eram os anos 60, as saias encurtavam, os Beatles faziam furor $e$, nesse balanço geral, a arquitetura, como não podia deixar de ser, também entrou na onda. Quem gostou mesmo foram os chamados decoradores. Ficava mais fácil, mesmo em países de tradiçâo, mas já livres da reconstrução do pós-guerra, vender objetos, cores e ambientes com o gancho da nostalgia.

Mas havia que sacudir mais, a permissividade pretendida trouxe de volta frontōes, pórticos, granitos, que com blindex e aluminio em formas áulicas deu a mistura alegre que ai vem para os novos edifícios.

Nascido nos Estados Unidos, o pósmodernismo, no bem e no mal, desembarcou no Brasil. As butiques da Mello Alves e Mário Ferraz estấo aí. Há uma récem-terminada lavanderia da rua Rocha Azevedo que é apropriada ao que se destina e agradável de ver e frequentar. Será o pós-modernismo borbulhante como na pintura da lavanderia ou é página a virar, como a fachada de loja da Mário Ferraz?

salvado caveia, 62, 6 arquileto, ex-diretor de 


\section{Roteiro de um arquiteto}

Folha de S. Paulo, São Paulo, 19 set. 1987

Nosso heroi chamou-se Charles Edouard Jeanneret no cartório de La Chaux-de-Fonds. Filho de um esmaltator de mostradores de relogios e de mãe musicista. Desde seus primeiros registros profissionais, percebe-se o iconoclasta, seu espírito inquieto e a curiosidade intelectual. Passa a chamar-se Le Corbusier, ou Corbu ou mais simplesmente LC, a sigla que adotará em projetos de arquitetura.

Troca os sete meses de neve do vale de Neuchatel pela Toscana, Atenas, Egeu e Istambul, que anota em exaustivos desenhos. Adquire a cidadania francesa, e em sua carteira de identidade declara como profissão, homme de lettres.

Perambula desejoso de investigar o novo, os mais modernos studios da época, Hoffman em Vienna, Sauvage e Perret em Paris, Behrens em Berlim, e o grupo do Deutscher Werkbund. Estes alemães consideram a máquina uma aliada, não se podia mais prescindir dela, ao contrário do movimento Arts and Crafts que havia sido fundado para evitar a "corrupção industrial.

Em 1914, a partir das primeiras devastações da guerra, LC concebe um sistema de estrutura pre-fabricada, DOM-INO, independente das divisões das paredes da casa. Seriam de rápida construção, baixo preço e permitiriam uma grande diversidade de agrupamento para evitar monotonia.

Com Amadee Ozenfant que conhece em 18 começa a expor seus quadros. Vai dedicar suas tardes à pintura. Fundam e dirigem a revista "L'Esprit Nouveau" (1929) e constituem em 26 o movimento "Purisme". Revela-se escritor brilhante quando em 23 lança "Vers une Architecture" que tornar-se-ia livro de cabeceira de tantos estudantes e jovens arquitetos por toda parte. Nele, ao lado de uma síntese da história da arquitetura como conquista e modificações de estruturas e ornamentos, discorre sobre a planeta ("a célula geradora, que traz e encerra a esséncia da sensação"), proporções, ritmos, espaços 
e superfcies. Sobressai em suas páginas, a presença fotográfica e as suas observações sobre automóveis, aviões, turbinas, transatlânticos, ou seja, áquinas feitas pr máquinas?

E de então a expressão "máquina de habitar" que tanto mal entendido causou desligado do contexto das páginas escritas.Era preciso "eliminar de nossas conciências e de nossas mentes todos os conceitos sepultados em relação à casa" e procurar objetivamente uma casa que fosse industrializada, sadia construtiva e moralmente, e "bela com toda a sensibilidade que os artistas podem conferir aos elementos funcionais". Seria o primeiro de muitos livros numa linguagem apaixonada e poética de um polêmico artista-escritor. À distância, certa critica cabe por sua insistente mecanicidade em certos projetos e pelas imposições de um sistema de vida que condiciona seus habitantes.

No pavilhão do "L'Esprit Nouveau" desenhado juntamente com seu primo Pierre Jeanneret, há uma reunião de arquitetura, escultura, pintura e móveis compatível com o que desenhavam, assim como a presença do jardim incluído no volume global da casa. Nesse pavilhão para a feira de Paris de 1925 comem a estar presentes alguns dos "Cinco pontos de um anova arquitetura" que apresenta com seu primo. No pequeno manifesto estão assinaladas algumas normas que começavam a ser um denominador comum das edificaões também de outros arquitetos.

A planta livre, desvinculada da estrutura (não mais, muros sobre muros); pilotis, colunas que suspendem a casa do sólo, permitindo ao jardim, correr por baixo; a janela em comprimento; a cobertura jardim; e como consequência, a fachada livre.

LC estará presente à exposição Weissenhof (1927) em Stuttgart ao lado dos principais arquitetos contemporâneos; assim como no desenho de móveis juntamente com Charlotte Perriand; no concurso para o Palácio da Sociedade das Nações em Genebra, que vai vencer, para depois darem o projeto a outro, na construção do Centrosoyus (União de Cooperativas) em Moscou e na fundação do CIAM (Congressos Internacionais de Arquitetura Moderna).

E mais livros, mais projetos com novas propostas: o delicioso e preciso jardim de 
cobertura para Charles de Beistegui, e em contra-partida, o monumentalismo moderno no projeto para o Palácio dos Soviets - não realizado, mas com enorme influência na cabeça de outros arquitetos.

Viagens com anotaões de desenho para urbanização de S. Paulo, Rio, Montevideu e Buenos Aires. O prédio com suas residências no alto, na Porte Molitor, tantas vezes reproduzido no Brasil.

No final do período entre guerras européias, cabe assinalar: O Museu de crescimento ilimitado, uma estrutura convencional com uma idéia original de instalação e desenvolvimento.

Um centro nacional para manifestções populares para 100.000 pessoas (estádio esportivo, cinema, teatro, desfiles, tribuna) abrigado ao sol, com estrutura e cobertura absolutamente revolucionárias.

Alguns pavilhões de feira de amostras, construções leves, flexíveis. O único realizado foi o Pavilhão dos Tempos Modernos para a Exposição de 1937 em Paris.

Turbilhonamente, imaginoso artista, em sua generosa distrubuição de idéias.

Há duas formas de expressão de seu desenho:A folha arquitetônica, técnica (onde inovou também no lay-out) e seus esboços e perspectivas à mão livre, a linha solta, sem sombras, que fizeram escola. Muitos arquitetos brasileiros ainda hoje desenham dessa maneira. De outro lado, seu desenho com apoio às outras artes visuais que exerceu ou de puro prazer do risco, de traço denso, vigoroso, numa linha Leger, Derain, ou longiquamente Piero della Francesca que conheceu na Toscana.

Para taperias e murais apoiava-se no desenho do "arquiteto" usando poucas mas enroscadas linhas com fortes manchas em cores primárias que privilegiava.

Viajou a muitos paises da Europa, ao Oriente e às Américas, com atenta inteligência sempre anotando em páginas e páginas, arquiteturas, rostos, animais, sugestões de espaços e modos de vida.

Esteve no Brasil em 29 como citado, em 36 voltou ao Rio a convite para o projeto 
do Ministério de Educação, e em 63 para ver Brasília e outras obras Corbusianas.

Pela sua arrebatada personalidade; pelo espírito barroco e o amor ao discurso, características de nossa formação - de todas as estrelas do movimento de arquitetura moderna, para os brasileiros, Le Corbusier foi a mais cintilante.

A partir do fim da segunda guerra mundial, LC já famoso fora do círculo do siniciados e de vanguarda, come e receber encomendas de edificações de grande porte onde vai jogar idéias até então esquematizadas.

A unidade de habitação de Marselha é cronologicamente, a primeira. Trata-se de uma megaestrutura em concreto armado sobre pilotis que abriga um grande número de apartamantos, uma série de lojas a meio caminho da altura do prédio e uma cobertura para área de lazer de crianças. Essa conceituação trouxe críticas; dos apartamentos, serem estreitos e muito longos, de cozinhas pequenas (para marselheses!). Seus habitantes preferiram fazer as compras fora, e a cobertura com seu terraço de múltiplas formas, torres e cores, atraiu sempre mais arquitetos com câmeras fotográficas, que as próprias crianças.

A capela de Ronchamp é uma quase escultura abstrata. LC trabalhou cinco anos a partir do projeto que esteve na primeira Bienal de São Paulo, mudando, refazendo, retocando. Pronta, todo o lirismo corbusiano, esplende sobre a colina. Encimada por poderosa voluta que lhe serve de cobertura, estão as largas enseadas de muros cóncavos, torres semi-cilíndircas, todas em muros brancos, rugosos, com sulcos e aberturas que criam sombras. Dentro, o volume como negativo das superfícies descritas, onde se insinuam luzes através de pequenos vidros de cor: Egeu e Bizancio.

Memória, criação e amor. A nave de Deus chegara.

La tourette, outra importante obra religiosa é diferente. Um grande retângulo com pátio interno, com cada superfície do paralelepípedo trabalhada diferentemente. Luzes, nuânces, natureza.

No centro de Artes Visuais Carpenter, na universidade de Harvard, o arquiteto in- 
verte repetindo uma mesma forma elíptica em torno de um quadrado central. Rampas, quebra-sóis nas grandes curvas exteriores. Afinal, não é a arquitetura, "o jogo sábio, correto e magnífico dos volumes sob a luz" como o autor proclamou desde sempre?

Em Chandigar na Índia, que ele botou no mapa, LC em sua última década de vida, vê realizada, mesmo se em fragmento, suas propostas de urbanista ao lado de alguns edifícios de governo. Mas deixemos os monumentos da capital do Pinjab, que são suficientemente divulgados.

Citemos dois projetos, entre outros, realizados em Ahmedabad. A Associação dos Tecelões, de forte expressividade no tratamento externo do volume, com rampa de acesso sabiamente colocada como contraponto da composição.

Na casa Sarabhai os materiais s+ao simples, tradicionais, uma planta tranquila com cobertura em abóbadas abatidas. Jardim com água. Uma jóia de arquitetura e poesia que a poucos eleitos é permitido com tal discreção e beleza.

Em seu último ano de vida, LC é chamado a Veneza que tanto amava, para o projeto do hospital. Como verdadeiro amoroso propõe edificações baixas para não perturbar a escala da laguna. O proieto não foi executado. Pena, pois coadunava-se com a mágia da cidade.

Le Corbusier morreu nadando no Mediterrâneo. Ele merecia. 


\section{Antepassado do teatro paulista localizado na França}

\section{SALVADOR CANDIA}

Especial para of Folhe

A Opera de Paris é o antepassado do Teatro Municipal de São Paulo. Aquela faz parte das obras que barão Hausmann executou no plano de renovação da cidade na segunda metade do século passado. 0 arquiteto Garnier vencera o concurso instituido pelo governo francés e executou a obra. Rasgou-se a avenida da Opera para dar-lhe o destaque que a edificacão exigia, e o teatro tornou-se "ponto focal".

Em São Paulo passou-se, urbanística e arquitetonicamente, caso semelhante. Aqui o velho centro do "triângulo", iria transpor o Anhangabaú com 0 novo e imponente teatro. Inaugurado em 1911 na margem esquerda do rio, criou-se a praça que recebe 0 nome do arquiteto capitåo da equipe executora da obra. A praça Ramos de Azevedo formava o contraponto com a do Patriarca na margem direita, ligadas pelo viaduto do Chá, entăo em estrutura de ferro.

Esse largo vale natural que se preservou até hoje deu à Paulicéia a grandeza de seu centro. Sua escala é tal que mesmo os atuais arranhacéus da rua Libero Badaró e o Banespa'de um lado; e do outro, o edifício da atual Eletropaulo e mais o Mappin em frente ao teatro não lhe diminuem 0 ar de metrópole.

Se a obra de Garnier foi elevada à honraria de destaque urbanístico, o Municipal teve um tratamento ainda mais sutil, em que a lateral do Anhangabaú teve seu desnivel graciosamente vencido com o monumento a Carlos Gomes e as palmeiras imperiais que funcionam como esguias arquiteturas verticais em curva.

\section{Paris na América}

0 teatro é em estilo eclético e evoca o de Paris no foyer e principalmente na escadaria monumental interna em mármore branco forrado em tapete vermelho. Mas é um sem-número de detalhes que fazem (ou faziam) sua grandiosa elegância. Os cristais das luminárias, as escadas laterais internas, os vitrais, o antigo delicioso mosáico do piso que circundava a sala da platéia, contam (ou contavam) do requinte da construçăo. Até pouco mais de trinta anos atrás, havia as maravilhosas cadeiras de palha da platéia, balcōes e foyer feitas no Liceu, havia toda a estrutura metálica leve e dourada com belos parapeitos, que compunham a sala.

Todo esse deslumbrante mundo criado por artesãos de marcenaria, serralheria, cristais, pinturas, tacos e tantos outros pormenores que fazem a essência mesmo da arquitetura, como arte coletiva que é, desapareceram em boa parte na "reforma" para o quarto centenário da cidade, quando mãos espúrias assumiram as obras em nome de mesquinhas tecnicalidades acústicas e de visão do palco.

0 teatro até 1952 era emocionante além do espetáculo ou música que levava. Ele era uma emoção em si. Lá os paulistas iam sonhar, "rir seu riso ou derramar seu pranto", encantar-se. Não era só casa de espetáculo, era o espetáculo em si, desde que chegávamos.

Lemos que está sendo restaurado, respeitando o original. A ver.

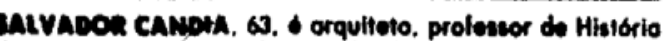
do Arse, ex-dirotor da Foculdode de Arquilaturo de intrecsidode Mockensio. $\because$ 
